Key Words:

Engineered Trench

Long-Term Waste Stability

Low-Level Waste Disposal

Retention:

Permanent

\title{
LONG-TERM WASTE STABILIZATION PARAMETER ESTIMATION, SAVANNAH RIVER SITE, AIKEN, SOUTH CAROLINA (U)
}

\author{
William E. Jones \\ Savannah River Technology Center \\ William T. Li \\ Site Geotechnical Services
}

SEPTEMBER 2001

Westinghouse Savannah River Company

Savannah River Site

Aiken, SC 29808

Prepared for the U.S. Department of Energy Under

Contract Number DE-AC09-96SR18500 
This document was prepared in conjunction with work accomplished under Contract No. DEAC09-96SR18500 with the U.S. Department of Energy.

\section{DISCLAIMER}

This report was prepared as an account of work sponsored by an agency of the United States Government. Neither the United States Government nor any agency thereof, nor any of their employees, makes any warranty, express or implied, or assumes any legal liability or responsibility for the accuracy, completeness, or usefulness of any information, apparatus, product or process disclosed, or represents that its use would not infringe privately owned rights. Reference herein to any specific commercial product, process or service by trade name, trademark, manufacturer, or otherwise does not necessarily constitute or imply its endorsement, recommendation, or favoring by the United States Government or any agency thereof. The views and opinions of authors expressed herein do not necessarily state or reflect those of the United States Government or any agency thereof.

This report has been reproduced directly from the best available copy.

Available for sale to the public, in paper, from: U.S. Department of Commerce, National Technical Information Service, 5285 Port Royal Road, Springfield, VA 22161

phone: (800) 553-6847

fax: (703) 605-6900

email: orders@ntis.fedworld.gov

online ordering: http://www.ntis.gov/support/index.html

Available electronically at http://www.osti.gov/bridge

Available for a processing fee to U.S. Department of Energy and its contractors, in paper, from: U.S. Department of Energy, Office of Scientific and Technical Information, P.O. Box 62, Oak Ridge, TN 37831-0062

phone: (865)576-8401

fax: (865)576-5728

email: reports@adonis.osti.gov 
Key Words:

Engineered Trench

Long-Term Waste Stability

Low-Level Waste Disposal

Retention:

Permanent

\title{
LONG-TERM WASTE STABILIZATION PARAMETER ESTIMATION, SAVANNAH RIVER SITE, AIKEN, SOUTH CAROLINA (U)
}

\author{
William E. Jones \\ Savannah River Technology Center \\ William T. Li \\ Site Geotechnical Services
}

SEPTEMBER 2001

Westinghouse Savannah River Company

Savannah River Site

Aiken, SC 29808

Prepared for the U.S. Department of Energy Under

Contract Number DE-AC09-96SR18500

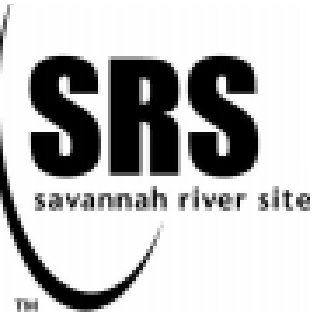




\section{REVIEWS AND APPROVALS}

William E. Jones, Environmental Restoration Technology

Date

William T. Li, Site Geotechnical Services

Date

Mark A. Phifer, Reviewer, Environmental Restoration Technology

Date

Mary K. Harris, Level 4 Manager, Environmental Restoration Technology

Date

Robert S. Aylward, Level 3 Manager, Environmental Restoration Technology

Date

Peter I. Hudson, Planning and Technology Manager, Solid Waste Division

Date 


\section{TABLE OF CONTENTS}

LIST OF FIGURES ......................................................................................................................iv

LIST OF TABLES ............................................................................................................................... iv

LIST OF ACRONYMS..................................................................................................................... v

ACKNOWLEDGEMENTS...................................................................................................... vi

1.0 EXECUTIVE SUMMARY ................................................................................... 1

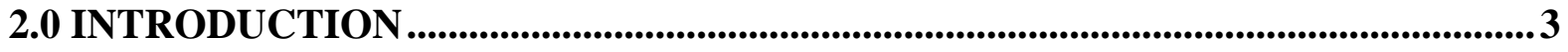

2.1 BACKGROUND ..................................................................................................................

2.2 OBJECTIVE AND APPROACH .....................................................................4

2.3 DESCRIPTION OF STUDY AREA ..............................................................................5

2.3.1 Engineered Trench Area Geology ...................................................................................5

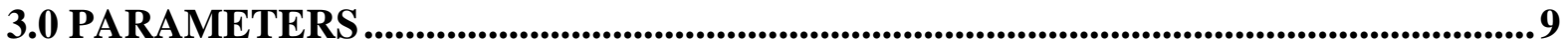

3.1 ENGINEERED TRENCH LOCATION AND CONFIGURATION .........................9

3.2 SOIL CHARACTERISTICS ......................................................................10

3.2.1 Vadose Zone Soil Moisture Content ................................................................10

3.2.2 Soil Chemical Characteristics.............................................................................................11

3.2.3 Trench Area Geotechnical Characteristics ................................................................14

3.3 DYNAMIC COMPACTION.............................................................................................15

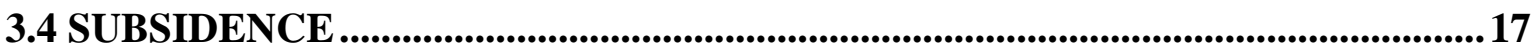

3.4.1 Static Surcharge..............................................................................................................21

3.4.2 Subsidence Potential and Subsidence-Potential Reduction ...................................21

3.4.3 Corrosion ..............................................................................................................................23

3.5 CONTAINER CHARACTERISTICS AND CONFIGURATION............................24

3.6 SOFT-SIDED CONTAINERS........................................................................................29

3.7 WASTE CHARACTERISTICS .........................................................................30

3.8 SEISMIC CHARACTERISTICS......................................................................................33

3.9 CLIMATE CHARACTERISTICS..................................................................................35

4.0 DOE-SITE DISPOSAL METHODS AND VOLUMES .................................................37

5.0 CONCLUSIONS.....................................................................................................................43

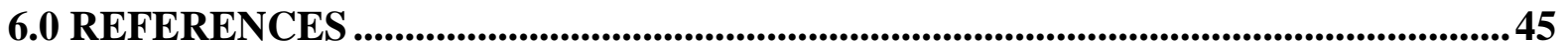

\section{APPENDICES}

Appendix A C-DCP-E-00001 SWMF Low Level Waste Mega-Trench 49

Appendix B Geotechnical Data Summary for Mega-Trench Site 147

Appendix C B-25 Exhumation - May 2-3, 2001

Appendix D Procurement Specifications 261

Burial Box Specification - 1986

C-SPP-G-00101 Low Level Waste B-12 and B-25 Box 271

Specification -2001 


\section{LIST OF FIGURES}

Figure 1. Savannah River Site, E Area, and Engineered Trench Area Location Map

(modified from WSRC, 2000b) .................................................................................

Figure 2. Engineered Trench Geotechnical Conceptual Model (not to scale) ........................ 15

Figure 3. View of 1993 Dynamic Compaction Test Results (McMullin and Dendler, 1994)16

Figure 4. B-25 Containers Stacked Four-High (Phifer and Wilhite, 2001) ..........................22

Figure 5. Waste Sort Facility/Super Compactor Facility B-25 Process Flow Diagram (Phifer

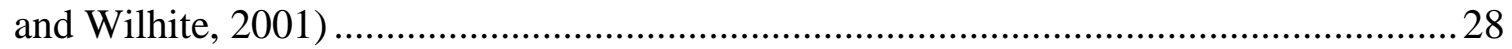

\section{LIST OF TABLES}

Table 1. Savannah River Site and Burial Ground Complex (E Area) Soils Total Metals

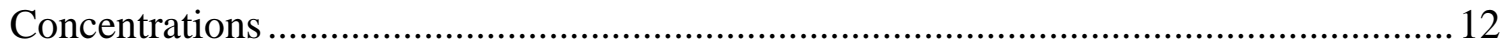

Table 2. B-25 Exhumation Soil Sample Analytical Results (Law-Gibb, 2001) ..................... 13

Table 3. Load Test Results (Dames and Moore, 1987) ......................................................... 18

Table 4. B-25 Deformation With Applied Weight (Yau, 1986) …………………….......... 19

Table 5. Closure Cap Subsidence Demonstration Summary Results (Phifer and Wilhite,

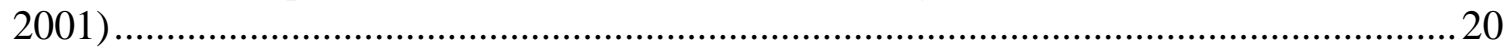

Table 6. Relative Subsidence Potential and Relative Subsidence Potential Reduction (Phifer and Wilhite, 2001) ............................................................................................... 23

Table 7. Waste Containers meeting Engineered Trench Waste Acceptance Criteria (Phifer

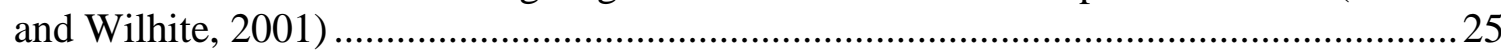

Table 8. Past and Future Low-Level Waste Volumes for DOE's 20 Major Waste-Generating Sites (GAO, 2000) …………………................................................................... 37

Table 9. DOE's Active Waste Management Disposal Facilities' Waste Disposal Volumes

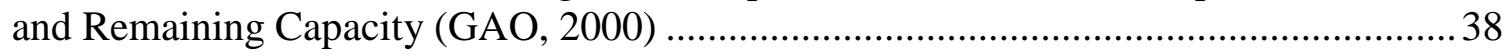




\section{LIST OF ACRONYMS}

$\begin{array}{ll}\text { ASTM } & \text { American Society for Testing and Material } \\ \text { bls } & \text { below land surface } \\ { }^{\circ} \mathrm{C} & \text { degrees centigrade } \\ \text { cm } & \text { centimeter(s) } \\ \text { D\&D } & \text { Decontamination and Decommissioning } \\ \text { DOE } & \text { United States Department of Energy } \\ \text { DWPF } & \text { Defense Waste Processing Facility } \\ \text { EPA } & \text { United States Environmental Protection Agency } \\ \text { ERD } & \text { Environmental Restoration Department } \\ \text { ET } & \text { Engineered Trench \#1 } \\ { }^{\circ} \text { F } & \text { degrees Fahrenheit } \\ \text { FML } & \text { Flexible Membrane Liner } \\ \text { ft } & \text { foot/feet } \\ \text { FY } & \text { fiscal year } \\ \text { g } & \text { gram(s) } \\ \text { GCL } & \text { Geosynthetic Clay Liner } \\ \text { in. } & \text { inch } \\ \text { INEEL } & \text { Idaho National Engineering and Environmental Laboratory } \\ \text { kg } & \text { kilogram } \\ \text { km } & \text { kilometer } \\ \text { LAWV } & \text { Low Activity Waste Vault } \\ \text { lb } & \text { pound } \\ \text { LLW } & \text { Low-level waste } \\ \text { m } & \text { meter(s) } \\ \text { mg } & \text { milligram } \\ \text { mi } & \text { mile } \\ \text { MMI } & \text { Modified Mercalli Index } \\ \text { msl } & \text { mean sea level } \\ \text { MWMF } & \text { Mixed Waste Management Facility } \\ \text { NASA } & \text { United States National Aeronautics and Space Administration } \\ \text { psi } & \text { pounds per square inch } \\ \text { RWMC } & \text { Radioactive Waste Management Complex } \\ \text { SCF } & \text { Supercompaction Facility } \\ \text { SRS } & \text { Savannah River Site } \\ \text { SRTC } & \text { Savannah River Technology Center } \\ \text { SWD } & \text { Solid Waste Division } \\ \text { TSA } & \text { Temporary Storage Area } \\ \text { USCS } & \text { Unified Soil Classification System } \\ \text { WAC } & \text { Waste Acceptance Criteria } \\ \text { WSF } & \text { Waste Sorting Facility } \\ \text { WSRC } & \text { Westinghouse Savannah River Company } \\ & \end{array}$




\section{ACKNOWLEDGEMENTS}

We would like to acknowledge the input and helpful suggestions provided by

Mark Phifer, Chung Gong, Kerry Dunn, Elmer Wilhite, and Michael Serrato. 


\subsection{EXECUTIVE SUMMARY}

Department of Energy Order 435.1, Radioactive Waste Management, requires that certain Performance Objectives be met over a 1,000-year post-closure period, in order to protect the public, environment, and workers. This objective is realized by specific requirements designed to minimize radionuclide transport from the disposal facilities. The requirement to achieve long-term stability, minimize subsidence, and minimize the need for long-term maintenance for long-term cover systems is one such requirement.

Engineered Trench \#1 (ET) is a low-level radioactive waste disposal trench located in E-Area, Savannah River Site. The first phase of the ET has been constructed and steel B-25 waste containers are currently being placed. This fiscal year, and over the next two fiscal years, TTP SR11SS29, will use the ET as a case study to evaluate long-term waste stabilization design for long-term cover systems. The case study will include:

- Finite element modeling of waste container (B-25) behavior

- Corrosion study to evaluate B-25 long-term structural stability

- Cost evaluation and impact on long-term maintenance for stabilization methods modeled

- Risk-based evaluation of the structural finite element model results by integration with the Performance Assessment

- Production of a generic, risk-based design methodology for evaluating and selecting physical stabilization options for long-term cover systems

This report summarizes parameters to be incorporated in the finite element model, and includes some parameters related to the corrosion study. Parameters include ET configuration, soil, container, waste, seismic, and climate characteristics. Information related to the currently planned stabilization method (dynamic compaction) is included, as is information related to a potential new disposal method, the use of soft-sided bags rather than B-25s. 
This page intentionally left blank.

Page 2 of 298 
WSRC-TR-2001-00323

\subsection{INTRODUCTION}

\subsection{BACKGROUND}

A May 2001 report by the U.S. Department of Energy (DOE) Office of Inspector General estimates the DOE has disposed nearly 69 million $\mathrm{ft}^{3}\left(1.95\right.$ million $\left.\mathrm{m}^{3}\right)$ of low-level radioactive waste at its facilities (DOE, 2001). To put this in perspective, 3.5 million $\mathrm{ft}^{3}$ $\left(100,000 \mathrm{~m}^{3}\right)$ is similar in volume to a 7-story building covering the area of a football field (DOE, 1998). So, the nearly 69 million $\mathrm{ft}^{3}\left(1.95\right.$ million $\left.\mathrm{m}^{3}\right)$ disposed to date is about the volume of 20 football-field-size, 7-story buildings. Over the next 70 years, DOE plans to dispose an additional 358 million $\mathrm{ft}^{3}\left(10.14\right.$ million $\left.\mathrm{m}^{3}\right)$, a volume roughly equivalent to 102 football-field-size, 7-story buildings. Most of this material will be generated over the next two decades as part of DOE's environmental restoration activities (DOE, 1998).

According to DOE Orders 5820.2A and 435.1, the preferred locations for disposing low-level materials (in order of priority) are: at the site of origin, at other DOE sites (i.e., Nevada Test Site or Hanford Site), and at commercial facilities (DOE, 2001).

The limited availability of disposal alternatives is the principal factor influencing DOE decisions about the treatment, storage, and disposal of the low-level and mixed wastes from its 20 major waste-generating sites. Four of DOE's six disposal sites - Idaho National Engineering and Environmental Laboratory; Los Alamos National Laboratory, New Mexico; Oak Ridge Reservation, Tennessee; and Savannah River Site (SRS), South Carolina - are restricted to disposing almost exclusively of their own low-level wastes (and no mixed wastes) because of limits on their remaining disposal capacity and/or unfavorable site conditions, such as proximity to groundwater or relatively wet climates. The two other disposal sites - the Hanford Site in Washington State and the Nevada Test Site - have relatively dry climates and enough capacity to dispose of nearly all the low-level and mixed wastes generated at DOE's nuclear facilities nationwide (GAO, 2000). A summary of the various DOE waste-generating and disposal sites is presented in Section 3.0.

The Savannah River Site (SRS) is a DOE facility that was set aside in 1950 as a controlled area for production of nuclear materials for national defense. The DOE and its contractors are responsible for the operation of the SRS. Westinghouse Savannah River Company (WSRC) currently manages and operates the site. SRS and other DOE sites use shallow land burial facilities (i.e., trenches) to dispose some low-level radioactive waste.

DOE Order 435.1 (DOE, 1999), Radioactive Waste Management, and its companion manual and guidance require that certain Performance Objectives be met over a 1,000 year postclosure period, in order to protect the public, environment, and workers. This objective is realized by specific requirements designed to minimize radionuclide transport from the disposal facilities. The requirement to achieve long-term stability, minimize subsidence, and minimize the need for long-term maintenance for long-term cover systems is one such requirement. 
Buried materials can experience settlement due to consolidation of underlying materials by several processes. These processes include compression of materials under their own weight and the weight of any overlying materials or loads, chemical and biological degradation, and other mechanisms. The magnitude, distribution, and rate of settlement are governed by factors such as material age, type, density and thickness, loading, and moisture (EPA, 2001).

At SRS and other DOE sites, waste containers (called B-25 containers), with from approximately 10 percent to as much as 90 percent void space, are placed in the disposal trenches. Dames and Moore (1987) estimated the typical B-25 contained 70 percent void space and 30 percent waste material. Corrosion and degradation of these carbon-steel containers can result in significant subsidence over time. Subsidence can compromise the structural integrity of the long-term cover system, resulting in increased radionuclide transport into the environment. The selection of cost effective and appropriate stabilization of both containerized and bulk waste is required in order to maintain long-term cover system stability and stakeholder acceptance of long-term disposal practices.

Current SRS disposal of low-level radioactive waste contained in stacked B-25 containers within Engineered Trench is anticipated to continue for the foreseeable future. The current SRS baseline option for waste physical stabilization is dynamic compaction immediately prior to construction of the final cover at closure. However, the cost of dynamic compaction is approximately $\$ 200,000$ per acre and DOE's low-level radioactive waste sites constitute hundreds of acres. Additionally, the dynamic compaction conducted to date at DOE facilities has not eliminated future subsidence potential, but has only reduced it by less than $50 \%$. Therefore, significant future maintenance activities are likely to be required at these facilities.

\subsection{OBJECTIVE AND APP ROACH}

Fiscal Year (FY) 2001 tasks under Technical Task Plan SR11SS29 encompass developing a better understanding of the structural stability of B-25 container disposal using Engineered Trench \#1 as a case study.

- Task 1 is a finite element parametric study to determine the parameters that have the most impact upon long-term structural stability and subsidence of the cover system.

- Task 2 is a corrosion evaluation using a B-25 container exhumed near the Engineered Trench (ET).

- Task 3 is this technical report.

This report summarizes parameter estimations for use in the structural finite-element modeling of a selected ET waste physical-stabilization option, to be performed in FY 2002. The SRS ET case study will be completed in time to allow modification of current disposal practices and/or the baseline stabilization, as appropriate, prior to facility closure. 
WSRC-TR-2001-00323

\subsection{DESCRIPTION OF STUDY AREA}

The SRS comprises approximately 300 square miles $\left(\mathrm{mi}^{2}\right)$ within Aiken, Barnwell, and Allendale counties in southwestern South Carolina. The center of the SRS is 22.5 miles (mi; 36.2 kilometers $(\mathrm{km})$ ) southeast of Augusta, Georgia, approximately 100 miles from the Atlantic Coast within the Upper Atlantic Coastal Plain Physiographic Province. The Savannah River forms the southwest boundary of the SRS. The SRS lies on the Aiken Plateau of the Atlantic Coastal Plain at an average elevation of 300 feet above mean sea level (ft msl; 91 meters above mean sea level (m msl)). The Aiken Plateau is well drained, although many poorly-drained sinks and depressions exist, especially in upland areas. Overall, the Aiken Plateau displays highly dissected topography, characterized by broad inter-fluvial areas separated by narrow, steep-sided valleys. Local relief can attain $280 \mathrm{ft}$ (85 m; Siple, 1967). E-Area is located near the SRS geographic center (Figure 1).

\subsubsection{Engineered Trench Area Geology}

The geology of the SRS includes sediments of the Atlantic Coastal Plain. The Atlantic Coastal Plain consists of southeast-dipping, unconsolidated and semi-consolidated strata that extend from the Piedmont Province at the Fall Line to the edge of the continental shelf. Strata range from Late Cretaceous to Miocene in age and rest unconformably on crystalline and sedimentary basement rock. The sediment comprises interbedded sand, muddy sand, and mud (clay and silt), with a subordinate amount of calcareous sediment. The sedimentology of these strata indicates deposition in deltaic and near-shore environments that experienced considerable fluvial influence (Fallaw and Price, 1995). Several recent reports describe the geology and lithostratigraphy of the SRS (Fallaw and Sargent, 1982; Colquhoun et al., 1983; Logan and Euler, 1989; Fallaw et al., 1990; Aadland et al., 1991; Fallaw and Price, 1992; and Aadland et al., 1995).

The ET will be constructed primarily within the "Upland Unit", with the trench bottom near the "Upland Unit"/Tobacco Road Formation contact. The "Upland Unit" is an informal stratigraphic term applied to terrestrial, probably fluvial, deposits that occur at higher elevations in some places in the southwestern South Carolina Coastal Plain. This unit overlies the Barnwell Group's Tobacco Road Formation in the South Carolina Upper Coastal Plain, where SRS is located. The unit occurs at the surface at higher elevations in many places around and within the SRS, but it is not present at all higher elevations. The sediments are poorly sorted, clayey-to-silty sands, with lenses and layers of conglomerates, pebbly sands, and clays. Clay casts are abundant. Weathered feldspar is abundant in places. Color is variable and facies changes are abrupt. The "Upland Unit" is up to $69 \mathrm{ft}(21 \mathrm{~m})$ thick in areas at SRS. Abrupt thickness changes are due to channeling of the underlying Tobacco Road Formation during "Upland" deposition and subsequent erosion of the "Upland" unit itself. Much of this unit corresponds to the Miocene Hawthorne and Formation, and the Tertiary alluvial gravels identified in previous publications (WSRC, 1997; WSRC, 2000b). 


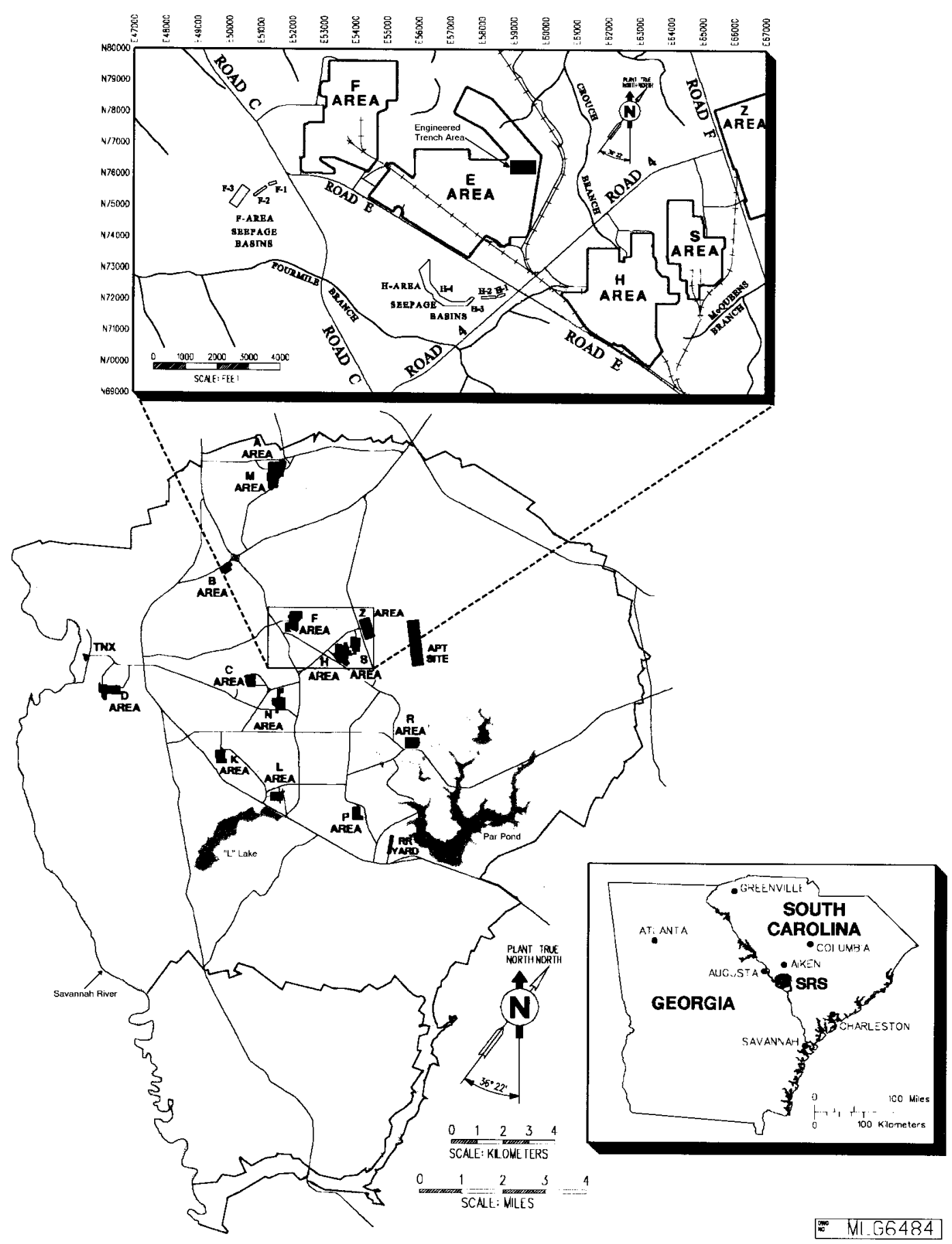

Figure 1. Savannah River Site, E Area, and Engineered Trench Area Location Map (modified from WSRC, 2000b) 
WSRC-TR-2001-00323

The Late Eocene Tobacco Road Formation consists of moderately to poorly sorted, red, brown, tan, purple, orange, and yellow, fine to coarse, clayey quartz sand. Pebble layers are common, as are clay laminae and beds. Ophiomorpha burrows are abundant in parts of the formation. The sediments have the characteristics of lower Delta plain to shallow marine deposits. The top of the Tobacco Road Formation is characterized by the change from a comparatively well sorted sand to the more poorly sorted sand, pebbly sand, and clay of the overlying "Upland" unit. Contact between the units constitutes the "Upland" unconformity. The unconformity is very irregular due to fluvial incision that accompanied deposition of the overlying "Upland" unit and later erosion, as mentioned in the previous paragraph.

Thickness is variable as a result of erosive processes, but is at least $50 \mathrm{ft}(15 \mathrm{~m})$ in places (WSRC, 2000b; WSRC, 1997).

Subsurface characterization associated with the E-Area Vadose Zone Monitoring System was performed in 1999. The vadose zone underlying E Area extends to a depth of about $69 \mathrm{ft}$ $(21 \mathrm{~m})$. E-Area disposal trenches, including the ET, are typically constructed within the uppermost $26 \mathrm{ft}(8 \mathrm{~m})$. Split-spoon sampling, Shelby-tube sampling and laboratory testing, and PiezoCone Penetrometer Testing were used to develop a geological model for determining optimum monitoring instrument locations. The model indicates three three major lithologic strata are located beneath the E-Area. The A-stratum dominates the vadose zone's upper $23 \mathrm{ft}(7 \mathrm{~m})$, and is a predominantly clay layer ("Upland" unit). The B-stratum, characterized by higher sand content than either the overlying A-stratum or underlying C-stratum, begins at about the $23 \mathrm{ft}(7 \mathrm{~m})$ depth and extends to approximately $59 \mathrm{ft}(18 \mathrm{~m})$ depth (Tobacco Road Formation). Within the underlying C-stratum's predominantly silty sands (Dry Branch Formation) is where the water table is located, just above the locally termed "Tan Clay" (WSRC, 2000b). 
This page intentionally left blank.

Page 8 of 298 


\subsection{PARAMETERS}

\subsection{ENGINEERED TRENCH LOCATION AND CONFIGURATION}

The ET is located in E Area (see Figure 1). It will have a capacity of approximately 9,100 cubic meters in the first phase, with additional sections to be constructed as required. The ET is sized to allow stacking B-25s four-high. Trench depth is approximately 17 to $20 \mathrm{ft}(6 \mathrm{~m})$ below ground surface. First phase trench-bottom dimensions are approximately $150 \mathrm{ft}$ (45 $\mathrm{m}) \mathrm{x} 210 \mathrm{ft}(64 \mathrm{~m})$. First phase ground surface dimensions are approximately $200 \mathrm{ft}(61 \mathrm{~m}) \mathrm{x}$ $260 \mathrm{ft}(79 \mathrm{~m})$, at a typical elevation of $280 \mathrm{ft}(84.8 \mathrm{~m}) \mathrm{msl}$.

The trench bottom is compacted using a minimum of five passes of a vibratory roller having a dynamic force of 30,000 lbs per drum. The ET bottom is constructed with a geotextile filter underlying a crusher run layer. The geotextile is non-woven, spun-bonded, continuous filament of 100 percent polypropylene, and providing a minimum puncture resistance of 70 $\mathrm{lbs}$, a minimum Mullen Burst pressure of 140 psi., and equivalent apparent opening of 70 to 140 size sieve. A granite gravel (Georgia Department of Transportation Standard Specifications Section 815-01, also known as Georgia \#25 Crusher Run) layer approximately 6 in. thick is placed atop the geotextile layer. The gravel size gradation is:

$\begin{array}{ll}\text { Sieve Size } & \text { Percent Passing by Weight } \\ 2 \text { in. } & 100 \\ 1.5 \text { in. } & 97-100 \\ 0.75 \text { in. } & 60-90 \\ \# 10 & 25-45 \\ \# 60 & 5-30 \\ \# 200 & 0-15\end{array}$

Once the trench is filled with B-25s, the B-25s will be covered in the same manner as the slit trenches [i.e., minimum $4 \mathrm{ft}(1.2 \mathrm{~m})$ soil thickness, consolidated by the bulldozer pushing soil over the tops of the B-25s]. The ET is being constructed using standard heavy-construction equipment (e.g., backhoe and dump truck). Construction details for the Engineered Trench (formerly called the Mega Trench) are presented in Appendix A, which includes Design Change Package C-DCP-E-00001.

The ET design allows extending the next trench section while operation continues in the previous section. A roadway leading into the ET is about $30 \mathrm{ft}(9.1 \mathrm{~m})$ wide, with a fivepercent grade, and designed to AASHTO HS-20 loads. A flat-bed truck, fork lift, or crane may be used for disposing B-25s. A 35-ft-minimum (10.6-m-minimum) interior turning radius for heavy equipment is allowed on the ET base. The base is sloped to move water runoff to a low-point sump for collection and pumping (using a portable pump on an elevated surface). The Performance Category is PC-1, designed per the SRS Engineering Standards No. 01110. 
The ET bottom is constructed with a sump to collect any runoff for analysis prior to disposal. Elevation for the first phase is $261 \mathrm{ft}(79.1 \mathrm{~m}) \mathrm{msl}$ along the trench-bottom perimeter, sloping downward toward the sump perimeter at $260 \mathrm{ft}(78.8 \mathrm{~m}) \mathrm{msl}$. Sump-bottom minimum elevation (top of Geoweb/concrete) is $243 \mathrm{ft}(73.6 \mathrm{~m}) \mathrm{msl}$, with maximum depth $17 \mathrm{ft}$ $(5.2 \mathrm{~m})$. Sump-top dimensions are approximately $60 \mathrm{ft}(18.2 \mathrm{~m}) \times 70 \mathrm{ft}(21.3 \mathrm{~m})$. Sumpbottom dimensions are approximately $30 \mathrm{ft}(9.1 \mathrm{~m})$ x $40 \mathrm{ft}(12.2 \mathrm{~m})$. The sump is designed to accommodate rainfall from a $6 \mathrm{hr} .-25$ year storm event for one-third of the ET area.

The ET floor is used to accommodate the difference between the design storm event $(24 \mathrm{hr}$. 500 year return period) and the $6 \mathrm{hr} .-25$ year storm event. Water depth within the ET will not be allowed to exceed $2 \mathrm{ft}(0.61 \mathrm{~m})$, to prevent B-25s from floating. The sump design allows the sump to be pumped out in $4 \mathrm{hrs}$. A rigid pipe is located near the sump to move water away from the sump and direct the water, at the top of the slope, toward the existing drainage ditch.

The ET also has a small submersible non-clogging industrial pump, to feed a sample station above the sump walls. The sample station allows an operator to sample the small pump's discharge. The existing performance assessment requires a minimum $25 \mathrm{ft}(7.6 \mathrm{~m})$ of undisturbed soil between the trench floor and the underlying water table. Sump sides have designed slopes at 1:1. Side-slopes are stabilized using $8 \mathrm{oz}$. minimum, geotextile fabric overlain by 4-in. ( $0.1 \mathrm{~m}$ )-deep GW20V Geoweb (manufactured by Presto Products Co., Appleton, WI) with 4,000 psi. concrete infill. Six TK-89 tendons per Geoweb section are typical for all sump sides (SRS Engineering, 2000).

The ET walls are sloped to allow personnel to work safely at the trench base. Typical elevation at the top of the trench side-slope is $278 \mathrm{ft} \mathrm{msl}(84.2 \mathrm{~m} \mathrm{msl})$. Minimum side-slope is 1:1. The side-slope is designed with a safety factor of 1.5 against slope stability failure where site-specific strength data are not available. Erosion control features for keeping the walls intact include erosion control matting and seeding of slopes. Life expectancy of the entire trench is at least 20 years.

\subsection{SOIL CHARACTERIST ICS}

\subsubsection{Vadose Zone Soil Moistu re Content}

E-Area Vadose Zone Monitoring System time domain reflectometer sensor data indicate that water content is very consistent over time. Average water contents are $0.284 \mathrm{~m}^{3} / \mathrm{m}^{3}$, from a depth of about 18-20 ft bls in the Upland Formation; $0.181 \mathrm{~m}^{3} / \mathrm{m}^{3}$, from a depth of about 40 to $42 \mathrm{ft}$ bls in the Tobacco Road Formation, and $0.266 \mathrm{~m}^{3} / \mathrm{m}^{3}$, from a depth of about 58 to $60 \mathrm{ft}$ bls in the Dry Branch Formation. Advanced tensiometer measurements indicate soil tension is relatively constant, ranging between $-100 \mathrm{~cm}$ (wetter) to $-200 \mathrm{~cm}$ (dryer), and is consistent with expected tensions for SRS soils. Water potential appears unaffected by daily or yearly infiltration events at the depths measured [approximately $18 \mathrm{ft}(5.5 \mathrm{~m})$ to about $60 \mathrm{ft}(18.2 \mathrm{~m})]$. The total variation in water potential was less than $100 \mathrm{~cm}$. in all tensiometers over a 3.5 month study period (WSRC, 2000b). 


\subsubsection{Soil Chemical Character istics}

\subsubsection{1 $\mathrm{pH}$}

SRS shallow soil chemical and physical properties from areas not impacted by DOE activities are summarized in Looney, et al. (1990). Overall, $\mathrm{pH}$ values are indicated from 4.15 to 6.22 for shallow (6 to 120 inches deep) samples obtained for their study. Looney, et al. (1990) also cites a previous study that indicates $\mathrm{pH}$ values from 4.09 to 7.17 for shallow (surface to 30 inches deep) clayey soils and 4.69 to 5.68 for sandy soils. The Looney, et al. (1990) sampling depths are shallower than the ET total depth (up to $10 \mathrm{ft}$ deep, rather than $20 \mathrm{ft}$ deep). However, the values do give an indication of the general $\mathrm{pH}$ range to be expected for SRS soils - from just over 4 to just over 7.

Soil $\mathrm{pH}$ measurements obtained from backfill material (depth $9.5 \mathrm{ft}$ ) during the B-25 excavation on May 2 and 3, 2001, ranged from 5.3 to 5.7. These measurements were made using a Cole-Parmer Model 5992-62 soil pH electrode, consistent with American Society for Testing and Materials (ASTM) designation G 51-95 (Reapproved 2000) Standard Test Method for Measuring pH of Soil for Use in Corrosion Testing (ASTM, 2000).

Measurements were also made with pHydrion Vivid 1-11 pH color indication paper, made by Micro Essential Laboratory, Brooklyn, New York. Paper color indicated soil $\mathrm{pH}$ in the range of 5 to 6 . These field values are generally consistent with the values used in the Dames and Moore (1987) B-25 corrosion study based on literature values for $\mathrm{pH}$ and resistivity. SRS soils were assumed to be acidic, with $\mathrm{pH}$ values ranging from 4.5 to 5.5.

\subsubsection{Metals and Inorganic Compounds}

SRS and E-Area background soil total metals values are summarized in Table 1. SRS values are from Looney, et al. (1990). E-Area values are from samples obtained at approximately $20 \mathrm{ft}$ to $24 \mathrm{ft}$ below land surface (bls) in the Burial Ground Complex (EPD, 1995).

Chloride Chloride is commonly detected in SRS soils. Concentrations ranging from $0.7 \mathrm{mg} / \mathrm{kg}$ to approximately $118 \mathrm{mg} / \mathrm{kg}$ are reported by Looney et al. (1990).

Nitrate Looney, et al. (1990) report nitrate in 70 percent of their 168 shallow soil samples. Concentrations range from below detection to $44.4 \mathrm{mg} / \mathrm{kg}$.

Nitrite Nitrite is reported below the nominal detection limit for all samples (Looney, et al., 1990).

Phosphate Phosphate is not commonly detected in SRS soils - Looney et al. (1990) report detection in less than 10 percent of samples analyzed. Concentrations ranged from below detection to $13.7 \mathrm{mg} / \mathrm{kg}$.

Sulfate Looney, et al. (1990) report sulfate detected in approximately 70 percent of 168 samples. Concentrations ranged from below detection to approximately $25.1 \mathrm{mg} / \mathrm{kg}$. 
WSRC-TR-2001-00323

Table 1. Savannah River Site and Burial Ground Complex (E Area) Soils Total Metals Concentrations

\begin{tabular}{|l|l|l|}
\hline Constituent & $\begin{array}{l}\text { SRS Shallow Soils* } \\
\text { Concentration }(\mathbf{m g} / \mathbf{k g})\end{array}$ & $\begin{array}{l}\text { BGC Soils }(\mathbf{2 0} \mathbf{f t} \mathbf{b l s}) \text { *** } \\
\text { Concentration }(\mathbf{m g} / \mathbf{k g})\end{array}$ \\
\hline Copper & ND to 14 & ND to 9.3 \\
\hline Iron & 886 to 79,600 & 5,300 to 35,000 \\
\hline Lead & ND to 16.7 & ND to 14 \\
\hline Magnesium & 12.9 to 759 & 33 to 1,600 \\
\hline Manganese & ND to 498 & 11 to 110 \\
\hline Mercury & ND to 0.89 & ND to 0.23 \\
\hline Nickel & ND to 17.9 & ND to 230 \\
\hline Potassium & ND to 1,118 & ND to 960 \\
\hline Selenium & ND to 1.66 & ND to 11 \\
\hline Silver & ND to 1.8 & ND to 3.7 \\
\hline Sodium & ND to 760 & ND to 110 \\
\hline Thallium & ND & 5.5 to 7.4 \\
\hline Vanadium & ND to 72.1 & 13 to 98 \\
\hline Zinc & 1.8 to 267 & ND to 15 \\
\hline & & \\
\hline
\end{tabular}

ND $=$ Not Detected

*Looney, et al. (1990)

$* * \operatorname{EPD}(1995)$

\subsubsection{B-25 Exhumation Soil A nalytical Results}

On May 2-3, 2001, a B-25 was exhumed in E Area as part of a corrosion study (see section 2.4.1). A soil sample obtained adjacent to the B-25 on May 2, from a depth of $9.5 \mathrm{ft}$ bls, was shipped to Law-Gibb Engineering, Inc. (Law-Gibb) for analysis. A summary of the analytical results (Law-Gibb, 2001) is presented in Table 2.

The moisture content measurement reported in Table 2 is lower than would be expected based on field observations during sampling and available reflectometer and Shelby tube data from nearby sampling of similar material and depths (see Section 2.2.1 and Appendix B). Shelby tube sample moisture measurements from depths similar to that from which the B-25 was exhumed range from 11.4 to 27.0 percent by weight (Appendix B). 
WSRC-TR-2001-00323

Table 2. B-25 Exhumation Soil Sample Analytical Results (Law-Gibb, 2001)

\begin{tabular}{|l|l|l|}
\hline Analytical Method & Parameter & Analytical Results \\
\hline ASTM D854 & Specific Gravity & 2.67 \\
\hline ASTM D2216 & $\begin{array}{l}\text { Moisture Content (as } \\
\text { received) }\end{array}$ & 1.9 percent by weight \\
\hline ASTM D4972 & $\mathrm{pH}$ & 4.57 \\
\hline ASTM D516-90 & Sulfate Ion & $<100 \mathrm{mg} / \mathrm{kg}$ \\
\hline ASTM D512-90 & Chloride Ion & $<21 \mathrm{mg} / \mathrm{kg}$ \\
\hline ASTM G57 & Resistivity (as received) & $5.8 \times 10^{6} \mathrm{ohm}-\mathrm{cm}$ \\
\hline ASTM G57 & Resistivity (minimum) & $3.0 \times 10^{4} \mathrm{ohm}-\mathrm{cm}$ \\
\hline
\end{tabular}

Additional resistivity and moisture measurement details were obtained by phone conversation and fax from Law-Gibb (personal communication, Harry Johnson to William E. Jones, October 16, 2001). After discussing the reported Law-Gibb moisture content value, it is concluded that the reported value does not reflect field conditions. Soil moisture content values representing field conditions are included in Section 3.2.3 and Appendix B. The additional resistivity and moisture measurements provided by Law-Gibb are listed below.

$\begin{array}{ll}\text { Resistivity (ohm-cm) } & \begin{array}{l}\text { Moisture Content } \\ \text { (percent by weight) }\end{array} \\ 5.829 \times 10^{6} & 2.4 \\ 7.63 \times 10^{5} & 0.9 \\ 3.01 \times 10^{4} & 31.1 \\ 3.04 \times 10^{4} & 53.5\end{array}$

These resistivity and moisture content values suggest a resistivity of approximately $1 \times 10^{4} \mathrm{ohm}-\mathrm{cm}$ would be expected in typical ET area field moisture conditions. This resistivity value is also consistent with Dames and Moore (1987), a corrosion study wherein a resistivity value of $1.0 \times 10^{4} \mathrm{ohm}-\mathrm{cm}$ is taken to be representative of soils to which B-25 would be exposed (see Section 2.4.1). Based on resistivity and field and laboratory-reported $\mathrm{pH}$ measurements, the soil encountered around the exhumed B-25 would be classified as slightly corrosive according to United States Department of Agriculture Guide for Interpreting Soils (USDA, 1971). 


\subsubsection{Trench Area Geotechnic al Characteristics}

At least 10 piezocone penetration tests have been performed and 10 geotechnical boreholes drilled in the ET area. Piezocone penetration test data include sleeve friction, tip resistance, pore pressure, friction ratio, and resistivity. Borehole data include standard penetration testing blow counts, field classification, and soil descriptions. Laboratory soil tests include sieve analyses, Atterberg limits, moisture contents, density, and strength tests. Results from these tests are summarized in a letter report from William T. Li, Site Geotechnical Services. The report is included as Appendix B.

The geotechnical data indicate four general soil layers above the water table. These layers are defined primarily by geotechnical properties measured by piezocone penetration testing (e.g., tip stress and friction ratio), and are not necessarily the same as geologically or hydrologically defined strata. The ET will be constructed largely within the upper two layers. The surficial geotechnical layer, Layer A, is predominantly clayey sands with intermittent sandy clay lenses, and ranges from about 5 to $15 \mathrm{ft}$ (1.5 to $4.5 \mathrm{~m})$ thick. Underlying Layer A is Layer B, predominantly clayey sands and sandy clays ranging from about 7 to $10 \mathrm{ft}$ ( 2.1 to $3.0 \mathrm{~m}$ ) thick. Layer C underlies Layer B. Layer C is about $25 \mathrm{ft}$ $(7.6 \mathrm{~m})$ thick, comprising predominantly clayey sands. The lowermost few feet of some portions of the ET may encounter the uppermost Layer C. Most of the ET sump is within Layer C. Underlying Layer C, and including the water table in most areas of the ET, is Layer D. Layer D is predominantly silty sand, and about 6 to $9 \mathrm{ft}$ (1.8 to $2.7 \mathrm{~m})$ thick.

Layer A characteristics from soil samples EMTUD1-ST1 [Unified Soil Classification System (USCS) soil classification SC] and EMTUD2-ST1 (USCS classification CH) include moisture contents from 27.0 to 11.4 percent. Atterberg limits for these two samples are LL 53 to 90 percent, PL 25 to 35 percent, and PI 28 to 55 percent.

Layer B characteristics from soil samples EMTUD1-ST2 (USCS classification SC) and EMTUD3-ST1 (USCS classification SC) include moisture contents from 15.0 to 15.8 percent. Atterberg limits for these two samples are LL 44 to 49 percent, PL 26 percent, and PI 18 to 23 percent.

Layer C characteristics from soil samples EMTUD2-ST2 (USCS classification SC) and EMTUD4-ST1 (USCS classification SC) include moisture contents from 14.8 to 16.3 percent. Atterberg limits for these two samples are LL 40 to 44 percent, PL 23 to 24 percent, and PI 16 to 21 percent. Additional geotechnical characteristics such as grain-size distribution and triaxial compression tests for all soil samples are included in the letter report presented in Appendix B. A generalized geotechnical conceptual model is presented in Figure 2. 
WSRC-TR-2001-00323

Land Surface

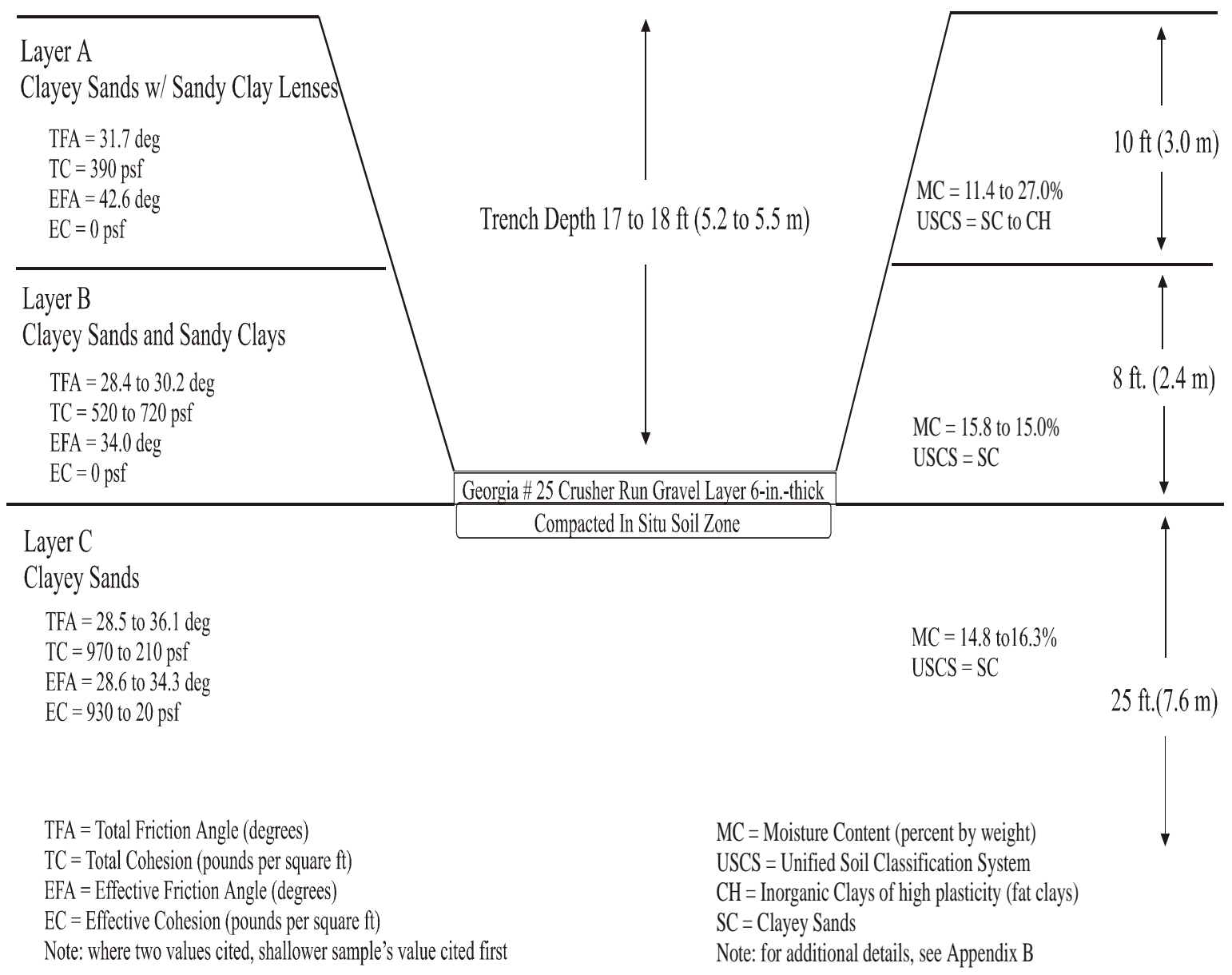

Figure 2. Engineered Trench Geotechnical Conceptual Model (not to scale)

\subsection{DYNAMIC COMPACTION}

Dynamic compaction is simply dropping a heavy weight repeatedly to compact underlying materials. A dynamic compaction test for the Mixed Waste Management Facility (MWMF) was performed in 1988 (Main, 1988 and 1989a; Phifer, 1991). This testing was performed in trenches with and without randomly dumped B-25s. Therefore, it is of limited relevance to dynamic compaction for a trench containing only stacked B-25s. The testing showed that dynamic compaction can be performed safely in both low-level and intermediate-level waste trenches.

A large-scale E-Area dynamic compaction evaluation is described in McMullin and Dendler (1994), McMullin (1994), and McMullin (1992). The primary evaluation objective was to determine if dynamic compaction of buried low-level waste trench materials would cause damage or failure to the adjacent MWMF closure system. Vibrations from dynamic compaction were observed to potentially damage the kaolin clay cap, although cap hydraulic conductivity was not affected. Recommendations were to use a 50-ft buffer between dynamic compaction locations and the MWMF cap. 
A second objective was to quantify the success of dynamic compaction in consolidating buried B-25 containers containing low-level waste. A full-scale model of an engineered lowlevel waste trench with 168 B-25s stacked 4-high, 7-long, and 6-wide, containing simulated waste was constructed adjacent to a 3-ft-thick kaolin clay cap similar to that of the MWMF. An 8-ft-dia., 42,000 lb. weight was dropped from a height of $42 \mathrm{ft}$ for either 20 drops or a 6-ft-displacement, which ever came first (Drop Zone A), or until displacement appeared to be negligible (Drop Zone B).

Following the dynamic compaction, B-25s were exhumed and the degree of compaction quantified. In general, the upper B-25s were more compacted than the bottom B-25s. The upper B-25s formed a fused layer by lateral spread and interlocking, which may inhibit further dynamic compaction effectiveness. Some B-25s were breached. Failed B-25s and simulated waste materials were overlying each other so tightly that, in some cases, the cranes extracting the containers tore metal rather than separating the containers. The outside edges of the B-25 matrix were not effectively consolidated.

Figure 3 shows the westerly edge of excavated B-25s (Area A compacted with traditional success criterion; Area B over- compacted). McMullin and Dendler (1994) indicates compaction in drop Area B was about 30 percent greater than drop Area A. Bottom B-25s in Drop Zone A particularly showed little compaction, while those in Zone B showed more consolidation. In particular, the bottom B-25 tier was not compacted in Area A. The overall results were that while some B-25s were significantly compressed, others were not.

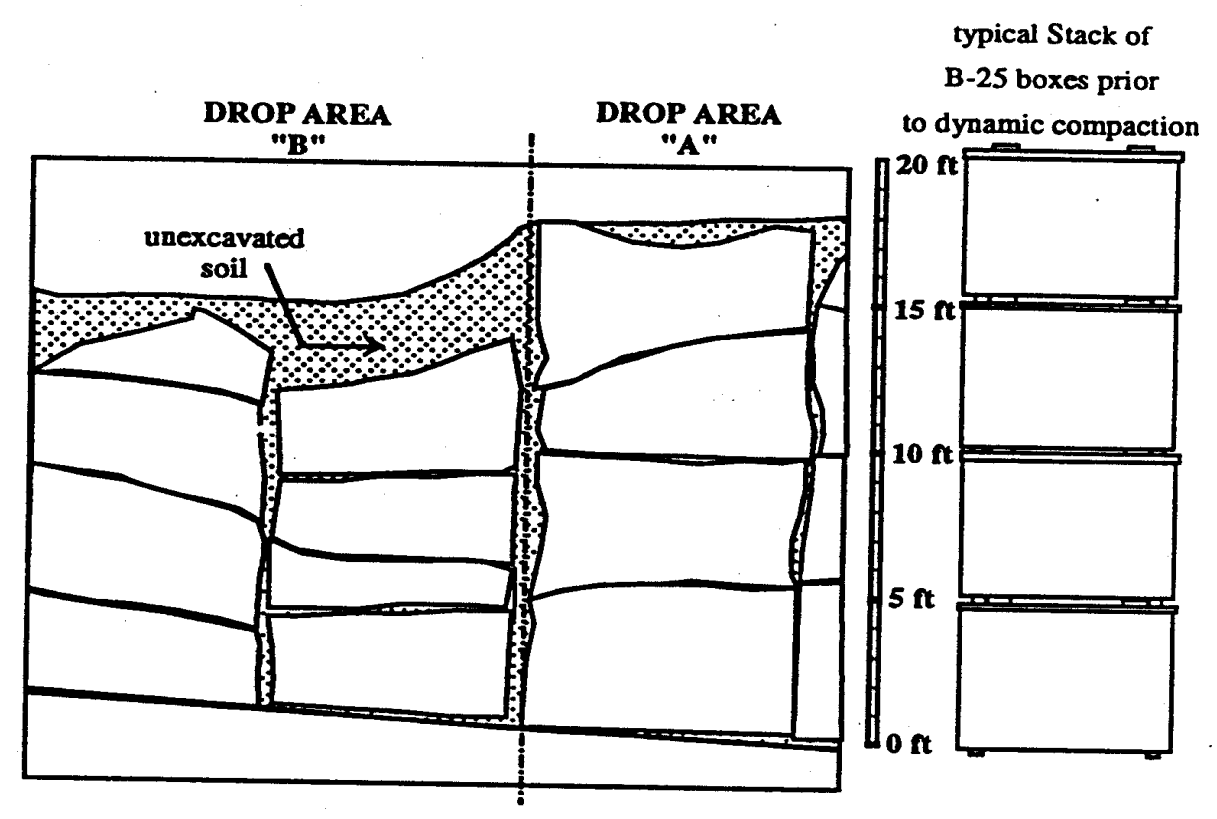

Figure 3. View of 1993 Dynamic Compaction Test Results (McMullin and Dendler, 1994) 
WSRC-TR-2001-00323

The SRS Project Management Department performed dynamic compaction of 58 acres of the Mixed Waste Management Facility in 1989. The 1.5-acre trench (containing stacked B-25 containers) had previously received a 25 -ft-thick static surcharge of soil over a one-year period. Dynamic compaction of this trench resulted in "...5 to 6 foot craters with an average of 12 drops and final displacements between drops of less than 1/2-foot." (Phifer, 1991).

Phifer and Serrato (2000) estimate SRS dynamic compaction costs at $\$ 100,000$ for mobilization/demobilization, and $\$ 200,000$ per acre. They go on to recommend evaluation of the following:

- Biodegradable waste minimization

- Use of low-density, high-strength, durable material to fill B-25 void space

- B-25 corrosion study

- Replacement of carbon steel with non-corroding material

- Placement of waste and soil in layers which are individually compacted

- Use of grout or lean fill to fill void spaces between containers

\subsection{SUBSIDENCE}

An early E-Area trench subsidence study is documented in Dames and Moore (1987). The study evaluated subsidence related to trench disposal (including Engineered Low-Level Trench Number 1) using B-25s in the Mixed Waste Management Facility, near the ET. At the time of the study, typical B-25 void space was estimated at 70 percent. Waste material was assumed to be rubber materials (30 percent), paper materials (30 percent), cloth articles (20 percent), plastic articles (18 percent), and tools ( 2 percent). Failure modes analyzed by plate-and-shell theory to estimate potential subsidence included:

- Elastic shortening or deformation of containers due to weight of soil cap and overlying containers with waste

- Buckling potential of the metal containers as construction of the soil cap commences

- Total collapse of the metal containers with complete closure of the void space and consolidation of the waste contents

- Effect of corrosion on the long-term subsidence

Subsidence due to linear elastic B-25 deformation or shortening was determined to be insignificant. Buckling analysis (not including increased resistance from neighboring B-25s, contents, B-25 lid and base, or inherent rigidity) indicated the B25s would begin to crush before the soil cap was completed. With $1 \mathrm{ft}$ to $10 \mathrm{ft}$ of soil loading, the bottom B-25 in a stack of 4 would begin to collapse, and the top B-25 would show signs of distress and begin to buckle. The uncertainty inherent in the buckling analysis was estimated as a factor of 2 to 5 , with results that agreed closely with an SRS load test (to failure) of a B-25. A summary of that load test, simulating loading that the lid of the uppermost B-25 would experience under uniform loading from the fill material, is presented in Table 3. 
Table 3. Load Test Results (Dames and Moore, 1987)

\begin{tabular}{|l|l|l|}
\hline Load (lbs) & Observations & $\begin{array}{l}\text { Equivalent Height } \\
\text { of Soil* (ft) }\end{array}$ \\
\hline 7,300 & Lid began to buckle, breach of containment & 3.3 \\
\hline 12,000 & Failure of corner & 5.5 \\
\hline 26,000 & $\begin{array}{l}\text { Continued wall buckling, lid pulled away from } \\
\text { container }\end{array}$ & 11.8 \\
\hline 34,000 & Risers and lower perimeter began to deform & 10.1 \\
\hline 41,000 & Continued deformation & 12.2 \\
\hline 46,000 & Total lower perimeter failure, containment breached & 13.7 \\
\hline
\end{tabular}

Based on estimated soil unit wt. 120 pounds per cubic ft.

Dames and Moore (1987) concludes that B-25 buckling would occur in a random manner over a long time period throughout the ELLT-1 trench, partly due to restraint provided by surrounding B-25s. Collapse would first occur under the soil cap crown, where stress is greatest. An estimated 25 to 33 percent of the total void space in the four stacked B-25s would be lost due to initial random failure [approximately 2.5 to $3.5 \mathrm{ft}$ ( 8.3 to $1.1 \mathrm{~m}$ ) of subsidence]. Over time, uneven corrosion effects would cause additional collapse, inducing additional random failures.

Maximum subsidence where B-25s were stacked 4-high in ELLT-1 was expected to be approximately $14.5 \mathrm{ft}(4.4 \mathrm{~m})$, or a reduction in total height of 83 percent. A 75 percent reduction in waste material thickness (50 percent of the waste was expected to decompose) was expected. The $14.5 \mathrm{ft}$ (4.4 m) of ultimate subsidence was expected to occur regardless of the amount of fill placed above the B-25s, since it represents closing of void space and waste compression. Overall, subsidence was expected to progress as an initial settlement during construction, followed by progressive, somewhat erratic settlement over a long time (Dames and Moore, 1987).

The actual height of soil anticipated to be placed over ET B-25s is in the order of 4 to 6 feet (1.2 to $1.8 \mathrm{~m})$. So, initial collapse might be expected to be less that this model suggests. However, the May 3, 2001, exhumation of a B-25 that had been buried in March 1993 showed that the lid had been forced into the B-25 by the overlying $8 \mathrm{ft}(2.4 \mathrm{~m})$ of soil. This indicates a possible initial collapse of about 1 to 2 feet

Yau (1986) describes the B-25 structural response to burial as occurring from two different loading patterns. The uppermost containers are subjected to distributed soil pressure on the lid plates. All underlying B-25s are subjected to compression of the wall plates because the bottom plate of each B-25 is stiffened by girders that transmit the soil pressure from the top to the wall plates rather than the lid plates of the B-25 layers underlying the uppermost B-25 layer. Table 4 summarizes B-25 deformation characteristics described in Yau (1986). 
Table 4. B-25 Deformation With Applied Weight (Yau, 1986)

\section{B-25 Lid Plate Deformation (uppermost B-25s directly overlain by soil)}

\begin{tabular}{|l|l|l|l|l|}
\hline PSI & \multicolumn{1}{|c|}{ Lbs } & \multicolumn{1}{|c|}{ Lbs/ft } & \multicolumn{1}{|c|}{$\begin{array}{c}\text { Equivalent Height } \\
\text { of Soil (ft)* }\end{array}$} & Occurrence \\
\hline 0.2 & 660 & 28 & 0.27 & inelastic lid deformation begins \\
\hline 1.3 & 4,500 & 190 & 1.8 & bent rim starts to unbend \\
\hline 3.6 & 12,000 & 505 & 4.8 & lid starts to slip \\
\hline 7.8 & 26,000 & 1,095 & 10.5 & lid starts to cave into container \\
\hline
\end{tabular}

Side Plate Deformation (B-25s underlying the uppermost B-25 layer)

\begin{tabular}{|l|l|l|l|l|}
\hline PSI & Lbs & Lbs/ft & $\begin{array}{l}\text { Equivalent Height } \\
\text { of Soil (ft)* }\end{array}$ & Occurrence \\
\hline 8.5 & 29,000 & 1,220 & 11.7 & buckling of sides begins \\
\hline 11.7 & 40,000 & 1,685 & 16.2 & complete B-25 collapse \\
\hline
\end{tabular}

*Assumes soil weight $90 \mathrm{lbs} / \mathrm{ft}^{3}$ dry density (104 lbs/ft ${ }^{3}$ wet density). Test results describe behavior of single B-25 stack, and does not include side plate support provided by adjacent stacked B-25s. Actual B-25s in trench would require greater loading to produce deformation due to side support provided by adjacent B-25s.

Performance of a kaolin cap as the result of subsidence was evaluated by Dr. Richard C. Warner in a 1988 field demonstration. The demonstration concluded that a 2 -ft compacted kaolin clay layer can span a 3 to 3.5-ft-wide cavity without subsiding. A 4-ft-wide cavity would eventually cause the layer to fail and subside. Warner's study also demonstrated that saturated soil conditions reduce the cavity-width that a kaolin layer can span (Phifer and Wilhite, 2001).

The SRS Environmental Restoration Department performed a clayey sand and Flexible Membrane Liner (FML) / Geosynthetic Clay Liner (GCL) cap subsidence field demonstration during 1992 and 1993. Table 5 provides a summary of the demonstration results along with a comparison to Warner's kaolin clay cap subsidence field demonstration. Other observations made during this demonstration include the following (Phifer and Wilhite, 2001):

- Failure began at the center of the cavity for both the clayey sand and FML/GCL caps.

- Significant surface loading (i.e. $7500 \mathrm{lbs} / \mathrm{ft}^{2}$ ) on the clayey sand and FML/GCL caps with underlying cavities could cause failure in a very short duration.

- Clayey sand and FML/GCL caps with underlying cavities and no surface loading could span the cavities for significant periods prior to failure (i.e. 3 months). 
WSRC-TR-2001-00323

Table 5. Closure Cap Subsidence Demonstration Summary Results (Phifer and Wilhite, 2001)

\begin{tabular}{|c|c|c|c|}
\hline Parameter & Kaolin Cap $^{\mathbf{1}}$ & Clayey Sand Cap $^{\mathbf{2}}$ & FML/GCL Cap $^{\mathbf{3}}$ \\
\hline $\begin{array}{c}\text { Span at Failure (ft), } \\
\text { Unsaturated } \\
\text { Conditions }\end{array}$ & 4 & 6 & 7 \\
\hline $\begin{array}{c}\text { Span at Failure (ft), } \\
\text { Saturated Conditions }\end{array}$ & 2.5 & 5 & 7 \\
\hline $\begin{array}{c}\text { Hydraulic } \\
\text { Conductivity (cm/s) }\end{array}$ & $1.2 \mathrm{E}-08$ & E- 06 & 10 \\
\hline $\begin{array}{c}\text { Underlying Cavity } \\
\text { Impact on Hydraulic } \\
\text { Conductivity }\end{array}$ & $\begin{array}{c}\text { Increased prior to } \\
\text { collapse }\end{array}$ & $\begin{array}{c}\text { Remained constant } \\
\text { until collapse }\end{array}$ & $\begin{array}{c}\text { Remained constant } \\
\text { with strain until } \\
\text { tensile failure } \\
\text { occurred (i.e. tearing) }\end{array}$ \\
\hline Mode of Failure & Catastrophically & Catastrophically & $\begin{array}{c}\text { Incremental } \\
\text { subsidence until } \\
\text { tensile failure }\end{array}$ \\
\hline
\end{tabular}

${ }^{1}$ 2-foot thick kaolin clay layer (>90\% passing \#200 sieve)

${ }^{2} 2$-foot thick clayey sand layer [SC material based on the Unified Soil Classification System (USCS)]

${ }^{3}$ A 40-mil thick, high density polyethylene (HDPE), flexible membrane liner (FML) over a geosynthetic clay liner (GCL) containing bentonite over a 2-foot thick clayey sand layer (USCS SC material) (Serrato, 1994)

An examination of long-term waste subsidence potential for the ET is documented in Phifer and Wilhite (2001). Their study evaluates subsidence associated with B-25 disposal with and without dynamic compaction after placement within the ET, and with and without super compaction of waste prior to placement within B-25s. Their recommendations are that the following options receive further consideration along with other options that may be more technically effective and cost efficient:

- Use of tertiary dynamic compaction

- Combined use of the Waste Sort Facility/Supercompaction Facility and tertiary dynamic compaction

Use of B-25 containers results in a large inherent subsidence potential which cannot be totally eliminated by any of the methods evaluated. Changing to a disposal container with less structural integrity or waiting until the B-25 containers have degraded before performing dynamic compaction might reduce the subsidence potential more than the cases evaluated. 
WSRC-TR-2001-00323

Phifer and Wilhite (2001) recommend that the use of B-25 containers for waste disposal in Engineered Trenches be reconsidered. B-25 container usage results in a large inherent subsidence potential, and is assumed to require an extended period requiring post-closure maintenance. Both of these conditions result in high long-term maintenance costs. If it is determined that B-25 containers will continue to be used, they recommend that an evaluation be conducted to optimize subsidence treatment, capping, and long-term maintenance strategies. Phifer and Wilhite (2001) recommend the SRS Solid Waste Division take an integrated approach that considers the implications of and interactions between disposal operations, subsidence treatments, closure methodology, and long-term maintenance requirements. Such an approach would produce an overall strategy which is both technically effective and cost efficient.

\subsubsection{Static Surcharge}

A monitoring program to investigate the effects of applying a static load, or surcharge, on stacked B-25s in an SRS trench is described in a letter report by Chas. T. Main, Inc. (Main, $1989 \mathrm{~b})$. The one-year program evaluated the potential of large overburdens [25 ft $(7.6 \mathrm{~m})$ soil thickness] to induce subsidence on stacked B-25s in Engineered Low Level Trench Number 1 (ELLT \#1). The report concludes that surcharging yields 2 to $3 \mathrm{ft}$ (0.6 to $0.9 \mathrm{~m})$ of settlement, and is not an acceptable method of waste densification for trenches containing stacked B-25s. These results appear consistent with observations in the preceding paragraph that indicate greater loading is required to produce deformation when B-25s are stacked sideby-side than a load placed on a single B-25 stack.

\subsubsection{Subsidence Potential and Subsidence-Potential Reduction}

Phifer and Wilhite (2001) present an evaluation of ET subsidence potential and subsidencepotential reduction. Their in-depth study uses the most recent and complete information regarding the ET B-25 configuration and subsidence-reduction measures that are presently being considered by Solid Waste. The basic B-25 configuration is presented in Figure 4.

The subsidence-reduction measures evaluated by Phifer and Wilhite (2001) assume the waste bulk density will eventually become $1.5 \mathrm{~g} / \mathrm{cm}^{3}$. This density is both a typical bulk density for soil and within the range of bulk density measured for exhumed buried waste at the SRS Sanitary Landfill. Another starting-point assumption is the base relative subsidence potential against which the subsidence treatment methods are evaluated: $15.1 \mathrm{ft}(4.6 \mathrm{~m})$ for a stack of four uncompacted B-25 containers prior to placement of the interim soil cover.

The first subsidence-reduction method is placement of the interim soil cover over the uncompacted B-25s. This likely results in pushing the uppermost B-25's lid into the container, resulting in elimination of about $1.5 \mathrm{ft}(0.46 \mathrm{~m} ; 9.9$ percent reduction) of subsidence potential. 


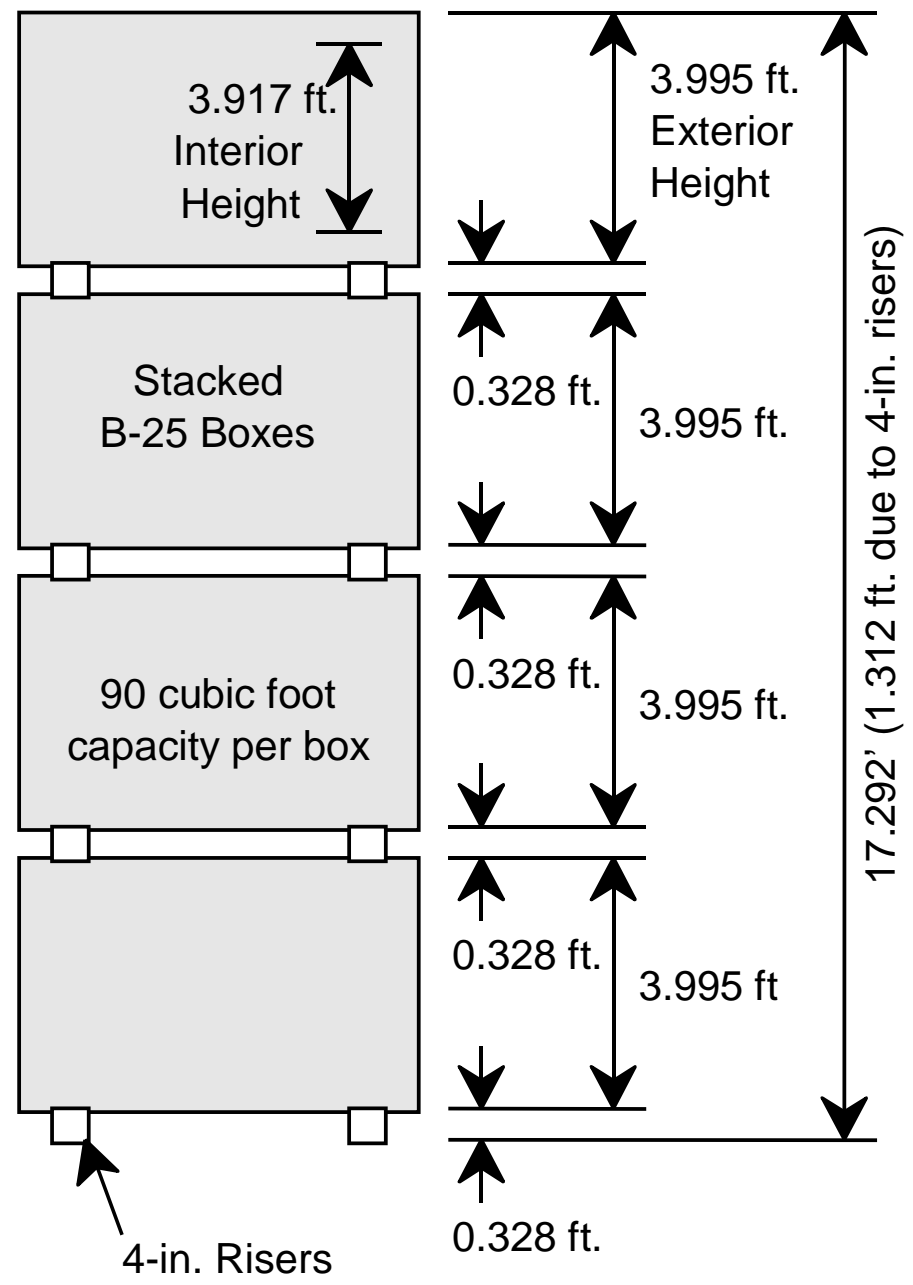

Not to Scale

Figure 4. B-25 Containers Stacked Four-High (Phifer and Wilhite, 2001)

Processing the waste through the WSF/SCF prior to disposal and placement of the interim soil cover likely results in a relative subsidence potential of $11.7 \mathrm{ft}(3.57 \mathrm{~m} ; 22.5$ percent reduction). The subsidence potential for standard dynamic compaction (treats about 50 percent of trench surface area) of B-25s containing waste that has not been processed through the WSF/SCF is $10.4 \mathrm{ft}$ ( $3.16 \mathrm{~m} ; 31.9$ percent reduction). The subsidence potential for tertiary dynamic compaction (treats 100 percent of trench surface area) of B-25s containing waste that has not been processed through the WSF/SCF is $7.2 \mathrm{ft}(2.18 \mathrm{~m} ; 52.5$ percent reduction).

Standard dynamic compaction of B-25s containing waste that has been processed through the WSF/SCF has a subsidence potential of $9.2 \mathrm{ft}$ ( $2.79 \mathrm{~m} ; 39.4$ percent reduction). Tertiary dynamic compaction of B-25s containing waste that has been processed through the $\mathrm{WSF} / \mathrm{SCF}$ has a subsidence potential of $6.6 \mathrm{ft}(2.01 \mathrm{~m} ; 56.3$ percent reduction). A summary of subsidence-reduction methods, subsidence potential, and percent subsidence potential reduction is presented in Table 6 . 
Table 6. Relative Subsidence Potential and Relative Subsidence Potential Reduction (Phifer and Wilhite, 2001)

\begin{tabular}{|c|c|c|}
\hline Subsidence Treatment Method & $\begin{array}{c}\text { Relative Subsidence } \\
\text { Potential (ft) }\end{array}$ & $\begin{array}{c}\text { Relative Subsidence } \\
\text { Potential Reduction (\%) }\end{array}$ \\
\hline Base Subsidence Potential $^{1}$ & 15.1 & 0.0 \\
\hline ISC & 13.6 & 9.9 \\
\hline ISC and WSF/SCF & 11.7 & 22.6 \\
\hline ISC and SDC & 10.4 & 31.2 \\
\hline ISC and TDC & 7.2 & 52.4 \\
\hline ISC, WSF/SCF, and SDC & 9.2 & 39.5 \\
\hline ISC, WSF/SCF, and TDC & 6.6 & 56.3 \\
\hline
\end{tabular}

${ }^{1}$ Subsidence Potential of a stack of four uncompacted B-25 boxes prior to the placement of the interim soil cover

ISC = Interim Soil Cover; WSF/SCF = Waste Sort Facility / Super Compactor Facility; $\mathrm{SDC}=$ Standard Dynamic Compaction; TDC $=$ Tertiary Dynamic Compaction

\subsubsection{Corrosion}

McMullin and Dendler (1994) point out that the B-25 design purpose is to contain low-level waste at the generation point, to protect workers, and to facilitate transportation to the burial site. B-25s were not intended to provide waste containment within a burial location. They do, by default, help minimize waste migration. The B-25 containers used in the dynamic compaction testing revealed that dynamic compaction accelerated the B-25 corrosion rate by bending and tearing the metal and by breaking the protective paint bonds. As part of an earlier corrosion study, 3 B-25 containers were buried uncompacted at a location near the dynamic compaction test location. When those B-25s were exhumed after four years, they showed no observable corrosion. After being in the ground for 6 months, the dynamically compacted B-25s demonstrated accelerated corrosion and degradation (McMullin and Dendler, 1994).

A detailed corrosion evaluation based upon an exhumed E-Area B-25 is in preparation. The B-25 was exhumed on May 3, 2001, from a depth of about 8 to $12 \mathrm{ft}$ bls. Soil samples were obtained for corrosion related laboratory analyses. The corrosion evaluation is being led by Kerry Dunn, Savannah River Technology Center (SRTC). Conclusions from the corrosion evaluation, including a paradigm for corrosion rates and B-25 stability through time, will be used in the future for predicting subsidence rates. A description of the excavation and photographs of the B-25 prior to burial and during exhumation are included in Appendix C. 
WSRC-TR-2001-00323

The B-25 exhumed for corrosion evaluation was one of those used for the dynamic compaction test. The B-25 was somewhat flexed in some areas when buried, but in overall structurally sound shape. Photographs of the B-25 prior to burial are included in Appendix C. The exhumed B-25 showed a fairly consistent covering of blistered outer paint layer underlain by either primer or pitted steel (Appendix C). This suggests that corrosion becomes apparent on painted, relatively undamaged portions somewhere between 4 and 8 years after burial for uncompacted B-25s. The dynamic compaction test results indicate that if corrosion minimization is important, dynamic compaction should not be used.

Corrosion was evaluated in the Dames and Moore (1987) study based on literature values for $\mathrm{pH}$ and resistivity. SRS soils were assumed to be moderately to strongly acid, with $\mathrm{pH}$ values ranging from 4.5 to 5.5. These values are consistent with those measured by soil $\mathrm{pH}$ probe (5.4 to 5.7) and $\mathrm{pH}$ indicator paper (5 to 6 range) during the May 3, 2001, B-25 exhumation. Electrical resistivity values ranging from $3.0 \times 10^{3} \mathrm{ohm}-\mathrm{cm}$ to $3.5 \times 10^{4} \mathrm{ohm}-$ $\mathrm{cm}$ were cited for F- and H-Area soils by Dames and Moore (1987), with a value of $1.0 \times 10^{4}$ ohm-cm taken to be representative.

Resistivity values ranging $5.8 \times 10^{6} \mathrm{ohm}-\mathrm{cm}$ (as received) to $3.0 \times 10^{4} \mathrm{ohm}-\mathrm{cm}$ (resistivity minimum), depending on soil moisture, are reported for the soil sample obtained during the May 2001 B-25 exhumation (see Section 3.2.2). Based on these measurements, a value of $1 \times 10^{4} \mathrm{ohm}-\mathrm{cm}$ is believed to represent typical field moisture conditions, substantiating the Dames and Moore (1987) assumption. Overall, Dames and Moore (1987) considered the soil moderately to mildly corrosive. Assuming a pH of 4.5 and soil resistivity of $1.0 \times 10^{4} \mathrm{ohm}$ $\mathrm{cm}$, Dames and Moore (1987) estimated 30 years would be required to perforate 14-gauge carbon steel.

Maximum subsidence where B-25s were stacked 4-high in ELLT-1 was expected to be approximately $14.5 \mathrm{ft}(4.42 \mathrm{~m})$, or a reduction in total height of 83 percent. A 75 percent reduction in waste material thickness (50 percent of the waste was expected to decompose) was expected. The $14.5 \mathrm{ft}$ (4.42 m) of ultimate subsidence was expected to occur regardless of the amount of fill placed above the B-25s, since it represents closing of void space and waste compression. Overall, subsidence was expected to progress as an initial settlement during construction, followed by progressive, somewhat erratic settlement over a long time (Dames and Moore, 1987).

\subsection{CONTAINER CHARAC TERISTICS AND CONFIGURATION}

As described in Phifer and Wilhite (2001), data from the SRS Waste Information Tracking System (WITS) on about 6,900 waste containers meeting Waste Acceptance Criteria (WAC) for the Engineered Trench are presented in Table 7. The containers are those located in the Low Activity Waste Vault (LAWV) and temporary storage areas associated with the LAWV (i.e., TRAN1, TRAN2, TRAN5, TRAN6, and TRAN7) and containers located in the Engineered Trench and associated temporary storage areas (i.e., ET-TSA). The information presented, for each type of container, includes the container description, the number of containers, and the average density for that container type. Statistics (i.e., average, standard deviation, minimum, maximum, and median) on the density of containers are also presented. 
WSRC-TR-2001-00323

\section{Table 7. Waste Containers meeting Engineered Trench Waste Acceptance Criteria (Phifer and Wilhite, 2001)}

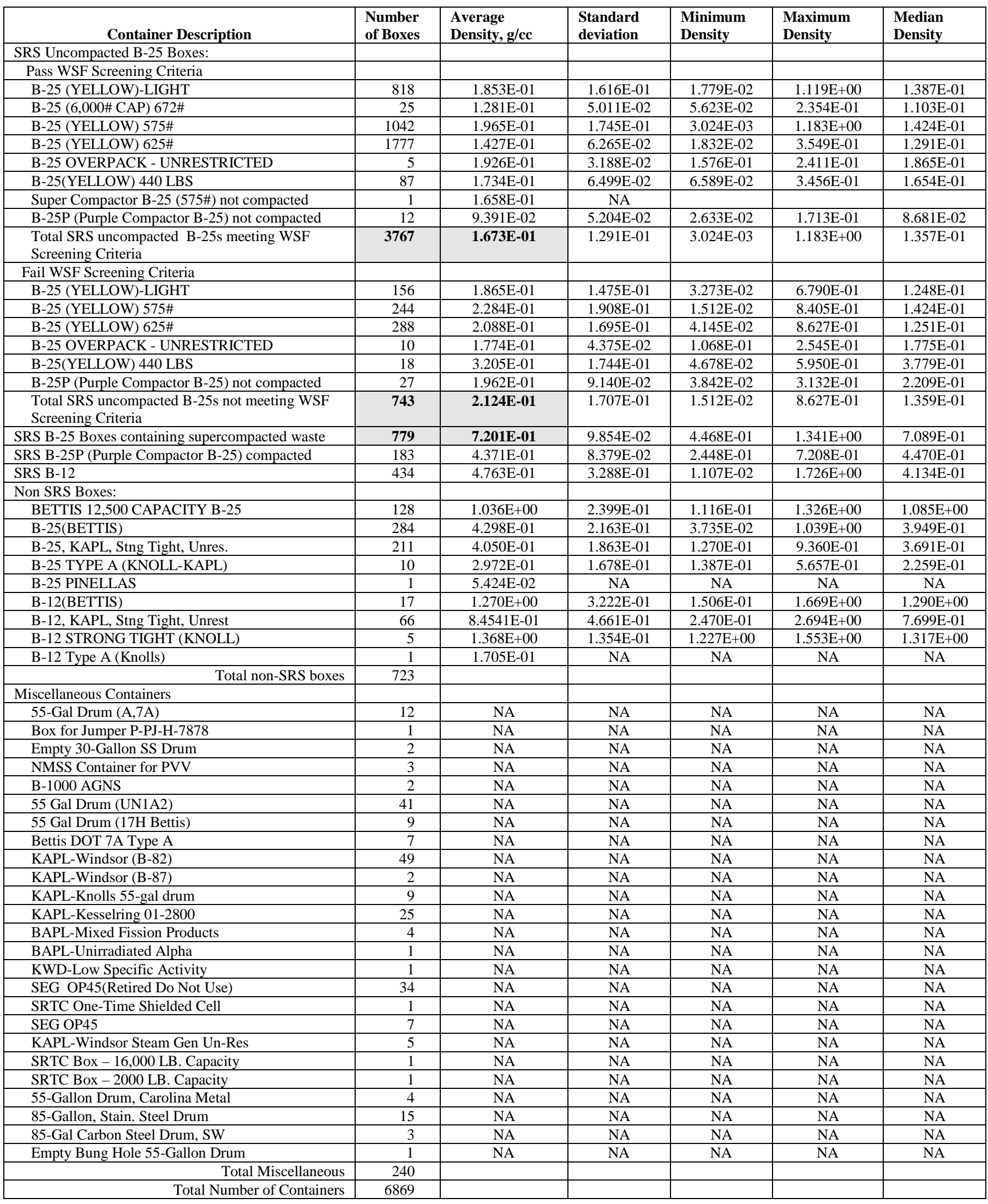


WSRC-TR-2001-00323

The data are subdivided into several categories, SRS containers, non-SRS containers, and miscellaneous containers. The SRS containers are further subdivided into the following categories:

- B-25 containers containing non-compacted waste that pass the Waste Sort Facility (WSF) screening criteria

- B-25 containers containing non-compacted waste that fail the WSF screening criteria

- B-25 containers containing supercompacted waste

- B-25 containers containing compacted waste from the 253-H compactor (purple containers)

- B-12 containers

The non-SRS containers are subdivided into two categories: B-25 containers and B-12 containers.

To facilitate projection of waste subsidence and consequent trench cap disruption, only the SRS B-25 containers containing non-compacted and supercompacted waste were considered by Phifer and Wilhite (2001). These containers represented $77 \%$ of the total number of containers. The B-25 containers containing compacted waste from the $253-\mathrm{H}$ compactor were not included because that compactor is no longer operational.

The inside dimensions of B-25 containers are 1.83 meters long, 1.17 meters wide and 1.19 meters high ( 6 feet long, 3.83 feet wide, and 3.917 feet high). The outside dimensions are 1.85 meters long, 1.19 meters wide and 1.32 meters high (6.078 feet long, 3.911 feet wide, and 4.323 feet high). The interior volume of a B-25 is $2.55 \mathrm{~m}^{3}\left(90 \mathrm{ft}^{3}\right)$ (Phifer and Wilhite, 2001).

Waste received for potential supercompaction was considered by Phifer and Wilhite (2001) to be processed in one of the following two ways:

- Waste received from the generators in B-25 Containers is processed through the WSF, if it passes the WSF screening criteria, and it is supercompacted in the Super Compactor Facility (SCF), if it passes the SCF compaction criteria.

- Pre-sorted compactable waste is also received at the SCF from the generators in 55-gallon drums. This waste is ready for supercompaction and does not require processing through the WSF.

Approximately $30 \%$ of the B-25 containers received, on the average, do not pass the WSF screening criteria. Of the B-25 containers sent to the WSF/SCF, about $15 \%$ are rejected because the contents were unacceptable for supercompaction. Therefore, Phifer and Wilhite (2001) assume that $60 \%$ of the SRS B-25 containers received by SWD can be supercompacted. 
WSRC-TR-2001-00323

These B-25 containers which can be supercompacted, are supercompacted by removing the waste from the B-25 containers and placing it in 55-gallon drums. The drums are then supercompacted. The supercompacted drums are then loaded into a B-25 container prior to emplacement in the Engineered Trench.

The 779 supercompacted SRS B-25 containers listed in Table 7 contained 6,095 compacted 55-gallon drums of waste that were received directly from the generators at the SCF ready for compaction and therefore were not processed through the WSF. Phifer and Wilhite (2001) assume that the split between compacted 55-gallon drums of waste both processed through the WSF and received directly from the generators at SCF is accurately represented by the fraction of each type of drum in the supercompacted SRS B-25 containers. On the average, 40 supercompacted drums are contained in a B-25 container. The median number of drums is 39 , the maximum is 68 , the minimum is 24 , and the standard deviation is 7.5 drums. Empty 55-gallon drums weigh $36 \pm 7.2$ pounds (1.633E04 $\pm 3.266 \mathrm{E} 03$ grams).

From Table 7, the average density of uncompacted B-25 containers that pass the WSF screening criteria is 0.1673 grams per cubic centimeter $\left(\mathrm{g} / \mathrm{cm}^{3}\right)$. The average density of uncompacted B-25 containers that do not pass the WSF screening criteria is $0.2124 \mathrm{~g} / \mathrm{cm}^{3}$ (see Table 7). The average density of B-25 containers containing supercompacted waste is $0.7201 \mathrm{~g} / \mathrm{cm}^{3}$ (Table 7). The average weight of B-25 containers, including the container itself, that pass the WSF screening criteria but fail the SCF compaction criteria is $748,430 \mathrm{~g}$.

Based upon the above data, Phifer and Wilhite (2001) have determined the following:

- Using the SCF facility, both uncompacted and supercompacted B-25s would be disposed in the Engineered Trench. Figure 5 provides the WSF/SCF B-25 process flow diagram based upon the receipt of 100 B-25 boxes by SWD. As shown in Figure 5, every 100 B-25 boxes received by SWD that meet the WAC for the Engineered Trench result in the following for disposal in the Engineered Trench:

- Approximately 40 uncompacted B-25 boxes with an average waste density of $0.2067 \mathrm{~g} / \mathrm{cm}^{3}$ would be produced.

- Approximately 21 supercompacted B-25 boxes with an average waste density of $0.7201 \mathrm{~g} / \mathrm{cm}^{3}$ would be produced due to processing through the WSF.

- Approximately 5 supercompacted B-25 boxes with an average waste density of $0.7201 \mathrm{~g} / \mathrm{cm}^{3}$ would be produced due to pre-sorted compactable waste received from the generators in 55-gallon drums.

- A total of approximately 66 B-25 boxes with an average waste density of $0.4088 \mathrm{~g} / \mathrm{cm}^{3}$, of which approximately $39 \%$ are supercompacted and $61 \%$ are uncompacted, would be disposed in the Engineered Trench. 
WSRC-TR-2001-00323

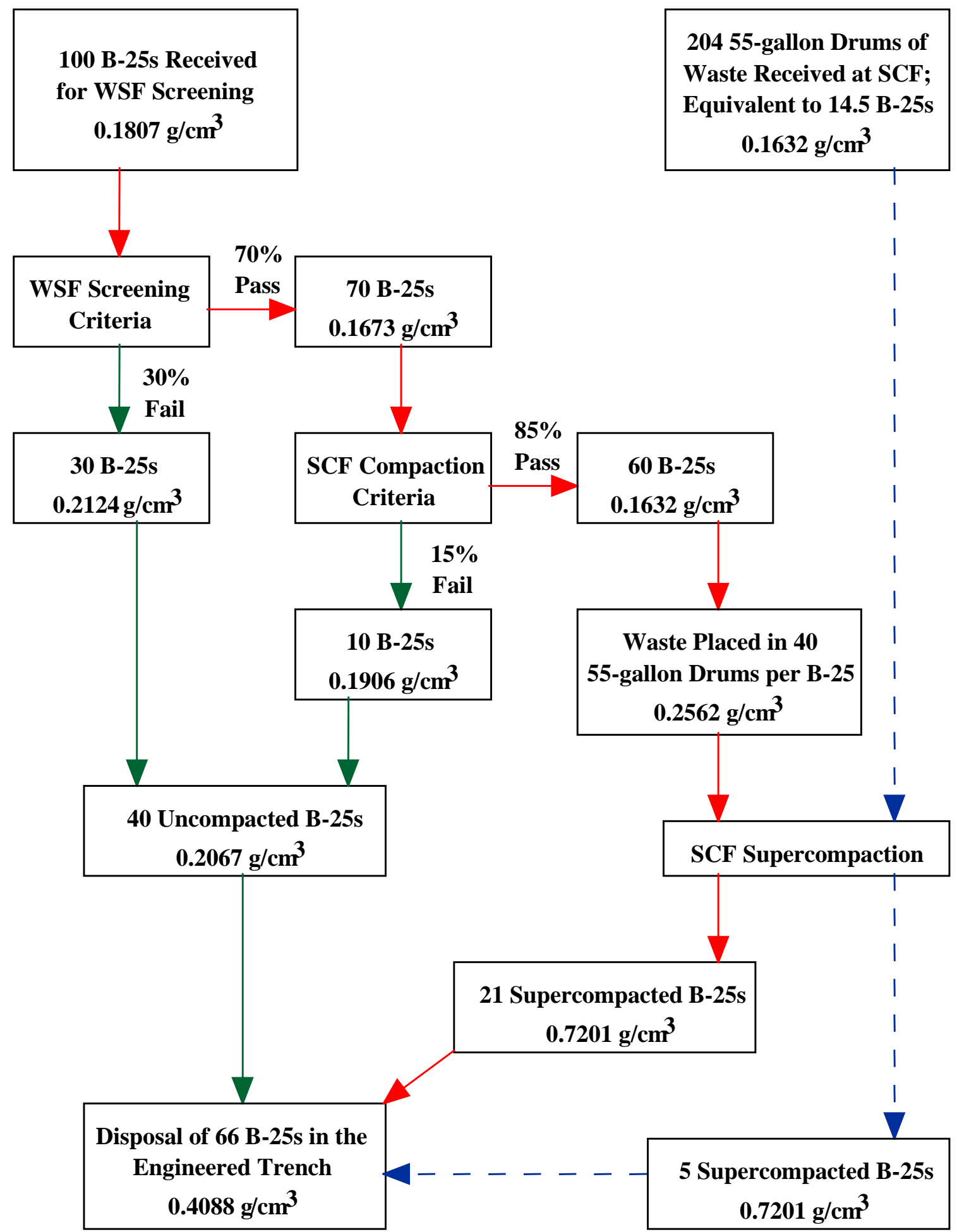

Figure 5. Waste Sort Facility/Super Compactor Facility B-25 Process Flow Diagram (Phifer and Wilhite, 2001) 
- If the B-25 containers meeting the Waste Acceptance Criteria (WAC) were not processed through the WSF/SCF prior to disposal in the Engineered Trench, and if the waste received directly from the generators in 55-gallon drums was instead received in B-25 containers, the average density of the waste within the uncompacted B-25s would be $0.1785 \mathrm{~g} / \mathrm{cm}^{3}$.

- The average B-25 container in an Engineered Trench containing B-25s which have been processed through the WSF/SCF is equivalent to 1.72 average B-25 boxes in an Engineered Trench containing only uncompacted B-25s on a mass equivalent basis. Processing through the WSF/SCF results in disposal of a mixture of supercompacted and uncompacted B-25 boxes.

The majority of waste containers to be placed in the ET will be 90 cubic ft B-25 containers. B-25s are made of hot-rolled, 12-gauge carbon steel (ASTM-A569-93). Some older documents refer to 14-gauge low-carbon steel construction (Dames and Moore, 1987; Yau, 1986). Both interior and exterior are painted. Both an older (1986) B-25 procurement specification referring to 14-gauge steel and a more recent (2000) B-25 procurement specification referring to 12-gauge steel are included in Appendix D.

According to Yau (1986), mechanical properties like tensile and yield strength are not published by steel producers, because the steel in thin sheet form is not suitable for consideration of structural resistances. Yau (1986) cites personal communication with Bethlehem Steel, Inc., indicating minimum yield strength of $Y=35 \mathrm{ksi}$, and tensile strength of $U=43 \mathrm{ksi}$. Because of its high ductility with a maximum strain of 35 percent, the sheet metal is generally used for deformable containers. The side plates are stiffened by V-shaped crimps, and the bottom plate is stiffened by three channel risers (also called girders). Only the lid plate is not stiffened. The lid plate has a turned-down rim, which folds over the side like a shoe container cover. When the container is ready for burial, up to 12 angled steel pegs approximately 3 in. wide are driven into the buckles on the side walls to secure the lid.

\subsection{SOFT-SIDED CONTAINERS}

Another containerization method under consideration for ET application is soft-sided disposable containers. Two vendors have demonstrated this technology at SRS. For information purposes, the available vendor's product is described here.

The Transport Plastics, Inc., Lift-Liner ${ }^{\mathrm{TM}}$ soft-sided waste packaging system includes a 25-ml. woven outer polypropylene fabric shell with a 2-ml. Water-resistant coating and a 45-ml. double layer polypropylene inner liner. The outer shell is equipped with 18 lifting straps made of 2 in. polyester seat belt webbing material. The containers meet the U.S. Department of Transportation (DOT) requirements for transport of low specific activity and surface contaminated objects. 
WSRC-TR-2001-00323

The system includes a loading frame used to support the shell and inner liner during loading and a lifting/spreader bar. The lifting/spreader bar attaches to the lifting straps for hoisting the container from the loading frame onto a transport vehicle. A small forklift can move the empty loading frame and lifting/spreader bar. The empty bags are light and compact enough to move by hand. Each container has a capacity of 260 cubic $\mathrm{ft}$ and holds up to 24,000 lbs. This is almost three times the weight and capacity of a B-25. There is a one-time cost of about $\$ 7,000$ for the loading frame and lifting/spreader bar. The soft-sided containers cost about $\$ 380$ per bag. This results in a savings of about $\$ 1,800$ in container cost for each bag filled versus filling three B-25s. Smaller size bags equivalent in size to a B-25 are also being developed and tested.

Soft-sided containers are currently being evaluated at SRTC by B.T. Butcher and co-workers, as replacements for some B-25s at SRS. One obvious advantage over B-25s is the very significant reduction in void space, with concomitant reduction in subsidence and increase in long-term stability. Soft-sided containers might be placed similarly to sanitary waste, with a layer of soil between layers of containers. Even with layers of soil, compaction could result in a total waste/compacted soil thickness only half the height of the current 4-high B-25 height.

One disposal method (conceived by Mark Phifer) that could be considered for finite element modeling is placement of soft-sided containers in a "pillow" configuration. The "pillow" could be covered by a bentonite or high-density polyethylene (HDPE) "cap," and possibly underlain by a bentonite or HDPE seal and/or a gravel capillary break. The "pillow" could also be overlain by 10 to $12 \mathrm{ft}$ of native soil (providing static surcharge, compaction, and isolation from intruders). The native soil could be covered at the surface by climax vegetation. Such a configuration could provide truly long-term stability with minimal subsidence and maintenance.

\subsection{WASTE CHARACTER ISTICS}

The ET will contain low-level radioactive waste (LLW). LLW is radioactive waste that is not classified as high-level waste, transuranic waste, spent fuel, or by-product material as defined in DOE Order 435.1, and does not contain Resource Conservation and Recovery Act-regulated hazardous waste (WSRC, 2000d). It consists of radioactively-contaminated materials such as miscellaneous job control waste, small equipment, plastic sheeting, gloves, wood, debris, and soil.

SRS operations classify LLW as long-lived, intermediate-level waste, and low-activity waste. Long-lived waste has higher quantities of long-lived isotopes (such as carbon-14).

Intermediate-level waste consists of waste material that radiates greater than 200 millirem per hour from an unshielded engineered metal container at $5 \mathrm{~cm}$. Intermediate-level waste is further differentiated by the presence of tritium. Low-activity waste consists of waste material that radiates less than 200 millirem per hour from an unshielded, engineered metal container at $5 \mathrm{~cm}$. The LLW Program does not currently accept liquid waste, wastes containing transuranic radionuclides greater than $100 \mathrm{nCi} / \mathrm{g}$, or mixed waste for storage and disposal. The primary isotopes of concern are tritium, iodine-129, cesium-137, strontium-90, plutonium-238, and plutonium-239 (WSRC, 2000d). 
SRS has 13 LLW streams (treatability groups) in a wide range of physical forms. At present, the LLW facilities (including nine onsite storage facilities, vault disposal units, and trenches, including the ET) are forecast to receive about 6,000 cubic meters of LLW for disposition per year. This amount is predicted to gradually decrease in the future. Currently, compactable LLW is segregated from non-compactable LLW in the WSF, and is processed in the SCF before disposal in order to maximize disposal space. The remainder is being stored pending processing in the on-site segregation/supercompaction facilities. LLW system operations include shallow land disposal for suitable waste forms (soil, debris, wood, components in grout, boxed LLW); storage of naval reactor components and contaminated large equipment pending disposal; continued disposal of LLW in the Low-Activity Waste Vaults; and continued disposal of intermediate-level waste in the Intermediate Level Non-Tritiated Vault and the Intermediate Level Tritiated Vault. The following treatability groups may be placed in the ET (WSRC, 2000d).

\section{SRS-LLW-1, No Treatment Low- Level Bulk Waste}

\author{
SRS-LLW-2, \\ Low-Level Waste Direct \\ to Compactor
}

\author{
SRS-LLW-3, \\ Low Activity Bulk Waste
}

SRS-LLW-4, Bulk Metal to Direct Disposal
This treatability group consists of boxed Low-Level Bulk Waste received from Naval Reactor facilities and onsite generators. This waste requires no treatment and is packaged for direct disposal. As much as 60 percent of this waste will qualify for disposal in the ET, with the remainder disposed in the E-Area Vaults.

This treatability group includes three separate known waste streams: Low-Level Alpha Waste, compactable waste packaged in drums by generators for compaction, and, for planning purposes, a portion of the projected waste from the Tritium Extraction Facility (FY06). It is estimated that 60 percent of this treatability group will be disposed in the ET, with the remainder disposed in the E-Area Vaults.

This treatability group consists of legacy waste stored in B-25s and newly generated Low Activity Waste. The waste is primarily paper, plastic, rubber, and cloth job control waste. Some wood and small amounts of metal may also be present. About 90 percent of the legacy waste will be compactable. Newly generated waste will be packaged directly for compaction/direct disposal. Once treated (compacted), about 60 percent of the waste will be disposed in the ET, with the remainder disposed in the E-Area Vaults.

This stream consists of facility 232-F equipment (legacy), and future job control, scrap, and components. A small quantity of LLW from the mixed LLW program (but not mixed LLW) will be disposed. Most of this material is not considered a candidate for decontamination and will be segregated by the generator for direct disposal. The preferred disposal option for most of this waste is direct disposal in the ET. The 232-F equipment has a preferred disposal option of the DOE-Nevada Test Site, due to high tritium levels. 
SRS-LLW-5, Incinerable Low Activity Liquid Waste

SRS-LLW-6, Bulk Metal to Survey/ Decontamination

\section{SRS-LLW-7, Contaminated Large Equipment to Survey/Decontamination}

SRS-LLW-9, Contaminated Large Equipment to Size Reduction
This waste is primarily oil, oil and water, or water, with some chemical waste. Some of the liquids have high tritium levels that make them unsuitable for onsite or commercial treatment. Options for treatment include commercial treatment through combustion, stabilization, or detritiation (technology still in development). The Toxic Substances Control Act Incinerator at Oak Ridge Reservation (not currently available) may become available. The preferred treatment option, the SRS Consolidated Incineration Facility, is not currently available. The preferred disposal option after treatment for the majority of this group is the ET, with the remainder disposed in the E-Area Vaults.

This stream will consist of newly generated scrap and components which have been segregated at the generator for survey and decontamination. Following survey and/or decontamination, about 75 percent of this stream will be disposed through free release/sanitary landfill. The portion not suitable for free-release/sanitary landfill disposal may be disposed in an E-Area slit-trench if it cannot be containerized, or in the ET if it can be containerized.

This stream consists of material or components that are too large for disposal in a standard container. These types of material include pumps, jumpers, scaffolding, trailers, process equipment, etc., presently in storage and expected to be generated by future Environmental Restoration Department (ERD) and Decontamination and Decommissioning (D\&D) activities. The preferred option is decontamination and free release. A second option is disposition by vendor. The least preferred option is trench disposal within a grout/stabilizing matrix (called components-in-grout), probably in a slit-trench or, possibly, in the ET, which would require approval for expanded trench use and possible regulatory exemptions.

For this stream, large equipment is material or components, such as reactor process water heat exchangers, that are too large to fit in a standard waste container. The heat exchangers make up the majority of the volume. The majority of this stream will require extensive decontamination prior to treatment/disposal. Disposition is anticipated to be 50 percent to beneficial re-use, and 50 percent to an E-Area trench. Components with higher contamination levels will be disposed in a grout/stabilizing matrix, most likely within a slit-trench or, possibly, the ET. 
SRS-TRU-1, TRU Waste Less Than 100nCi/g Alpha Contaminated (NonMixed) Drums
This waste group is alpha contaminated low-level waste currently classified and being managed as transuranic (TRU) waste. The waste is packaged in Type $7 \mathrm{~A}$ or $17 \mathrm{C}$ drums with 90-mil polyethylene liners, for which the inventory records report 0 grams of $\mathrm{Pu}-238$. The drums contain low-density job control waste: hydrogenous materials (plastics, wipes, etc.), metal tools, inner containers, polyvinyl chloride bags, tape, gloves, shoecovers, celite, swipes, paper, glass, hut plastic, motors, metal, scales, valves, adsorbed liquids, etc. Solid Waste's preferred treatment option is supercompaction at SRS, with disposal in E-Area trenches, possibly including the ET (WSRC, 2000d).

\subsection{SEISMIC CHARACTER ISTICS}

The largest known earthquake to affect the site region was the Charleston earthquake of 1886. This Modified Mercalli Index (MMI) X earthquake struck Charleston, South Carolina, on August 31, 1886. The greatest intensity felt at SRS has been estimated at MMI VI-VII (felt by all; everyone runs outdoors; damage negligible in buildings of good structure, but considerable in poorly built structures) as a result of the Charleston earthquake. Minor tremors from aftershocks of the 1886 Charleston event were also felt in the area where SRS is now located. Intensities of these tremors were estimated to be equal to or less than MMI IV (WSRC, 2000a).

Seismic-activity producing earthquakes of estimated MMI up to V to VII have occurred in the Bowman, South Carolina, area (about $95 \mathrm{~km}$ northeast of SRS) over the last 200 years. These earthquakes produced acceleration at SRS of less than 0.1 times the earth's gravitational acceleration. An earthquake (MMI VIII) that struck Union County, South Carolina, about $160 \mathrm{~km}$ north-northeast of SRS, in 1913 was felt at Aiken (6 km northnorthwest of SRS) with an MMI of II to III (vibration indoors like a passing truck).

SRS has been operating a continuous recording seismic network onsite since the mid-1970s. The network was developed to monitor SRS and regional seismic activity that may potentially impact the safety of existing or planned structures and systems. Three earthquakes of MMI III or less have occurred with epicentral locations within the boundaries of SRS.

- An MMI III earthquake occurred on June 9, 1985, with local duration magnitude of 2.6. The mean annual probability of an intensity III event at SRS is about $10^{-1}$, according to Stephenson et al. (1985).

- An MMI I-II earthquake occurred on August 5, 1988, with local duration magnitude of 2.0. On May 17, 1997, an earthquake with duration magnitude of about 2.3 occurred near GunSite 51 ( about $16 \mathrm{~km}$ south of A Area).

- On October 8, 2001, an earthquake of estimated duration magnitude 2.5 occurred about 2.5 miles northeast of F Area, according to Donald Stevenson, with ERD's Site Geotechnical Services group (personal communication, Donald Stevenson to Mike Lewis, October 8, 2001). 
WSRC-TR-2001-00323

None of the earthquakes triggered the seismic alarms at SRS facilities, which are triggered when ground acceleration equals or exceeds 0.002 times the earth's gravitational acceleration. The epicenters of these earthquakes appear to be located within about $10 \mathrm{~km}$. of the intersection of a northwest-trending fault and the northeast-trending border fault at the northern edge of the Dunbarton Triassic basin. The epicenters are relatively shallow (1 to $3 \mathrm{~km}$ below ground surface) (WSRC, 2000a; WSRC, 2000b).

The recurrence interval for a Charleston-sized shock (MMI X) for the Charleston area and for the Coastal Plain is on the order of 1,000 years, at the 95 percent confidence level. A recurrence of the 1886 Charleston earthquake would result in an intensity of MMI VII at SRS. Recurrence of earthquakes associated with other known seismic zones in the region are not expected to be of greater intensity nor cause greater shaking at SRS (WSRC, 2000a).

A geotechnical seismic assessment was performed in 1995 for the Defense Waste Processing Facility (DWPF) in S-Area, located less than $1 \mathrm{~km}$ north of the ET (WSRC, 1995). The assessment concludes that neither geologic nor geotechnical hazards exist based on the design basis earthquake that would adversely affect the DWPF. Static and dynamic structure settlements were within tolerable limits, and liquefaction susceptibility was negligible for the seismic events analyzed. Although this study was not performed at the ET itself, the area is close enough to indicate the soils within and above which the ET will be emplaced are relatively sound, and not predisposed to weaken significantly due to seismic activity.

Another liquefaction probability assessment was performed for $\mathrm{H}$ Area, located across Road 4 from E Area (WSRC, 2000c). This assessment particularly evaluates Tobacco Road Formation soil strength properties using cone penetrometer data. The bottom of the ET will likely be at, or just above, the contact between the Tobacco Road Formation and the overlying Upland Formation. The H-Area liquefaction study concludes that the H-Area Tobacco Road Formation met liquefaction-potential requirements. This indicates the Tobacco Road Formation at the nearby ET should not be predisposed to liquefaction due to seismic activity.

In summary, the recurrence interval for a Charleston-sized shock (MMI X) for the Charleston area and for the Coastal Plain is on the order of 1,000 years. A recurrence of the 1886 Charleston earthquake would result in an intensity of MMI VII at SRS. The soils surrounding the ET are not predisposed to liquefaction. Although unobserved to date, given B-25 structural degradation through time, the behavior of disposed materials within the ET may include consolidation and subsidence associated with future seismic events. 


\subsection{CLIMATE CHARACTE RISTICS}

The southeastern United States has a humid, subtropical climate characterized by relatively short, mild winters and long, warm, and humid summers. Summer-like weather typically lasts from May through September, when the area is subject to the persistent presence of the Atlantic subtropical anticyclone (i.e., the "Bermuda" high). The humid conditions often result in scattered afternoon thunderstorms. Average seasonal rainfall is usually lowest during the fall (Cook et al., 2000).

The weather is changeable during the winter as mid-latitude low-pressure systems and fronts migrate through the region. Measurable snowfall is rare. Spring is characterized by a higher frequency of tornadoes and severe thunderstorms than the other seasons. During spring, temperatures are mild and the humidity is relatively low (Cook et al., 2000).

The average annual temperature at SRS is $64.7^{\circ} \mathrm{F}$. July is the warmest month of the year, with an average daily maximum of $92^{\circ} \mathrm{F}$ and an average daily minimum near $72^{\circ} \mathrm{F}$. January is the coldest month, with an average daily high around $56^{\circ} \mathrm{F}$ and an average daily low of $36^{\circ} \mathrm{F}$. Temperature extremes recorded at SRS since 1961 are $107^{\circ} \mathrm{F}$ in July 1986 and $-3{ }^{\circ} \mathrm{F}$ in January 1985 (Cook et al., 2000).

Annual precipitation averages $49.5 \mathrm{in}$. Summer is the wettest season of the year with an average monthly rainfall of $5.2 \mathrm{in}$. Fall is the driest season with an average monthly rainfall of 3.3 in. Relative humidity averages 70 percent annually with an average daily maximum of 91 percent and an average daily minimum of 45 percent (Cook et al., 2000).

Winds are most frequently from the northeast and southwest sectors. Measurements of turbulence are used to determine whether the atmosphere has relatively high, moderate, or low potential to disperse airborne pollutants (commonly identified as unstable, neutral, or stable atmospheric conditions, respectively). Generally, SRS atmospheric conditions were categorized as unstable 56 percent of the time (Cook, et al., 2000).

U.S. Environmental Protection Agency (EPA) and National Aeronautic and Space Administration (NASA) studies indicate human activities have changed the atmosphere's chemical composition (EPA, 1997; EPA, 1998; NASA, 2001). Carbon dioxide, methane, nitrous oxide, and chlorofluorocarbons, the primary "greenhouse gases," have increased. These gases have undisputed heat-trapping properties. Though the specific climatic response is uncertain, meteorological data indicate detectable changes. Likely responses include increases in temperature and changes in precipitation, soil moisture, and sea level, which could have adverse effects on ecological and groundwater systems, human health, and the economy. 
WSRC-TR-2001-00323

Long-term climate changes may affect long-term cover system stability. Changes in precipitation may enhance erosion rates. Changes in temperature and rainfall can result in floral and faunal suite changes, particularly by making conditions intolerable to already marginal species. Interestingly, EPA (1998) makes the following statement regarding the effect of increased rainfall on buried hazardous waste at SRS:

The effect of buried hazardous wastes on groundwater quality, particularly in Barnwell County and near the Savannah River Plant, is a concern in South Carolina. Although the effects of climate change on the movement of pollutants are not well understood, changes in infiltration rates could affect the rate at which pollutants migrate through an aquifer. Increased precipitation could contribute to groundwater contamination by increasing the inflow of contaminants into nearby aquifers.

Global mean surface temperatures have increased $0.6-1.2^{\circ} \mathrm{F}$ between 1890 and 1996. The average temperature in Columbia, South Carolina, has increased $1.3{ }^{\circ} \mathrm{F}$ over the last century, while precipitation has increased by up to 20 percent in many parts of the state (EPA, 1998). Regional climate change calculations are much less reliable than global ones. Regional climate may become more variable, with increased frequency and intensity of some extreme weather critical to ecological systems (droughts, floods, frosts, cloudiness, hot or cold spells, and associated fire and pest outbreaks; EPA 1998).

Based on projections made by the Intergovernmental Panel on Climate Change and results from the United Kingdom Hadley Centre's climate model (HadCM2), EPA (1998) cites temperatures in South Carolina could increase by $3{ }^{\circ} \mathrm{F}$ (a range of $1-5{ }^{\circ} \mathrm{F}$ ) over the next 100 years (slightly less in winter and summer, slightly more in spring and fall). Precipitation increase is estimated at 15 percent (range 5-30 percent) in spring, slightly more in summer and fall, and slightly less in winter. Near the Aiken County, South Carolina area, precipitation increase is estimated around 10 percent over the next century. Near the Richmond and Columbia County, Georgia area, across the Savannah River from SRS, precipitation increase is also estimated around 10 percent over the next century (EPA, 1997). Ironically, though increased precipitation is predicted, decreased soil moisture is also predicted, due to increased temperatures.

The EPA (1998) predictions are consistent with preliminary regional projections for the southeastern U.S. cited in NASA (2001). Southeastern region temperatures are predicted to increase by about $4.1^{\circ} \mathrm{F}\left(2.3^{\circ} \mathrm{C}\right)$ by the year 2090 . The increase occurrence is projected in a slightly nonlinear manner, with about a $1.8^{\circ} \mathrm{F}\left(1^{\circ} \mathrm{C}\right)$ increase over the next 30 years.

Precipitation is projected to increase 3 percent over the next 30 years and by about 20 percent by the end of the century (NASA, 2001).

In summary, SRS climate change predictions are available for the next century. Predictions indicate subtropical conditions continue, with temperatures and precipitation increasing. 


\subsection{DOE-SITE DISPOSA L METHODS AND VOLUMES}

To provide perspective on the enormity of the DOE complex low-level waste volume, past and future disposal volumes for DOE's 20 major waste-generating sites are summarized in Table 8.

Table 8. Past and Future Low-Level Waste Volumes for DOE's 20 Major WasteGenerating Sites (GAO, 2000)

\begin{tabular}{|c|c|c|c|}
\hline DOE Site & Disposal Completed $\left(\mathrm{m}^{3}\right)$ & Disposal Planned $\left(\mathrm{m}^{\mathbf{3}}\right)$ & Total $\left(\mathbf{m}^{3}\right)$ \\
\hline $\begin{array}{l}\text { Argonne National } \\
\text { Laboratory, East, IL }\end{array}$ & 886 & 623 & 1,509 \\
\hline $\begin{array}{l}\text { Bettis Atomic Power } \\
\text { Laboratory, PA }\end{array}$ & 12,254 & 3,642 & 15,896 \\
\hline $\begin{array}{l}\text { Brookhaven National } \\
\text { Laboratory, NY }\end{array}$ & 1,403 & not available & 1,403 \\
\hline $\begin{array}{l}\text { Fernald Environmental } \\
\text { Management Project, } \mathrm{OH}\end{array}$ & 439,017 & $2,173,271$ & $2,612,288$ \\
\hline Hanford Site, WA & 495,049 & 128,707 & 623,756 \\
\hline $\begin{array}{l}\text { Idaho National Engr. and } \\
\text { Environ. Laboratory, ID }\end{array}$ & 98,5000 & 26,000 & 124,500 \\
\hline $\begin{array}{l}\text { Knolls Atomic Power } \\
\text { Laboratory, NY }\end{array}$ & 5,763 & 6,267 & 12,030 \\
\hline $\begin{array}{l}\text { Lawrence Livermore } \\
\text { National Laboratory, CA }\end{array}$ & 5,641 & 6,350 & 11,991 \\
\hline $\begin{array}{l}\text { Los Alamos National } \\
\text { Laboratory, NM }\end{array}$ & 223,400 & 273,000 & 496,400 \\
\hline Mound Plant, $\mathrm{OH}$ & 54,798 & 103,321 & 158,119 \\
\hline Nevada Test Site, NV & 243,000 & 119,983 & 362,983 \\
\hline Oak Ridge Reservation, TN & 4,253 & 579,191 & 583,444 \\
\hline $\begin{array}{l}\text { Paducah Gaseous Diffusion } \\
\text { Plant, KY }\end{array}$ & not available & 11,000 & 11,000 \\
\hline Pantex Plant, TX & 3,070 & not available & 3,070 \\
\hline $\begin{array}{l}\text { Portsmouth Gaseous } \\
\text { Diffusion Plant, OH }\end{array}$ & 978 & 14,387 & 15,365 \\
\hline $\begin{array}{l}\text { RMI Titanium Company, } \\
\text { OH }\end{array}$ & 44 & 10,477 & 10,521 \\
\hline $\begin{array}{l}\text { Rocky Flats Environmental } \\
\text { Technology Site, CO }\end{array}$ & 9,424 & 157,436 & 166,860 \\
\hline $\begin{array}{l}\text { Sandia National } \\
\text { Laboratories, NM }\end{array}$ & 2,047 & 4,220 & 6,267 \\
\hline Savannah River Site, SC & 353,911 & 407,000 & 760,911 \\
\hline $\begin{array}{l}\text { West Valley Demonstration } \\
\text { Project, NY }\end{array}$ & 11,988 & 56,634 & 68,622 \\
\hline Total & $1,965,426$ & 4,081,509 & $6,046,935$ \\
\hline
\end{tabular}


Six DOE sites have active disposal facilities for low-level and/or mixed wastes (GAO, 2000). All six sites are located where DOE and its predecessor agencies generated low-level and mixed wastes through a variety of activities, from producing nuclear weapons, to operating nuclear reactors, to conducting nuclear research. The Sites have historically disposed lowlevel wastes in burial grounds, many of which are currently undergoing environmental remediation. Table 9 (from GAO, 2000) presents the six sites, the volumes of low-level waste disposed, and capacity for additional waste.

Table 9. DOE's Active Waste Management Disposal Facilities' Waste Disposal Volumes and Remaining Capacity (GAO, 2000)

\begin{tabular}{|l|l|c|c|}
\hline Disposal Facility & DOE Site & $\begin{array}{c}\text { Disposed Low-Level } \\
\left.\text { Waste Volume } \mathbf{~ m}^{\mathbf{3}}\right)\end{array}$ & $\begin{array}{c}\text { Remaining } \\
\left.\text { Capacity } \mathbf{~ m}^{\mathbf{3}}\right)\end{array}$ \\
\hline $\begin{array}{l}\text { Hanford 200 Area } \\
\text { Low-Level Burial } \\
\text { Grounds }\end{array}$ & Hanford Site & 380,500 & 934,000 \\
\hline $\begin{array}{l}\text { Radioactive Waste } \\
\text { Management } \\
\text { Complex }\end{array}$ & INEEL & 98,500 & 64,300 \\
\hline $\begin{array}{l}\text { Area G of Technical } \\
\text { Area-54 Material } \\
\text { Disposal Area }\end{array}$ & LANL & & 273,000 \\
\hline $\begin{array}{l}\text { Radioactive Waste } \\
\text { Management Sites } \\
\text { Areas 3 and 5 }\end{array}$ & Nevada Test Site & 223,400 & $2,400,000$ \\
\hline $\begin{array}{l}\text { Interim Waste } \\
\text { Management Facility }\end{array}$ & ORNL & 551,000 & 1,760 \\
\hline $\begin{array}{l}\text { E-Area LLW and } \\
\text { Saltstone Disposal } \\
\text { Facility }\end{array}$ & SRS & 3,640 & 133,300 \\
\hline Total & & $\mathbf{1 , 2 8 6 , 9 5 1}$ & $\mathbf{3 , 8 0 6 , 3 6 0}$ \\
\hline
\end{tabular}

The following brief descriptions of site disposal methods (other than SRS) are from GAO (2000). Although the specific purpose of the present report is to provide site-specific parametric information for the ET case study, the greater purpose for this overall task is to provide a risk- and cost-based methodology for evaluating long-term disposal options. This methodology should be adaptable to all DOE long-term, low-level radioactive waste disposal facilities. Therefore, summarizing this DOE complex-wide information here provides perspective for the scope and variety of DOE's low-level disposal. 
Hanford Site Active Low-Level Burial Grounds cover about $1 \mathrm{mi}^{2}\left(2.6 \mathrm{~km}^{2}\right)$ in the middle of the site. Each burial ground comprises a number of trenches, which will be filled with wastes contained, for the most part, in wooden containers or drums. Most of the trenches are used to dispose of DOE's wastes, but one is reserved for contaminated reactors from naval vessels operated by the Department of Defense. These reactors will be buried 1 to $20 \mathrm{ft}$ bls $(0.3$ to $6.1 \mathrm{~m})$. The Hanford Low-Level Burial Grounds can accept virtually all types of low-level wastes. The site has developed performance assessments that demonstrate its disposal operations are protective of human health and the environment. The eight active low-level burial grounds are located on a plateau approximately $200 \mathrm{ft}(60.6 \mathrm{~m})$ above the water table. The site's annual rainfall (about 6 in.; $0.15 \mathrm{~m}$ ) is less than the amount of evaporation, thus limiting the downward migration of contaminants.

INEEL Radioactive Waste Management Complex (RWMC) occupies about $890 \mathrm{mi}^{2}$ $\left(2,305 \mathrm{~km}^{2}\right)$ of dry, cool desert in southeastern Idaho. The site once had 52 active nuclear reactors, and reprocessed spent nuclear fuel for decades. Currently, the site's primary missions include storing spent nuclear fuel and treating and eventually disposing transuranic wastes offsite. The site's Radioactive Waste Management Complex (RWMC) covers roughly 144 acres (58.3 hectares), and is used for interim transuranic waste storage and lowlevel waste disposal. The four active, conjoined low-level waste disposal pits cover about 6 acres (2.4 hectares) adjacent to the transuranic waste storage areas. The pits are also adjacent to previously-filled waste burial grounds managed by the INEEL ER program. The site is fairly remote and dry. Average annual rainfall is 9 in. $(0.23 \mathrm{~m})$. Groundwater is about $700 \mathrm{ft}$ (212.1 m) bls.

RWMC primarily disposes of low-level wastes in containers such as large (4- x 4- x 8-ft; $1.2-\mathrm{x} 1.2 \times 2.4 \mathrm{~m})$ wood and metal containers, which are stacked $20 \mathrm{ft}(6.1 \mathrm{~m})$ high in unlined pits. To conserve disposal capacity and increase long-term stability, low-level wastes are sized and compacted at the site's Waste Experimental Reduction Facility prior to disposal. Smaller quantities of remote-handled low-level wastes are disposed in special concrete vaults in one area within the disposal pits. All low-level wastes disposed at RWMC are from INEEL. In FY 99, the facility disposed about 6,000 cubic meters of waste, almost eliminating the site's backlog of stored low-level waste. Current DOE plans assume the disposal facility will accept contact-handled low-level waste through 2006 and remotehandled waste through 2008.

\section{Los Alamos National Laboratory Area G of Technical Area-54 Material Disposal Area} began accepting wastes in about 1959. This area occupies approximately 64 acres (25.9 hectares) on top of a mesa adjacent to the highway between the laboratory and the nearby community of White Rock. The relatively dry climate [average annual rainfall 14 in. $(0.35 \mathrm{~m})$ in Area $\mathrm{G}]$ and volcanic bedrock combine to limit potential contaminant migration from the facility. The water table lies $800 \mathrm{ft}(242.4 \mathrm{~m})$ below the mesa surface. The mesa edges ultimately limit the disposal facility's expansion potential, but additional acreage could be developed beyond the area currently used. 
WSRC-TR-2001-00323

The facility disposes low-level waste using shallow land disposal in either pits or shafts. Approximately 40 disposal pits have been used in Area G, four of which are currently active. The unlined pits, which are no more than $65 \mathrm{ft}$ deep, are filled with an average of 10 to 12 tiers of tightly stacked wastes. The layers of waste are covered with backfill to build the tiers. During waste emplacement, pipes are installed for environmental sampling during operations and after closure. To optimize its disposal capacity, Los Alamos uses a compactor to reduce the volumes of some low-level wastes by as much as 8 to 1 . Metal waste containers are used.

Most of Los Alamos' low-level wastes come to Technical Area-54 from over 2,000 onsite generators, with a limited amount from offsite. Because Los Alamos expects to continue its current missions into the foreseeable future, it is attempting to conserve the site's limited disposal capacity for anticipated onsite wastes.

Nevada Test Site Area 3 and Area 5 Radioactive Waste Management Sites are located in southeastern Nevada, about $65 \mathrm{mi}$. (104.6 km) northwest of Las Vegas. From 1951 through 1992, DOE and its predecessor agencies conducted 928 nuclear tests at the site, 100 atmospheric and 828 underground. Many of the testing areas will require long-term institutional controls to prevent inadvertent exposure to residual contamination. Area 3 and Area 5 are well within the site boundaries. Both areas are arid, receiving 4 to 6 in. of rain annually. There is no nearby surface water, and the water table is approximately $1,600 \mathrm{ft}$ $(484.8 \mathrm{~m})$ below Area 3 and $800 \mathrm{ft}(242.4 \mathrm{~m})$ below Area 5.

The Area 3 site covers about 120 acres (48.6 hectares) and currently disposes low-level wastes in seven subsidence craters that resulted from underground nuclear tests. The seven craters make up five disposal units. In two cases, the area between craters was excavated to make two craters into a single disposal unit. The subsidence craters require little excavation before being used for disposal (in contrast to the engineered trenches in Area 5 and at other DOE sites). Low-level bulk wastes arrive in large cargo containers or soft containers, some of which can be rolled off hydraulic truck beds, reducing necessary handling.

The Area 5 site comprises 732 acres (296.2 hectares), 92 acres (37.2 hectares) of which are currently used for shallow land disposal. The wastes are accepted in containers, drums, or soft packages and are stacked in a stair-step manner within 22 engineered and excavated disposal trenches. As the trenches fill, the wastes are covered with clean soil until the facility can be permanently closed.

The Nevada Test Site has been disposing low-level waste from other sites since the 1960s, with larger quantities accepted since the mid-1970s. Offsite wastes comprised approximately 57 percent of the total volume of low-level waste disposed from 1974 through 1997. During the last five years of this period, offsite wastes accounted for approximately 95 percent of the total volume of low-level waste disposed at the site. In fact, the Nevada Test Site accepted more than 41 percent of all low-level waste disposed in DOE's shallow land disposal facilities from 1987 through 1996. 
Oak Ridge Reservation Interim Waste Management Facility - Oak Ridge Reservation, established in 1942, occupies approximately $55 \mathrm{mi}^{2}\left(142.5 \mathrm{~km}^{2}\right)$ in eastern Tennessee, near Knoxville. The site has included uranium enrichment, isotope separation, and plutonium production facilities, among others. Hydrologic conditions make the site unsuitable for shallow land disposal of radioactive wastes. The Oak Ridge climate is humid, with annual average rainfall of $55 \mathrm{in}$. $(1.4 \mathrm{~m})$ Depth to groundwater is shallow [less than $20 \mathrm{ft}(6.1 \mathrm{~m})$ in some areas and averaging 20 to $50 \mathrm{ft}(6.1$ to $15.2 \mathrm{~m})]$. Groundwater is discharged to the surface in some areas, to onsite streams and springs. The Clinch River and six tributaries run through the reservation, and a major aquifer underlies the site.

Because of this wet environment, Oak Ridge's only low-level waste disposal facility, the Interim Waste Management Facility (IWMF), is an aboveground, high-cost engineered facility. Modular concrete vaults are filled with low-level wastes encapsulated in concrete. The vaults are placed on concrete pads, and grout is used to fill void spaces within the vaults. A concrete lid with a seal is place on each vault following the grouting operation. IWMF has a total of six $18 \mathrm{~m}$ x $27 \mathrm{~m}$ concrete pads, a leachate collection system, and a monitoring capability. The facility is expensive, and its use for long-term disposal has been questioned.

No significant amount of waste was disposed in IWMF during FY99 due to costs and the re-evaluation of the facility's performance assessment and waste acceptance criteria. The site will eventually load vaults onto the already-constructed pads. These vaults will be filled primarily with waste containing high-activity, short-lived isotopes like cesium and strontium. The facility cannot accept much of the low-level waste generated at the site, and its disposal capacity is limited to $5,400 \mathrm{~m}^{3}$. 
This page intentionally left blank.

Page 42 of 298 
WSRC-TR-2001-00323

\subsection{CONCLUSIONS}

This report details parameters to be used in FY02 finite element modeling related to longterm waste stability. Parameters related to B-25 corrosion evaluation are also included. Work performed in FY01 has indicated a number of additional details that may be considered for this finite element modeling. One would be the response of the uppermost B-25 to soil loading. The placement of a minimum 4-ft-thick soil cover may be sufficient to push the top of the uppermost B-25 down inside the container. This would change the response of the stack to dynamic compaction, possibly transferring the greatest energy to the second and third B-25 from the top.

Another detail is the discovery during the B-25 exhumation that the uppermost B-25 was full of water and soil, and that the underlying B-25 was half-full of water. This suggests additional study of the dynamics of moisture accumulation within buried B-25s should be performed. It also suggests the performance of B-25s in isolating waste (previously considered not to take place) should be evaluated.

Another detail that should be considered is that most of the B-25s in the ET will not necessarily be in contact with soil over large portions of their surface area. Most of the B-25s will be in close proximity to other B-25s, and would provide some degree of lateral support to adjacent containers. The effect of lateral support/incomplete soil contact on corrosion rate and physical stability should be considered.

FY02 structural modeling will focus on the most likely ET waste stabilization method to be implemented. This will begin by discussing all the possible stabilization methods with SRS SWD and SWD-funded scientists and engineers who are evaluating disposal alternatives. The most likely alternatives will be used for structural finite element modeling. Later, in FY03, the modeled method will be incorporated into the ET performance assessment. The methodology for evaluating choices for long-term stabilization will be incorporated into a guidance document for DOE complex-wide distribution. The methodology should be adaptable to long-term disposal facilities using various disposal methods and in various climate zones.

One method under consideration is the use of soft-sided containers. A general conceptual model for this method might be to place the same waste volume (same radioactivity content) in a mounded configuration of layers of soft-sided bags. The bag layers might be separated by soil layers, with each soil/bag layer compacted. The bag mound might be underlain and/or overlain by a low-permeability layer. The mound could then be covered with a thick soil layer and planted with naturally occurring vegetation designed as closely as possible to that of the area's natural climax vegetation. Such a design would substantially reduce future subsidence compared to disposal using B-25 containers (whether or not the B-25s are dynamically compacted or contain supercompacted waste). Reduced subsidence should yield lower long-term maintenance cost. 
WSRC-TR-2001-00323

Another method might be to allow the B-25s to naturally weaken by corrosion prior to applying dynamic compaction and construction of a new cap. This concept would assume that after the B-25s have structurally degraded, dynamic compaction would yield greater consolidation (and less subsidence) than when performed while the B-25s are relatively pristine.

An additional method under consideration is the use of static surcharge rather than dynamic compaction. With this method, the thick mound of soil providing the surcharge also provides sufficient soil to fill in subsidence while still providing a cover. Whichever method is selected, cost and operational requirements (such as health and safety) must be met.

As DOE looks toward long-term stewardship, the overall goal for all long-term disposal facilities should be, "...to develop disposal systems that will change in harmony with the landscape in which it is sited" (Caldwell and Reith, 1993). This should include planning for the eventual development of a "climax" vegetated cover and anticipating subsidence. Caldwell and Reith (1993) state, "Our obligation is to free subsequent generations of the responsibility for caretaking our hazardous residues, not to saddle them with housekeeping chores which, if neglected, will result in the re-pollution of the environment that we worked so hard to clean." Selecting the best long-term waste stabilization method and providing the best possible input for a disposal site's performance assessment are steps toward fulfilling this obligation. 
WSRC-TR-2001-00323

\subsection{REFERENCES}

Aadland, R. K., Harris, M. K., Lewis, C. M., Gaughan, T. F., and Westbrook, T. M., 1991. "Hydrostratigraphy of the General Separations Area, Savannah River Site (SRS), South Carolina," WSRC-RP-91-13, Westinghouse Savannah River Company, Aiken, SC 29808.

Aadland, R. K., Gellici, J. A, and Thayer, P. A., 1995. "Hydrogeologic Framework of WestCentral South Carolina," Report 5, Water Resources Division, South Carolina Department of Natural Resources, Columbia, SC.

ASTM, 2000. Designation G 51-95 (Reapproved 2000) Standard Test Method for Measuring $\mathrm{pH}$ of Soil for Use in Corrosion Testing, American Society for Testing and Materials, West Conshohocken, PA 19428-2959.

Caldwell, J. A. and Reith, C. C., 1993. Principles and Practice of Waste Encapsulation, Lewis Publishers, Chelsea, Michigan, 48118.

Colquhoun, D. J., Woollen, I. D., Van Nieuwenhuise, D. S., Padgett, G. G., Oldham, R. W., Boylan, D. C., Bishop, J. W., and Howell, P. D., 1983. "Surface and Subsurface Stratigraphy, Structure and Aquifers of the South Carolina Coastal Plain," South Carolina Department of Health and Environmental Control Report, ISBN 0-9613154-0-7, Columbia, SC.

Cook, J.R., McDowell-Boyer, L., Yu, A.D., Kocher, D.C., Wilhite, E.L., and Young, K.E., 2000. "Radiological Performance Assessment for the E-Area Vaults Disposal Facility," WSRC-RP-94-0218, Rev. 1, January, 31, 2000, Westinghouse Savannah River Company, Aiken SC 29808.

Dames and Moore, Inc., 1987. "Subsidence Study B-25 Metal Containers Mixed Waste Management Facility," DMSRP-97, March 4, 1997, letter report Charles T. Allen to Alex Guanlao, E.I. duPont de Nemours \& Company, Inc., Savannah River Plant, Aiken, SC 29808.

DOE, 1998. "Disposal of Low-Level and Low-Level Mixed Waste," DOE/IG-0426, Audit Report, Office of Inspector General, September 1988, Washington, D.C. 20585.

DOE, 1999. "Radioactive Waste Management," Order 435.1, July 9, 1999, U.S. Department of Energy, Washington, D.C.

DOE, 2001. "Utilization of the Department's Low-Level Waste Disposal Facilities," DOE/IG-0505, Audit Report, Office of Inspector General, May 2001, Washington, D.C. 20585.

EPA, 1997. "Climate Change and Georgia," EPA 230-F-97-008j, September 1997, United States Environmental Protection Agency, Office of Policy, Planning and Evaluation, Washington, D.C. 20460. 
EPA, 1998. "Climate Change and South Carolina," EPA 236-F-98-007w, September 1998, United States Environmental Protection Agency, Office of Policy, Washington, D.C. 20460.

EPA, 2001. "Reusing Cleaned Up Superfund Sites: Recreational Use of Land Above Hazardous Waste Containment Areas," EPA 540-K-01-002, OSWER 9230.0-93, United States Environmental Protection Agency, March 2001, Washington, D.C. 20460.

EPD, 1995. "Quality Control Summary Report for the Burial Ground Complex Field Investigation - Phase 2B," ESH-EMS-950316, Environmental Protection Department, Environmental Monitoring Section, Westinghouse Savannah River Company, June 1, 1995, Aiken, SC 29808.

Fallaw, W. C., and Sargent, K. A., 1982. "Subsurface Geology of the A/M Areas at the Savannah River Plant.” SRT-EST-97-187, Final Report for Subcontract AX 715063, E. I. duPont de Nemours \& Co., Savannah River laboratory, Aiken, SC 29808.

Fallaw, W. C. and Price, V., 1992. "Outline of Stratigraphy at the Savannah River Site", Geological Investigations of the Central Savannah River Area, South Carolina and Georgia, Fallaw, W. C., and Price, V., eds., Carolina Geological Society Field Trip Guide Book, November 13-15, 1992, CGS-92-B-11-1-33, U.S. Department of Energy and S.C. Geological Survey.

Fallaw, W. C. and Price, V., 1995. "Stratigraphy of the Savannah River Site and Vicinity," Southeastern Geology, 35: 21-58.

Fallaw, W. C., Price, V., and Thayer, P., 1990. "Stratigraphy of the Savannah River Site, South Carolina", Savannah River Region: Transition Between the Gulf and Atlantic Coastal Plains, Proceedings of the Second Bald Head Island Conference on Coastal Plains Geology, University of North Carolina at Wilmington, pp 29-32.

GAO, 2000. Low-Level Radioactive Wastes Department of Energy Has Opportunity to Reduce Disposal Costs, GAO/RCED-00-64, Report to Congressional Requestors, General Accounting Office, April 2000, Washington, D.C. 20585.

Law-Gibb, 2001. "Transmittal of Test Results: B-25 Soil Sampling Investigation," Geotechnical Testing Services, WSRC Site Wide - Task Release No. 68, Law Engineering Project No. 50161-7-0108 (Phase 68), letter report from David M. Jensen to Bruce Triplett, July 20, 2001, LAW Engineering and Environmental Services, Inc., Atlanta, Georgia, 30324.

Logan, W. R. and Euler, G. M., 1989. “Geology and Groundwater Resources of Allendale, Bamberg, and Barnwell Counties and Part of Aiken County, South Carolina," South Carolina Water Resources Commission Report 155, Columbia, SC.

Looney, B. B., Eddy, C. A., Ramdeen, M., Pickett, J., Rogers, V., Scott, M. T., and Shirley, P. A., 1990. "Geochemical and Physical Properties of Soils and Shallow Sediments at the Savannah River Site (U)," WSRC-RP-90-1031, Westinghouse Savannah River Company, August 31, 1990, Aiken, SC 29808. 
WSRC-TR-2001-00323

Main, Chas. T., Inc., 1988. "Summary Report for the Dynamic Compaction Test Program," September 1, 1988, Charlotte, NC 28224.

Main, Chas. T., Inc., 1989a. "Summary Report for the Dynamic Compaction Test Program," Rev. 1, January 31, 1989, Charlotte, NC 28224.

Main, Chas. T., Inc., 1989b. "EWR 863231 - Savannah River Site MWMF Closure - Static Surcharge Test Program at ELLT \#1 - Final Report (U)," October 26, 1989, Charlotte, NC 28209.

McMullin, S.R., 1992. "Evaluation of the Success of Dynamic Compaction of Low Level Waste Burial Trenches Containing B-25 Containers (U)," WSRC-MS-92-428, Westinghouse Savannah River Company, Aiken, SC 29808.

McMullin, S.R., 1994. "Evaluation of Dynamic Compaction of Low Level Waste Burial Trenches Containing B-25 Containers," WSRC-RP-94-737, Westinghouse Savannah River Company, Aiken, SC 29808.

McMullin, S.R. and Dendler, S.A., 1994. "Dynamic Compaction Facility Test Report (U)," WSRC-TR-94-0159, Rev. 1, Westinghouse Savannah River Company, Aiken, SC 29898.

NASA, 2001. DRAFT Preparing for a Changing Climate: Potential Consequences of Climate Variability and Change - Southeast: A Report of the Southeast Regional Climate Assessment Team for the U.S. Global Change Research Program, March 2001, National Aeronautics and Space Administration, Global Hydrology and Climate Center, Huntsville, AL.

Personal Communication, Harry Johnson, Law-Gibb Engineering, Inc. to William E. Jones, Savannah River Technology Center, facsimile transmission and phone conversation, October 16, 2001.

Personal Communication, Donald Stevenson, Savannah River Site, Site Geotechnical Services to Mike Lewis, Savannah River Site, Site Geotechnical Services, electronic mail transmission, October 8, 2001.

Phifer, M.A., 1991. "Closure of a Mixed Waste Landfill - Lessons Learned, Proceedings," Waste Management 1991, Tucson AZ.

Phifer, M.A. and Wilhite, E.L., 2001. "Waste Subsidence Potential Versus Supercompaction,” WSRC-RP-2001-00613, Westinghouse Savannah River Company, Aiken, SC 29808.

Phifer, M.A. and Serrato, M.G., 2000. "Preliminary E-Area Trench Subsidence Evaluation," SRT-EST-2000-00105, Interoffice Memorandum, January, 18, 2000, Westinghouse Savannah River Company, Aiken, SC 29808. 
Siple, G. E., 1967. "Geology and Ground Water of the Savannah River Plant and Vicinity, South Carolina," U.S. Geological Survey Water Supply Paper 1841.

SRS Engineering, 2000. SRS E-Area Low Level Waste Engineered Trench Drawings: Site Plan and Details (U), C-CV-E-0125; Sections and Details (U), C-CV-E-0126; Sections and Details (U), C-CV0E-0127; General Notes (U), C-CV-E-0128; and, Erosion and Sediment Reduction Details (U), Rev. 0, July 20, 2000, SRS Project Engineering \& Construction Department/Environmental Restoration Department, Aiken, SC 29808.

Stephenson, D.E., Talwani, P., and Rawlins, J., 1985. "Savannah River Plant Earthquake of June 1985," DPST-85-583, E.I. du Pont de Nemours \& Co., Savannah River Laboratory, Aiken, SC 29808.

USDA, 1971. Guide for Interpreting Soils, United States Department of Agriculture, Soil Conservation Service, November, 1971.

WSRC, 1995. “Geotechnical Seismic Assessment Report for Defense Waste Processing Facility (DWPF) (U)," Rev. 0, WSRC-TR-95-00072, Westinghouse Savannah River Company, Aiken, SC 29898.

WSRC, 1997. “Composite Analysis E-Area Vaults and Saltstone Disposal Facilities,” Rev. 0, WSRC-RP-97-311, Westinghouse Savannah River Company, Aiken, SC 29808.

WSRC, 2000a. "Closure Plan for the E-Area Low-Level Waste Facility," WSRC-RP-2000-00425, Rev. 0, September 15, 2000, Westinghouse Savannah River Company, Aiken, SC 29808.

WSRC, 2000b. "Carolina Geological Society 2000 Field Trip Guidebook," WSRC-MS-2000-00606, Westinghouse Savannah River Company, Aiken, SC 29808.

WSRC, 2000c. "Probability of Liquefaction for H-Area, Savannah River Site," WSRC-TR2000-00039, Rev. 0, August 31, 2000, Westinghouse Savannah River Company, Aiken, SC 29808.

WSRC, 2000d. "System Plan for Solid Waste Management," WSRC-RP-99-01092, Rev. 3, December, 2000, Westinghouse Savannah River Company, Aiken, SC 29808.

Yau, W.W.F., 1986. "Structural Responses of B-25 Containers to Burial Ground Operation," DPST-86-335, letter report to J.R. Knight, March 14, 1986, Savannah River Laboratory, Aiken, SC 29808 


\section{APPENDIX A}

\section{C-DCP-E-00001}

SWMF LOW LEVEL WASTE MEGA-TRENCH (U)

Rev. 0

July 20, 2000 
This page intentionally left blank. 


\section{Design Change Package Cover Sheet Design Change Package}

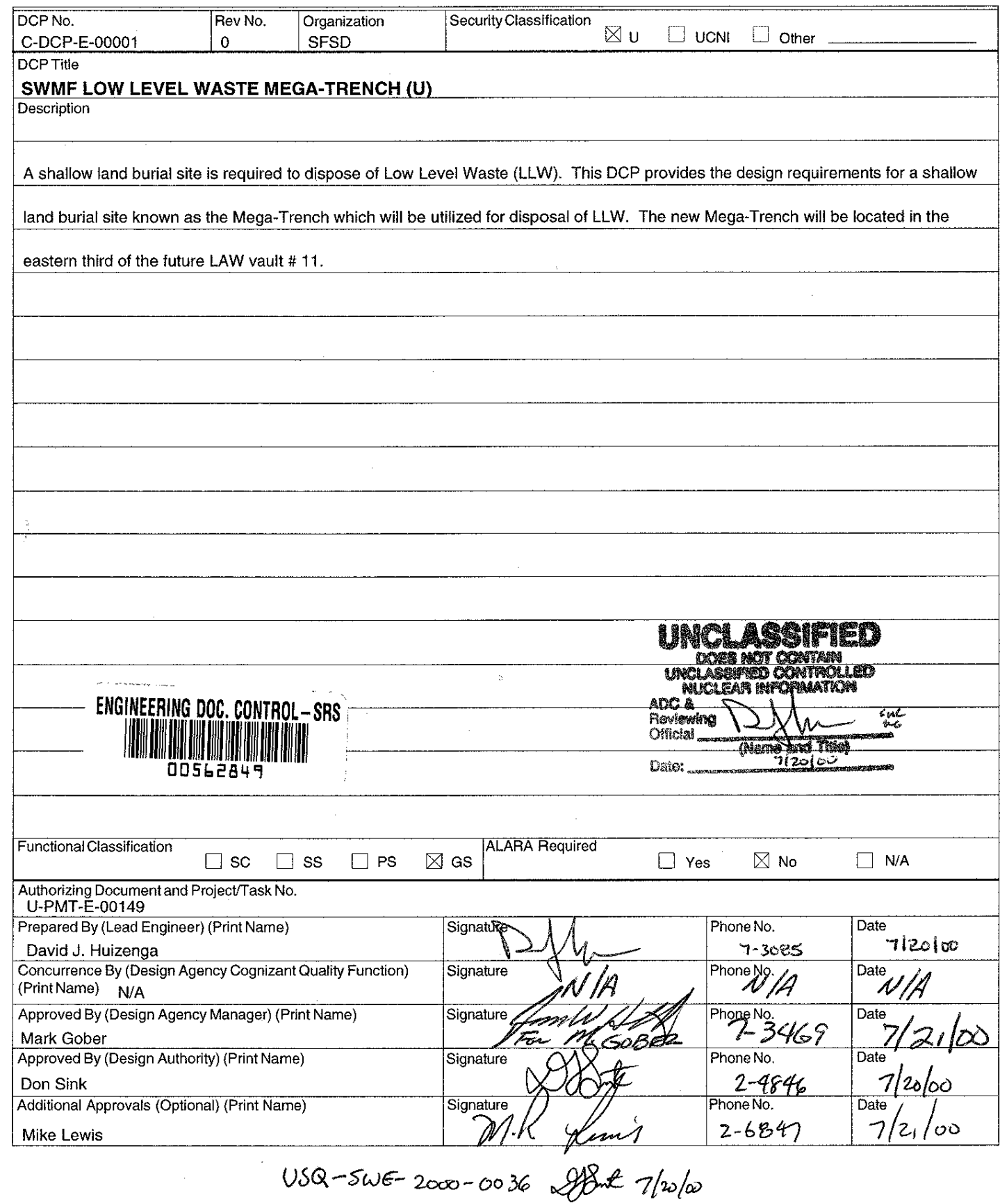


OSR 19-2112\#(2.5.92)

Design Change Package Revision Summary Sheet

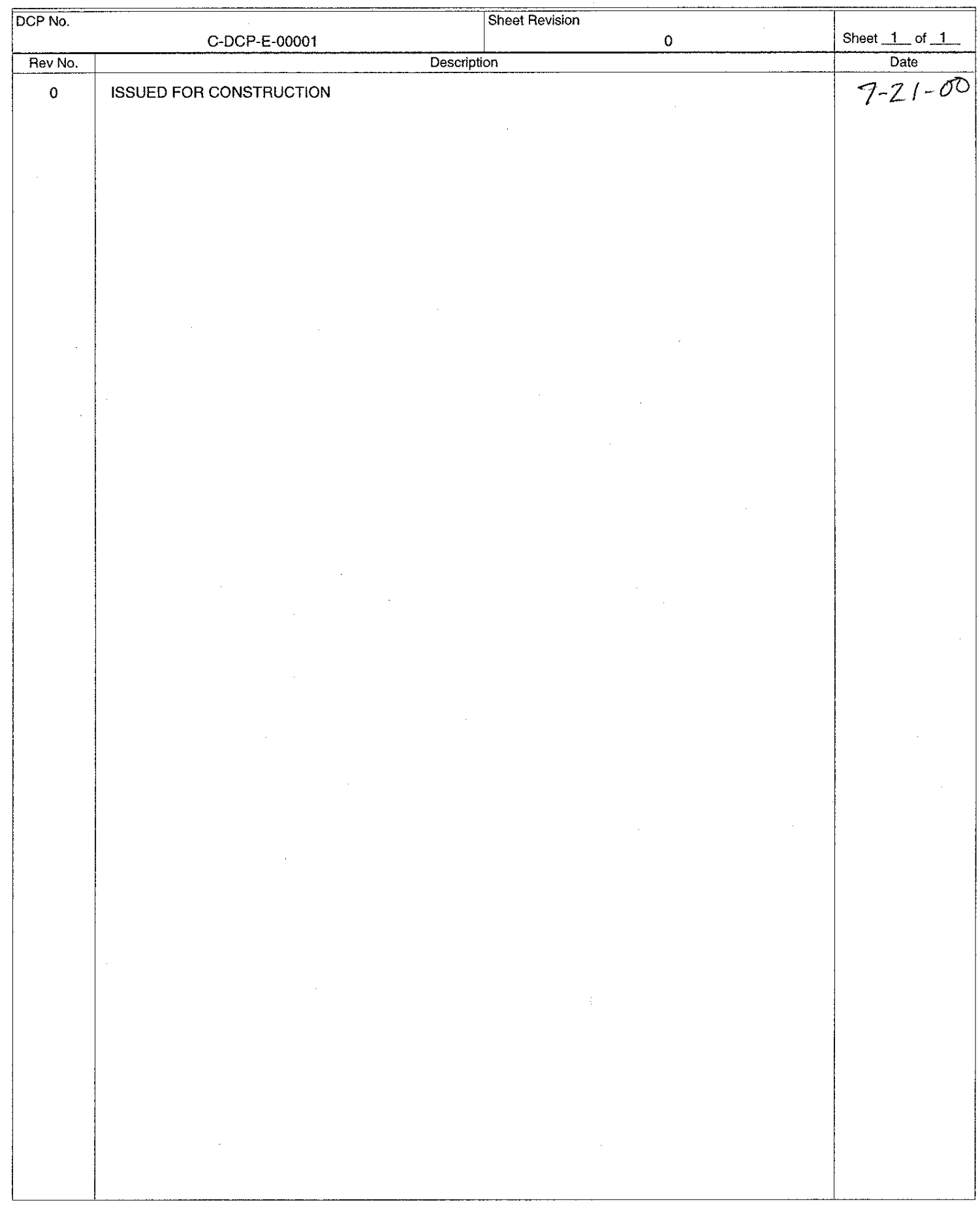

Page 52 of 298 


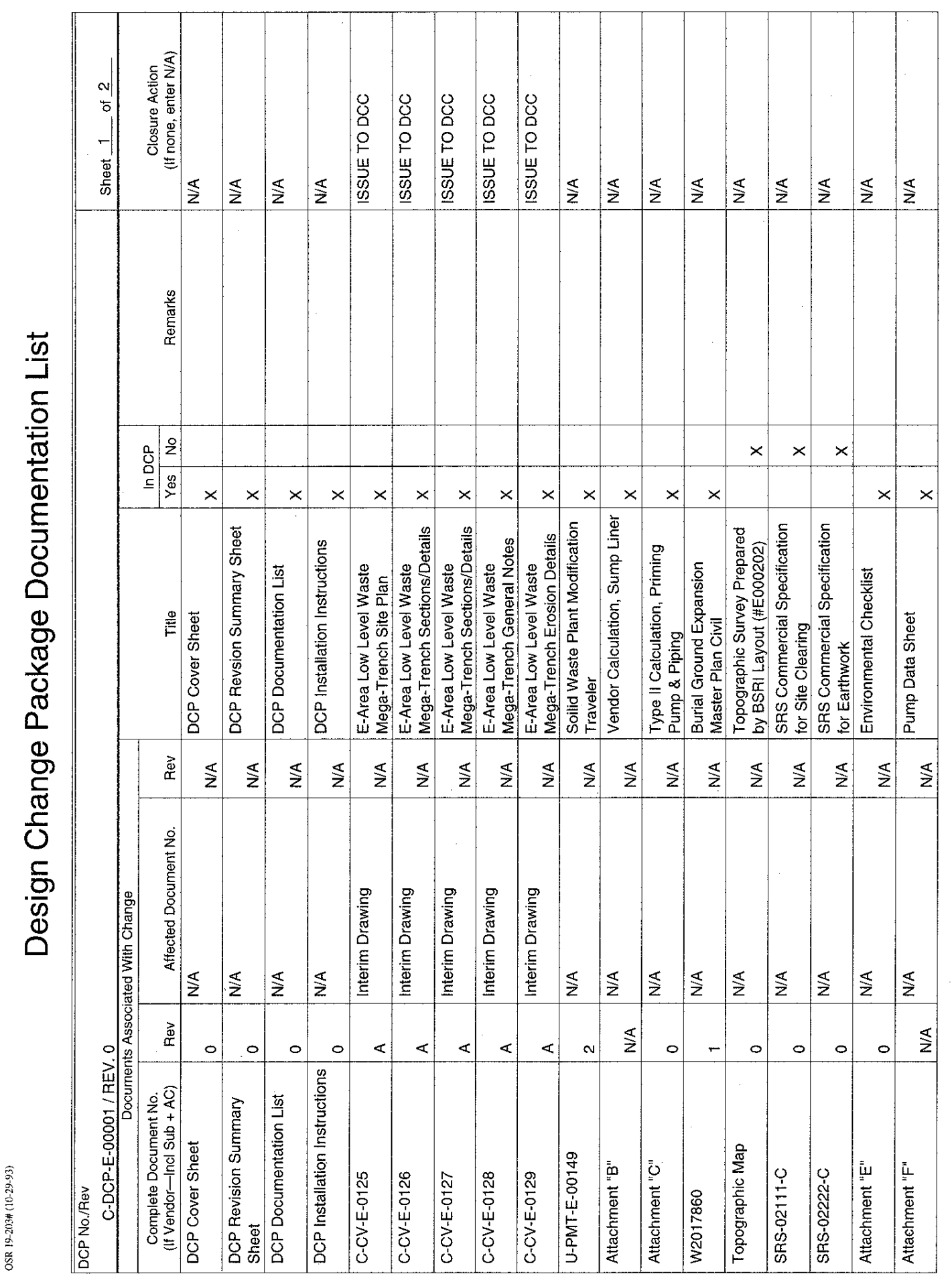

Page 53 of 298 


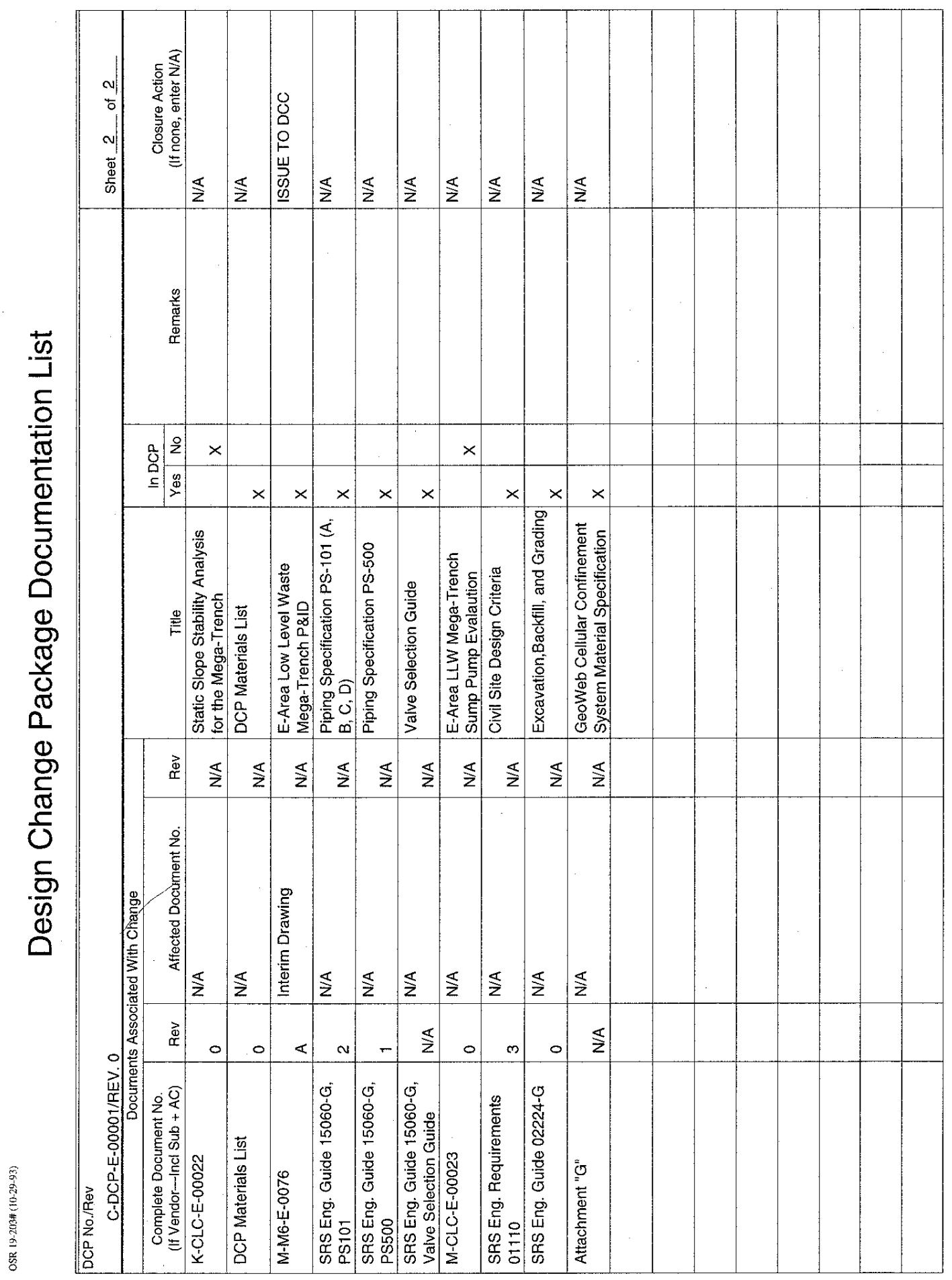

Page 54 of 298 


\section{INSTALLATION INSTRUCTIONS}

\section{Personnel Performing Work Shall}

- STOP WORK AND OBTAIN GUIDANCE FROM EITHER THE SYSTEM ENGINEER OR THE DCP ORIGINATOR PRIOR TO PERFORMING ANY TASK WHICH IS NOT FULLY UNDERSTOOD.

- STOP WORK AND OBTAIN A RESOLUTION FOR ANY "AS FOUND" CONDITION WITHIN THE WORK SCOPE OF THIS DCP THAT IS NOT CORRECTLY DEPICITED WITHIN THE DCP. RESOLUTIONS THAT REQUIRE A CHANGE TO THE DCP WILL BE IN WRITING (DCF).

- THE REFERENCED ENGINEERING GUIDES ARE REQUIREMENTS AND THE WORD "SHOULD" WHEN USED SHALL BE UNDERSTOOD TO MEAN "SHALL".

\section{Codes \& Standards}

1997 Edition of the Uniform Building Code 29 CFR 1926 Subpart P

SRS Engineering Guide 15060-G, Application of ASME B31.3

WSRC 3Q Environmental Compliance Manual, Procedure 12.2 (Stormwater Management and Sedimentation Reduction)

WSRC 8Q Employee Safety Manual, Procedure 34 (Excavations and Trenches)

SRS Engineering Standard 01110 R/4 (SRS Civil Site Design Criteria)

Solid Waste Plant Modification Traveler, U-PMT-E-00149 R/2

\section{General Notes}

1. The existing performance assessment requires a minimum of 25 feet of undisturbed soil between the bottom of the trench and the ground water table. This design is based on an assumed maximum water table elevation of 231.5 feet. Measurements taken from surrounding ground water wells BGO-3DR, BGO-4D, BGX-10D and BGX-11D indicate that the water table elevation could range from 230.7 feet to 240.1 feet. The actual water table elevation where the new mega-trench will be located shall be determined prior to construction. Design Engineering shall be notified if actual water table elevation is higher than the assumed value of 231.5 feet.

2. Prepare a Stormwater Management \& Sediment Reduction Plan (SMSRP) in coordination with EPD/Environmental Support Section and U.S. Dept. of Agriculture/Natural Resources Conservation Service (EPD/ESS and USDA/NRCS). The requirements of SC Regulation 72-300, the General Permit, and the NPDES General Permit (land disturbances greater than 5 acres) must be met for plan approval by EPD/ESS (ref. WSRC 3Q, Procedure 12.2).

3. Obtain an authorized Site Clearance Permit (OSR 3-121), as required, prior to start of construction (ref WSRC 8Q, Procedure 34).

4. Stock piling of excavated materials shall be performed only in areas designated by WSRC.

\section{Sump Liner}

1. The sump liner detailed in this DCP will not prevent liquids from passing through the bottom or sides of the sump. It is assumed that the operator of this facility will utilize other means to contain and dispose of contaminated liquids which may enter the sump.

2. Excavate and shape foundation soils so top of installed Geoweb section is flush with or slightly lower than the final grade as indicated on the drawings.

3. Install a 8-oz nonwoven geotextile underlayer on prepared surfaces. Ensure required overlaps are maintained and outer edges of geotextile are buried a minimum of 6 inches below grade.

4. Feed precut lengths of tendon material through aligned holes in cell walls of Geoweb section before expanding individual sections into position. Tie off end of tendons with a knot that cannot pass 


\section{INSTALLATION INSTRUCTIONS}

through hole in cell walls. Tie knots to provide full tendon strength and not slip under tensioning of tendon.

5. Anchor tendons and Geoweb sections at crest of slope and expand down slope surface.

6. Confirm each Geoweb section is expanded uniformly to the required dimensions and outer cells of each layer are correctly aligned. Interleaf or overlap edges of adjacent sections in each layer, according to which side wall profiles abut. Ensure upper surfaces adjoining Geoweb sections are flush at joint and adjoining cells are fully anchored.

7. Attach specified restraint pins to tendons at specified intervals to achieve necessary load transfer.

8. Place 4,000 psi concrete infill in expanded cells with suitable material handling equipment. Limit drop height to a maximum of 3 feet. Avoid displacement of Geoweb sections by infilling from crest of slope to toe of slope.

9. Overfill cells and manually compact or vibrate concrete. Screed surfaces to ensure finished surface is flush with top edges of cells and apply a rake finish.

\section{Discharge Line}

1. The discharge line shall be a 6 " $\phi$ PVC pipe with a ultraviolet inhibitor. Install discharge line in accordance with this DCP and SRS Engineering Guide 15060-G, PS500.

2. Install thrust blocks in accordance with this DCP.

3. Install a drain line with a valve at the inlet of the discharge line.

4. Install a rirrap apron at outlet of discharge line.

5. Attach portable sump pump to the PVC discharge line with a flexible hose. The fitting(s) installed on the end of the discharge line, shall be selected by construction to accommodate the use of a flexible hose.

\section{Suction Line}

1. The suction line shall be a $6 " \phi$ schedule 40 gal vanized carbon steel pipe for a distance of approximately 3' from the pump inlet flange. The remainder of the suction line shall be a 6"o flexible hose. The 6" $\phi$ flexible hose shall extend from the end of the galvanized carbon steel pipe to the bottom of the sump. The 6" $\phi$ schedule 40 galvanized carbon steel pipe shall be sloped from the pump inlet flange toward the sump in order to minimize the loads on the pump housing.

2. Install suction line in accordance with this DCP and SRS Engineering Guide 15060-G, PS101B.

3. Install carbon steel pipe priming line, return line, and sampling line with associated valves and connections on the 6" $\phi$ schedule 40 galvanized carbon steel line. The piping and valves shall be orientated in a manner that allows for ease of operation.

4. Install priming line, return line, sample line, and associated valves in accordance with this DCP and SRS Engineering Guide 15060-G, PS101B.

5. Attach foot valve and inlet strainer to the inlet end of the 6" $\phi$ flexible hose at the bottom of the sump.

6. Attach 2" $\phi$ return line to the $2 " \phi$ galvanized carbon steel return line. $2 " \phi$ return line shall extend into the sump a minimum of $15^{\prime}$.

7. Attach 2" $\phi$ priming line, priming pump, and associated electrical cable per the pump manufacturer's installation instructions.

8. Install the portable generator per the manufacturer's installation instructions.

9. Install one (1) $10^{\prime}-0^{\prime \prime}$ long copper clad steel ground rod for generator ground connection. 


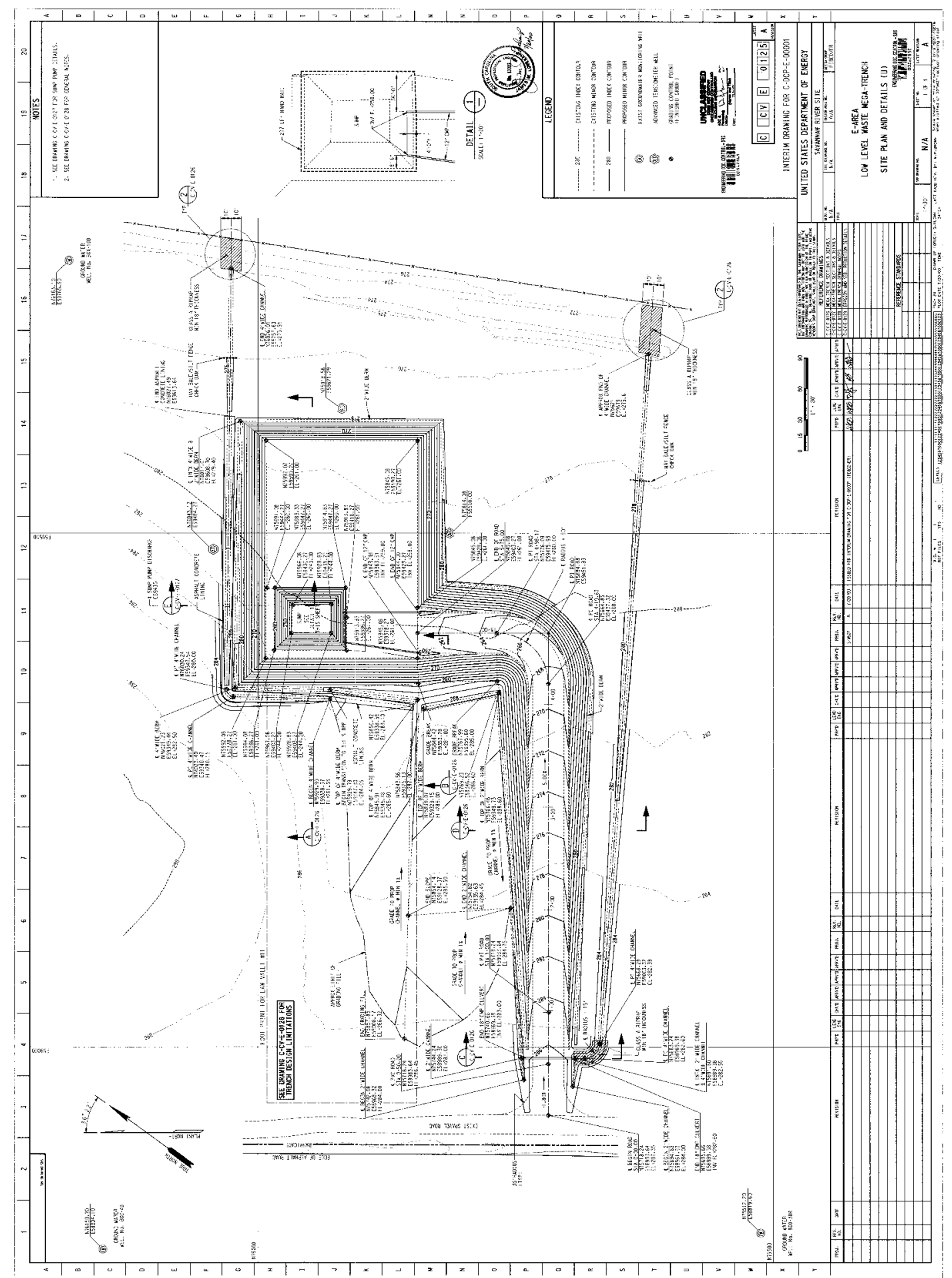




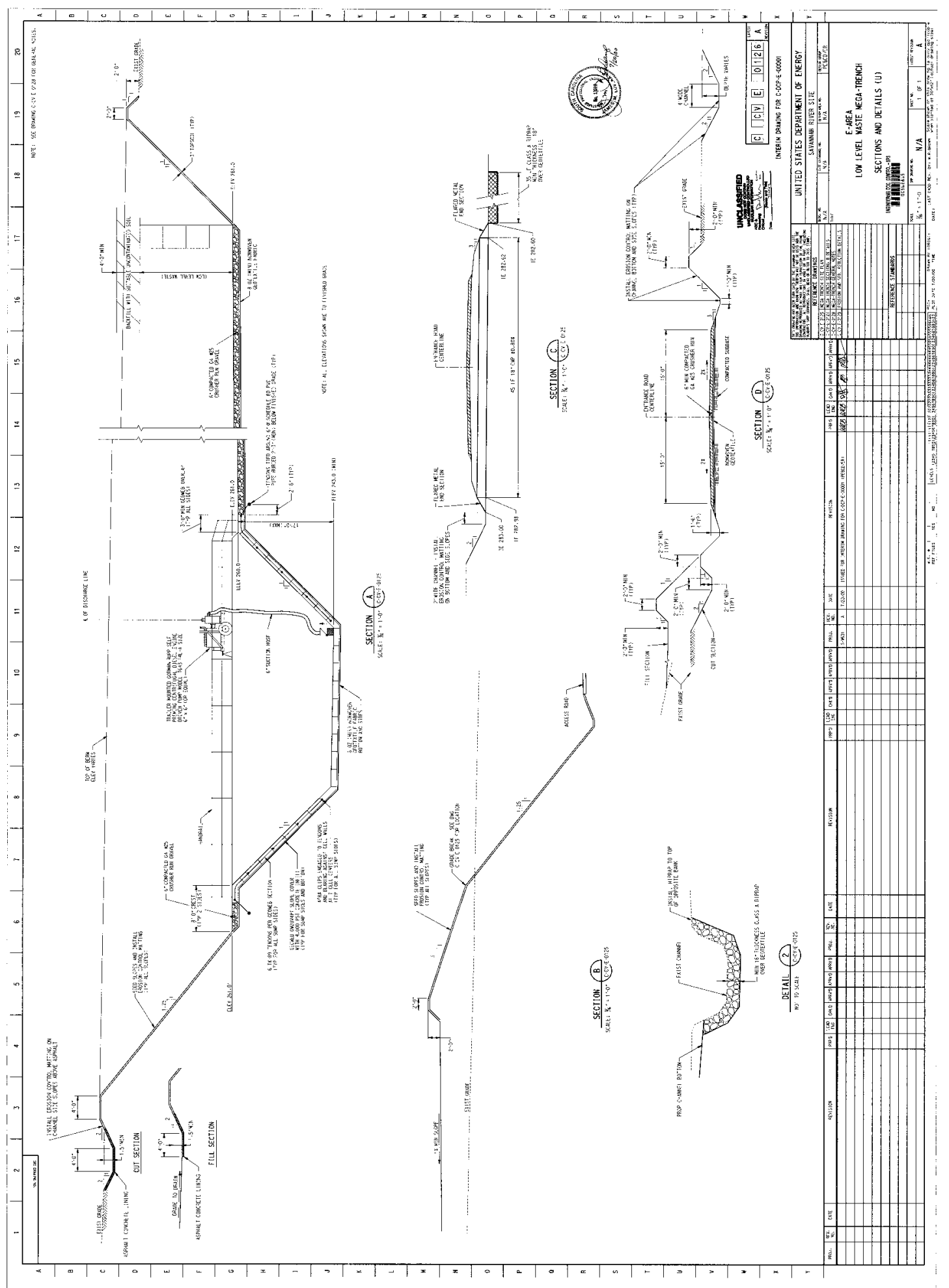

Page 58 of 298 


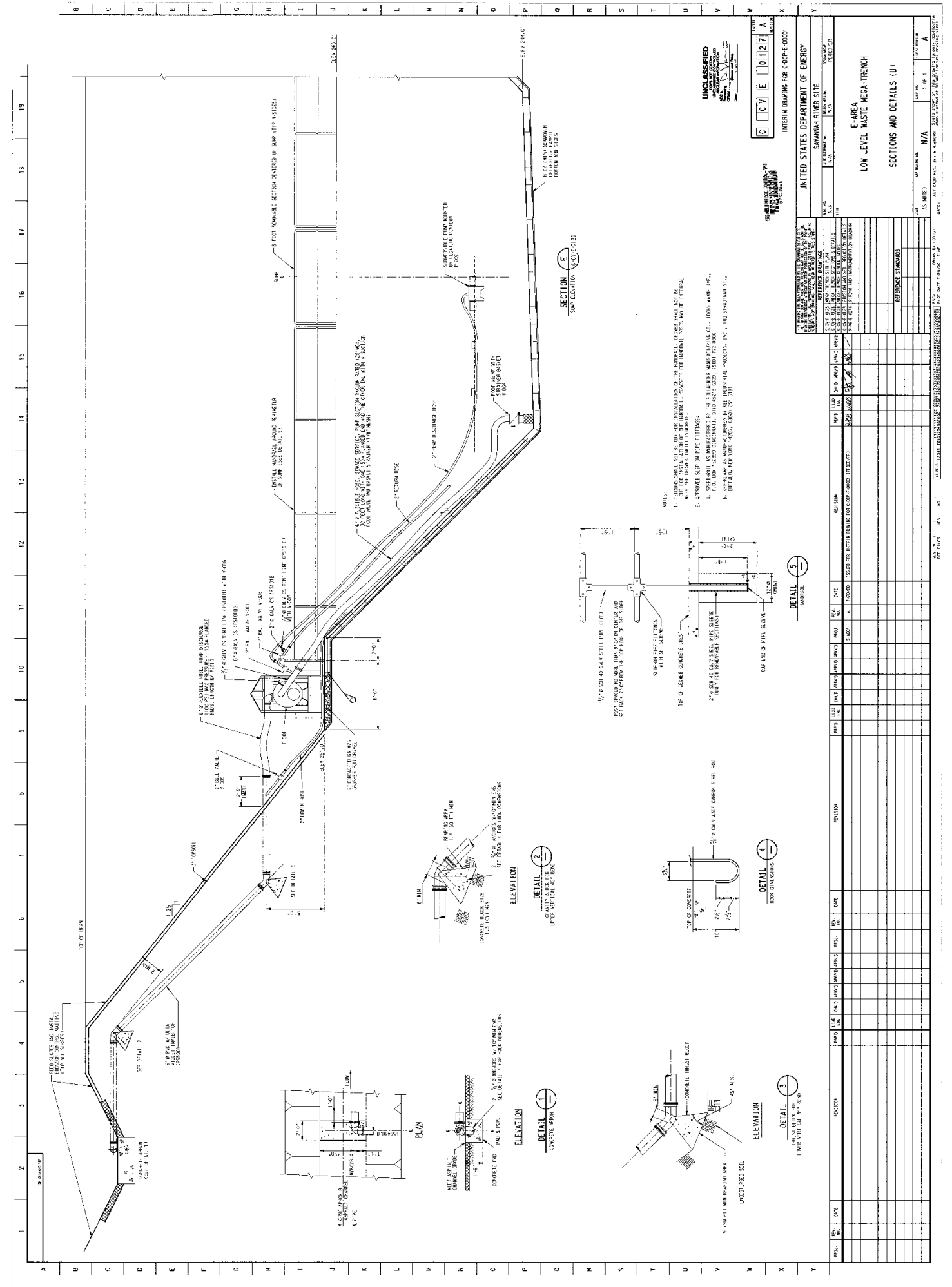

Page 59 of 298 


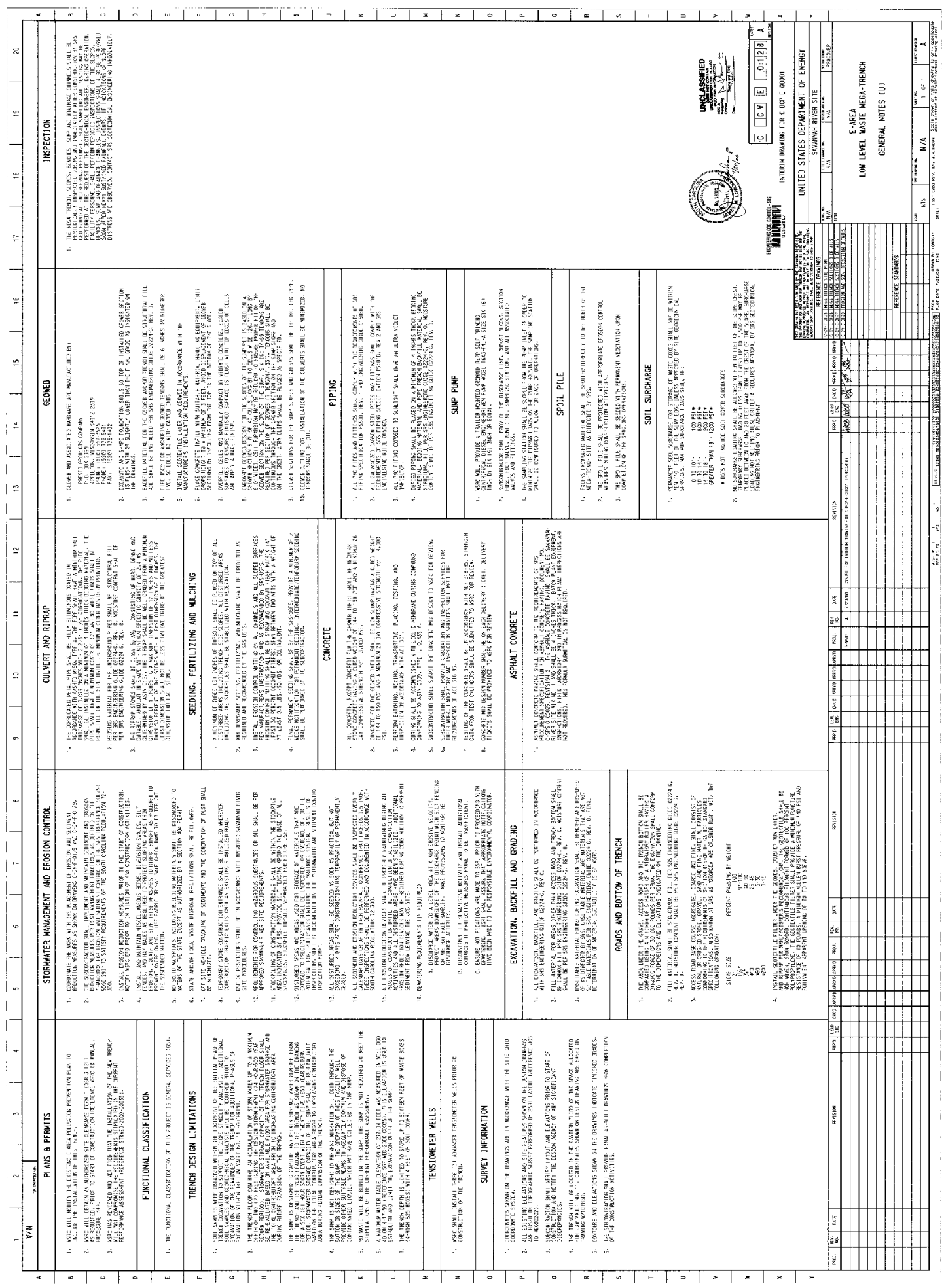




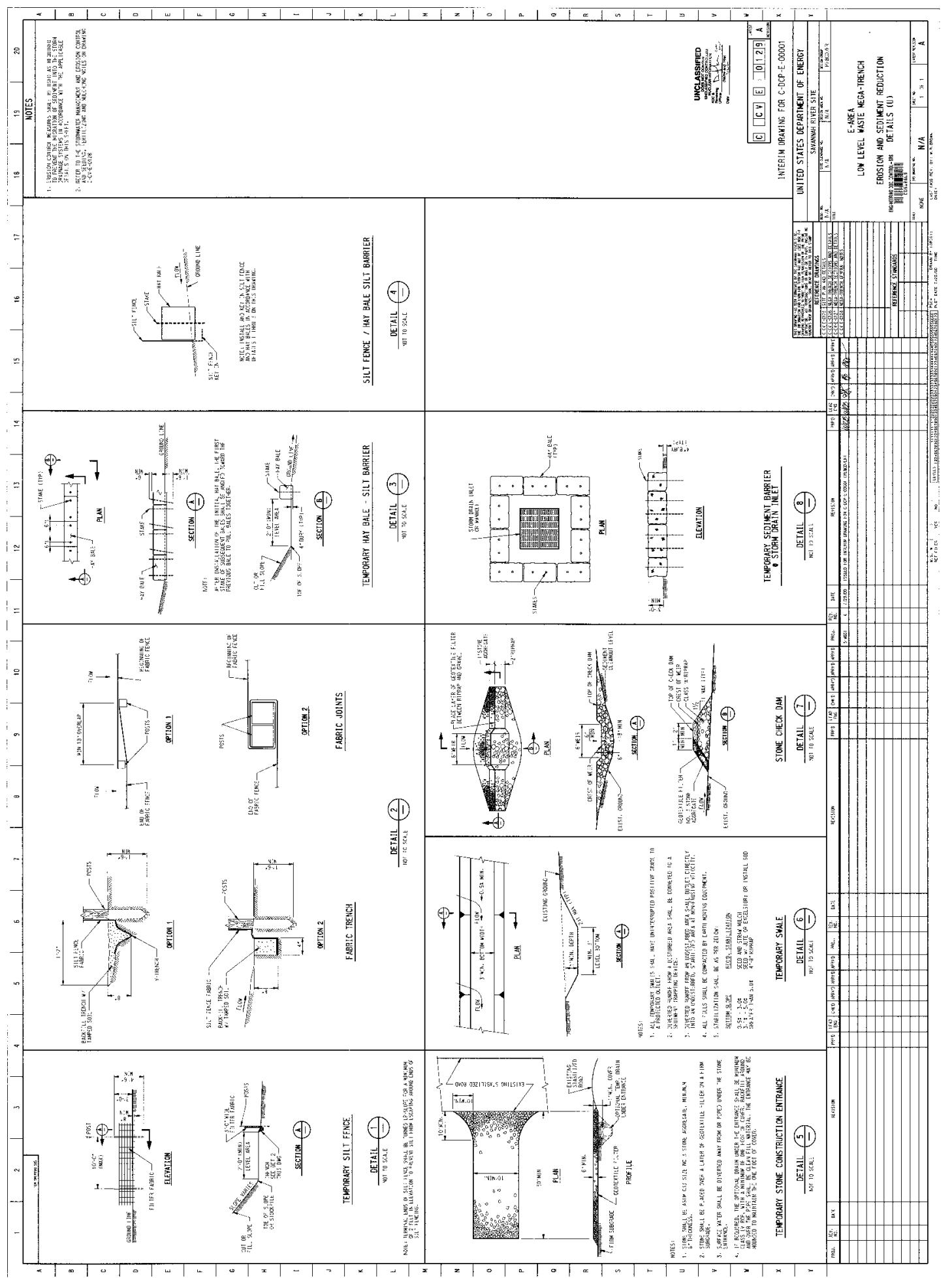




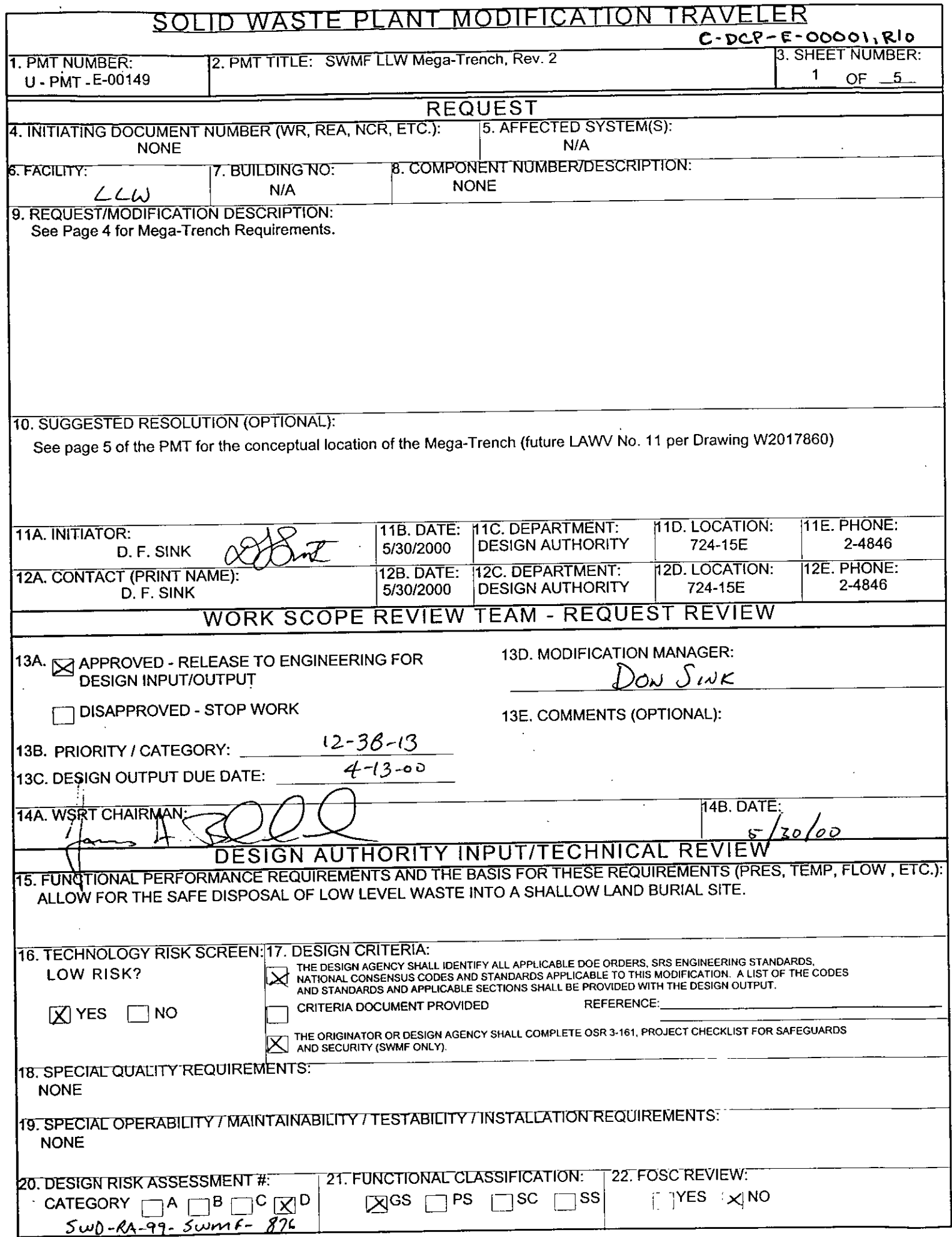




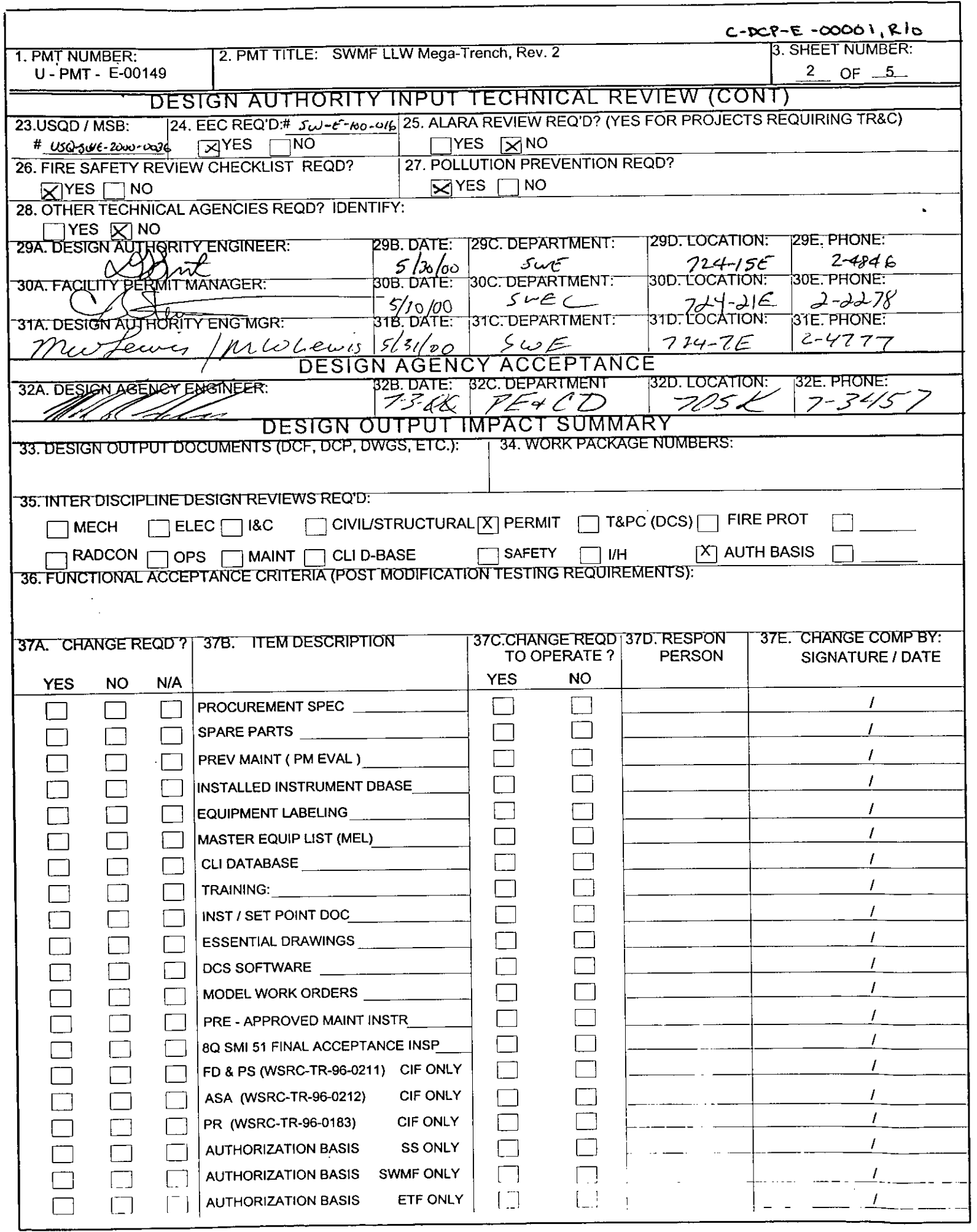




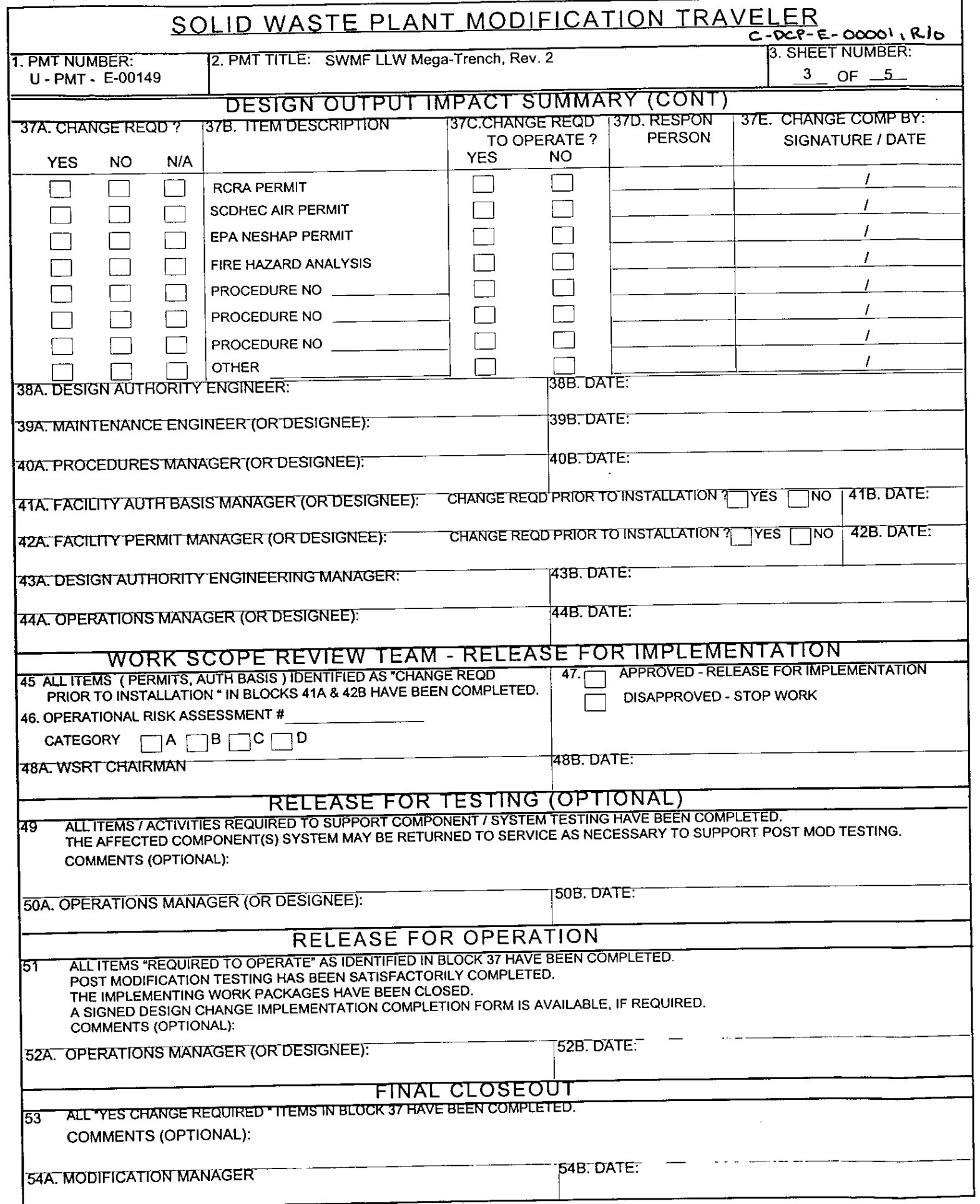


Provide a shallow land burial site ("Mega-Trench") for the disposal of Low Level Waste. The location of the Mega-Trench should be located in future LAW Vault \#11. The trench should be designed to stack 4 B-25's high in depth. The trench will be designed and constructed in sections of thirds due to limited funds for FY00. The design should provide allowances for extending the next section of the trench while operation continues in the previous section. The Mega-Trench will allow the drive-in function of flat bed trucks, fork lifts, or a crane for disposing of waste containers. The base of the MegaTrench should allow for a minimum interior turning radius of at least $35 \mathrm{ft}$ for heavy equipment. The roadway leading into the Mega-Trench should be at least 30 feet wide with a 5\% grade and be designed to AASHTO HS-20 loads. The base of the MegaTrench should be sloped to move water runoff to a low point sump for collection and pumping (using a portable pump on an elevated surface). The Performance Category of the Mega-Trench is PC- 1 and shall be designed per the SRS Engineering Standards No.01110. The sump shall be designed to accommodate rainfall from a 6 hour -25 year storm event for third of the Mega-Trench area. The Mega-Trench floor should be used to accommodate the difference between the design storm event ( 24 hour - 500 year return period) and the 6 hour -25 year storm event. However, the depth of water at the trench bottom shall not exceed 2 feet of water to prevent waste containers from floating. The Mega-Trench side slope shall be designed with factor of safety of 1.5 against slope stability failure if site specific strength data is not available. If site specific strength data is obtained, a factor of safety less than 1.5 can be used. In no case shall the factor of safety against slope stability failure be less than 1.2. The sump should be able to be pumped out in 4 hours. A rigid pipe should be located near the pump to move water away from the sump and direct the water, at the top of the slope, toward the existing drainage ditch. In addition, the Mega-Trench should be provided with a small submersible non-clogging industrial pump. This pump should feed a sample station, located above the sump walls. This sample station should allow an operator to pull a sample off the discharge of the small pump. This station should provide a series of valves, which would allow the discharge water from the small pump to either be redirected back into the sump during the sampling process or direct the discharge water to prime the diesel engine driven pump and suction hose within 15 minutes. This small pump should be powered by a small gas generator located near the sampling station. The Mega-Trench walls should be sloped back to allow personnel to work safely at the base. Also, the sloped walls should be provided with erosion control features for keeping the walls intact. The life expectancy of the entire trench will be at least 20 years. The MegaTrench design should be reviewed by SRTC prior to issuance for potential impacts to the Performance Assessment. 

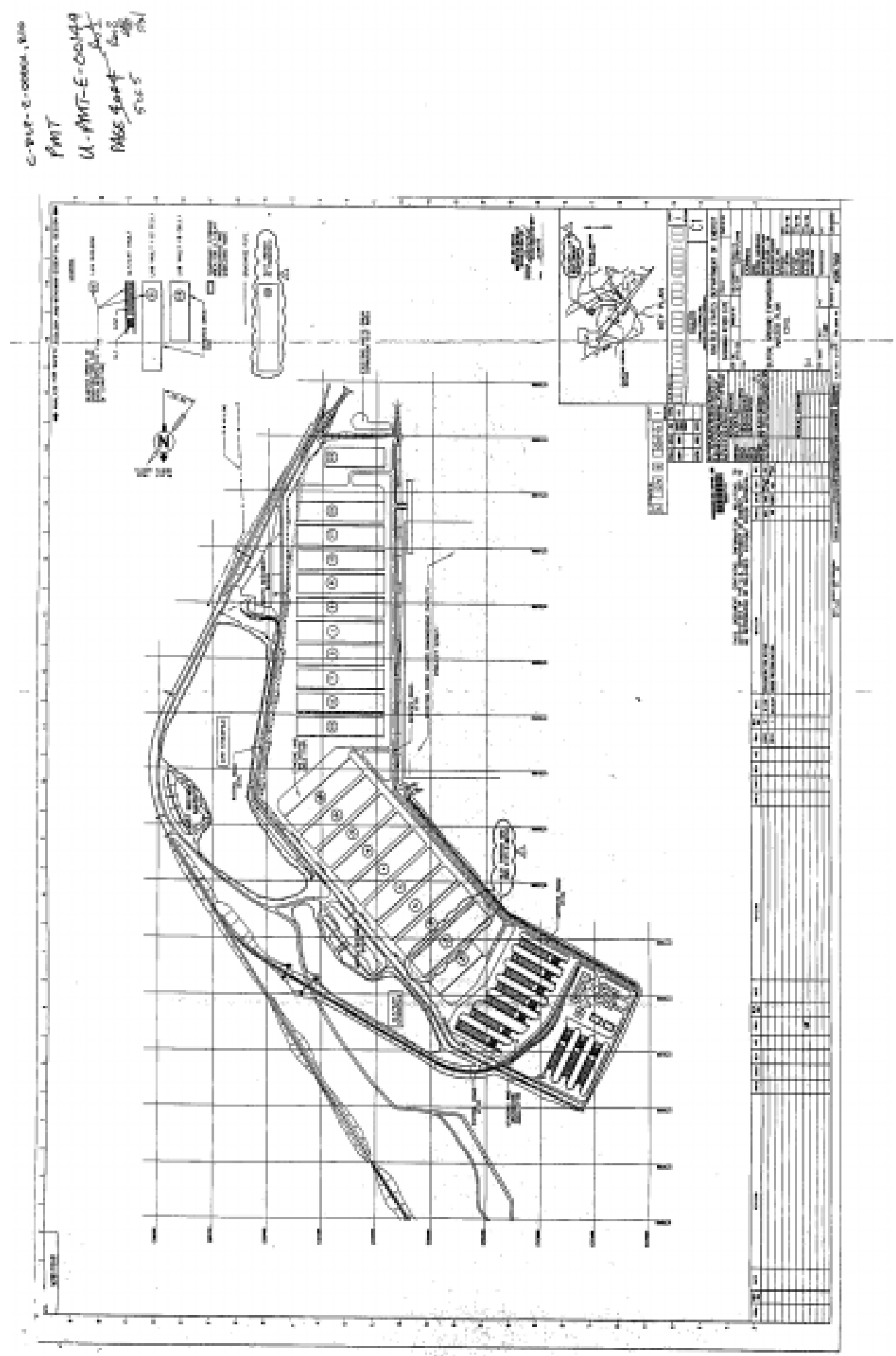

Page 66 of 298 
InterSol Engineering Inc.

C- DCP-E- $00001, R 10$ ATTACHMENT $B$

540 Moorelands Cr., Mitton, Ontario, Canada L9T 484

PAGE BI OF B6

Telfax: 905-875-1329

FAX TRANSMISSION SHEET

FAX \#

803-557-3323

DATE

July 18,2000

$\begin{aligned} \text { ATTENTION: } & \text { David Huizenga } \\ \text { Cc: } & \text { Vicki Ginter (Stable Soil Technologies) }\end{aligned}$

COMPANY:

FROM: Jamie Walls

MEMO:

No. of Pages (including this page) $=6$

Re: Savannah River Nuclear Site (\# ID549600079)

Per your fax to Andy Lister of this morning, please tind attached a preliminary design for a Geoweb stope cover for an $18 \mathrm{ft}$ high, 1:1 slope, on the above referenced project.

Based on the assumptions listed on the drawing, the driving force (due to gravity) and resisting shear lorce along the geotextile/soil interface of an $18 \mathrm{ft}$ high slope would be $902 \mathrm{lb} / \mathrm{ft}$ and $479 \mathrm{lb} / \mathrm{ft}$ respectively. Again considering the use of Presto TK-89 tendons a 6 tendon anchor system would provide an additional 'factored' resisting force up to $432 \mathrm{lb} / \mathrm{ft}$ : a $3 \mathrm{ft}$ horizontal crest embedment would provide a resisting force of $80 \mathrm{tb} / \mathrm{t}$ resulting in a required deadman anchorage of $422-80=342 \mathrm{lb} / \mathrm{tt}$. For the assumed trench backfitt soil properties, a 6 inch diameter pipe deadrian would require a $22 \mathrm{ft}$ embedment depith to develop a factor of safety against pullout greater than $15 \mathrm{~s}, \mathrm{t}$.

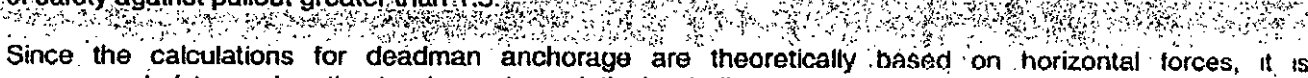
recommended to anchor the tendons at a relatively shallow angle of inclination. Typically, we use an inclination of $2 \mathrm{H}: 1 \mathrm{~V}$ to $1.5 \mathrm{H}: 1 \mathrm{~V}$. Assuming a $1.5 \mathrm{H}: 1 \mathrm{~V}$ inclination the offset distance from the top end of the Geoweb to the center of the pipe would be $2.66 \mathrm{ft}$.

The preliminary design is based on $4^{n}$ deep GW20V Geoweb sections. As drawn the cell dimensions are $8.9^{\prime \prime}$ by $10.2^{\prime \prime}$ resulting in 39 cell by 10 cell dimensions of $28.9 \mathrm{ft}$ by $8.5 \mathrm{ft}$ wide. Since the nearest section size produced by Presto is 40 cells long by 10 cells wide it will be necessary to reduce cell expansion from $8.9^{\prime \prime}$ to 8.67 " or incorporate the extra cell at the top or bottom of the system.

I trust that the prellminary design will be sufficient for your immediate project requirements. If you have any questions, or require additional information, please contact me. PS Part of your message may have been deleted or not reccived last week. Therefore, I did not know
who to return the call to. 


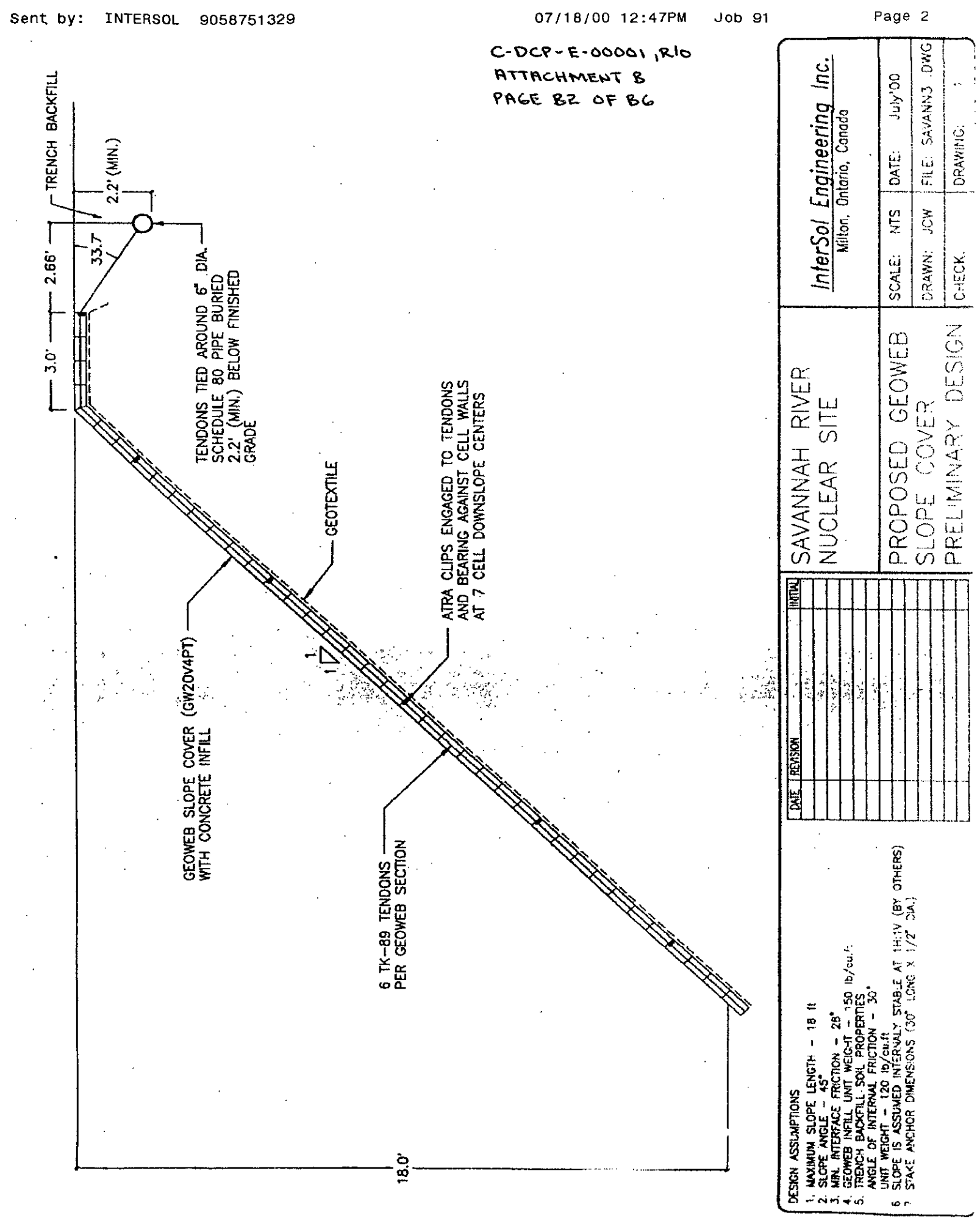


Sent by: INTERSOL 9058751329

WebCover - Version 1.2

Project:

Prepared by Savan JCW

English or Metric (E or M)

Slope Angle

Slope Length (ft)

Interface Friction (degrees)

Cell Size? 8 or 16 (in)

Web thickness (in.)

Infill Unit Weight (b/cu.ft.)

Additional Cover (in.)

Cover Unit Weight (lb/cu.ft.)

Design Factor of Safety

Tue Load (lb/fl)

Passive Resistance at toe ( $Y$ or $N)$

Angle of internal friction of soil at toe

Unit weight of soil at toe (lb/cu.ft)

Infill type

Tendon type

Factared Geoweb Tensile (lb/ft)

Driving Force (b/ti)

Factored Driving Force $(\mathrm{b} / \mathrm{ft})$

Factored Driving Force (b/ft)

Resisting Force $(\mathrm{lb} / \mathrm{ft})$

Passive Earth Force ( $(\mathrm{b} / \mathrm{ft})$

Available Resistance (b/ft)

$\therefore$ A

Factor of Safety

Maximum Available F.S.

STAKE (J-PIN) ANCHOR DETAILS

Net Driving (lb/sq.fi)

Max. Geoweb Length (ft)

Max. Downslope Spacing (in)

Length (in)

Diameter or Width (in)

Downslope Spacing (in)

Horizontal Spacing (in)

Soil Friction (degrees)

Soil Cohesion (tb/sq.ft)

Unit Weight (lb/cu.ft)

Kp (Coefficient)

Buried Stake Length (ft)

Stake Resistance (lb)

Number of Rows of Stakes

Stake Resistance $(\mathrm{lb} / \mathrm{t} t)$

Stake Resistance (lb/sq.ft)
07/18/00 12:48PM Job 91

Page 3
C-DCP-E-00001, R10

ATTACHMENT B

PAGE B3 OF BG

InterSol Engineering Inc

Date:

26-Apr-00

\begin{tabular}{|c|c|}
\hline \multicolumn{2}{|l|}{$E$} \\
\hline 45 & Slope $(H: V)$ \\
\hline 25.5 & 1.00 \\
\hline 28 & Vort, Height (ft) \\
\hline 8.9 & 18.0 \\
\hline 4 & Infill $W_{t}(\mathrm{lb} / \mathrm{ft})$ \\
\hline 150 & 1275.0 \\
\hline 0 & Cover $W_{t}(\mathrm{lb} / \mathrm{ft})$ \\
\hline 0 & 0.0 \\
\hline 1 & Total Wi $(\mid b / f t)$ \\
\hline $\begin{array}{l}0 \\
N\end{array}$ & 1275.0 \\
\hline 0 & \\
\hline 0 & \\
\hline te & \\
\hline
\end{tabular}

$\begin{aligned} 89.9 & \text { Uesign Tensile } \\ 901.6 & \text { Weight+Toe Load } \\ 901.6 & \text { Weight Only } \\ 901.6 & \text { Weight+Toe Load } \\ 479.4 & \text { Shear Only } \\ 0.0 & \\ 0.0 & \text { Geoweb } \\ 0.53 & \text { Shear + Passive } \\ 0.63 & \text { Anchored Geoweb }\end{aligned}$

$\begin{aligned} 16.56 & \text { Factored } \\ 5.4 & \text { Unrestrained }\end{aligned}$

65

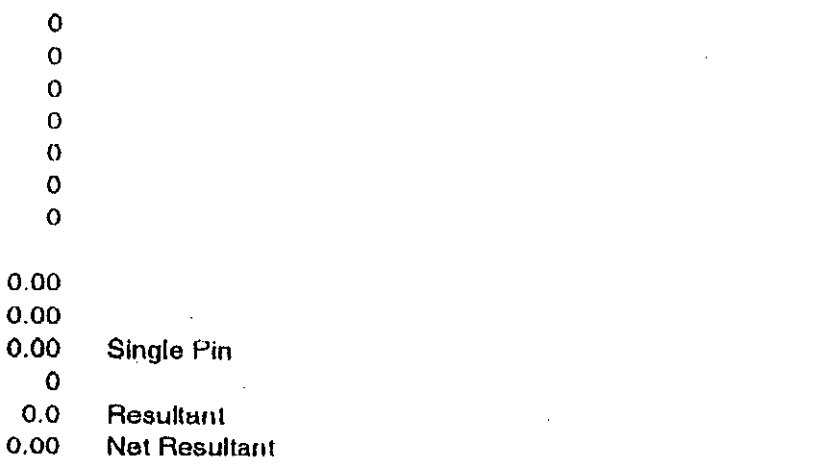


Sent by: INTERSOL 9058751329

Resisting Force $(\mathrm{lb} / \mathrm{ft})$

Faclor of Safety

Maximum Available F.S.

TENDONS

Required Tension (lb/ft)

Required Tension (lb/ft)

Ultimate Strength (lb)

r.s. (Creep)

F.S. (Knots)

F.S. (Construction damage)

F.S. (Chemical/Biological Durability)

F.S. (Overall Uncertainties)

Tendons Cenlers (in)

Tendons/Slot

Available TensionvSlot (lb)

Available Tension (lb/ft)

Factor of Safely

Max. Available F.S.

Max. Available F.S.

CREST/SLOPE ANCHORAGE

Required Arichorage (lb/ft)

$\therefore$ Hórizontal Embedment Length (ft)

Depth Below.Cirest (in)

Slope Angle of Key Trench (degrees)

Depth of Key Trench (in)

Horiz. Length at Botlom of Trench (in)

Soil Unit Weight (lb/cu.ft)

Soil Friction (degrees)

Available Resisting Force (lb/ft)

Available Crest Factor of Safety

Required Tendon/Deadman Anchorage

Available F.S. with deadman anchorage

SUMMARY OF TENDON REQUIREMENTS

Tendon/Geoweb Section (tt)

Tendon Density (ff/sq.ft)

SUMMARY OF PIN REQUIREMENTS

Stakes/Geoweb Section

Stake Density (pins/sq.ft)
$07 / 18 / 0012: 48 P M$ Job 91

C-DCP-E-00001, R1O

ATTACHMENT \&

479.4

Shear,Passive,Stakes

PAGE 84 OF 86

Shear,Passive,Stakes

0.63 Anchored Geoweb

332.3

422.2

Tendons + Geoweb tensile

Tendons only

2000

1.2

1.5

1.1

1.1

1.5

10.2

0.6

367.3

432.1

OK

0.53

1.11

1.01

Anchored GW \& Tendons

Anchored tendons only

422.2

ANCHORAGE REQUIRED

3. From Slope Face to Key Trench Bottom of Geoweb

Page 4 


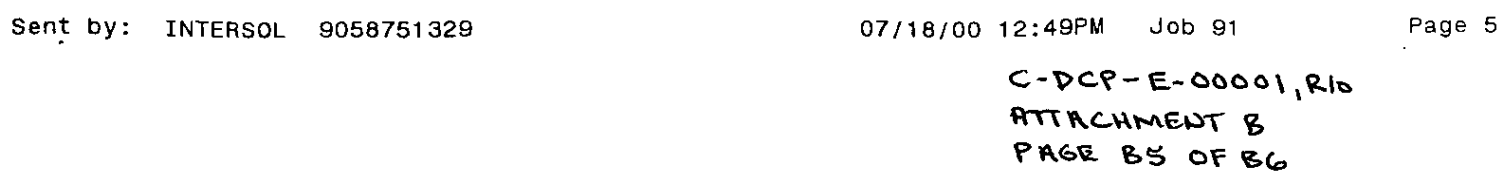

Deadman Anchorage in Granular Solls - Ovesun Method

English or Metric (E or $M)$

Required Anchorage

Height of Deadman, $h$

Width of Deadman, w

Unit weight of Deadman

Length of Deadman, I

Depth to base of Deadman; $\mathrm{H}$

Distance between conters, $L$

Friction angle - soil cover

Unil weight of soil cover

Deadman/Soil Friction

W- Weight of Deadman

$\mathrm{am}$

$\mathrm{Ka}$

$\mathrm{Ka}$

$\mathrm{Pa}$

Fa

$\mathrm{Kg} \quad$ Fig. $4 \mathrm{c} \quad \tan ($ delta $)=0.000$

Ro

E

B

A

Ault

Tult

Factor of Safety (Deadman)

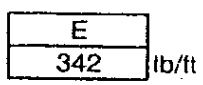

\begin{tabular}{|c|c|}
\hline 0.5 & $\mathrm{ft}$ \\
\hline 0.5 & $\mathrm{ft}$ \\
\hline 0 & $\mathrm{lb} / \mathrm{ft}$ \\
\hline 1 & $\mathrm{ft}$ \\
\hline 2.2 & $\mathrm{ft}$ \\
\hline 1 & $\mathrm{ft}$ \\
\hline 30 & $\mathrm{degrees}$ \\
\hline 120 & $\mathrm{lb} / \mathrm{b} \cdot \mathrm{ft}$ \\
\hline 0 & degrees \\
\hline
\end{tabular}

$0.00 \quad \mathrm{~b} / \mathrm{ft}$

234

0.333

290.4

96.8

$-55.9$

Chart Rankine Coulonts

$\begin{array}{lll}3.00 & 3.00 & 3.00\end{array}$

$\begin{array}{lll}2.67 & 2.67 & 2.67\end{array}$

$\begin{array}{lll}0.77 & 0.77 & 0.77\end{array}$

$\begin{array}{lll}0.00 & 0.00 & 0.00\end{array}$

$4.68, \quad 4.68 \quad 4.68$

$547.3: 547.3 \quad 547.3$

$547.3 \quad 547.3 \quad 547.3$

$\begin{array}{lll}1.60 & 1.60 & 1.60\end{array}$ 


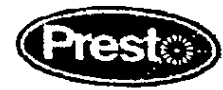

\section{GEOWEB(B) CELLULAR PAGE BG OF BG $\checkmark$ SERITS MATAR CONFINCMEN'T SIYSIIIM $\checkmark$ SERIES MATERIAL SPFCIFICATION}

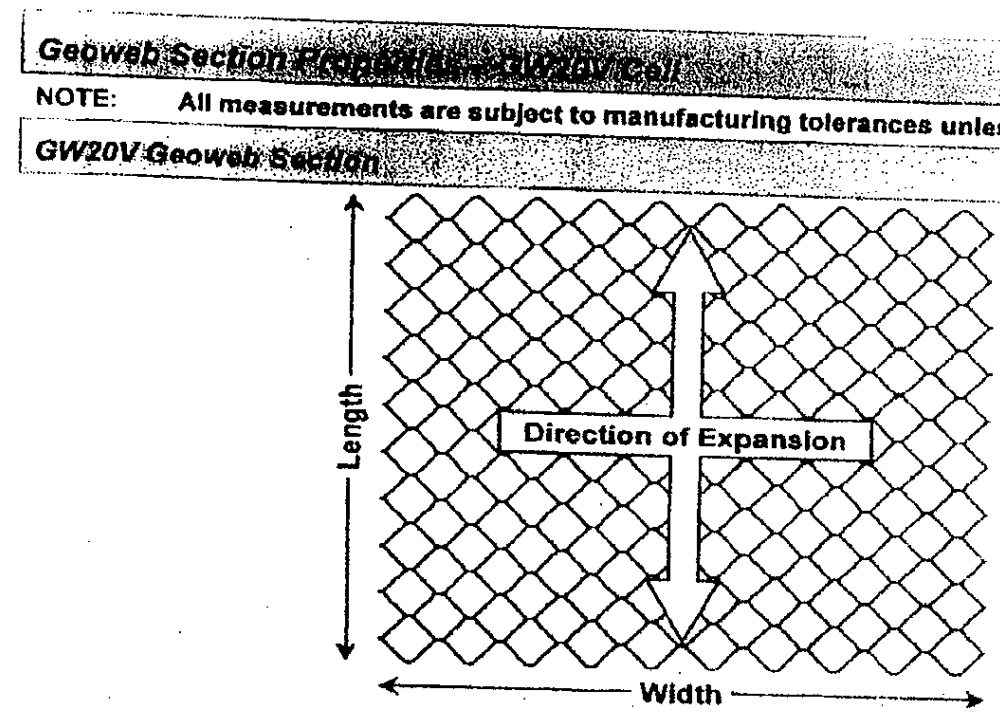

Figure 3 GWzov Geoweb Section

Presto Geoweb GW2OV section dimensions shall be as indicated in Figure 3 . Sections shall havet nomenclature of "GW2OVOWWLL" where "GW2OV" Indicates the cell size, "D" Indicates the cell depth if shall have expanded dimensions per cells wide, and " $L L$ " Indicates ltie number of cells long sections is GW20V8 to25 where the section cell tepte. An example of the GW20V Geoweb section nomenclaturt 25 cells in length.

\begin{tabular}{|c|c|c|c|c|c|c|c|c|c|c|}
\hline \multirow{3}{*}{$\begin{array}{c}\text { Cells } \\
\text { Long } \\
18\end{array}$} & \multicolumn{4}{|c|}{$\begin{array}{l}\text { Minimum Expansion } \\
\text { Length }\end{array}$} & \multicolumn{4}{|c|}{$\begin{array}{l}\text { Maxlmum Expansion } \\
\text { Length }\end{array}$} & \multicolumn{2}{|c|}{$\begin{array}{l}\text { Nominal } \\
\text { Area }\end{array}$} \\
\hline & 37 & $\frac{11}{120}$ & $\frac{m}{2}$ & ti & $\underline{\mathbf{m}}$ & ff & $\mathbf{m}$ & $f t$ & $\mathbf{m}^{\prime}$ & $\mathrm{te}$ \\
\hline & 47 & 12.0 & 2.8 & 9.2 & 4.4 & 14.5 & 23 & 7.7 & 10.4 & 113 \\
\hline 27 & 4.3 & 14.0 & & & 51 & 16.9 & & & 121 & I: \\
\hline 25 & 51 & 16.7 & & & 6.1 & 20,1 & & & $14 \therefore$ & 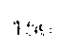 \\
\hline 29 & 59 & 19.4 & & & 7.1 & 233 & & & $16 t$ & $19:$ \\
\hline 34 & 69 & 22.7 & & & 83 & 27.3 & & & 101 & $\therefore$ \\
\hline 40 & 81 & 26.7 & & & 9.8 & 322 & & & 231 & , \\
\hline
\end{tabular}


Calculation Sheet

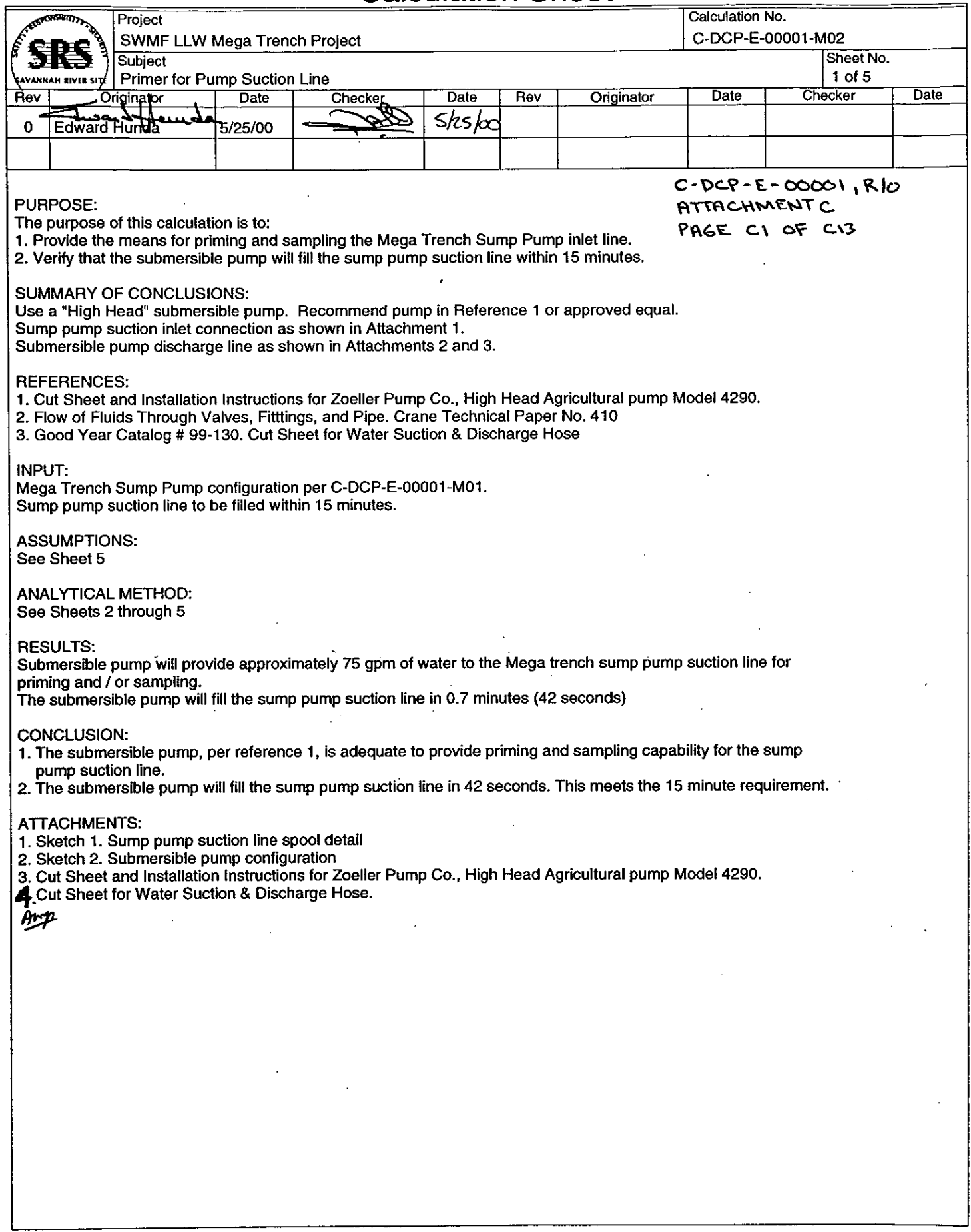


SWMF LLW Mega Trench Project

Primer Pump
C-DCP-E-00001-M02
Revision 0

Page 2 of 5

$C-D C P-E-00001, R I O$

ATTACHMENT $C$

PAGE CL OF CI3
Note: Pump flow is determined by iteration. Match flow rate with total dynamic head $(\mathrm{Ht})$ in pump curve (Attachment 3 ).

Flow $:=75 \quad$ gpm

Hose size: $2^{n}$

$\mathrm{Q}:=\frac{\text { Flow }}{7.481}$

$\mathrm{q}:=\frac{\mathrm{Q}}{60}$

$\mathbf{d}_{\mathrm{i}}:=2$

$\mathrm{D}_{\mathrm{i}}:=\frac{\mathrm{d}_{\mathrm{i}}}{12}$

$\mathrm{A}:=\pi \cdot \frac{\mathrm{D}_{\mathrm{i}}^{2}}{4}$

Fluid velocity:

$\mathbf{v}:=\frac{\mathrm{q}}{\mathrm{A}}$

or $\quad v=7.659 \quad \frac{\mathrm{ft}}{\mathrm{sec}}$

$h_{d}:=20$

Properties for water at standard conditions:

$\rho:=62.3$

$$
\frac{\mathrm{lb}}{\mathrm{ft}^{3}}
$$

$\mu:=.95$

centipoise
Reference 1

Reference 2

Reference 1

vertical elevation $(f t)$

Reynolds number:

$\operatorname{Re}:=123.9 \cdot \frac{d_{j} \cdot v \cdot p}{\mu}$

or $\quad \operatorname{Re}=1.245 \times 10^{5}$

Reference 2

$f_{h}:=0.0305$

Reference 2 \& Assumption 1

$\mathrm{g}_{\mathrm{c}} \equiv 32.2$ 
SWMF LLW Mega Trench Project

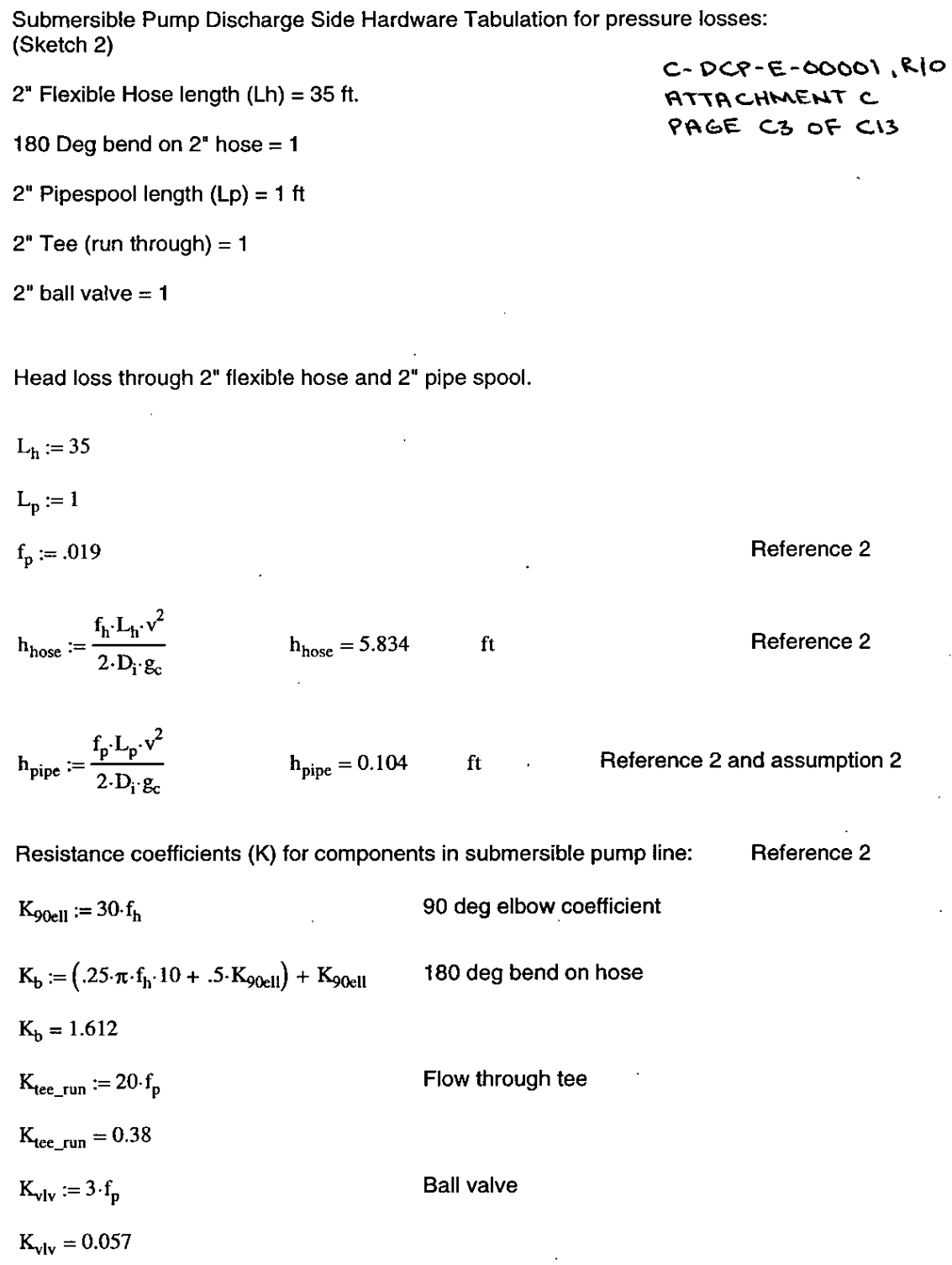


SWMF LLW Mega Trench Project

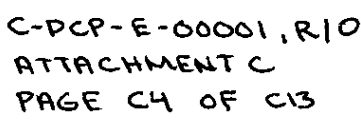

$\mathrm{h}_{\mathrm{b}}:=\mathrm{K}_{\mathrm{b}} \cdot \frac{\mathrm{v}^{2}}{2 \cdot \mathrm{g}_{\mathrm{r}}}$

$h_{b}=1.468$

ft

180 deg bend on hose

$h_{\text {tee }}:=K_{\text {lee_run }} \cdot \frac{v^{2}}{2 \cdot g_{c}}$

$\mathrm{h}_{\text {tee }}=0.346$

$\mathrm{ft}$

Flow through tee

$\mathrm{h}_{\mathrm{vlv}}:=\mathrm{K}_{\mathrm{vlv}} \cdot \frac{\mathrm{v}^{2}}{2 \cdot \mathrm{g}_{\mathrm{c}}}$

$\mathrm{h}_{\mathrm{vlv}}=0.052$

$\mathrm{ft}$

Ball valve

Head loss through line

$h_{\text {dyn }}:=h_{\text {hose }}+h_{\text {pipe }}+h_{b}+h_{\text {tee }}+h_{\text {vlv }}$

$\mathfrak{h}_{\text {dyn }}=7.804 \quad \mathrm{ft}$

Total discharge head loss

$H_{t}:=h_{d}+h_{d y n} \quad$ or

$\mathrm{H}_{\mathrm{t}}=27.8 \quad \mathrm{ft}$

SUMP PUMP SUCTION LINE FILL TIME CALCULATION

Suction Line Cross sectional area:

$\mathrm{A}_{\text {suc }}:=.2 \mathrm{ft}^{2}$ C-DCP-E-00001-M01

Suction Line total length:

$\mathrm{L}_{\mathrm{suc}}:=35 \mathrm{ft}$

Suction line volume

$\mathrm{V}_{\text {suc }}:=\mathrm{A}_{\text {suc }} \cdot \mathrm{L}_{\text {suc }}$ or $\quad \mathrm{V}_{\text {suc }}=7 \quad \mathrm{ft}^{3}$

Suction line volume conversion to gallons. Use 7.48 galions per cubic foot.

$\mathrm{V}_{\text {suc_gal }}:=\mathrm{V}_{\text {suc }} \cdot 7.4$ or $\quad \mathrm{V}_{\text {suc_gal }}=52.36 \quad$ gallons

Pump flow

Flow $=75 \quad$ gallons per minute 
SWMF LLW Mega Trench Project Primer Pump

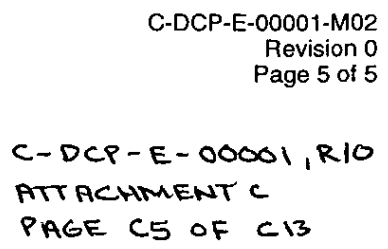

$$
\begin{aligned}
& t_{\text {fill }}:=\frac{V_{\text {suc_gal }}}{\text { Flow }} \text { minutes } \\
& t_{\text {fill }}=0.698 \quad \text { minutes }
\end{aligned}
$$

\section{RESULTS}

Submersible pump will provide approximately $75 \mathrm{gpm}$ of water to the Mega Trench sump pump suction line for priming and or sampling.

Submersible pump will fill the sump pump suction line in 0.7 minutes (42 seconds)

See Attachment 1 for sump pump inlet spool detail.

See Attachments 2 and 3 for submersible pump configuration and details.

\section{ASSUMPTIONS}

1. Relative roughness for hose material to be equivalent to cast iron. This will result in conservative values for flow calculations

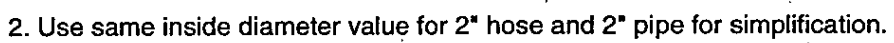
The difference ( $2^{\prime \prime}$ for hose and $2.067^{\prime \prime}$ for pipe) is inconsequential for this calculation. 


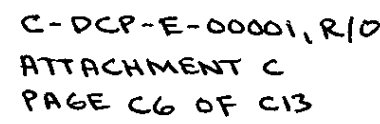

PAGE CG OF CI3

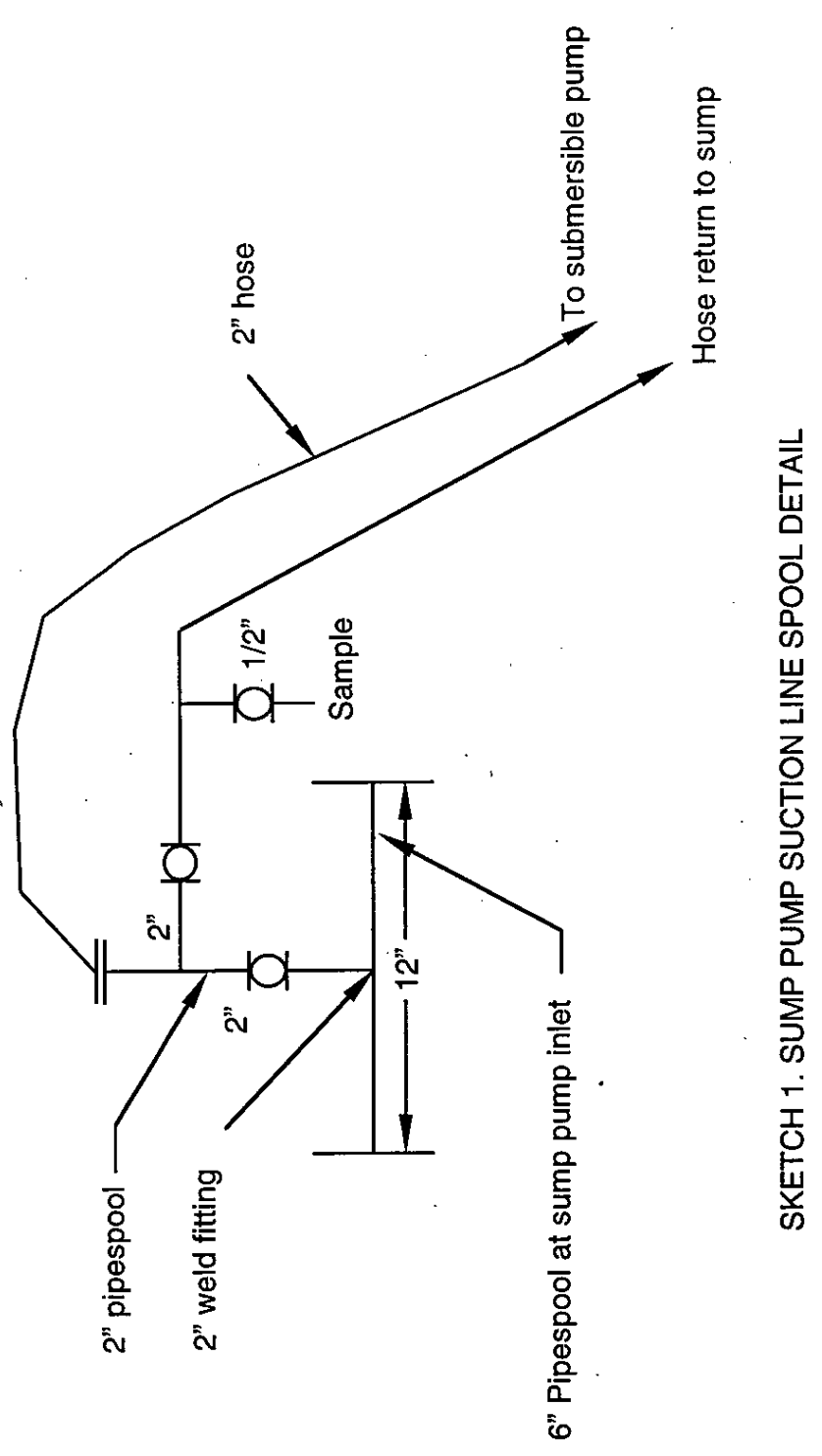

Page 78 of 298 


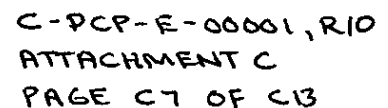

PAGE CI OF $C 13$
C-DCP-E-00001-M02
Revision 0
Attachment 2
Page 1 of 1

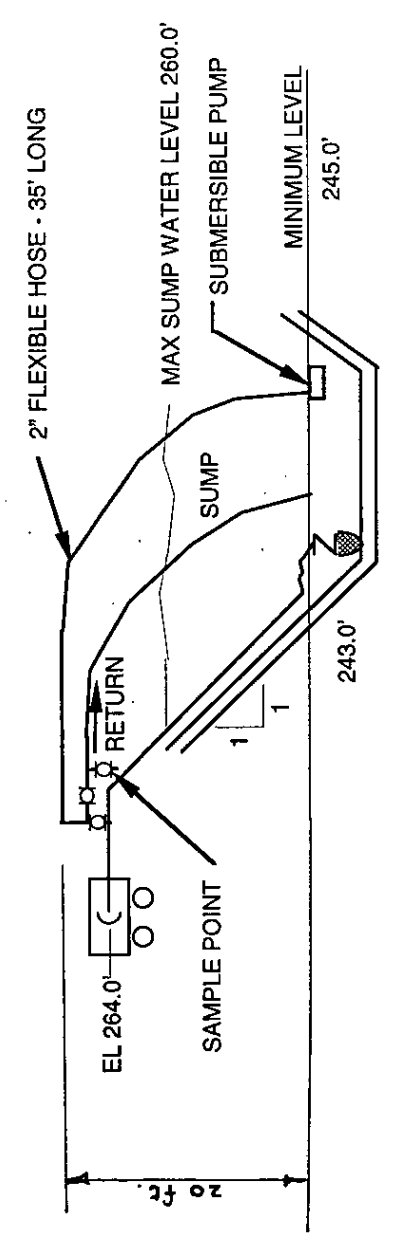

Page 79 of 298 
"QUALITV PLMAS SINEE 1939"
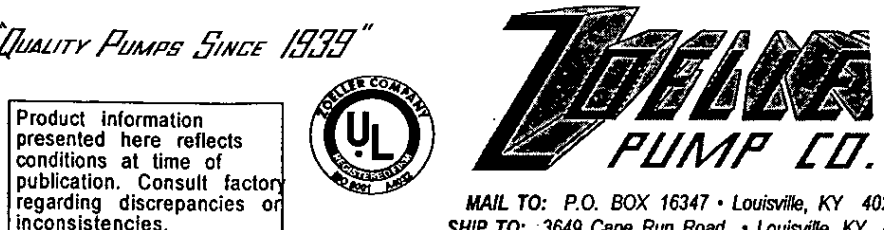

MAIL TO: P.O. BOX 16347 - Louisville, $K Y$ 40256-0347 SHIP TO: -3649 Cane Run Road • Louisville, KY 40211-1961 (502) 778-2731 - 1. (800) 928-PUMP - FAX (502) 774-3624

\section{COMPARE THESE FEATURES}

- Non-Clogging vortex impeller.

- Passes 11/2" spherical solids.

- Available with $2^{n}$ or $3^{n}$ NPT vertical flange discharge.

- Durable cast iron construction with stainless steel screws and handle.

- Corrosion resistant powder coated epoxy finith

- 50' UL listed neoprene jacketed power cable. Extra lengths, $75-100 \mathrm{ft}$ available.

- Motor - 230V, 60Hz, 3450 RPM, 1 HP (4290), 2 HP (4291), oil-filled, hermetically sealed, thermal overload protection with automatic reset.

- Available in both $1 \& 3$ Phase.

- Maximum operating temp. $130^{\circ} \mathrm{F}\left(54^{\circ} \mathrm{C}\right)$.

- Shaft Seals - Carbon and ceramic.

- Neoprene gaskets and seals.

- Double shaft seals provides extra protection for motor.

- Large clearances to prevent stoppage from build up of solids.

- Pump flotation devices available for Lagoon installations. (See FM1473)

- Width 12 7/8", Height 20 1/2".

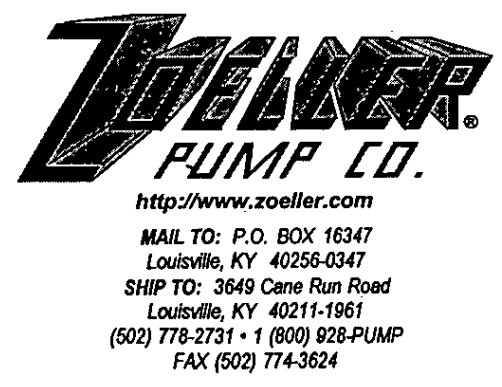

(20).

"ZuALITY PLNDS SINCE 1939"

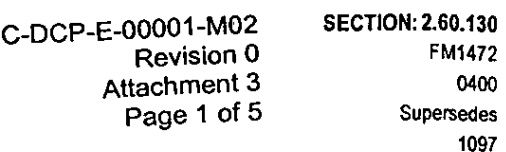

visit our web site: http://www.zoel/er.com C-DCP-E-00001,R10 ATTACHMENT C PAGE CB OF CI3

4290 - 4291 Double Seal Series

(For Pump Prefix Identification see News \& Views 0052) HIGH HEAD

\section{"AGRICULTURAL"}

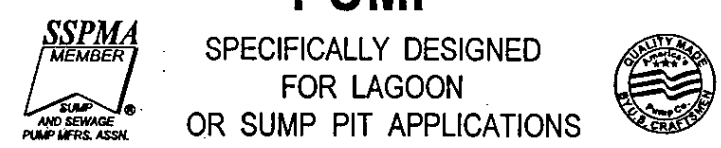

OR SUMP PIT APPLICATIONS

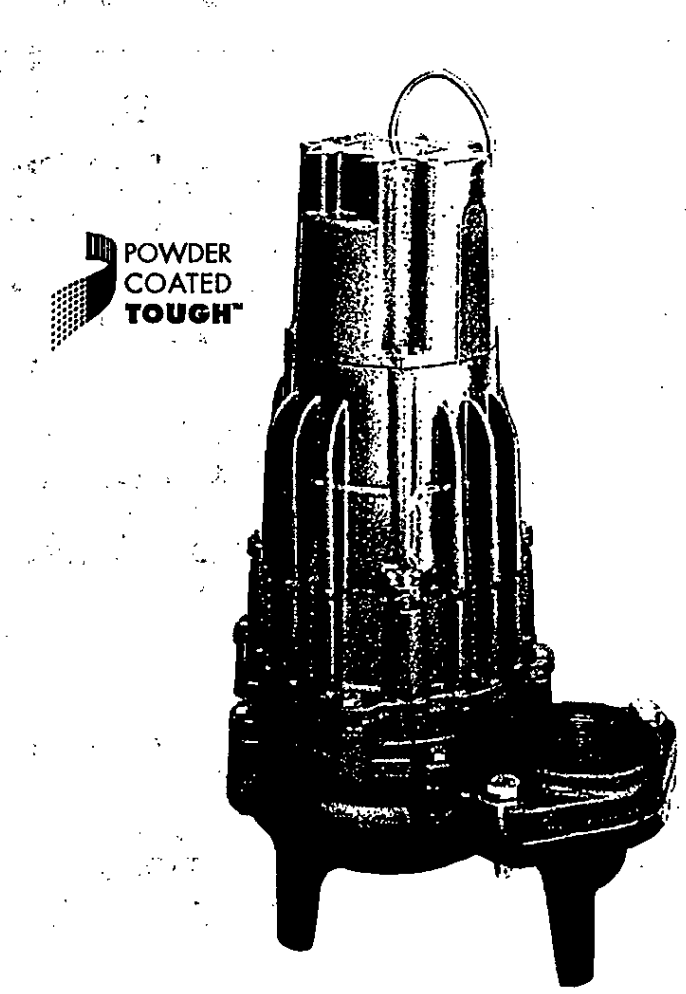

Copyright 2000 Zoeller Co. All rights reserved. 
"ZuALITr PuMPS SINCE 1939"

Product information presented here reflects

conditions at time of

publication. Consult factory

regarding discrepancies or

inconsistencies.
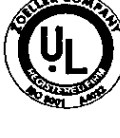

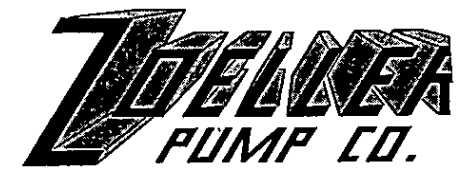

MAlL TO: P.O. BOX 16347 • Louisville, KY 40256-0347 SHIP TO: 3649 Cane Run Road + Louisville, KY 40211-1961 (502) $778-2731$ - 1 (800) 928-PUMP + FAX (502) 774-3624

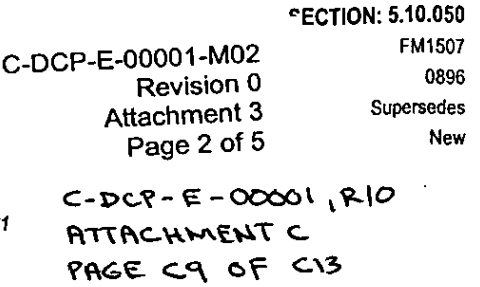

AGRICULTURAL PONTOON \& ACCESSORIES SPECIFICATIONS
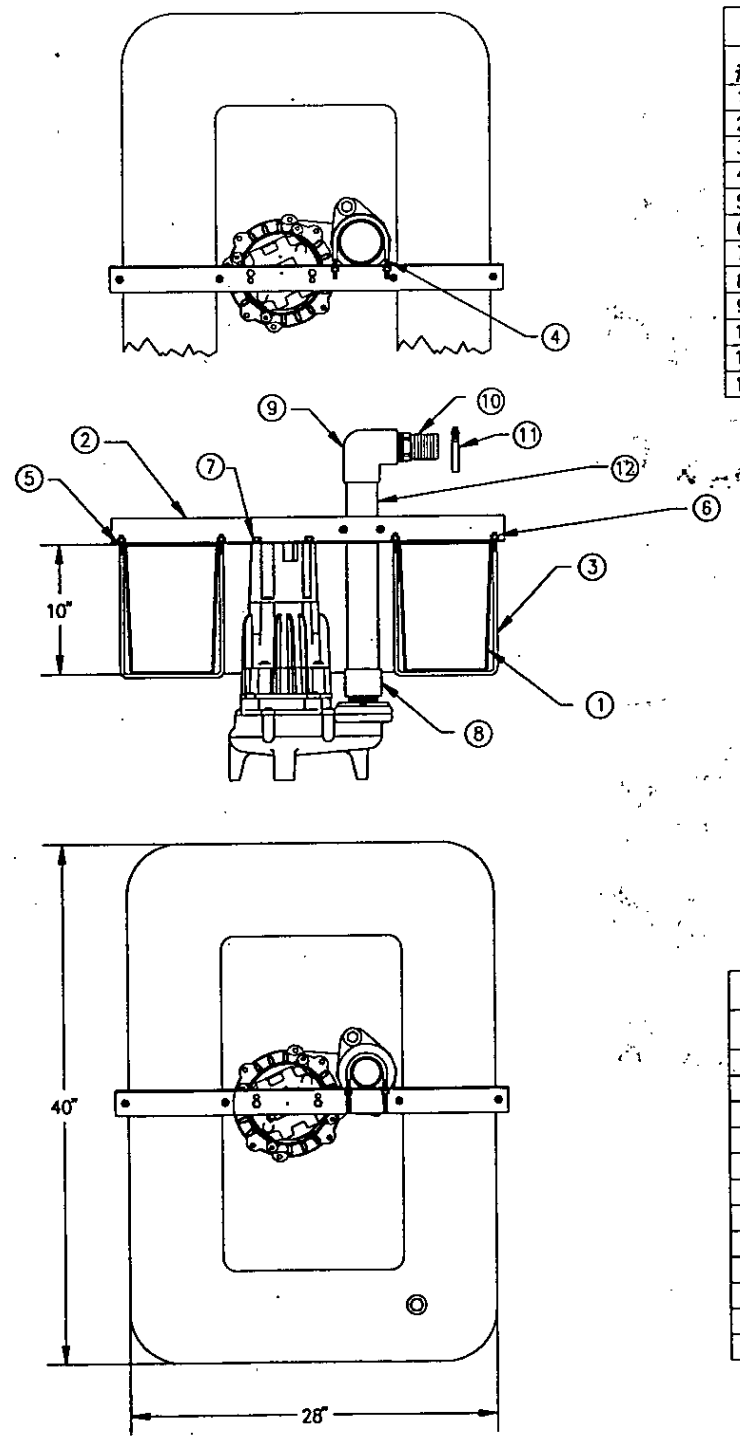
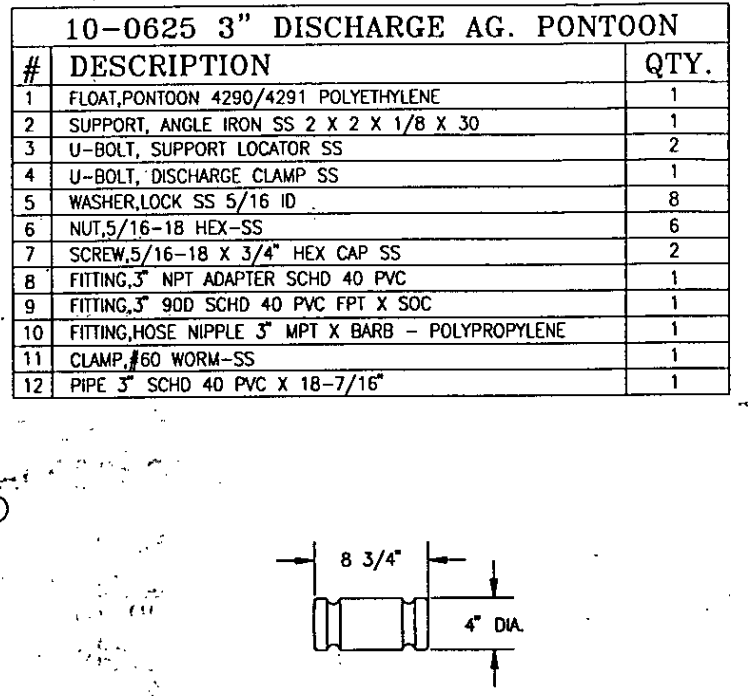

\begin{tabular}{|c|c|}
\hline 10-0631 AG. HOS] & \\
\hline DESCRIPTION & QTY \\
\hline 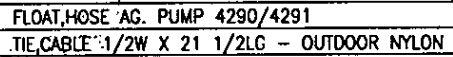 & 8 \\
\hline
\end{tabular}

\begin{tabular}{|c|c|c|}
\hline \multicolumn{3}{|c|}{ 10-0624 2" DISCHARGE AG. PONTOON } \\
\hline$\#$ & DESCRIPTION & QTY. \\
\hline 4 & FLOAT,PONIOON 4290/4291 POLYETHYLENE & 1 \\
\hline 2 & SUPPORI, ANGLE IRON SS $2 \times 2 \times 1 / 8 \times 30$ & 1 \\
\hline$\overline{3}$ & U-BOLT, SUPPORT LOCATOR SS & $\overline{2}$ \\
\hline 4 & U-BOLT, DISCHARGE CLAMP SS & 1 \\
\hline 5 & WASHER,LOCK SS $5 / 16^{n}$ & 8 \\
\hline 6 & NUT.5/16-18 HEX-SS & 6 \\
\hline 7 & SCREW $.5 / 16-18 \times 3 / 4^{*}$ HEX CAP SS & $\overline{2}$ \\
\hline 8 & FITTING, $2^{2}$ NPT ADAPTER SCHD. 40 PVC & 1 \\
\hline 9 & FITING,2" 900 SCHO 40 PVC FPI $\times$ SOC & 1 \\
\hline 10 & FITING,HOSE NIPPLE $2 *$ MPT $\times$ BARB - POLYPROPYLENE & 1 \\
\hline 11 & CLAMP, 136 WORM-SS & 1 \\
\hline 12 & PIPE, 2 SCHD 40 PVC $\times 18-7 / 16$ & 1 \\
\hline
\end{tabular}

SK1653 
Fig. 1

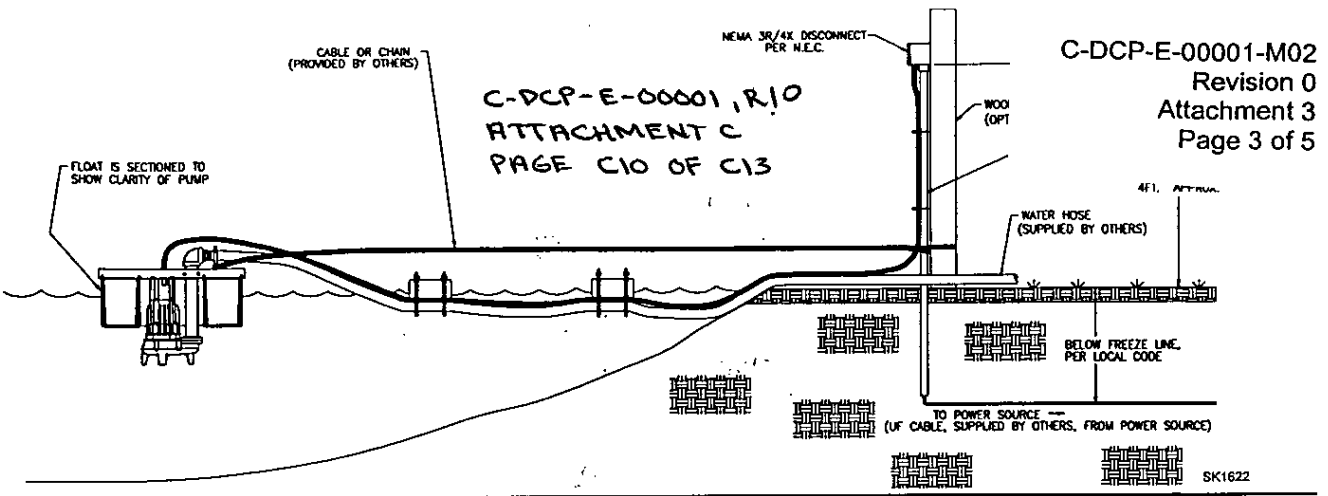

\section{TYPICAL LAGOON INSTALLATION}

(1) Electrical wiring and enclosures must be in accordance with the $\mathrm{Na}$ tional Electrical Code, and any other applicable state and local electrical requirements.

(2) Secure power cord on both ends. Tie off at the pontoon and strap rigidly to the pole support below the wiring enclosure.

(3) Connect flexible pipe to pump discharge using stainless steel hose clamp. Instali pipe floats approximately 10 feet apart to ensure flotation.

(4) The pipe floats can also be used to support the power cable if the wiring terminal box and discharge pipe connection are located in the same area. If wiring terminal box is located in a different area, separate floats may be required to prevent power cable from drooping and entanglement with lagoon debris.

(5) Three phase pumps require motor starters. Refer to Zoeller FMO825 :-

(6) Voltage at the terminal point of the power supply line must be $90 \%$ or greater than the motor rated voltage when pump is running. Ex. 200 $208 \mathrm{~V}$ pumps must have $180 / 187 \mathrm{~V}$ at the termination point (terminal box). $230 \mathrm{~V}$ pumps must have $207 \mathrm{~V}$ at the termination point. These voltages are required for proper motor operations and to avoid overheating and motor damage. See Fig. 2 for guide on wire size to avoid excessive voltage drops in the power supply line.

(7) If the power source for the terminal box connection is located at some distance away, the guideline in Fig. 2 must be followed to help assure, the required voltage at the terminal box.

(8) Do not use plug caps and receptacles. Use rigid connection with proper fuses and/or circuit breakers with strain relief on poweri cable at entry to the enclosure.

(9) Pump must be mounted no more than 10 degrees from vertical and secured to prevent torquing. Use Zoeller Pontoon assembly P/N 10 0624 for $2^{n}$ discharge, or $10-0625$ for $3^{n}$ discharge requirements.

(10) Pump must operate with motor and pump housing totally submerged

Fig. 3

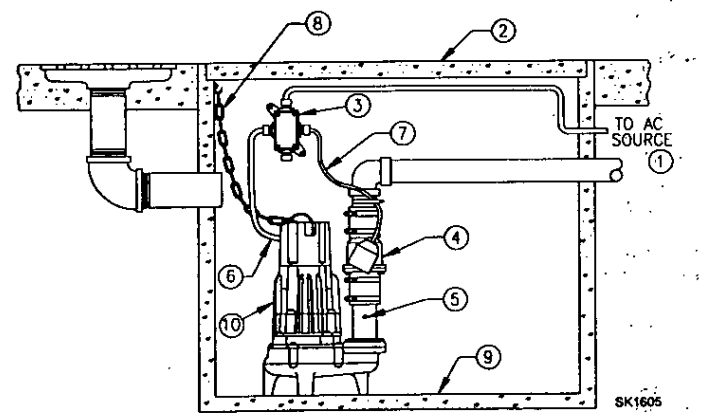

in the water for adequate cooling. Zoeller Pontoon P/N 10-0624/ 10-0625 and hardware will assure proper depth of submersion.

(11) Do not attempt to locate the pump pontoon by pulling on the power cord. Install a chain, flexible cable or plastic rope for this purpose.

(12) Agriculture pumps are designed for pumping water with a maximum of $3 \%$ solids up to $1 \frac{1}{2} 2^{\prime \prime}$ in particle size. Addition of make up water and lagoon maintenance is required for trouble free pump operation.

(13) Agriculture pumps are subject to calcium, lime or salt build up. Pump must be de-scaled on a regular maintenance schedule to prevent clogging and overheating of motors. The addition of chemlcals In flush tanks and make up water is essential for controlling the ammonia in the wash down water and subsequent scaling of pumps in the lagoon.

(14) First, second and third generation lagoons and lagoons for nurseries and farrowing houses will require different maintenance schedules. and farrowing houses will require different maintenance schedules. Normally pumps will require de-scaling quarterly. This schedule will vary with size of lagoon, make up water and the chemicals used for
control. It will be necessary to establish a pump maintenance schedute for each application from observation of scale build up.

Failure to provide this routine maintenance may void pump warranty.

Fig. 2

\begin{tabular}{|c|c|c|c|c|c|}
\hline \multirow{3}{*}{ AWG, } & \multicolumn{5}{|c|}{ MAXIMUM LENGTH OF WRE - FT. } \\
\cline { 2 - 6 } WURE SlZZE & \multicolumn{5}{|c|}{ PUMP VOLTAGES } \\
\cline { 2 - 6 } & $208 \mathrm{~V}-1 \mathrm{PH}$ & $230 \mathrm{~V}-1 \mathrm{PH}$ & $208 \mathrm{~V}-3 \mathrm{PH}$ & $230 \mathrm{~V}-3 \mathrm{PH}$ & $460 \mathrm{~V}-3 \mathrm{PH}$ \\
\hline 12 & 120 & 150 & 160 & 220 & 800 \\
$10 \ldots$ & 210 & 280 & 370 & 400 & 1500 \\
8 & 330 & 450 & 900 & 740 & - \\
6 & 550 & 620 & 900 & 1100 & - \\
\hline
\end{tabular}

\section{PIT SYSTEMS}

(1) Electric wiring and protection must be in accordance with the $\mathrm{Na}$ tional.Electric code and any other applicable state and local electrical codes.

(2) All instaliations require a basin cover to prevent debris from falling into the basin and to minimize the possibility of accidental injury.

(3) Wire pump to power source through a Zoeller J-Box P/N 10-0002, watertight junction box in accordance with the National Electrical code. (See FM0513)

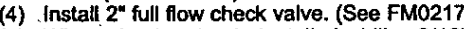

(5). When check valve is installed, drill a $3 / 16^{\prime \prime}$ diameter hole in the discharge pipe below the check valve. The hole is necessary to avoid Bir lock of the pump on start-up.

(6) Secure power cord to avoid entanglement with the float switch

(7) Pump must be level and the tethered float switch must be free and not -held up on the pump apparatus or pit pecullarities and is secured so that the pump will shut off at the proper level.

(8) Chain oricable should be Installed for removing pump from the pit.

(8) Chain or cable should be Installed for removing pump from

(10) Purnp must be de-scaled when used for pumping water containing animal waste. A regular maintenance schedule, minimum of three months, is required based on condition of water and cheml cal used for controlling the bulld up of ammonia.

Fallure to provide this routine malntenance may vold pump warranty.

(c) Copyright 1998 Zoeller $\mathrm{Co}$. All rights reserved. 

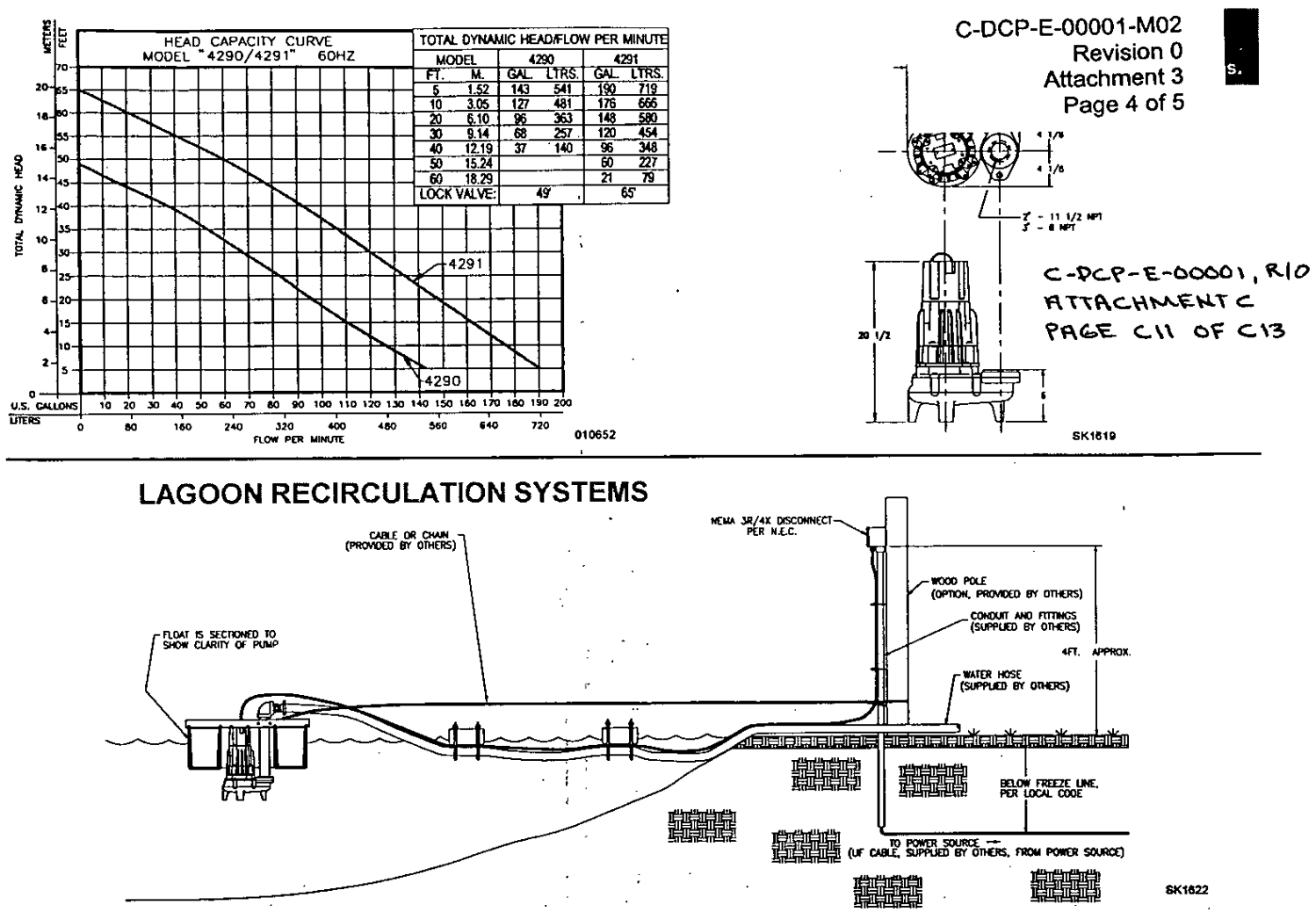

PIT SYSTEMS

Pump Pontoons (See FM1 507 for Specs.)

PIN 10-0624 Pontoon and hardware kit for connection to 2 discharge conduit.

P/N 10-0625 Pontoon and hardware kit for connection to $3^{*}$ discharge conduit.

Pipe Floats

P/N 10-0631 Inciudes four floats with nylon pipe straps.

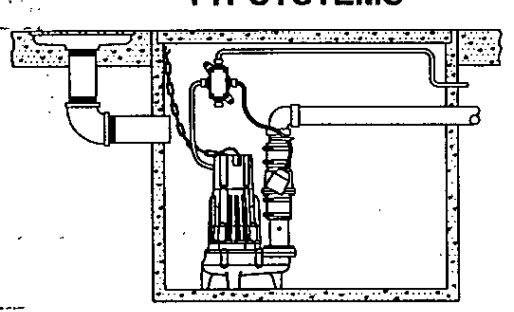

sk1805

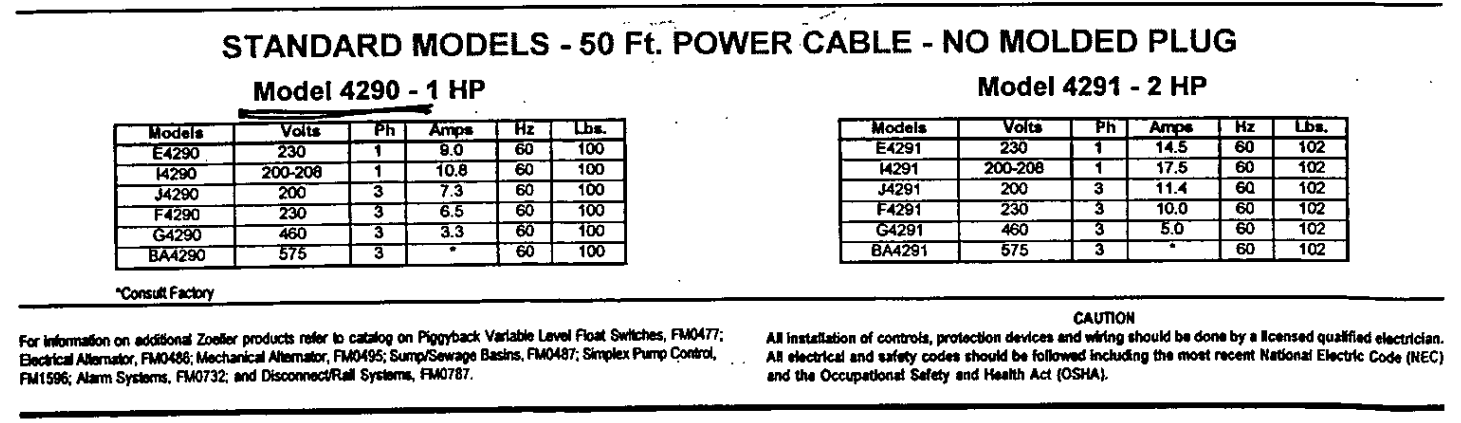

\section{RESERVE POWERED DESIGN}

For unusual conditions a reserve safety factor is engineered into the design of every Zoeller pump.

- Copyright 2000 Zoeller Co. All rights reserved. 


EASY DO'S \& DON'T'S FOR INSTALLING AGRICULTURAL P
1. DO read thoroughly all installation material provided with the pump.
2. DO inspect pump for any visible damage caused by shipping. Contact dealer if pump ap
3. DO clean all debris from sumps. Be sure that the pump will have a hard, flat surface beneath it.
DO NOT install on sand, gravel or dirt.
4. DO be sure that the sump is large enough to allow proper clearance for the level control switch(es) to operate
properly.
5. DO make certain pump is mounted on pontoon properly for lagoon
applications
6. DO Always Disconnect Pump From Power Source Before Handling.
DO always connect to a separately protected and properly grounded circuit.
DO NOT ever cut, splice, or damage power cord.
DO NOT carry or lift pump by its power cord.
DO NOT use an extension cord with a submersible pump.
7. DO install a check valve and a union in the discharge.line for pit applications.
DO NOT use a discharge pipe smaller than the pump discharge.
8. DONOT use a submersible pumpas a trench or excavation pump, or for pumping gasolineor otherhazardous
liquids.
9. DO test pump immediately after installation to be sure that the system is working properly.
10. DO cover pit with an adequate pit cover.
11. DO review all applicable local and national codes and verify that the installation conforms to each of them.
12. DO consult manufacturer for clarifications or questions.
13. DO consider a Two PumpSystem with an alarm (See FM0532) where an installation may become overloaded
or primary pump failure would result in property damages.

The following will help assure longer pump life. If not completed or checked when pump is installed, the Limited warranty may be affected.

A. The voltage at the supply cord termination point must be $90 \%$ or greater than motor rated voltage when pump is running. B. The power cord must be terminated in a NEMA 3R' or $4 X$ disconnect box per the NEC.

C. Pump must be mounted within 10 degrees of vertical.

D. Pump must be anchored to stop torquing while running, starting or stopping, relative to the float or anchor point.

E. Pump must be under water at all times and pump fluids with less than $3 \%$ solids.

G. The pump must be maintained on a regular basis. (De-scaled regülarly to prevent deposits from stalling unit).

\section{LIMITED WARRANTY'}

Zoeller Pump Company warrants, to the purchaser and subsequent owner during the warranty period, every new Zoeller Pump Company product to be free from defects in material and workmanship under normal use and service, when properly installed, used and maintained, for a period of one year from date of instaliation or 18 months from date of manufacturer, whichẹver comes first. Parts that fail, (within one year of installation or 18 months of manufacturer, whichever comes first) that inspections determine to be defective in material or workmanship, will be repaired, replaced or remanufactured at Zoeller Pump Company's option, provided however, that by so doing we will not be obligated to replace an entire assembly, the entire mechanism or the complete unit. No allowance will be made for shipping charges, damages, labor or other charges that may occur due to product failure, repair or replacement.

This warranty does not apply to any material that has been disassembled without prior approval of Zoeller Pump Company. subjected to misuse, misapplication, neglect, alteration, accident or act of God; that has not been installed, operated or maintained in accordance with Zoeller Pump Company installation instructions; that has been exposed to but not limited to the following: sand, gravel, cement, mud, tar, hydrocarbons or hydrocarbon derivatives (oil, gasoline, solvents, etc), wash towels or feminine sanitary products, etc. or other abrasive or corrosive substances.

This warranty is in lieu of all other warranties expressed or implied; and we do not authorize any representative or other person to assume for us any other liability in connection with our products.

Contact Zoeller Pump Company, 3649 Cane Run Road, Louisville, Kentucky 40211-1961, Attention: Customer Service Department to obtain any needed repair or replacement of part(s) or additional înformation pertaining to our warranty.

ZOELLER PUMP COMPANY EXPRESSLY DISCLAIMS LIABILITY FOR SPÉCIAL, CONSEQUENTIAL OR INCIDENTAL DAMAGES ORBREACH OF EXPRESSED ORIMPLIED WARRANTY AND ANY IMPLIED WARRANTY OF FITNESS FORA PARTICULAR PURPOSE AND OF MERCHANTABILITY SHALL BE LIMITED TO THE DURATION OF THE EXPRESSED WARRANTY.

Some states do not allow limitations on the duration of an implied warranty. so the above limitation may not apply to you. Some states do not allow the exclusion or limitation of incidental or consequential damages, so the above limitation or exclusion may not apply to you.

This warranty gives you specific legal rights and you may also have other rights which vary from state to state. 


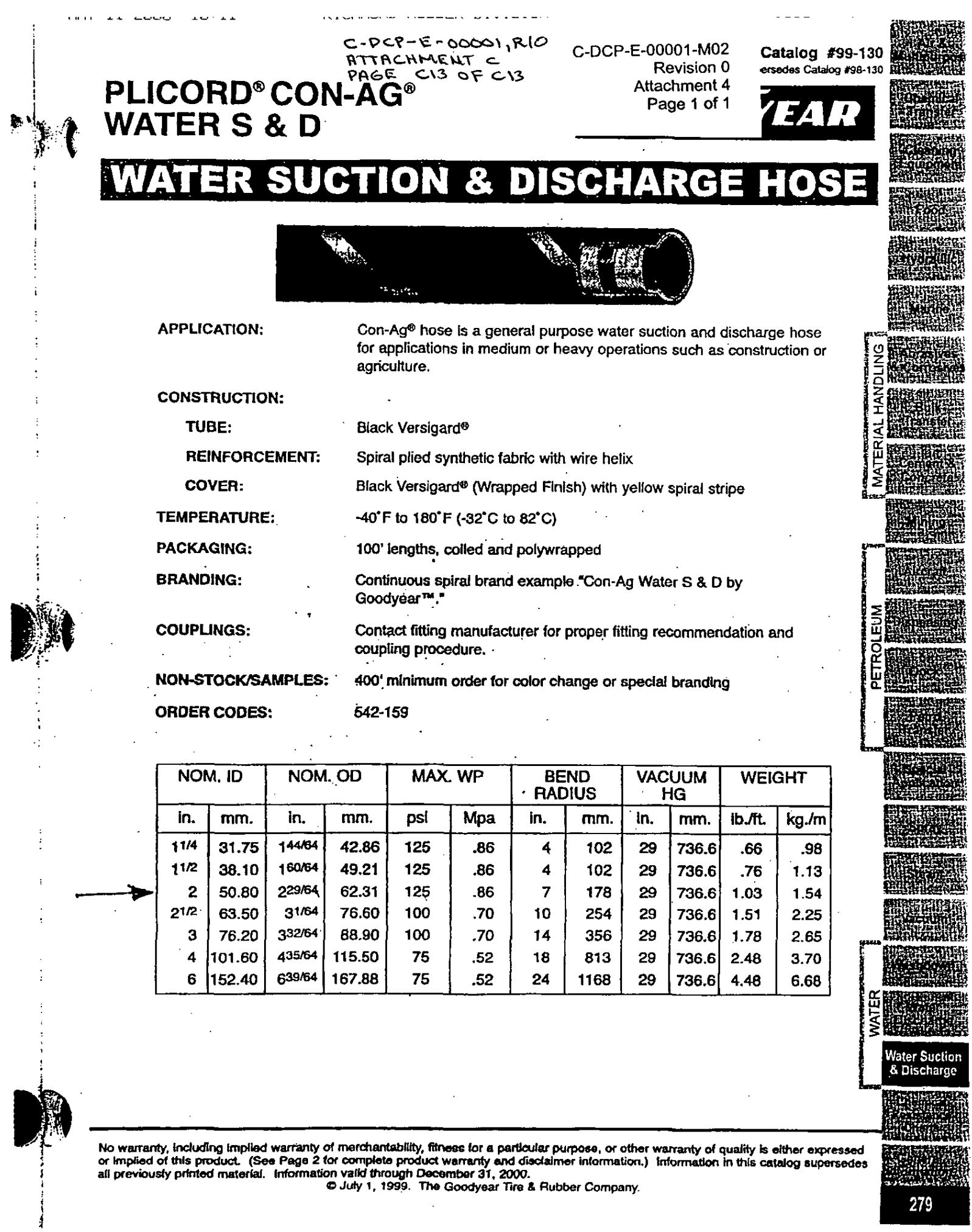


0
2
8
8
0
$u$
0
0
0
0

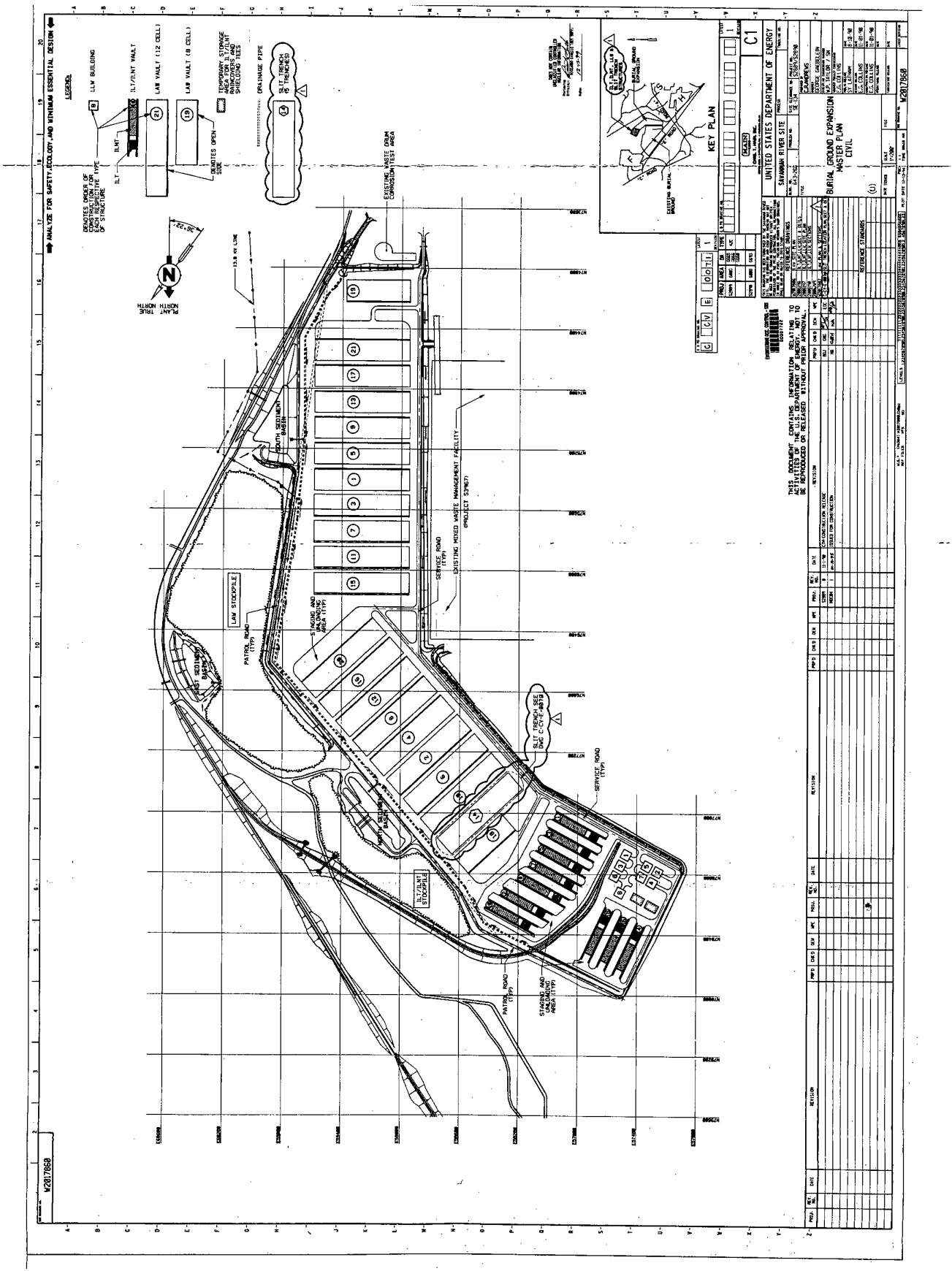

Page 86 of 298 


\section{WESTINGHOUSE SAVANNAH RIVER COMPANY INTEROFFICE MEMORANDUM}

February 9. 2000

TO: Don Sink, Solid Waste Engineering, 724-15E

FROM: J. R. Brookshire 241-168H

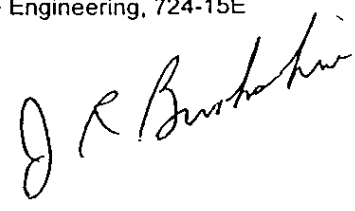

(U)

NOTICE OF NEPA APPROVAL (NONA)
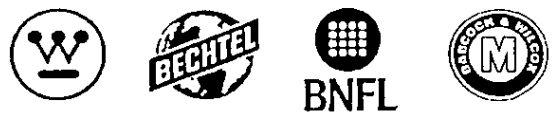

SWD-SWE-2000-00029 C-DCP -E- $00001, R / O$ ATTACHMENT E PAGE EI OF EG

EEC No.: SW-E-2000-001 Rev. No.: 0

Title:

SWMF LLW MEGA TRENCH

It has been determined that no further National Environmental Policy Act (NEPA) documentation is required for the scope of work identified in the subject Environmental Evaluation Checklist (EEC). The proposed action is documented as being:

\o further NEPA is required as all prescreens are "NO"

ㅁ $\mathrm{CX}$ granted by DOE (Must meet all requirements of 10 CFR 1021.410(b)):

ه Covered by previous NEPA documentation:

Waste Management EIS

The requirements of NEPA for the proposed activity have been satisfied and you are no longer restricted by NEPA to proceed with this action. Please note, however, that this concurrence relates to NEPA only. All other applicable environmental, safety, and management activities must be met for activities related to this action.

File this determination and the original Environmental Evaluation Checklist with the proposed project or activity file.

If you determine that actions or modifications outside of the originally approved scope of work must be performed, these changes must be submitted for evaluation to insure continued compliance with the National Environmental Policy Act.

Attached: Signed EEC

cc: C. B. Stevens, 724-21E

T. E. West, 724-36E

Document Control, 705-3C 


\section{Environmental Evaluation Checklist (EEC) \\ NEPA/Environmental Permits \\ $C-D C P-E=00001, R 10$ \\ EEC NO. SW - E - 2000-001 \\ ATTACHMENT E \\ Rev No. 0}

Instructions:

PAGE EZ OF EG

- Fill in both the NEPA and Permits portion of the checklist

- Submit one copy of the completed Checklist with supplemental information to the Department NEPA Coordinator (DNC). The DNC will distribute to the Site NEPA Coordinator for NEPA level determination by DOE.

Submit one copy of the completed Checklist with supplemental information to the Department Environmental Coordinator (EC). The EC will

distribute the completed checklist to the SW Waste Forecast Coordinator (where applicable).

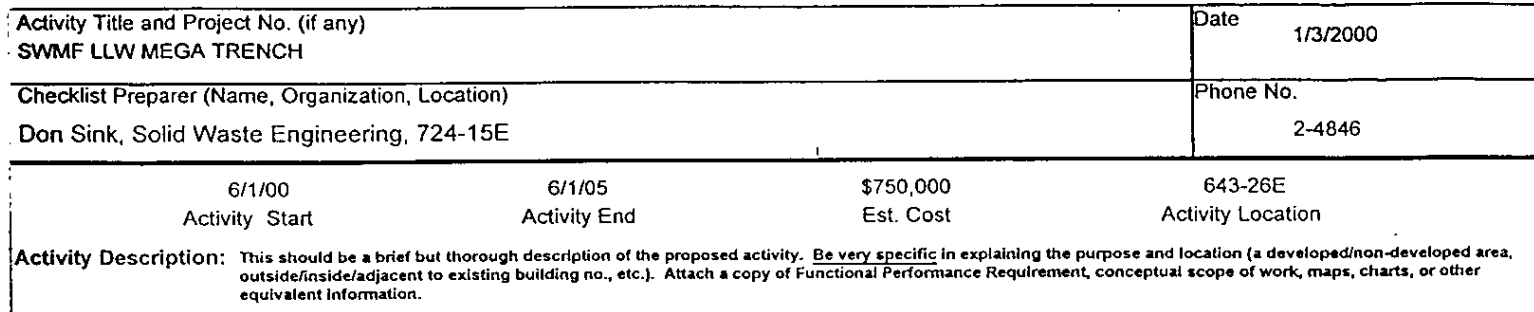

Summary:

Provide a shallow land burial site (i.e. 'Mega-Trench') for the disposal of containerized Low Level Waste. The location of the Mega-Trench shall be located in future LAWW Vault No. 11. The trench shall be designed to accommodate stacking 4 to 5 B-25's high in depth. The Mega-Trench will allow the drive-in function of flat bed trucks and fork lift trucks or a crane for disposing of waste containers. The base shall have structural features for allowing components to be grout in a selected portion of the Mega-Trerich. The base of the Mega-Trench shall be sloped to move water runoff to a low point sump for collection and pumping. The Mega-Trench's walls shall be sloped back to allow personnel to work safely at the base. Also, the walls shall be provided with erosion control features for keeping the walls intact.

Detailed Description:

Attachments (FPR, CDR, System Description, etc.)? o Yes o No

Refer to PMT NUMBER: U - PMT-E- 000149. The depth of the trench will be dictated by the elevation of the water table versus the Performance Assessment requirements. The life expectancy of the trench shall be at least five years. The location of the trench is shown on Drawing W2017860.

Additional NEPA considerations:

LIW for shallow land disposal are discussed in the Waste Management EIS, 0217, page. B-105 and page 55252 in the ROD for LLW. EEC activity is covered by EIS 0217.

GL Peterson 


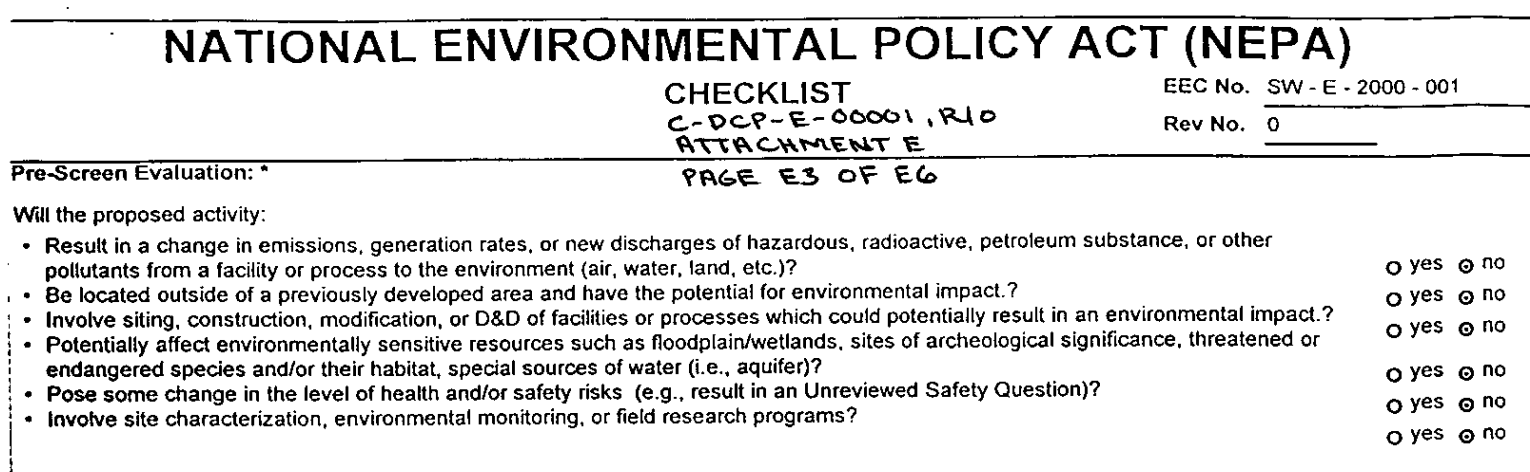

*Note: - If any unknown, call Department NEPA Coordinator (DNC) for consultation.

- If all are "NO", no further NEPA action needed. Consult with DNC to verify; file with project \& complete PERMITS CHECKLIST. - If any are "Yes", complete rest of NEPA CHECKLIST \& the PERMITS CHECKLIST.

Environmental Impacts Evaluation: (Note: If any are "Yes", provide specifics/supplemental information.) Air

- Will there be a new air emission or a change in the quantity or quality of an existing air emission?

o yes o no

Surface Water

- Will there be a liquid release to streams, swamps, wetlands, seepage basins, storm drains, process sewers, ponds, or lakes?. - Will river or stream water be utilized?

o yes $\odot$ no

Groundwater

- Will there be a discharge to groundwater?

0 yes o no

- Will groundwater be utitized?

0 yes o no

Safety

- Is there a potential exposure to hazardous substances (e.g., radiological/oxic/chemical materials)?

- Is there a potential for explosion or criticality?

- Does action involve transportation of hazardous materials?

o yes o no

0 yes $\odot$ no

NaturaUCultural Resources

- Is there a potential for impacts on wetlands, swamps, streams, river beds, ponds, set aside areas?

0 yes $\odot$ no

- Is there a potential for impacts on wetlands, swamps, streams,
- Is there a potential impact on fish/wildife resources or habitats?

- Is there a potential impact on protected species (e.g., sensitive, rare, threatened, endangered)?

- Is there a potential for impacting archeological sites?

- Does this action require a site clearance/site use permit?

0 yes $\odot$ no

0 yes $O$ no

0 yes 0 no

o yes o no

o yes o no

For Department NEPA Coordinator and Site NEPA Coordinator Use Only (NEPA Recommendation)

- Are there potential cumulative effects when combined with other actions?

0 yes o no

- Is the proposed activity a component of a larger line item project?

[] No further NEPA is required as all prescreens are "NO".

D CX applied for by DNC (Must meet all requirements of 10 CFR 1021.410(b)):

a Covered by previous NEPA Documentation (CX, EA, EIS):

a Additional NEPA Documentation Required: $\square$ EA $\square$ EIS 口 $\overline{S A}$

\section{Waste Management ElS}

(document title/number)

o yes o no

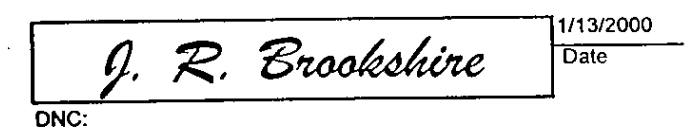

(document title)

\begin{tabular}{|c|c|}
\hline \multirow[b]{2}{*}{ Greg Petersan } & $2 / 3 / 2000$ \\
\hline & Date \\
\hline
\end{tabular}

For DOE NEPA Compliance Officer Use Only (NEPA Determination)

Based on my review of information conveyed to me and in my possession concerning the proposed action, as NEPA Compliance Otficer (as authorized Based on my review of (A), thave determined that the proposed action fits within the specified class of actions of 10 CFR $1021 \mathrm{dtd}$.: 1996

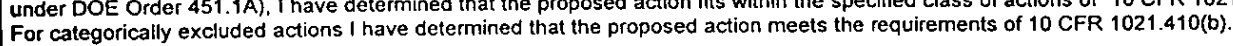

Approved

Approved w/ Comments

Not Approved - Alternate NEPA Action Required:

Dot Approved - Alternate NEPA Action Required:

Page 2 


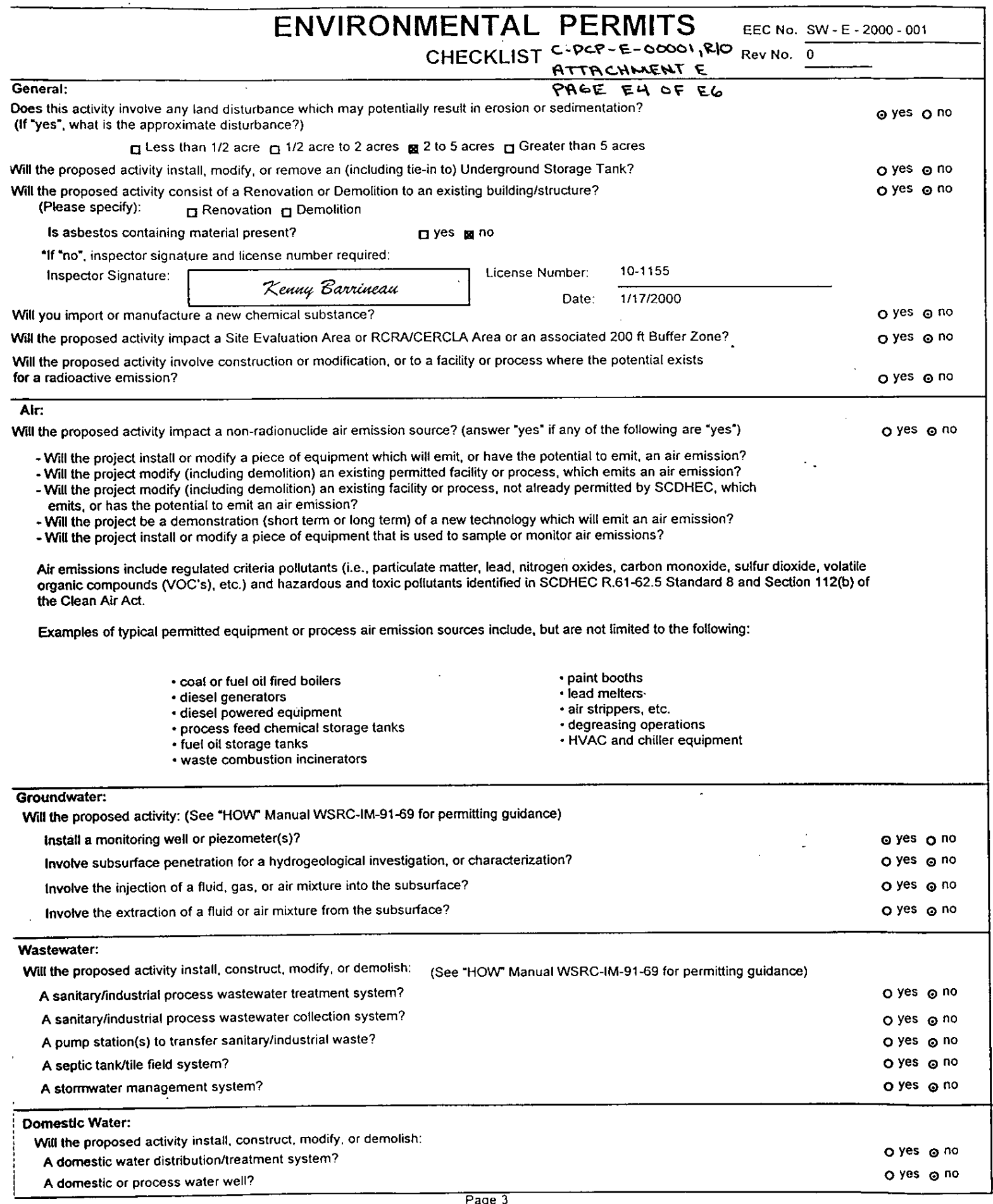




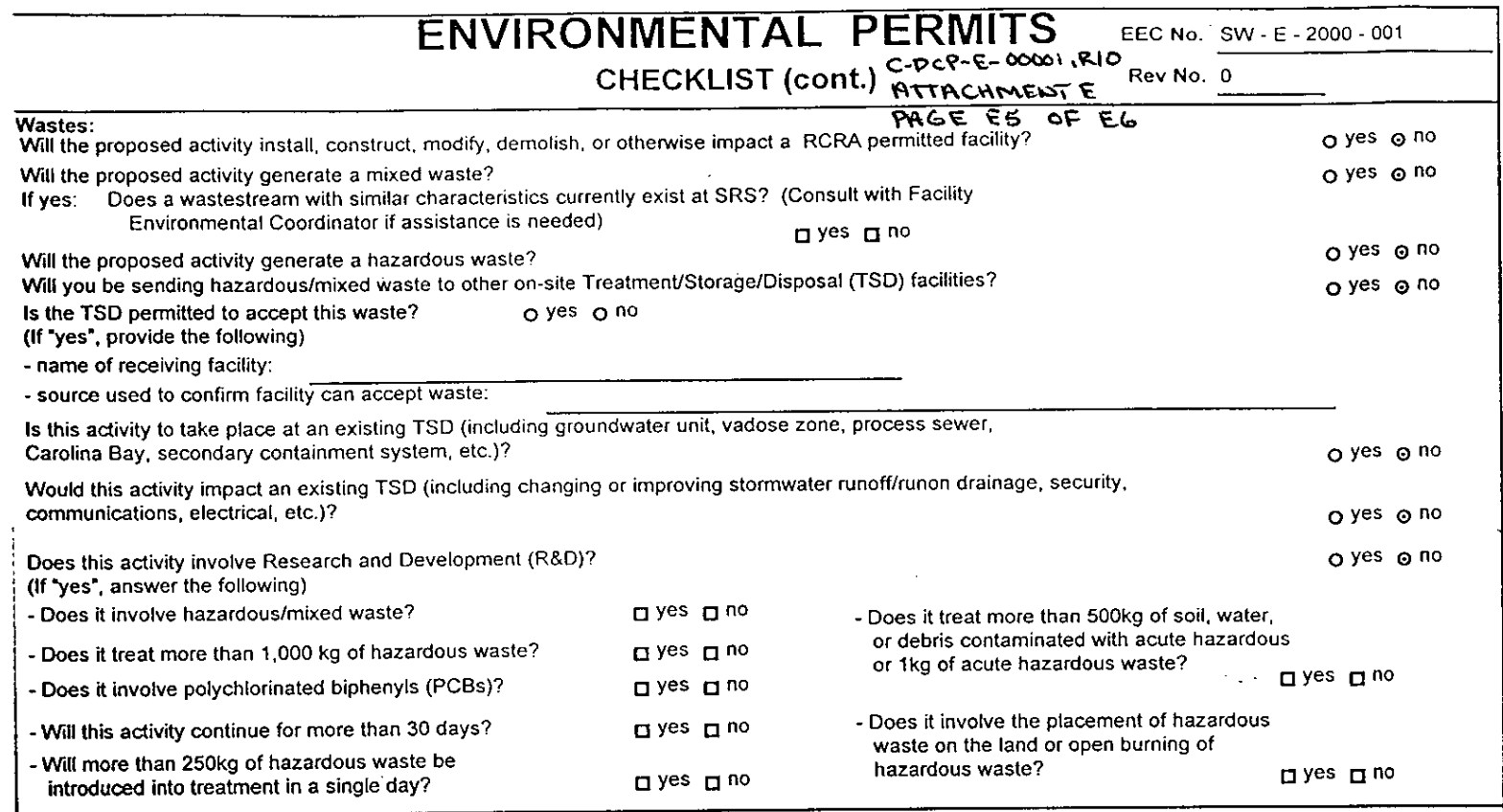

Waste Identification, Generation and Management:

Will the proposed activity include the purchase of lead or lead components? (If "yes", complete OSR 29-6 for each item and

o yes o no

submit with Checklist)

Will the proposed activity disturb soil, sludge or water at or near a RCRAVCERCLA Unit or Site Evaluation Area?

o yes o no

If "yes", were any listed wastes disposed of at this facility? (Consult with Facility EC if assistance is needed)

o yes o no

If "yes", please contact EPD for guidance regarding the investigation-Derived Waste Management Plan.

Does this activity result in a new liquid and/or solid waste generation (one-time or continuous), or a change in the quantity or the

characteristic of an existing waste stream? If "yes" check all that apply:
D TRU
$\square$ Hazardous
口TSCA (PCB)
Mixed - Covered by LDR FFCA $\square$ Suspect Hazardous $\square$ Wastewater
$\begin{array}{lll}\square \text { Low-Level } & \text { Sanitary/Industrial } & \text { acute Hazardous } \\ \square \text { High-Level } & \square \text { Used/Waste Oil } & \square \text { Other...(specify) }\end{array}$

Where will waste be stored/disposed/treated?

Is the facility permitted to manage this waste?

o yes o no

If "yes", complete the following items and submit with the Checklist

$\square$ Source utilized to confirm facility is permitted to accept the waste.

$\square$ Description of generated waste.

Dates generation is to begin/end.

Estimate of waste generation rate for each category

Description of activity/process generating waste.

$\square$ Description of waste reduction principles (reducing the volume, mass, or toxicity) for this activity

Has the proposed activity been evaluated for waste minimization/pollution prevention?

$\odot$ yes o no

For Department EC use only:

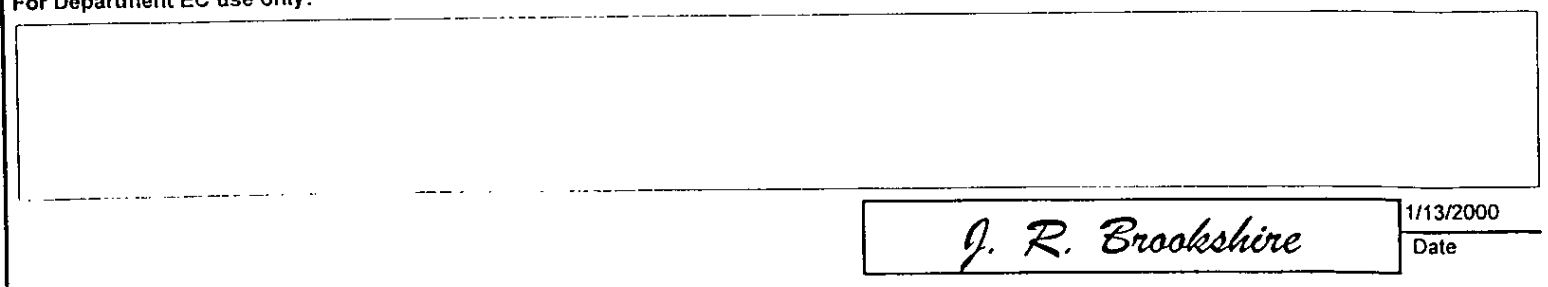

Page 4 
Author: Mark Gober at SRCCC08

Date: $3 / 21 / 00 \quad 7: 05$ AM

Normal

TO: Don Sink at SRCCHOB

Subject: Re[3]: Grading Permit

. Message Contents

FYI

Subject: Re [3] : Grading Permit

Author: Pearce Atkins at SRCCA15

Date: $3 / 20 / 008: 21 \mathrm{AM}$

I would like to have an "informal" review of the drawing prior to issuance of design. When design is issued a copy should be sent to Sharon Nicodemus, 2-2266, for inclusion in the area stormwater PPP

Subject: Re[2]: Grading Permit

Author: Mark Gober at SRCCCOB

Date: $3 / 20 / 008: 07$ AM

An Erosion Control plan is not required, per Pearce, and any needed erosion control information will be included in the final design drawings.

Our task will be enveloped by the E. Area Pollution Prevention plan and this plan will be needed to be updated to include this design.

Reply separator

Subject: Re: Grading Permit

Author: Mark Fachada at SRCCC01

Date: $3 / 20 / 007: 21$ AM

Mark,

Does this include the Erosion Control Plan? Are we enveloped by the E-Area plan?

Subject: Grading Permit

Author: Mark Gober at sRCCCOs

Date: $3 / 17 / 00 \quad 08: 25 \mathrm{AM}$

Reply Separator

I talked with pearce yesterday regarding the need for a grading permit for the Mega Trench Project and he stated the following:

A Grading permit is not required for this project since this

excavation is within the fence of $E$ Area. He define this task as an industrial excavation and compared it to a land fill operation. 


\section{SOLID WASTE MANAGEMENT FACILITY}

\section{UNCLASSWHED FACSMMUE TRANSMITTAL}

FAX NUMBER: (803) 952-4405

DATE:

$$
3 / 16 / 00
$$

FAX LOCATION: 724-7E

TIME: $11: 00$ th

TO: M. GoBCr

LOCATION: $205 K$

TELEPHONE NO:

FROM: FAX NO: $7-3323$

LOCATION:

TELEPHONE NO:

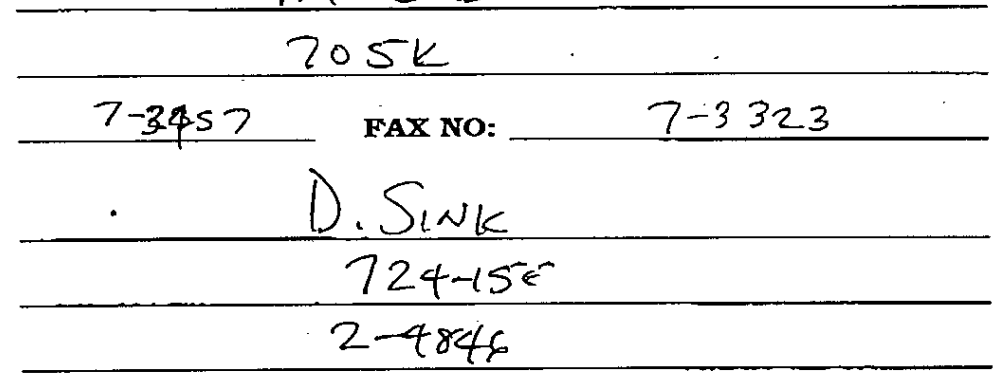

TOTAL NUMEER OF PAGES: MESSAGE: ThtIS IS THtE PUMA INFRMMATLON.

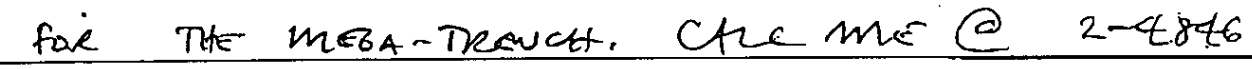
TOD SCUSS.

PLEASE CALL (803) $952-4846$ IF THERE IS ANY TROUBLE WITH THE RECEIPT OF THIS TRANSMITTAL. 


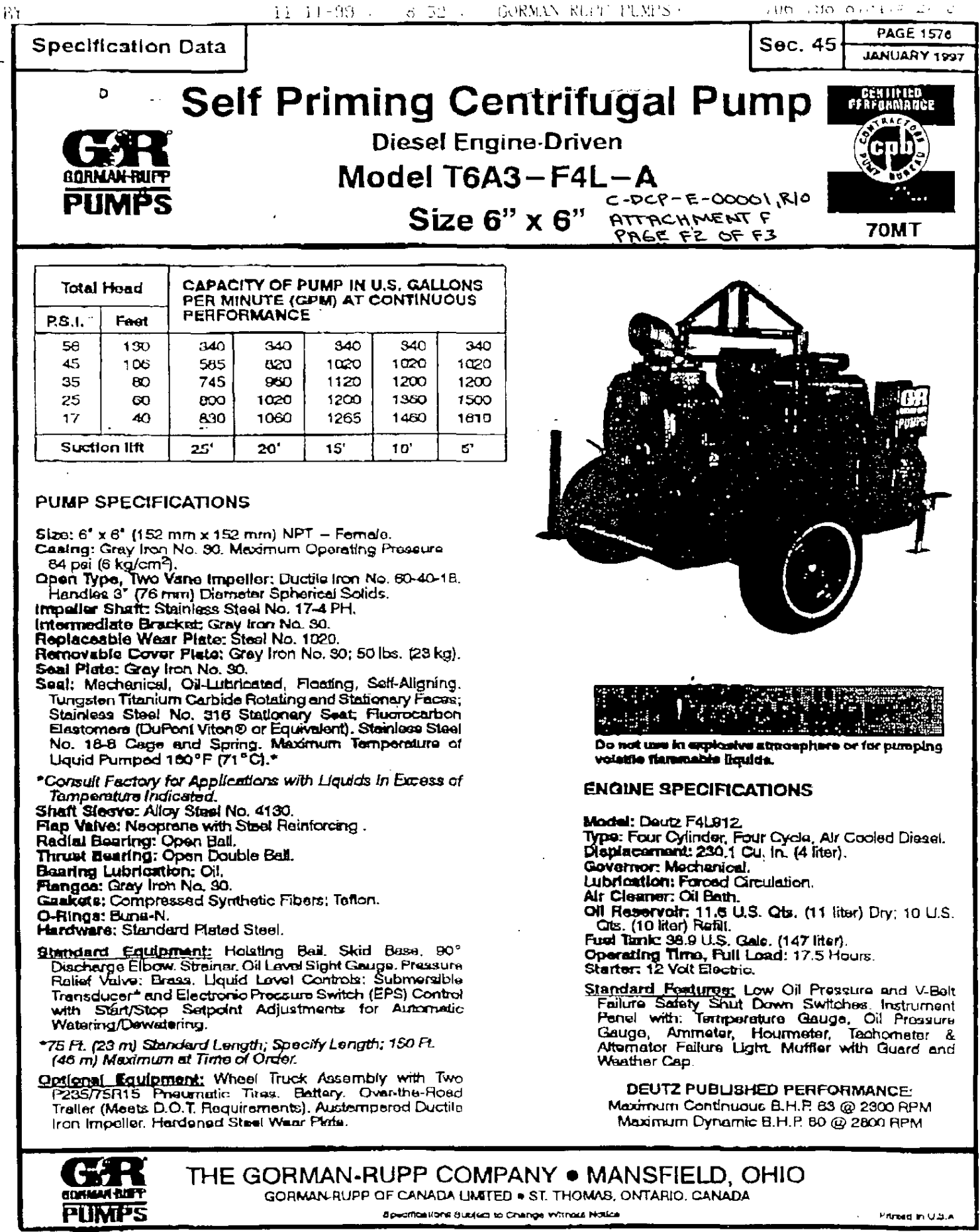

Q. Conytight by the Gorman Rupp Compary 1907 


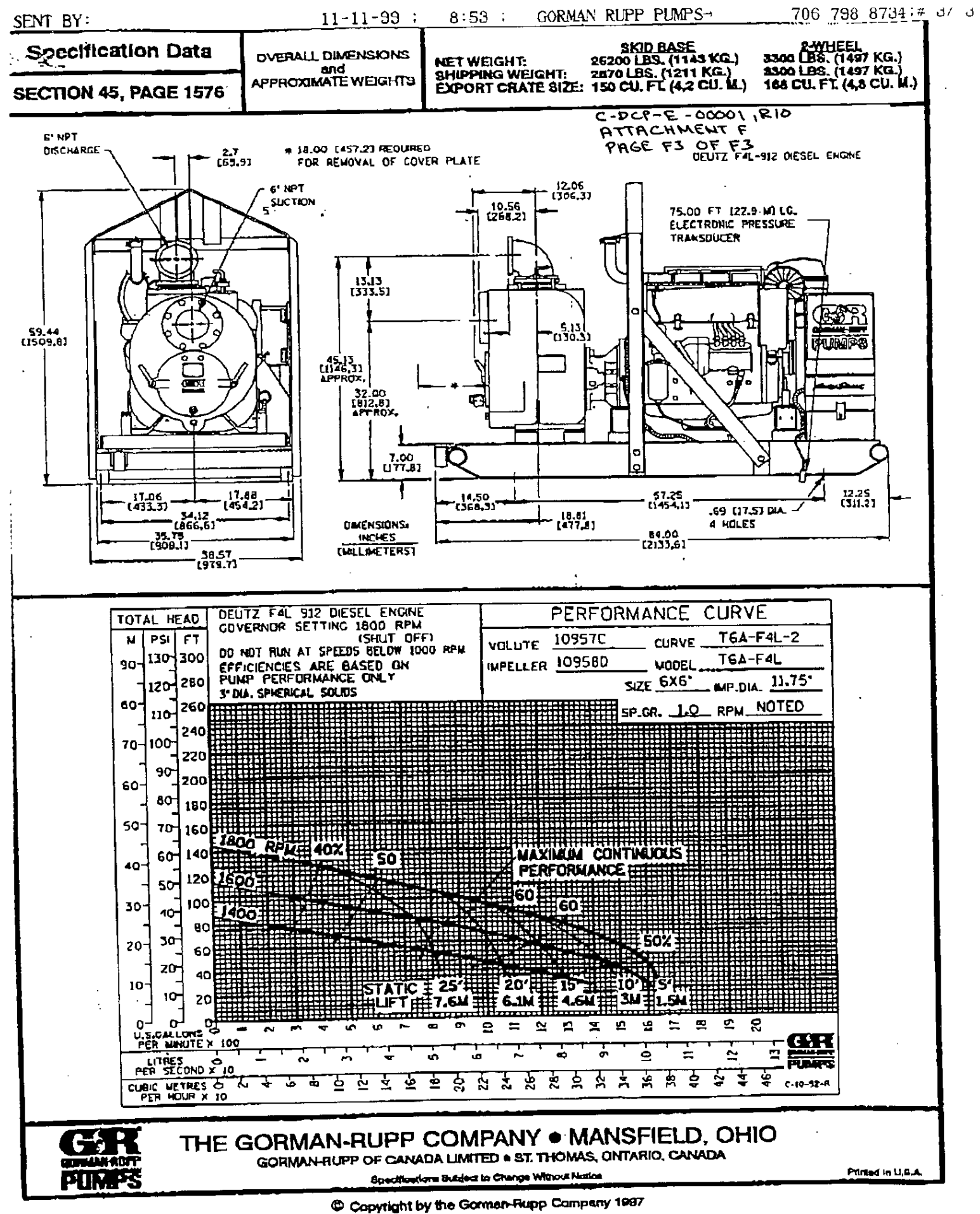

Page 95 of 298 


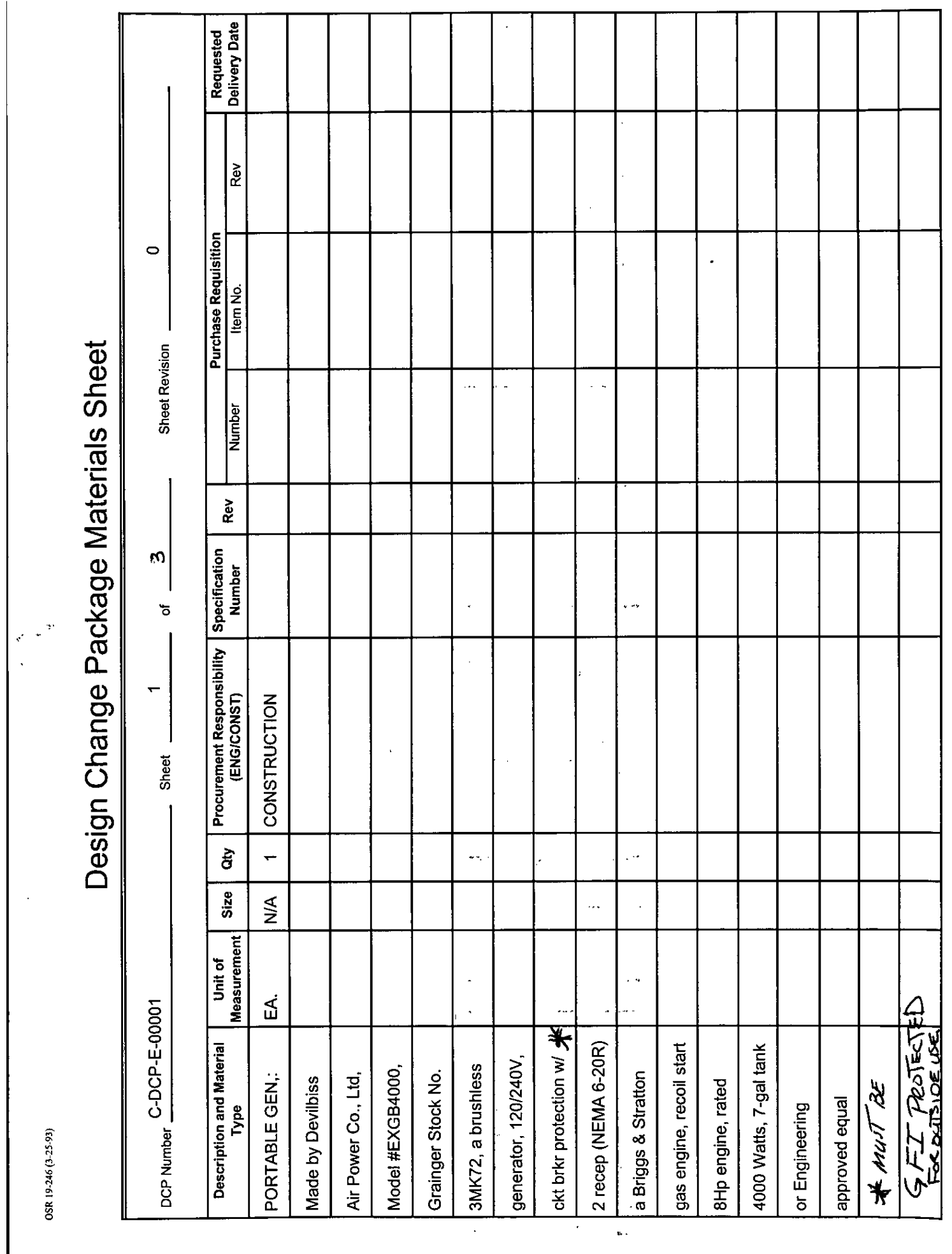

Page 96 of 298 


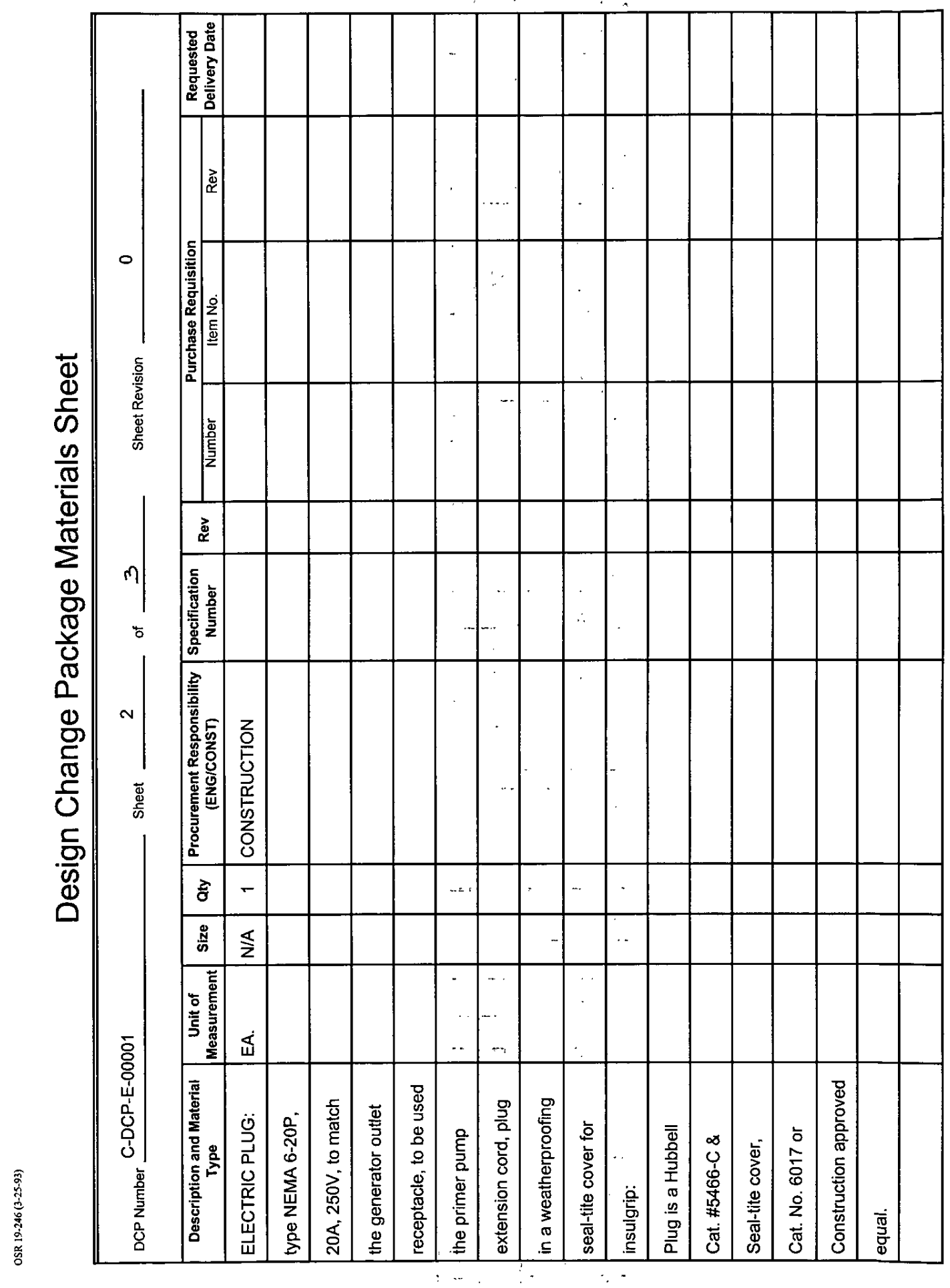

Page 97 of 298 


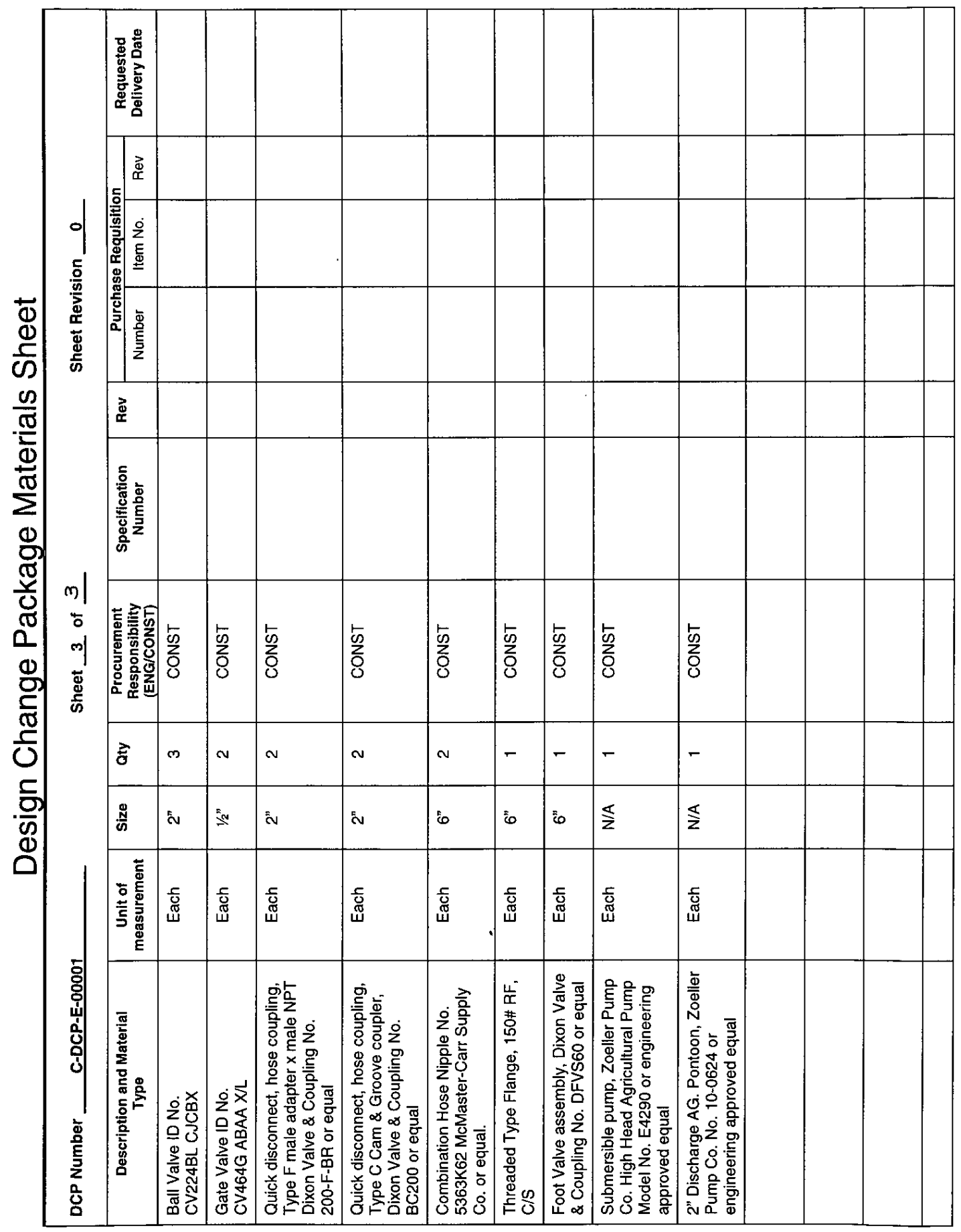

Page 98 of 298 


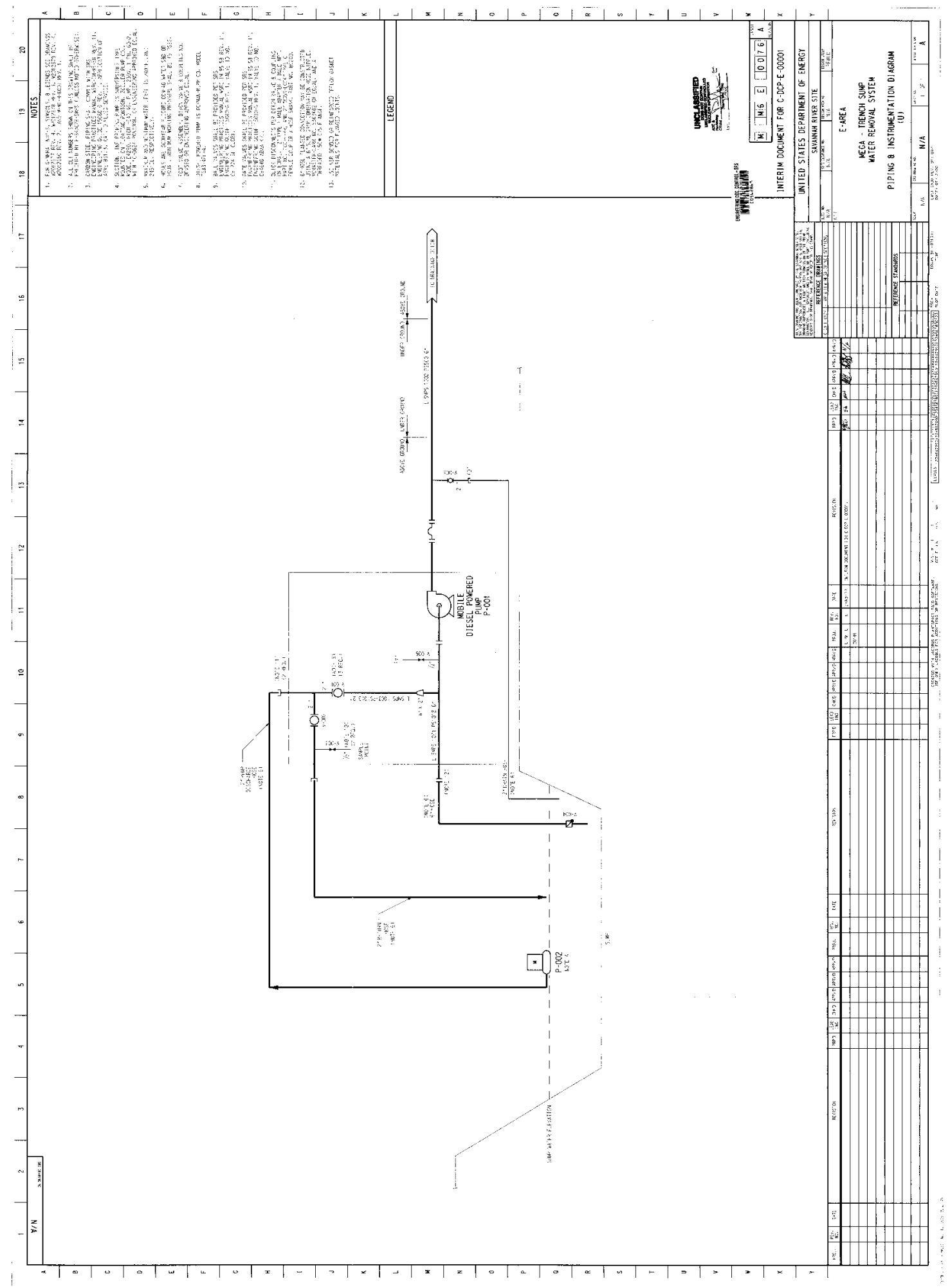

Page 99 of 298 
PS-101[A,B,C,D]

BACK TO: [Piping Specification Index]
http://apps01.srs.gov/engineering/Guides/15060-G/ps/PS_101.htn C-DCP-E- 00001 , RIO PAGE 1 OFG

\begin{tabular}{|c|r|}
\hline $\begin{array}{c}\text { Piping Specification } \\
\text { PS-101 (A,B,C,D) }\end{array}$ & GUIDE NO: 15060 \\
DATE: $3 / 3 / 97$ \\
Revision:2 \\
ESB TECH COMMITTEE: Piping and Valves
\end{tabular}

\section{Design Parameters}

\begin{tabular}{|l|c|c|c|c|c|c|c|}
\hline P-Spec. & \multicolumn{3}{|c|}{ PS-101(A, B, C, D) } \\
\hline Design Pressure $(\mathrm{psig})$ & 285 & 260 & 230 & 200 & 170 & 140 & 125 \\
\hline Design Temperature $\left({ }^{\circ} \mathrm{F}\right)$ & 100 & 200 & 300 & 400 & 500 & 600 & 650 \\
\hline Minimum Temperature $\left(^{\circ} \mathrm{F}\right)$ & -20 & -20 & -20 & -20 & -20 & -20 & -20 \\
\hline Minimum Test Pressure (psig) & 430 & 390 & 345 & 300 & 270 & 245 & 225 \\
\hline
\end{tabular}

\begin{tabular}{|r|l|}
\hline Calculation Reference: & M-CLC-G-00231 \\
\hline Code of Reference: & B31.31994 Addenda \\
\hline Fluid Service: & Normal \\
\hline Material: & Carbon Steel \\
\hline Pressure Rating: & Class 150 \\
\hline
\end{tabular}

\section{General Notes:}


1. This piping specification provides the required information to meet the pressure design requirements of the ASME B31.3 piping code. Additional requirements include, but are not limited to, support design, thermal expansion, material selection, examination, and testing. These additional requirements are addressed in ASME B31.3 and Engineering Guide 15060.

2. This piping specification was developed to address the requirements of ASME B31.3 Normal Fluid Service. This specification may be used for Category D fluid services without restrictions. For Category $M$ fluid services, and piping systems subjected to severe cyclic conditions, additional restrictions apply. These additional restrictions shall be addressed by Engineering.

3. Selection of the different options provided in this piping specification (i.e., socket-weld vs. buttweld fittings, slip-on vs. weldneck flanges, etc.) will affect the stress levels in the piping system. Components in an existing piping system shall be replaced in kind. If components are changed in an existing piping system, these changes shall be addressed by Engineering. For new piping system design, specific requirements for options shall be specified on the design drawings.

4. To address the fluid service requirement of a piping system, a corrosion allowance will need to be determined to select the required wall thickness. The fluid service requirements will also affect the selection of materials such as gaskets, valve seats and packing, etc.. The corrosion allowance shall be specified by the letter suffix in the piping specification identification (e.g., PS-101A)

5. Galvanized piping is acceptable where required for external corrosion protection.

6. The minimum test pressures to meet the hydrostatic test limits of ASME B31.3 are provided in the Design Parameters table above for the listed design pressures and temperatures. Actual system design pressures should be used to establish hydrostatic test pressures for testing. These test pressures are the minimum pressure requirements to be achieved throughout the entire piping system, adjustments may be required to account for elevation changes in the piping system. The maximum test pressure provided in the schedule tables below represent the pressure where the piping will reach its yield stress. These pressures shall not be exceeded at any location in the piping system. Valves, instruments, fittings and other components may have additional pressure limitations and may require isolation from the test pressure.

7. 3D bends are permitted for pipe sizes NPS $1 / 2$ through 6 .

8. Branch Connections shall be made with Tees for full size and one size smaller branches, and for all run sizes NPS 2 and smaller. Welded branch connections are otherwise permitted, and shall be reinforced if required as shown in the reinforcement table below.

9. Piping components not provided in this piping specification can be selected from the standards listed in Table 326.1 of ASME B31.3. Components used in piping systems that are not listed in this table are considered unlisted by the Code and require additional qualification.

10. The minimum design temperature may be limited by the need for impact testing of material and the qualification of the welding procedure. The temperature limits of the bolting material may also control the minimum design temperature.

11. Components of higher pressure ratings (e.g., thicker pipe or higher rated fittings and flanges) may be used in this specification without additional analysis. All changes shall be documented on design drawings.

\section{Joints}




\begin{tabular}{|l|l|l|}
\hline \multicolumn{1}{|c|}{ Joint } & Size & \multicolumn{1}{|c|}{ Component } \\
\hline Runs-Not allowed in PS-101D & $1 / 4-4$ & Threaded Fittings \\
\hline Runs-Not allowed in PS-101D & $1 / 4-2$ & Socket-Weld Fittings \\
\hline Runs & $1 / 4-24$ & Buttweld \\
\hline Maintenance & $1 / 4-24$ & Class 150 Flanges \\
\hline Fit-up to Flanged Components & $1 / 4-24$ & Class 150 Flanges \\
\hline Fit-up to Threaded Components & $1 / 4-6$ & Threaded piping per threaded Sch. Tables \\
\hline
\end{tabular}

\section{Piping}

\section{Allowable Materials}

\begin{tabular}{|l|c|c|c|c|c|c|}
\hline Component & Size & Rating & Standard & Material & $\begin{array}{c}\text { Material } \\
\text { Grade }\end{array}$ & $\begin{array}{c}\text { Additional } \\
\text { Requirements }\end{array}$ \\
\hline Piping & $\begin{array}{c}1 / 4- \\
24\end{array}$ & $\begin{array}{c}\text { Sch. } \\
\text { Tables }\end{array}$ & ANSI B36.10 & ASTM A53 & Grade B & Welded/Seamless \\
\hline Piping & $\begin{array}{c}1 / 4- \\
24\end{array}$ & $\begin{array}{c}\text { Sch. } \\
\text { Tables }\end{array}$ & ANSI B36.10 & ASTM A 106 & Grade B & Seamless \\
\hline
\end{tabular}

Required Pipe Schedules for Non-Threaded Pipe:

\begin{tabular}{|c|c|c|c|c|c|c|c|c|c|c|c|c|c|c|c|c|c|}
\hline P-SPEC & $\begin{array}{c}\text { Corrision } \\
\text { Allowance }\end{array}$ & $\begin{array}{c}\text { Pize } \\
\text { Size }\end{array}$ & $\mathbf{1 / 4}$ & $\mathbf{1 / 2}$ & $\mathbf{3 / 4}$ & $\mathbf{1}$ & $\begin{array}{c}\mathbf{1} \\
\mathbf{2}\end{array}$ & $\mathbf{2}$ & $\begin{array}{c}\mathbf{2} \\
\mathbf{1 / 2}\end{array}$ & $\mathbf{3}$ & $\mathbf{4}$ & $\mathbf{6}$ & $\mathbf{8}$ & $\mathbf{1 0}$ & $\mathbf{1 2}$ & $\mathbf{1 4}$ & $\mathbf{1 6}$ \\
\hline $\mathrm{A}$ & 0.00 & $\begin{array}{c}\text { Sch/ } \\
\text { Thick }\end{array}$ & STD & STD & STD & STD & STD & STD & STD & STD & STD & STD & STD & STD & STD & STD & STD \\
\hline B & $1 / 32$ & $\begin{array}{c}\text { Sch/ } \\
\text { Thick }\end{array}$ & STD & STD & STD & STD & STD & STD & STD & STD & STD & STD & STD & STD & STD & STD & STD \\
\hline C & $1 / 16$ & $\begin{array}{c}\text { Sch/ } \\
\text { Thick }\end{array}$ & STD & STD & STD & STD & STD & STD & STD & STD & STD & STD & STD & STD & STD & STD & STD \\
\hline D & $1 / 8$ & $\begin{array}{c}\text { Sch/ } \\
\text { Thick }\end{array}$ & - & XXS & 160 & 160 & 160 & 80 & 80 & 80 & STD & STD & STD & STD & STD & STD & STD \\
\hline
\end{tabular}

Required Pipe Schedules for Threaded Pipe: 


\begin{tabular}{|c|c|c|c|c|c|c|c|c|c|c|c|c|}
\hline P-SPEC & $\begin{array}{c}\text { Corrision } \\
\text { Allowance }\end{array}$ & $\begin{array}{l}\text { Pipe } \\
\text { Size }\end{array}$ & $1 / 4$ & $1 / 2$ & $3 / 4$ & 1 & $\mid \begin{array}{ll}1 & 1 / 2\end{array}$ & 2 & $21 / 2$ & 3 & 4 & 6 \\
\hline A & 0.00 & $\begin{array}{l}\text { Sch/ } \\
\text { Thick }\end{array}$ & 80 & 80 & 80 & 80 & 80 & STD & STD & STD & STD & STD \\
\hline $\mathrm{B}$ & $1 / 32$ & $\begin{array}{l}\text { Sch/ } \\
\text { Thick }\end{array}$ & 80 & 80 & 80 & 80 & 80 & STD & STD & STD & STD & STD \\
\hline $\mathrm{C}$ & $1 / 16$ & $\begin{array}{r}\text { Sch/ } \\
\text { Thick }\end{array}$ & -- & 80 & 80 & 80 & 80 & 80 & 80 & 80 & STD & STD \\
\hline D & $1 / 8$ & $\begin{array}{c}\text { Sch/ } \\
\text { Thick }\end{array}$ & - & XXS & 160 & 160 & 160 & 160 & 160 & 80 & 80 & 80 \\
\hline & \multicolumn{2}{|c|}{$\begin{array}{l}\text { Maximum Test } \\
\text { Pressure (psig) }\end{array}$} & 7210 & 5430 & 4670 & 4155 & 3450 & 1670 & 1640 & 1540 & 1445 & 1325 \\
\hline
\end{tabular}

Fittings

\begin{tabular}{|c|c|c|c|c|c|c|}
\hline \multicolumn{1}{|c|}{ Component } & Size & Rating & Standard & Material & $\begin{array}{c}\text { Material } \\
\text { Grade }\end{array}$ & $\begin{array}{c}\text { Additional } \\
\text { Requirements }\end{array}$ \\
\hline Threaded Fittings & $1 / 4-4$ & $2000 \#$ & ANSI B 16.11 & $\begin{array}{c}\text { ASTM } \\
\text { A105 }\end{array}$ & WPB & $\begin{array}{c}\text { Not allowed in } \\
\text { PS-101D }\end{array}$ \\
\hline \begin{tabular}{l|c|c|c|c|c|}
\hline Socket Weld - \\
Fittings
\end{tabular} & $1 / 4-2$ & $3000 \#$ & ANSI B 16.11 & $\begin{array}{c}\text { ASTM } \\
\text { A105 }\end{array}$ & WPB & $\begin{array}{c}\text { Not allowed in } \\
\text { PS-1010 }\end{array}$ \\
\hline Buttweld Fittings & $\begin{array}{c}1 / 4- \\
24\end{array}$ & $\begin{array}{c}\text { Sch. } \\
\text { Tables }\end{array}$ & ANSI B 16.9 & $\begin{array}{c}\text { ASTM } \\
\text { A234 }\end{array}$ & WPB & \\
\hline Buttweld Fittings & $\begin{array}{c}1 / 4- \\
24\end{array}$ & $\begin{array}{c}\text { Sch. } \\
\text { Tables }\end{array}$ & ANSI B 16.28 & $\begin{array}{c}\text { ASTM } \\
\text { A234 }\end{array}$ & WPB & \\
\hline
\end{tabular}

\section{Flanges}

\begin{tabular}{|c|c|c|c|c|c|c|}
\hline Component & Size & Rating & Standard & Material & $\begin{array}{c}\text { Material } \\
\text { Grade }\end{array}$ & $\begin{array}{c}\text { Additional } \\
\text { Requirements }\end{array}$ \\
\hline Threaded Flanges & $1 / 2-6$ & Class 150 & ANSI B 16.5 & ASTM A 105 & N/A & $\begin{array}{l}\text { Not allowed in } \\
\text { PS-101D }\end{array}$ \\
\hline $\begin{array}{l}\text { Socket-Weld } \\
\text { Flange }\end{array}$ & $1 / 2-2$ & Class 150: & ANSI B 16.5 & ASTM A 105 & N/A & $\begin{array}{l}\text { Not allowed in } \\
\text { PS-101D }\end{array}$ \\
\hline Weldneck Flange & $\begin{array}{c}1 / 2- \\
24\end{array}$ & Class 150 & ANSI B 16.5 & ASTM A 105 & N/A & \\
\hline Slip-On Flange & $\begin{array}{r}1 / 2- \\
24 \\
\end{array}$ & Class 150 & ANSI B 16.5 & ASTM A105 & N/A & \\
\hline Blind Flange & $\begin{array}{c}1 / 2- \\
24 \\
\end{array}$ & Class 150 & ANSI B 16.5 & ASTM A 105 & N/A & \\
\hline Backup Flange & $\begin{array}{c}1 / 2- \\
24\end{array}$ & Class 150 & ANSI B 16.5 & ASTM A 105 & N/A & \\
\hline
\end{tabular}


PAGE 5 OF 6

\section{Mechanical Fasteners}

\begin{tabular}{|c|c|c|c|c|c|}
\hline Component & Size & Standard & Material & $\begin{array}{c}\text { Material } \\
\text { Grade }\end{array}$ & Additional Requirements \\
\hline Bolts/Studs & $\begin{array}{c}1 / 2-1 \\
1 / 4\end{array}$ & ANSI B 18.2.1 & ASTM A193 & B7-HH & With $2 \mathrm{H}$ nuts only \\
\hline Bolts/Studs & $\begin{array}{c}1 / 2-1 \\
1 / 4\end{array}$ & ANSI B 18.2.1 & ASTM A 307 & Grade B-HH & $\begin{array}{l}\text { With A563 nuts only. } \\
\text { Limited }-20^{\circ} \mathrm{F} \text { to } 300^{\circ} \mathrm{F}\end{array}$ \\
\hline Nuts & $\begin{array}{c}1 / 2-1 \\
1 / 4\end{array}$ & ANSI B 18.2.2 & ASTM A194 & $2 \mathrm{H}-\mathrm{HH}$ & \\
\hline Nuts & $\begin{array}{c}1 / 2-1 \\
1 / 4\end{array}$ & ANSI B 18.2.2 & ASTM A563 & Grade A-HH & \\
\hline
\end{tabular}

\section{Welded Branches}

Branch welds in the following table must be reinforced.

\begin{tabular}{|c|c|c|c|c|c|c|c|c|}
\hline \multirow{2}{*}{$\begin{array}{c}\text { Branch } \\
\text { Angle }\end{array}$} & \multicolumn{2}{|c|}{$\begin{array}{c}\text { Corrosion Allow. }= \\
0.00\end{array}$} & \multicolumn{2}{|c|}{ Corrosion Allow. $=1 / 32$} & \multicolumn{2}{|c|}{$\begin{array}{c}\text { Corrosion Allow. }= \\
1 / 16\end{array}$} & \multicolumn{2}{|c|}{$\begin{array}{c}\text { Corrosion Allow. }= \\
1 / 8\end{array}$} \\
\hline & $\begin{array}{l}\text { Run } \\
\text { NPS }\end{array}$ & Branch NPS & $\begin{array}{l}\text { Run } \\
\text { NPS }\end{array}$ & Branch NPS & $\begin{array}{l}\text { Run } \\
\text { NPS }\end{array}$ & Branch NPS & $\begin{array}{l}\text { Run } \\
\text { NPS }\end{array}$ & Branch NPS \\
\hline \multirow{5}{*}{$90^{\circ}$} & 24 & $\begin{array}{c}3 / 4,11 / 2- \\
24\end{array}$ & 20 & $\begin{array}{c}3 / 4,11 / 2,2 \\
12-20\end{array}$ & 18 & $\begin{array}{c}1 / 4-2,3- \\
18\end{array}$ & 14 & $2,4-14$ \\
\hline & & & 24 & $1 / 4-24$ & 20 & $1 / 4-20$ & 16 & $2-16$ \\
\hline & & & & & 24 & $1 / 4-24$ & 18 & $3 / 4-18$ \\
\hline & & & & & & & 20 & $3 / 4-20$ \\
\hline & & & & & & & 24 & $3 / 4-24$ \\
\hline \multirow{5}{*}{$7^{\circ}$} & 24 & $3 / 4-24$ & 20 & $\begin{array}{c}3 / 4,11 / 2,2 \\
6-20 \\
\end{array}$ & 18 & $1 / 4-18$ & 14 & $2,4-14$ \\
\hline & & & 24 & $1 / 4-24$ & 20 & $1 / 4-20$ & 16 & $2-16$ \\
\hline & & & & & 24 & $1 / 4-24$ & 18 & $3 / 4-18$ \\
\hline & . & & & & & & 20 & $3 / 4-20$ \\
\hline & & & & & & & 24 & $3 / 4-24$ \\
\hline & 18 & 18 & 18 & 18 & 16 & $1 / 4,3 / 4,16$ & 12 & $4-12$ \\
\hline & 20 & $18-20$ & 20 & $1 / 2-20$ & 18 & $1 / 4-18$ & 14 & $2,4-14$ \\
\hline & 24 & $3 / 4-24$ & 24 & $1 / 4-24$ & 20 & $1 / 4-20$ & 16 & $3 / 4,2-16$ \\
\hline
\end{tabular}


PS-101[A,B,C,D $]$

http://apps01.srs.gov/engineering/Guides/15060-G/ps/PS 101 .htn $C-D C P-E-00001, R 1_{0}$ PAGE 6 OF 6

\begin{tabular}{|c|c|c|c|c|c|c|c|c|}
\hline \multirow[t]{3}{*}{$60^{\circ}$} & & & & & 24 & $1 / 4-24$ & 18 & $3 / 4-18$ \\
\hline & & & & & & & 20 & $3 / 4-20$ \\
\hline & & & & & & & 24 & $3 / 4-24$ \\
\hline \multirow{10}{*}{$45^{\circ}$} & 14 & 14 & 12 & 12 & 10 & 10 & 4 & 4 \\
\hline & 16 & $14-16$ & 14 & $12-14$ & 12 & 12 & 6 & 6 \\
\hline & 18 & $16-18$ & 16 & $14-16$ & 14 & $12-14$ & 8 & 8 \\
\hline & 20 & $2,6-20$ & 18 & $1 / 2-2,3-18$ & 16 & $1 / 4-16$ & 10 & $8-10$ \\
\hline & 24 & $1 / 2-24$ & 20 & $1 / 4-20$ & 18 & $1 / 4-18$ & 12 & $2,4-12$ \\
\hline & & & 24 & $1 / 4-24$ & 20 & $1 / 4-20$ & 14 & $2,-14$ \\
\hline & & & & & 24 & $1 / 4-24$ & 16 & $3 / 4-16$ \\
\hline & & & & & & & 18 & $3 / 4-18$ \\
\hline & & & & & & & 20 & $3 / 4-20$ \\
\hline & & & & & & & 24 & $3 / 4-24$ \\
\hline
\end{tabular}

BACK TO: [Piping Specification Index] 
PS-500

BACK TO: [Piping Specification Index]

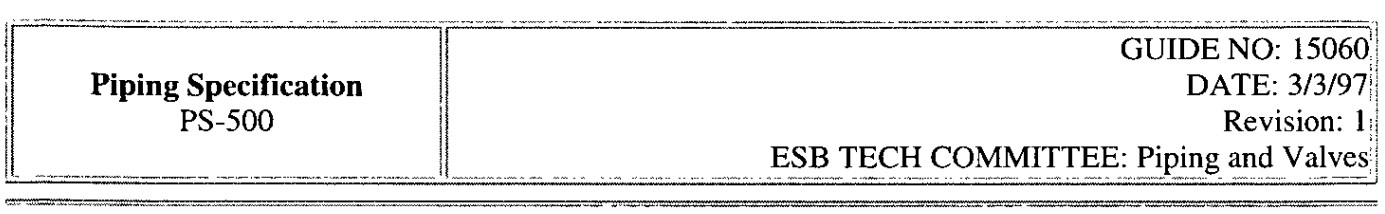

\section{Design Parameters}

\begin{tabular}{|l|c|}
\hline P-Spec. & PS-500 \\
\hline Design Pressure (psig) & 150 \\
\hline Design Temperature $\left.{ }^{\circ} \mathrm{F}\right)$ & 100 \\
\hline Minimum Temperature $\left.{ }^{\circ} \mathrm{F}\right)$ & 0 \\
\hline Minimum Test Pressure $(\mathrm{psig})$ & 225 \\
\hline
\end{tabular}

\begin{tabular}{|r|r|}
\hline Calculation Reference: & M-CLC-G-00231 \\
\hline Code of Reference: & B31.3 1994 Addenda \\
\hline Fluid Service: & Normal \\
\hline Material: & PVC \\
\hline Pressure Rating: & $150 \mathrm{psi}$ \\
\hline
\end{tabular}

\section{General Notes:}


1. This piping specification provides the required information to meet the pressure design requirements of the ASME B31.3 piping code. Additional requirements include, but are not limited to, support design, thermal expansion, material selection, examination, and testing. These additional requirements are addressed in ASME B31.3 and Engineering Guide 15060.

2. This piping specification was developed to address the requirements of ASME B31.3 Normal Fluid Service. This specification may be used for Category D fluid services without restrictions. For Category $M$ fluid service piping systems additional restrictions apply. These additional restrictions shall be addressed by Engineering.

3. Selection of the different options provided in this piping specification (i.e., socket-weld vs. buttweld fittings, slip-on vs. weldneck flanges, etc.) will affect the stress levels in the piping system. Components in an existing piping system shall be replaced in kind. If components are changed in an existing piping system, these changes shall be addressed by Engineering. For new piping system design, specific requirements for options shall be specified on the design drawings.

4. The minimum test pressure to meet the hydrostatic test limit of ASME B31.3 is provided in the Design Parameters table above for the listed design pressure and temperature. Actual system design pressures should be used to establish hydrostatic test pressures for testing. This test pressure is the minimum pressure to be achieved throughout the entire piping system, adjustments may be required to account for elevation changes in the piping system. The maximum test pressure provided in the schedule tables below shall not be exceeded at any location in the piping system. Valves, instruments, fittings and other components may have additional pressure limitations and may require isolation from the test pressure.

\section{Bends are not permitted for this piping specification.}

6. Piping components not provided in this piping specification can be selected from the standards listed in Table A326.1 of ASME B31.3. Components used in piping systems that are not listed in this table are considered unlisted by the Code and require additional qualification.

\section{PVC piping in all Fluid Service except Category D shall be safeguarded per ASME B31.3.}

8. Components of higher pressure ratings (e.g., thicker pipe or higher rated fittings and flanges) may be used in this specification without additional analysis. All changes shall be documented on design drawings.

9. Ultraviolet inhibitor shall be specified if piping is to be used above Ground.

Joints

\begin{tabular}{|l|l|l|}
\hline \multicolumn{1}{|c|}{ Joint } & Size & \multicolumn{1}{c|}{ Component } \\
\hline Runs & $1 / 4-6$ & Threaded Fittings \\
\hline Runs & $1 / 4-8$ & Solvent Welded Fittings \\
\hline Maintenance & $1 / 4-8$ & Class 150 Flanges/Sch. 80 PVC Flanges \\
\hline Fit-up to Flanged Components & $1 / 2-8$ & Class 150 Flanges/SCH. 80 PVC Flanges \\
\hline Fit-up to Threaded Components & $1 / 4-6$ & Threaded piping per threaded Sch. Tables \\
\hline Fit-up to Solvent Welded Components & $1 / 4-8$ & Solvent Welded Fittings \\
\hline
\end{tabular}

\section{Piping}


Allowable Materials

\begin{tabular}{|c|c|c|c|c|c|c|}
\hline Component & Size & Rating & Standard & Material & $\begin{array}{c}\text { Material } \\
\text { Grade }\end{array}$ & $\begin{array}{c}\text { Additional } \\
\text { Requirements }\end{array}$ \\
\hline Piping & $1 / 4-8$ & $\begin{array}{c}\text { Sch. } \\
\text { Tables }\end{array}$ & ASTM D1785 & $\begin{array}{c}\text { ASTM } \\
\text { D1784 }\end{array}$ & $12454-\mathrm{B}$ & Note 9 \\
\hline Piping & $1 / 4-8$ & $\begin{array}{c}\text { Sch. } \\
\text { Tables }\end{array}$ & ASTM D1785 & $\begin{array}{c}\text { ASTM } \\
\text { D1784 }\end{array}$ & $12454-\mathrm{C}$ & Note 9 \\
\hline
\end{tabular}

Required Pipe Schedules for Non-Threaded Pipe:

\begin{tabular}{|c|c|c|c|c|c|c|c|c|c|c|c|c|c|c|}
\hline $\begin{array}{c}\text { Corrision } \\
\text { Allowance }\end{array}$ & $\begin{array}{c}\text { Pipe } \\
\text { Size }\end{array}$ & $\mathbf{1 / 4}$ & $\mathbf{1 / 2}$ & $\mathbf{3 / 4}$ & $\mathbf{1}$ & $\mathbf{1}$ & $\mathbf{1} / \mathbf{2}$ & $\mathbf{2}$ & $\mathbf{2} 1 / 2$ & $\mathbf{3}$ & $\mathbf{4}$ & $\mathbf{6}$ & $\mathbf{8}$ \\
\hline 0.00 & $\begin{array}{c}\text { Sch/ } \\
\text { Thick }\end{array}$ & 40 & 40 & 40 & 40 & 40 & 40 & 40 & 40 & 40 & 80 & 80 \\
\hline & \begin{tabular}{|c|c|c|c|c|c|c|c|c|c|} 
Maximum Test \\
Pressure (psig)
\end{tabular} & 250 & 250 & 250 & 250 & 250 & 250 & 250 & 250 & 250 & 250 \\
\hline
\end{tabular}

Required Pipe Schedules for Threaded Pipe:

\begin{tabular}{|c|c|c|c|c|c|c|c|c|c|c|c|}
\hline $\begin{array}{c}\text { Corrision } \\
\text { Allowance }\end{array}$ & $\begin{array}{c}\text { Pipe } \\
\text { Size }\end{array}$ & $\mathbf{1 / 4}$ & $\mathbf{1} / \mathbf{2}$ & $\mathbf{3 / 4}$ & $\mathbf{1}$ & $\mathbf{1} 1 / \mathbf{2}$ & $\mathbf{2}$ & $\mathbf{2} 1 / 2$ & $\mathbf{3}$ & $\mathbf{4}$ & $\mathbf{6}$ \\
\hline 0.00 & $\begin{array}{c}\text { Sch/ } \\
\text { Thick }\end{array}$ & 80 & 80 & 80 & 80 & 80 & 80 & 80 & 80 & 80 & 80 \\
\hline $\begin{array}{l}\text { Maximum Test } \\
\text { Pressure (psig) }\end{array}$ & 250 & 250 & 250 & 250 & 250 & 250 & 250 & 250 & 250 & 250 \\
\hline
\end{tabular}

\section{Fittings}

\begin{tabular}{|c|c|c|c|c|c|c|}
\hline Component & Size & Rating & Standard & Material & $\begin{array}{c}\text { Material } \\
\text { Grade }\end{array}$ & $\begin{array}{c}\text { Additional } \\
\text { Requirements }\end{array}$ \\
\hline $\begin{array}{l}\text { Solvent Welded } \\
\text { Fittings }\end{array}$ & $\begin{array}{c}1 / 4- \\
4 \\
\end{array}$ & 40 & $\begin{array}{l}\text { ASTM } \\
\text { D2466 }\end{array}$ & $\begin{array}{l}\text { ASTM } \\
\text { D1784 } \\
\end{array}$ & $\begin{array}{l}12454-\mathrm{B}, \\
12454-\mathrm{C} \\
\end{array}$ & \\
\hline $\begin{array}{l}\text { Solvent Welded } \\
\text { Fittings }\end{array}$ & $\begin{array}{r}1 / 4 \\
8 \\
\end{array}$ & 80 & $\begin{array}{l}\text { ASTM } \\
\text { D2467 }\end{array}$ & $\begin{array}{l}\text { ASTM } \\
\text { D1784 }\end{array}$ & $\begin{array}{l}12454-\mathrm{B}, \\
12454-\mathrm{C}\end{array}$ & \\
\hline Threaded Fittings & $\begin{array}{c}1 / 4- \\
6\end{array}$ & 80 & $\begin{array}{l}\text { ASTM } \\
\text { D2464 }\end{array}$ & $\begin{array}{l}\text { ASTM } \\
\text { D1784 }\end{array}$ & $\begin{array}{l}12454-B \\
12454-C\end{array}$ & \\
\hline
\end{tabular}

\section{Flanges}


PS-500

http://apps01.srs.gov/engineering/Guides/15060-G/ps/PS_500.htn $C-D C P-E-00001, R 10$

PAGE 4 OF 4

\begin{tabular}{|c|c|c|c|c|c|c|}
\hline Component & Size & Rating & Standard & Material & $\begin{array}{c}\text { Material } \\
\text { Grade }\end{array}$ & $\begin{array}{c}\text { Additional } \\
\text { Requirements }\end{array}$ \\
\hline Threaded Flange & $\begin{array}{c}1 / 2- \\
8\end{array}$ & $\begin{array}{c}\text { Class } \\
150\end{array}$ & ANSI B 16.5 & $\begin{array}{c}\text { ASTM } \\
\text { A 105 }\end{array}$ & N/A & \\
\hline Threaded Flange & $\begin{array}{c}1 / 2- \\
8\end{array}$ & $\begin{array}{c}\text { Class } \\
150\end{array}$ & ANSI B 16.5 & $\begin{array}{c}\text { ASTM } \\
\text { A 182 }\end{array}$ & $304 \mathrm{~L} / 316 \mathrm{~L}$ & \\
\hline Solvent Welded & \begin{tabular}{c|c|c|c|c|}
$1 / 2-$ \\
Flange
\end{tabular} & Sch. 80 & Manufacturers & $\begin{array}{c}\text { ASTM } \\
\text { D1784 }\end{array}$ & $\begin{array}{l}12454-\mathrm{B}, \\
12454-\mathrm{C}\end{array}$ & \\
\hline
\end{tabular}

Mechanical Fasteners

\begin{tabular}{|l|c|c|c|c|c|}
\hline Component & Size & Standard & Material & Material Grade & Additional Requirements \\
\hline Bolts/Studs & $1 / 2-3 / 4$ & ANSI B 18.2.1 & ASTM A307 & Grade A & \\
\hline Nuts & $1 / 2-3 / 4$ & ANSI B 18.2.2 & ASTM A563 & Grade B & \\
\hline
\end{tabular}

BACK TO: [Piping Specification Index] 


\title{
Valve Selection Guide
}

\section{Back To Document}

\section{Example Valve ID Number}

\author{
$\underline{\mathbf{V}} \underline{\mathbf{0}} \underline{1} \underline{\mathbf{G W}}-\underline{\#}-\underline{\mathbf{A}} \underline{\mathbf{B}} \underline{\mathbf{C}} \underline{\mathrm{D}} \underline{\mathbf{E}}$ \\ $12345 \quad 6 \quad 7891011$ \\ 1. Accetable Standards - SRS Valve \\ 2. Basic Material (Body Material) \\ 3. Pressure Class \\ 4. Type of End Connection \\ 5. Type of Valve \\ 6. Valve Size \\ 7. Disc or Ball Material (optional) \\ 8. Seat Material (optional) \\ 9. Stem Material (optional) \\ 10. Packing Material (optional) \\ 11. Body Gasket Material (optional)
}

\section{Notes:}

1. ASTM A216 WCB or A 105

2. CF3, CF8, F304, or F304L

3. CF3M, CF8M, F316, or F316L

4. Use only in copper piping systems

5. Includes Swagelok and Parker tube fittings

6. Includes NBR and Buna-N

7. Use only non-asbestos

8. Non welded end stainless steel valves pressure rating is based on the high carbon (non L) grade.

9. Specify port requirement.

\section{Required Specification Features}


PAGE 2 OF 3

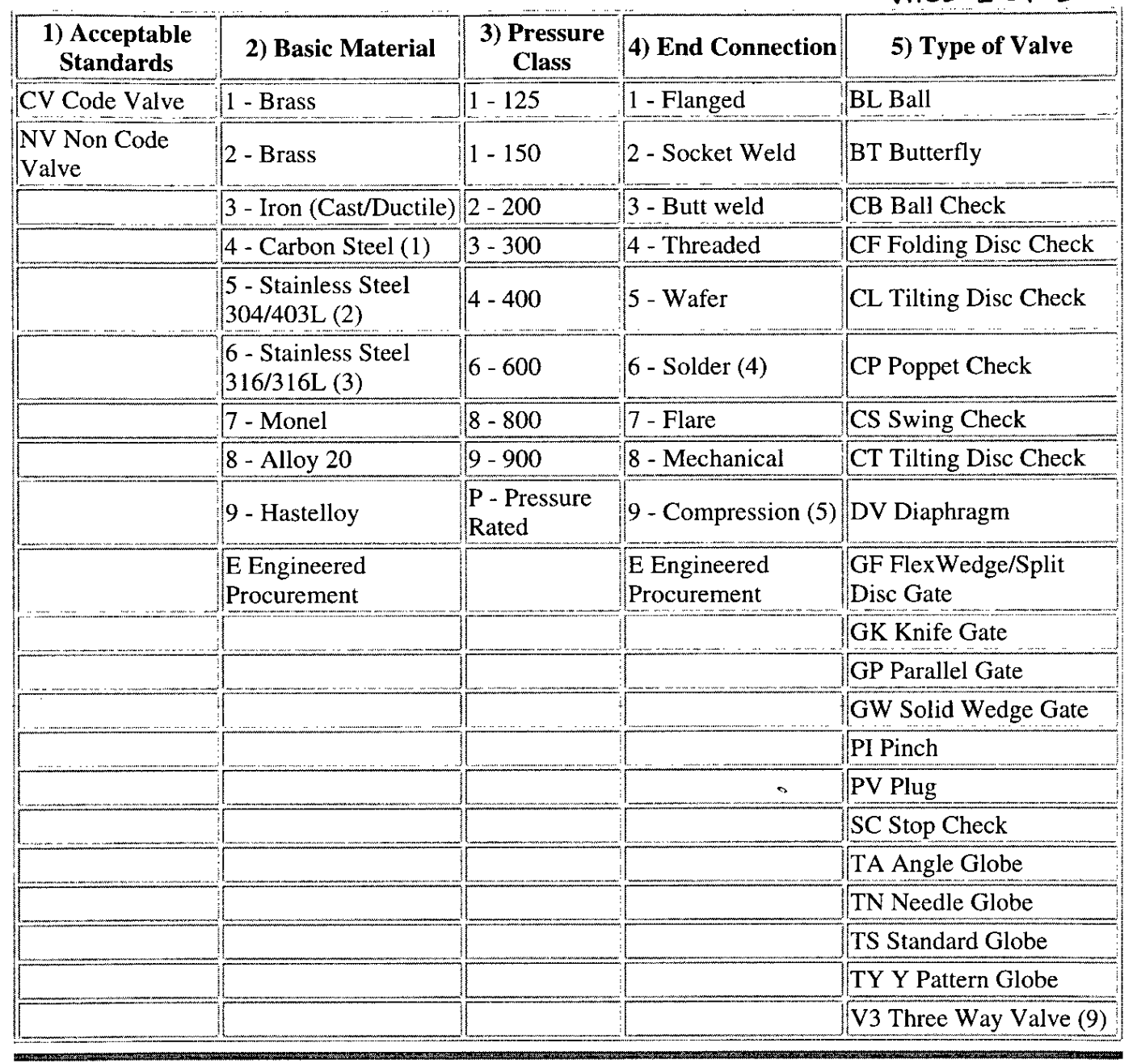

\section{Optional Specification Features}




\begin{tabular}{|c|c|c|c|c|}
\hline 7) Disc Material & 8) Seat Material & 9) Stem Material & $\begin{array}{l}\text { 10) Packing } \\
\text { Material }\end{array}$ & 11) Body Gasket \\
\hline $\begin{array}{l}\text { Chromium } \\
(11-13 \%)\end{array}$ & $\begin{array}{l}\text { A-Chromium } \\
(11-13 \%)\end{array}$ & $\begin{array}{l}\text { Chromium } \\
(11-13 \%)\end{array}$ & A Graphite & A Graphite \\
\hline $\begin{array}{l}\text { B Stellite (Hard } \\
\text { Face) }\end{array}$ & $\begin{array}{l}\text { B Stellite (Hard } \\
\text { Face) }\end{array}$ & B Carbon Steel & B Teflon & B Teflon \\
\hline C Bronze & C Bronze & C Bronze & C Natural Rubber & C Natural Rubber \\
\hline D Stainless Steel & D Stainless Steel & D Stainless Steel & D Nylon & D Nylon \\
\hline E Monel & E Monel & E Monel & E Nitrile (6) & E Nitrile (6) \\
\hline Alloy 20 & F-Alloy 20 & Alloy 20 & F Neoprene & F Neoprene \\
\hline G Hastelloy & G Hastelloy & G Hastelloy & G Viton & G Viton \\
\hline H Brass & H Brass & H Brass & H EPDM & H EPDM) \\
\hline I Nickle Copper & I Nickel Copper & I Nickel Copper & S Special (Specify) & I Ferrous \\
\hline J Teflon & J Teflon & S Special (Specify) & $\begin{array}{l}\text { X No Specific } \\
\text { Requirements (7) }\end{array}$ & J Non-Ferrous \\
\hline K Natural Rubber & K Natural Rubber & $\begin{array}{l}\text { X No Specific } \\
\text { Requirements (7) }\end{array}$ & & $\begin{array}{l}\text { K Spiral Wound } \\
\text { w/Teflon }\end{array}$ \\
\hline L Nylon & L Nylon & & & $\begin{array}{l}\text { L Spiral Wound w/ } \\
\text { Graphite }\end{array}$ \\
\hline M Nitrile (6) & M Nitrile (6) & & & S Special (Specify) \\
\hline N Neoprene & N Neoprene & & & $\begin{array}{l}\text { X No Specific } \\
\text { Requirements (7) }\end{array}$ \\
\hline O Viton & O Viton & & & \\
\hline P EPDM & P EPDM & & & \\
\hline Q Vespel & Q Vespel & & & \\
\hline S Special (Specify) & R UHMWPE & & & \\
\hline \multirow[t]{2}{*}{$\begin{array}{l}\text { X No Specific } \\
\text { Requirements (7) } \\
\end{array}$} & S Special (Specify) & & & \\
\hline & $\begin{array}{l}\text { X No Specific } \\
\text { Requirements (7) }\end{array}$ & & & \\
\hline
\end{tabular}


Return to Engineering Standard Home Page, Index

PAGI IOF 6

\begin{tabular}{|l|c|}
\hline SRS Engineering Standards Manual & Manual: WSRC-TM-95-1 \\
& ENGINEERING \\
& STANDARD \\
CIVIISSTTEDESIGN & STANDARD NO: 01110 \\
SRITERTA & DATE: 4/11/00 \\
REVISION: 3 \\
\end{tabular}

\begin{tabular}{|c|c|l|}
\hline REV & DATE & \multicolumn{1}{|c|}{ REVISION HISTORY } \\
\hline 0 & $8 / 1 / 95$ & DESCRIPTION OF REVISION \\
\hline 1 & $10 / 1 / 96$ & $\begin{array}{l}\text { Initial Issue } \\
\text { Reference to DOE Order 6430.1 A removed. Included DOE Order 420.1 } \\
\text { and reference to DOE-STD-1021 and Engineering Guide No. 02224-G. } \\
\text { Also editorial changes. }\end{array}$ \\
\hline 2 & $6 / 18 / 98$ & $\begin{array}{l}\text { Added Rainfall Intensity Curves for 50-, 500-, 2,000-, 10,000-, and } \\
\text { 100,000-, Year Return Periods, inserted Table 1, removed codes and } \\
\text { standards dates, included CLSM requirements. }\end{array}$ \\
\hline 3 & $\begin{array}{l}\text { Removed references to Standard Building Code (SBC), clarified use of } \\
\text { return period rainfall events and updated values given in Table 1, provided } \\
\text { guidance on flooding, removed reference to WSRC-IM-93-28 and added } \\
\text { reference to DOE/SR-5000-29, removed detailed requirements for clay } \\
\text { caps in section 5.4 , associated paragraph 3.1.6 standards, and replaced } \\
\text { with reference to Eng. Guide 02224-G. }\end{array}$ \\
\hline
\end{tabular}

\subsection{PURPOSE AND SCOPE}

1.1 This document delineates the site-specific civil design criteria to be used for all new facilities and modifications to existing facilities at the Savannah River Site when invoked by the Design Authority (Reference 6.1), and meets the criteria stipulated in DOE Order 420.1 (see Section 2.1).

This document applies to all functional classifications (Reference 6.2) of structures, systems and components.

1.2 All changes, deviations, additions and deletions shall be approved by the ESB.

\subsection{DOE ORDER AND STANDARDS APPLICABILITY}

2.1 DOE Order No. 420.1, Facility Safety

2.2 DOE Guide 420.1-Y, Interim Guidelines for the Mitigation of Natural Phenomena Hazards for Doe 


\subsection{NATIONAL CODES AND STANDARDS APPLICABILITY}

\subsection{General}

3.1.1 Applicability of the code and standards given in this document is limited to the extent of the reference in the text.

3.1.2 National codes and standards incorporated by reference in this document shall be the revision number/date at the time this document is invoked in the Design Output Documents, or as otherwise noted.

3.1.3 In case of conflict between various codes, standards, regulations and specifications, the more restrictive requirement shall apply. Conflict between codes, standards, regulations and specifications and these standards shall be brought to ESB for resolution.

3.1.4 Civil design shall be in accordance with DOE-STD-1020 and the UBC for PC-1 through PC-4 SSCs.

3.1.5 Since Performance Category PC-0 (Reference 6.15) applies only to lightweight equipment items, furniture, etc., no guidance is provided within this document.

\subsection{Codes, Standards and Regulations}

3.2.1 DOE Standard 1020-94, Natural Phenomena Hazards Design and Evaluation Criteria for Department of Energy Facilities

3.2.2 Uniform Building Code, International Conference of Building Officials, Whittier, California

3.2.3 DOE STD-1021-93, Natural Phenomena Hazards Performance Categorization Criteria for Structures, Systems and Components

3.2.4 Regulation 72-300, Standards for Stormwater Management and Sediment Control, South Carolina Department of Health and Environmental Control (SCDHEC).

\subsection{DEFINITIONS}

4.1 ASTM - American Society for Testing and Materials

4.2 CLSM - Controlled Low Strength Material (Reference 6.3)

4.3 DA - Design Authority (Reference 6.1)

4.4 DBFL - Design Basis Flood

4.5 DOE - Department of Energy

4.6 PE\&CD - Projects, Engineering and Construction Division at SRS

4.7 ESB - Engineering Standards Board at SRS 
4.8 Functional Classifications - As defined in Reference 6.2

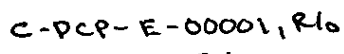

PAGE 3 OF 6

4.9 PC -1 through PC-4 - Performance Categories 1 through 4 (see Section 3.1.4)

4.10 SCDHEC - South Carolina Department of Health and Environmental Control

4.11 SRS - Savannah River Site

4.12 SSC - Structures, Systems, and Components

4.13 UBC - Uniform Building Code

4.14 WSRC - Westinghouse Savannah River Company

\subsection{REQUIRÉMENTS}

\subsection{General}

5.1.1 The responsibility for all design functions including the production of engineering drawings, procurement and project specifications and documents lies with PE\&CD and/or designated engineering service subcontractors. The appropriate individual representing these entities is referred to herein as the "Engineer."

5.1.2 The responsibility for all construction activities including the installation of vendor supplied and field procured items lies with PE\&CD and/or selected subcontractors. The appropriate individual representing these entities is referred herein as the "Constructor."

\subsection{Site Work}

5.2.1 Clearing and grubbing of all stumps and roots greater than $11 / 2 \mathrm{in}$. in diameter shall be done to a recommended depth of not less than 18 in. below rough grade or natural ground surface.

5.2.2 All timber, logs, stumps, roots, brush, rubble, excess topsoil and other trash (collectively called inert waste) shall be disposed of by the Constructor in accordance with Reference 6.4 .

\subsection{Excavation, Backfill and Site Grading}

5.3.1 Excavation, Backfill and Site Grading shall be performed in accordance with Engineering Guide No. 02224-G (Reference 6.12).

\subsection{Low Permeability Soil Layer}

5.4.1 Low permeability soil layer placement shall be performed in accordance with Engineering Guide No. 02224-G (Reference 6.12)

\subsection{Foundations}

5.5.1 The frost penetration depth at SRS is 5 in. below the finished grade. As a minimum, foundations of buildings shall be designed to meet the requirements of UBC. 


\subsection{Construction in Security Area}

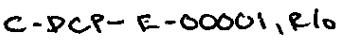

PAGE 4 OF 6

5.6.1 Location of buildings, poles, parking stalls, driving lanes, and any other features that may interfere with security systems within $20 \mathrm{ft}$ of a DOE security area shall be coordinated with WSRC Safeguards and Security Department.

\subsection{Stormwater Management and Sediment Control}

5.7.1 Stormwater management and sedimentation control at SRS shall be in accordance with Section 3.2 .4 and References 6.5 through 6.8 .

5.7.2 Land disturbing activity categories, plan approval and permit requirements for SRS have been stipulated in References 6.8 through 6.11 .

5.7.3 Facility drainage systems shall be designed, as a minimum, per the requirements of South Carolina Regulation 72-300, Standards for Stormwater Management and Sediment Reduction Regulation and SCDHEC Permit No. SCR 100000 (Ref. 6.11). The South Carolina Stormwater Management and Sedimentation Control Handbook for Land Disturbance Activities (Ref 6.5) provides supporting information and guidance on the development of permitting documentation. Appendix $G$ of the handbook provides the 24 hour storm event data for $1,2,5,10,25,50$, and 100 year return periods.

5.7.4 The required function of individual SSCs shall not be adversely impacted by the Design Basis Flood (DBFL) level resulting from the rainfall intensity at the return period applicable to the SSC. This flooding can be caused either by inadequate local storm water system and run off or can be due to back up in the site drainage basins (e.g. Upper Three Runs basin, etc.) and watersheds.

In addition to 5.7.3, potential for local area flooding shall be determined using the 24-hour storm event data appropriate for the SSC's Performance Category if the local accumulation is greater than that required by Section 5.7.3. If the results of this analysis, using the existing storm water management system or one designed in accordance with 5.7.3, demonstrate that flooding does not compromise the site SSCs, then it may be concluded that the facility stormwater management system is adequate. Note that local flooding in streets, parking lots, etc. may occur due to the DBFL precipitation. If flooding does have an unacceptable impact, then the design must be modified to:

increase drainage capacity to reduce the flooding to an acceptable level, move the impacted SSCs out of the flood zone, and/or provide local flood protection for the SSCs.

SRS Rainfall Accumulation values (Ref. 6.13) for 500 (PC-1), 2000 (PC-2), 10,000 (PC-3), and 100,000 (PC-4) year return periods are provided in Table 1

The flooding hazards in SRS areas resulting from non-local events; i.e., back up in the site drainage basins and watersheds, may be obtained from the report "Flood Hazard Recurrence Frequencies for C-, F-, E-, S-, H-, Y- and Z-Areas (U) (Ref 6.14).

5.7.5 R-Factors used in the Universal Soil Loss Equation for computation of storage shall be taken as follows (See Appendix G, Reference 6.5): 
Standard 01110 Rev 3

Aiken County 250

Barnwell County 275
http://apps01.srs.gov/engineering/Standards/01 110/01110.ht1

$$
\text { C-PCP-E-00001, R1O }
$$

PAGE $S$ OF 6

\subsection{Sanitary Landfill and Industrial Solid Waste Disposal}

5.8.1 For the design of the sanitary landfill and industrial solid waste disposal at SRS refer to the applicable local, state and federal regulations, and for permitting process, see Sections 1.10 and 2.10 of Reference 6.9 .

\subsection{Controlled Low Strength Material (CLSM)}

5.9.1 The delivery and supply of materials for CLSM are provided in SRS Procurement Specification C-SPS-G-00085, Furnishing and Delivery of Concrete. (Reference 6.3) Placement and installation testing requirements are provided in SRS Engineering Guide 02224-G, Excavation, Backfill and Site Grading. (Reference 6.12)

\subsection{REFERENCES}

6.1 SRS Procedure No. 1.10, Design Authority, Procedure Manual E7, Conduct of Engineering and Technical Support.

6.2 SRS Procedure No. 2.25, Functional Classifications, Procedure Manual E7, Conduct of Engineering and Technical Support.

6.3 SRS Procurement Specification No. C-SPS-G-00085, Furnishing and Delivery of Concrete.

6.4 SRS Procedure No. CMP-05-1.2, Procedure for the Disposal of Inert Construction Waste.

6.5 South Carolina Stormwater Management and Sedimentation Control Handbook for Land Disturbance Activities, SCDHEC.

6.6 South Carolina Stormwater Management and Sediment Control Sedimentology Resource, SCDHEC.

6.7 Soil Survey of Savannah River Plant Area, Parts of Aiken, Barnwell, and Allendale Counties, South Carolina, Soil Conservation Service, US Department of Agriculture.

6.8 WSRC Environmental Compliance (ECM) Manual 3Q, Procedure ECM 12.2, Stormwater Management and Sediment Reduction.

6.9 Manual No. WSRC-IM-91-69, SRS Environmental Permitting, "HOW" Manual, Sections 1.9 and 1.13.

6.10 DOE/SR-5000-29, Handbook for Erosion and Sediment Control on the Savannah River Site.

6.11 Permit No. SCR 100000 - SCDHEC NPDES General Permit for Stormwater Discharge from Construction Activities that are Classified as "Associated with Industrial Activity" by EPA Regulation, Issue Date: January 15,1998, Expiration Date: January 31, 2003.

6.12 SRS Engineering Guide No. 02224-G, Excavation, Backfill and Site Grading. 
6.13 Report No. WSRC-RP-98-00329, Tornado, Maximum Wind Gust, and Extreme Rainfall Event Frequencies at the Savannah River Site, September, 1998

6.14 Report No. WSRC-TR-99-0369, Flood Hazard Recurrence Frequencies for C-, F-, E-, S-, H-, Y- and Z-Areas (U), September, 1999

6.15 DOE-STD-1020-94, NPH Design and Evaluation Criteria for DOE Facilities

\subsection{FIGURES / TABLES}

7.1 Table 1- Rainfall Accumulation in Inches for 500-, 2000-, 10,000 -, and 100,000- Year Return Periods.

\begin{tabular}{|c|c|c|c|c|c|c|c|}
\hline \multirow{2}{*}{$\begin{array}{c}\text { Performance } \\
\text { Category }\end{array}$} & $\begin{array}{c}\text { Annual Hazard } \\
\text { Exceedance } \\
\text { Probability }\end{array}$ & $\begin{array}{c}\text { Return Period } \\
\text { (Years) }\end{array}$ & 15 min. & 1 hour & 3 hour & 6 hour & 24 hour \\
\hline PC-1 & $2 \times 10^{-3}$ & 500 & 2.6 & 4.7 & 6.7 & 7.4 & 10.3 \\
\hline PC-2 & $5 \times 10^{-4}$ & 2000 & 2.9 & 5.4 & 8.2 & 9.2 & 12.8 \\
\hline PC-3 & $1 \times 10^{-4}$ & 10,000 & 3.3 & 6.2 & 10.3 & 11.8 & 16.3 \\
\hline PC-4 & $1 \times 10^{-5}$ & 100,000 & 3.9 & 7.4 & 14.1 & 16.7 & 22.7 \\
\hline
\end{tabular}

Table 1

Rainfall Accumulation in Inches for 500-, 2000-, 10,000-, and 100,000- Year Return Periods. 


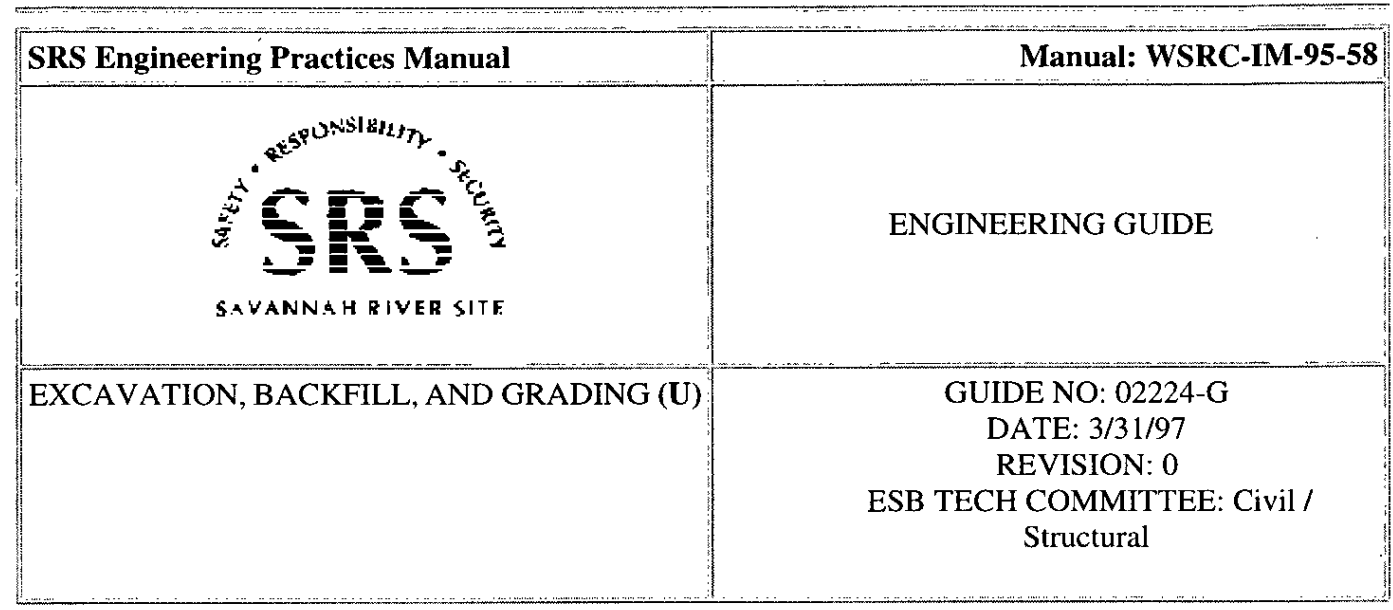

\section{REVISION HISTORY}

\begin{tabular}{|c|c|c|}
\hline REV & DATE DESCRIPTION OF REVISION \\
\hline 0 & $3 / 31 / 97$ & Initial Issue \\
\hline
\end{tabular}

\subsection{PURPOSE \& SCOPE}

\subsection{Purpose}

This document is an Engineering Guide and represents information considered appropriate for the Savannah River Site (SRS). It is written in mandatory language for adoption by projects and/or operation procedures for a facility. To be mandatory, the provisions in this Engineering Guide must be invoked by appropriate project or operation documents. If necessary, provisions in this Engineering Guide may be augmented by detailed requirements shown on project documents.

\subsection{Scope}

The scope of information contained herein is applicable for the excavation, hauling, stockpiling, disposal, backfilling, and grading of all soil and soil-like materials necessary for the construction of facilities at SRS.

1.2.1 Except as noted, the technical requirements described herein are applicable for the excavation, backfill, and site grading operations for all structures and facilities. Requirements for water impoundment structures, such as dams, dikes, and berms, and landfill liners and caps are included in project-specific specifications. The technical requirements are to be augmented further by the appropriate level of Quality Assurance requirements as stated on design drawings.

1.2.2 The Constructor shall control the quality of items and services to meet the requirements of this 
NEW 02224-G / LEFT ALIGN / 12/15/9:

http://apps01.srs.gov/engineering/Guides/02224-G/02224g.hts $C-P C P-E-\infty 0001$, R1O

PAGE 2 OF 12

document, the appropriate Quality Assessment Report requirements, and the requirements of other Codes and Standards as applicable.

\subsection{DOE ORDER APPLICABILITY}

Department of Energy (DOE) Order 420.1, Facility Safety, is applicable to the work described herein. Technical requirements, as specified, meet or exceed the minimum standards set by the above Order.

\subsection{NATIONAL CODES AND STANDARDS APPLICABILITY}

\subsection{General}

3.1.1 The applicability of the following Codes and Standards is limited to the extent of the reference in the text.

\begin{tabular}{|c|c|c|}
\hline ASTM & C39-94 & $\begin{array}{l}\text { Standard Test Method for Compressive Strength of Cylindrical Concrete } \\
\text { Specimens }\end{array}$ \\
\hline ASTM & D422-90 & Standard Test Method for Particle-Size Analysis of Soils \\
\hline ASTM & D $1556-90$ & $\begin{array}{l}\text { Standard Test Method for Density and Unit Weight of Soil In-Place by the } \\
\text { Sand-Cone Method }\end{array}$ \\
\hline ASTM & D1557-91 & $\begin{array}{l}\text { Test Method for Laboratory Compaction Characteristics of Soils Using } \\
\text { Modified Effort }\left(56,000 \mathrm{ft}-\mathrm{lbf} / \mathrm{ft}^{3}(2,700 \mathrm{kN}-\mathrm{m} / \mathrm{m} 3)\right)\end{array}$ \\
\hline ASTM & D1883-94 & $\begin{array}{l}\text { Standard Test Method for CBR (California Bearing Ratio) of } \\
\text { Laboratory-Compacted Soils }\end{array}$ \\
\hline ASTM & D2216-92 & $\begin{array}{l}\text { Standard Test Method for Laboratory Determination Water (Moisture) Content } \\
\text { of Soil and Rock }\end{array}$ \\
\hline ASTM & D2487-93 & $\begin{array}{l}\text { Classification of Soils for Engineering Purposes (Unified Soil Classification } \\
\text { System) }\end{array}$ \\
\hline ASTM & D2922-91 & $\begin{array}{l}\text { Standard Test Methods for Density of Soil and Soil- Aggregate In-Place by } \\
\text { Nuclear Methods (Shallow Depth) }\end{array}$ \\
\hline ASTM & D3017-93 & $\begin{array}{l}\text { Standard Test Method for Water Content of Soil and Rock by Nuclear Methods } \\
\text { (Shallow Depth) }\end{array}$ \\
\hline ASTM & D4318-95 & $\begin{array}{l}\text { Standard Test Method for Liquid Limit, Plastic Limit, and Plasticity Index of } \\
\text { Soils }\end{array}$ \\
\hline ASTM & D4643-93 & $\begin{array}{l}\text { Standard Test Method for Determination of Water (Moisture) Content of Soil } \\
\text { by the Microwave Oven Method }\end{array}$ \\
\hline
\end{tabular}


3.1.2 Later editions of the Codes and Standards may be used provided the minimum requirements specified herein are fully satisfied.

3.1.3 In case of conflicts between the various Codes and Standards, the more restrictive requirement shall apply. When conflict exists between the Codes, Standards, and engineering drawings, the latter shall prevail.

\subsection{DEFINITIONS}

Abbreviations used in this document shall have the following meanings:

ASTM American Society for Testing and Materials

CLSM Controlled Low Strength Material

DE Design Engineering

PS Production Support

GS General Services

PE\&CD Projects, Enginecring, and Construction Division

SRS Savannah River Site

SC Safety Class

SS Safety Significant

\subsection{GUIDANCE}

\subsection{General}

5.1.1 The responsibility for all design functions including the production of engineering drawings, procurement and project documents lies with PE\&CD. The appropriate individual representing these entities is referred to herein as the "Engineer".

5.1.2 The responsibility for all construction activities including the installation of vendor supplied and field procured items lies with PE\&CD and/or selected subcontractors. The appropriate individual representing these entities is referred to herein as the "Constructor".

5.1.3 Based on the appropriate project documents, such as QAR, design drawings shall establish the Functional Classification of construction for various structures, systems, and components. Unless noted otherwise, field inspection activities for SC and SS classifications shall be independently inspected by the quality control organization and inspections for PS and GS classifications shall be peer-verified by the Constructor's line organization.

5.1.4 Unless noted otherwise on drawings, site grading operations including common backfill need only be subject to Quality Assurance requirements that are appropriate for GS classification regardless of the design classification of the structures and facilities for which these operations are undertaken.

5.1.5 The agency responsible for all soil testing is referred to herein as the "Testing Agency".

5.1.6 Unless noted otherwise on design drawings, excavation and common backfill operations need only be subject to the Quality assurance requirements that are appropriate for General Service (GS) classification 
regardless of the structures or facilities for which the operations are undertaken.

\subsection{Excavation}

5.2.1 The Constructor shall determine the suitability of excavated soil for use as backfill as described in Section 5.4. Suitable material shall consist of material meeting the requirements for structural or common fill. All material shall be removed within the limits of excavation as shown on the design drawings.

5.2.2 Any soil suitable for reuse, as determined by the Constructor, shall be placed or stockpiled in designated areas. Excess material, unsuitable material, and excavated CLSM shall be disposed of in areas designated by the Engineer.

5.2.3 Prior to the commencement of stripping operations for grading, the site shall have been cleared and grubbed. Stripping shall include the removal of all topsoil and organic material to a maximum depth of one foot within the limits of site grading shown, unless otherwise directed by the Engineer. Directed removal of topsoil and organic material below this depth will be considered removal of soil unsuitable as backfill material.

5.2.4 Topsoil shall be stockpiled in the quantities and at the locations shown on engineering drawings. Stockpiled topsoil shall be fertile, friable, loamy, and free from subsoil, refuse, roots, heavy or stiff clay, stones larger than 1.5 inches, coarse sand, weeds, sticks, brush, litter, and other deleterious substances.

5.2.5 Different classes of material, based on gradation and plasticity as determined by the Constructor, shall be stockpiled separately as directed by the Engineer and shall be placed to provide natural drainage and a stable embankment. Stockpiles shall not exceed a height of 40 feet.

5.2.6 Excess topsoil, rubble, trash, organic material, and other inert waste shall be disposed of by the Constructor as indicated on design drawings or as directed by the Engineer.

5.2.7 Materials within the limits of excavation that are defined as non-compliant backfill within this specification shall be removed and disposed of appropriately.

5.2.8 Any work to be undertaken in the "wetlands" shall require a separate written authorization from the appropriate SRS implementing organization in accordance with their applicable procedures.

5.2.9 The final 6 inches of excavation beneath a load bearing surface shall be made using either smooth blade equipment or hand excavation. The bearing surface for footings, mats, grade beams, sumps, floor slabs, and other load carrying members shall be undisturbed naturally deposited inorganic soil or compacted structural fill. Bearing surfaces shall be approved by the Engineer for all SC and SS projects. PS and GS projects shall be inspected by the Constructor unless noted otherwise on the design drawings. All inspections shall take place prior to the placement of reinforcing steel and concrete forms. The Engineer reserves the right to disapprove a bearing surface after initial approval was given if the bearing surface has deteriorated or softened. The bearing surface shall then be reapproved after additional preparation is executed by the Constructor.

5.2.10 In the event that non-compliant fill materials are encountered at the construction elevation, the Engineer shall be notified. Where excavation is performed to elevations below those shown on the design drawings, the planned elevation shall be re-established. Elevations may be re-established by filling the space with concrete of a minimum 28-day strength of 2000 psi, CLSM, or by backfilling and compacting with suitable structural fill with written approval from the Engineer. 
5.2.11 All excavations shall conform to the lines, grades, sections, elevations, and tolerances shown on the drawings. Where no tolerances are specified, a tolerance of \pm 6 inches shall be utilized. A smooth grade shall be maintained to provide positive drainage at all times.

5.2.12 Ditches, gutters, and channel changes shall be cut accurately to the cross sections and grades shown. All roots, stumps, rocks, and foreign matter in the sides and bottom of ditches, gutters, and channels shall be trimmed and dressed or removed. Excavation below grades shown shall be backfilled to grade with suitable material. All ditches, gutters, and channel changes shall be maintained until final acceptance. No excavated material shall be deposited closer to the edges of the ditches than indicated and in no case less than 3 feet.

5.2.13 The method of excavation shall not weaken surrounding areas nor damage structures or parts thereof that are completed or under construction. Existing structures and utilities adjacent to excavations shall be protected and supported to prevent movement.

5.2.14 Shoring impacted by, or affecting, structures or facilities shall be provided by the Engineer. All other shoring shall be provided by the Constructor unless otherwise indicated on the design drawings.

5.2.15 Areas being excavated and areas to be filled shall be maintained in a clean condition free from leaves, brush, sticks, trash, and other debris.

5.2.16 Temporary roads shall be constructed by the Constructor as required to complete the work. At the completion of the project, these construction roads shall be removed and the land returned to the original condition unless otherwise specified.

5.2.17 Construction roadside slopes and spoil area slopes shall be graded to meet existing contours to prevent water accumulation and erosion.

\subsection{Drainage}

5.3.1 Excavation shall be performed such that the site area and the area directly adjacent to the site shall be continually and effectively drained. Water shall not be permitted to accumulate in the excavation. The excavation shall be drained by pumping or other satisfactory methods to prevent softening of the foundation bottom, undercutting of footings, or other action detrimental to proper construction procedures.

5.3.2 In the event unforeseen groundwater or contamination is encountered, the Constructor shall immediately notify the Engineer for disposition of groundwater or contaminants.

5.3.3 Rainfall and surface water shall be controlled and removed and discharged at locations indicated by the erosion control plan.

5.3.4 Construction roadside slopes and spoil area slopes shall be graded to meet existing contours to prevent water accumulation and erosion.

\subsection{Fill Materials}

5.4.1 Unless otherwise approved or designated, fill materials for earthwork construction shall be obtained from the excavation, stockpiles located near the work, designated borrow areas, or from other sources approved in writing by the Engineer. Material containing brush, roots, peat, sod, other organic material, 
rock greater than 2 inches in diameter, frozen material, or any other deleterious material shall not be used as, or in, backfill. Suitable fill material shall consist of any inorganic mineral soil that can be readily placed and spread and meets the requirements of this specification. Unsuitable excavated material and excavated CLSM shall be disposed of as directed by the Engineer.

5.4.2 Unless otherwise approved, borrow sources and stockpiles shall be excavated and maintained to provide satisfactory drainage.

5.4.3 Structural fill used for backfilling shall consist of well-graded sands (SW) or silty sands (SM) as defined per ASTM D2487 and shall be free of organic material, loam, trash, snow, ice, frozen soil, rock greater than 2 inches in diameter and greater than 1/2-inch at the exposed surface, and other objectionable material. Structural fill shall be well-graded within the following limits as determined in accordance with ASTM D422 with a plasticity index less than $15 \%$.

$\begin{array}{cc}\text { Sieve Size Percent } & \text { Passing By Weight } \\ \text { 3/8-inch } & 100 \\ \text { No. } 4 & 95 \text { to } 100 \\ \text { No. } 10 & 85 \text { to } 100 \\ \text { No. } 20 & 70 \text { to } 95 \\ \text { No. } 40 & 35 \text { to } 85 \\ \text { No. } 60 & 15 \text { to } 70 \\ \text { No. } 140 & 2 \text { to } 20 \\ \text { No. } 200 & 0 \text { to } 15\end{array}$

5.4.4 Common fill used for backfilling shall consist of soils defined per ASTM D2487 as SW, SP, SM, and $\mathrm{SC}$ and shall be free from organic material, loam, trash, snow, ice, frozen soil, rock greater than 3 inches in diameter and greater than 1 inch at the exposed surface, and other objectionable material. Common fill shall be compacted to a minimum in-place dry density of 100 pcf and shall be graded within the following limits as determined in accordance with ASTM D422. Unsuitable material and soil shall be disposed of as directed by the Engineer.

$\begin{array}{cc}\text { Sieve Size Percent } & \text { Passing By Weight } \\ \text { 3/4-inch } & 100 \\ \text { 3/8-inch } & 95 \text { to } 100 \\ \text { No. } 4 & 85 \text { to } 100 \\ \text { No. } 10 & 75 \text { to } 100 \\ \text { No. } 20 & 50 \text { to } 100 \\ \text { No. } 40 & 25 \text { to } 95 \\ \text { No. } 60 & 15 \text { to } 80 \\ \text { No. } 140 & 2 \text { to } 30 \\ \text { No. } 200 & 0 \text { to } 15\end{array}$

5.4.5 As a construction option, CLSM (Controlled Low Strength Material) may also be used as structural or common fill as approved by the Engineer. For specific requirements controlling production or placement of CLSM refer to Section 5.6 and Reference 6.1. 
NEW 02224-G / LEFT ALIGN / 12/15/9:

\subsection{Fill Placement}

http://apps01 srs. gov/engineering/Guides/02224-G/02224g.hu

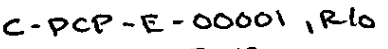

\subsubsection{Structural Fill}

5.5.1.1 Structural fill placed beneath foundations on approved subgrade is subject to the provisions of this section. After the completion of footings and walls, and prior to the placement of backfill, all forms will be removed and the excavation shall be cleaned of all trash, debris, and unsuitable material.

5.5.1.2 Subgrades for fills supporting roadway, light structures, or other loaded areas shall be proof-rolled with a 20-ton roller. All areas that "pump" or appear to be soft shall be replaced with compacted fill.

5.5.1.3 No backfill shall be placed on the foundation soils or around foundation concrete until the area has - been inspected and approved by the Constructor. Before placing backfill material, the subgrade shall be scarified to a minimum depth of at least 2 inches, moisture conditioned, if necessary, and compacted to the requirements as given in the sections below.

5.5.1.4 Backfill shall be placed in successive uniform loose layers and to a depth at which densities can be obtained. In no case shall any layer of loose material placed for compaction exceed 9 inches when hand-operated mechanical equipment is used and 12 inches when self-propelled or towed mechanical equipment is used. No backfilling against concrete shall be done until the concrete has attained a strength equal to $80 \%$ of the design strength, or as directed by the Engineer. If the subgrade concrete has been waterproofed, the backfilling shall be done so as not to damage the waterproofing or its protective materials. CLSM may be used against concrete immediately after form removal.

5.5.1.5 To ensure proper bonding between lifts, the Constructor shall scarify the previous compacted soil lift surface prior to placing the next lift. To ensure proper lift bonding, soil fill with substantial clay content, and other materials noted within the design documents, require scarification to a minimum depth of 2 inches to ensure proper bonding between lifts, or as directed by the Engineer. Granular materials shall be lightly scarified between lifts, unless noted otherwise. Scarification is not required when placing CLSM.

5.5.1.6 Prior to terminating work for the day, the final layer of compacted fill, after compaction, shall be rolled with a smooth-wheeled roller to eliminate ridges of soil left by tractors, trucks, and other compaction equipment. Fill layers shall not be placed on snow, ice, or soil that was permitted to freeze prior to compaction. In freezing weather, a layer of fill shall not be left in an uncompacted state at the close of a day's operations. Removal of these unsatisfactory materials will be required.

5.5.1.7 Desiccated contact surfaces of compacted fill layers, subgrades, or disturbed surfaces shall be scarified to a depth of 6 inches, moistened to the required moisture content, and compacted to the specified density.

5.5.1.8 Before placing additional fill, material that is soft and yielding as a result of excess water shall be replaced with suitable material or scarified and allowed to dry out to the specified moisture content and recompacted.

5.5.1.9 Oversize material as defined in Section 5.4.4 shall be removed from the backfill and disposed of in designated areas.

5.5.1.10 Structural fill shall be compacted to a minimum density of $95 \%$ of maximum dry density determined in accordance with ASTM D1557. 
5.5.1.11 Sloped ground surfaces steeper than one vertical to four horizontal on which fill is to be placed shall be plowed, stepped or benched, or broken up as required to facilitate bonding between the fill and the existing surface. Prepared surfaces on which compacted fill is to be placed shall maintain the required moisture content and compaction level.

\subsubsection{Common Fill}

5.5.2.1 Unless noted otherwise within the design documents, areas to receive fill shall be "common fill" areas.

5.5.2.2 In no case shall unsuitable material remain in or under the fill area. Placement and compaction procedures shall be the same as for Structural Fill described in Section 5.5.1, except for compaction criteria. Common backfill shall be compacted to a minimum of $90 \%$ of the maximum density as determined in accordance with ASTM D1557.

5.5.2.3 Fills shall be constructed at the locations and to lines and grades shown or required on drawings. The material shall be placed in successive horizontal layers with a loose thickness not to exceed 9 inches when hand-operated equipment is used and 12 inches when self-propelled mechanical equipment is used. The fill material shall be placed for the full width of the cross section and shall be compacted as required.

5.5.2.4 Sloped ground surfaces steeper than one vertical to four horizontal on which fill is to be placed shall be plowed, stepped or benched, or broken up as required to facilitate bonding between the fill and the existing surface.

5.5.2.5 Prepared surfaces on which compacted fill is to be placed shall be wetted or dried as may be required to obtain the moisture specified.

5.5.2.6 Material shall be placed in fill areas to form a homogeneous mass, free from lenses, pockets, streaks, and layers of material differing substantially in texture and gradation from surrounding material. Fill material with a substantial clay content and other materials as noted within the design documents are required to be scarified to a minimum depth of 2 inches to ensure proper bonding between lifts. Granular materials do not require scarification between lifts unless noted otherwise.

5.5.2.7 No fill shall be placed upon a frozen surface nor shall any ice or frozen earth be incorporated in the backfill.

\subsection{Controlled Low Strength Material (CLSM)}

5.6.1 The CLSM shall have a 28-day compressive strength of 30 to $150 \mathrm{psi}$. In-place pour density shall be within the range of 115 to 145 pcf. After the CLSM has set, the density may be determined by ASTM D2922 or ASTM D1556.

5.6.2 The water content of CLSM as placed shall be between 60 and 66 gallons per cubic yard unless noted otherwise by the engineer. Water addition, if required, shall be added to the CLSM batch upon receipt at the jobsite prior to any discharge and shall be mixed by a minimum of 30 revolutions of the drum. Any water added to the batch at the jobsite shall be recorded on the batch ticket by the receiving organization.

5.6.3 Preparation of subgrade prior to use of CLSM shall be the same as is required for soil backfill. Scarification and recompaction of undisturbed natural grade is not required. CLSM may be screeded, if required, to provide a uniform grade, but shall not be vibrated. 
5.6.4 CLSM is not designed to resist freeze and thaw or erosive weathering and requires erosion control as stipulated by the design documents. If erosion control is not stipulated, then a minimum of 6 inches of common soil backfill, select aggregate base coarse, or a protective wearing surface such as asphalt or concrete shall be placed over the CLSM. In areas where the native soil is highly impervious and standing water does not cause sloughing or penetrates the surface more than 1 inch, the CLSM may be deposited directly into 3 inches or less of standing water. Drainage must be provided to allow the displaced water to run-off.

\subsection{Moisture Control}

5.7.1 Unless otherwise designated or approved, for materials where a definable moisture-density curve can be established utilizing ASTM D1557, the moisture content during compaction shall be within $\pm 3 \%$ of optimum moisture content. For very clean sands where a definable moisture-density curve cannot be established, the material shall be saturated. Optimum moisture content will be determined by the Testing Agency per ASTM D1557. Moisture content is a guidance criteria and shall not be used as an acceptance criteria for compaction of any fill material.

5.7.2 Fill material to be compacted shall be moisture conditioned, as far as practicable, in the stockpiles or borrow sources. Fill material not maintaining a uniform moisture content shall be conditioned by flooding, sprinkling, aerating, harrowing, disking, draining, or other approved means. Natural moisture content of the fill material shall be determined by the Testing Agency in accordance with ASTM D2216 or D4643.

5.7.3 After placement of loose material in the fill area, the moisture content shall be adjusted as necessary to bring the material within required moisture content limits. The Testing Agency will verify moisture content per ASTM D2216, D3017, or D4643, as necessary. Material placed too wet for compaction shall be left to drain or shall be aerated and dried by disking and harrowing or otherwise mixed until the moisture content of the entire layer is uniform and within the specified limits. Sprinkling shall be by sprinkler trucks (or other suitable means for congested areas) equipped with pressure spray bars and valves to give a uniform and even application of water to the dry areas and control of the rate of water application at all times. Any section of the fill area containing material that is too wet or too dry shall not be compacted until the moisture content of the material is brought within the specified limits or the material shall be removed and replaced with material having a moisture content within the specified limits.

5.7.4 Placement of fill for which moisture conditioning is required shall be suspended when the ambient temperature is $35^{\circ} \mathrm{F}$ and falling.

\subsection{Compaction}

5.8.1 Material satisfactorily placed and spread and having a moisture content within the specified limits shall be compacted by vibratory or static rolling. Rolling shall be performed systematically on all portions of each area.

5.8.2 Unless otherwise approved by the Engineer, all roller trips shall be made in parallel paths. To ensure complete coverage of the area rolled, each trip of the roller shall overlap the adjacent trip by not less than 2 feet. If there is sufficient area, the dumping, spreading, sprinkling, mixing, and compacting may be performed at the same time at different points on the backfill surface.

5.8.3 Compaction equipment shall be suitable for the type of soil and magnitude of compaction required. All backfill not accessible to roller compaction shall be compacted by power tampers or vibratory 
compactors or other approved means to the same degree of compaction achieved by roller-compaction.

5.8.4 Material satisfactorily placed and spread in the fill, and having a moisture content uniformly distributed through the fill within the specified limits, shall be compacted by rolling to attain the satisfactory compaction of not less than $95 \%$ for structural fill and $90 \%$ for common fill (95\% for the top two feet of fill under roads, parking areas, and railroads) of the maximum dry density determined in accordance with ASTM D1557. Compliance shall be verified per ASTM D1556 or D2922.

\subsection{Test Fill}

5.9.1 Existing test fill data from previous work at SRS should be utilized for guidance on construction methodology for placement and compaction of backfill provided similar materials and placement conditions are maintained and per approval of the Engineer.

5.9.2 A test fill shall be required to evaluate specific compaction equipment or backfill materials not previously evaluated. The methods of handling, spreading, and moisture conditioning of the material shall be the same for the test fill as for the earthwork operations.

5.9.3 The test fill, using approved materials and specific methods, shall be constructed to include as a minimum the following variables for the evaluation of equipment to produce the required compaction: equipment type, number of equipment passes per lift, lift thickness, density per lift, moisture content, gradation, and Atterberg limits.

5.9.4 If more than one type of soil material is approved for backfill or fill, each material shall be tested separately in the test fill.

5.9.5 The Constructor shall monitor the test fill. The Testing Agency shall take test samples as often as required for evaluation of the compaction effort. Based on the evaluation, the Engineer may direct modification of the variables listed above.

\subsection{Grading}

5.10.1 All finished areas covered by the project, including excavated and filled sections, shall be smoothly and uniformly graded and free from surface irregularities according to the line, grade, and cross section shown on the design drawings. The degree of finish shall be that ordinarily obtainable from blade-grader operations unless otherwise specified.

5.10.2 Prior to placement of foundation material and subgrade areas for paving, the following shall be accomplished as required per Sections 5.5.1 and 5.5.2.

5.10.3 The surface of excavated or filled areas on which foundations, base course, or pavement are to be placed shall vary not more than \pm 0.1 foot from the established grade or approved cross section.

5.10.4 The surface of unfinished fills and subgrades shall be bladed smooth to a crown and rolled, with a smooth wheeled roller, at the conclusion of each day's work or before shutdown for any cause to permit adequate drainage. Ditches and gutters shall be finished to permit adequate drainage.

\subsection{Testing}

5.11.1 The Testing Agency shall conduct field density and related tests in the compacted fill and the 
related laboratory compaction testing to determine the relative degree of compaction and other properties. Field density tests shall be taken as required with at least one test each day for each area in which compaction is being carried out or at least one test for each 250 or 500 cubic yards of fill per'Table 1 . Testing shall be performed at a greater frequency, as determined by the Engineer, at the start of compaction for every new structure, facility, or project and in congested areas requiring small placement volumes.

5.11.2 Concurrent with construction, the Testing Agency shall take samples of the material from the borrow areas and fill and test these samples for moisture content, compaction, Atterberg limits, and gradation, and carry out any other control or record tests that may be required. Testing shall be performed by the Testing Agency as frequently as is deemed necessary by the Constructor. Retesting of fill that has failed criteria shall be at the discretion of the Engineer.

5.11.3 Use of the nuclear method for density and moisture determination shall require field calibration in accordance with ASTM D2922 and ASTM D3017. One sand cone density test in accordance with ASTM D1556 shall be performed for every ten nuclear density tests as verification.

5.11.4 Testing of CLSM shall be as required by design documents or as requested by Engineering or the Constructor. The following tests are applicable and shall conform to the standards listed below:

Compressive Strength: compressive strength tests shall be prepared in accordance with ASTM C 39 and be. used for information only. Strength tests shall be performed at cure times of 14 and 28 days and shall use a minimum of two specimens for each cure time.

Density: moist densities shall be obtained either by ASTM D 1556 or ASTM D2922 after a cure period of at least 24 hours.

Bearing Capacity: California Bearing Ratio shall be performed in accordance with ASTM D1883. Recommended tests shall be performed at cure times of 2,14 , and 28 days.

\subsection{Erosion Control}

Requirements for erosion control shall be as described on the design drawings.

\subsection{Inspection}

\subsubsection{Excavation and Backfill}

Prior to final acceptance, all work shall be inspected (by the Engineer, if so specifically stated on design drawings) for conformance to drawings and document requirements. A graded approach shall be used for inspection of excavation and backfill activities as specified in Table 1, which may include frequency of testing, adequacy of test results, and results of inspections on natural subgrades or compacted fill surfaces prior to placement of foundation concrete or additional backfill.

\subsubsection{Grading}

Prior to final acceptance, all work shall be inspected (by the Engineer, if so specifically stated on design drawings) for conformance to drawings and document requirements. As a minimum, a record shall be generated to document the inspection results for proper selection of the fill or backfill material, in-place density and moisture content of the compacted material, and excavation and grading within specified tolerance. 


\subsection{REFERENCES}

6.1 Procurement Specification for Furnishing and Delivery of Concrete; GS, PS, and SS (U), Specification No. C-SPS-G-00085.

\subsection{ATTACHMENTS}

7.1 Table 1. Graded Approach for Inspection of Excavation, Backfill, and Grading.

Table 1. Graded Approach for Inspection of Excavation, Backfill, and Grading

\section{INSPECTION ACTIVITY}

Excavation within specified tolerances

Subgrade inspection prior to backfill or concrete placement

Proper selection of fill material

In-place density of compacted material

In-place moisture content of structural fill material

Frequency of testing (minimum of once per specified volume)

Grading within specified tolerances

DOCUMENTATION RESPONSIBILITY

\section{SC SS PS GS}

$\mathrm{X}$

$X \quad X \quad X$

$\mathrm{X} \quad \mathrm{X}$

$\begin{array}{llll}X & X & X\end{array}$

$\mathrm{X} \quad \mathrm{X} \quad \mathrm{X} \quad \mathrm{X}$

Notes:

1. No testing required for individual, nonadjacent fills of less than 2 cubic yards.

2. No testing required for individual, nonadjacent fills of less than 5 cubic yards.

3. Q denotes Quality Organization independent inspection.

4. C denotes Constructor peer verification.

Return to Engineering Guide Home Page, Index 


\section{C- DCP - E- 00001, R10 \\ ATTACHMENT 6 \\ PAGE GI OF GIG

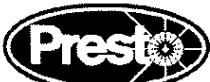 \\ GEOWEB ${ }^{\circledR}$ CELLULAR CONFINEMENT SYSTEM \\ MATERIAL SPECIFICATION}

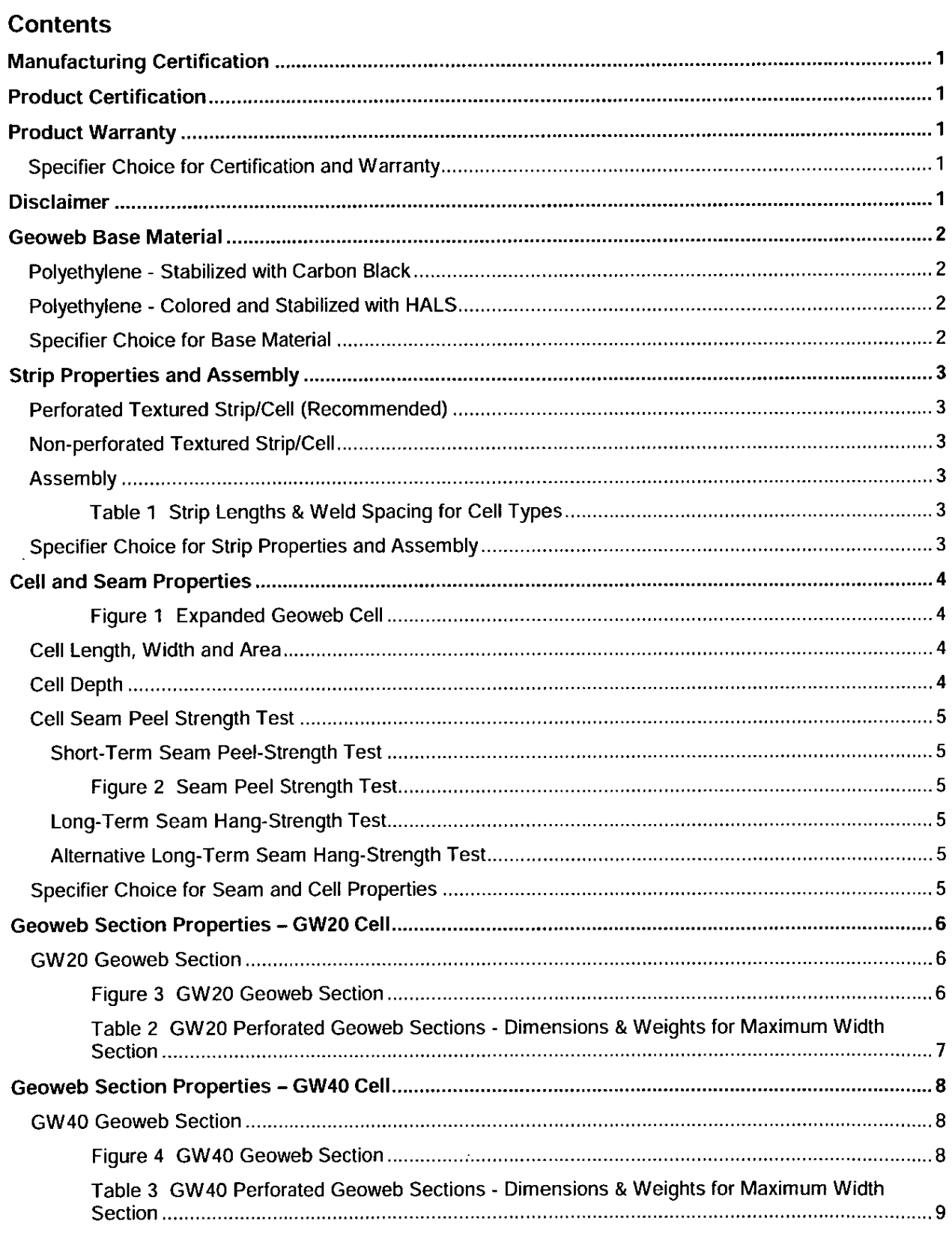




\section{$C-D C P-E-00001$, RIO \\ ATTRCHMENT $G$ \\ PAGE GR OF GIG Presty GEOWEB ${ }^{\circledR}$ CELLULAR CONFINEMENT SYSTEM
MATERIAL SPECIFICATION}

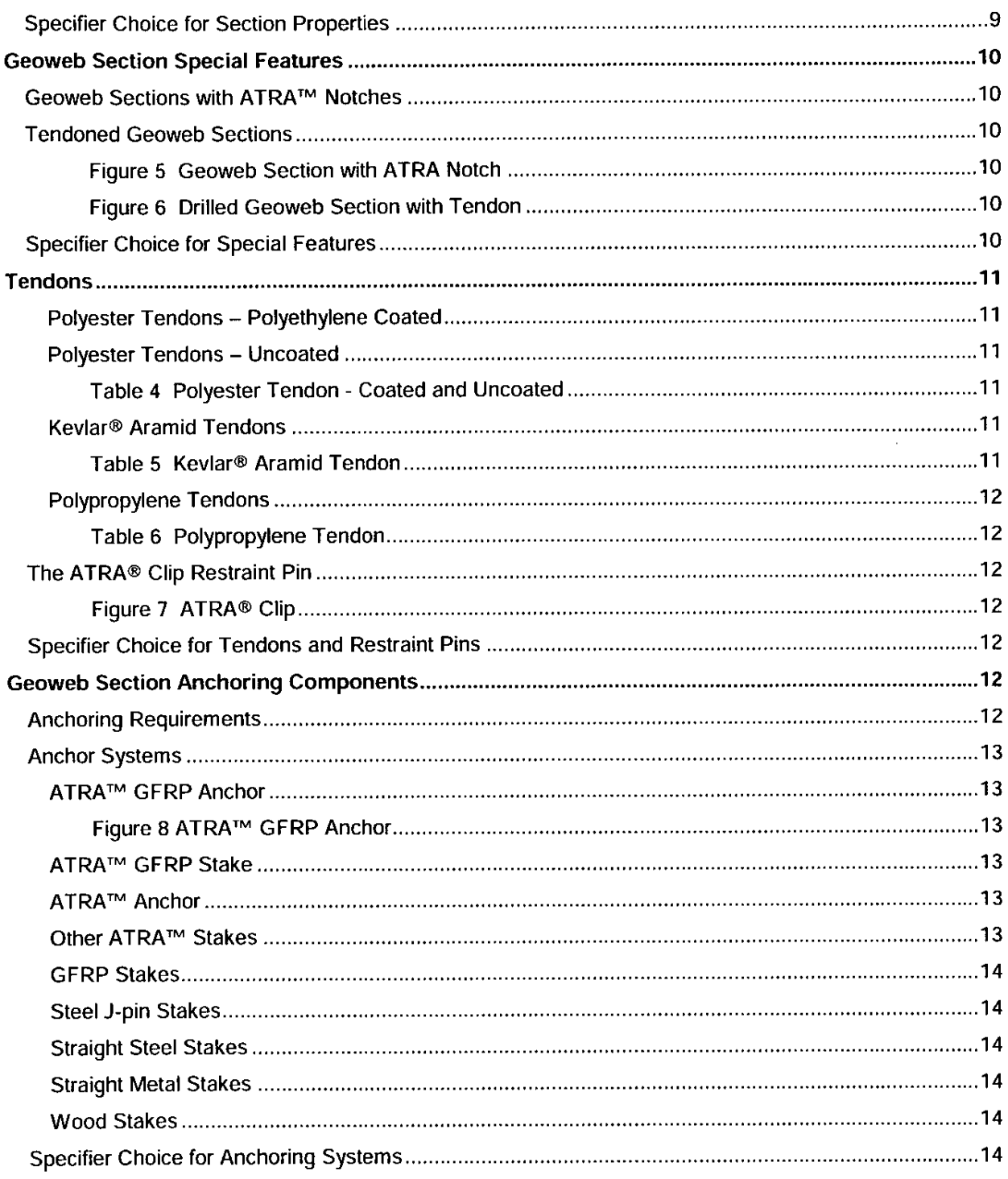




\section{C-DCP-E-00001, RIO ATTACHMENT 6 \\ GEOWEB ${ }^{\circledR}$ CELLULAR CONFINEMENT SYSTEM MATERIAL SPECIFICATION}

\section{Manufacturing Certification}

Presto Products Company (the manufacturer) shall have earned ISO 9002 certification for its qualitymanagement system at its Geoweb (geocell) cellular confinement system manufacturing plant.

\section{Product Certification}

Presto Products Company (the manufacturer) shall provide certification of compliance to all applicable testing procedures and related specifications upon the customer's written request. Request for certification shall be submitted no later than the date of order placement.

\section{Product Warranty}

Presto Products Company (the manufacturer) shall warrant each Geoweb cellular confinement system section that it ships to be free from defects in materials and workmanship at the time of manufacture. Presto's exclusive liability under this warranty or otherwise will be to furnish without charge to Presto's customer at the original f.o.b. point a replacement for any section which proves to be defective under normal use and service during the 10-year period which begins on the date of shipment by Presto. Presto reserves the right to inspect any allegedly defective section in order to verify the defect and ascertain its cause.

This warranty shall not cover defects attributable to causes or occurrences beyond Presto's control and unrelated to the manufacturing process, including, but not limited to, abuse, misuse, mishandling, neglect, improper storage, improper installation, improper alteration or improper application.

PRESTO MAKES NO OTHER WARRANTIES, EXPRESS OR IMPLIED, WRITTEN OR ORAL, INCLUDING, BUT NOT LIMITED TO, ANY WARRANTIES OR MERCHANTABILITY OR FITNESS FOR ANY PARTICULAR PURPOSE, IN CONNECTION WITH THE GEOWEB CELLULAR CONFINEMENT SYSTEM. In no event shall Presto be liable for any special, indirect, incidental or consequential damages for the breach of any express or implied warranty or for any other reason, including negligence, in connection with the Geoweb cellular confinement system.

\section{Specifier Choice for Certification and Warranty}

The Specifier shall determine the applicability of Manufacturing Certification, Product Certification and a Product Warranty and state which of the above is to be part of the project specifications.

\section{Disclaimer}

This document has been prepared for the benefit of customers interested in the Presto Geoweb Cellular Confinement System. It was reviewed carefully prior to publication. Presto Products Company assumes no liability and makes no guarantee or warranty as to its accuracy or completeness. Final determination of the suitability of any information or material for the use contemplated, or for its manner of use, is the sole responsibility of the user. Geoweb ${ }^{\circ}$ is a registered trademark of Presto Products Company. 


\section{C-DCP-E-00001, RIO ATTACMMENT 6 GEOWEB ${ }^{\circledR}$ CELLULAR CONFINEMENT SYSTEM MATERIAL SPECIFICATION}

\section{Geoweb Base Material}

NOTE: All measurements and colorants are subject to manufacturing tolerances unless otherwise stated.

\section{Polyethylene - Stabilized with Carbon Black}

Polyethylene used to make strips for Presto Geoweb sections shall have a density of $0.935-0.965 \mathrm{~g} / \mathrm{cm}^{3}$

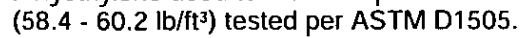

Polyethylene used to make strips for Presto Geoweb sections shall have an Environmental Stress Crack Resistance (ESCR) of 3000 hour tested per ASTM D1693.

Carbon black shall be used for ultra-violet light stabilization. Carbon black content shall be $1.5 \%-2 \%$ by weight through the addition of a carrier with a certified carbon black content. The carbon black shall be homogeneously distributed throughout the material.

The resin manufacturer's certification of polyethylene density and ESCR shall be available upon request from Presto (the Geoweb manufacturer). Presto shall certify the percentage of carbon black.

\section{Polyethylene - Colored and Stabilized with HALS}

Polyethylene used to make strips for Presto Geoweb sections shall have a density of $0.935-0.965 \mathrm{~g} / \mathrm{cm}^{3}$

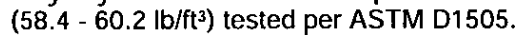

Polyethylene used to make strips for Presto Geoweb sections shall have an Environmental Stress Crack Resistance (ESCR) of 3000 hour tested per ASTM D1693.

The color(s) of the polyethylene shall be (Tan, Green, other). Colorants shall be non-heavy metal types. The colorant shall be homogeneously distributed throughout the material.

Hindered amine light stabilizer (HALS) shall be used for uitra-violet light stabilization. HALS content shall be $1.0 \%$ by weight through the addition of a carrier with a certified HALS concentrate. The HALS shall be homogeneously distributed throughout the material.

The resin manufacturer's certification of polyethylene density and ESCR shall be available upon request from Presto (the Geoweb manufacturer). Presto shall certify the percentage of HALS.

\section{Specifier Choice for Base Material}

The polyethylene used for all Geoweb material meets the same standards. The specifier shall state the desired color. The color determines which ultraviolet light stabilizer is to be used. Polyethylene stabilized with carbon black is used for most applications. Colored polyethylene stabilized with HALS is generally used for the facia strip for Geoweb earth retention systems. 


\section{$C-D C X-E-00001, K 10$ ATTACHMENT $G$ PAGE GS OF GI6 GEOWEB ${ }^{\circledR}$ CELLULAR CONFINEMENT SYSTEM MATERIAL SPECIFICATION} Prestio

\section{Strip Properties and Assembly}

NOTE: All measurements are subject to manufacturing tolerances unless otherwise stated.

\section{Perforated Textured Strip/Cell (Recommended)}

Polyethylene sheet used to make strips for Presto Geoweb sections shall have a thickness of $1.27 \mathrm{~mm}$ $-5 \%+10 \%(50 \mathrm{mil}-5 \%+10 \%)$ prior to any surface disruption. The strips shall have a perforated, textured surface. Performance: The peak friction angle between the surface of the perforated, textured plastic and a $\# 40$ silica sand at $100 \%$ relative density shall be no less than $85 \%$ of the peak friction angle of the silica sand in isolation when tested by the direct shear method per ASTM D 5321. The quantity of perforations shall remove $16 \% \pm 1 \%$ of the cell wall area. Material: The surface texturing shall be a multitude of rhomboidal (diamond shape) indentations. The rhomboidal indentations shall have a surface density of $22-31$ per $\mathrm{cm}^{2}(140-200$ per in $)$. The thickness of the textured sheet shall be $1.52 \mathrm{~mm} \pm 0.15 \mathrm{~mm}(60 \mathrm{mil} \pm 6 \mathrm{mil})$ determined per ASTM D5199. The perforations shall be horizontal rows of $10 \mathrm{~mm}(0.391 \mathrm{in})$ diameter holes. Perforations within each row shall be $19 \mathrm{~mm}(0.75 \mathrm{in})$ oncenter. Horizontal rows shall be staggered and separated $12 \mathrm{~mm}(0.50 \mathrm{in})$ relative to the hole centers. The edge of strip to the nearest edge of perforation shall be $8 \mathrm{~mm}(0.312 \mathrm{in})$ minimum and the centerline of the spot weld to the nearest edge of perforation shall be $6 \mathrm{~mm}(0.25 \mathrm{in})$ minimum.

\section{Non-perforated Textured Strip/Cell}

Polyethylene sheet used to make strips for Presto Geoweb sections shall have a thickness of $1.27 \mathrm{~mm}$ $-5 \%+10 \%(50$ mil $-5 \%+10 \%)$ prior to any surface disruption. The strips shall have a textured surface. Performance: The peak friction angle between the surface of the textured plastic and a $\# 40$ silica sand at $100 \%$ relative density shall be no less than $85 \%$ of the peak friction angle of the silica sand in isolation when tested by the direct shear method per ASTM D 5321. Material: The surface texturing shall be a multitude of rhomboidal (diamond shape) indentations. The rhomboidal indentations shall have a surface density of $22-31$ per $\mathrm{cm}^{2}\left(140-200\right.$ per in $\left.{ }^{2}\right)$. The thickness of the textured sheet shall be $1.52 \mathrm{~mm} \pm 0.15 \mathrm{~mm}$ (60 mil \pm 6 mil) determined per ASTM D5199.

\section{Assembly}

Presto Geoweb [Cell Type] sections shall be fabricated using strips of sheet polyethylene each having a length of ... (per Table 1) and a width equal to the cell depth. Polyethylene strips shall be connected using uniformly-spaced, full-depth, ultrasonic spot-welds. Welds shall be offset and aligned perpendicular to the longitudinal axis of the strip. Weld spacing shall be ... (per Table 1). The ultrasonic weld melt-pool width shall not exceed $25 \mathrm{~mm}$ (1.0 in).

Table 1 Strip Lengths \& Weld Spacing for Cell Types

\begin{tabular}{l|l|l} 
Cell Type & GW20 & GW40 \\
\hline Strip Length & $3.35 \mathrm{~m} \mathrm{(132} \mathrm{in)}$ & $3.35 \mathrm{~m} \mathrm{(132} \mathrm{in)}$ \\
\hline Weld Spacing & $330 \mathrm{~mm} \pm 2.5 \mathrm{~mm}(13.0 \mathrm{in} \pm 0.10 \mathrm{in})$ & $660 \mathrm{~mm} \pm 2.5 \mathrm{~mm}(26.0 \mathrm{in} \pm 0.10 \mathrm{in})$
\end{tabular}

\section{Specifier Choice for Strip Properties and Assembly}

The specifier shall state the desired strip/cell type: Perforated Textured or Non-Perforated Textured and use either the Performance or Material language. Refer to THE GEOWEB SYSTEM TECHNICAL OVERVIEW documents for recommendations. 


\section{C-DCP-E-00001, RIO ATTACHMENT $G$ \\ PAGE $G 6$ OF 616

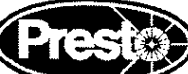 \\ GEOWEB ${ }^{\circledR}$ CELLULAR CONFINEMENT SYSTEM MATERIAL SPECIFICATION}

\section{Cell and Seam Properties}

NOTE: All measurements are nominal and subject to manufacturing tolerances unless otherwise stated.

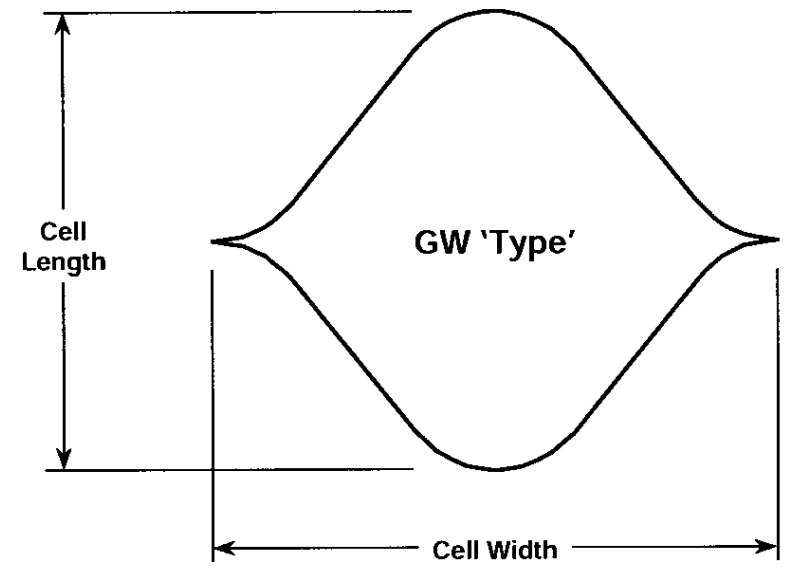

Figure 1 Expanded Geoweb Cell

Cell Length, Width and Area

The individual cells of the GW(TT) Geoweb section shall be uniform in shape and size when expanded. The nominal cell dimensions shall be of length (LL) and width (WW). Individual cells shall have a nominal area of $(A A)$. See Figure 1.

\begin{tabular}{llll} 
Type (TT) & Length (LL) & Width (WW) & Area (AA) \\
\hline GW20 & $200 \mathrm{~mm}(8.0 \mathrm{in})$ & $240 \mathrm{~mm}(9.6 \mathrm{in})$ & $240 \mathrm{~cm}^{2}\left(38 \mathrm{in}^{2}\right)$ \\
GW40 & $400 \mathrm{~mm}(16.0 \mathrm{in})$ & $480 \mathrm{~mm}(19.2 \mathrm{in})$ & $960 \mathrm{~cm}^{2}\left(153 \mathrm{in}^{2}\right)$
\end{tabular}

\section{Cell Depth}

The Geoweb section shall have a nominal cell depth of (DD).

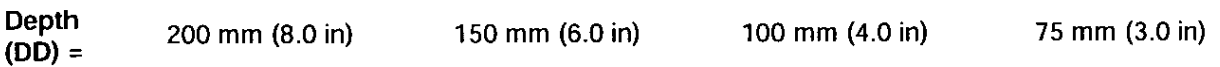




\section{C-DCP-E-0000I, R10 ATTACHTAENT G PAGE GT OF GI6 GEOWEB ${ }^{\circledR}$ CELLULAR CONFINEMENT SYSTEM MATERIAL SPECIFICATION} Prestio

\section{Cell Seam Peel Strength Test}

NOTE: All measurements are subject to manufacturing tolerances unless otherwise stated.

\section{Short-Term Seam Peel-Strength Test}

Cell seam strength shall be uniform over the full depth of the cell. Short-term peel strength shall be tested per U.S. Army Corps of Engineers Technical Report GL-86-19, Appendix A. See Figure 2. Minimum seam peel strengths shall be...

- $2000 \mathrm{~N}(450 \mathrm{lb}$ ) for the $200 \mathrm{~mm}$ (8.0 in) depth cell.

- $1420 \mathrm{~N}(320 \mathrm{lbf})$ for the $150 \mathrm{~mm}(6.0 \mathrm{in})$ depth cell.

- $1000 \mathrm{~N}(225 \mathrm{lbf})$ for the $100 \mathrm{~mm}$ (4.0 in) depth cell.

- $710 \mathrm{~N}(160 \mathrm{lbf})$ for the $75 \mathrm{~mm}$ (3.0 in) depth cell.

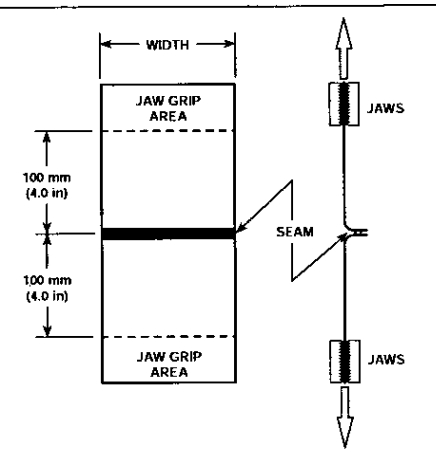

Figure 2 Seam Peel Strength Test

\section{Long-Term Seam Hang-Strength Test}

Seam hang-strength test shall be performed for a period of 7 days minimum in a temperature-controlled environment that undergoes change on a 1-hour cycle from room temperature to $54 \mathrm{C}(130 \mathrm{~F})$. Room temperature is defined in ASTM E41. Test samples shall be made by welding two $100 \mathrm{~mm}(4.0 \mathrm{in})$ wide polyethylene strips together. A test sample consisting of two carbon-black stabilized strips shall support a $72.5 \mathrm{~kg}(160 \mathrm{lb})$ load for the test period. A test sample consisting of a carbon black stabilized strip and a HALS stabilized strip shall support a $63.5 \mathrm{~kg}(140 \mathrm{lb})$ load for the test period.

\section{Alternative Long-Term Seam Hang-Strength Test}

Seam hang-strength test shall be performed for a period of $\mathbf{3 0}$ days minimum at room temperature. Room temperature is defined in ASTM E41. Test samples shall be made by welding two $100 \mathrm{~mm}(4.0 \mathrm{in})$ wide polyethylene strips together. A test sample consisting of two carbon-black stabilized strips shall support a $72.5 \mathrm{~kg}(160 \mathrm{lb})$ load for the test period. A test sample consisting of a carbon black stabilized strip and a HALS stabilized strip shall support a $63.5 \mathrm{~kg}(140 \mathrm{lb})$ load for the test period.

\section{Specifier Choice for Seam and Cell Properties}

The specifier shall state the desired cell size: either the GW20 or GW40 Geoweb section and the cell depth. Refer to THE GEOWEB SYSTEM TECHNICAL OVERVIEW documents for recommendations.

The specifier shall also state the Short-Term Seam Peel-Strength Test and either the Long-Term Seam Hang-Strength Test (recommended) or the Alternative Long-Term Seam Hang-Strength Test. There are three possibilities for seams for a Geoweb section. First, is two carbon black stabilized strips welded together. This is most typical for Geoweb sections used in all application areas. Second, is a carbon black strip welded to a HALS stabilized strip. This is typically used when a colored facia is desired on the Geoweb earth retention system. Third, is two HALS stabilized strips welded together. However, this is uncommon and would apply only to fully colored Geoweb sections. Presto should be consulted before specifying fully colored Geoweb sections. In the Long Term and the Alternative Long Term Seam HangStrength Test, the load capacity is given for seams made of two carbon black stabilized strips welded together and a carbon black stabilized strip welded to a HALS stabilized strip. 


\section{$C$ - DCP-E - O0OO I, RIO \\ ATTACHMENT G \\ GEOWEB ${ }^{\circledR}$ CELLULAR CONFINEMENT SYSTEM MATERIAL SPECIFICATION}

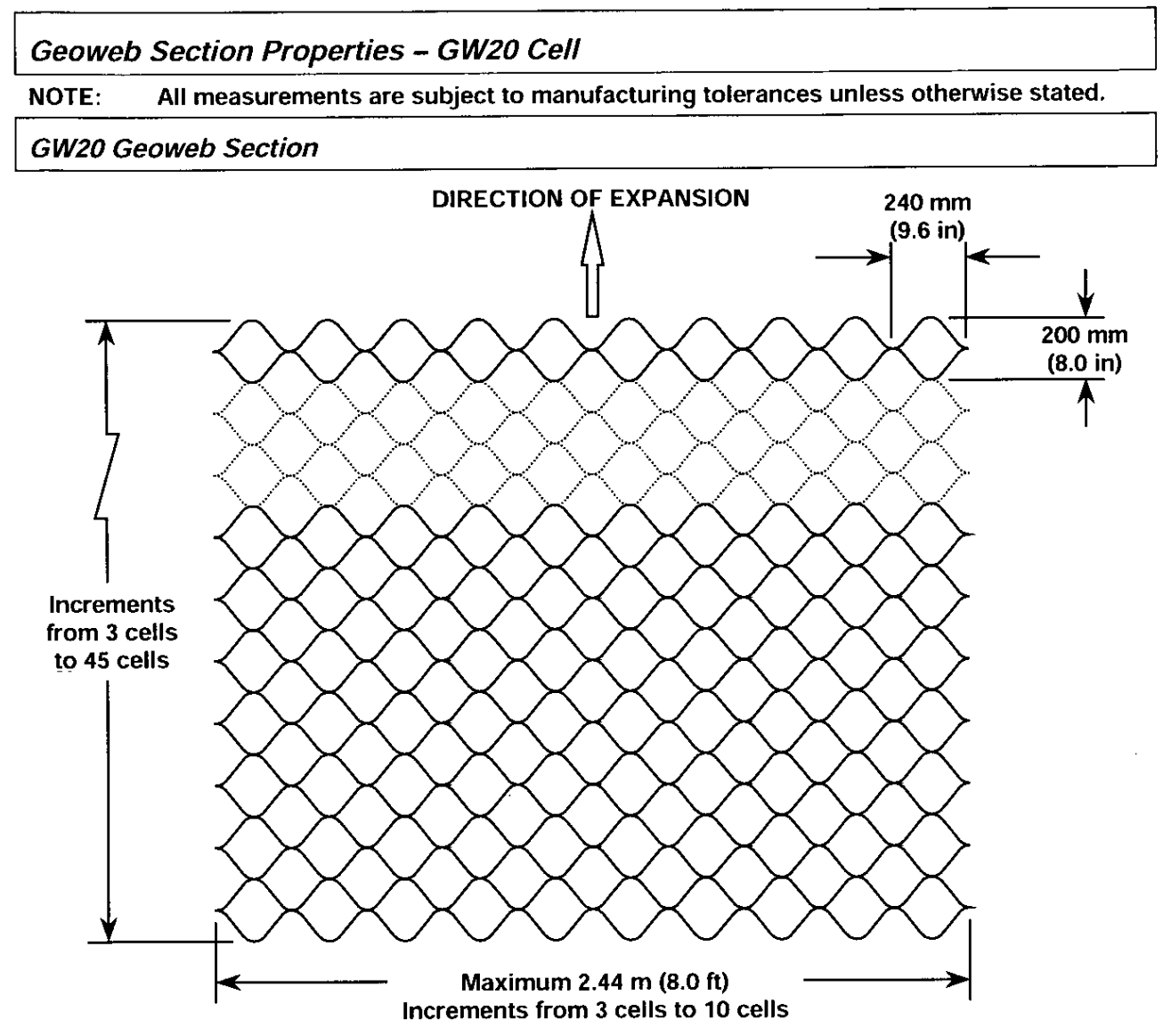

Figure 3 GW20 Geoweb Section

Presto Geoweb GW20 section dimensions shall be as indicated in Figure 3. Sections shall have a nomenclature of "GW20DDWWLL" where "GW20" indicates the cell size, "DD" indicates the cell depth in inches, "WW" indicates the number of cells wide, and "LL" indicates the number of cells long. Sections shall have expanded dimensions and weights per Table 2. An example of the GW20 Geoweb section nomenclature is GW20081030 where the section cell depth is 8.0 in or $200 \mathrm{~mm}$ and the section is 10 cells wide and 30 cells in length. 


\section{C-DCP-E- $00001, R 10$ \\ ATTACHMENT G \\ PAGE G9 OF GI6 FESP GEOWEB ${ }^{\circledR}$ CELLULAR CONFINEMENT SYSTEM
MATERIAL SPECIFICATION}

\begin{tabular}{|c|c|c|c|c|c|c|c|c|c|c|c|c|c|c|c|c|}
\hline \multirow{2}{*}{\multicolumn{3}{|c|}{$\begin{array}{l}\text { GW20 } \\
\text { Geoweb Section }\end{array}$}} & \multicolumn{2}{|c|}{ Length } & \multicolumn{2}{|c|}{ Width (10 cells) } & \multicolumn{2}{|c|}{ Area } & \multicolumn{8}{|c|}{ Weight per Section, kg (lb) } \\
\hline & & & \multirow{2}{*}{$\frac{m}{0.61}$} & \multirow{2}{*}{$\frac{(\mathrm{ft})}{(2.0)}$} & \multirow{2}{*}{$\frac{m}{2.44}$} & \multirow{2}{*}{$\frac{(\mathrm{ft})}{(8.0)}$} & \multirow{2}{*}{$\frac{\mathrm{m}^{2}}{1.49}$} & \multirow{2}{*}{$\frac{\left(f^{2}\right)}{(16.0)}$} & \multicolumn{2}{|c|}{ Where $\mathrm{DD}=03$} & \multicolumn{2}{|c|}{ Where DD $=04$} & \multicolumn{2}{|c|}{ Where DD $=06$} & \multicolumn{2}{|c|}{ Where $\mathrm{DD}=08$} \\
\hline GW20 DD & 10 & & & & & & & & 1.56 & $(3.5)$ & 2.11 & $(4.7)$ & 3.13 & (6.9) & 4.22 & $(9.3)$ \\
\hline GW20 DD & 10 & 04 & 0.81 & $(2.7)$ & 2.44 & $(8.0)$ & 1.98 & (21.3) & 2.09 & (4.6) & 2.81 & $(6.2)$ & 4.17 & $(9,2)$ & 5.62 & (12.4) \\
\hline GW20 DD & 10 & 05 & 1.02 & $(3.3)$ & 2.44 & $(8.0)$ & 2.48 & $(26.7)$ & 2.61 & (5.8) & 3.52 & (7.8) & 5.22 & $(11.5)$ & 7.03 & $(15.5)$ \\
\hline GW20 DD & 10 & 06 & 1.22 & $(4,0)$ & 2.44 & (8.0) & 2.97 & $(32.0)$ & 3.13 & $(6.9)$ & 4.22 & $(9.3)$ & 6.26 & (13.8) & 8.44 & (18.6) \\
\hline GW20 DD & 10 & 07 & 1.42 & $(4.7)$ & 2.44 & $(8.0)$ & 3.47 & $(37.3)$ & 3.65 & $(8.1)$ & 4.92 & (10.9) & 7.30 & (16.1) & 9.84 & (21.7) \\
\hline GW20 DD & 10 & 08 & 1.63 & (5.3) & 2.44 & $(8.0)$ & 3.96 & $(42.7)$ & 4.17 & $(9.2)$ & 5.62 & (12.4) & 8.35 & $(18.4)$ & 11.25 & (24.8) \\
\hline GW20 DD & 10 & 09 & 1.83 & $(6.0)$ & 2.44 & $\{8.0)$ & 4,46 & $(48.0)$ & 4.69 & (10.4) & 6.33 & (14.0) & 9.39 & $(20.7)$ & 12.66 & (27.9) \\
\hline GW20 DD & 10 & 10 & 2.03 & (6.7) & 2.44 & (8.0) & 4.95 & $(53.3)$ & 5.22 & (11.5) & 7.03 & (15.5) & 10.43 & $(23.0)$ & 14.06 & $(31.0)$ \\
\hline GW20 DD & 10 & 11 & 2.24 & $(7.3)$ & 2.44 & $(8.0)$ & 5.45 & $(58.7)$ & 5.74 & $(12.7)$ & 7.73 & (17.1) & 11.48 & $(25.3)$ & 15.47 & $(34.1)$ \\
\hline GW20 DD & 10 & 12 & 2.44 & (8.0) & 2.44 & $(8.0)$ & 5.95 & $(64.0)$ & 6.26 & (13.8) & 8.44 & (18.6) & 12.52 & $(27.6)$ & 16.87 & $(37.2)$ \\
\hline GW20 DD & 10 & 13 & 2.64 & $(8.7)$ & 2.44 & (8.0) & 6.44 & $(69.3)$ & 6.78 & $(15.0)$ & 9.14 & (20.2) & 13.56 & $(29.9)$ & 18.28 & $(40.3)$ \\
\hline GW20 DD & 10 & 14 & 2.84 & $(9.3)$ & 2.44 & $(8.0)$ & 6.94 & $(74.7)$ & 7.30 & $(16.1)$ & 9.84 & $(21.7)$ & 14.61 & $(32.2)$ & 19.69 & (43.4) \\
\hline GW2O DD & 10 & 15 & 3.05 & $(10.0)$ & 2.44 & (8.0) & 7.43 & $(B 0.0)$ & 7.82 & (17.3) & 10.55 & (23.3) & 15.65 & $(34.5)$ & 21.09 & $(46.5)$ \\
\hline GW20 DD & 10 & 16 & 3.25 & (10.7) & 2.44 & $(8.0)$ & 7.93 & $(85.3)$ & 8.35 & (18.4) & 11.25 & (24.8) & 16.69 & $(36.8)$ & 22.50 & $(49.6)$ \\
\hline GW20 DD & 10 & 17 & 3.45 & (11.3) & 2.44 & $(8.0)$ & 8.42 & $(90.7)$ & 8.87 & (19.6) & 11.95 & $(26.4)$ & 17.74 & (39.1) & 23.90 & (52.7) \\
\hline GW20 DD & 10 & 18 & 3.66 & (12.0) & 2.44 & $(8.0)$ & 8.92 & $(96.0)$ & 9.39 & $(20.7)$ & 12.66 & (27.9) & 18.78 & (41.4) & 25.31 & (55.8) \\
\hline GW20 DD & 10 & 19 & 3.86 & $\{12.7)$ & 2.44 & $(8.0)$ & 9.41 & (101.3) & 9.91 & (21.9) & 13.36 & (29.5) & 19.82 & $(43.7)$ & 26.72 & $(58.9)$ \\
\hline GW20 DD & 10 & 20 & 4.06 & (13.3) & 2.44 & (8.0) & 9.91 & $(106.7)$ & 10.43 & $(23.0)$ & 14.06 & (31.0) & 20.87 & $(46.0)$ & 28.12 & $(62.0)$ \\
\hline GW20 DD & 10 & 21 & 4.27 & $(14.0)$ & 2.44 & $(8.0)$ & 10.41 & $(112.0)$ & 10.95 & (24.2) & 14.76 & (32.6) & 21.91 & $(48.3)$ & 29.53 & $(65.1)$ \\
\hline GW20 DD & 10 & 22 & 4.47 & $(14.7)$ & 2.44 & $(8.0)$ & 10.90 & $(117.3)$ & 11.48 & (25.3) & 15.47 & (34.1) & 22.95 & $(50.6)$ & 30.93 & $(68.2)$ \\
\hline GW20 DD & 10 & 23 & 4.67 & $(15.3)$ & 2.44 & $(8.0)$ & 11.40 & $(122.7)$ & 12.00 & (26.5) & 16.17 & (35.7) & 24.00 & $(52.9)$ & 32.34 & $(71.3)$ \\
\hline GW20 DD & 10 & 24 & 4.88 & (16.0) & 2.44 & $(8.0)$ & 11.89 & $(128.0)$ & 12.52 & (27.6) & 16.87 & (37.2) & 25.04 & $(55,2)$ & 33.75 & $(74.4)$ \\
\hline GW20 DD & 10 & 25 & 5.08 & (16.7) & 2.44 & $(8.0)$ & 12.39 & (133.3) & 13.04 & (28.8) & 17.58 & (38.8) & 26.08 & (57.5) & 35.15 & $(77.5)$ \\
\hline GW2O DO & 10 & 26 & 5.28 & $(17.3)$ & 2.44 & $(8.0)$ & 12.88 & (138.7) & 13.56 & (29.9) & $18.2 \mathrm{~B}$ & $(40.3)$ & 27.12 & $(59.8)$ & 36.56 & $(80.6)$ \\
\hline GW20 DD & 10 & 27 & 5.49 & $(18.0)$ & 2.44 & (8.0) & 13.38 & $(144,0)$ & 14.08 & (31.1) & 18.98 & (41.9) & 28.17 & (62.1) & 37.97 & $(83.7)$ \\
\hline GW20 DD & 10 & 28 & 5.69 & (18.7) & 2.44 & $(8.0)$ & 13.87 & $(149.3)$ & 14.61 & (32.2) & 19.69 & (43.4) & 29.21 & $(64.4)$ & 39.37 & (86.8) \\
\hline GW20 OD & 10 & 29 & 5.89 & $(19.3)$ & 2.44 & (8.0) & 14.37 & $(154.7)$ & 15.13 & (33.4) & 20.39 & $(45.0)$ & 30.25 & $(66.7)$ & 40.78 & (89.9) \\
\hline GW20 DD & 10 & 30 & 6.10 & $(20.0)$ & 2.44 & $(8.0)$ & 14.86 & $(160.0)$ & 15.65 & (34.5) & 21.09 & (46.5) & 31.30 & $(69.0)$ & 42.18 & $(93.0)$ \\
\hline GW20 DD & 10 & 31 & 6.30 & (20.7) & 2.44 & $(8.0)$ & 15.36 & (165.3) & 16.17 & (35.7) & 21.80 & (48.1) & 32.34 & $(71.3)$ & 43.59 & $(96.1)$ \\
\hline GW20 DD & 10 & 32 & 6.50 & (21.3) & 2.44 & (B.0) & 15.86 & $(170.7)$ & 16.69 & (36.8) & 22.50 & (49.6) & 33.38 & (73.6) & 45.00 & $(99.2)$ \\
\hline GW2O DD & 10 & 33 & 6.71 & $(22.0)$ & 2.44 & (8.0) & 16.35 & $(176.0)$ & 17.21 & $(38.0)$ & 23.20 & (51.2) & 34,43 & (75.9) & 46.40 & $\{102.3\}$ \\
\hline GW20 DD & 10 & 34 & 6.91 & $(22.7)$ & 2.44 & (8.0) & 16.85 & (181.3) & 17.74 & $(39.1)$ & 23.90 & (52.7) & 35.47 & (78.2) & 47.81 & (105.4) \\
\hline GW2O DO & 10 & 35 & 7.11 & (23.3) & 2.44 & (8.0) & 17.34 & (186.7) & 18.26 & $(40.3)$ & 24.61 & (54.3) & 36.51 & $(80.5)$ & 49.21 & (108.5) \\
\hline GW20 DD & 10 & 36 & 7.32 & (24.0) & 2.44 & (8.0) & 17.84 & $(192.0)$ & 18.78 & (41.4) & 25.31 & (55.8) & 37.56 & (82.8) & 50.62 & (111.6) \\
\hline GW20 DD & 10 & 37 & 7.52 & (24.7) & 2.44 & $(8.0)$ & 18.33 & (197.3) & 19.30 & (42.6) & 26.01 & (57.4) & 38.60 & (85.1) & 52.03 & (114.7) \\
\hline GW20 DD & 10 & 38 & 7.72 & (25.3) & 2.44 & $(8.0)$ & 18.83 & $(202.7)$ & 19.82 & (43.7) & 26.72 & (58.9) & 39.64 & $(87.4)$ & 53.43 & $(077.8)$ \\
\hline GW2O OD & 10 & 39 & 7.92 & $(26.0)$ & 2.44 & $(8.0)$ & 19.32 & $(208.0)$ & 20.34 & (44.9) & 27.42 & $(60.5)$ & 40.69 & (89.7) & 54.84 & (120.9) \\
\hline GW20 DD & 10 & 40 & 8.13 & (26.7) & 2.44 & (8.0) & 19.82 & $(213.3)$ & 20.87 & $(46.0)$ & 28.12 & (62.0) & 41.73 & $(92.0)$ & 56.25 & (124.0) \\
\hline GW20 DD & 10 & 41 & 8.33 & (27.3) & 2.44 & (8.0) & 20.31 & $(218.7)$ & 21.39 & (47.2) & 28.83 & (63.6) & 42.77 & $(94.3)$ & 57.65 & (127.1) \\
\hline GW20 DD & 10 & 42 & 8.53 & $\{28.0\}$ & 2.44 & (8.0) & 20.81 & $(224.0)$ & 21.91 & $(48.3)$ & 29.53 & (65.1) & 43.82 & (96.6) & 59.06 & (130.2) \\
\hline GW20 DD & 10 & 43 & 8.74 & (28.7) & 2.44 & (8.0) & 21.31 & (229.3) & 22.43 & (49.5) & 30.23 & $(66.7)$ & 44.86 & $(98.9)$ & 60.46 & (133.3) \\
\hline GW20 DD & 10 & 44 & 8.94 & (29.3) & 2.44 & (8.0) & 21.80 & $(234.7)$ & 22.95 & (50.6) & 30.93 & (68.2) & 45.90 & (101.2) & 61.87 & (136.4) \\
\hline GW20 DD & 10 & 45 & 9.14 & $(30.0)$ & 2.44 & $(8.0)$ & 22.30 & $(240.0)$ & 23.47 & (51.8) & 31.64 & (69.8) & 46.95 & (103.5) & 63.28 & (139.5) \\
\hline
\end{tabular}

NOTE: To obtain non-perforated Geoweb section weights increase table weights by approximately $16 \% \pm 1 \%$. 


\section{C-DCP-E-00001, RUOO ATTACHMENT $G$ \\ PAGE GIO OF GI6 GEOWEB ${ }^{\circledR}$ CELLULAR CONFINEMENT SYSTEM MATERIAL SPECIFICATION}

Geoweb Section Properties - GW40 Cell
NOTE: All measurements are subject to manufacturing tolerances unless otherwise stated.
GW40 Geoweb Section

DIRECTION OF EXPANSION

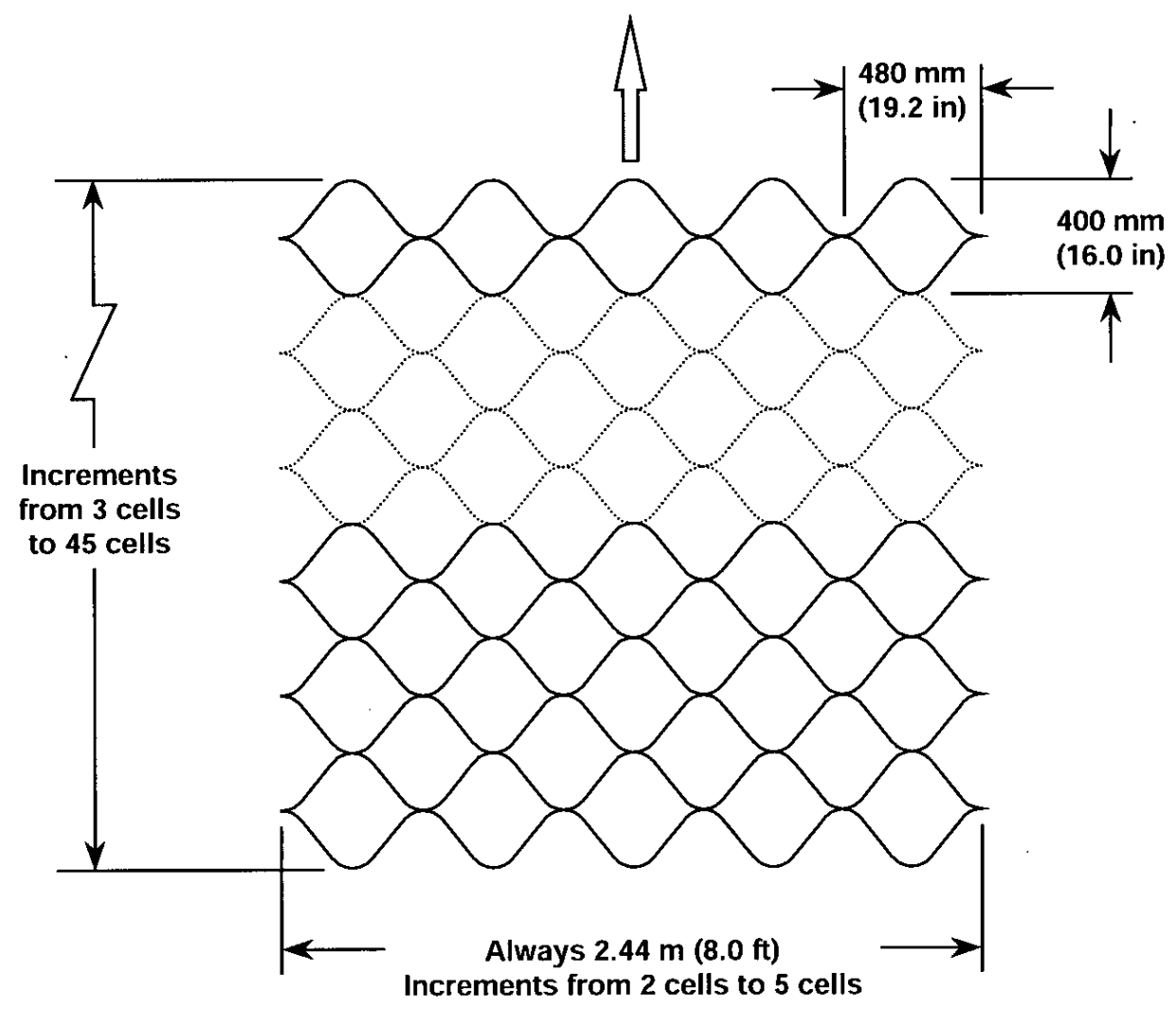

Figure 4 GW40 Geoweb Section

Presto Geoweb GW40 section dimensions shall be as indicated in Figure 4. Sections shall have a nomenclature of "GW $40 D D W W L L$ " where "GW40" indicates the cell size, "DD" indicates the cell depth in inches, "WW" indicates the number of cells wide, and "LL" indicates the number of cells long. Sections shall have expanded dimensions and weights per Table 3. An example of the GW40 Geoweb section nomenclature is GW 40080530 where the section cell depth is 8.0 in or $200 \mathrm{~mm}$ and the section is 5 cells wide and 30 cells in length. 


\section{C-DCP-E-OOOOI,RIO ATTACHMENT $G$ \\ PAGE GII OF GI6

Prest9 GEOWEB ${ }^{\circledR}$ CELLULAR CONFINEMENT SYSTEM
MATERIAL SPECIFICATION

\begin{tabular}{|c|c|c|c|c|c|c|c|c|c|c|c|c|c|c|c|}
\hline \multirow{2}{*}{\multicolumn{2}{|c|}{$\begin{array}{l}\text { Gw40 } \\
\text { Geoweb Section }\end{array}$}} & \multicolumn{2}{|c|}{ Length } & \multicolumn{2}{|c|}{ Width (05 cells) } & \multicolumn{2}{|c|}{ Area } & \multicolumn{8}{|c|}{ Weight per Section, kg (lb) } \\
\hline & & \multirow{2}{*}{$\frac{m}{0.61}$} & \multirow{2}{*}{$\frac{(\mathrm{t})}{(2.0)}$} & \multirow{2}{*}{$\frac{m}{2.44}$} & \multirow{2}{*}{$\frac{(\mathrm{ft})}{(8.0)}$} & \multirow{2}{*}{$\frac{\mathrm{m}^{2}}{1.49}$} & \multirow{2}{*}{$\frac{\left(\left(t^{2}\right)\right.}{(16.0)}$} & \multicolumn{2}{|c|}{ Where $\mathrm{DD}=03$} & \multicolumn{2}{|c|}{ Where $\mathrm{DO}=04$} & \multicolumn{2}{|c|}{ Where $D D=06$} & \multicolumn{2}{|c|}{ Where $D O=08$} \\
\hline GW40 DD & $\begin{array}{lll}5 & 03\end{array}$ & & & & & & & 1.56 & $(3.5)$ & 2.11 & (4.7) & 3.13 & (6.9) & 4.22 & $(9.3)$ \\
\hline GW4O DD & $\begin{array}{ll}5 & 04\end{array}$ & 0.81 & (2.7) & 2.44 & (8.0) & 1.98 & $(21.3)$ & 2.09 & (4.6) & 2.81 & (6.2) & 4.17 & (9.2) & 5.62 & (12.4) \\
\hline GW40 DD & 505 & 1.02 & $(3.3)$ & 2.44 & $(8.0)$ & 2.48 & $(26.7)$ & 2.61 & $(5.8)$ & 3.52 & (7.8) & 5.22 & (11.5) & 7.03 & $(15.5)$ \\
\hline GW40 DD & 506 & 1.22 & $(4.0)$ & 2.44 & $(8.0)$ & 2.97 & (32.0) & 3.13 & (6.9) & 4.22 & $(9.3)$ & 6.26 & (13.8) & 8.44 & (18.6) \\
\hline GW40 DD & $\begin{array}{lll}5 & 07\end{array}$ & 1.42 & (4.7) & 2.44 & $(8.0)$ & 3.47 & $(37.3)$ & 3.65 & $\{8.1)$ & 4.92 & (10.9) & 7.30 & (16.1) & 9.84 & $(21.7)$ \\
\hline GW40 OD & 508 & 1.63 & $(5.3)$ & 2.44 & $(8.0)$ & 3.96 & $(42.7)$ & 4.17 & (9.2) & 5.62 & (12.4) & 8.35 & (18.4) & 11.25 & $(24.8)$ \\
\hline GW40 DD & 509 & 1.83 & $(6.0)$ & 2.44 & $(8.0)$ & 4.46 & $(4 \mathrm{~B} .0)$ & 4.69 & $(10.4)$ & 6.33 & (14.0) & 9.39 & (20.7) & 12.66 & $(27.9)$ \\
\hline GW40 DD & 510 & 2.03 & $(6.7)$ & 2.44 & $(8.0)$ & 4.95 & (53.3) & 5.22 & $(11.5)$ & 7.03 & $(15.5)$ & 10.43 & $(23.0)$ & 14.06 & $(31.0)$ \\
\hline GW40 DD & 511 & 2.24 & $(7.3)$ & 2.44 & $(8.0)$ & 5.45 & $(58.7)$ & 5.74 & $(12.7)$ & 7.73 & (17.1) & 11.48 & (25.3) & 15.47 & (34.1) \\
\hline GW4O DD & $\begin{array}{ll}512 \\
12\end{array}$ & 2.44 & $(8.0)$ & 2.44 & $(8.0)$ & 5.95 & $(64.0)$ & 6.26 & $(13.8)$ & 8.44 & (18.6) & 12.52 & (27.6) & 16.87 & (37.2) \\
\hline GW40 DD & 513 & 2.64 & $(8.7)$ & 2.44 & $(8.0)$ & 6.44 & $(69.3)$ & 6.78 & $(15.0)$ & 9.14 & $(20.2)$ & 13.56 & (29.9) & 18.28 & $(40.3)$ \\
\hline GW40 DD & 514 & 2.84 & $(9.3)$ & 2.44 & $(8.0)$ & 6.94 & $(74.7)$ & 7.30 & (16.1) & 9.84 & $(21.7)$ & 14.61 & (32.2) & 19.69 & (43.4) \\
\hline GW40 DD & $\begin{array}{ll}5 & 15\end{array}$ & 3.05 & $(10.0)$ & 2.44 & $(8.0)$ & 7.43 & $(80.0)$ & 7.82 & $(17.3)$ & 10.55 & $(23.3)$ & 15.65 & $(34.5)$ & 21.09 & $(46.5)$ \\
\hline GW40 DD & 516 & 3.25 & (10.7) & 2.44 & $(8.0)$ & 7.93 & $(85.3)$ & 8.35 & $(18.4)$ & 11.25 & (24.8) & 16.69 & $(36.8)$ & 22.50 & $(49.6)$ \\
\hline GW40 DD & $\begin{array}{ll}5 & 17\end{array}$ & 3.45 & (11.3) & 2.44 & $\langle 8.0\rangle$ & 8.42 & $(90.7)$ & 8.87 & (19.6) & 11.95 & (26.4) & 17.74 & $(39.1)$ & 23.90 & $(52.7)$ \\
\hline GW40 DD & 518 & 3.66 & $(12.0)$ & 2.44 & $(8.0)$ & 8.92 & $(96.0)$ & 9.39 & $(20.7)$ & 12.66 & (27.9) & 18.78 & $(41,4)$ & 25.31 & (55.8) \\
\hline GW4O DD & $\begin{array}{ll}5 & 19\end{array}$ & 3.86 & $(12.7)$ & 2.44 & $(8.0)$ & 9.41 & (101.3) & 9.91 & (21.9) & 13.36 & (29.5) & 19.82 & $(43.7)$ & 26.72 & (58.9) \\
\hline GW40 DD & 520 & 4.06 & (13.3) & 2.44 & $(8.0)$ & 9.91 & (106.7) & 10.43 & $(23.0)$ & 14.06 & $(31.0)$ & 20.87 & $(46.0)$ & 28.12 & $(62.0)$ \\
\hline GW40 DD & 521 & 4.27 & (14.0) & 2.44 & $(8.0)$ & 10.41 & $(112.0)$ & 10.95 & $(24,2)$ & 14.76 & (32.6) & 21.91 & $(48.3)$ & 29.53 & $(65.1)$ \\
\hline GW40 DD & 522 & 4.47 & (14.7) & 2.44 & $(8.0)$ & 10.90 & (117.3) & 11.48 & $(25.3)$ & 15.47 & (34.1) & 22.95 & $\{50.6\rangle$ & 30.93 & $(68.2)$ \\
\hline GW40 DD & 523 & 4.67 & (15.3) & 2.44 & $(8.0)$ & 11.40 & $(122.7)$ & 12.00 & $(26.5)$ & 16.17 & $(35.7)$ & 24.00 & $(52.9)$ & 32.34 & $(71.3)$ \\
\hline GW40 DD & 524 & 4.88 & (16.0) & 2.44 & $(8.0)$ & 11.89 & (128.0) & 12.52 & $(27.6)$ & 16.87 & $(37.2)$ & 25.04 & $(55.2)$ & 33.75 & $(74.4)$ \\
\hline GW40 DD & 525 & 5.08 & $(16.7)$ & 2.44 & $(8.0)$ & 12.39 & (133.3) & 13.04 & $(28.8)$ & 17.58 & $(38.8)$ & 26.08 & $(57.5)$ & 35.15 & $(77.5)$ \\
\hline GW40 DD & 526 & 5.28 & (17.3) & 2.44 & $(8.0\rangle$ & 12.88 & (138.7) & 13.56 & $(29.9)$ & 18.28 & $(40.3)$ & 27.12 & $(59.8)$ & 36.56 & $(80.6)$ \\
\hline GW40 DD & 527 & 5.49 & (18.0) & 2.44 & $(8.0)$ & 13.38 & (144.0) & 14.08 & $(31.1)$ & 18.98 & (41.9) & 28.17 & $(62.1)$ & 37.97 & $(83.7)$ \\
\hline GW40 DD & 528 & 5.69 & (18.7) & 2.44 & $(8.0)$ & 13.87 & (149.3) & 14.61 & $(32.2)$ & 19.69 & (43.4) & 29.21 & $(64.4)$ & 39.37 & $(\mathrm{~B} 6.8)$ \\
\hline GW40 DD & 529 & 5.89 & (19.3) & 2.44 & $(8.0)$ & 14.37 & $(154.7)$ & 15.13 & $(33.4)$ & 20.39 & $(45.0)$ & 30.25 & $(66.7)$ & 40.78 & (89.9) \\
\hline GW40 DD & 530 & 6.10 & (20.0) & 2.44 & $(8.0)$ & 14.86 & $(160.0)$ & 15.65 & $(34.5)$ & 21.09 & (46.5) & 31.30 & $(69.0)$ & 42.18 & (93.0) \\
\hline GW40 DD & $\begin{array}{ll}5 & 31\end{array}$ & 6.30 & (20.7) & 2.44 & $(8.0)$ & 15.36 & $(165.3)$ & 16.17 & $(35.7)$ & 21.80 & $(48.1)$ & 32.34 & $(71,3)$ & 43.59 & $(96.1)$ \\
\hline GW40 DO & 532 & 6.50 & (21.3) & 2.44 & (8.0) & 15.86 & $(170.7)$ & 16.69 & $(36.8)$ & 22.50 & $(49.6)$ & 33.38 & $(73.6)$ & 45.00 & $(99.2)$ \\
\hline GW40 DD & 533 & 6.71 & (22.0) & 2.44 & $(8.0)$ & 16.35 & $(176.0)$ & 17.21 & $(38.0)$ & 23.20 & $(51.2)$ & 34.43 & $(75.9)$ & 46.40 & $(102.3)$ \\
\hline GW40 DD & 534 & 6.91 & $(22.7)$ & 2.44 & (8.0) & 16.85 & (181.3) & 17.74 & $(39.1)$ & 23.90 & $(52.7)$ & 35.47 & $(78.2)$ & 47.81 & (105.4) \\
\hline GW40 DD & 535 & 7.11 & (23.3) & 2.44 & (B.0) & 17.34 & (186.7) & 18.26 & $(40.3)$ & 24.61 & (54.3) & 36.51 & $(80.5)$ & 49.21 & (108.5) \\
\hline GW40 DD & 536 & 7.32 & $(24,0)$ & 2.44 & $(8.0)$ & 17.84 & (192.0) & 18.78 & (41.4) & 25.31 & $(55.8)$ & 37.56 & $(82.8)$ & 50.62 & $(111,6)$ \\
\hline GW40 DD & 537 & 7.52 & $(24.7)$ & 2.44 & (8.0) & 18.33 & (197.3) & 19.30 & $(42,6)$ & 26.01 & $(57.4)$ & 38.60 & $(85.1)$ & 52.03 & (114.7) \\
\hline GW40 DD & 538 & 7.72 & $(25.3)$ & 2.44 & (8.0) & 18.83 & (202.7) & 19.82 & $(43.7)$ & 26.72 & (58.9) & 39.64 & $(87.4)$ & 53.43 & $(117.8)$ \\
\hline GW40 DD & 539 & 7.92 & $(26.0)$ & 2.44 & $(8.0)$ & 19.32 & $(208.0)$ & 20.34 & $(44.9)$ & 27.42 & $(60.5)$ & 40.69 & (B9.7) & 54.84 & (120.9) \\
\hline GW40 DD & 540 & 8.13 & (26.7) & 2.44 & $(8.0)$ & 19.82 & $(273.3)$ & 20.87 & $(46.0)$ & 28.12 & $(62.0)$ & 41.73 & $(92.0)$ & 56.25 & $(124,0)$ \\
\hline GW40 DD & 541 & 8.33 & (27.3) & 2.44 & (8.0) & 20.31 & (218.7) & 21.39 & $(47.2)$ & 28.83 & $(63.6)$ & 42.77 & $(94.3)$ & 57.65 & (127.1) \\
\hline GW40 DD & 542 & 8.53 & $(28.0)$ & 2.44 & $(8.0)$ & 20.81 & $(224.0)$ & 21.91 & $(48.3)$ & 29.53 & (65.1) & 43.82 & $(96.6)$ & 59.06 & (130.2) \\
\hline GW4O DD & $\begin{array}{ll}5 & 43\end{array}$ & 8.74 & (28.7) & 2.44 & (8.0) & 21.31 & (229.3) & 22.43 & $(49.5)$ & 30.23 & $(66.7)$ & 44.86 & $(98.9\rangle$ & 60.46 & $(133.3)$ \\
\hline GW4ODD & 544 & 8.94 & (29.3) & 2.44 & $(8.0)$ & 21.80 & (234.7) & 22.95 & $(50.6)$ & 30.93 & (68.2) & 45.90 & $(101.2)$ & 61.87 & (136.4) \\
\hline GW40 DD & 545 & 9.14 & $(30.0)$ & 2.44 & $(8.0)$ & 22.30 & $(240.0)$ & 23.47 & (51.8) & 31.64 & $(69.8)$ & 46.95 & (103.5) & 63.28 & (139.5) \\
\hline NOTE: & & i. & $F$ & art & 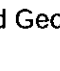 & oh & 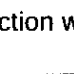 & irat & (1) & ta & 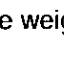 & teh & annr & mat & \\
\hline
\end{tabular}

The specifier shall state the desired Geoweb section type(s) and size(s). Refer to THE GEOWEB

SYSTEM TECHNICAL OVERVIEW documents for recommendations. 


\section{C-PCK - E-UUUU, RO ATTACHMENT $G$ \\ PAGE GIZ OF GI6

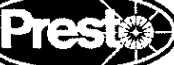 \\ GEOWEB ${ }^{\circledR}$ CELLULAR CONFINEMENT SYSTEM MATERIAL SPECIFICATION}

\section{Geoweb Section Special Features}

NOTE: All measurements are subject to manufacturing tolerances unless otherwise stated.

\section{Geoweb Sections with ATRA ${ }^{\text {MM }}$ Notches}

Geoweb sections shall have ATRA ${ }^{\text {TM }}$ notches to allow the driving of the ATRA ${ }^{\text {TM }}$ Anchors and/or J-Pin anchors below the top of the cell wall. ATRA ${ }^{\mathrm{TM}}$ notches shall be a $20 \mathrm{~mm}$ wide $\times 20 \mathrm{~mm}$ deep $(3 / 4 \mathrm{in} \mathrm{x}$ $3 / 4$ in) notch cut into the Geoweb section at the primary weld locations. The vertical center of the notch with respect to the weld shall be located $\pm 10 \mathrm{~mm}$ ( $3 / 8 \mathrm{in})$ off the weld line. See Figure 5 .

\section{Tendoned Geoweb Sections}

Geoweb sections shall be provided with a series of aligned holes through the cell walls for the insertion of tendons. Tendons are inserted in the field such that they pass through the Geoweb section in the direction of expansion. Hole diameter shall be $10 \mathrm{~mm}(0.375 \mathrm{in})$ and positioned according to the requirements of the tendon design. See Figure 6.

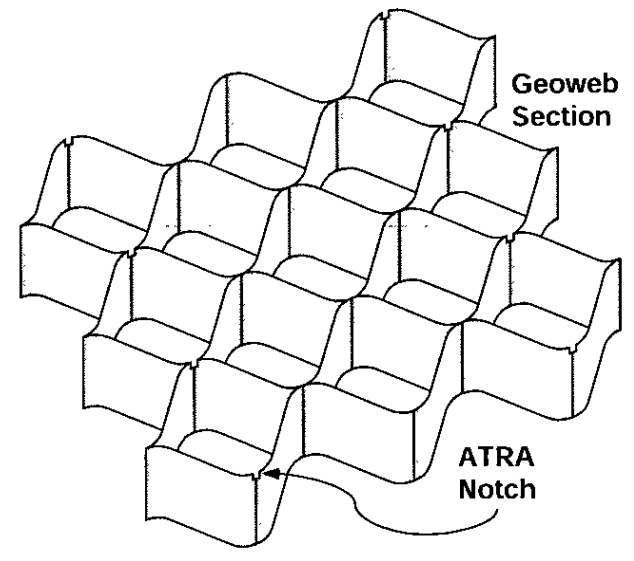

Figure 5 Geoweb Section with ATRA Notch

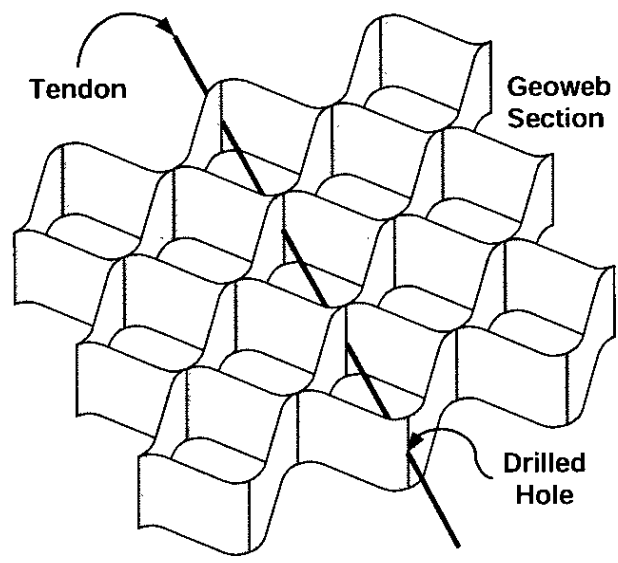

Figure 6 Drilled Geoweb Section with Tendon

\section{Specifier Choice for Special Features}

The specifier shall state which of the special Geoweb section features are required for the application. Refer to THE GEOWEB SYSTEM TECHNICAL OVERVIEW documents for recommendations. 


\section{$C-P C P-E-00001, K 10$ ATTACHMENT 6 \\ PAGE GI3 OF G16

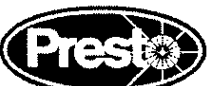 \\ GEOWEB ${ }^{\circledR}$ CELLULAR CONFINEMENT SYSTEM MATERIAL SPECIFICATION}

\section{Tendons}

\section{Polyester Tendons - Polyethylene Coated}

The polyester tendon shall be manufactured from bright, high-tenacity, industrial-continuous-filament polyester yarn woven into a round braided cord consisting of a parallel filament inner core covered with 32 strands of braided polyester. The overall mass shall be $12 \mathrm{~kg} / 1000 \mathrm{~m}(8.1 \mathrm{lb} / 1000 \mathrm{ft})$. Elongation shall be approximately $10 \%$ at $450 \mathrm{~kg}(1000 \mathrm{lbf})$ load. The coating over the polyester tendon shall be lowdensity polyethylene with a thickness of $0.4-0.6 \mathrm{~mm}(15-25 \mathrm{mils})$. The tendon reference name, diameter / width and minimum-break-strength shall be per Table 4.

\section{Polyester Tendons - Uncoated}

The polyester tendon shall be manufactured from bright, high-tenacity, industrial-continuous-filament polyester yarn woven into a braided strap. Elongation shall be $9-15 \%$ at break. The tendon reference name, diameter / width and minimum break-strength shall be per Table 4.

\begin{tabular}{|c|c|c|c|c|}
\hline \multirow{2}{*}{ Reference Name } & \multicolumn{2}{|c|}{ Tendon Diameter / Width } & \multicolumn{2}{|c|}{ Tendon Minimum Break-strength } \\
\hline & $\mathrm{mm}$ & in & $\mathbf{k N}$ & Ibf \\
\hline TPC-71 (coated) & $5 \mathrm{dia}$ & $0.180 \mathrm{dia}$ & 7.12 & 1600 \\
\hline TP-31 (uncoated) & 13 & 0.500 & 3.11 & 700 \\
\hline TP-67 (uncoated) & 19 & 0.750 & 6.70 & 1506 \\
\hline TP-93 (uncoated) & 19 & 0.750 & 9.30 & 2090 \\
\hline
\end{tabular}

\section{Kevlar@ Aramid Tendons}

The Kevlar ${ }^{\circledR}$ aramid tendon shall be a woven strap having the reference name, width and minimum breakstrength per Table 5.

Table 5 Kevlar® Aramid Tendon

\begin{tabular}{c|cc|cc} 
Reference Name & \multicolumn{2}{|c|}{ Tendon Diameter / Width } & \multicolumn{2}{c}{ Tendon Minimum Break-strength } \\
& mm & in & kN & Ibf \\
\hline TK-89 & 10 & 0.375 & 8.90 & 2000 \\
TPP-133 & 16 & 0.625 & 13.34 & 3000
\end{tabular}




\section{C - UCY- $=-00 \mathrm{BS} 1$, HO ATTACHMENT $G$ \\ PAGF GIY OF GI6

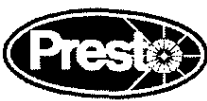 \\ GEOWEB $^{\circledR}$ CELLULAR CONFINEMENT SYSTEM MATERIAL SPECIFICATION}

\section{Polypropylene Tendons}

The polypropylene tendon shall be 3-strand twisted rope having the reference name, diameter and minimum break-strength per Table 6 .

Table 6 Polypropylene Tendon

\begin{tabular}{c|cc|cc}
\hline \multirow{2}{*}{ Reference Name } & \multicolumn{2}{|c|}{ Tendon Diameter / Width } & \multicolumn{2}{|c}{ Tendon Minimum Break-strength } \\
& $\mathrm{mm}$ & in & $\mathrm{kN}$ & $\mathrm{Ibf}$ \\
\hline TPP-44 & $6 \mathrm{dia}$ & $0.25 \mathrm{dia}$ & 4.40 & 990
\end{tabular}

The ATRA® Clip Restraint Pin

The ATRA ${ }^{\circledR}$ Clip shall be used as a load transfer pin within the tendoned Geoweb $^{\star}$ system. The ATRA ${ }^{\circledR}$ Clip Restraint Pin shall transfer load from the infilled Geoweb cells to the tendon. The ATRA ${ }^{\otimes}$ Clip shall be molded from high-strength polyethylene.

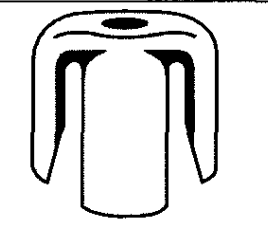

Figure 7 ATRA® Clip

\section{Specifier Choice for Tendons and Restraint Pins}

The specifier shall state which tendon is to be used. Tendon strength must meet design requirements for the application. The specifier shall also state if the ATRA $\otimes$ Clip restraint pin is needed. Refer to $T H E$ GEOWEB SYSTEM TECHNICAL OVERVIEW documents for recommendations

\section{Geoweb Section Anchoring Components}

NOTE: All measurements are subject to manufacturing tolerances unless otherwise stated.

\section{Anchoring Requirements}

Geoweb sections, with or without tendons, shall be anchored in accordance with construction drawings. Rows of ATRA ${ }^{\text {TM }}$ Anchors or stake anchors shall engage and bear against the cell walls, or engage and hold the integral tendons against the foundation soil. The size, type and distribution of ATRA ${ }^{\mathrm{TM}}$ Anchor (stake anchors) shall be in accordance with the construction drawings. 


\section{C- DCY- E- BUSOS, R-18 ATTACHMENT $G$ \\ PAGE GIS OF GI6 GEOWEB ${ }^{\circledR}$ CELLULAR CONFINEMENT SYSTEM MATERIAL SPECIFICATION}

\section{Anchor Systems}

ATRA $^{\text {TM }}$ GFRP Anchor

The ATRA ${ }^{\text {TM }}$ GFRP Anchor shall be a pre-assembled unit consisting of the ATRA ${ }^{\circledR}$ Clip inserted onto the ATRA ${ }^{\text {TM }}$ GFRP Stake so that the end of the Stake is flush with or $3 \mathrm{~mm}(1 / 8 \mathrm{in})$ maximum above the top of the ATRA ${ }^{\circledR}$ Clip. Prior to inserting the ATRA ${ }^{\otimes}$ Clip on the end of the stake, the stake end shall be ground or filed so it has a bevel and is free from all burrs.

\section{ATRA $^{\text {TM }}$ GFRP Stake}

The ATRA ${ }^{\text {TM }}$ GFRP Stake shall be composed of glass fiber reinforced polymer with a sand-coating. Glass reinforcement content shall be $75 \%$ minimum by weight and shall be continuous longitudinal filament. The use of non-continuous filament is strictly prohibited. Polymer shall be vinyl ester, isopthalic polyester, or other matrix material. The outer surface of the Stake shall be sand coated and deformed by a helical wrap of glass. The ATRA ${ }^{\mathrm{TM}}$ GFRP Stake shall have a minimum tensile strength of $655 \mathrm{MPa}$ (95 ksi) per ASTM D638. The Stake shall be non-magnetic, non-conducting and corrosion resistant. The Stake diameter shall be $12-13 \mathrm{~mm}(1 / 2 \mathrm{in})$. The length shall be per construction drawings. Prior to inserting the ATRA ${ }^{\circledR}$ Clip on the end of the stake, the stake end shall be ground or filed so it has a bevel and is free from all burrs.

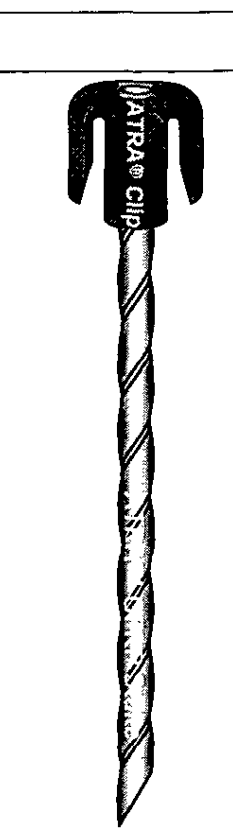

Figure 8 ATRA $^{\text {TM }}$ GFRP Anchor

\section{ATRA $^{\text {TM }}$ Anchor}

The ATRA ${ }^{\text {TM }}$ Anchor shall be made by properly inserting the ATRA $\otimes$ Clip onto the ATRA ${ }^{\text {TM }}$ Stake so that the end of the Stake is flush with or $3 \mathrm{~mm}(1 / 8 \mathrm{in})$ maximum above the top of the ATRA® Clip. Prior to inserting the ATRA ${ }^{\circledR}$ Clip on the end of the stake, the stake end shall be ground or filed so it has a bevel and is free from all burrs.

\section{Other ATRA ${ }^{\text {m }}$ Stakes}

1. The ATRA ${ }^{\mathrm{TM}}$ Stake shall consist of straight $12-13 \mathrm{~mm}$ (\#4) steel reinforcing rod. The Stake length shall be per construction drawings. Prior to inserting the ATRA ${ }^{\circledR}$ Clip on the end of the stake, the stake end shall be ground or filed so it has a bevel and is free from all burrs.

2. The ATRA ${ }^{\mathrm{TM}}$ Stake shall consist of straight $12-13 \mathrm{~mm}(\# 4)$ steel reinforcing rod hot dipped galvanized per AASHTO M-218. The Stake length shall be per construction drawings. Prior to inserting the ATRA ${ }^{\circledR}$ Clip on the end of the stake, the stake end shall be ground or filed so it has a bevel and is free from all burrs.

3. The ATRA ${ }^{\mathrm{TM}}$ Stake shall consist of straight $12-13 \mathrm{~mm}(1 / 2 \mathrm{in})$

(state metal type) rod. The Stake length shall be per construction drawings. Prior to inserting the ATRA ${ }^{\circledR}$ Clip on the end of the stake, the stake end shall be ground or filed so it has a bevel and is free from all burrs. 


\section{LUULI: I- UUUU I IIUU \\ ATTACHMENT $G$ \\ GEOWEB® CELLULAR CONFINEMENT SYSTEM \\ Preste \\ MATERIAL SPECIFICATION}

\section{GFRP Stakes}

The GF,RP Stake shall be composed of glass fiber reinforced polymer with a sand-coating. Glass reinforcement content shall be $75 \%$ minimum by weight and shall be continuous longitudinal filament. The use of non-continuous filament is strictly prohibited. Polymer shall be vinyl ester, isopthalic polyester, or other matrix material. The outer surface of the stake shall be sand coated and deformed by a helical wrap of'glass. The stake shall have a minimum tensile strength of $655 \mathrm{MPa}(95 \mathrm{ksi})$ per ASTM D638. The stake shall be non-magnetic, non-conducting and corrosion resistant. The stake diameter and length shall be per construction drawings.

\section{Steel J-pin Stakes}

Steel J-pin stakes shall be fabricated from mild steel or reinforcing steel rod. Each stake shall have a minimum-radius, 180 -degree return at one end. Rod diameter shall be $8 \mathrm{~mm}(0.3125 \mathrm{in}), 10 \mathrm{~mm}$ $(0.375 \mathrm{in}), 12 \mathrm{~mm}(0.50 \mathrm{in}), 16 \mathrm{~mm}(0.625 \mathrm{in})$ or $20 \mathrm{~mm}(0.75 \mathrm{in})$. Stake length shall be per the construction drawings. When specified, galvanizing shall be per AASHTO M-218.

\section{Straight Steel Stakes}

Straight steel stakes shall be fabricated from mild steel or reinforcing steel rod. Rod diameter shall be $8 \mathrm{~mm}(0.3125 \mathrm{in}), 10 \mathrm{~mm}(0.375 \mathrm{in}), 12 \mathrm{~mm}(0.50 \mathrm{in}), 16 \mathrm{~mm}(0.625 \mathrm{in})$ or $20 \mathrm{~mm}(0.75 \mathrm{in})$. Stake length shall be per the construction drawings. When specified, galvanizing shall be per AASHTO M-218.

\section{Straight Metal Stakes}

Straight metal shall be fabricated from (state metal type) rod. Rod diameter shall be $8 \mathrm{~mm}(0.3125 \mathrm{in}), 10 \mathrm{~mm}(0.375 \mathrm{in}), 12 \mathrm{~mm}(0.50 \mathrm{in}), 16 \mathrm{~mm}(0.625 \mathrm{in})$ or $20 \mathrm{~mm}(0.75 \mathrm{in})$. Stake length shall be per the construction drawings.

\section{Wood Stakes}

Wood stakes shall be made from (state wood type) and shall be free from knots that effect the strength of the stake. The stakes shall have a cross section of by and be long.

\section{Specifier Choice for Anchoring Systems}

The specifier shall state which of the anchoring methods are required for the application and choose from the stated options. Refer to THE GEOWEB SLOPE PROTECTION SYSTEM and/or CHANNEL PROTECTION SVSTEM TECHNICAL OVERVIEW for recommendations. Note, the glass fiber reinforced polymer ATRA ${ }^{\text {TM }}$ GFRP Stake is available from Presto separately or with the ATRA $\otimes$ Clip already attached to form the ATRA ${ }^{T M}$ GFRP Anchor. Other ATRA ${ }^{T M}$ Stakes are not available from Presto. 


\section{APPENDIX B}

\section{GEOTECHNICAL DATA SUMMARY FOR MEGA-TRENCH SITE}

May 2001 
This page intentionally left blank. 
This document summarizes the geotechnical data for the Savannah River Site (SRS) E-Area Low Level Waste Mega-trench site. Figure 1 shows the location of the Mega-trench along with the geotechnical exploration locations.

Engineering layers were identified based on piezocone penetration test (CPTU) results and substantiated with a geotechnical borehole log as well as other CPTU results in the vicinity. Figure 2 shows the geotechnical profile at the Mega-trench site. Geotechnical profile also shows the CPTU tip stress and friction ratio, Standard Penetration Test blow count, and soil sample locations.

Geotechnical investigation results including piezocone penetration test soundings, geotechnical boreholes, groundwater monitoring wells, and laboratory tests are described in the following sections.

\section{A. Piezocone Penetration Test Soundings}

Ten piezocone penetration test (CPTU) soundings were conducted in the vicinity of the Megatrench site. The coordinates, elevations, and depths of these CPTU soundings are:

\begin{tabular}{|c|c|c|c|c|}
\hline $\begin{array}{c}\text { CPTU } \\
\text { No. }\end{array}$ & $\begin{array}{c}\text { North } \\
\text { Coordinate } \\
\text { (feet) }\end{array}$ & $\begin{array}{c}\text { East } \\
\text { Coordinate } \\
\text { (feet) }\end{array}$ & $\begin{array}{c}\text { Ground } \\
\text { Elevation } \\
\text { (feet MSL) }\end{array}$ & $\begin{array}{c}\text { Depth } \\
\text { (feet) }\end{array}$ \\
\hline MEGA-CPT-1 & 75,830 & 59,625 & 276.7 & 67.7 \\
\hline MEGA-CPT-2 & 75,830 & 59,350 & 281.3 & 71.3 \\
\hline MEGA-CPT-3 & 75,830 & 59,000 & 286.8 & 74.9 \\
\hline MEGA-CPT-4 & 76,050 & 59,200 & 289.9 & 76.9 \\
\hline MEGA-CPT-5 & 76,050 & 59,600 & 278.1 & 70.0 \\
\hline MEGA-CPT-6 & 75,930 & 59,450 & 279.6 & 65.9 \\
\hline MEGA-CPT-7 & 75,930 & 59,100 & 285.0 & 72.0 \\
\hline At North & 76,041 & 59,484 & 281.4 & 63.0 \\
\hline At East & 75,919 & 59,621 & 277.0 & 60.0 \\
\hline At South & 75,814 & 59,500 & 278.7 & 60.0 \\
\hline
\end{tabular}

Appendix A contains the CPTU sounding results including the sleeve resistance, tip resistance, pore pressure, friction ratio, and resistivity. 


\section{B. Geotechnical Boreholes}

Ten geotechnical boreholes were drilled for a previous investigation near the Mega-trench site. The coordinates, elevations, and depths of these boreholes are:

\begin{tabular}{|c|c|c|c|c|}
\hline $\begin{array}{c}\text { Borehole } \\
\text { No. }\end{array}$ & $\begin{array}{c}\text { North } \\
\text { Coordinate } \\
\text { (feet) }\end{array}$ & $\begin{array}{c}\text { East } \\
\text { Coordinate } \\
\text { (feet) }\end{array}$ & $\begin{array}{c}\text { Ground } \\
\text { Elevation } \\
\text { (feet MSL) }\end{array}$ & $\begin{array}{c}\text { Depth } \\
\text { (feet) }\end{array}$ \\
\hline B10 & 75,580 & 58,895 & 291.4 & 65.5 \\
\hline B11 & 75,557 & 59,400 & 286.8 & 61.5 \\
\hline B12 & 75,600 & 59,743 & 283.1 & 65.5 \\
\hline B13 & 75,990 & 58,950 & 295.7 & 51.5 \\
\hline B14 & 76,000 & 59,408 & 289.9 & 140 \\
\hline B15 & 75,998 & 59,742 & 284.9 & 61.5 \\
\hline EMTUD1 & 75,919 & 59,355 & 281.3 & 50.0 \\
\hline EMTUD2 & 76,013 & 59,484 & 280.3 & 36.0 \\
\hline EMTUD3 & 75,919 & 59,609 & 277.2 & 16.0 \\
\hline EMTUD4 & 75,826 & 59,484 & 278.8 & 27.0 \\
\hline
\end{tabular}

Appendix B contains the geotechnical borehole logs including the SPT blow counts, field classifications, and soil descriptions.

\section{Groundwater Monitoring Wells}

Groundwater level data from WSRC-TR-98-0045, The Regional Water Table of the Savannah River Site and Related Coverages, September 1998, and monitoring wells near the Mega-trench site were used to determine the groundwater elevation. Wells monitoring Aquifer D were used to estimate the groundwater elevation at the Mega-trench site. The coordinates of these wells are:

\begin{tabular}{|c|c|c|}
\hline Well No. & Northing (feet) & Easting (feet) \\
\hline BG30 & 75,550 & 58,809 \\
\hline BG31 & 75,950 & 58,804 \\
\hline BG32 & 76,350 & 58,804 \\
\hline BGO3D & 75,351 & 58,809 \\
\hline BGO3DR & 75,512 & 58,820 \\
\hline BGO4D & 76,150 & 58,804 \\
\hline BGO5D & 76,478 & 58,785 \\
\hline BGX10D & 76,183 & 59,766 \\
\hline BGX11D & 75,301 & 59,581 \\
\hline
\end{tabular}


Appendix $\mathrm{C}$ contains a map showing ground water monitoring wall locations and a plot showing ground water elevation readings from these wells. Groundwater elevations at the Mega-trench site were obtained by interpolating the groundwater elevations in the surrounding area. The maximum groundwater elevation at the Mega-trench site was estimated to be 240 feet Mean Sea Level (MSL).

\section{Laboratory Tests}

Laboratory tests were performed for the Mega-trench site from the following seven undisturbed samples:

\begin{tabular}{|c|c|c|c|c|c|c|c|}
\hline \multirow{2}{*}{$\begin{array}{c}\text { Sample } \\
\text { No. }\end{array}$} & \multirow{2}{*}{$\begin{array}{l}\text { Northing } \\
\text { (ft) }\end{array}$} & \multirow{2}{*}{$\begin{array}{c}\text { Easting } \\
\text { (ft) }\end{array}$} & \multirow{2}{*}{$\begin{array}{l}\text { Surface } \\
\text { (ft, msl) }\end{array}$} & \multicolumn{2}{|c|}{ Elevation (ft, msl) } & \multicolumn{2}{|c|}{ Depth (feet) } \\
\hline & & & & From & To & From & to \\
\hline EMTUD1-ST1 & 75,919 & 59,355 & 281.3 & 276.3 & 274.3 & 5.0 & 7.0 \\
\hline EMTUD1-ST2 & 75,919 & 59,355 & 281.3 & 268.3 & 266.3 & 13.0 & 15.0 \\
\hline EMTUD1-ST3 & 75,919 & 59,355 & 281.3 & 233.3 & 231.3 & 48.0 & 50.0 \\
\hline EMTUD2-ST1 & 76,013 & 59,484 & 280.3 & 273.3 & 271.3 & 7.0 & 9.0 \\
\hline EMTUD2-ST2 & 76,013 & 59,484 & 280.3 & 246.3 & 244.3 & 34.0 & 36.0 \\
\hline EMTUD3-ST1 & 75,919 & 59,609 & 277.2 & 263.2 & 261.2 & 14.0 & 16.0 \\
\hline EMTUD4-ST1 & 75,826 & 59,484 & 278.8 & 253.8 & 251.8 & 25.0 & 27.0 \\
\hline
\end{tabular}

Tests for a previous investigation were performed on the following sample:

\begin{tabular}{|c|c|c|c|c|c|c|c|}
\hline $\begin{array}{c}\text { Sample } \\
\text { No. }\end{array}$ & Northing & Easting & \multicolumn{2}{|c|}{$\begin{array}{c}\text { Surface } \\
(\mathbf{f t})\end{array}$} & \multicolumn{2}{|c|}{ Elevation (ft) msl) } & \multicolumn{2}{|c|}{ Depth (feet) } \\
\cline { 5 - 8 } & $(\mathbf{f t}, \mathbf{m s l})$ & From & To & From & to \\
\hline B-14-ST-1 & 76,000 & 59,408 & 289.9 & 231.8 & 230.6 & 58.1 & 59.3 \\
\hline
\end{tabular}

Appendix D provides the detailed laboratory test results including sieve analyses, moisture contents, Atterberg limits, and strength tests.

\section{(1) Sieve Analysis}

Sieve Analyses were performed per ASTM D 421. The results are:

\begin{tabular}{|c|c|c|c|c|c|c|c|c|c|c|c|}
\hline \multirow{3}{*}{$\begin{array}{c}\text { Sample } \\
\text { No. }\end{array}$} & \multicolumn{2}{|c|}{ Depth } & \multicolumn{9}{|c|}{ U.S. Standard Sieve Sizes / Opening Sizes (mm) } \\
\hline & from & to & $3 / 4$ & $3 / 8$ & 4 & 10 & 20 & 40 & 60 & 140 & 200 \\
\hline & (feet) & (feet) & 19.05 & 9.525 & 4.750 & 2.000 & 0.850 & 0.425 & 0.250 & 0.106 & 0.075 \\
\hline EMTUD1-ST1 & 5 & 7 & 100 & 98 & 95.6 & 91 & 77 & 54 & 40 & 30 & 28.2 \\
\hline EMTUD1-ST2 & 13 & 15 & - & - & - & 100 & 94 & 82 & 74 & 50 & 34.5 \\
\hline EMTUD1-ST3 & 48 & 50 & - & 100 & 99.4 & 99 & 90 & 72 & 47 & 13 & 12.5 \\
\hline EMTUD2-ST1 & 7 & 9 & - & - & - & & 100 & 99 & 97 & 91 & 88.3 \\
\hline EMTUD2-ST2 & 34 & 36 & - & - & - & 100 & 91 & 72 & 56 & 19 & 15.9 \\
\hline EMTUD3-ST1 & 14 & 16 & - & - & - & 100 & 93 & 77 & 68 & 47 & 33.1 \\
\hline EMTUD4-ST1 & 25 & 7 & - & - & - & 100 & 90 & 63 & 48 & 24 & 21.9 \\
\hline
\end{tabular}


Sieve analysis was performed for a previous investigation using slightly different sieve sizes:

\begin{tabular}{|c|c|c|c|c|c|c|c|c|c|c|c|}
\hline \multirow{3}{*}{$\begin{array}{c}\text { Sample } \\
\text { No. }\end{array}$} & \multicolumn{2}{|c|}{ Depth } & \multicolumn{9}{|c|}{ U.S. Standard Sieve Sizes / Opening Sizes (mm) } \\
\hline & from & to & $3 / 4$ & $3 / 8$ & 4 & 10 & 20 & 40 & 60 & 100 & 200 \\
\hline & (feet) & (feet) & 19.05 & 9.525 & 4.750 & 2.000 & 0.850 & 0.425 & 0.250 & 0.150 & $\mathbf{0 . 0 7 5}$ \\
\hline B-14 ST-1 & 53 & 55 & - & - & - & 100 & 91 & 77 & 50 & 18 & 12.0 \\
\hline
\end{tabular}

A figure showing the grain size distribution of the soils for various layers and a figure showing the plasticity chart per ASTM D2487 are also included in Appendix D.

\section{(2) Atterberg Limits, Moisture Content, and Classifications}

Atterberg Limits and moisture content were determined per ASTM D4318 and ASTM D2216, respectively. The results are:

\begin{tabular}{|c|c|c|c|c|c|c|c|}
\hline \multirow[b]{2}{*}{$\begin{array}{c}\text { Sample } \\
\text { No. }\end{array}$} & \multicolumn{2}{|c|}{ Depth } & \multicolumn{3}{|c|}{ Atterberg Limits } & \multirow{2}{*}{$\begin{array}{c}\text { Moisture } \\
\text { Content } \\
(\%)\end{array}$} & \multirow[b]{2}{*}{ USCS } \\
\hline & $\begin{array}{l}\text { from } \\
\text { (feet) }\end{array}$ & $\begin{array}{c}\text { to } \\
\text { (feet) }\end{array}$ & $\begin{array}{c}\mathbf{L L} \\
(\%)\end{array}$ & $\begin{array}{l}\text { PL } \\
(\%)\end{array}$ & $\begin{array}{c}\text { PI } \\
(\%)\end{array}$ & & \\
\hline EMTUD1-ST1 & 5 & 7 & 53 & 25 & 28 & 11.4 & $\mathrm{SC}$ \\
\hline EMTUD1-ST2 & 13 & 15 & 44 & 26 & 18 & 15.8 & $\mathrm{SC}$ \\
\hline EMTUD1-ST3 & 48 & 50 & 29 & 25 & 4 & 14.1 & SM \\
\hline EMTUD2-ST1 & 7 & 9 & 90 & 35 & 55 & 27.0 & $\mathrm{CH}$ \\
\hline EMTUD2-ST2 & 34 & 36 & 40 & 24 & 16 & 16.3 & $\mathrm{SC}$ \\
\hline EMTUD3-ST1 & 14 & 16 & 49 & 26 & 23 & 15.0 & $\mathrm{SC}$ \\
\hline EMTUD4-ST1 & 25 & 7 & 44 & 23 & 21 & 14.8 & $\mathrm{SC}$ \\
\hline B-14 ST-1 & 53 & 55 & NP & NP & NP & 21.2 & SM \\
\hline
\end{tabular}

\section{(3) Soil density}

Soil density tests were performed for a previous investigation. The results are:

\begin{tabular}{|c|c|c|c|c|c|c|}
\hline $\begin{array}{c}\text { Boring } \\
\text { No. }\end{array}$ & $\begin{array}{c}\text { Sample } \\
\text { No. }\end{array}$ & $\begin{array}{c}\text { Sample } \\
\text { Depth } \\
\text { (feet) }\end{array}$ & $\begin{array}{c}\text { USCS } \\
\text { Soil } \\
\text { Class }\end{array}$ & $\begin{array}{c}\text { Moisture } \\
\text { Content } \\
(\boldsymbol{\%})\end{array}$ & $\begin{array}{c}\text { Unit dry } \\
\text { weight } \\
\text { (pcf) }\end{array}$ & $\begin{array}{c}\text { Unit total } \\
\text { weight } \\
\text { (pcf) }\end{array}$ \\
\hline B-10 & C-3 & 16.90 & CH & 25.7 & 98.1 & 123.3 \\
\hline B-14 & ST-1 & 58.70 & SM & 21.2 & 100.5 & 211.8 \\
\hline
\end{tabular}




\section{(4) Soil Strength}

Strength properties obtained from laboratory tests for each layer are summarized as follows:

\begin{tabular}{|c|c|c|c|c|c|}
\hline $\begin{array}{c}\text { Layer } \\
\text { No. }\end{array}$ & $\begin{array}{c}\text { Sample } \\
\text { No. }\end{array}$ & $\begin{array}{c}\text { Total } \\
\text { friction angle } \\
\phi \\
\text { (degrees) }\end{array}$ & $\begin{array}{c}\text { Total } \\
\text { cohesion } \\
\mathbf{c} \\
(\mathbf{p s f})\end{array}$ & $\begin{array}{c}\text { Effective } \\
\text { friction angle } \\
\phi \\
\text { (degrees) }\end{array}$ & $\begin{array}{c}\text { Effective } \\
\text { cohesion } \\
\mathbf{c} \\
(\mathbf{p s f})\end{array}$ \\
\hline A & EMTUD2-ST1 & 31.7 & 390 & 42.6 & 0 \\
\hline B & EMTUD1-ST2 & 28.4 & 520 & 34.0 & 0 \\
\hline B & EMTUD3-ST1 & 30.2 & 720 & 34.0 & 0 \\
\hline C & EMTUD2-ST2 & 36.1 & 210 & 34.3 & 20 \\
\hline C & EMTUD4-ST1 & 28.5 & 970 & 28.6 & 930 \\
\hline D & EMTUD1-ST3 & 40.3 & 0 & 34.5 & 0 \\
\hline
\end{tabular}




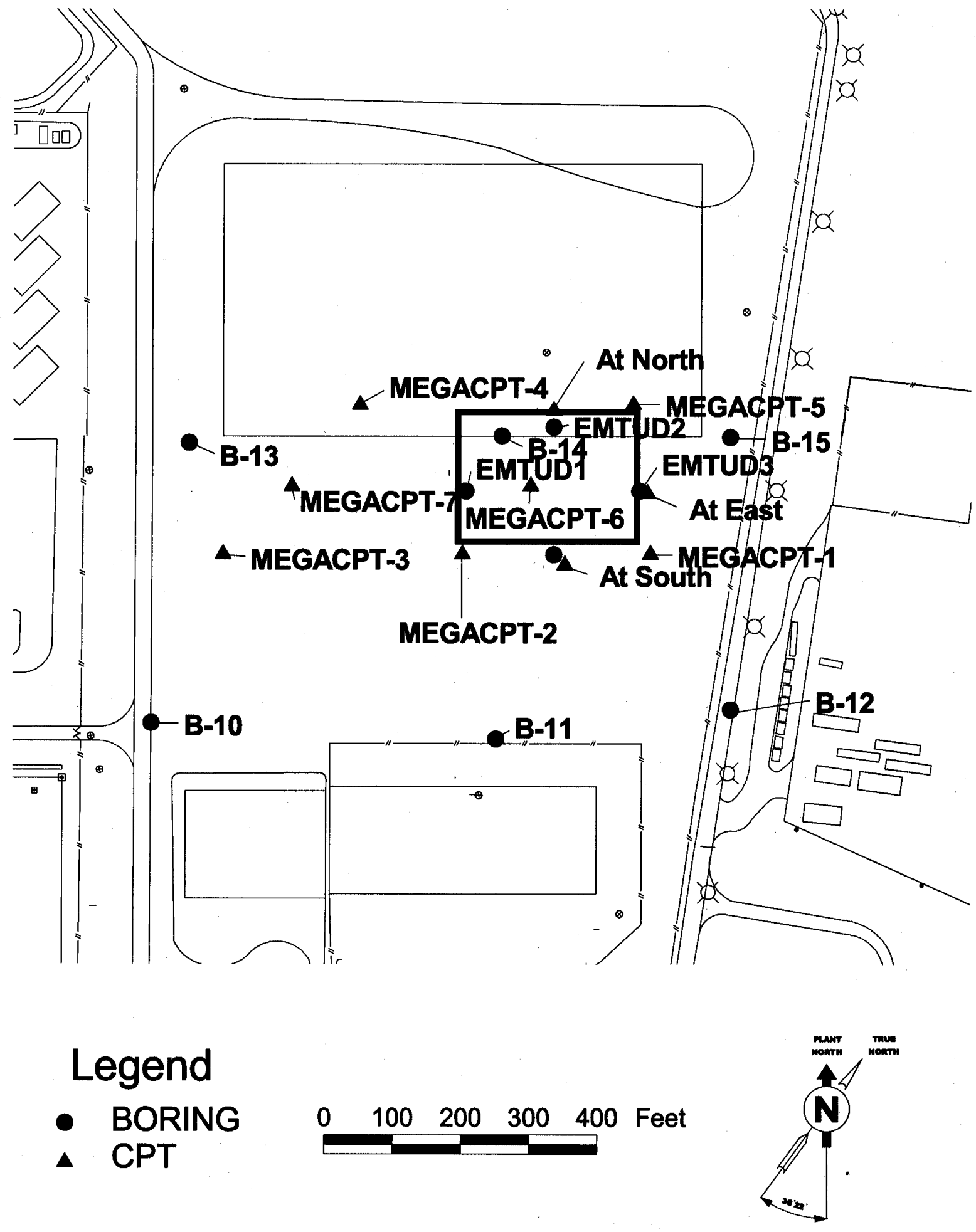

Figure 1. Geotechnical exploratory locations 
ช

ชิ

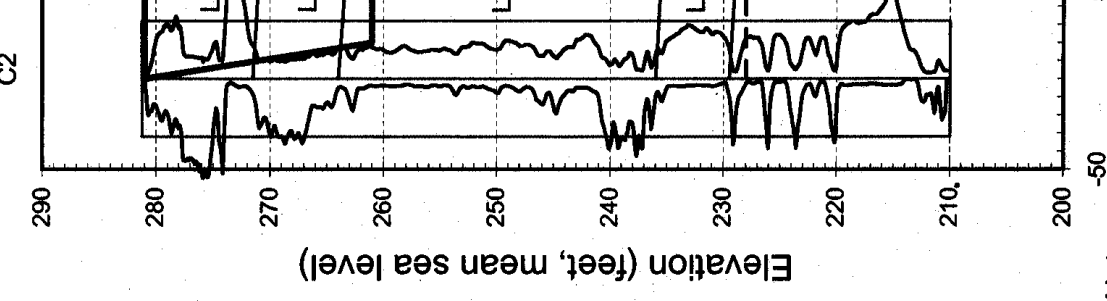

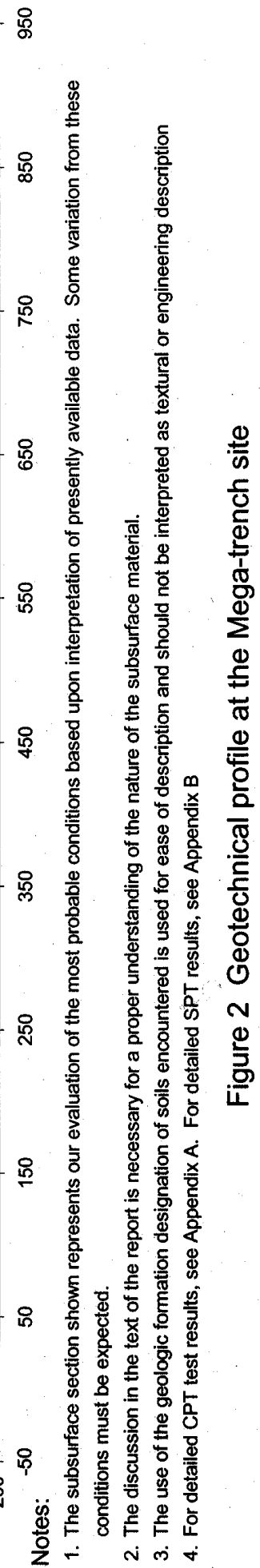

Figure 2. Geotechnical profile at the Mega-trench site 
This page intentionally left blank. 


\section{Appendix A}

\section{Piezocone Penetration Test Soundings}


This page intentionally left blank. 


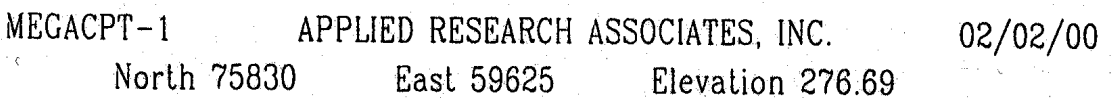
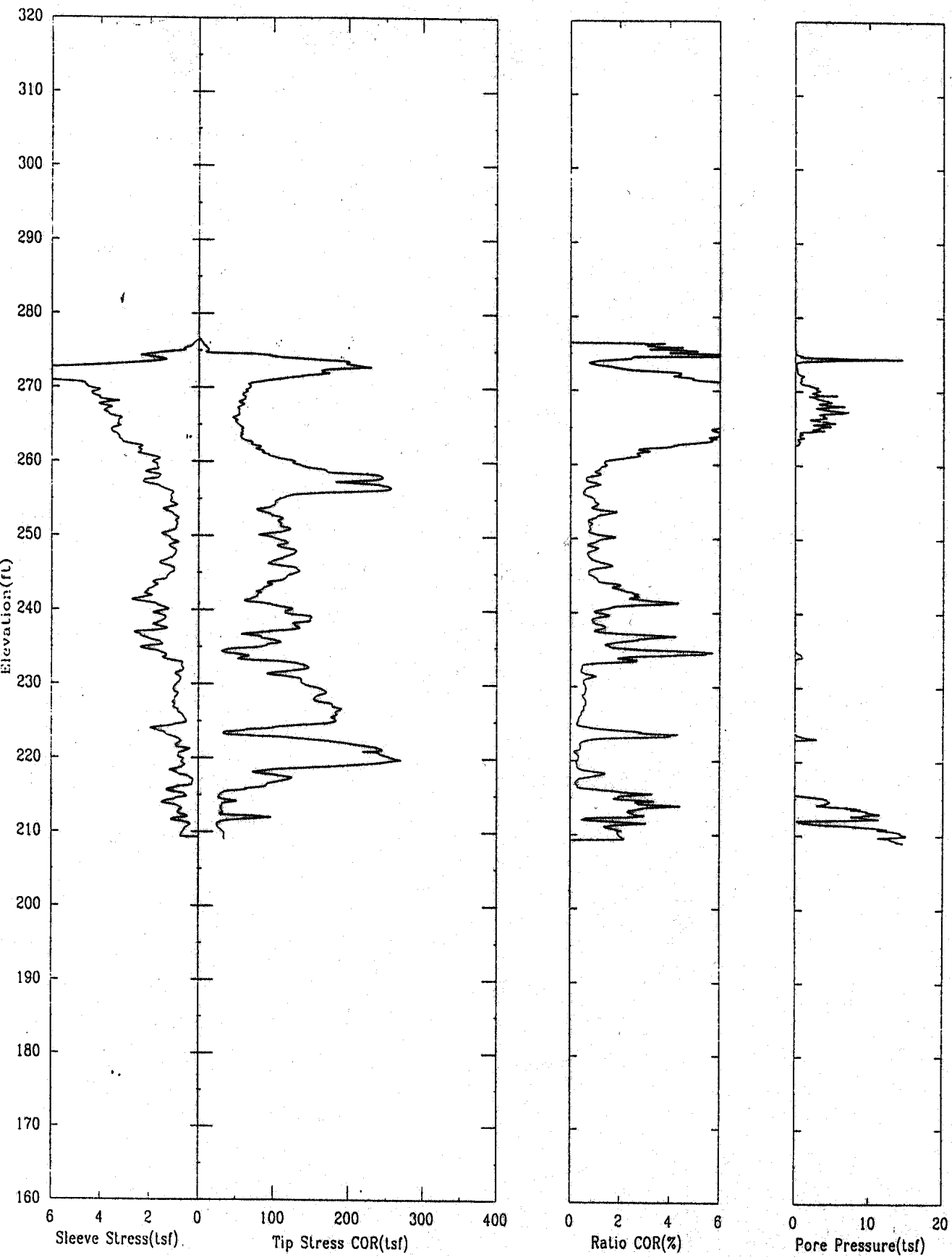

File 302F002.ECP 
MEGACPT -

APPLIED RESEARCH ASSOCIATES, INC.

$02 / 02 / 00$ North $75830 \quad$ East $59625 \quad$ Elevation 276.69
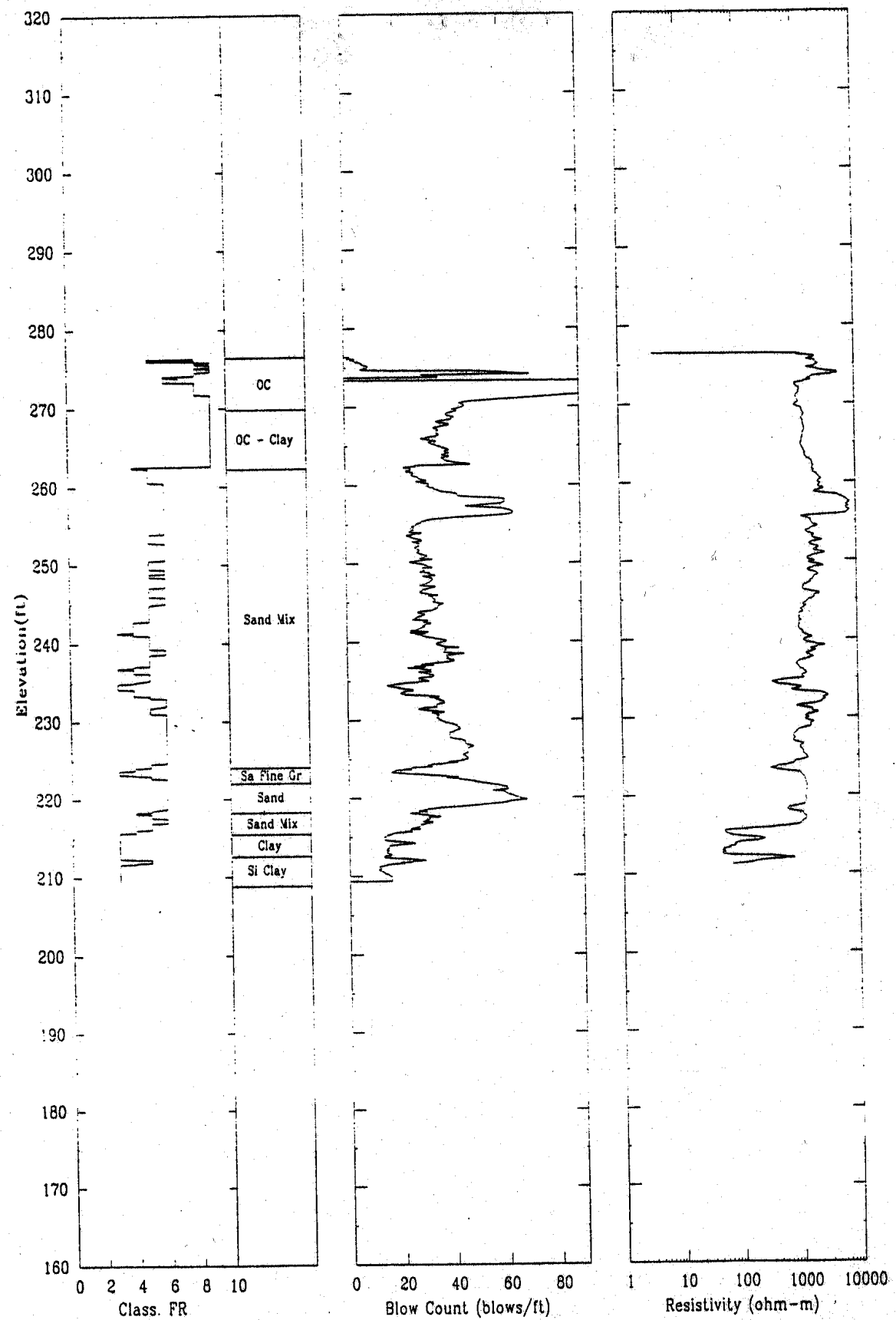

File 302F002.ECP 


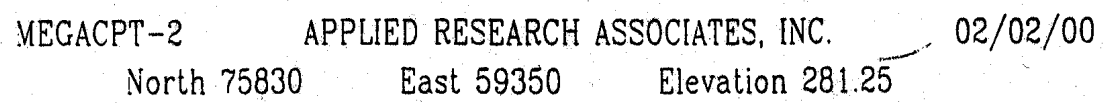

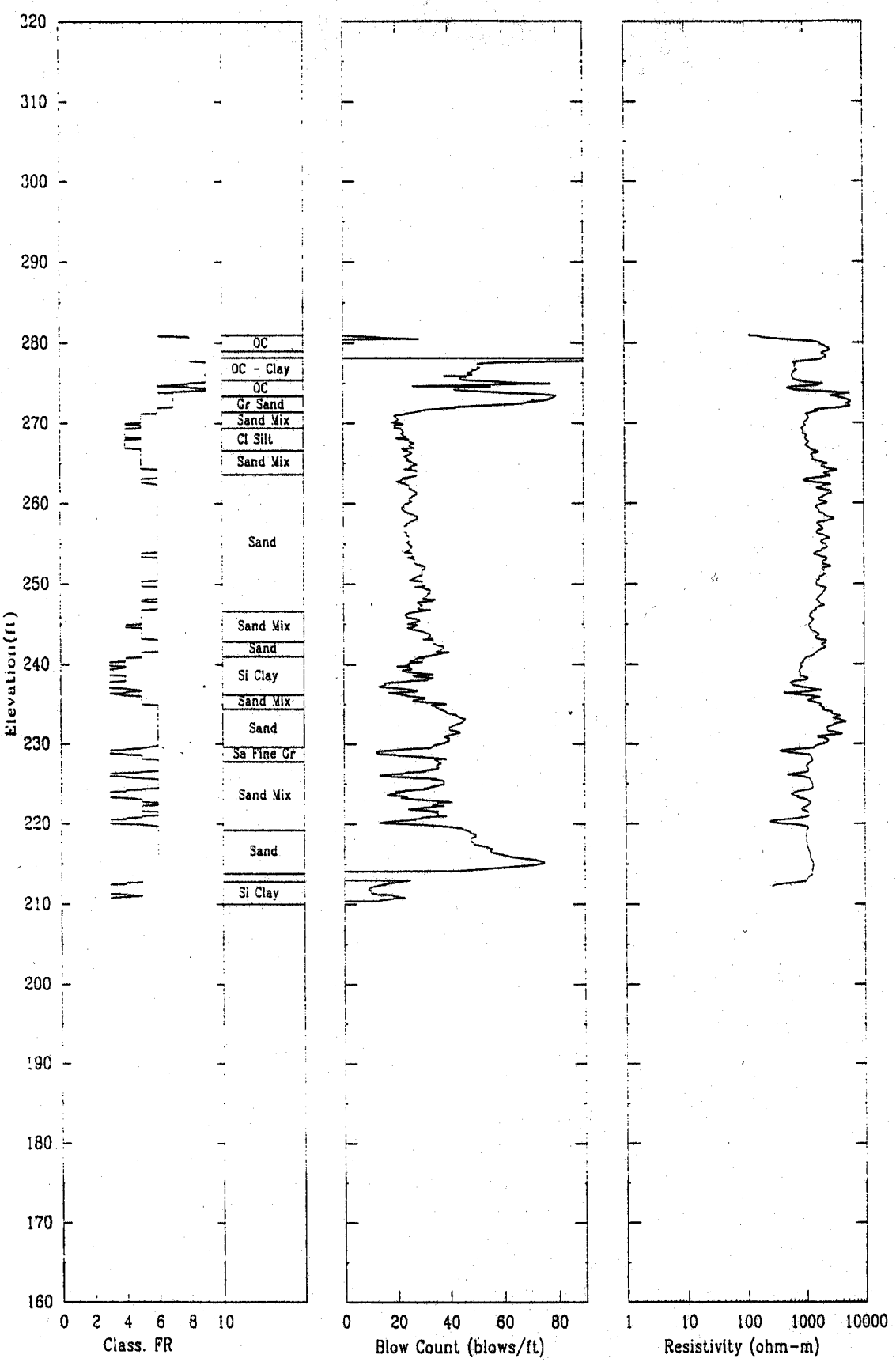

File 302F004r.ECP 
MEGACPT-2 APPLIED RESEARCH ASSOCIATES, INC.

$02 / 02 / 00$

North $75830 \quad$ East $59350 \quad$ Elevation 281.25
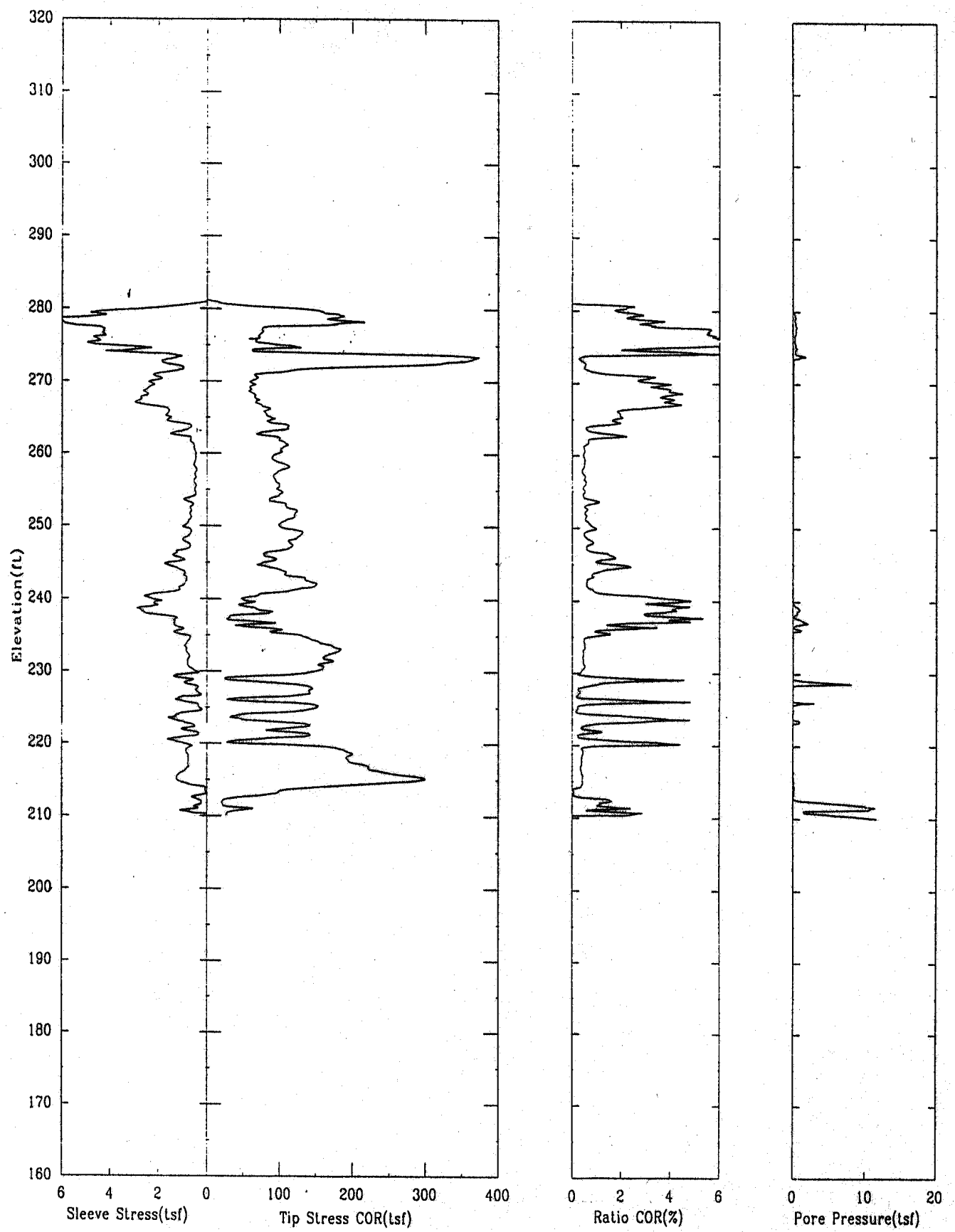

File 302F004r.ECP 
MEGACPT -3

PPLIED RESEARCH ASSOCIATES, INC.

$02 / 02 / 00$

North $75830 \quad$ East $59000 \quad$ Elevation 286.79
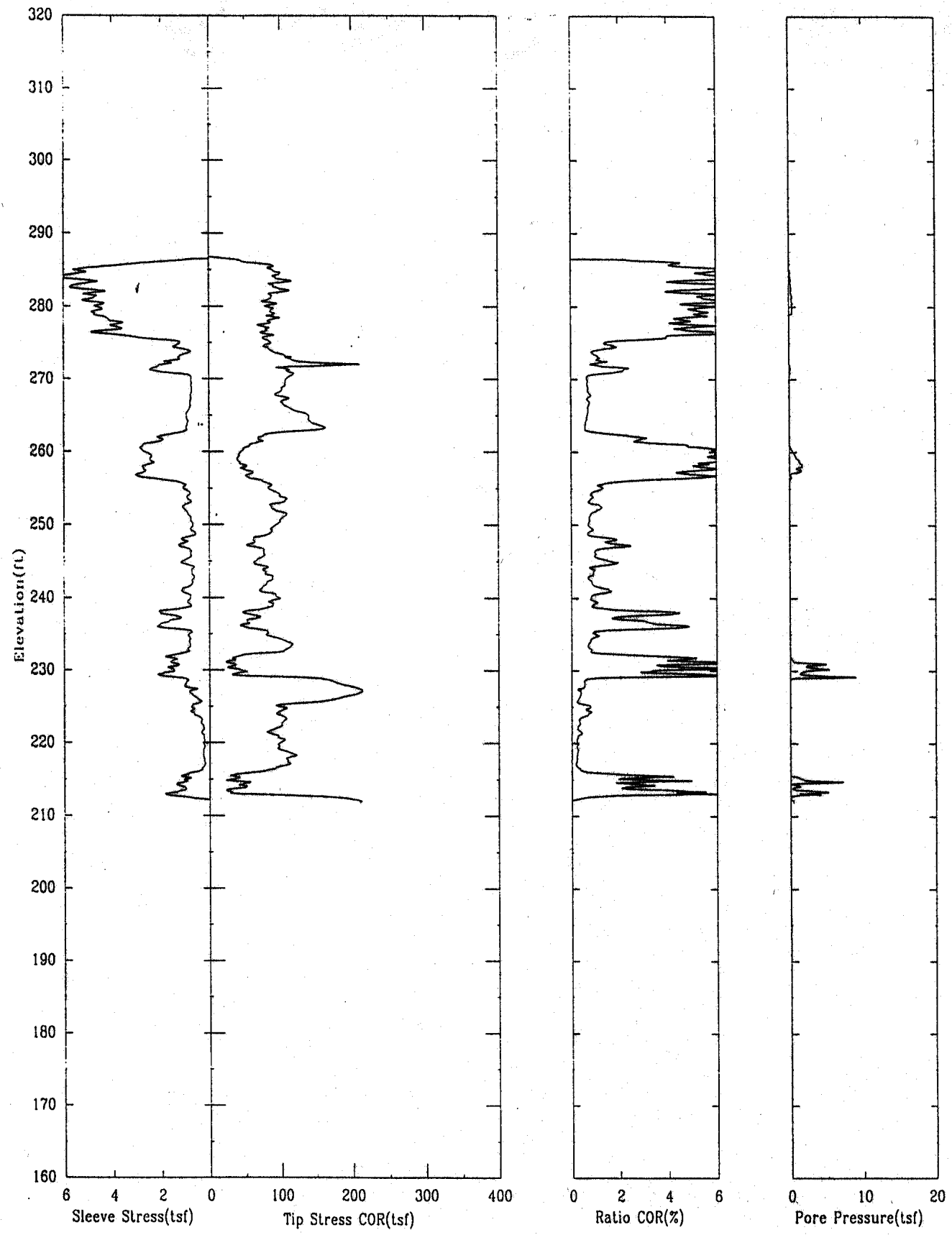

File 302F006.ECP 
MEGACPT -3 APPLIED RESEARCH ASSOCIATES, INC.

$02 / 02 / 00$ Vorth $75830 \quad$ East $59000 \quad$ Elevation 286.79
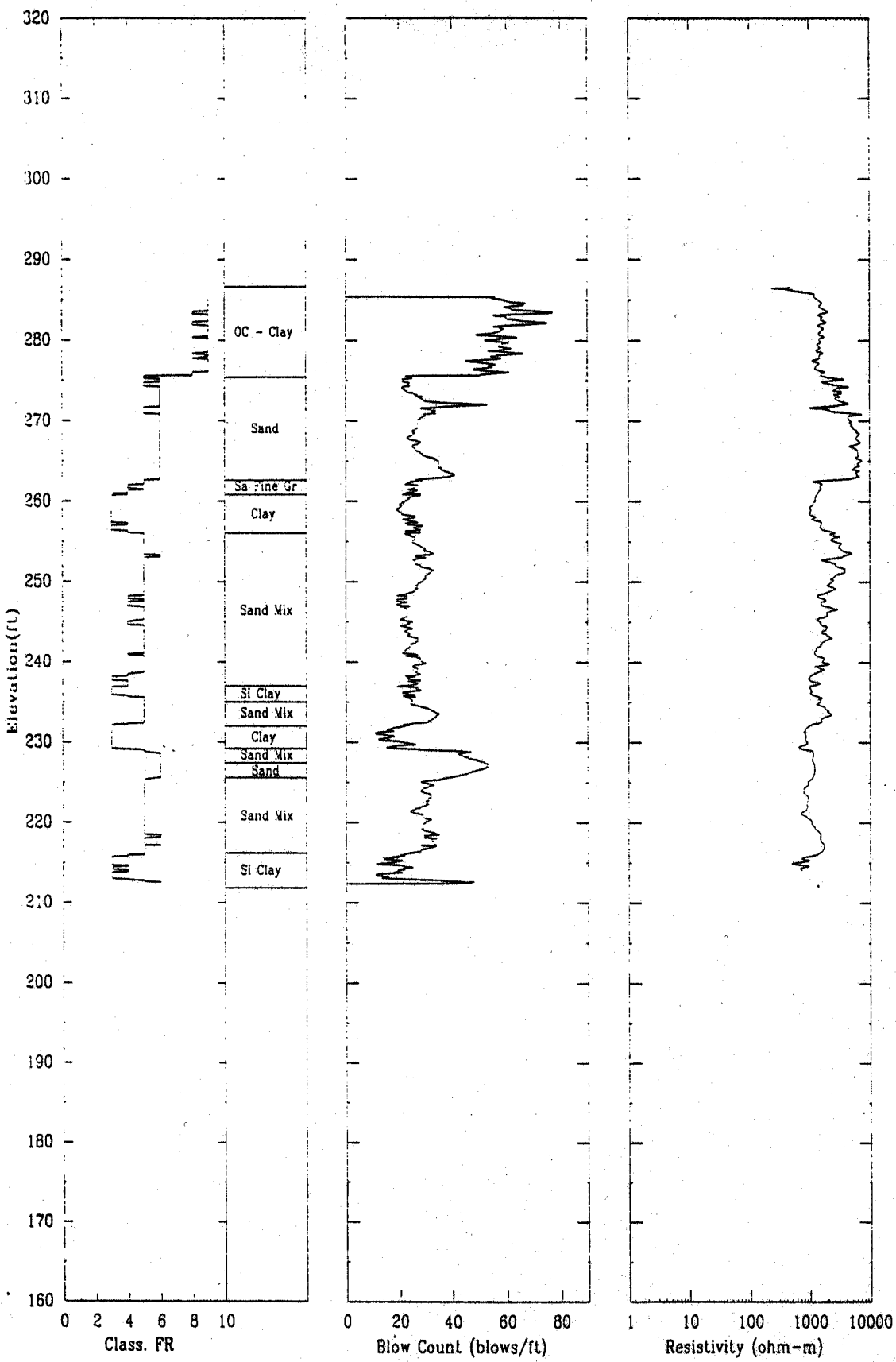

File 302F006.ECP 
MEGACPT-4 APPLIED RESEARCH ASSOCIATES, INC. 02/02/00 North $76050 \quad$ East $59200 \quad$ Elevation 289.86
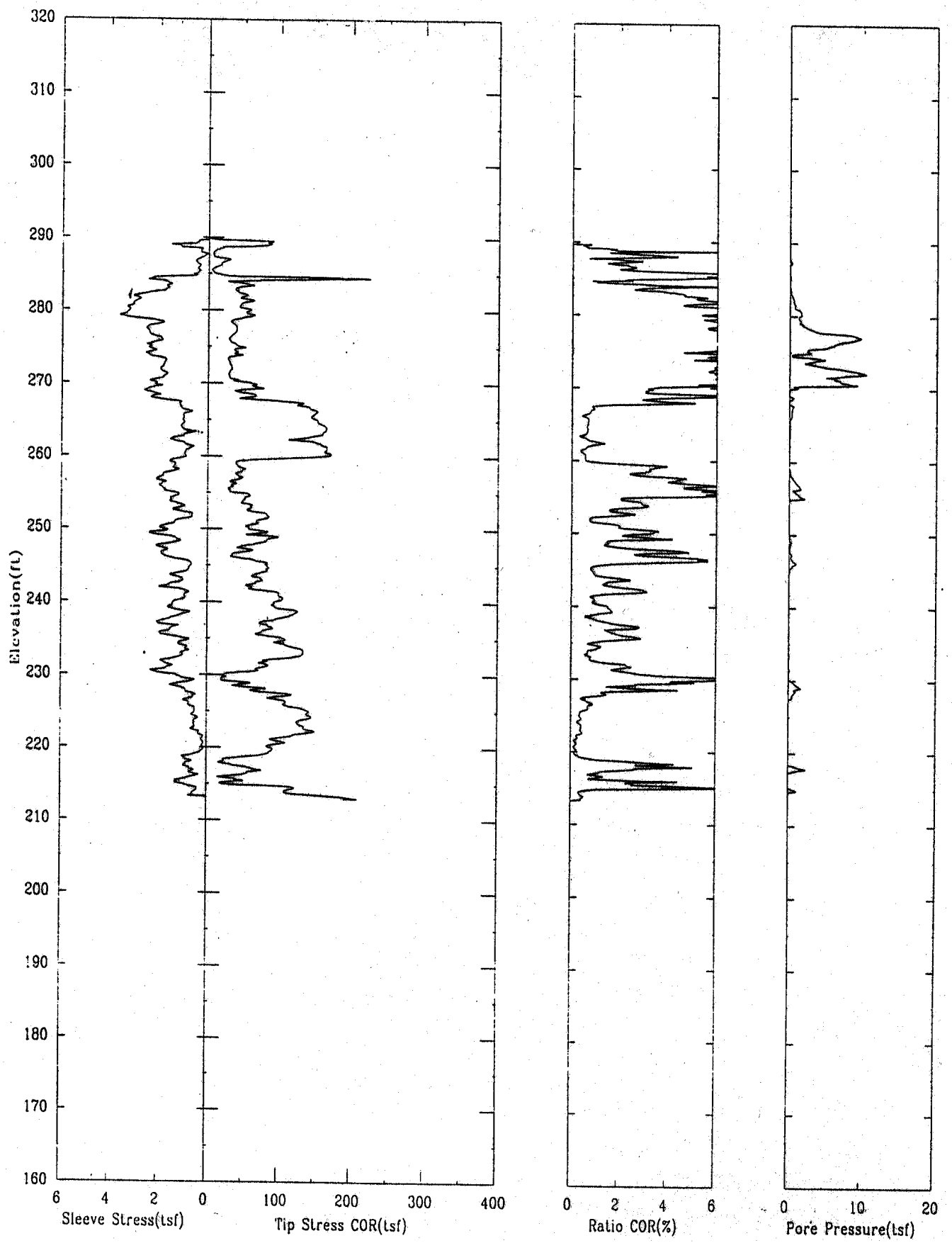

File 302F008.ECP 


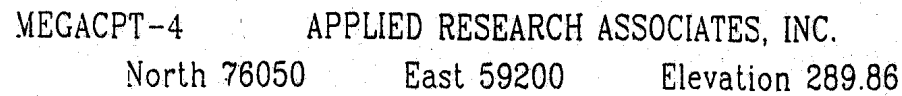

$02 / 02 / 00$

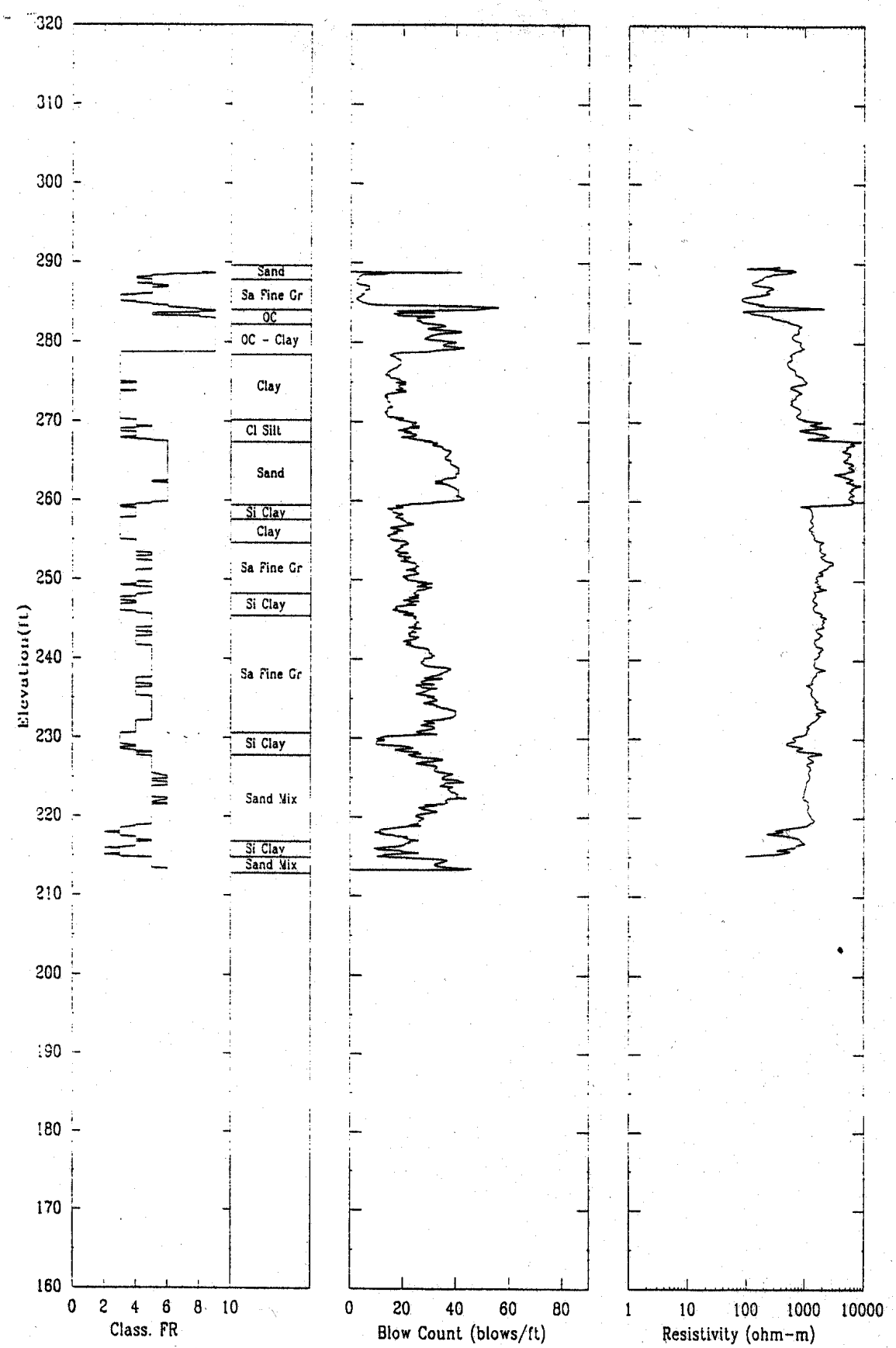

File 302F008.ECP 


$$
\begin{array}{cccc}
\text { MEGACPT }-5 & \text { APPLIED RESEARCH ASSOCIATES, INC. } & 02 / 03 / 00 \\
\text { North } 76050 & \text { East } 59600 & \text { Elevation 278.11 }
\end{array}
$$
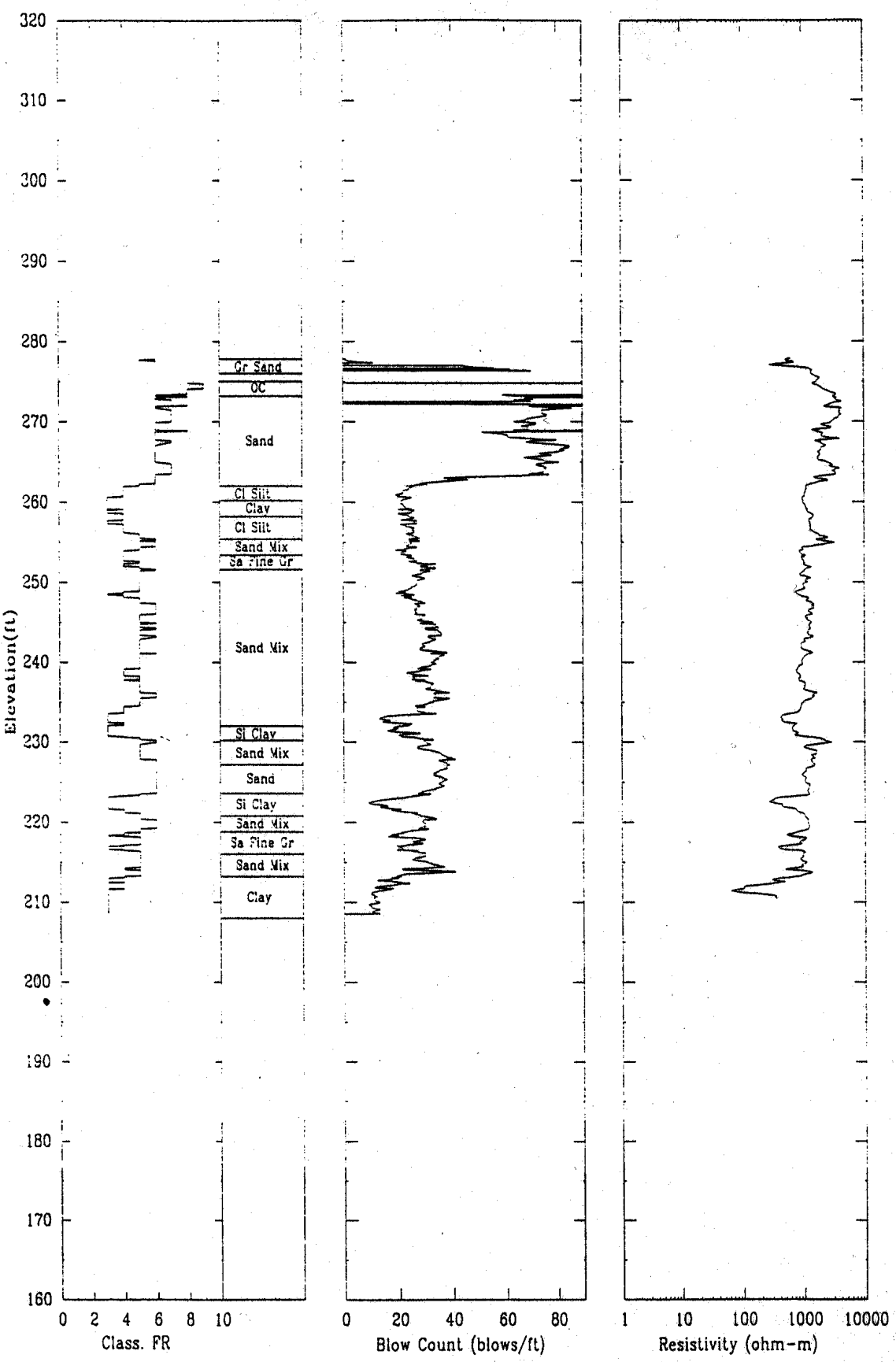

File 303F002.8CP 
VEGACPT -5

APPLIED RESEARCH ASSOCIATES, INC.

$02 / 03 / 00$

North $76050 \quad$ East $59600 \quad$ Elevation 278.11
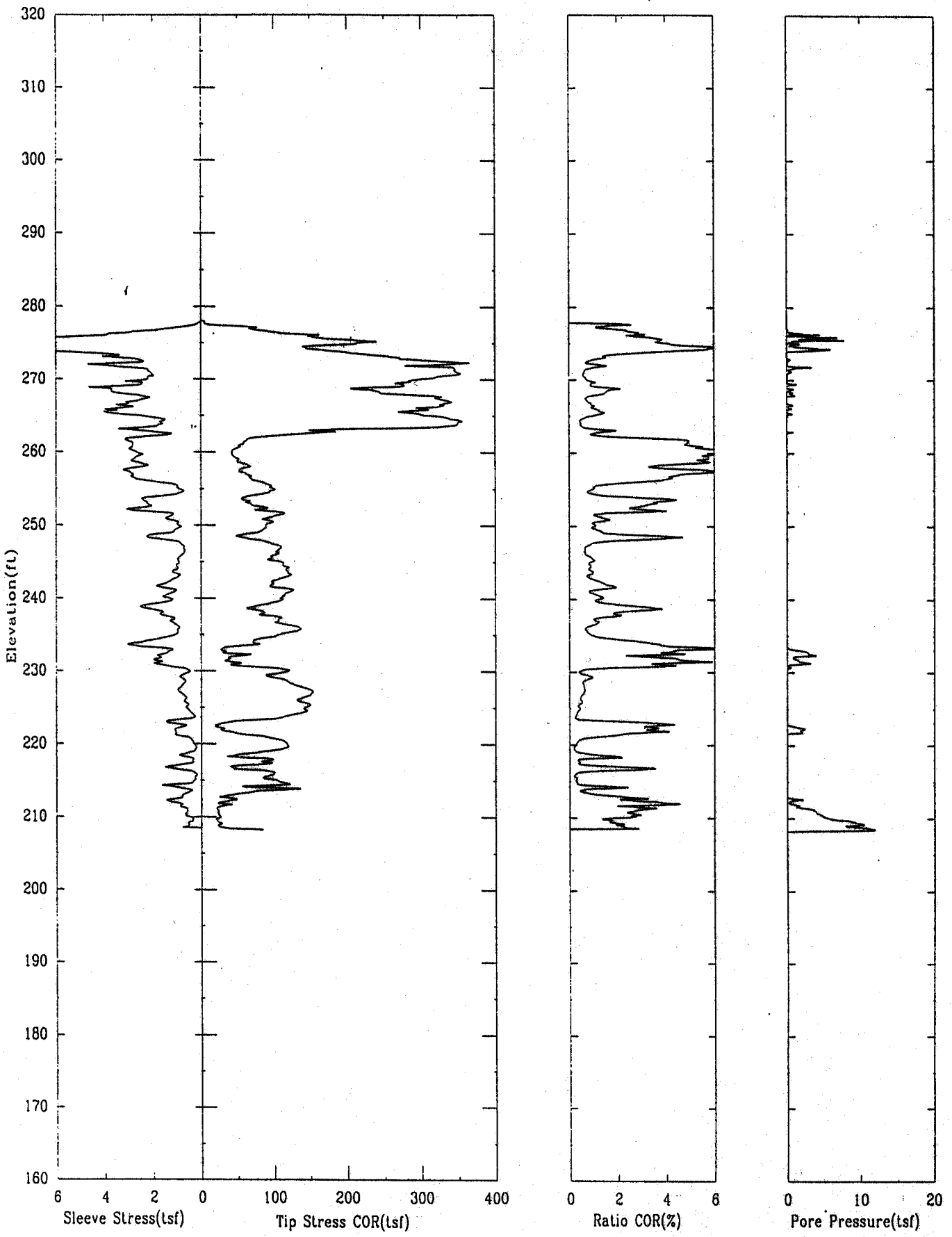

File 303F002.ECP 


$\begin{array}{llll}\text { MEGACPT }-6 & \text { APPLIED RESEARCH ASSOCIATES, INC. } & 02 / 03 / 00 \\ \text { North } 75930 & \text { East } 59450 & \text { Elevation 279.59 } & \end{array}$
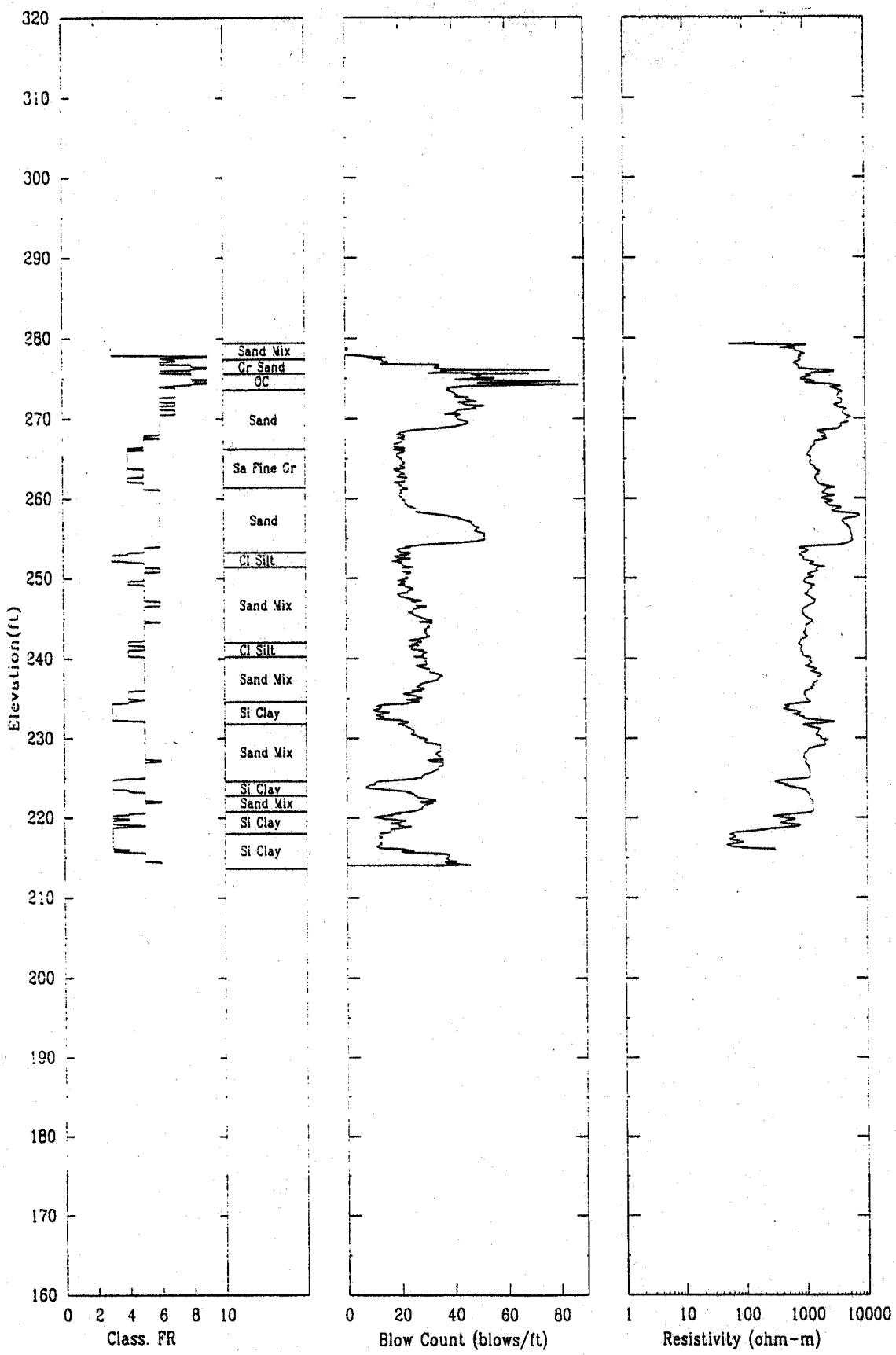

File 303F008.êCP 
$\begin{array}{cccc}\text { MEGACPT }-6 & \text { APPLIED RESEARCH ASSOCIATES, INC. } & 02 / 03 / 00 \\ \text { North } 75930 & \text { East } 59450 & \text { Elevation } 279.59 & \end{array}$
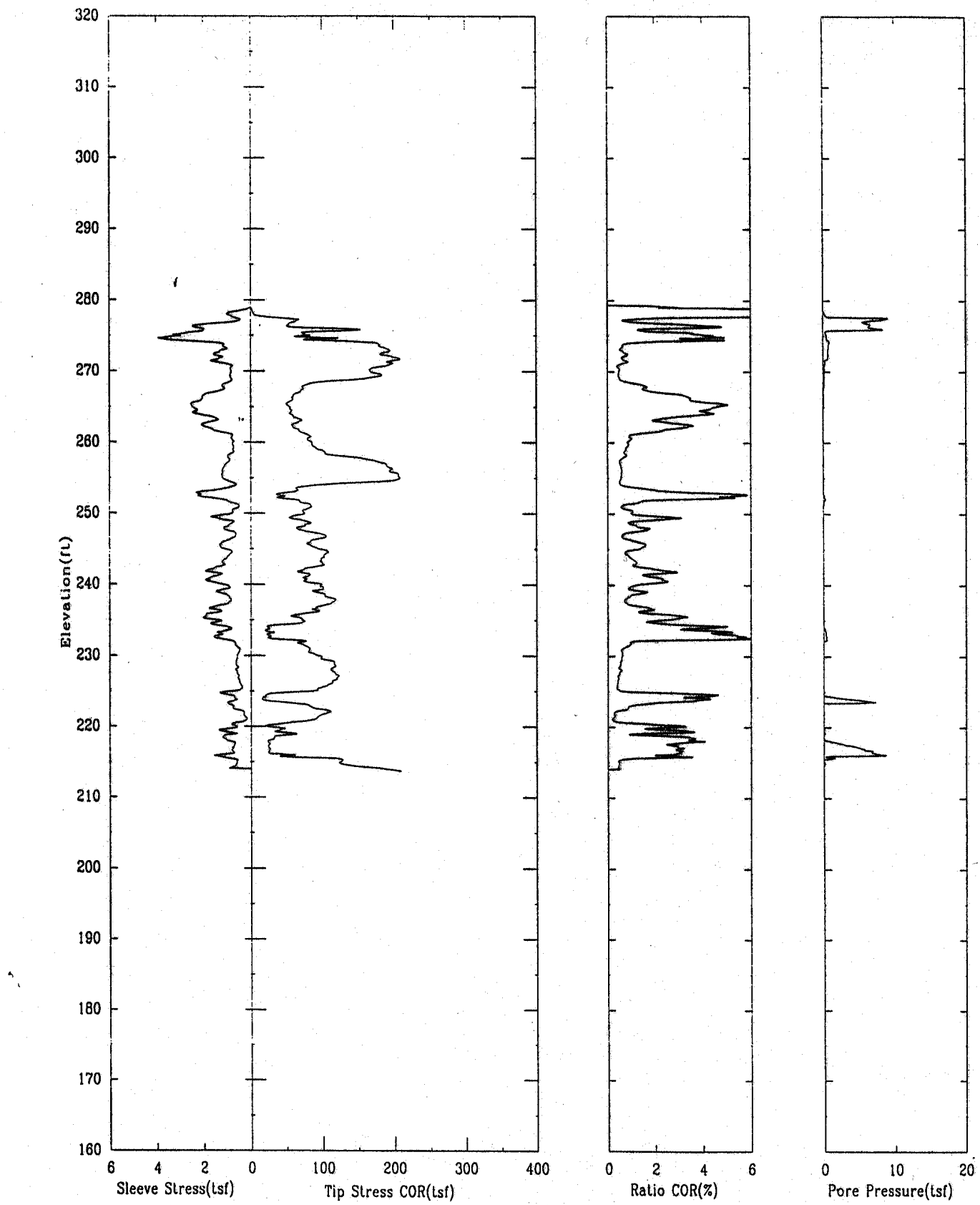

File 303F008.8CP 
MEGACPT-7 APPLIED RESEARCH ASSOCIATES, INC. 02/03/00 North $75930 \quad$ East $59100 \quad$ Elevation 285.02
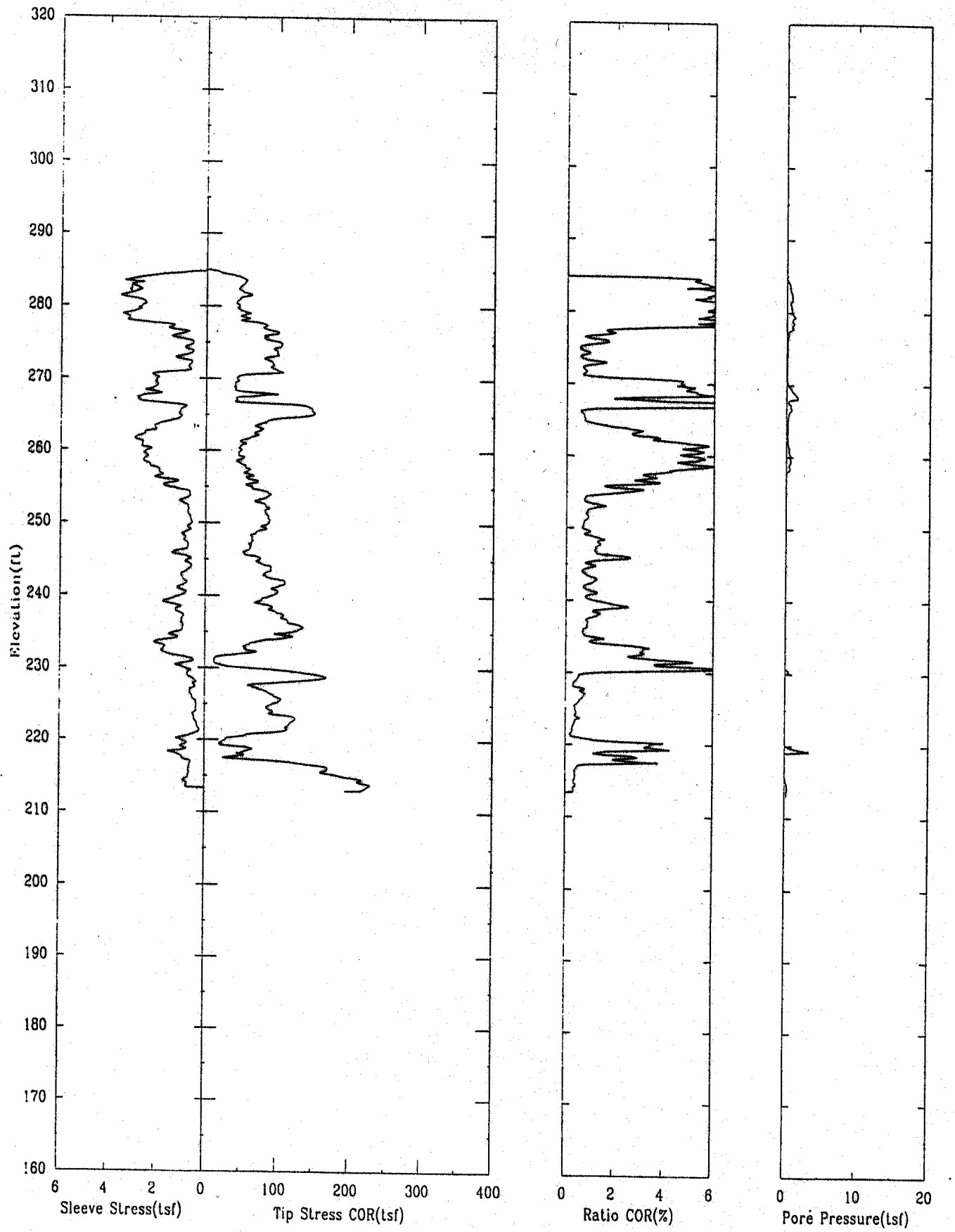

File 303F010.ECP 

MEGACPT -7 APPLIED RESEARCH ASSOCIATES, INC. 02/03/00 North $75930 \quad$ East $59100 \quad$ Elevation 285.02

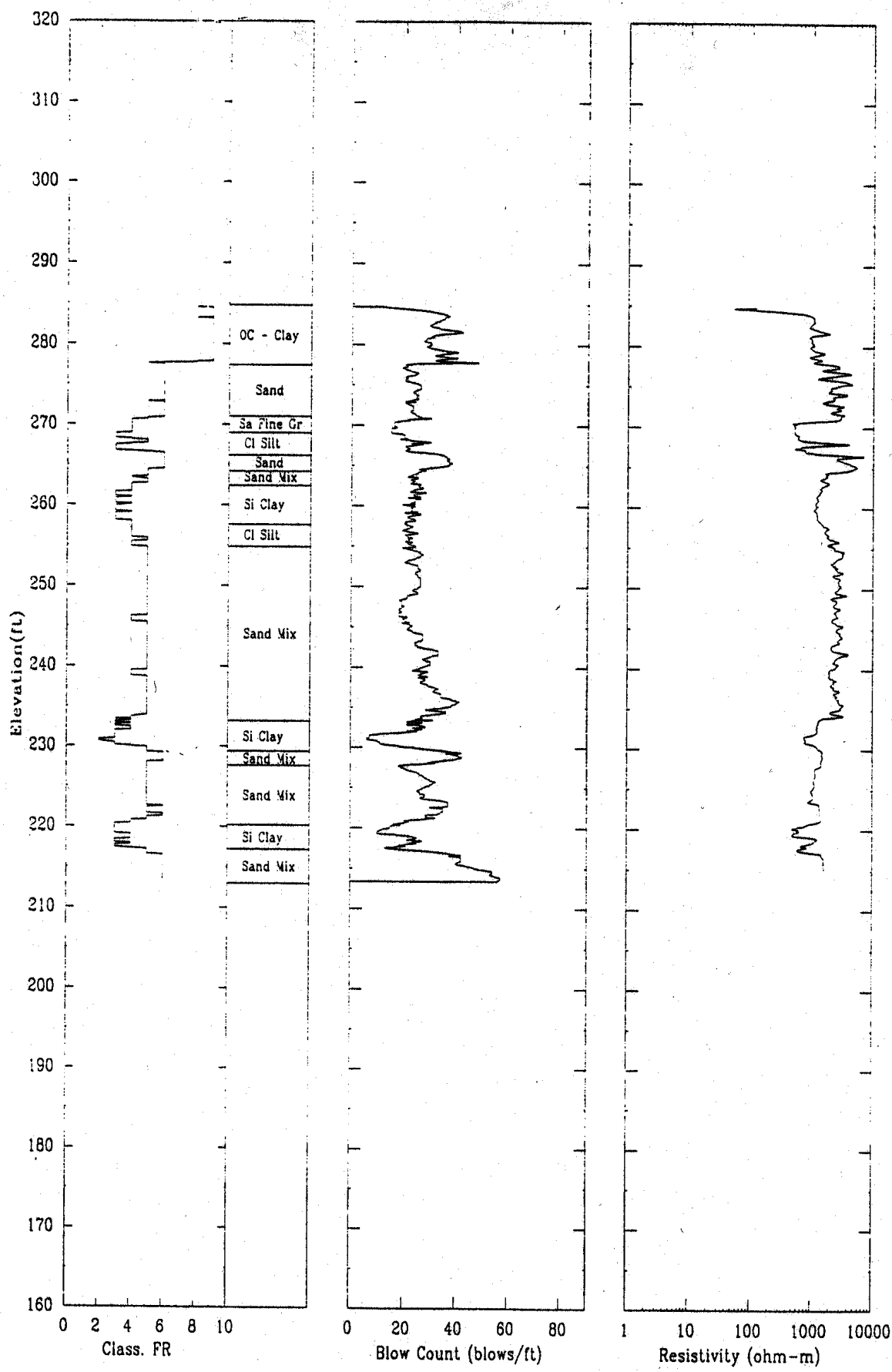

File 303F010.2CP 
AT NORTH APPLIED RESEARCH ASSOCIATES, INC. 06/28/00

North $76041 \quad$ East $59484 \quad$ Elevation 281.41
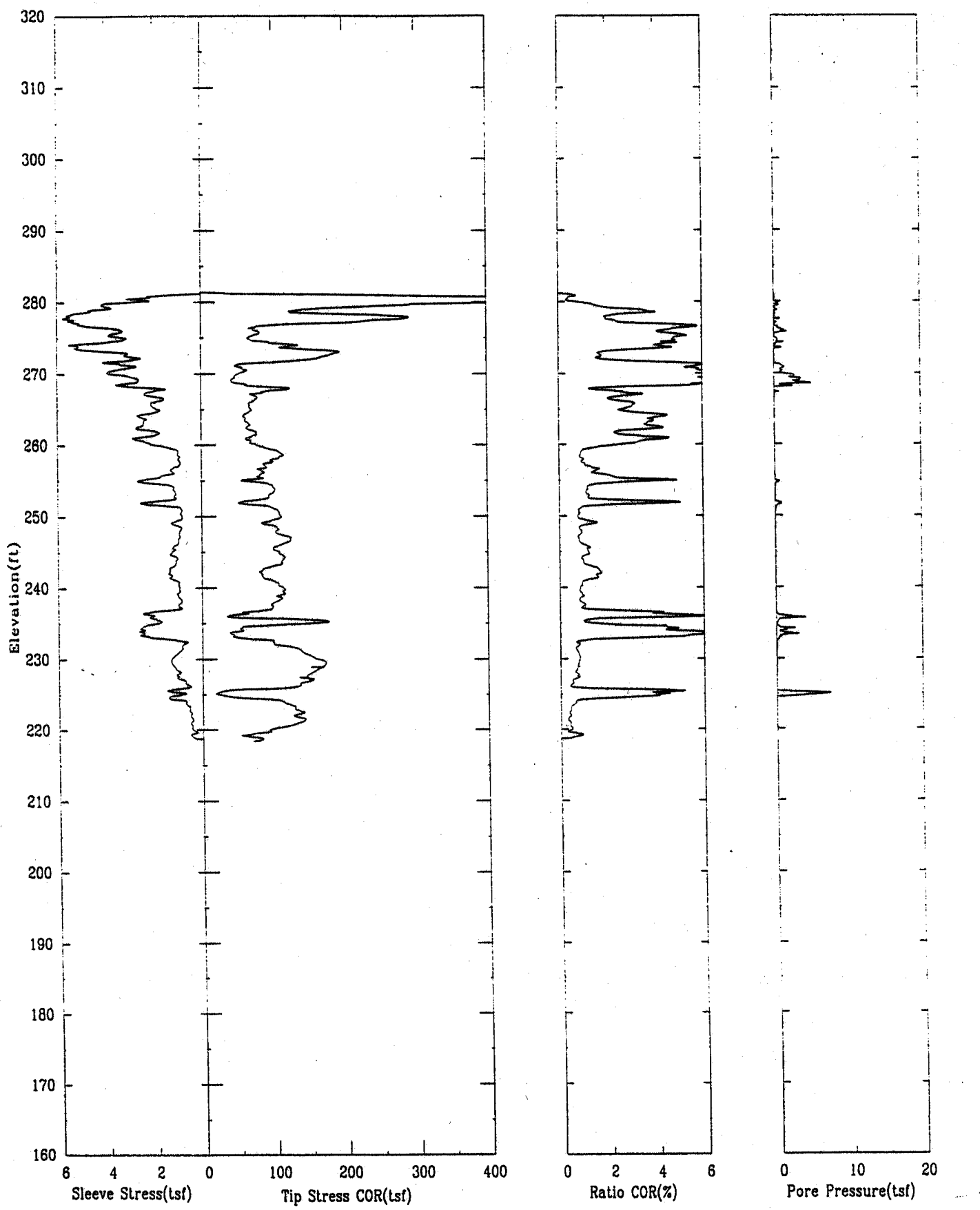

File 428U001.ECP 
AT NORTH APPLIED RESEARCH ASSOCIATES, INC. 06/28/00 North 76041 East $59484 \quad$ Elevation 281.41
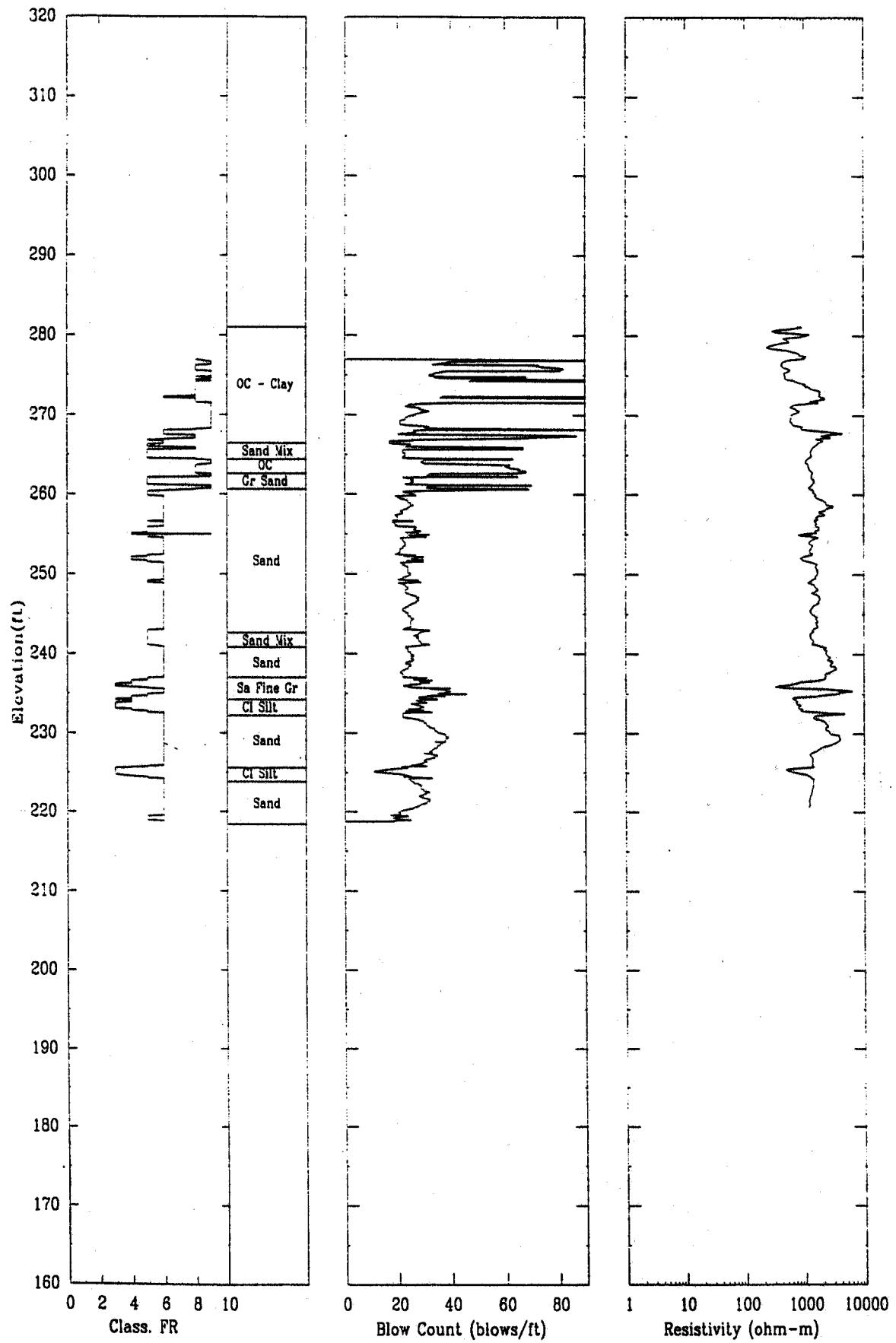

File 42BU001.ECP 
$\begin{array}{lll}\text { AT EAST } & \text { APPLIED RESEARCH ASSOCIATES, INC. } & 06 / 26 / 00 \\ \text { North } 75918.58 & \text { East } 59621.27 & \text { Elevation } 276.97\end{array}$
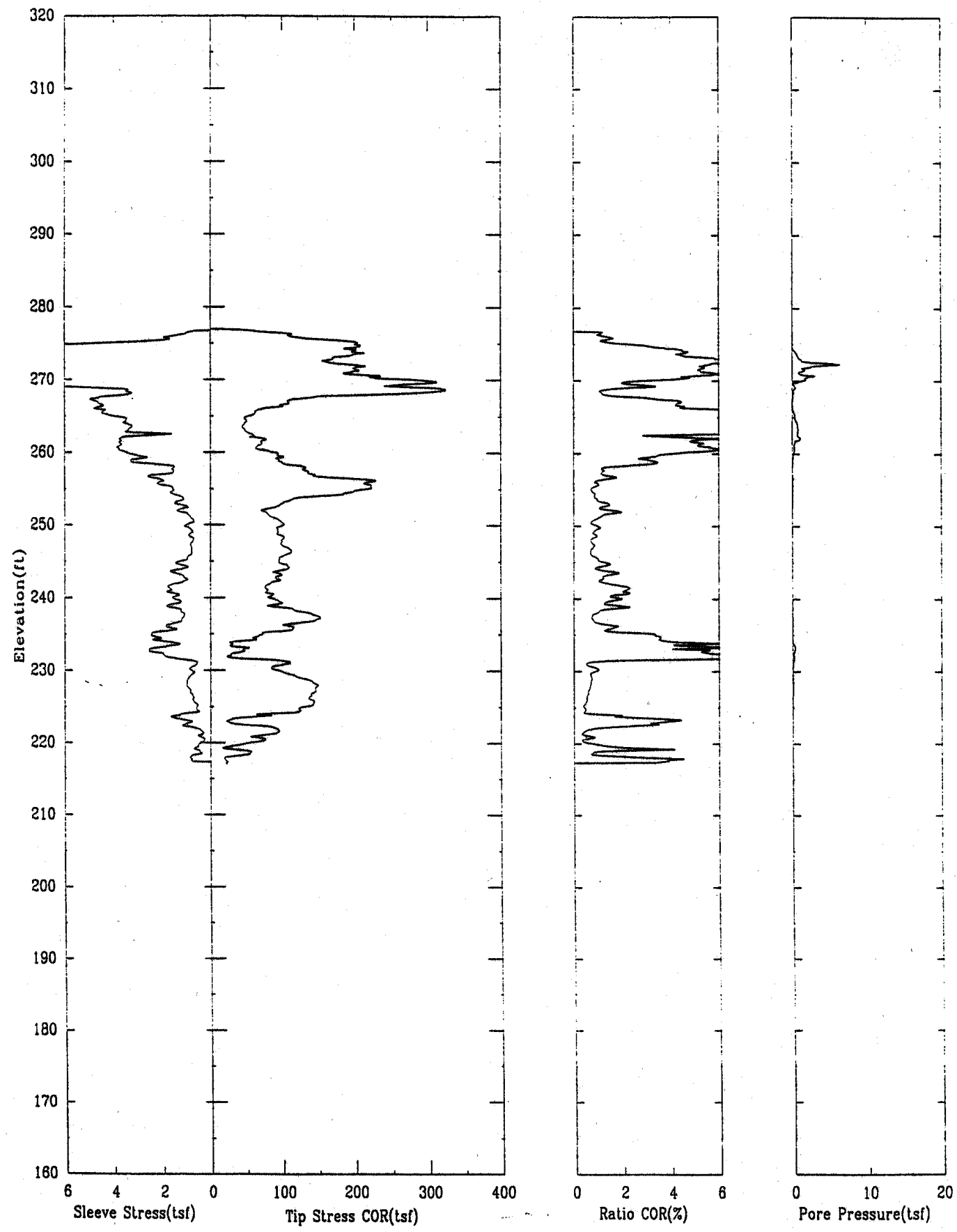

Plie 428U003.ECP 
AT EAST APPLIED RESEARCH ASSOCIATES, INC. $06 / 26 / 00$ North $75918.58 \quad$ East 59621.27 Elevation 276.97
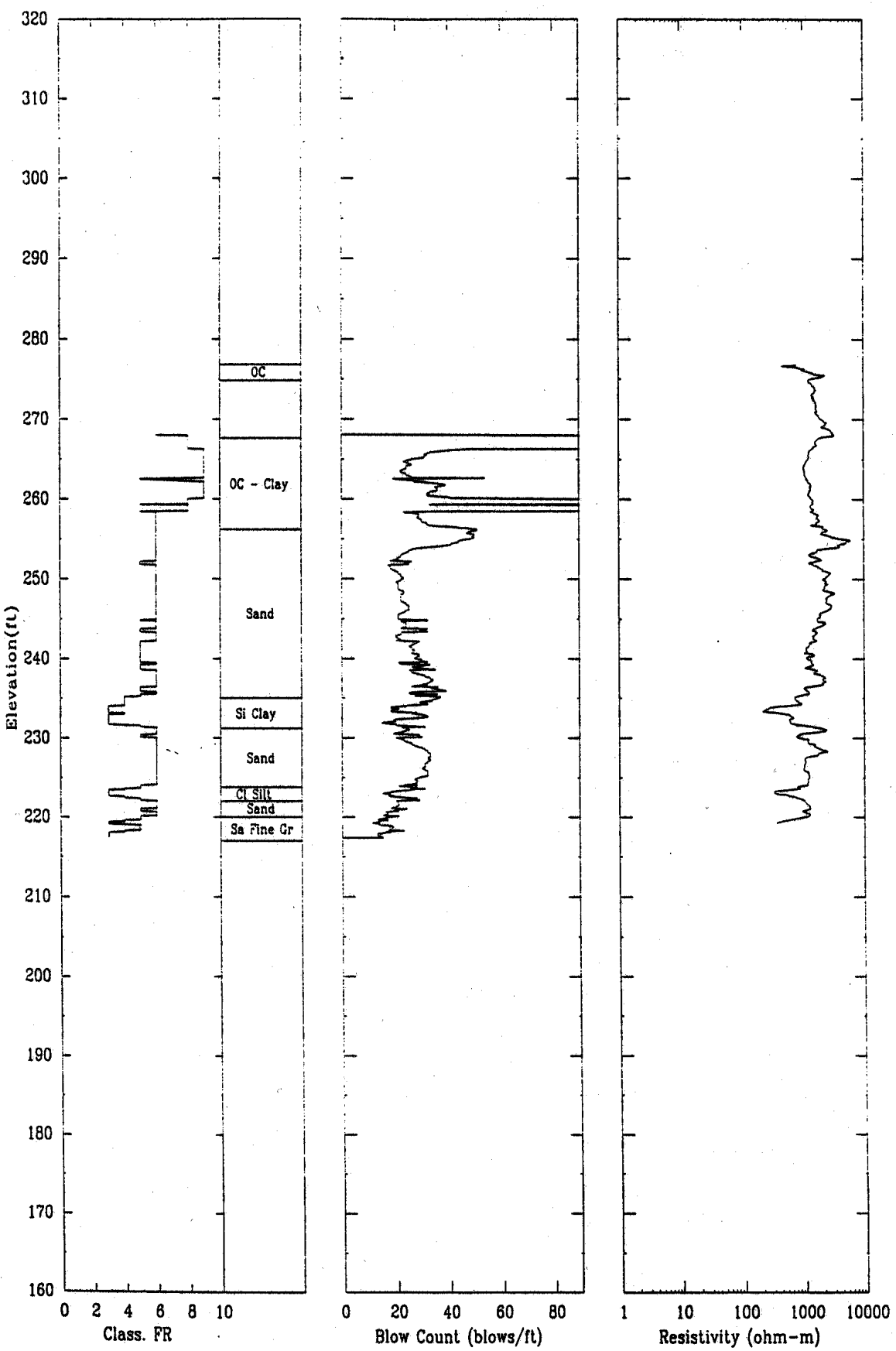

File $4280003.8 C P$ 

AT SOUTH APPLIED RESEARCH ASSOCIATES, INC. 06/27/00 North $75814.08 \quad$ East $59500.00 \quad$ Elevation 278.66
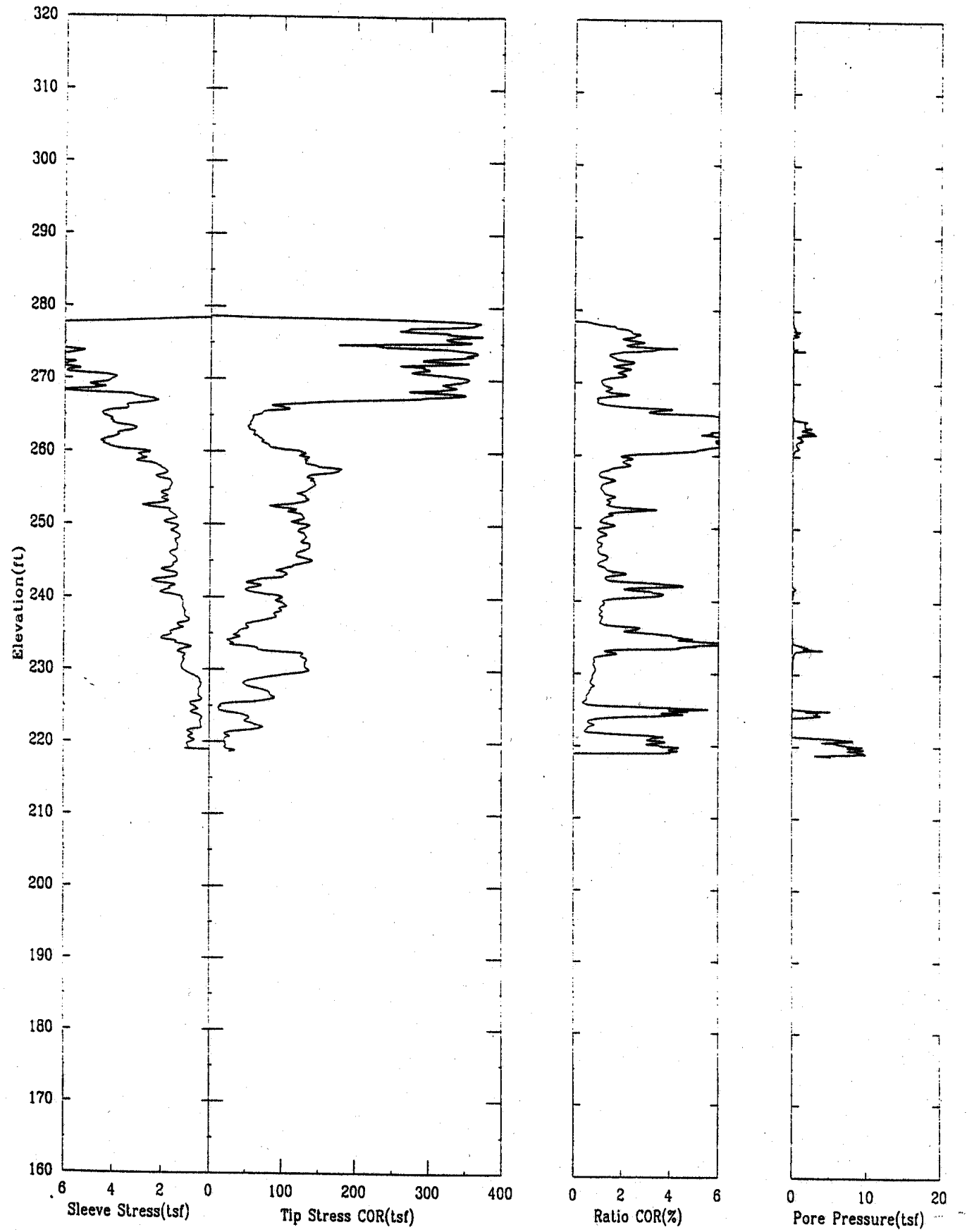

File 427U001.ECP 
AT SOLTH APPLIED RESEARCH ASSOCIATES, INC. 06/27/00 North $75814.08 \quad$ East $59500.00 \quad$ Elevation 278.66
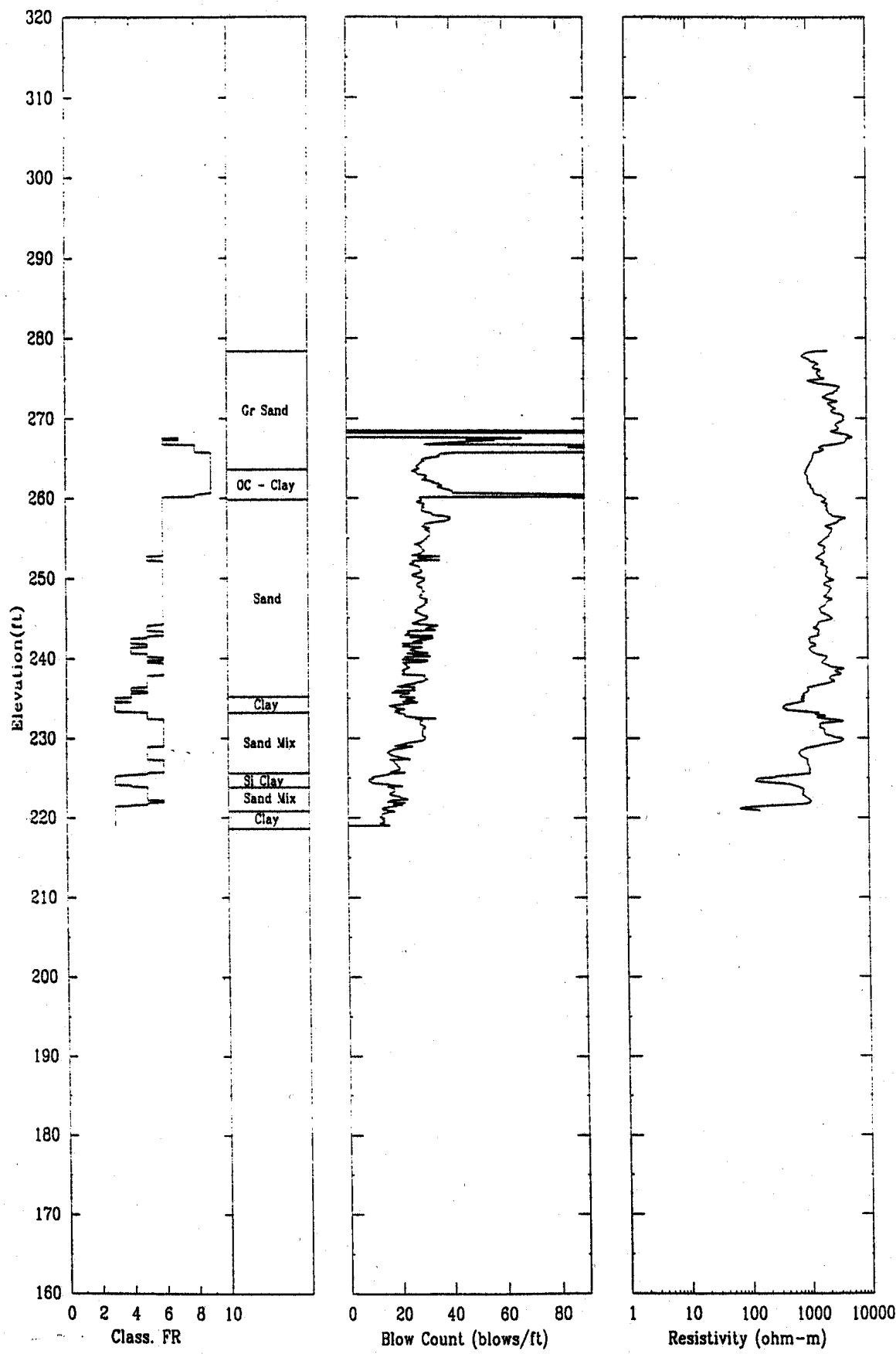

File 427U001.ECP 


\section{Appendix B}

\section{Geotechnical Borehole Logs}


This page intentionally left blank. 


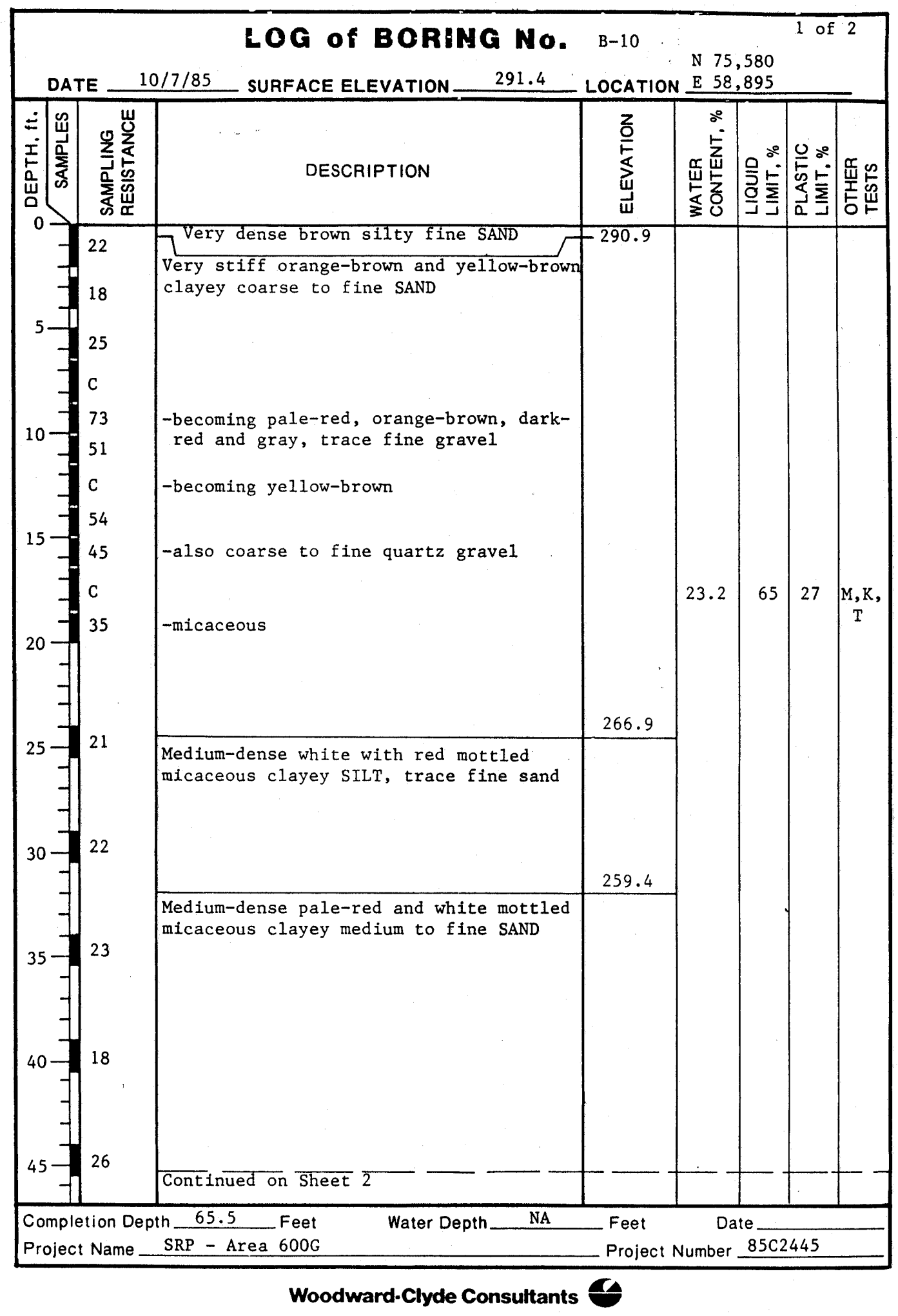

Page 181 of 298 


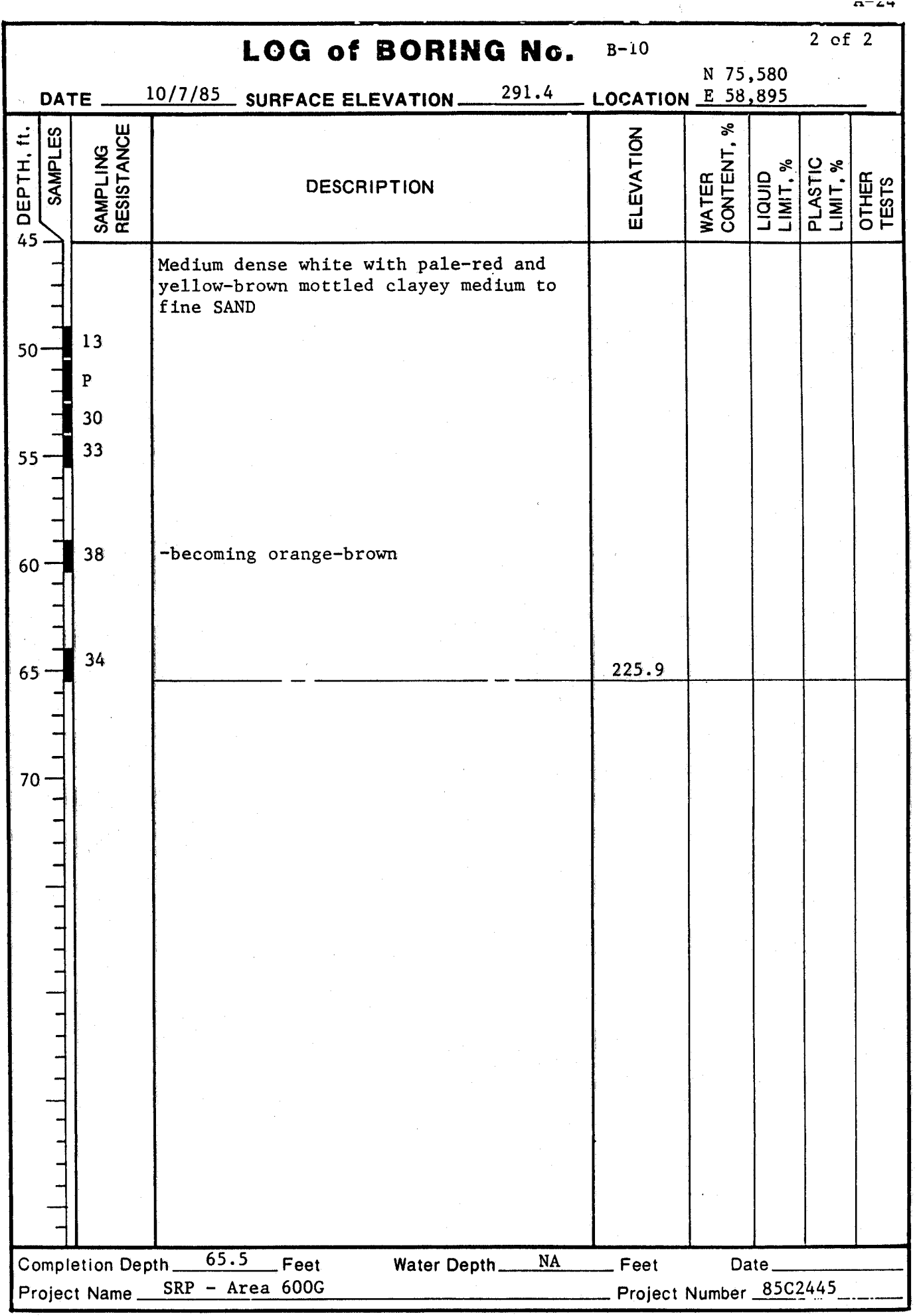

Woodward-Clyde Consultants 


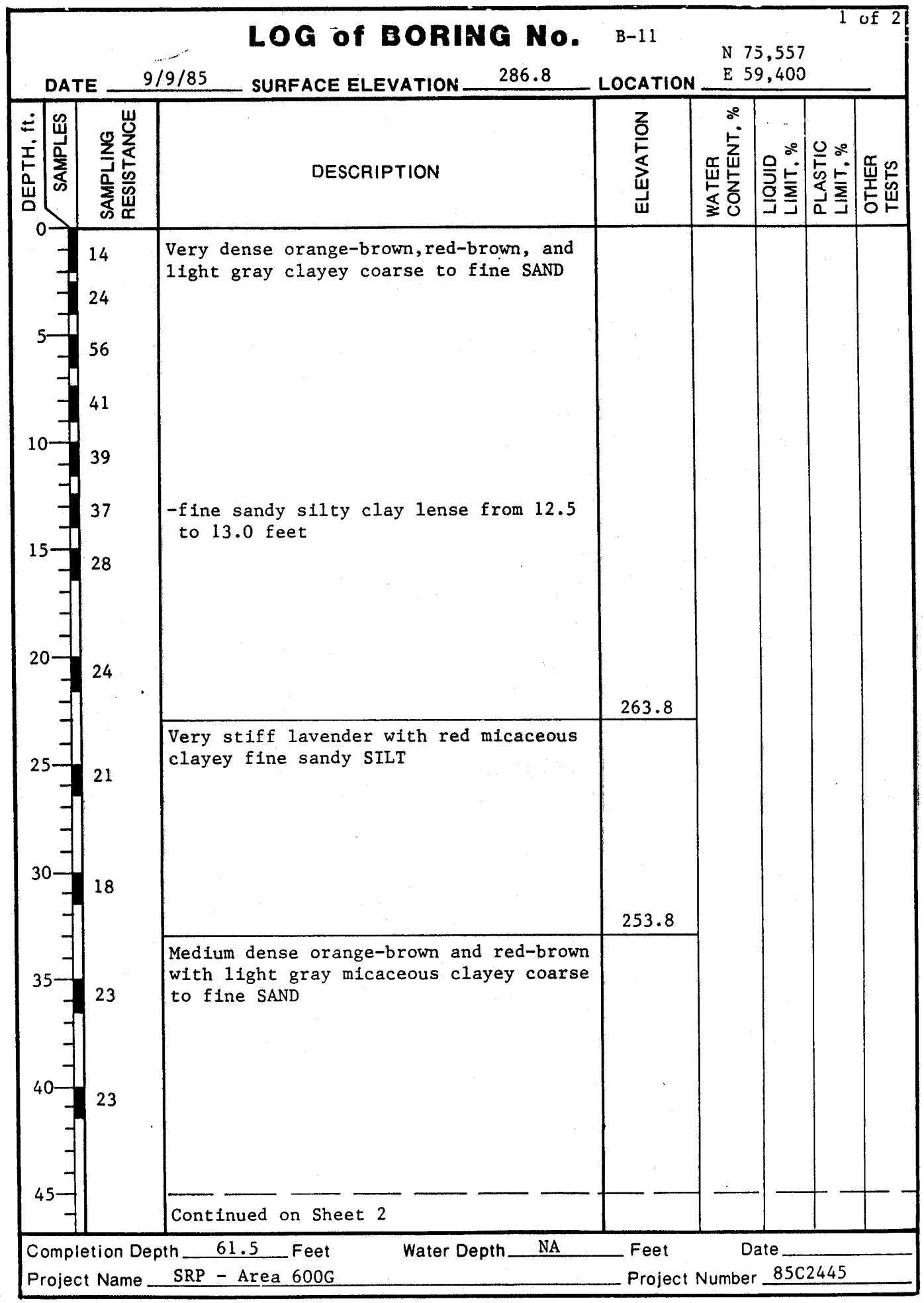

Woodward.Clyde Consultants 


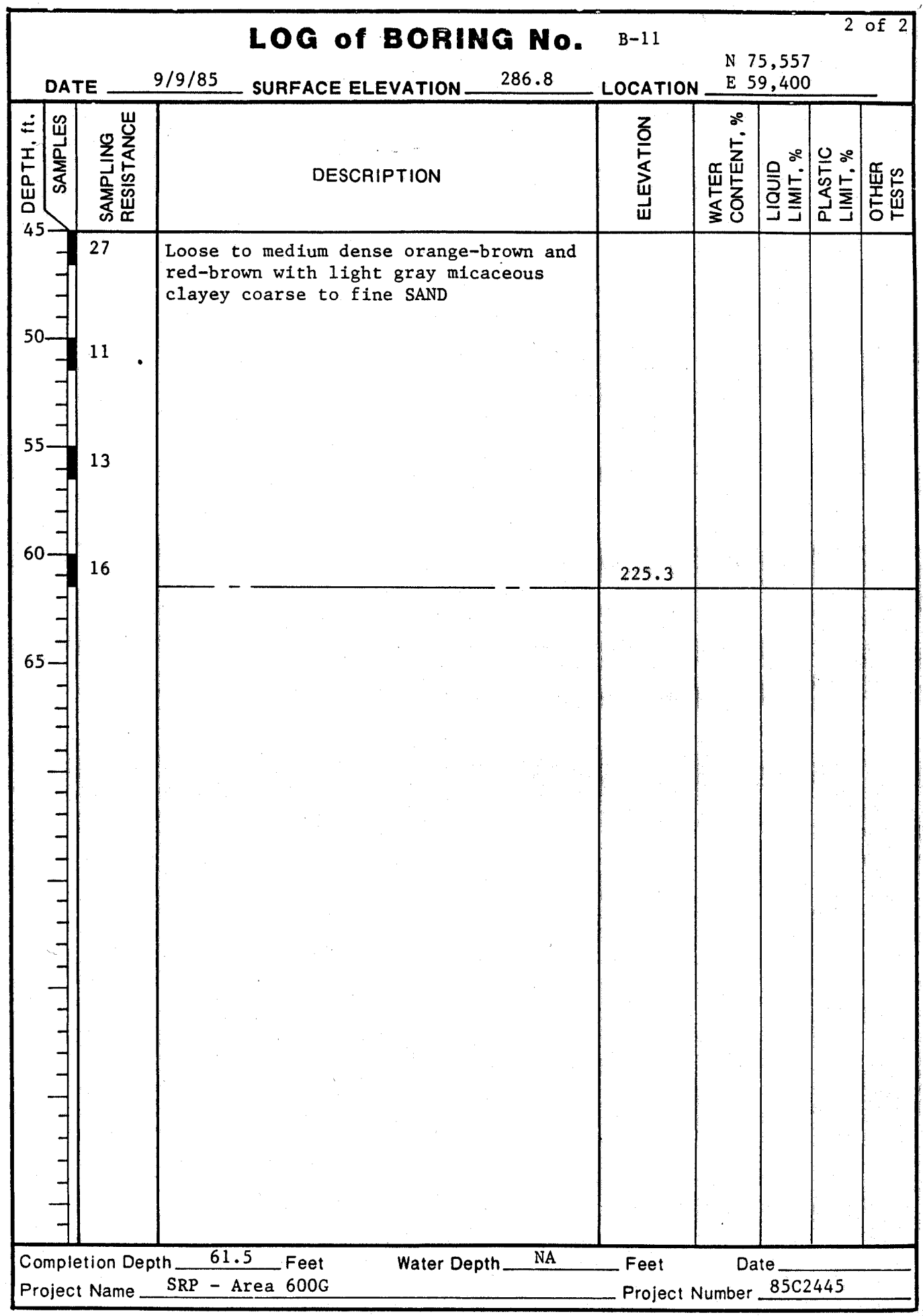

Woodward-Clyde Consultants 


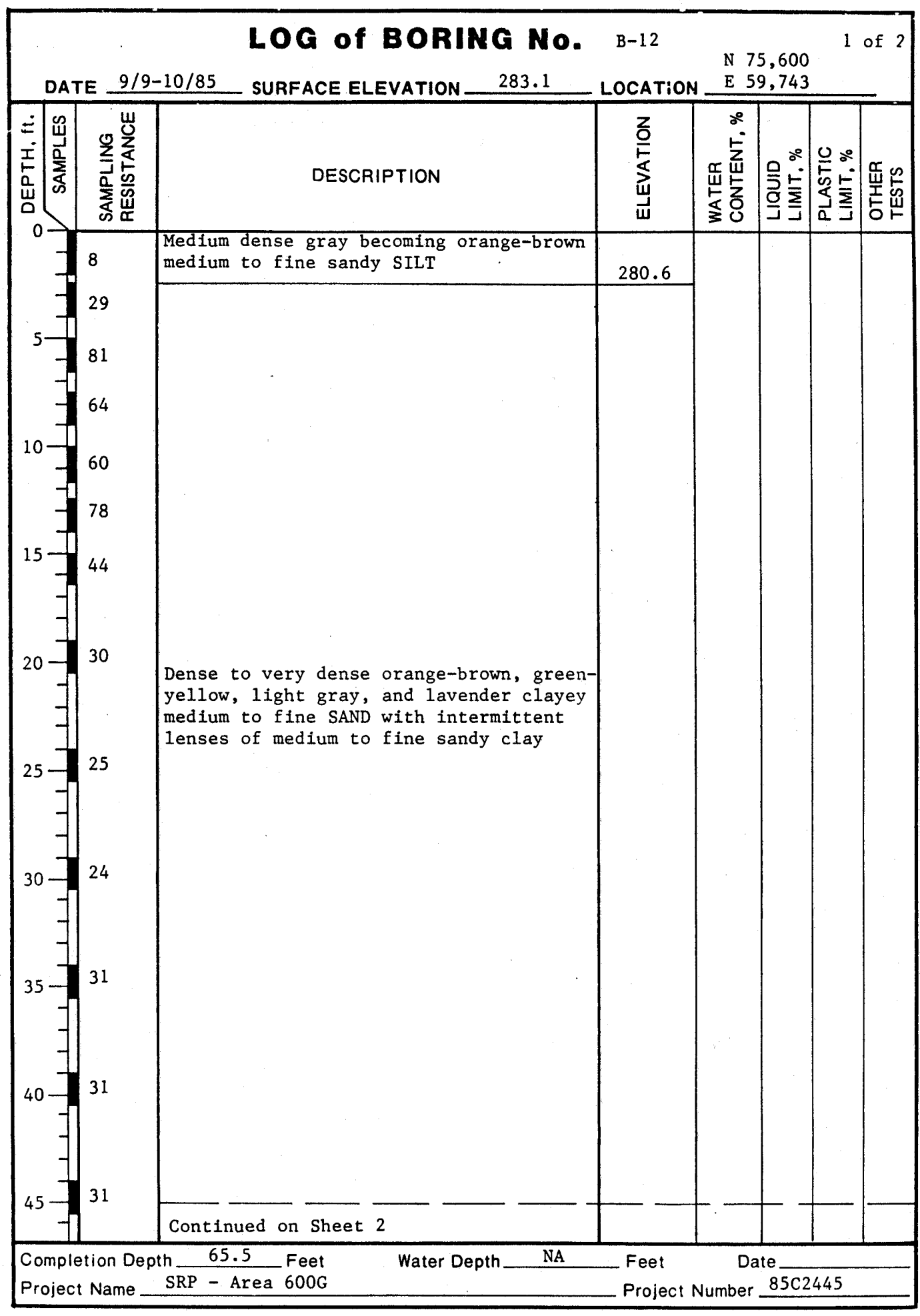

Woodward-Clyde Consultants 


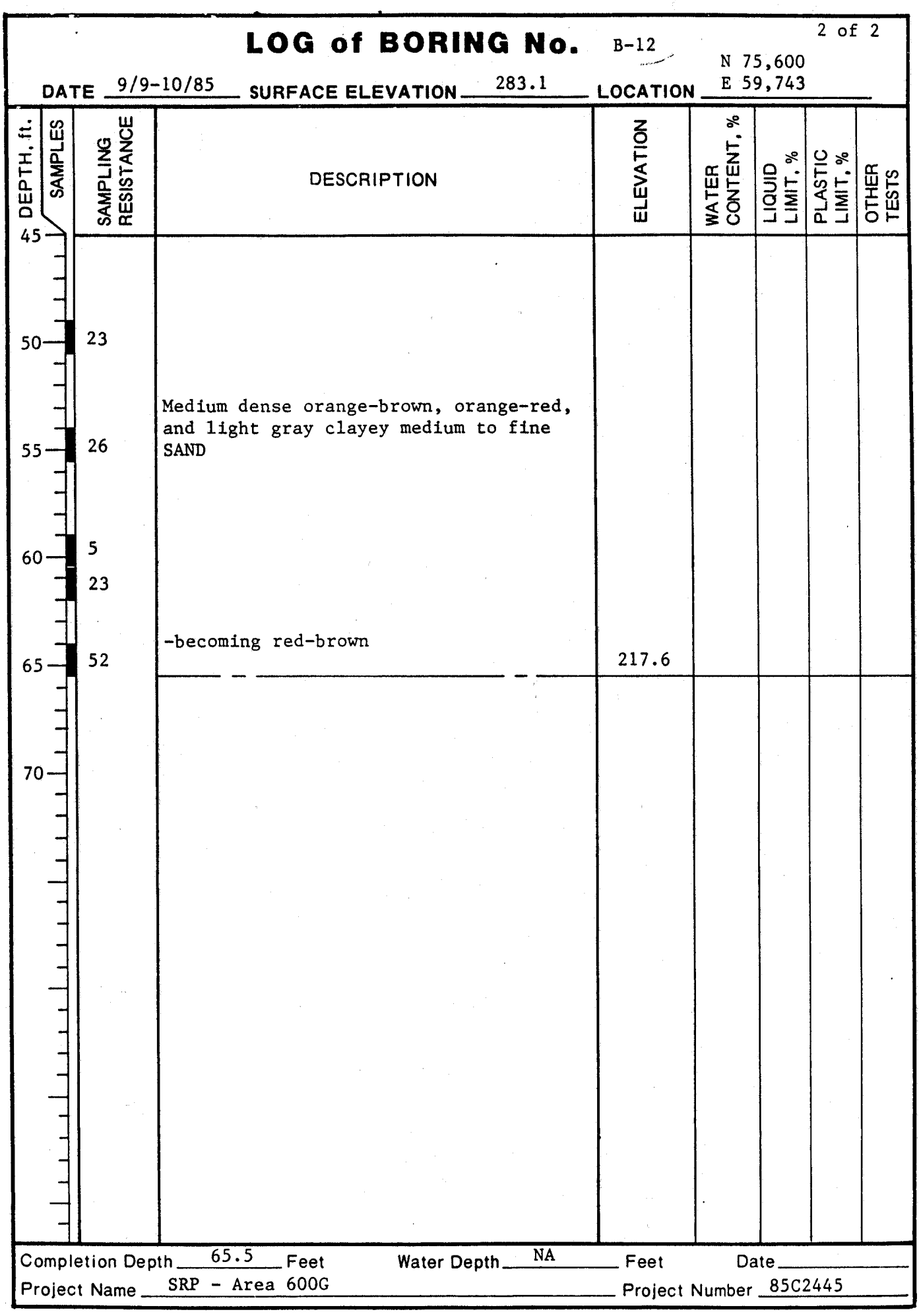

Woodward-Clyde Consultants

Page 186 of 298 


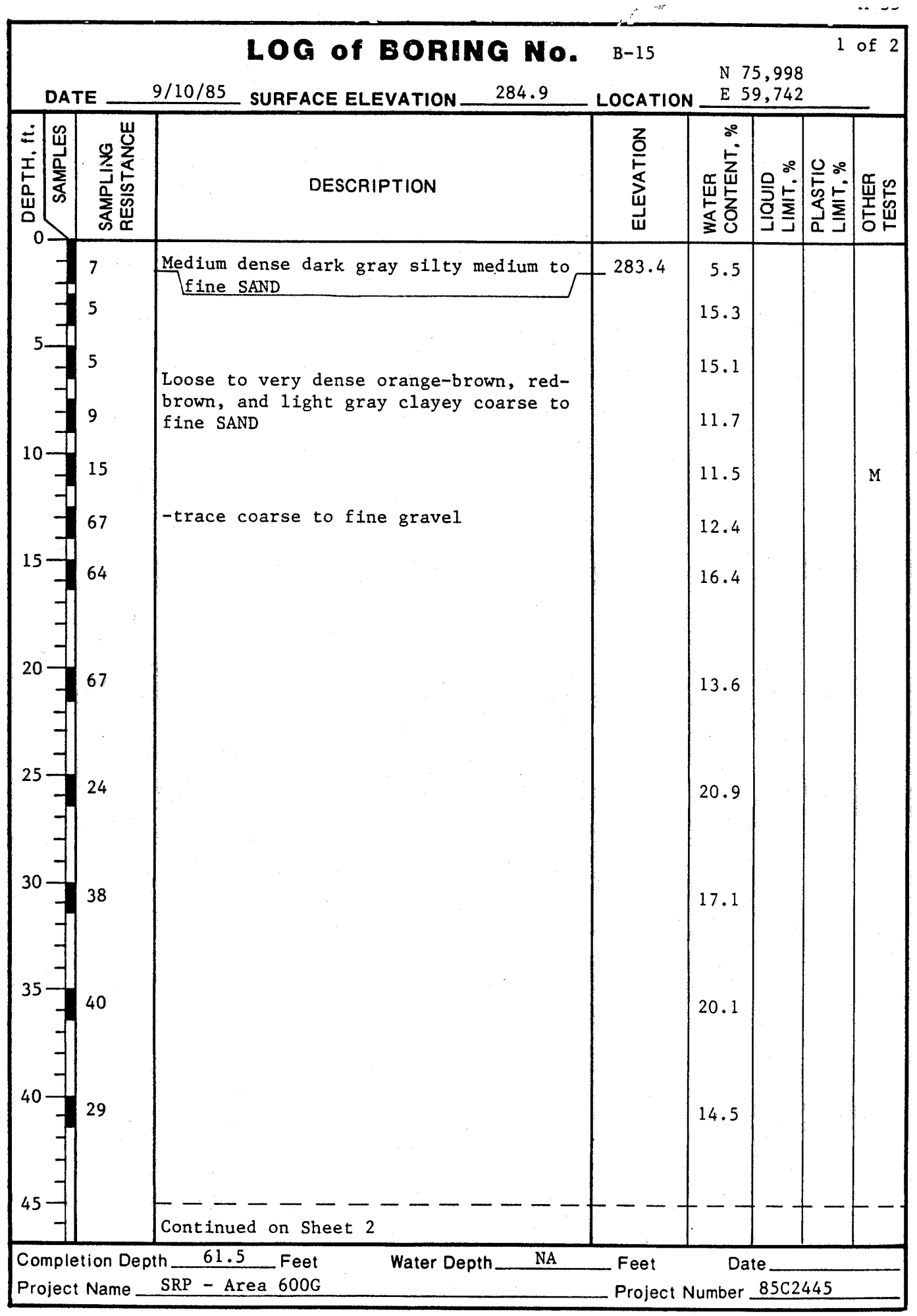

Woodward-Clyde Consultants 


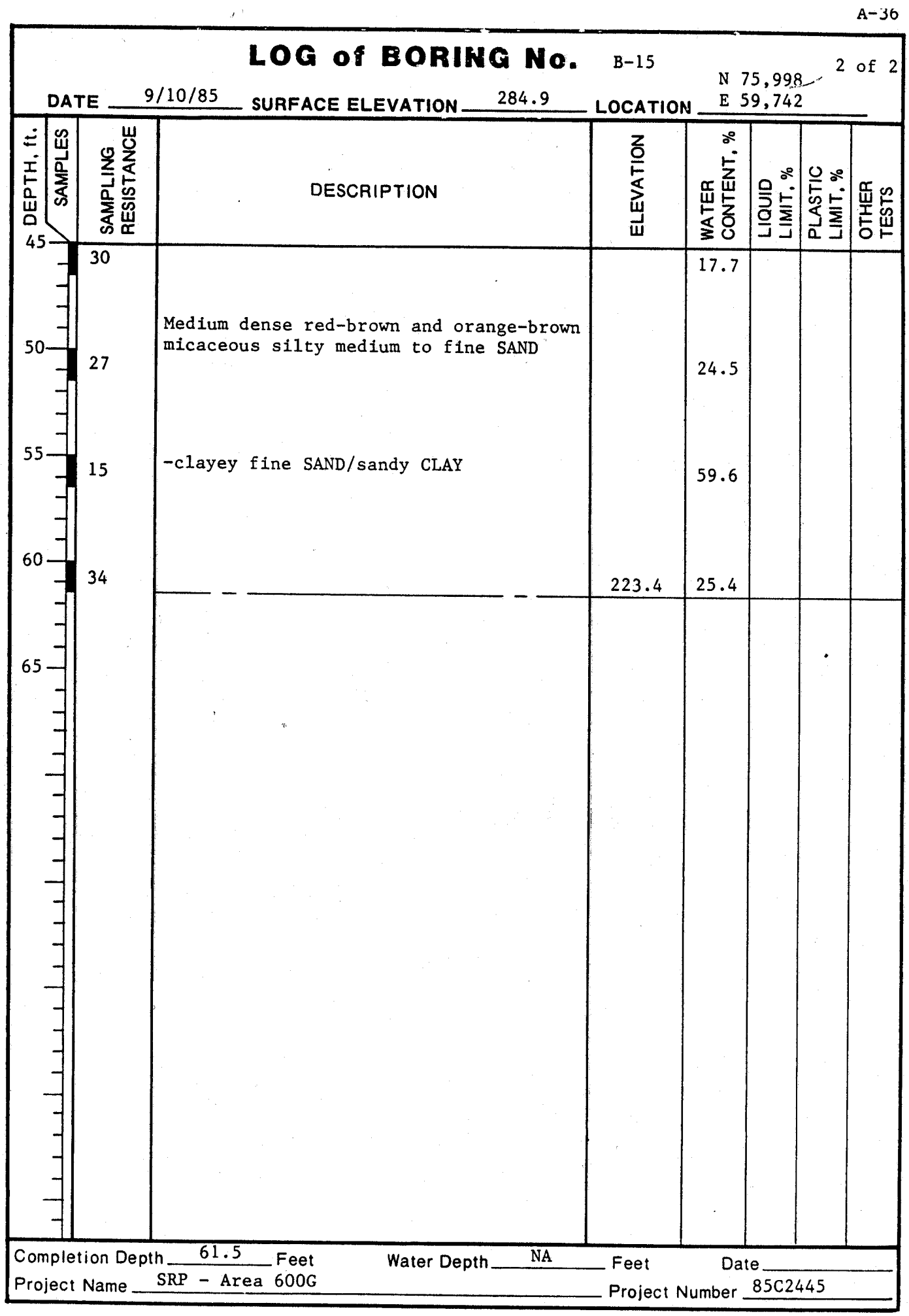

Woodward.Clyde Consultants

Page 188 of 298 


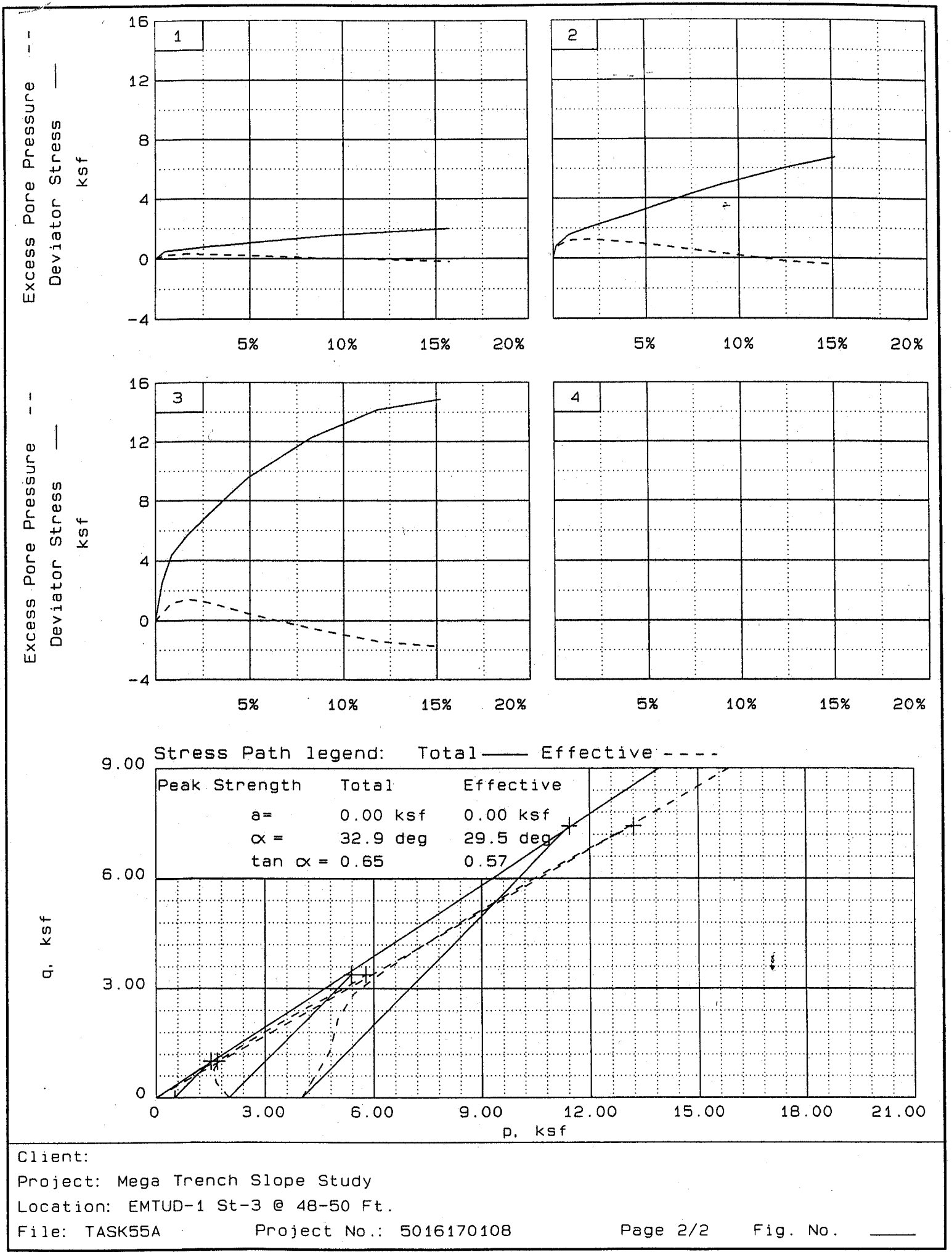

Page 189 of 298 


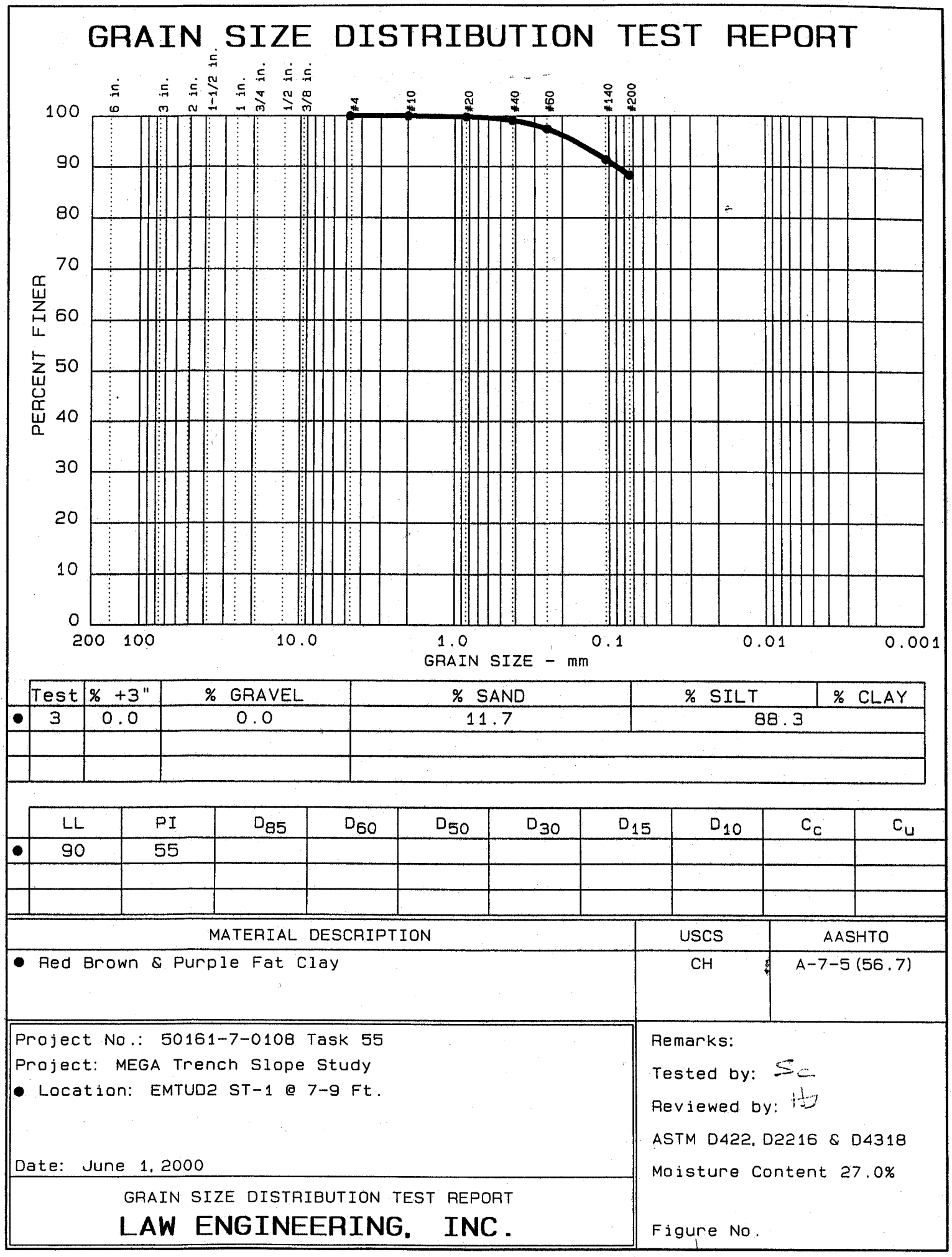




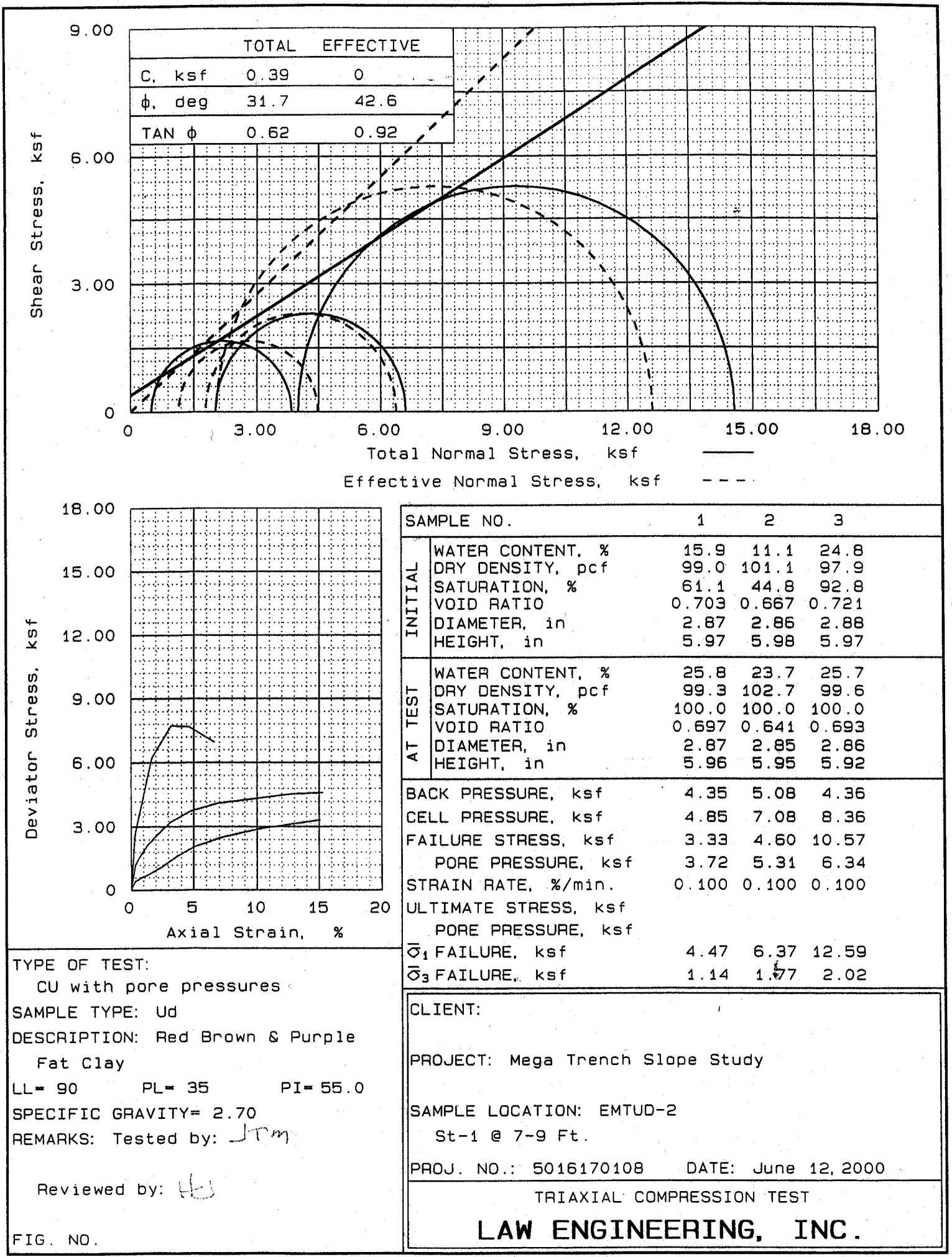




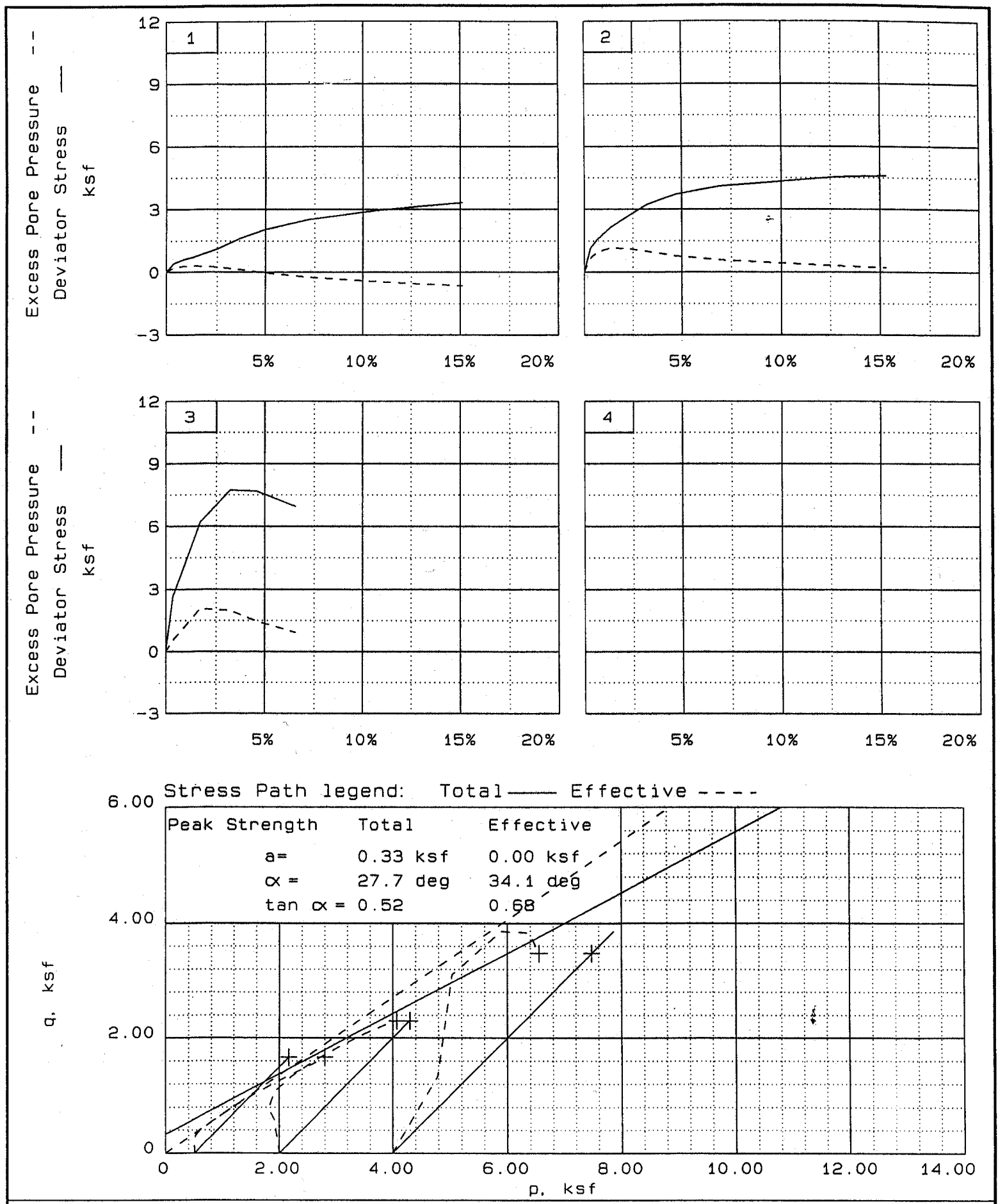

Client:

Project: Mega Trench Slope Study

Location: EMTUD-2 St-1 e 7-9 Ft.

File: TASK55B

Project No.: 5016170108

Page $2 / 2$ Fig. No.

Page 192 of 298 


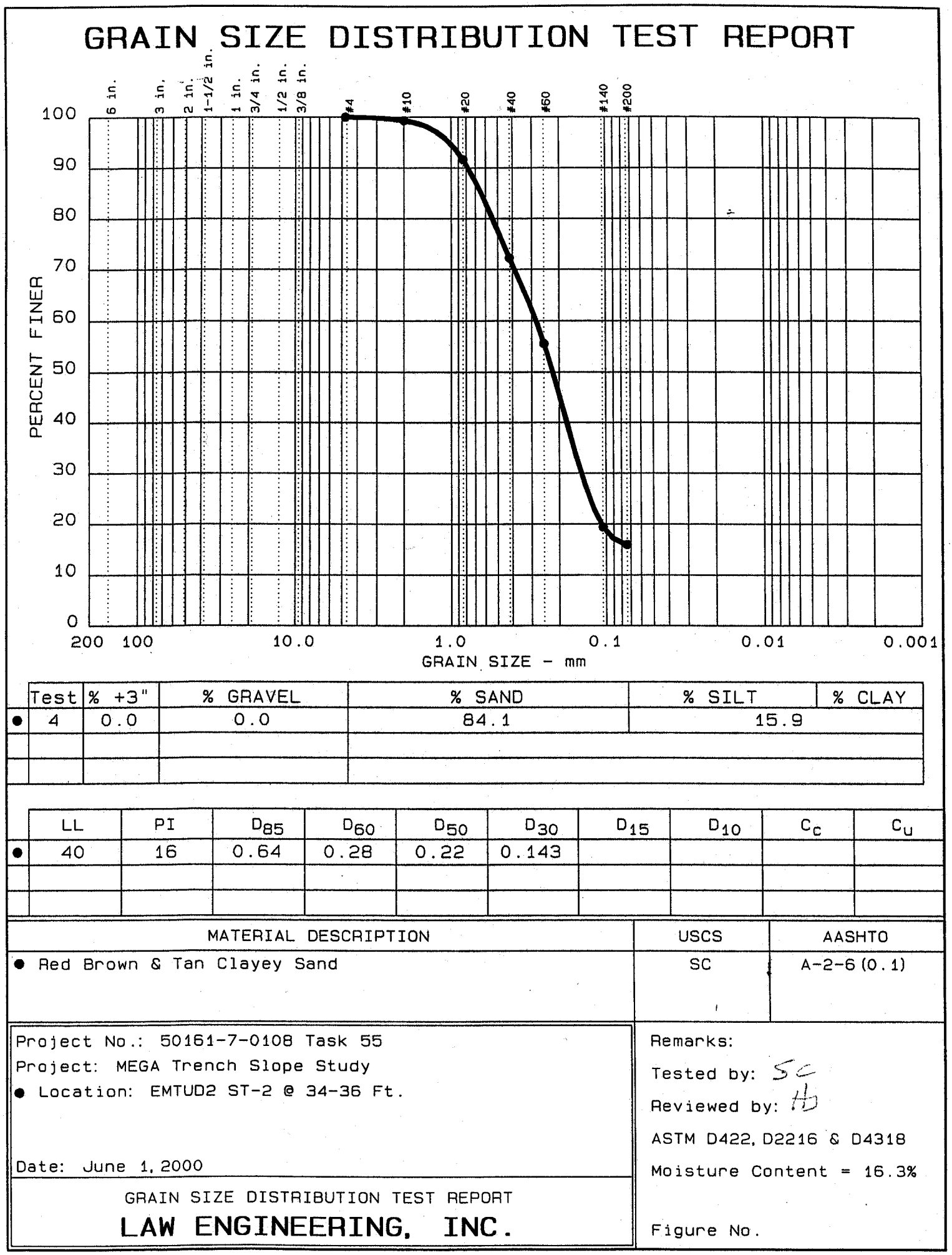




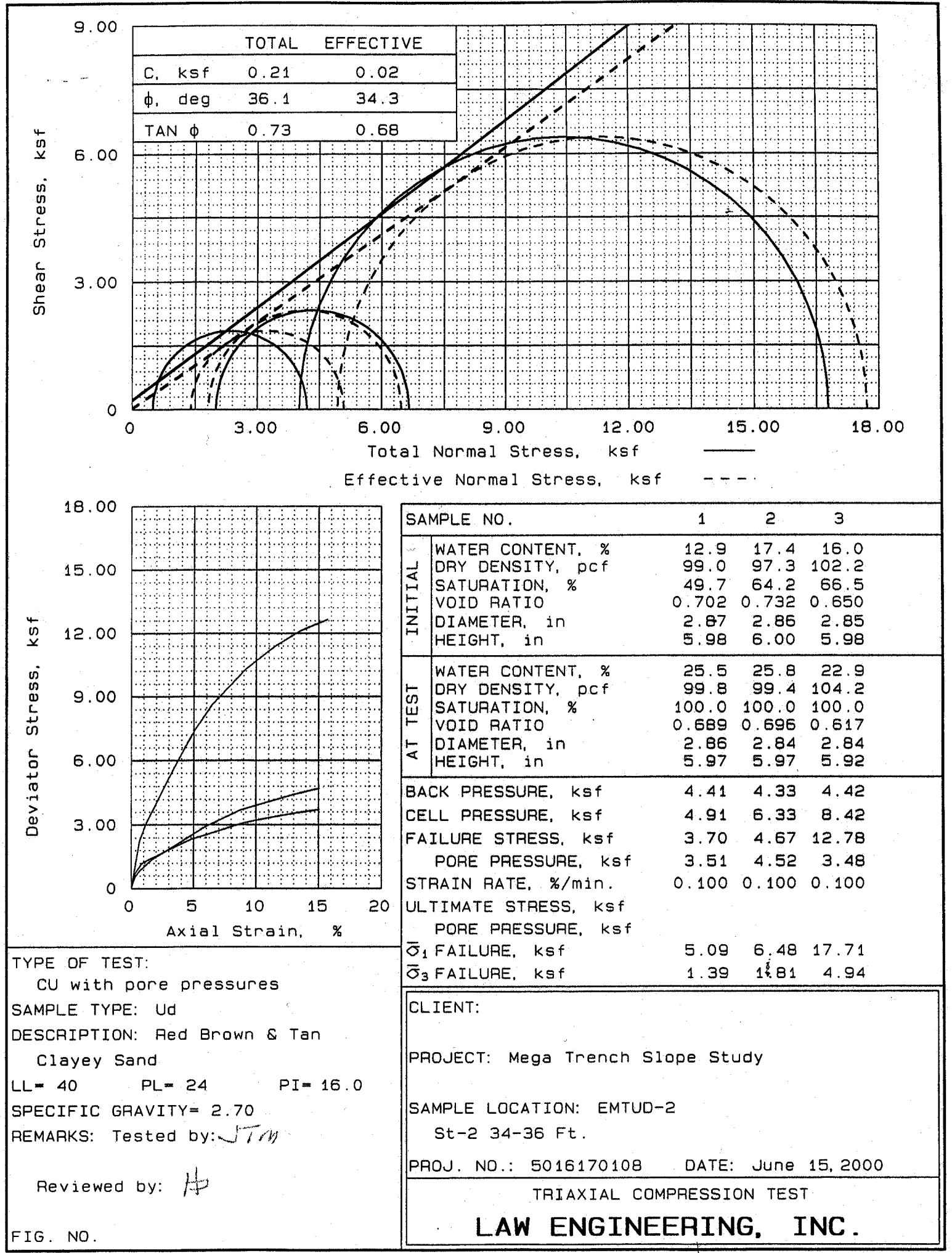



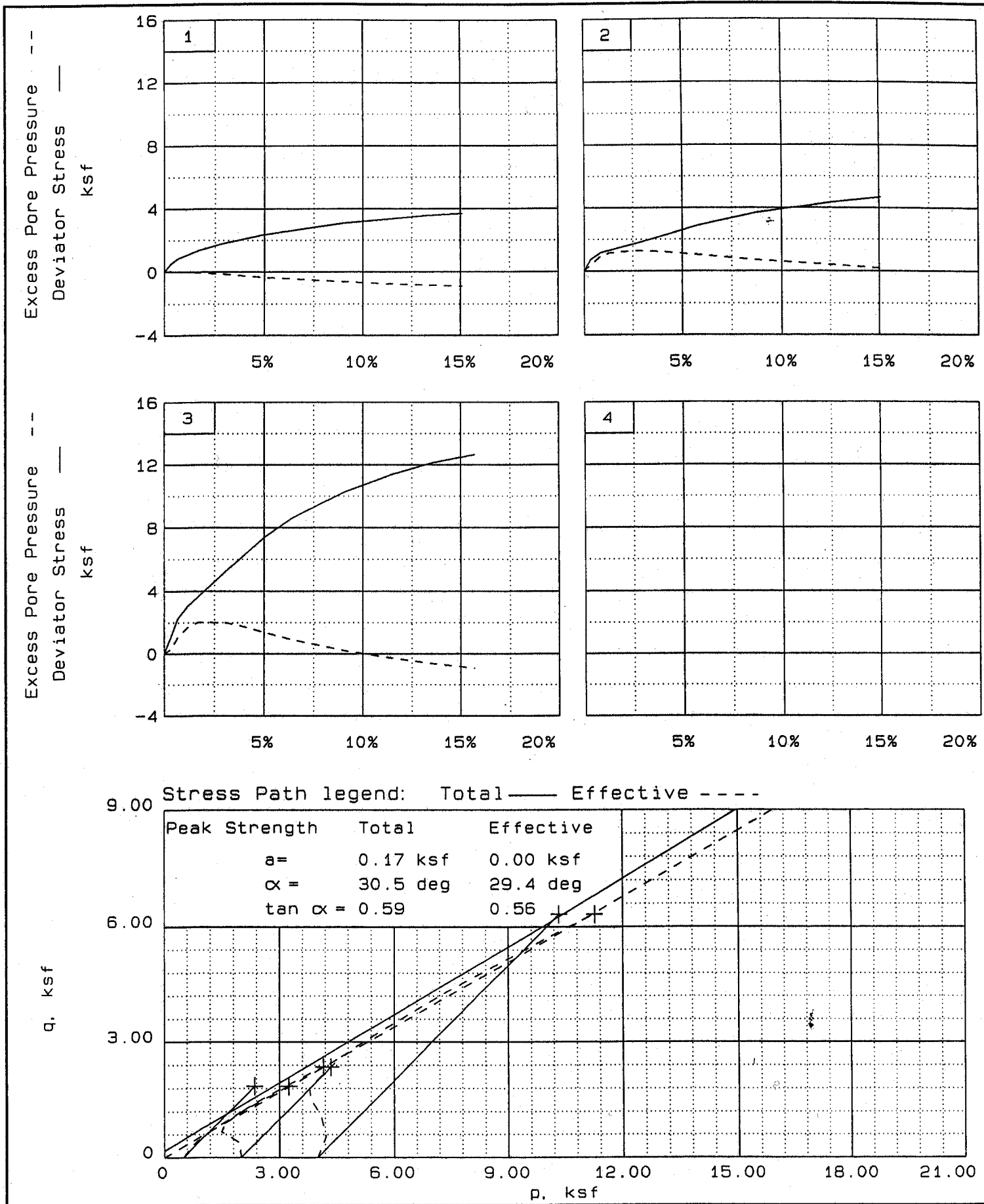

Client:

Project: Mega Trench Slope Study

Location: EMTUD-2 St-2 34-36 Ft.

File: TASK55D

Project No.: 5016170108

Page $2 / 2$ Fig. No. 


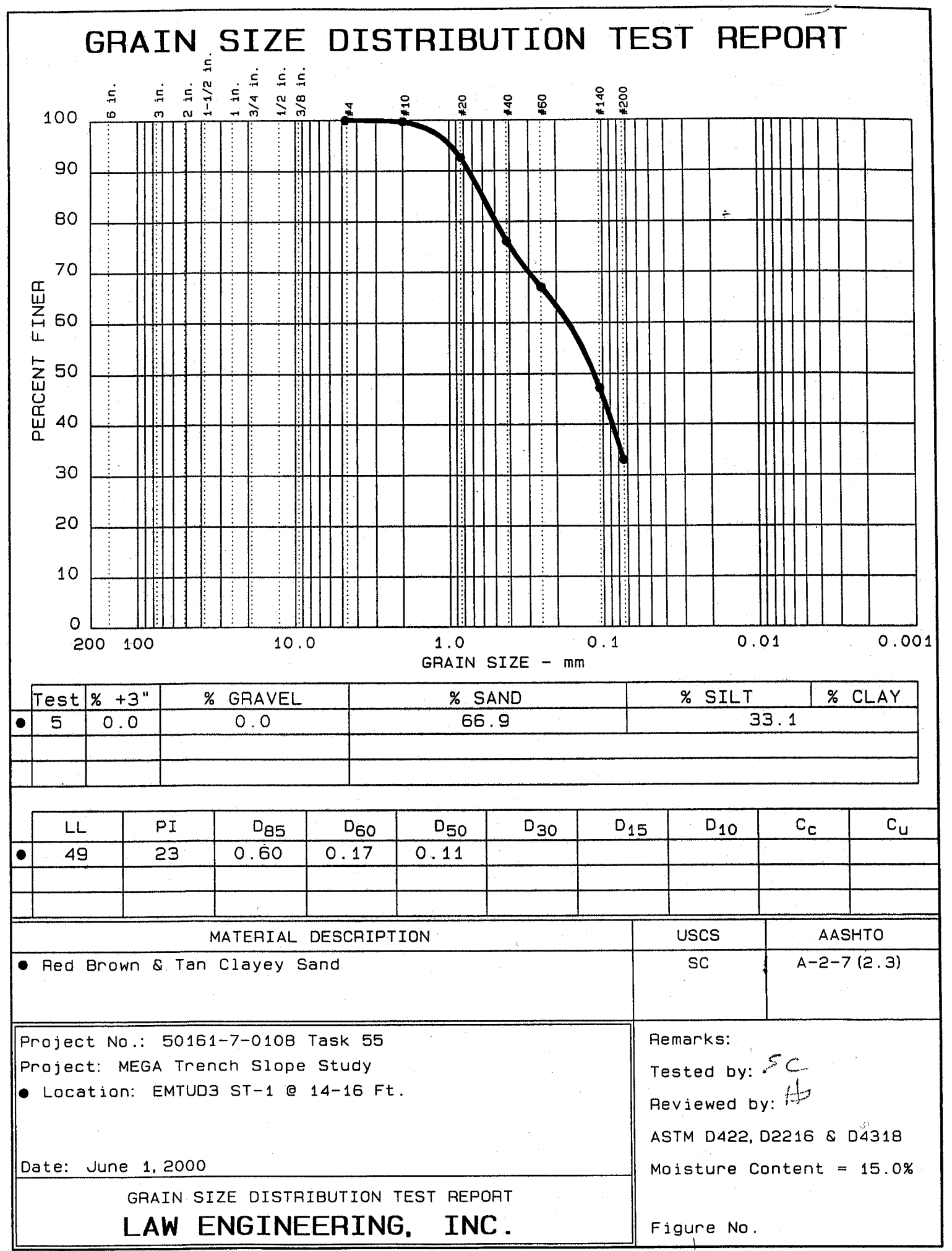




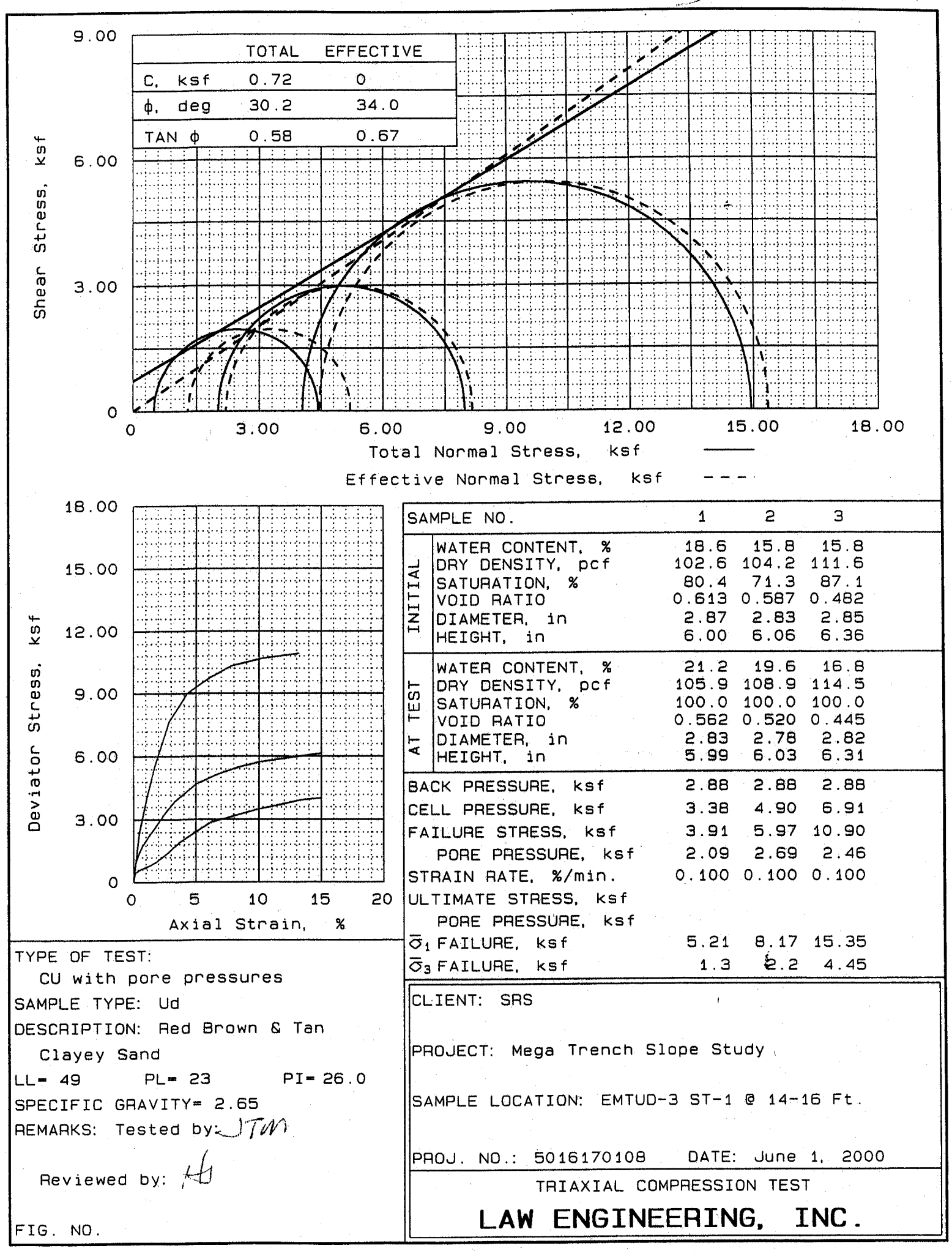



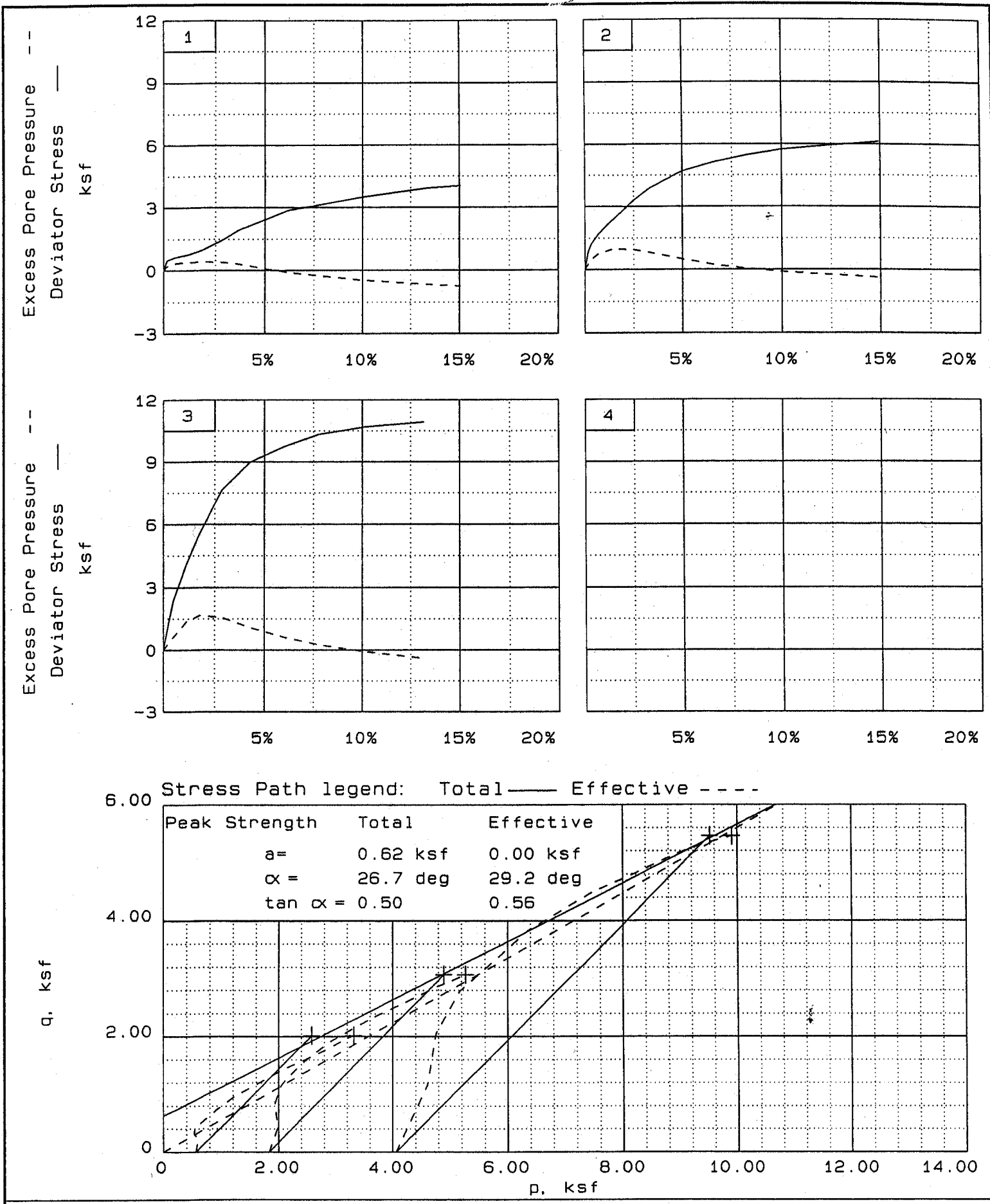

Client: SRS

Project: Mega Trench Slope Study

Location: EMTUD-3 ST-1 @ 1.4-16 Ft.

File: TASK55

Project No.: 5016170108

Page 2/2 Fig. No. 


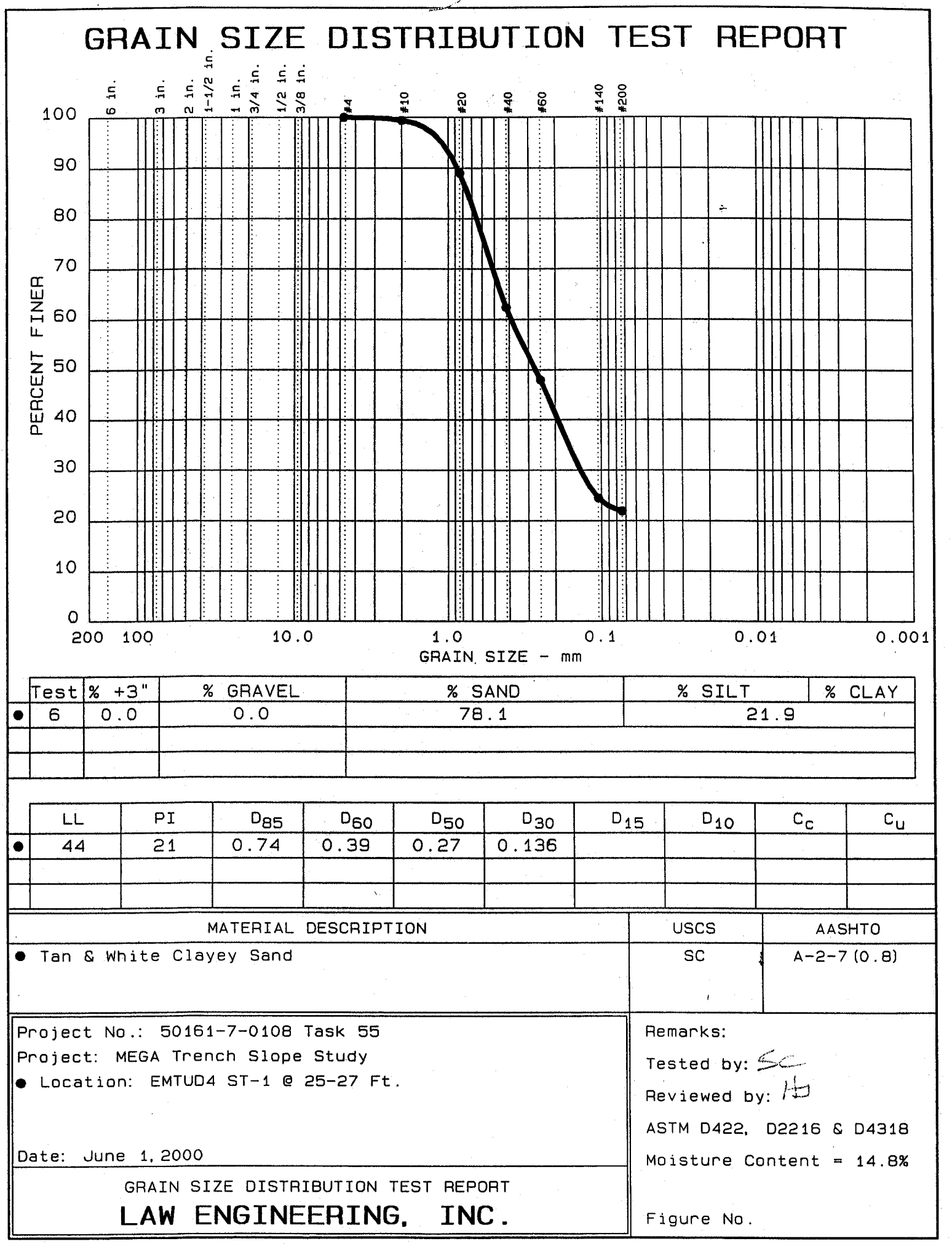




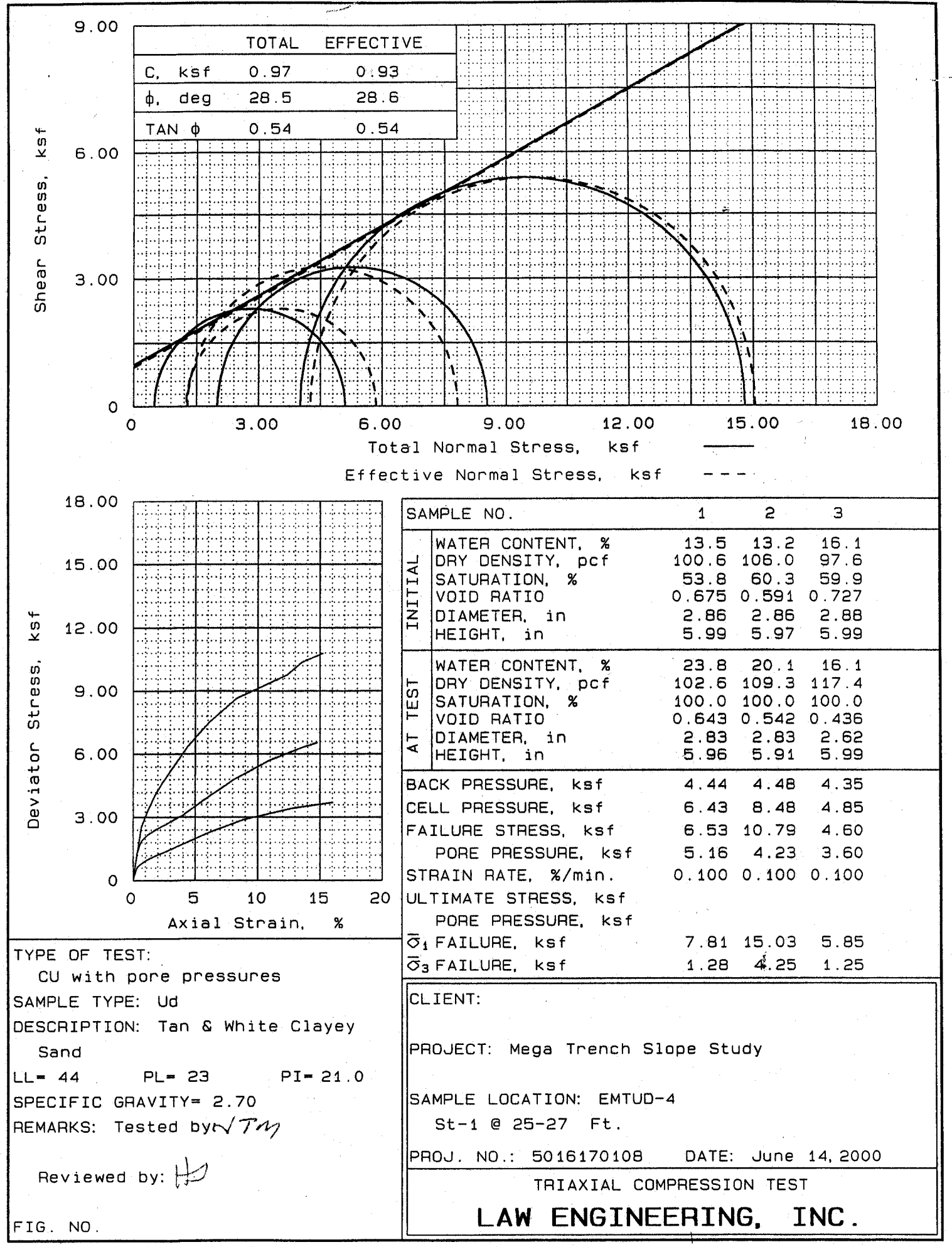




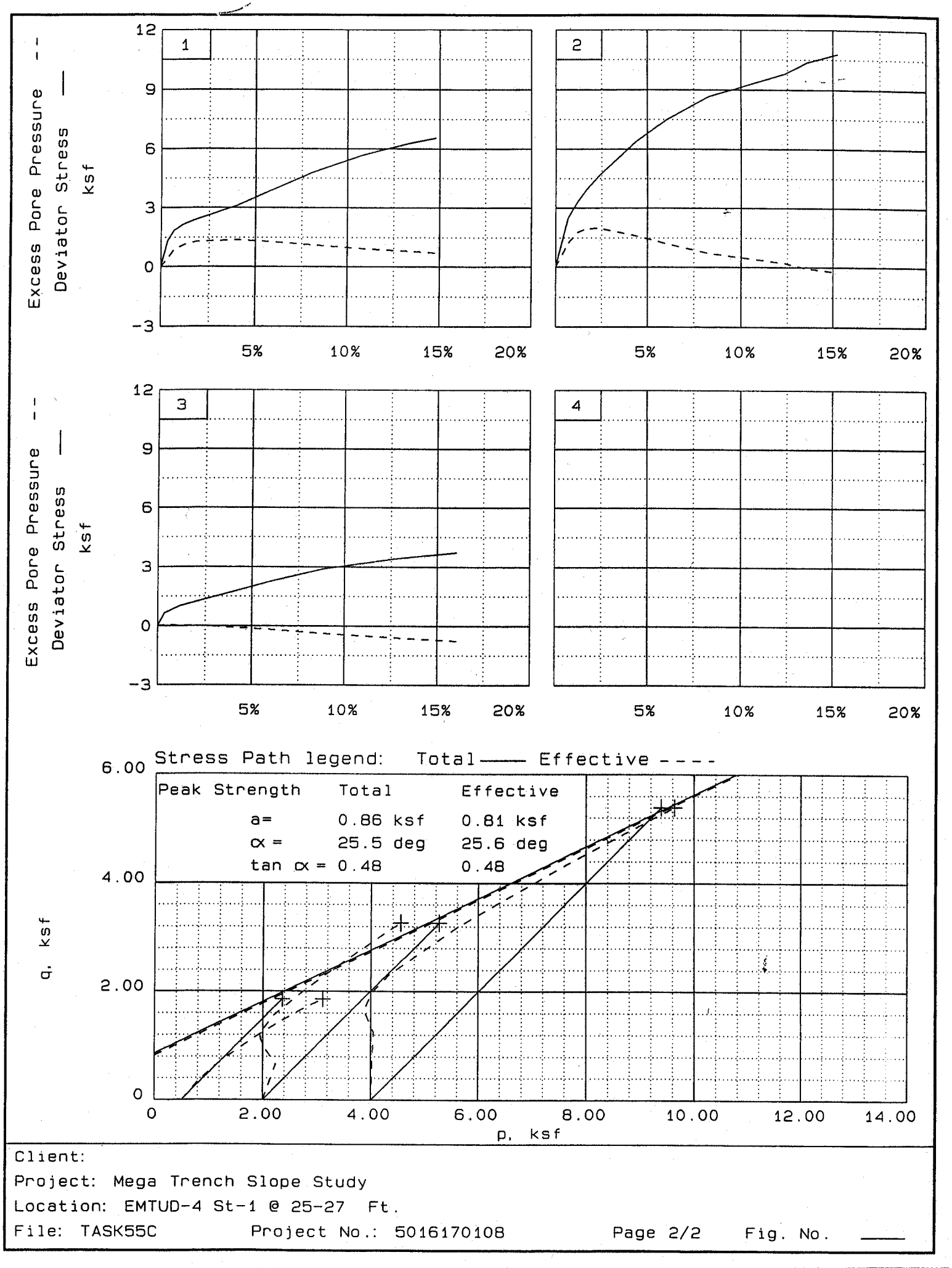

Page 201 of 298 


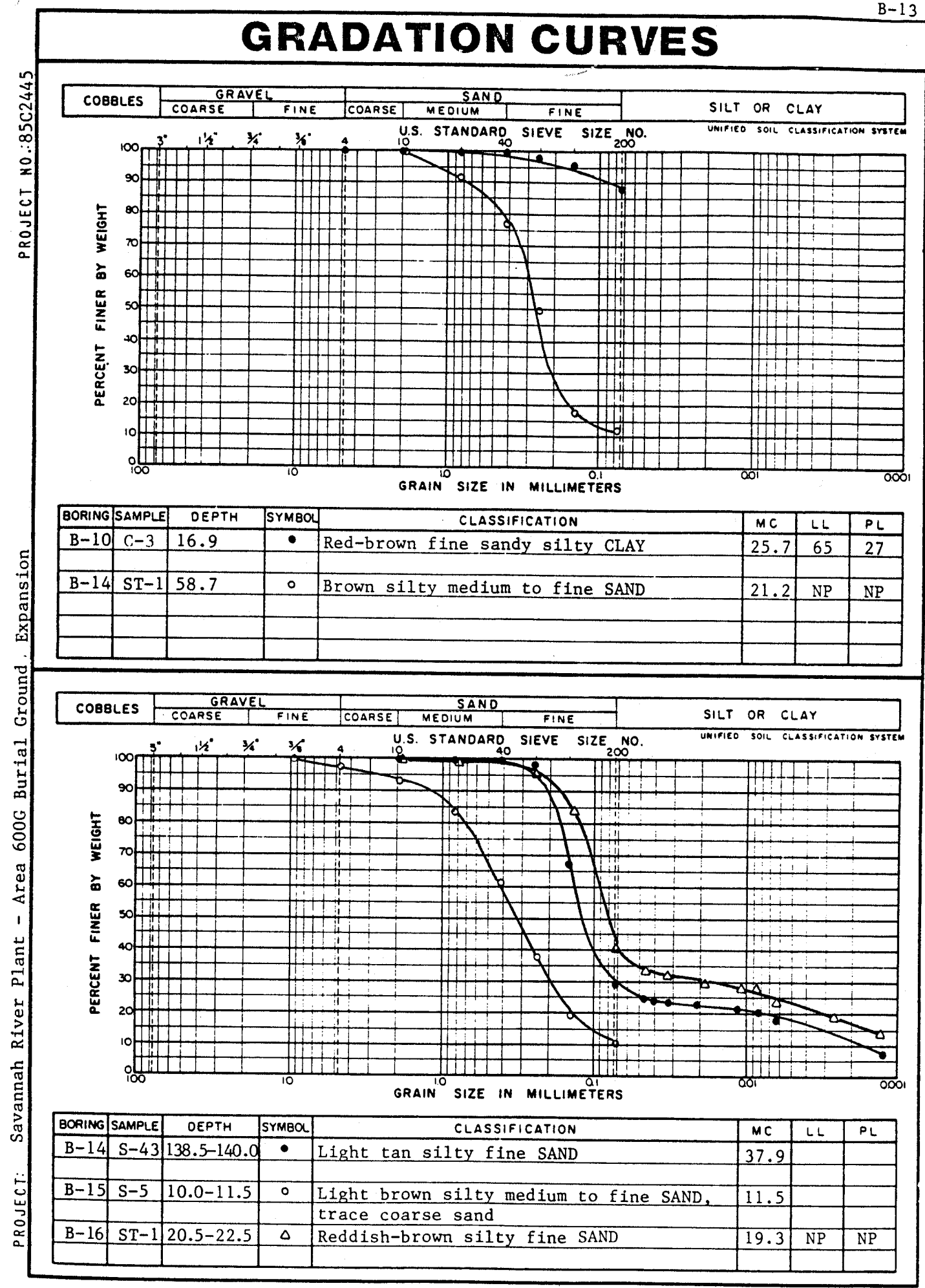

Woodward-Clyde Consultants

Page 202 of 298 


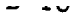

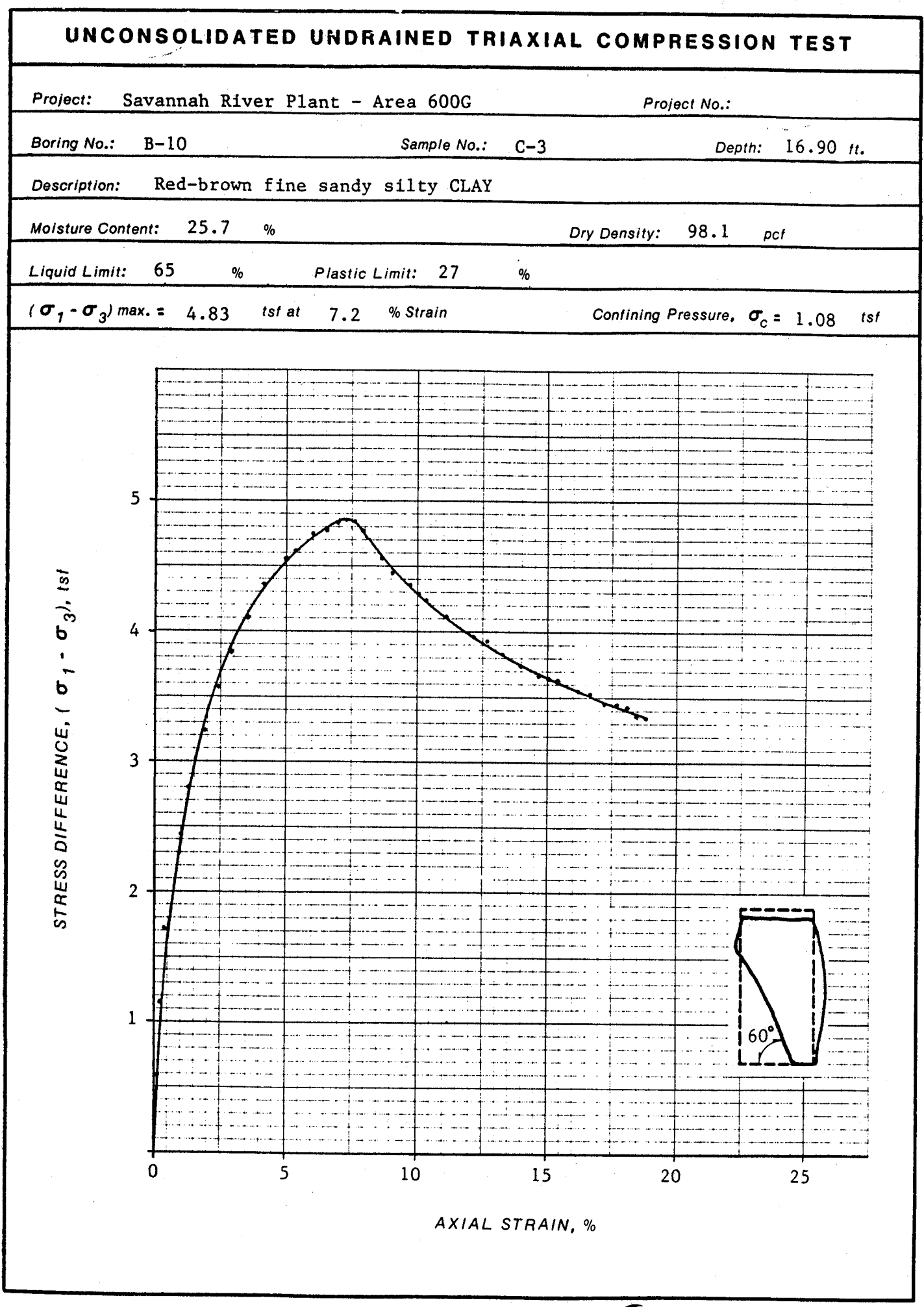

Woodward-Clyde Consultants

Page 203 of 298 
UNCONSOLIDATED UNDRAINED TRIAXIAL COMPRESSION TEST

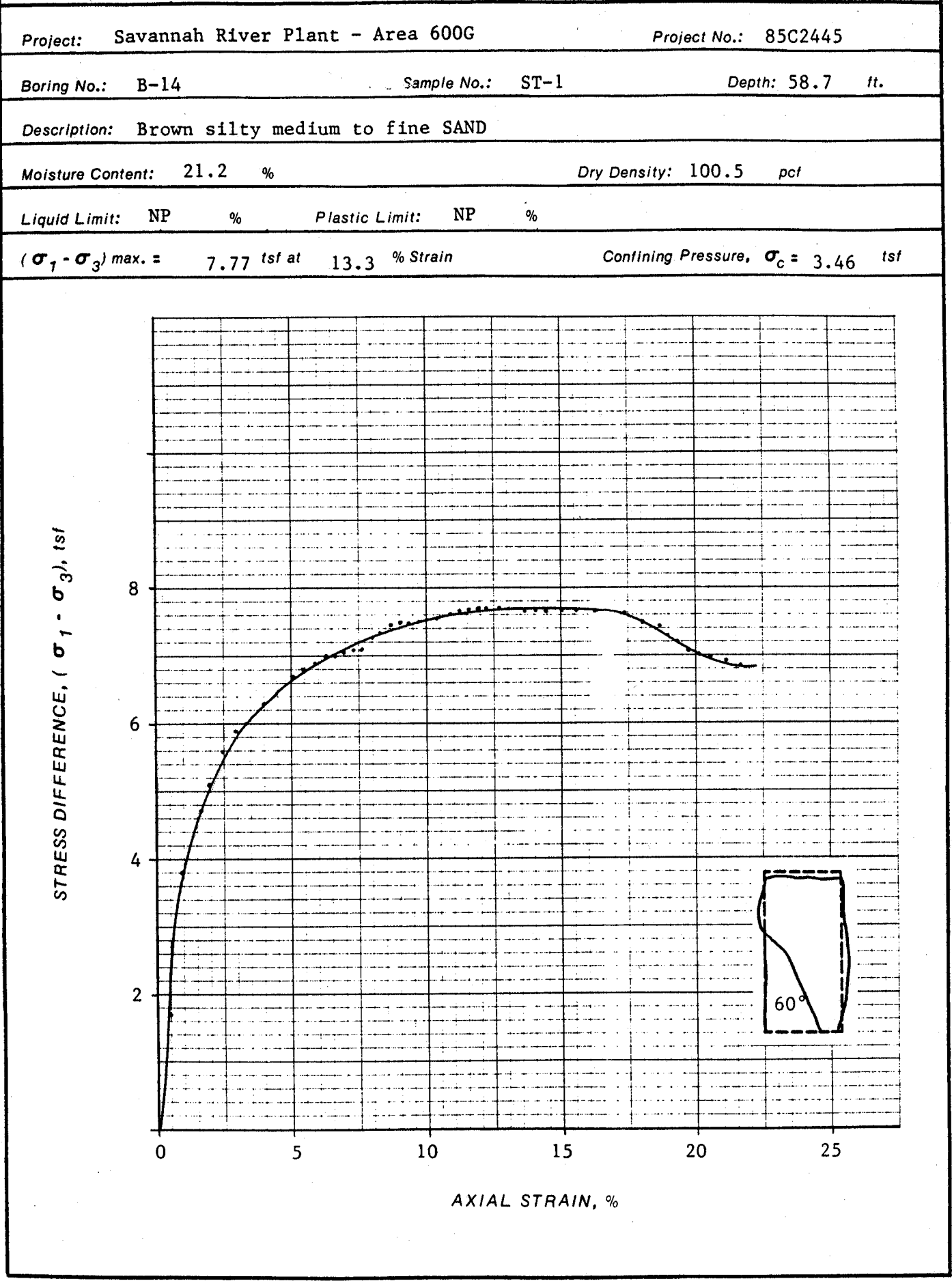

Woodward-Clyde Consultants 


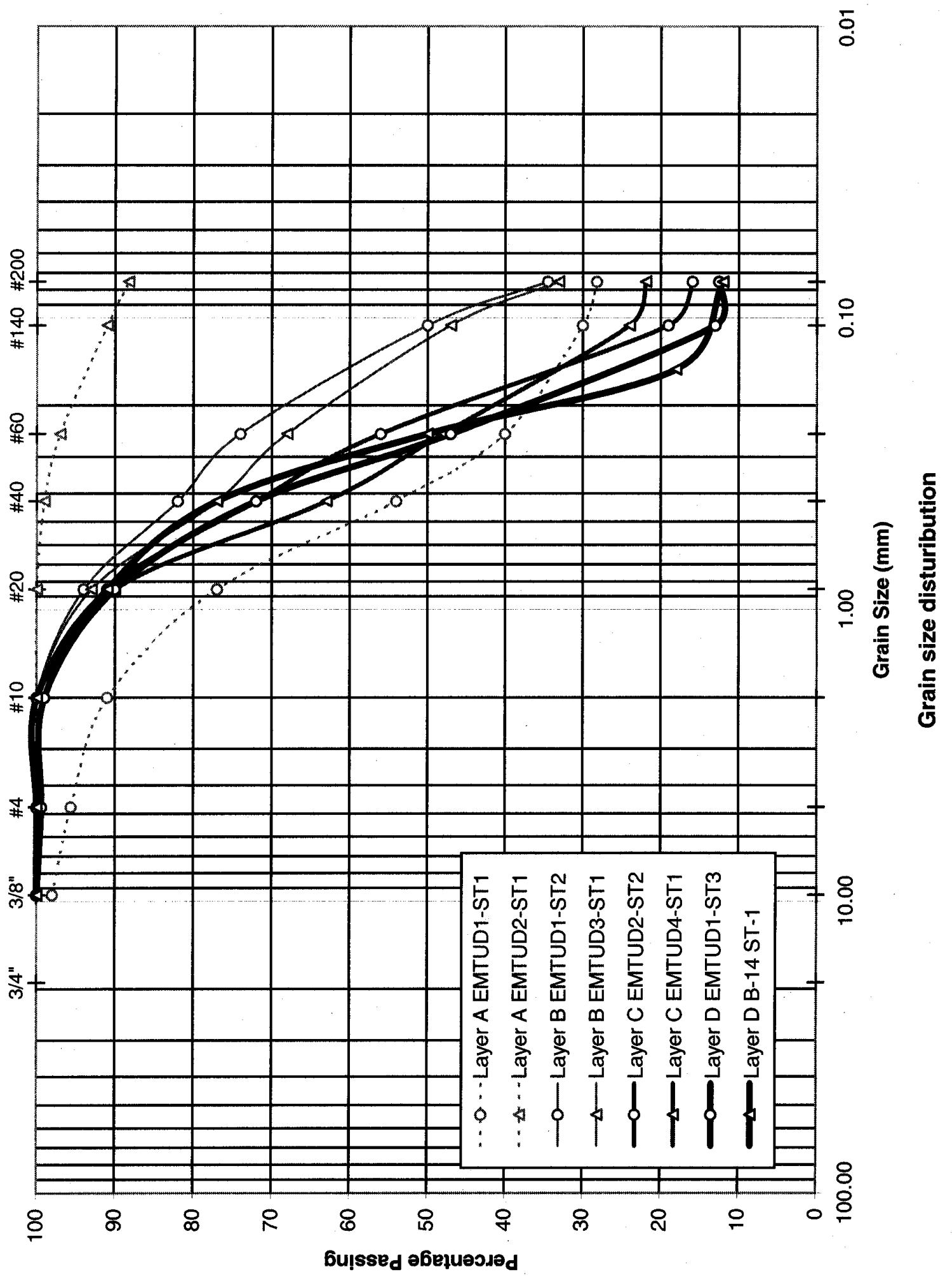

Page 205 of 298 


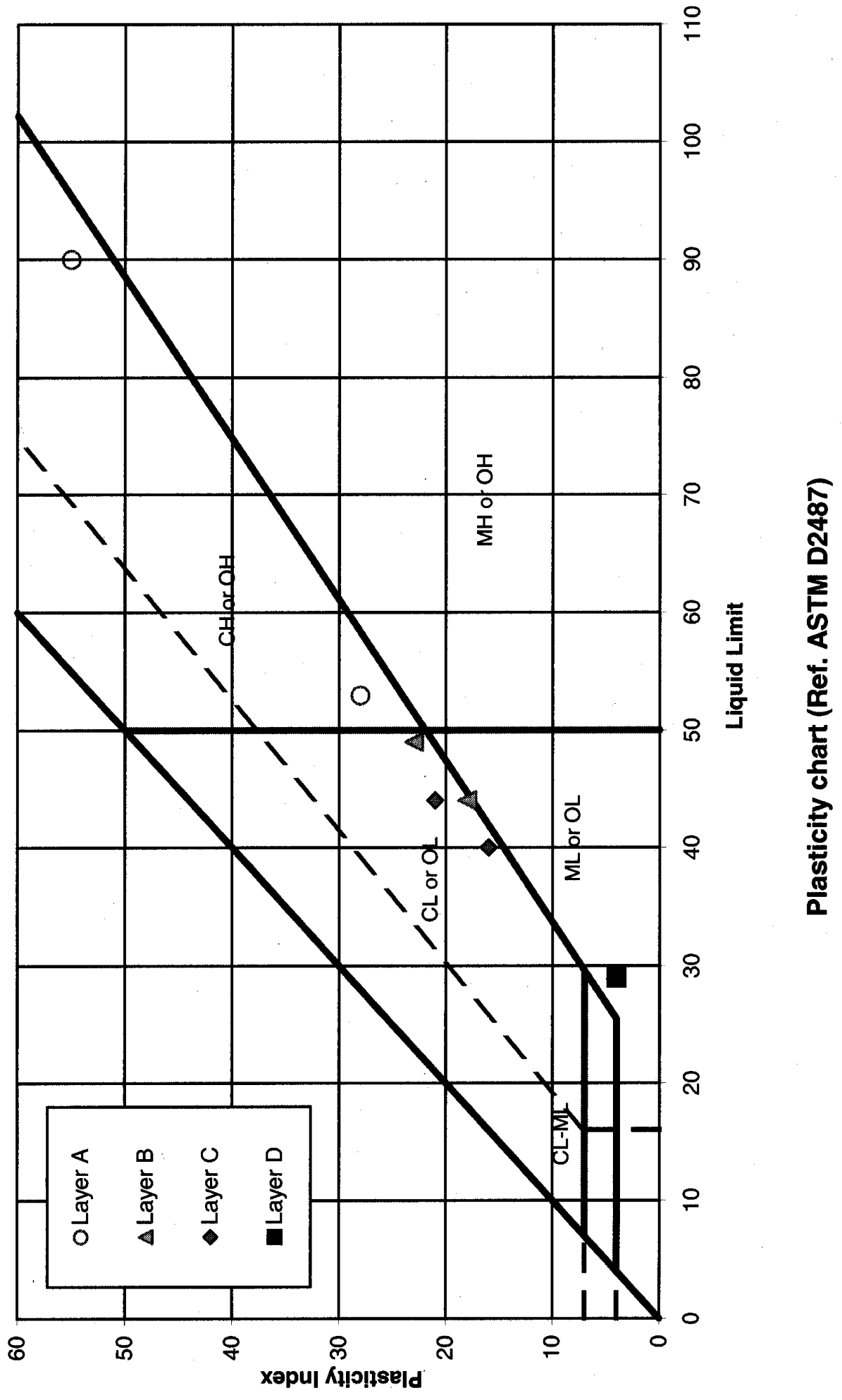

Page 206 of 298 
A-29

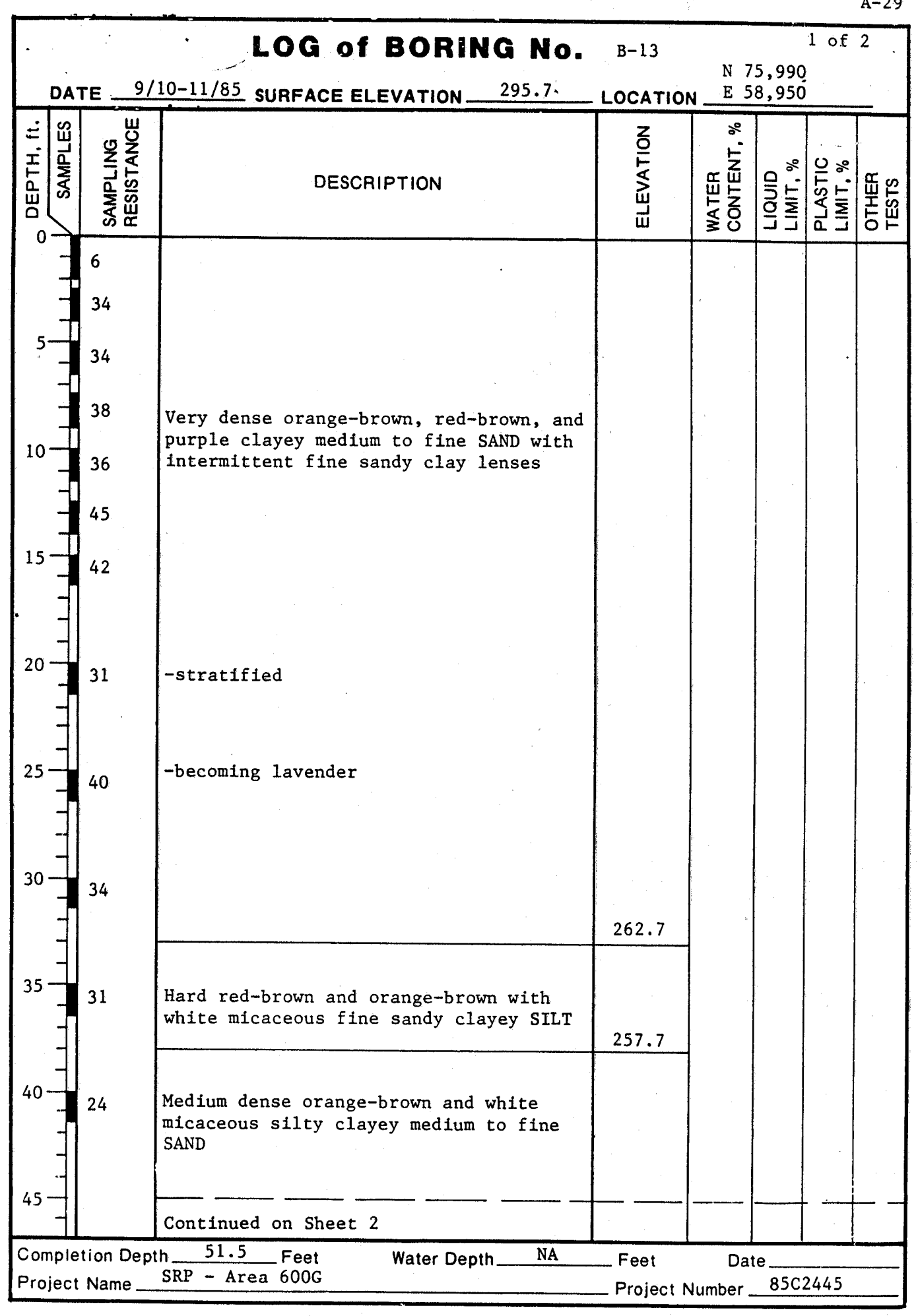

Woodward-Clyde Consultants 


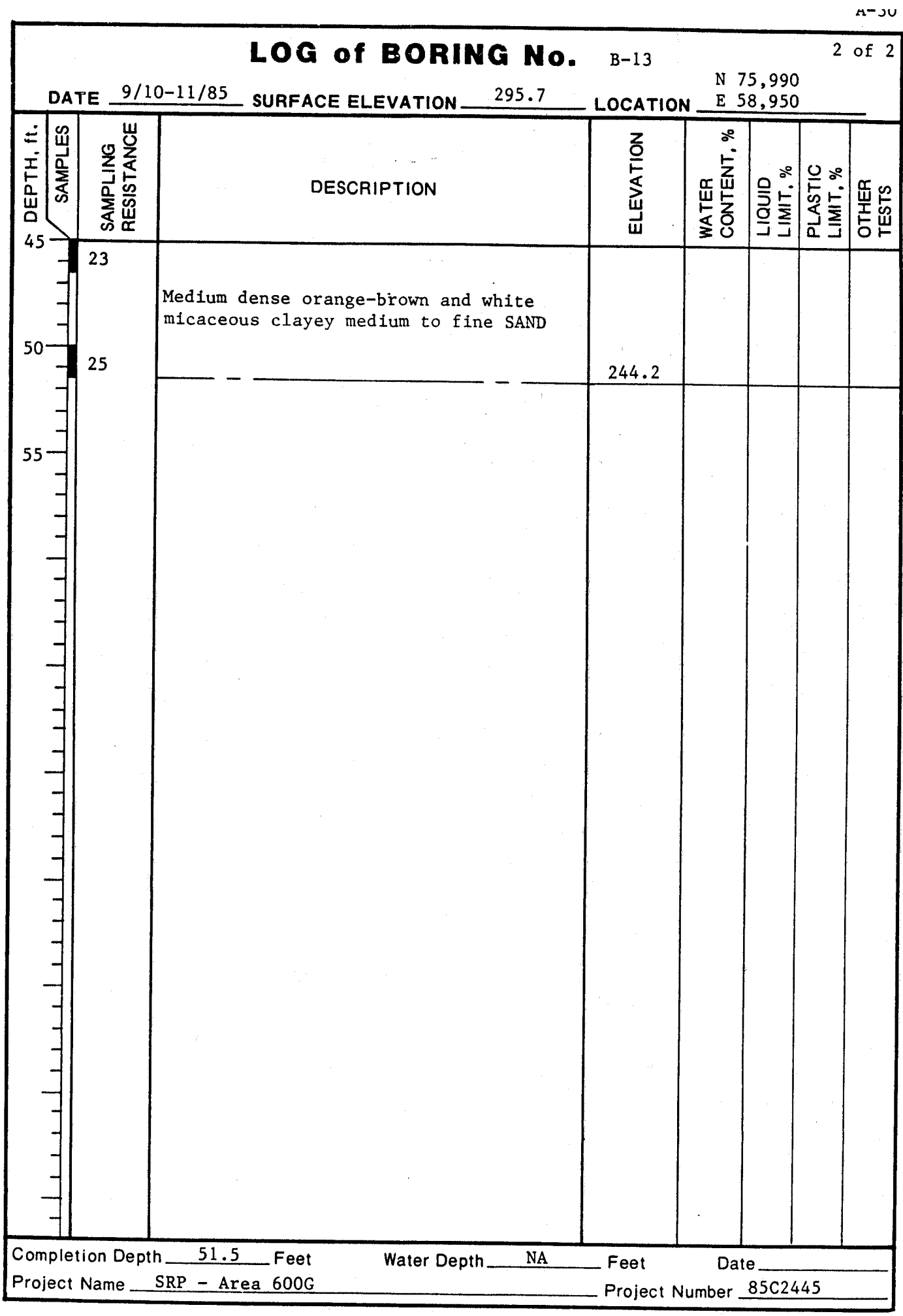

Woodward.Clyde Consultants

Page 208 of 298 


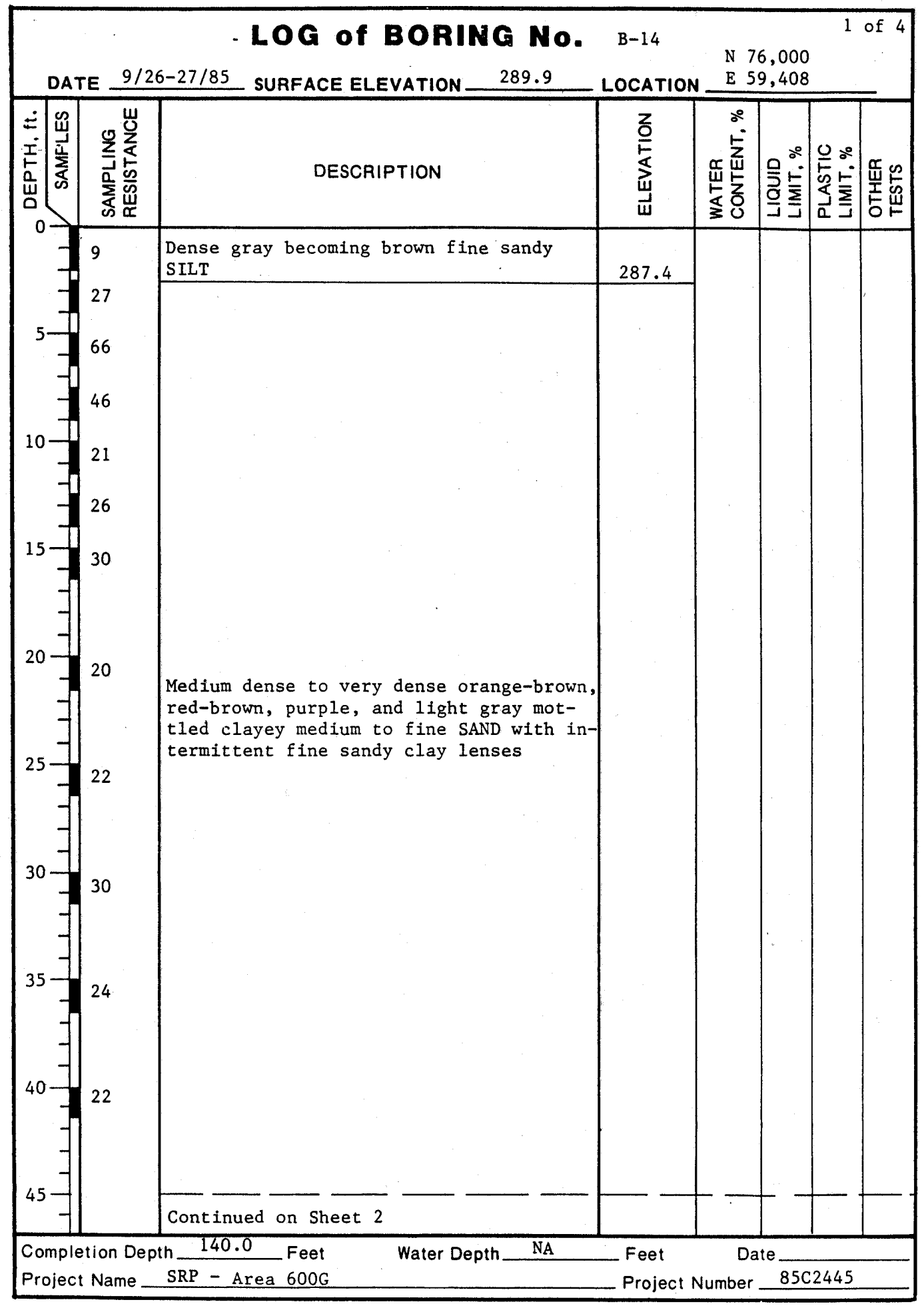

Woodward-Clyde Consultants 


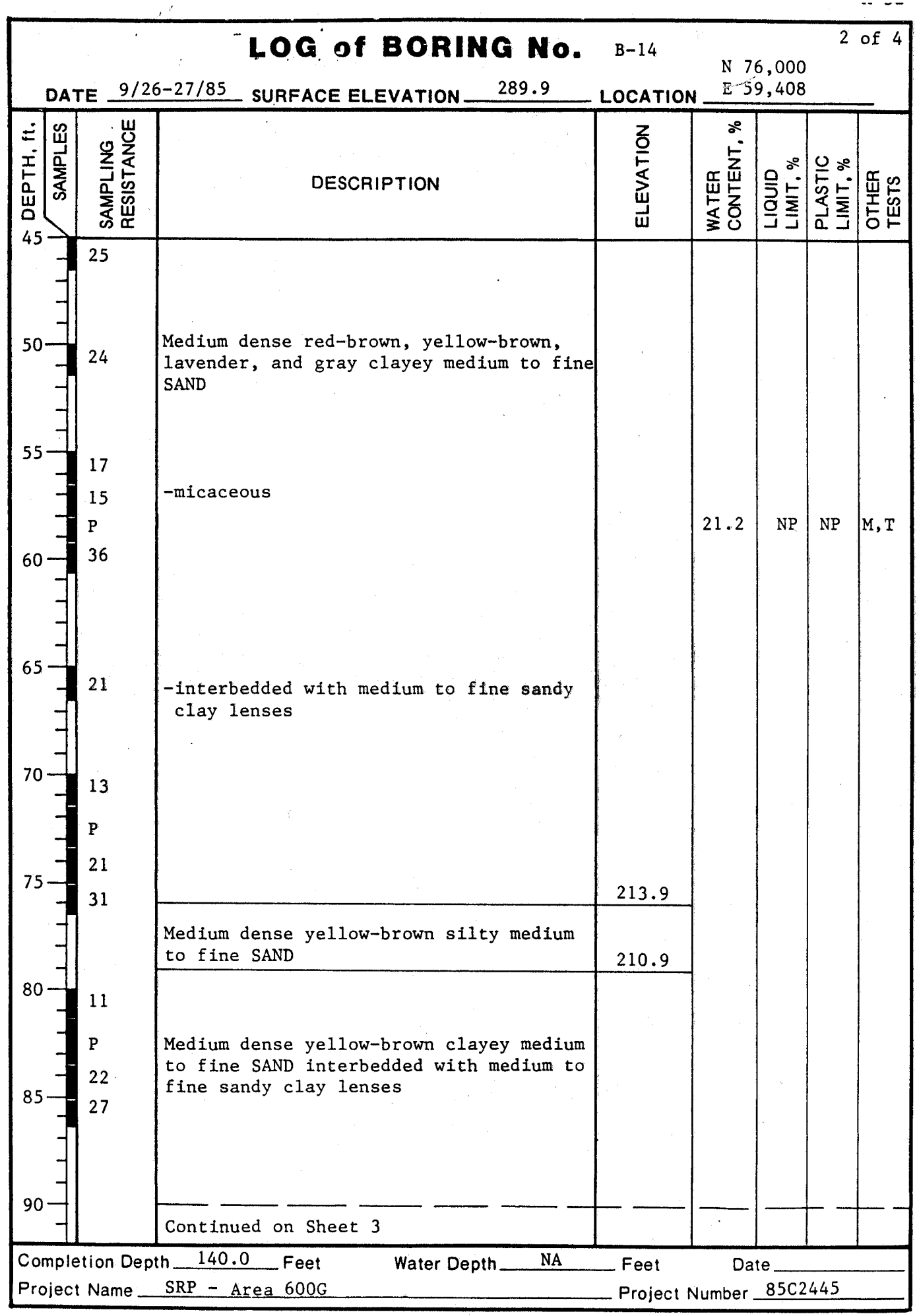

Woodward-Clyde Consultants 


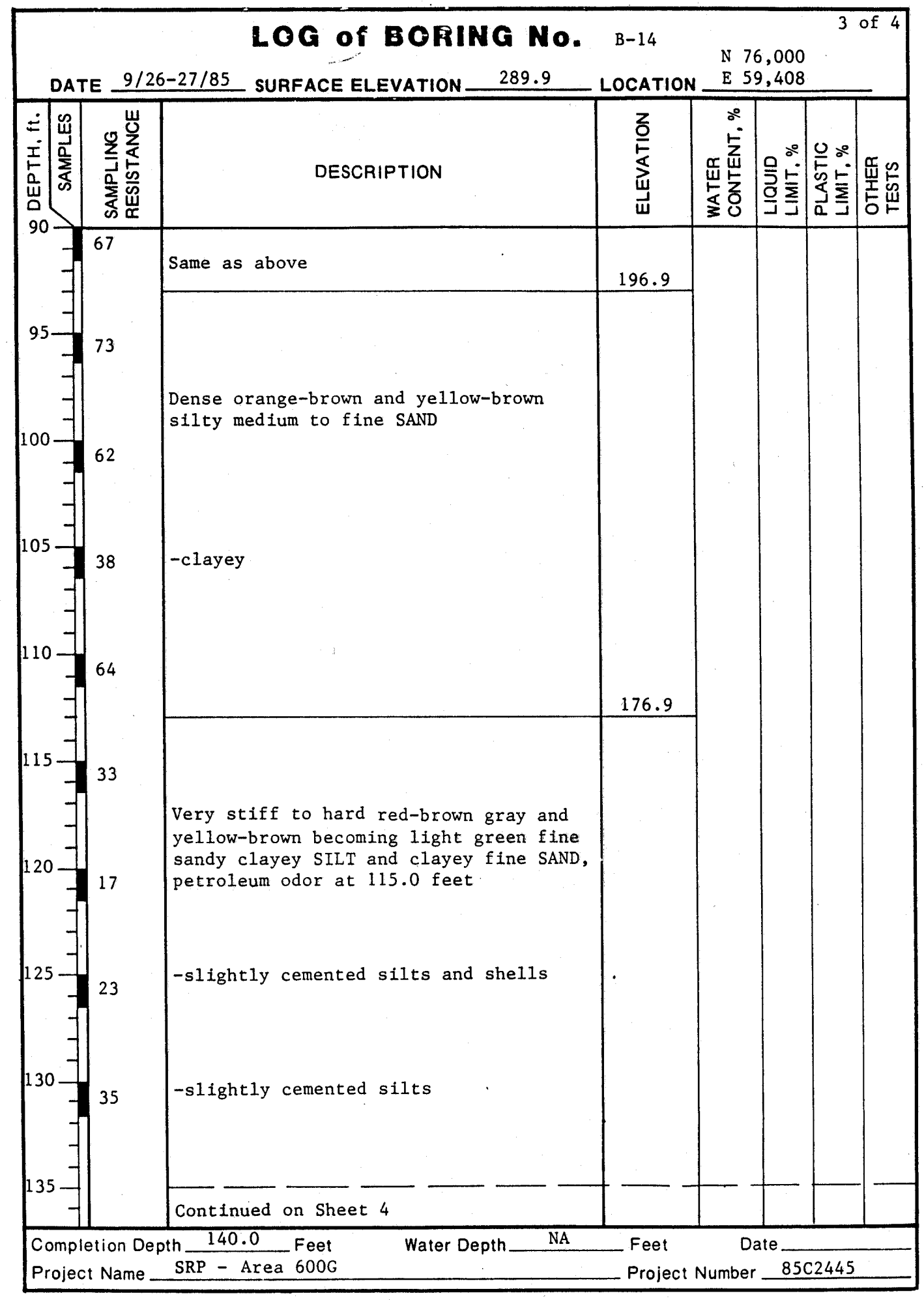

Woodward-Clyde Consultants 


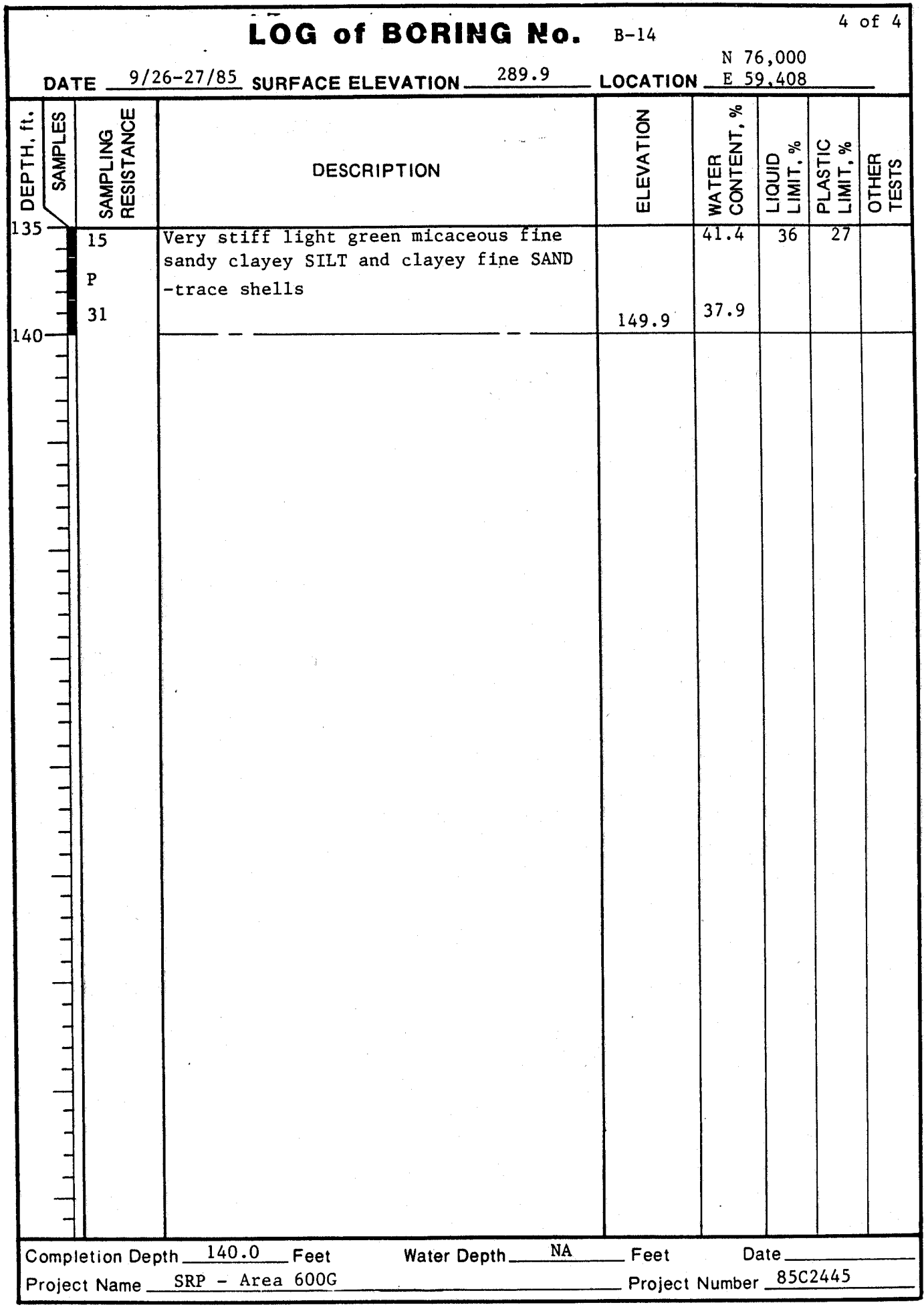

Woodward-Clyde Consultants 


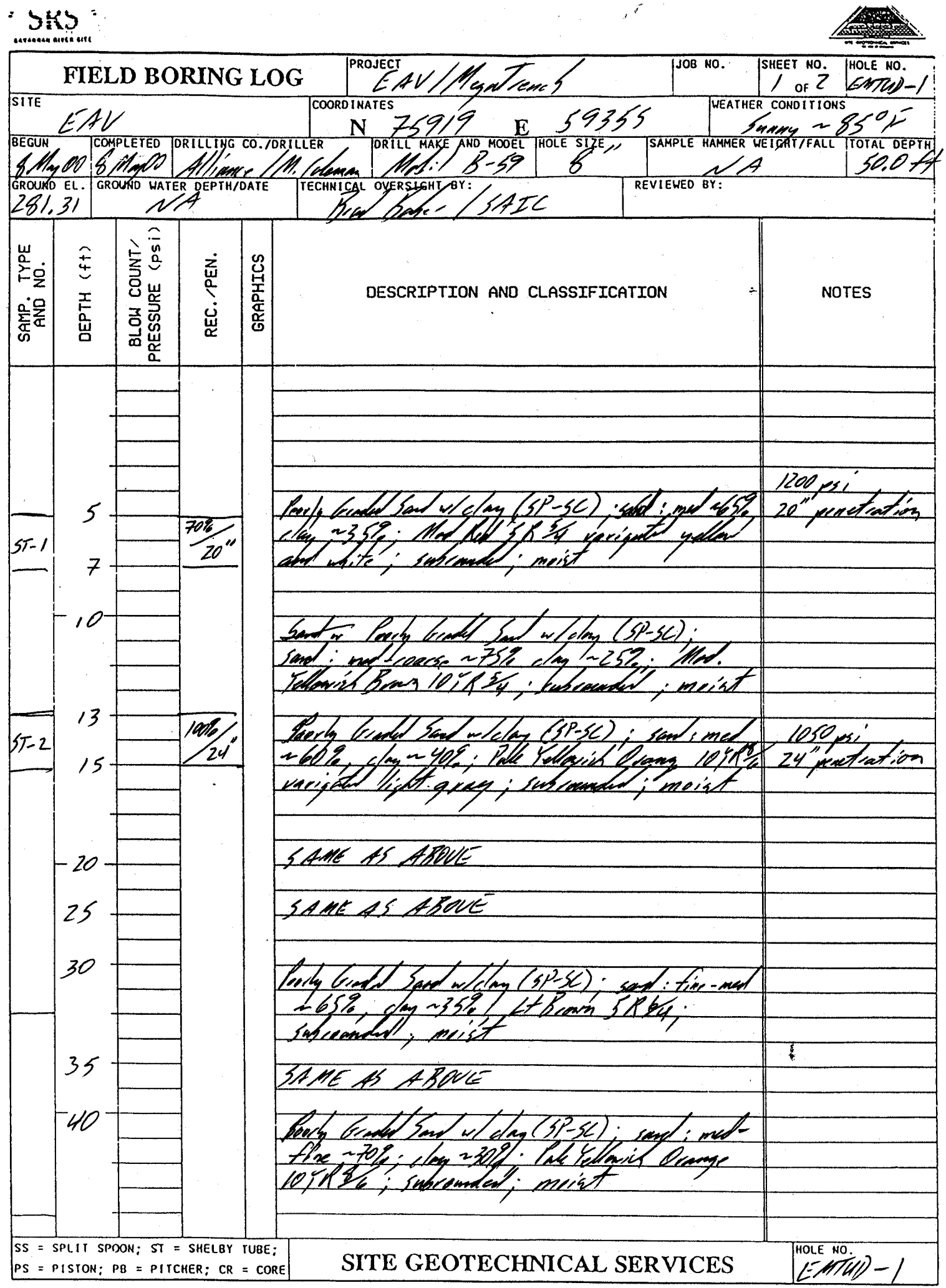

Page 213 of 298 


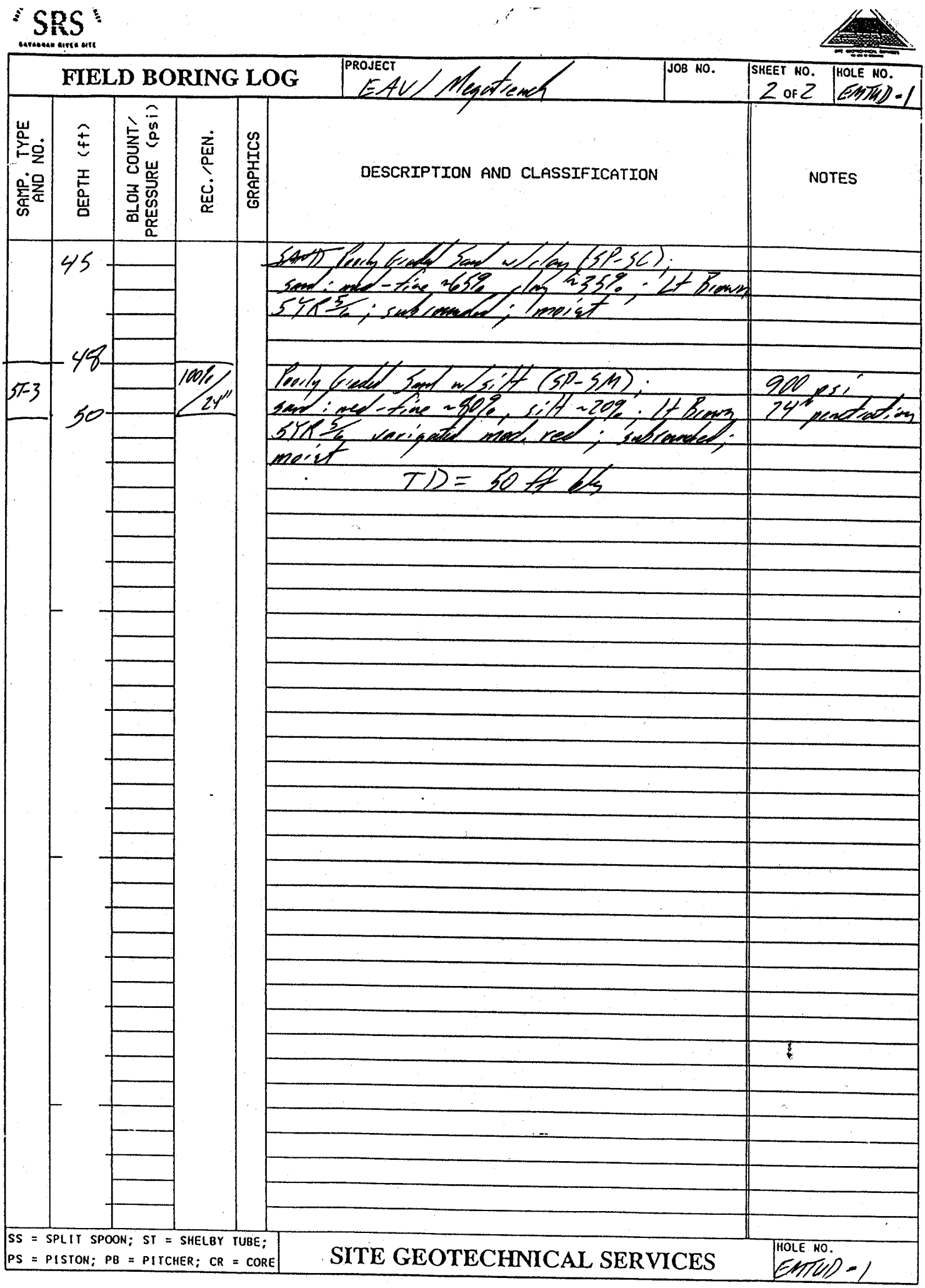

Page 214 of 298 


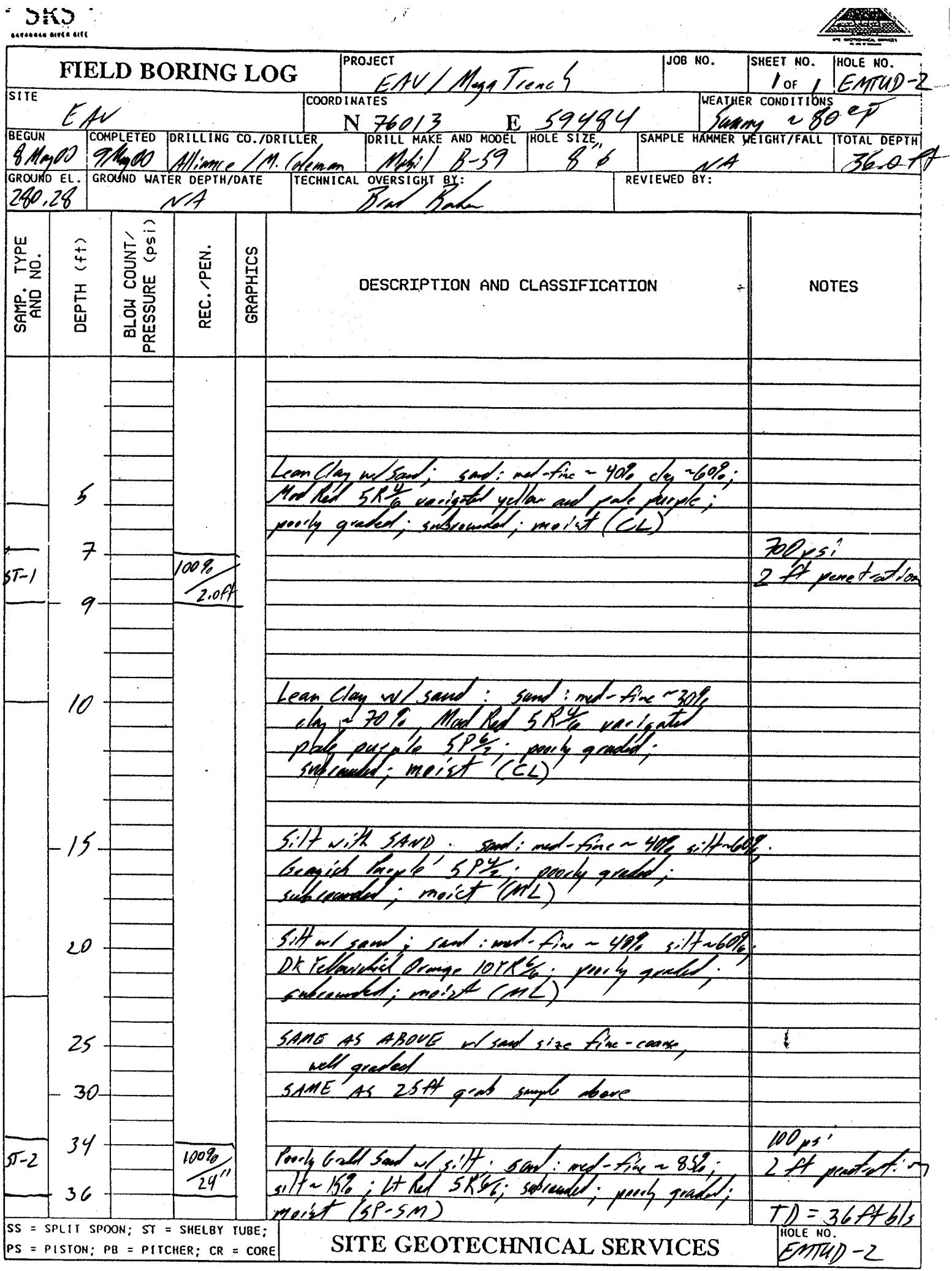

Page 215 of 298 


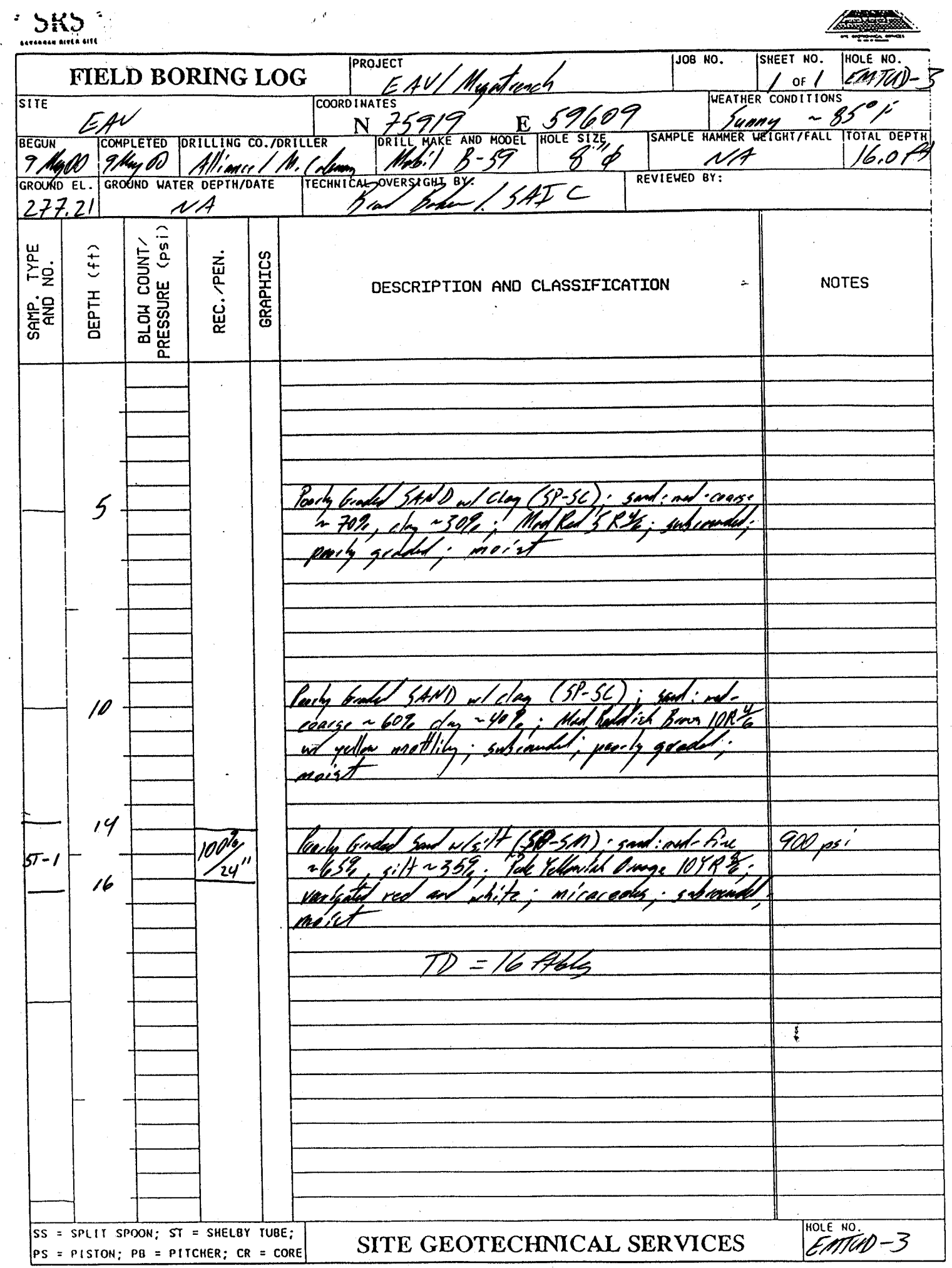

Page 216 of 298 


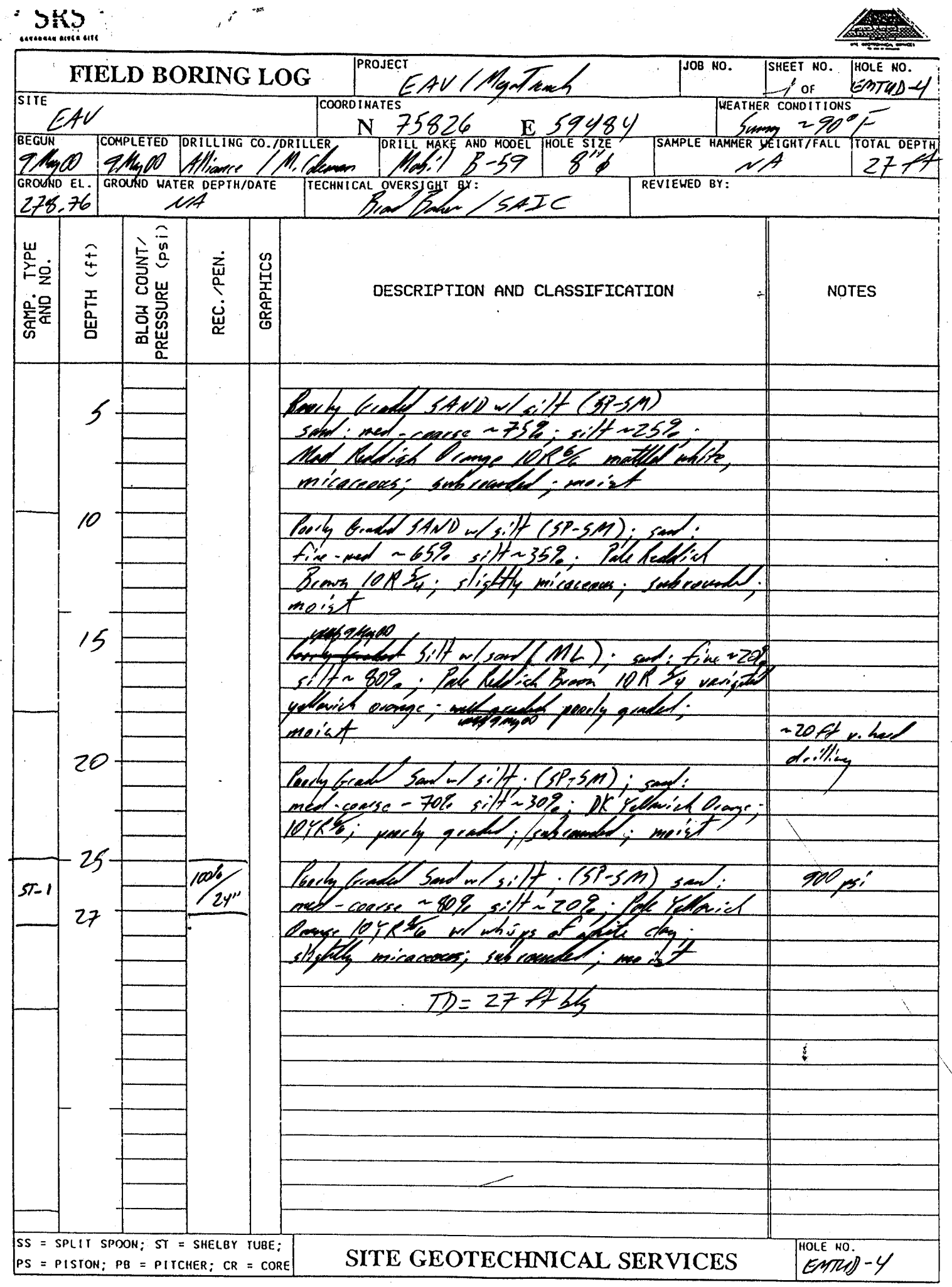


This page intentionally left blank.

Page 218 of 298 


\section{Appendix C}

\section{Ground Water Elevations}


This page intentionally left blank. 


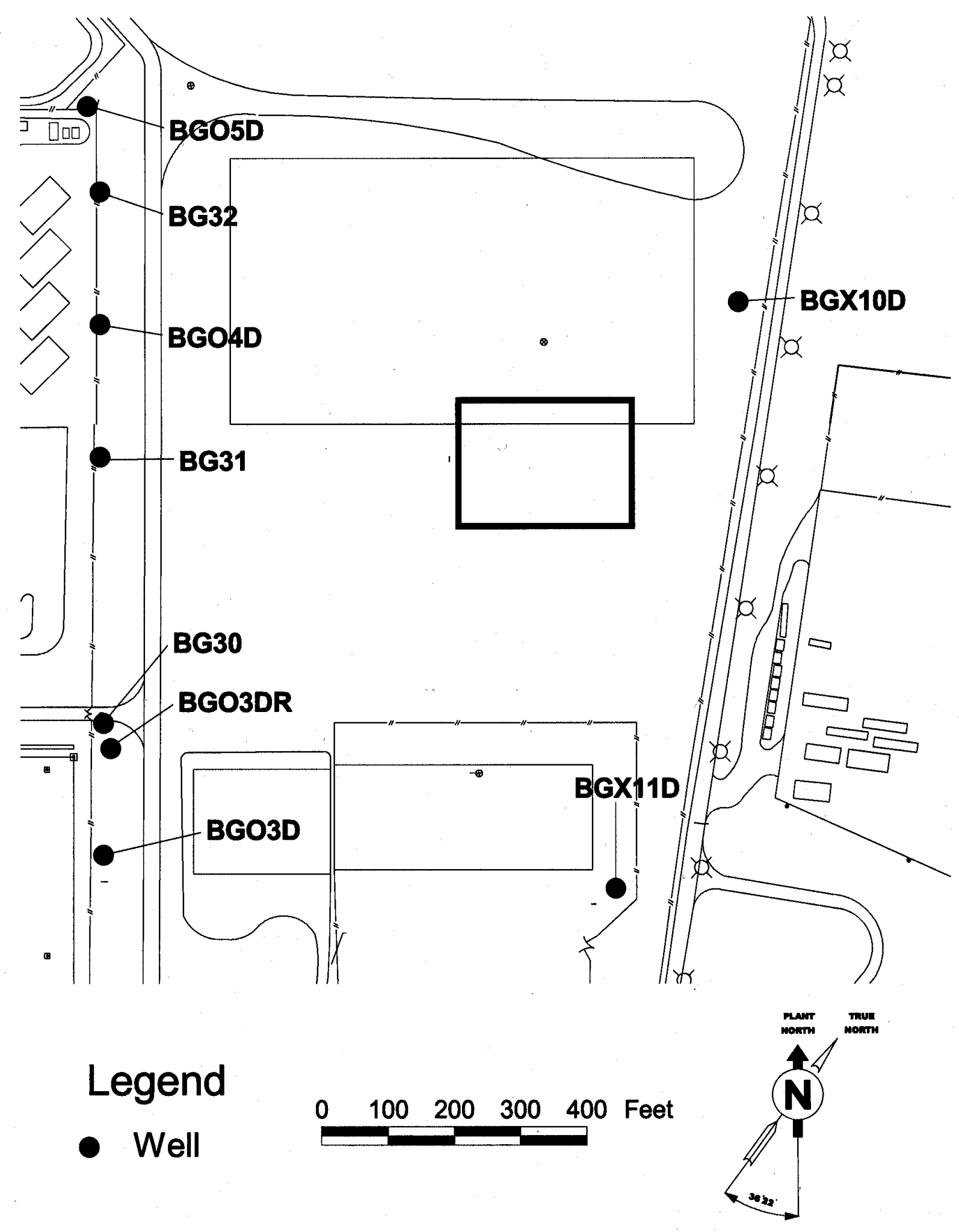

Groundwater monitoring well locations

Page 221 of 298 


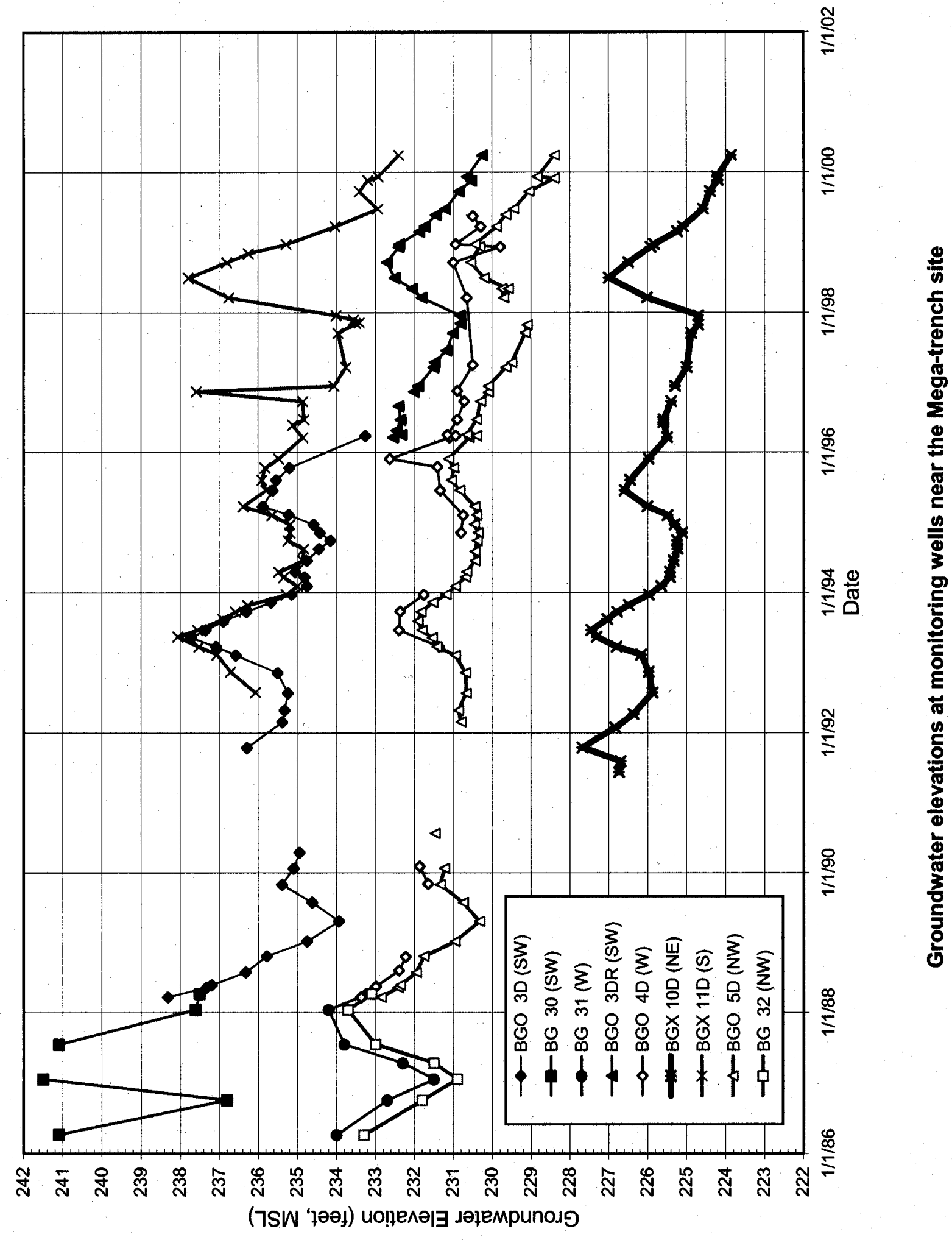




\section{Appendix D}

\section{Laboratory Test Results}


This page intentionally left blank. 


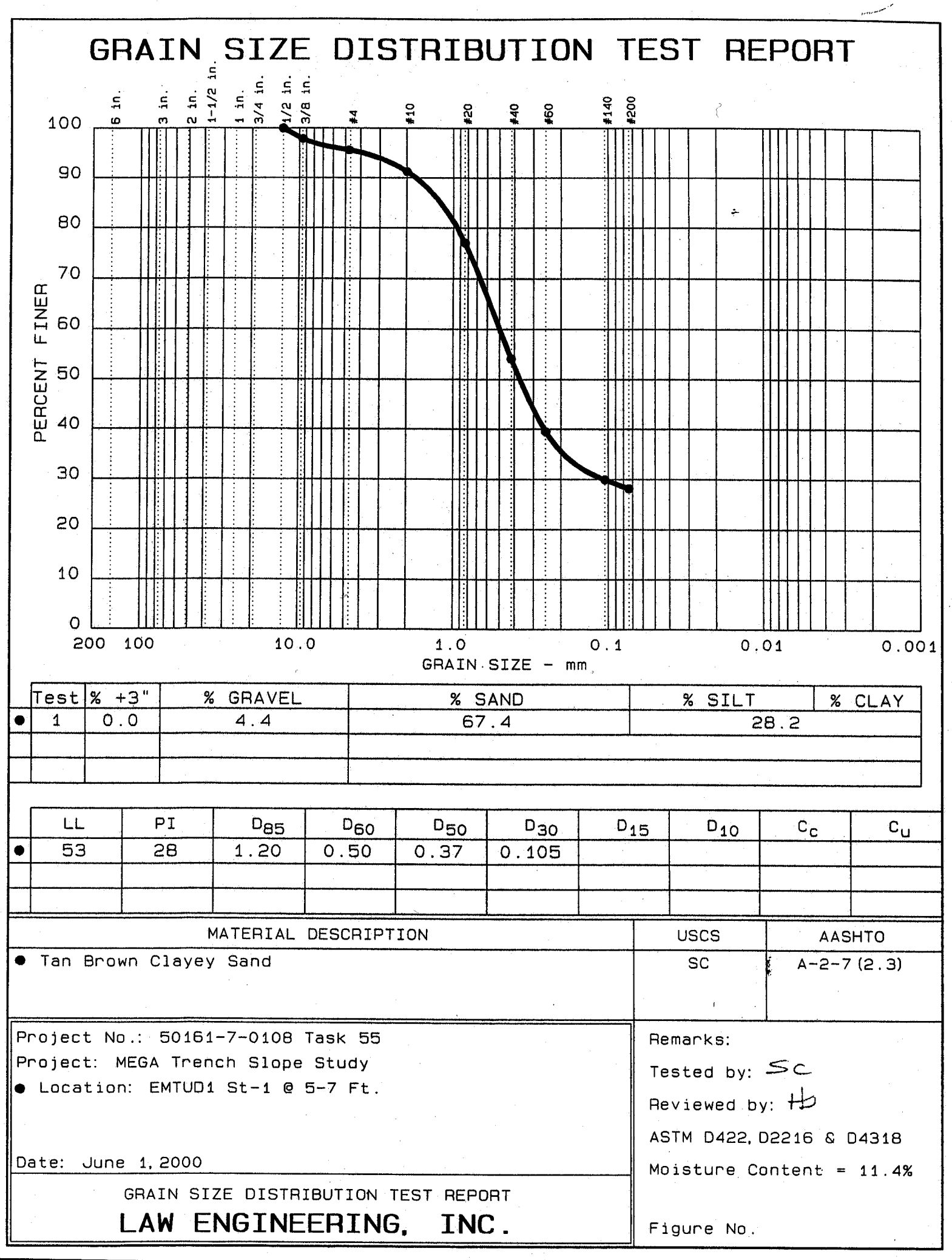

Page 225 of 298 


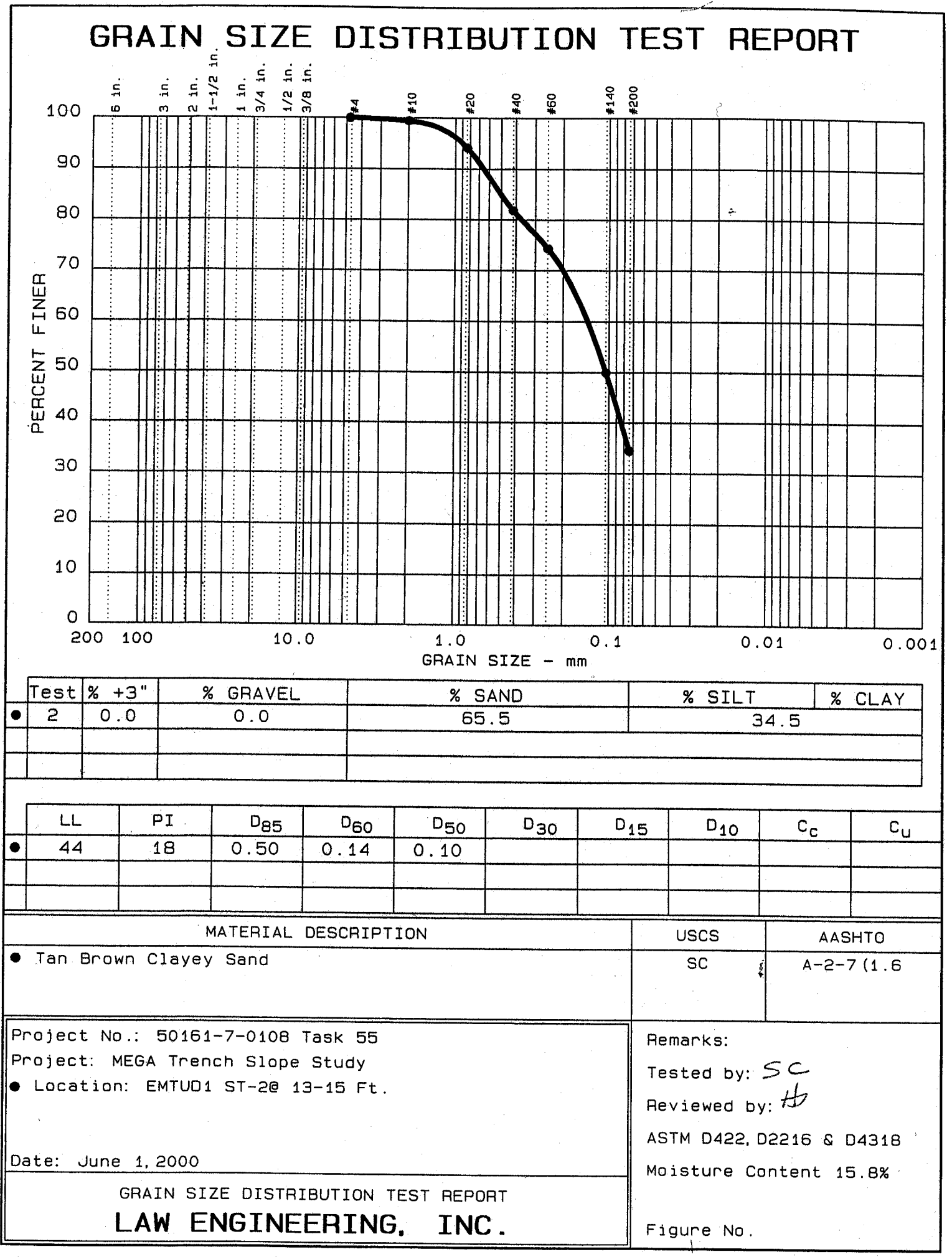




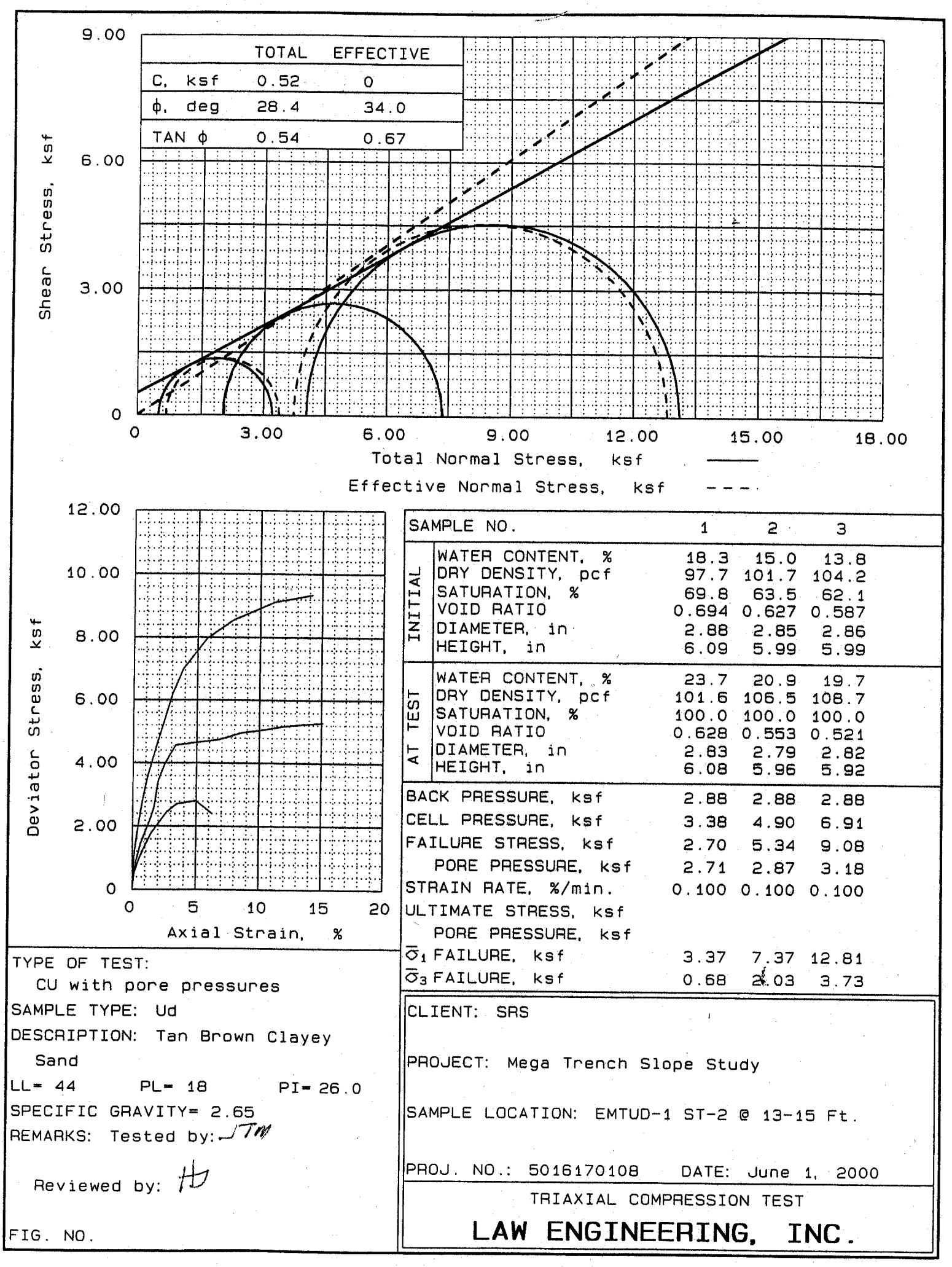

Page 227 of 298 


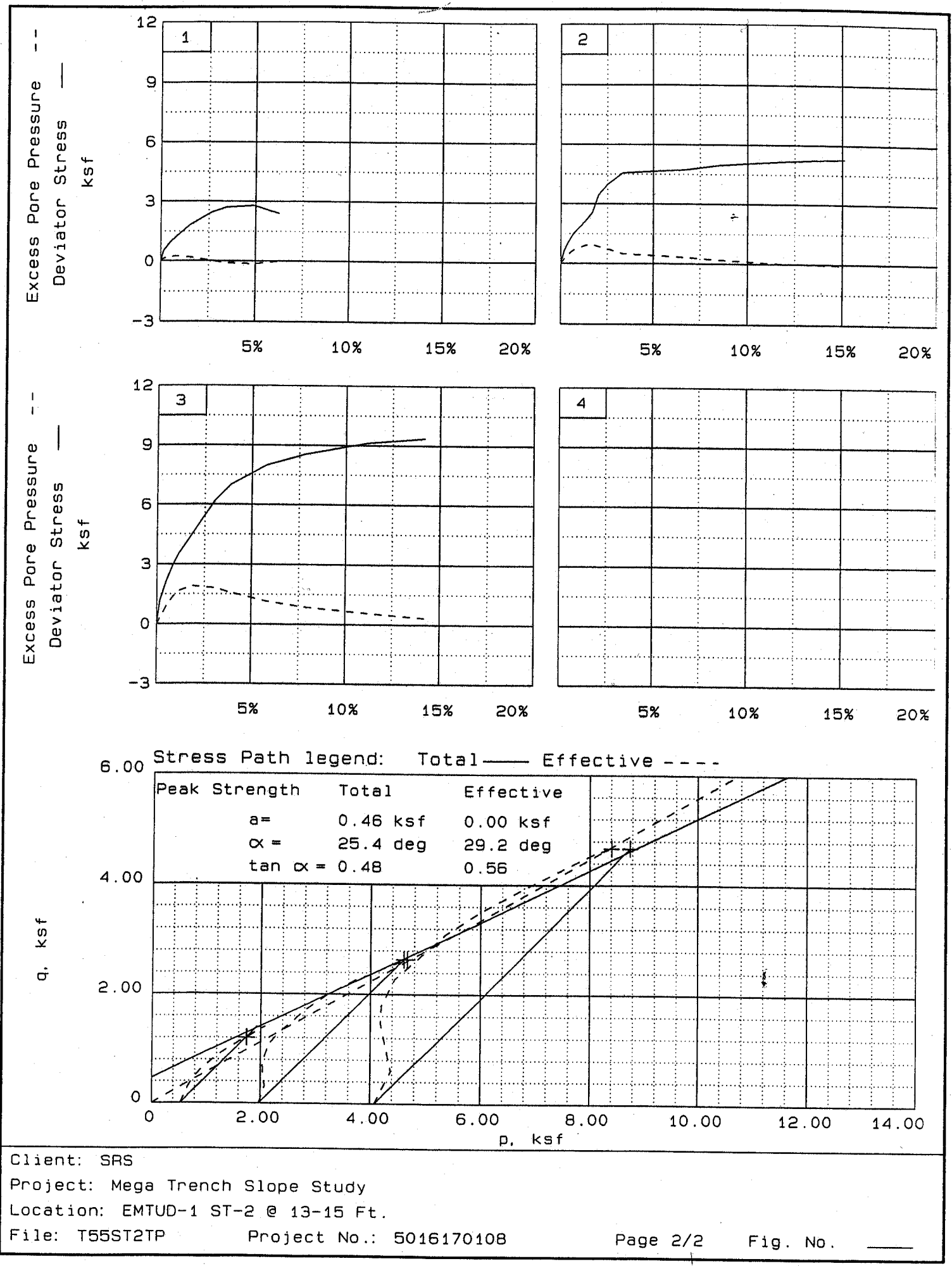

Page 228 of 298 


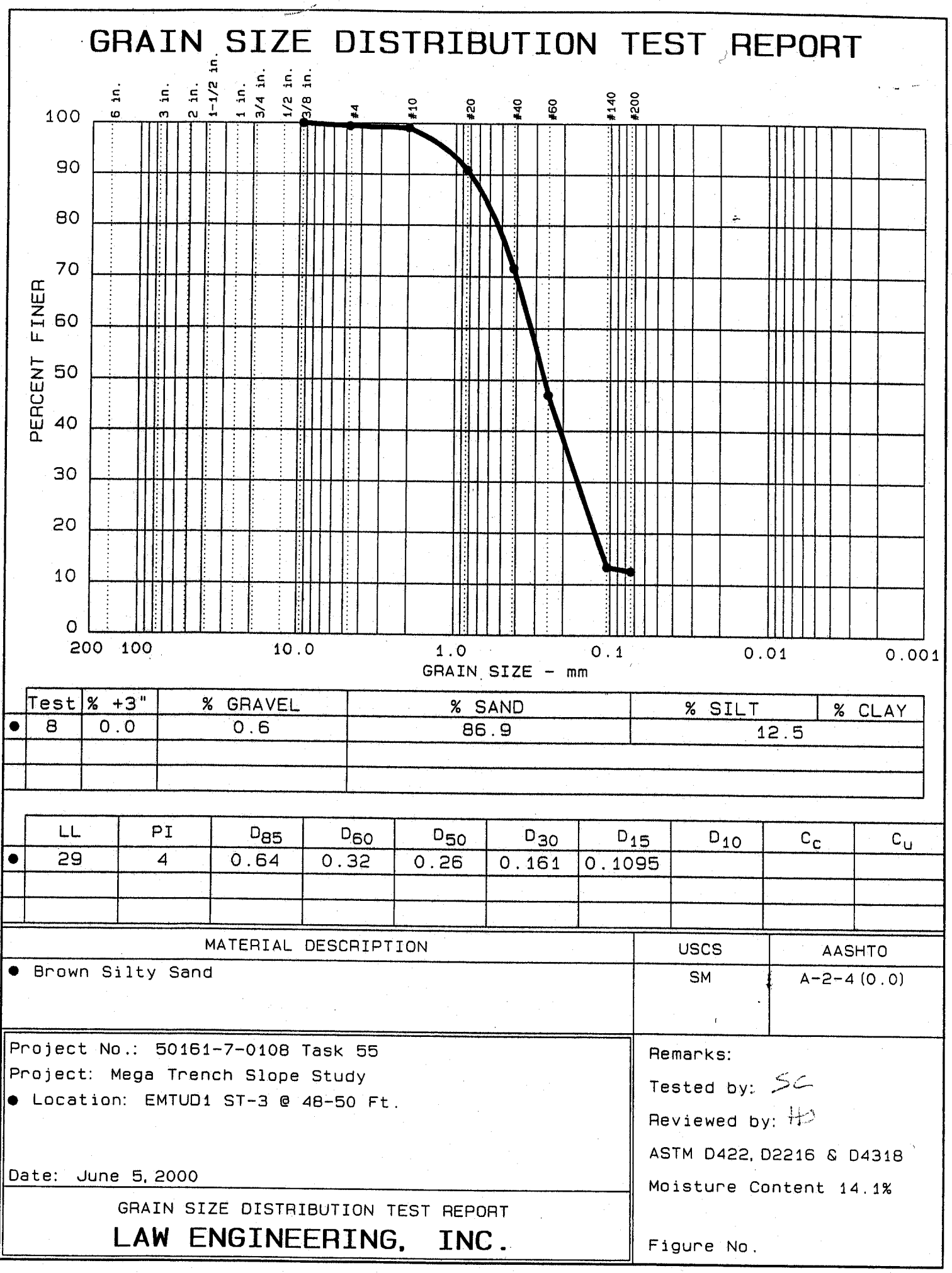

Page 229 of 298 


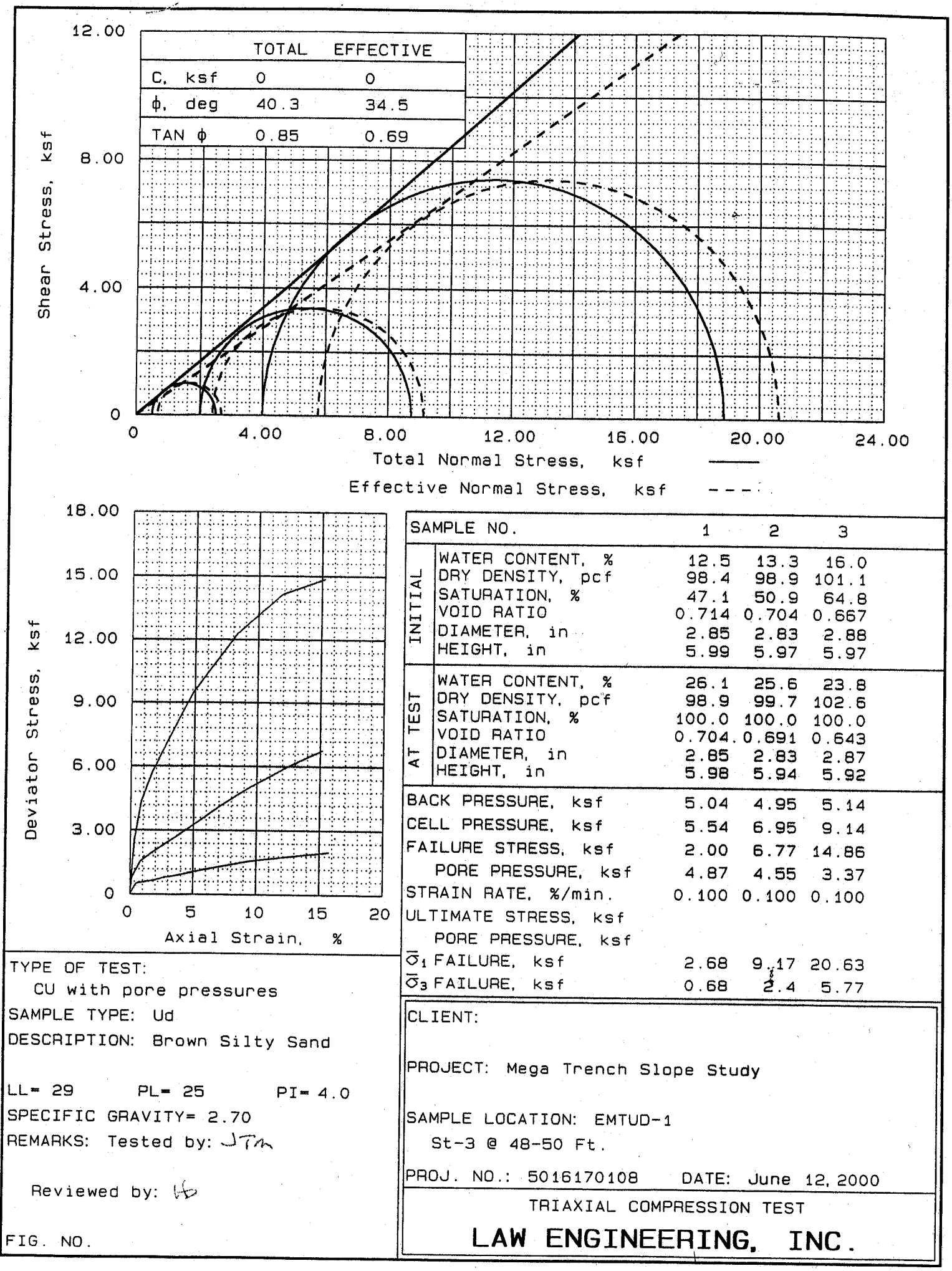


APPENDIX C

\section{B-25 EXHUMATION}

MAY 2-3, 2001

Page 231 of 298 
This page intentionally left blank. 


\section{APPENDIX C}

\section{LIST OF FIGURES}

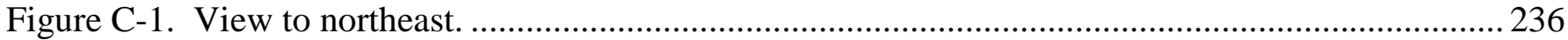

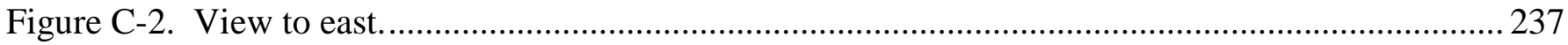

Figure C-3. View of northwestern B-25 sides, looking east. .................................................... 237

Figure C-4. Layout of B-25 containers and other objects buried March 15, 1993 as part of ground-

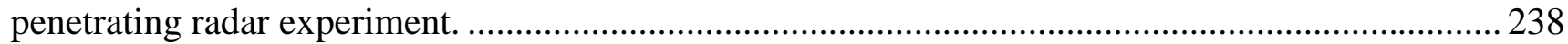

Figure C-5. Prior to excavation, May 2, 2001. B-25 location marked by orange paint on asphalt and

grass. View to northeast.................................................................................................. 239

Figure C-6. Surface soils adjacent to B-25 location at start of excavation, May 2, 2001. View to west.239

Figure C-7. South B-25 corner by probe. Note B-25 is full of water and soil, May 2, 2001. View to

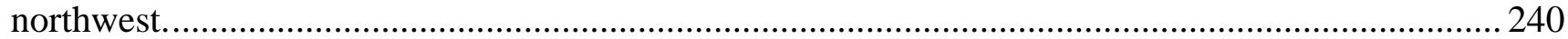

Figure C-8. South B-25 corner by probe. Note B-25 is full of water, May 2, 2001. View to west. ...... 240

Figure C-9. B-25 southeast side, May 3, 2001. Container designation " 66 " and original contents hand-

labeled "wood" visible on upper-right (upper eastern) corner. View to west. ............................... 241

Figure C-10. B-25 southeast side, May 3, 2001. View to west..................................................... 241

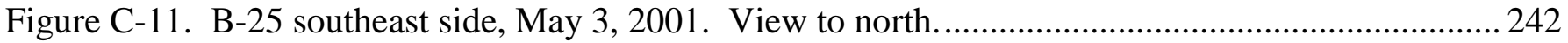

Figure C-12. B-25 southeast side, May 3, 2001. View to northeast................................................243

Figure C-13. B-25 southeast side, May 3, 2001. View to northwest. ............................................. 244

Figure C-14. B-25 northwest side, May 3, 2001. View to east.....................................................24

Figure C-15. B-25 northwest side, May 3, 2001. View to northeast................................................ 245

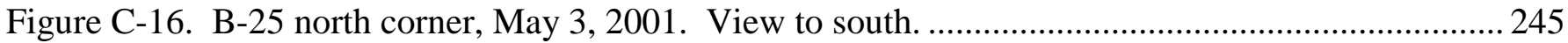

Figure C-17. B-25 north corner, May 3, 2001. View to southwest.................................................. 246

Figure C-18. B-25 south corner, southeast side close-up, May 3, 2001. Note ribbon-like delaminated

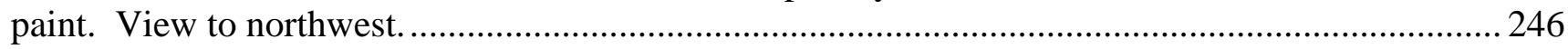

Figure C-19. B-25 south corner, southwest side close-up, May 3, 2001. Note ribbon-like delaminated paint. View to east. .................................................................................................. 247

Figure C-20. Piece of soil about $1 \mathrm{ft}$. wide which fell from B-25 side, May 3, 2001. Note adhesion of

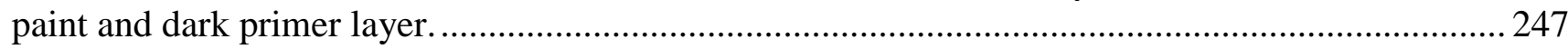

Figure C-21. B-25 west corner, northwest side, close-up, May 3, 2001. Original contents hand-label

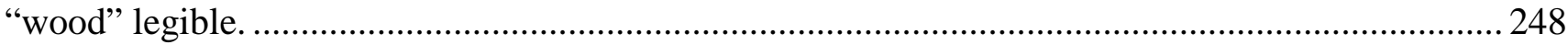

Figure C-22. B-25 west corner, northwest side, close-up, May 3, 2001. Dark corrosion product wiped off to expose container " 66 " designation. ..................................................................................249

FigureC- 23. B-25 northwest side close-up, May 3, 2001. Note some blisters lacking paint covering,

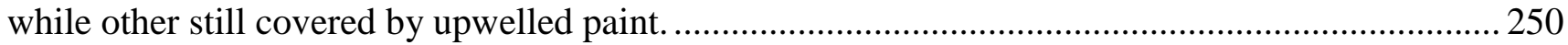

Figure C-24. B-25 southeast side close-up, May 3, 2001. Note some blisters lacking paint covering, while other still covered by upwelled paint.................................................................... 250

Figure C-25. B-25 south corner close-up, May 3, 2001. Note B-25 is full of water and soil............... 251

Figure C-26. B-25 upper edge. Top has been pushed down into B-25 and covered with soil. Note delaminated paint along edge. 
Figure C-27. B-25 being cleared for removal from excavation. Note water and soil within B-25........253

Figure C-28. Wood simulated waste within B-25 underlying the excavated B-25, northwest side.........253

Figure C-29. Wood simulated waste within B-25 underlying the excavated B-25, northwest side. Note

in-place saturated soil that has accumulated on lid of underlying B-25.

Figure C-30. Close-up of wood simulated waste within B-25 underlying the excavated B-25, northwest

side. Water within underlying B-25 is visible along top of photograph.

Figure C-31. Initial lifting of B-25. Cables inadvertently run through handles on top of underlying B-25

pulled its lid up. B-25 was lowered, and cables re-routed to leave underlying B-25 top in place. ... 255

Figure C-32. B-25 being lifted from excavation.

255

Figure C-33. B-25 turned on side at grade to remove soil and water to facilitate transport to laboratory.

Note soil thickness approximately $2 \mathrm{ft}$. toward center of lid.

Figure C-34. B-25 turned on side at grade to remove soil and water to facilitate transport to laboratory.

Note wood simulated waste material.

Figure C-35. Chain of Custody form for samples. ......................................................................... 257

Figure C-36. Daily Activities Report for May 2, 2001. ................................................................. 258

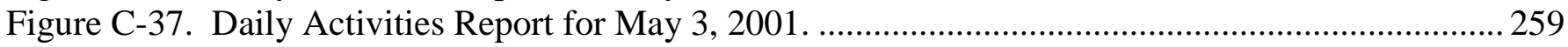




\section{B-25 EXHUMATION, MAY 2-3, 2001}

On March 15, 1993, four B-25 containers were buried in E Area, just east of the Old Burial Grounds. The B-25s were buried as part of a remote sensing experiment, designed to locate buried objects using groundpenetrating radar. Simulated waste material (wood) had been placed within the B-25s, as part of their previous use in the dynamic compaction experiment described in McMullin and Dendler (1994). The B-25s were in relatively good condition at burial, with some wall-flexure visible in the photographs taken prior to burial (Figures C-1 through C-4). The burial location is within a clean area.

The uppermost of the four B-25s was exhumed on May 3, 2001. It was transported to the FAB Laboratory in 773-A, where detailed corrosion evaluation was to be performed by Kerry Dunn, SRTC. The evaluation included documenting the general box condition, total area degraded or perforated by pitting, rate of corrosion, condition of protective coatings, physical and chemical form of box corrosion products, and other metallurgical examinations.

The exhumation began on May 2, 2001. Soils were removed to the top of the B-25. The top of the box was at a depth of $8 \mathrm{ft}$ bls. Soil adjacent to the box was obtained at a depth of $9.5 \mathrm{ft}$ for corrosion-related analyses, such as $\mathrm{pH}$, resistivity, chloride, and sulfate. The sample was shipped to Law-Gibb Engineering (see Table 2 in text). The B-25 was not uncovered and exhumed until the following day to allow sufficient time for exhumation and transportation in one day.

The B-25 to be exhumed had a label with the number 66 on the top side-corner. The word "WOOD" was written under the label. The B-25 appeared to be in good overall condition from outside the excavation. Large areas of rust were not obvious. On closer inspection from within the excavation, the B-25 sides appeared to be relatively uniformly covered with blisters under the yellow-painted exterior. Some blisters contained water. Some blisters overlay obvious pitting corrosion. The yellow paint was underlain by a very dark gray to black primer coating. On at least one area of the container lip, the paint-layer was loosened to the point that it would separate from the primer-layer on contact.

The top of the uppermost B-25 (the one exhumed) was about 6 in. to $2 \mathrm{ft}$ inside the B-25 and overlain by soil. The container was also full to the top with water. The B-25 interior beneath the top contained simulated waste, soil, and water. Samples of this water were obtained for analysis, and will be described in the corrosion report. The top of the underlying B-25 (which was not exhumed) was solidly in place. Some mud, but little soil was on top of the underlying B-25. Upon lifting the uppermost B-25 from the excavation, one cable was inadvertently placed through a handle on the top of the underlying B-25. This caused the top of the underlying B-25 to be lifted up. After repositioning the cable, the top of the underlying B-25 was raised by hand for examination of the interior. The underlying B-25 contained no visible soil and was about half-filled with water. The rubber gasket lining the underlying B-25 lid and forms the contact between the container sides and the lid, appeared to be in overall good condition. The interior sides were dark, apparently with the primer coating. The wood material in both B-25s was very dark and saturated, and there was a distinct "landfill" odor, which might suggest anaerobic conditions within the containers. 
Upon raising the B-25 to land surface, the container was tipped over to remove the soil on top, making the container safer to handle and transport. Photographs (C-5 through C-34) of the exhumation are included in sequence of occurrence. A copy of the chain-of-custody for the soil sample is included (Figure C-35), as are daily activity reports for the exhumation (Figures C-36 and C-37).

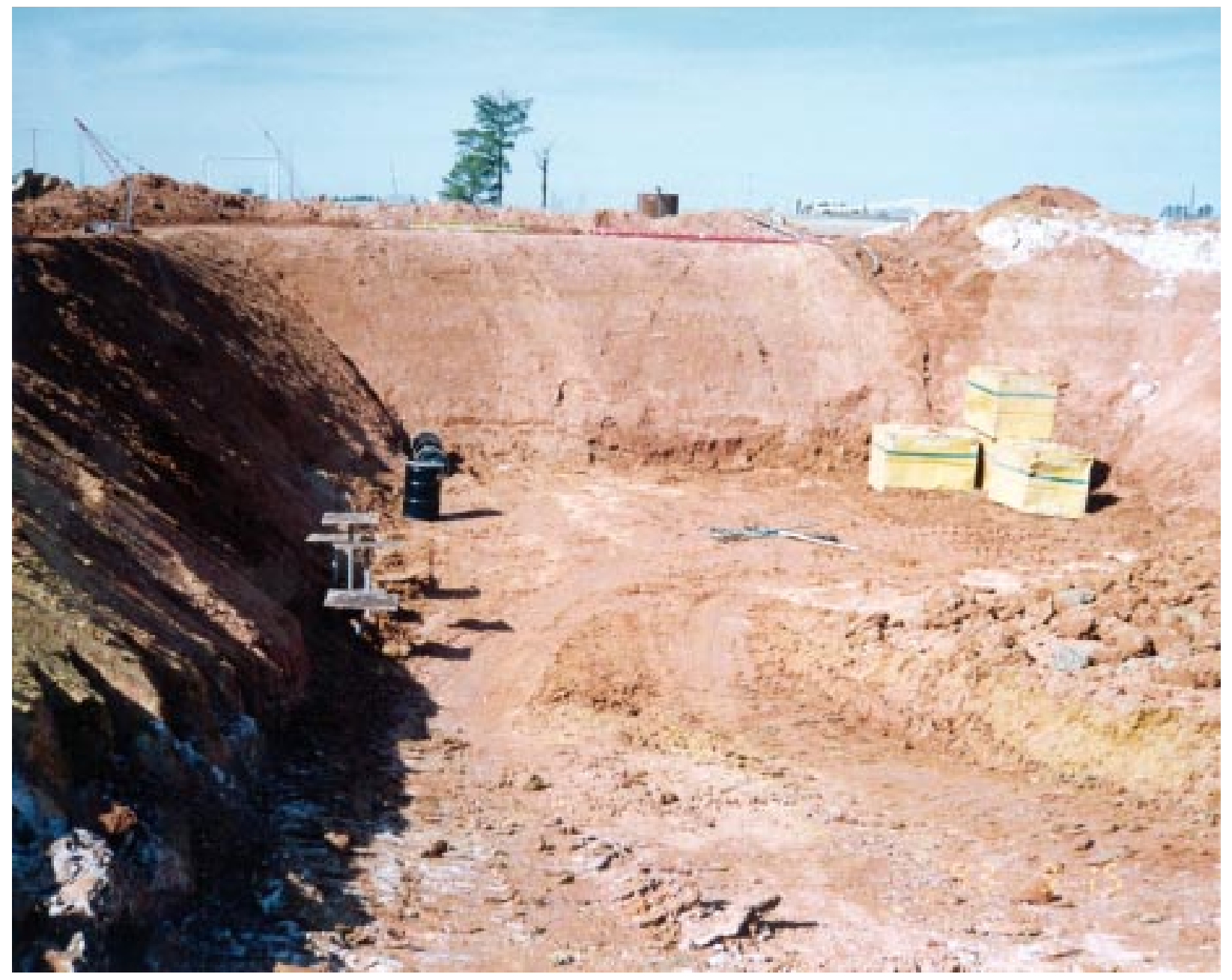

Figure C-1. View to northeast.

NOTE: Figures C-1 throuth C-4 show the burial of B-25 containers previously used in dynamic compaction study, March 15, 1993. [See McMullin and Dendler (1994).] The containers and other objects were buried as part of a ground-penetrating radar experiment.

Uppermost B-25 (shown in Figures C-1 through C-3) exhumed May 3, 2001 for corrosion study. 


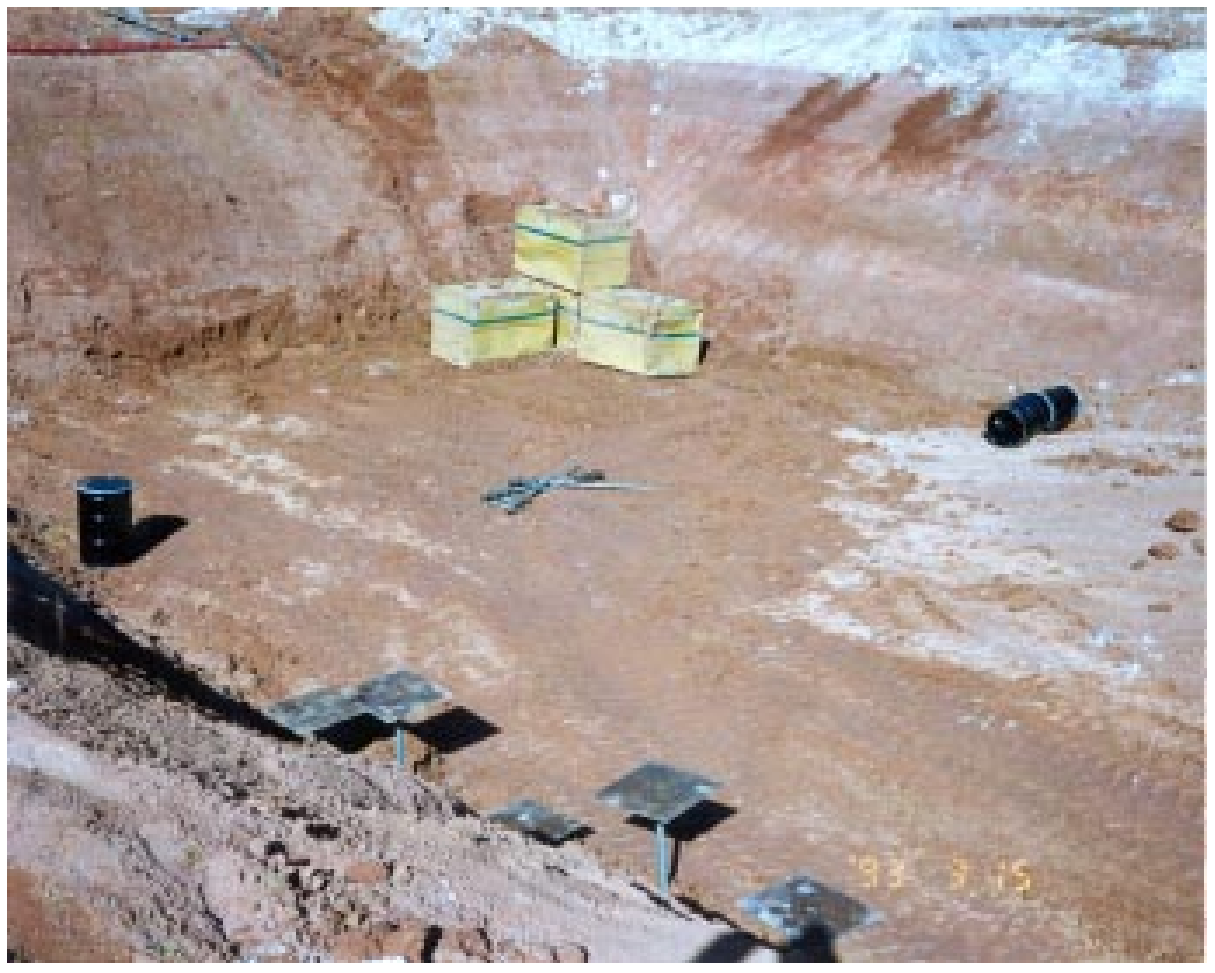

Figure C-2. View to east.

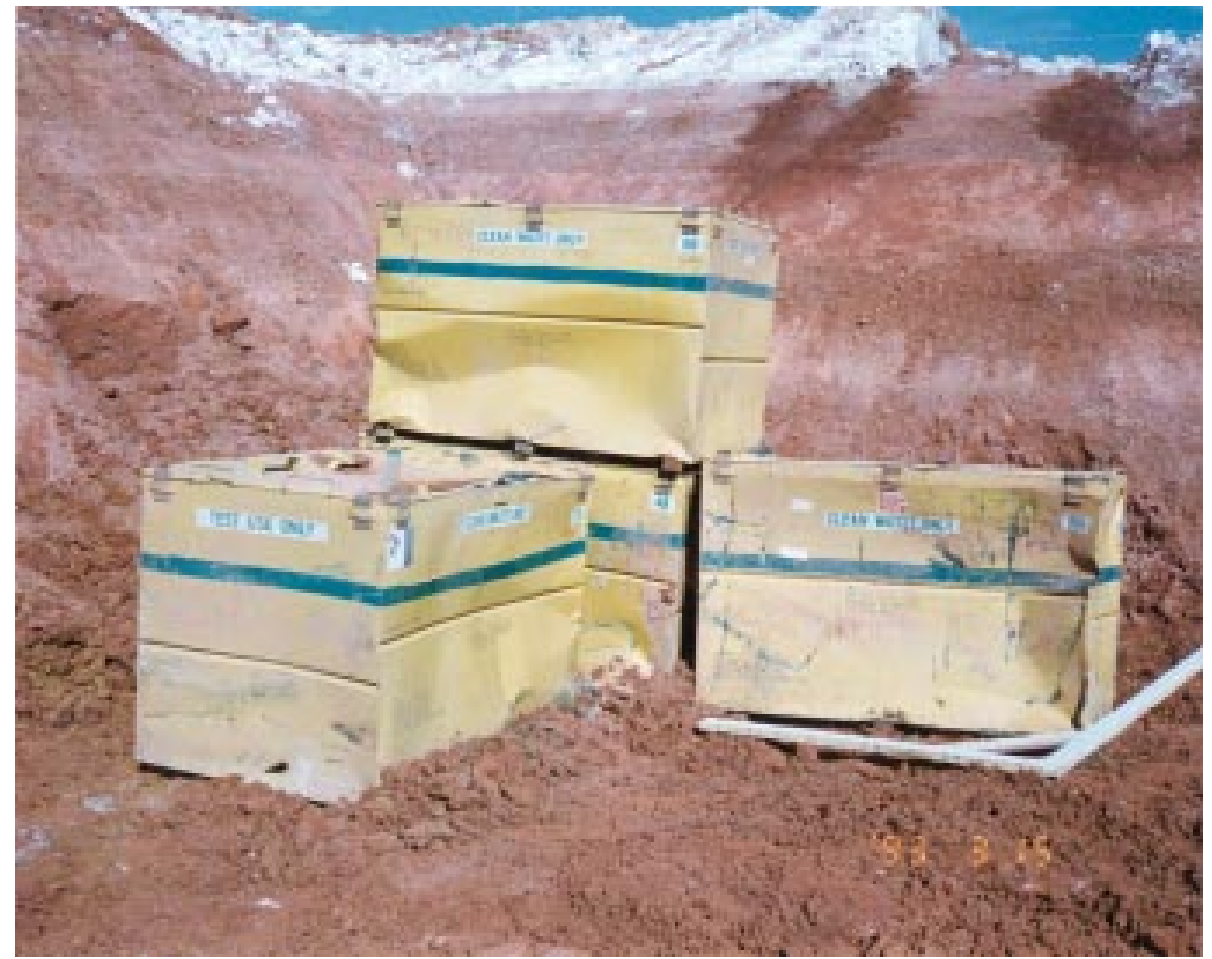

Figure C-3. View of northwestern B-25 sides, looking east. 


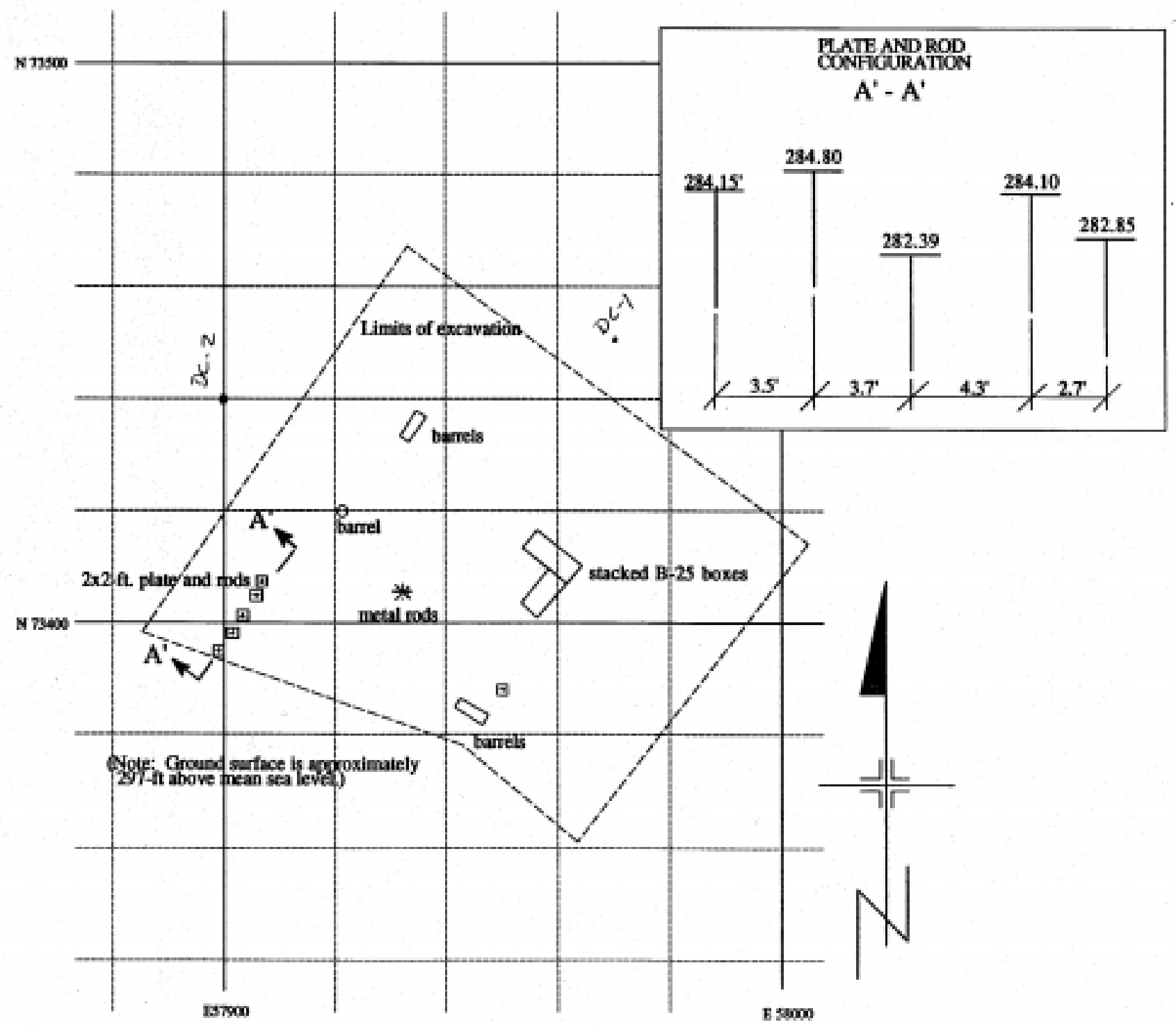

Figure C-4. Layout of B-25 containers and other objects buried March 15, 1993 as part of groundpenetrating radar experiment. 


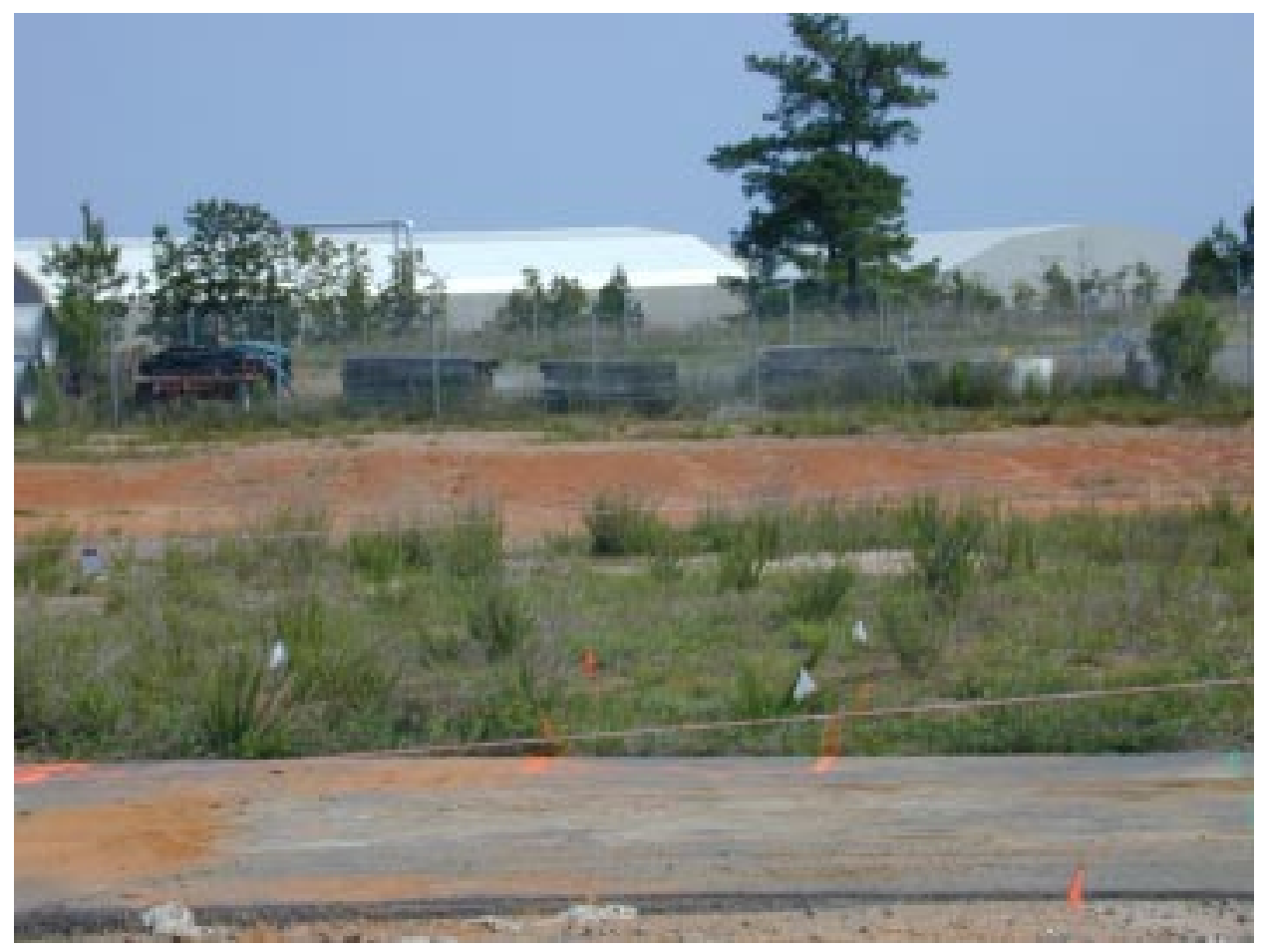

Figure C-5. Prior to excavation, May 2, 2001. B-25 location marked by orange paint on asphalt and grass. View to northeast.

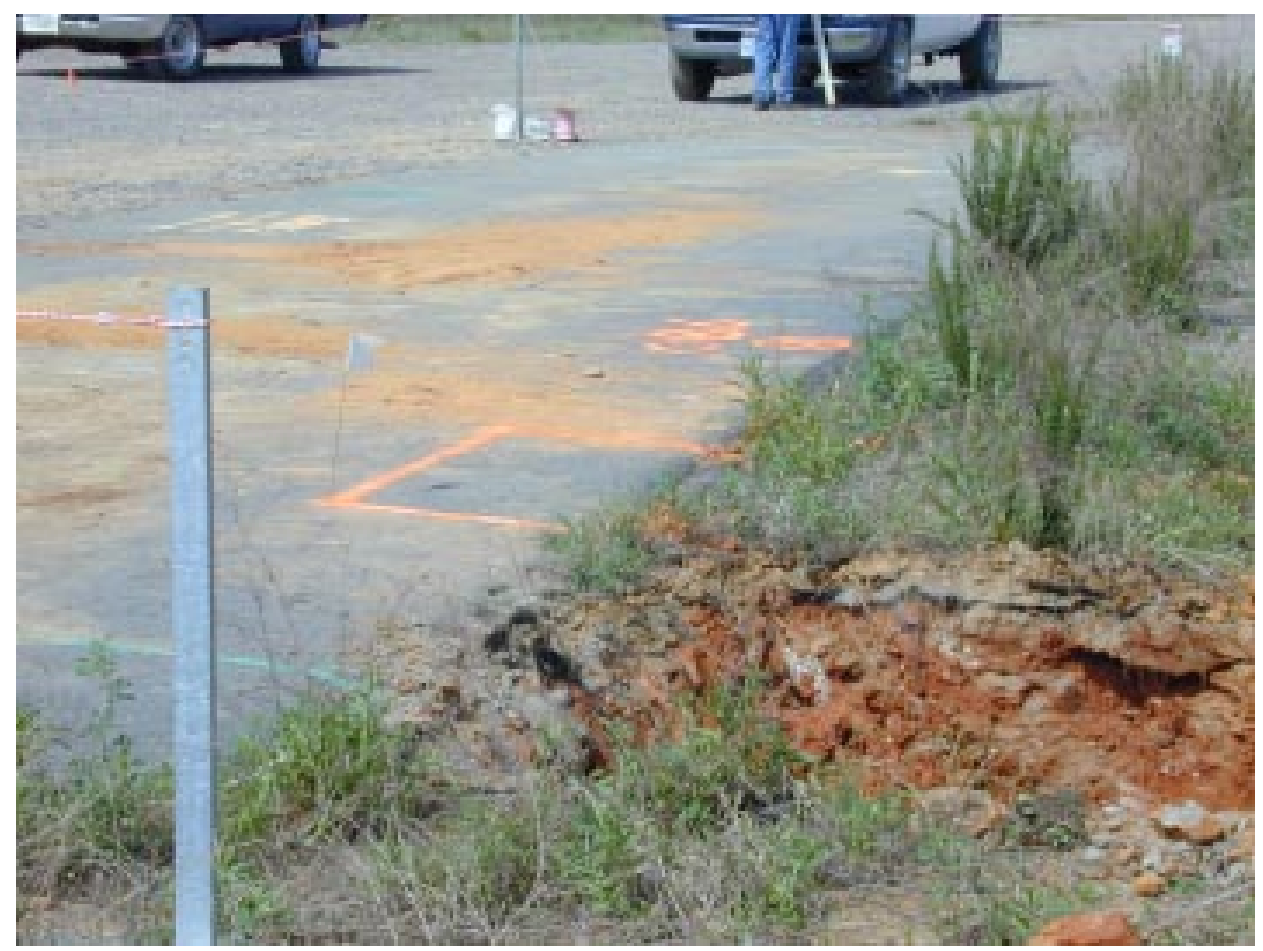

Figure C-6. Surface soils adjacent to B-25 location at start of excavation, May 2, 2001. View to west. 


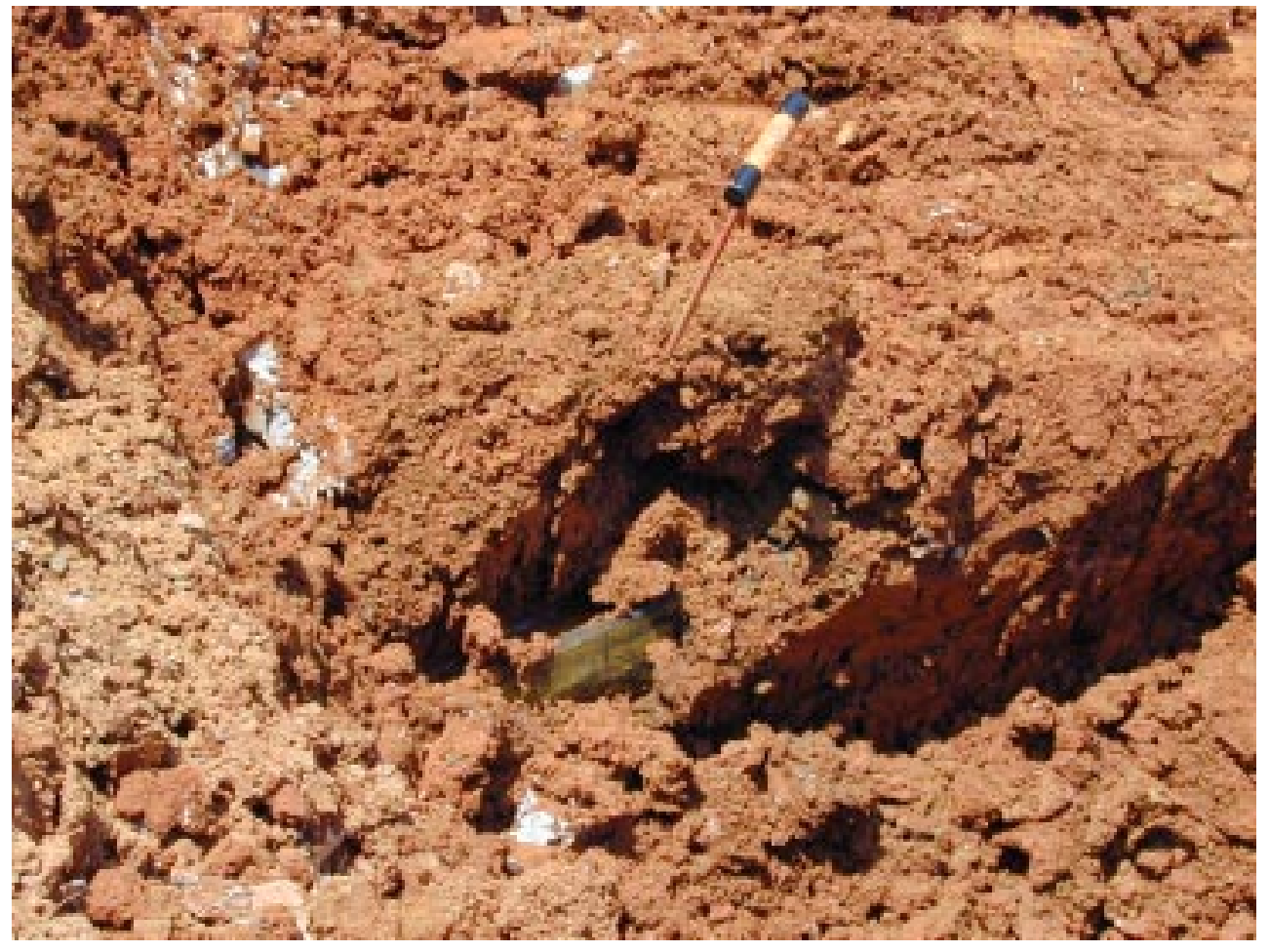

Figure C-7. South B-25 corner by probe. Note B-25 is full of water and soil, May 2, 2001. View to northwest.

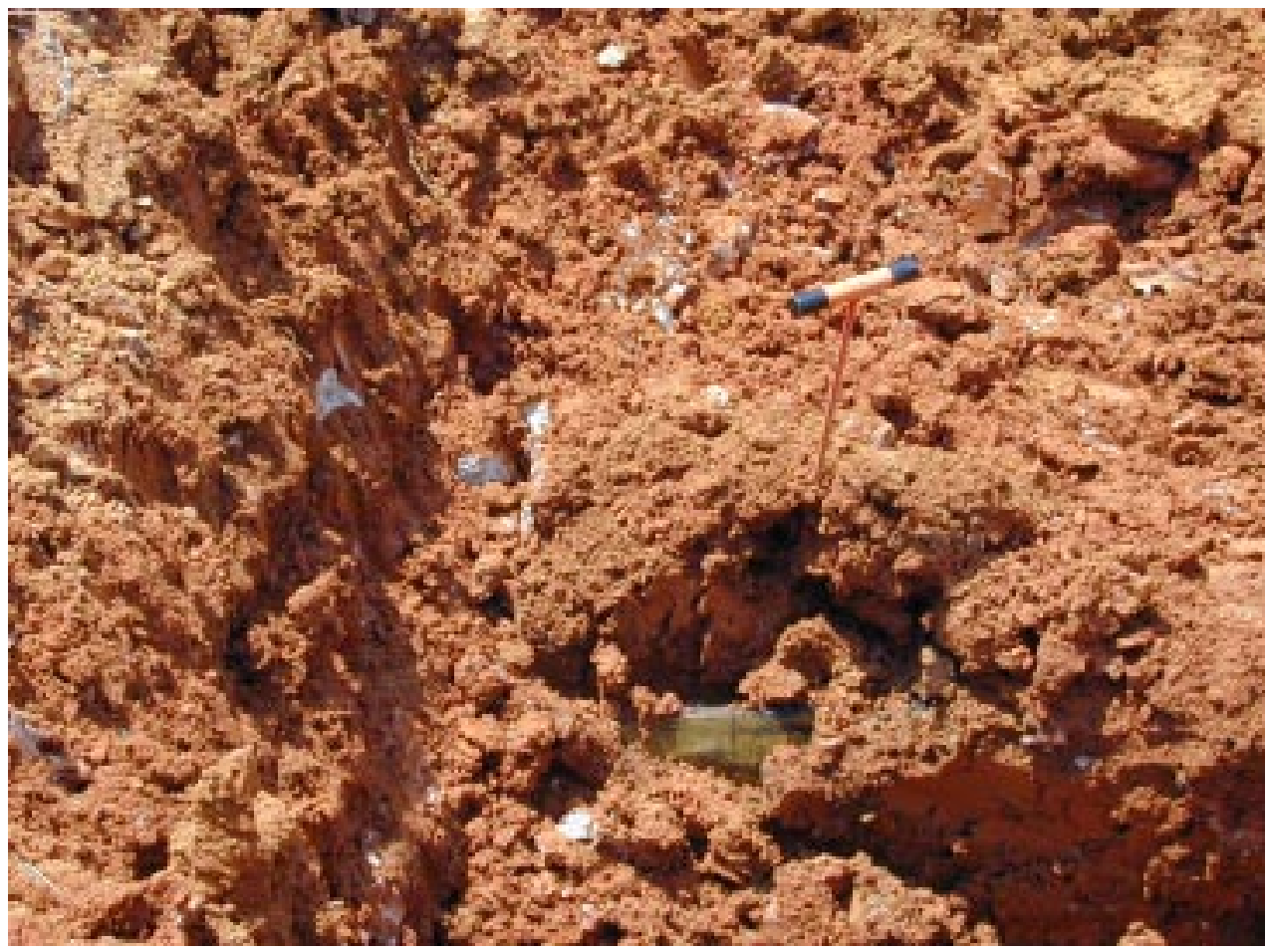

Figure C-8. South B-25 corner by probe. Note B-25 is full of water, May 2, 2001. View to west. 


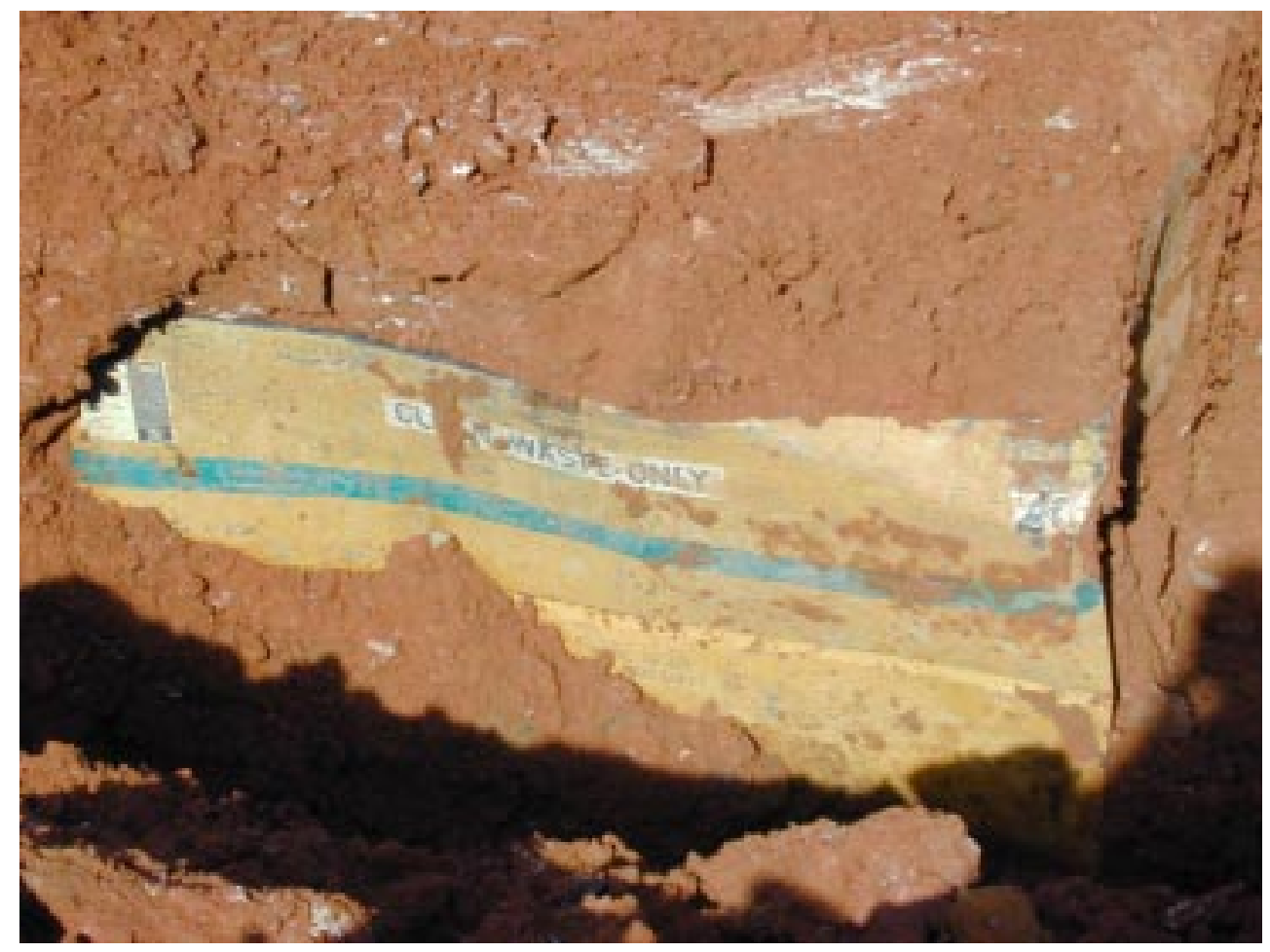

Figure C-9. B-25 southeast side, May 3, 2001. Container designation "66" and original contents hand-labeled "wood" visible on upper-right (upper eastern) corner. View to west.

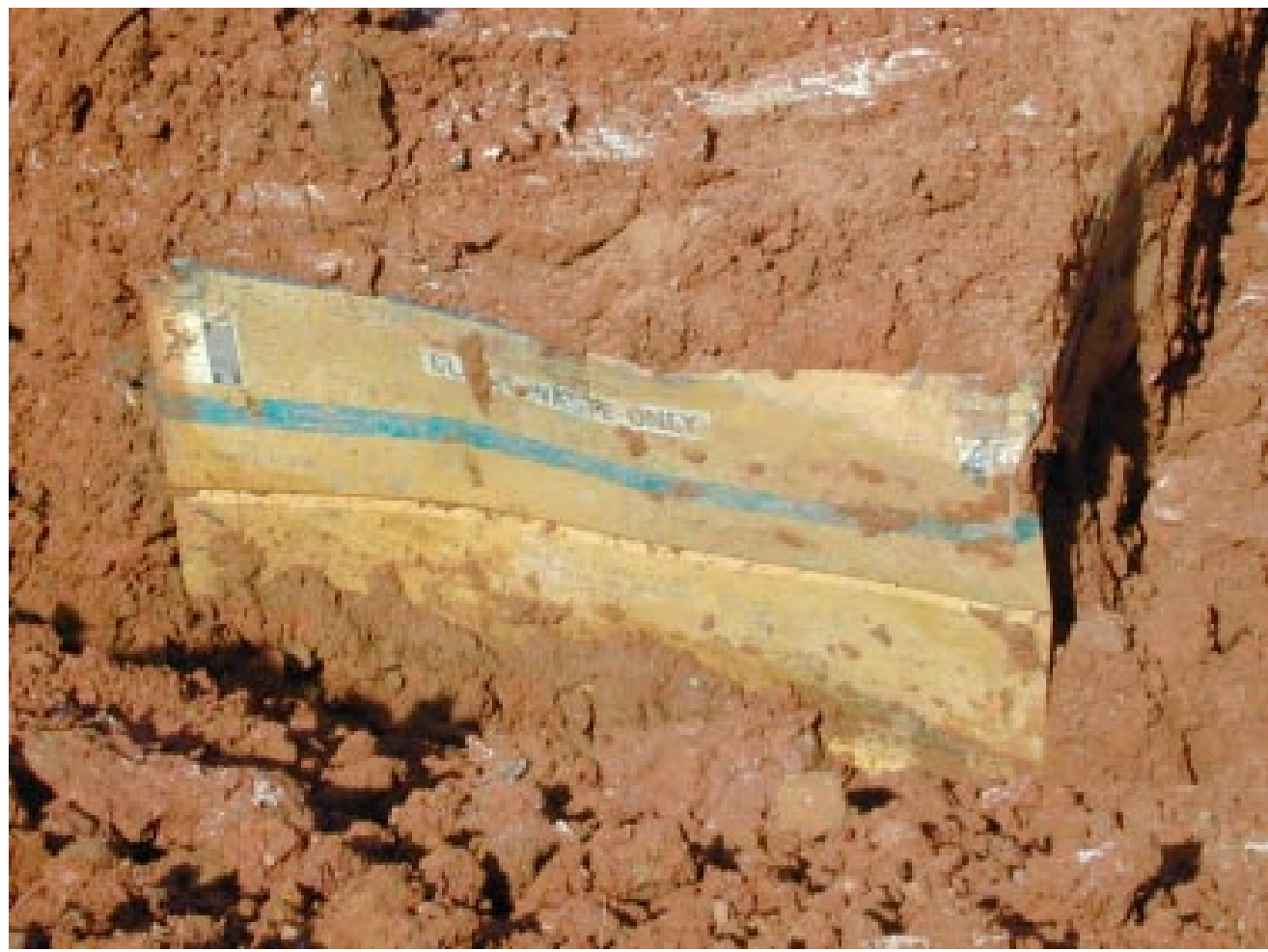

Figure C-10. B-25 southeast side, May 3, 2001. View to west. 


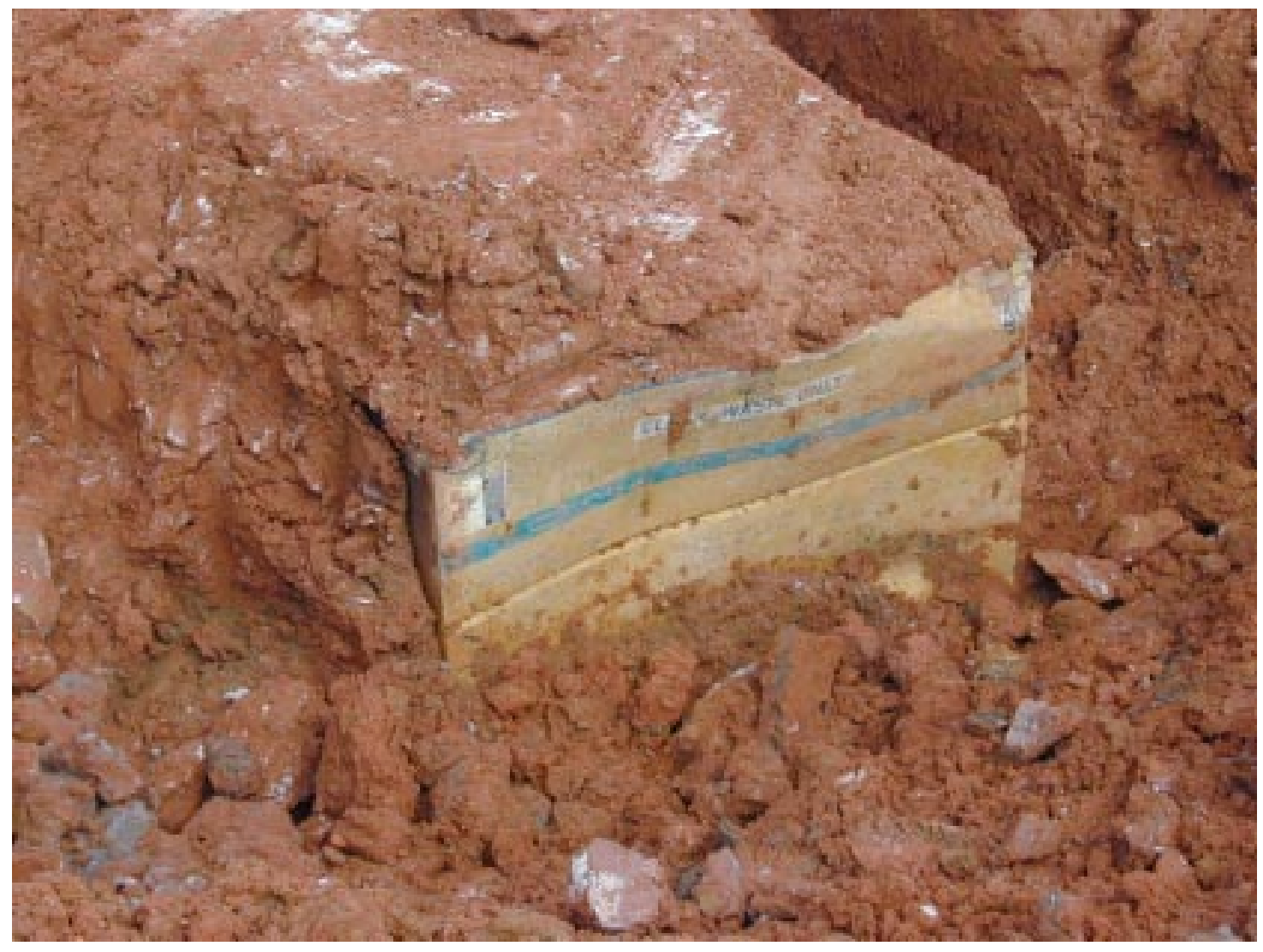

Figure C-11. B-25 southeast side, May 3, 2001. View to north. 


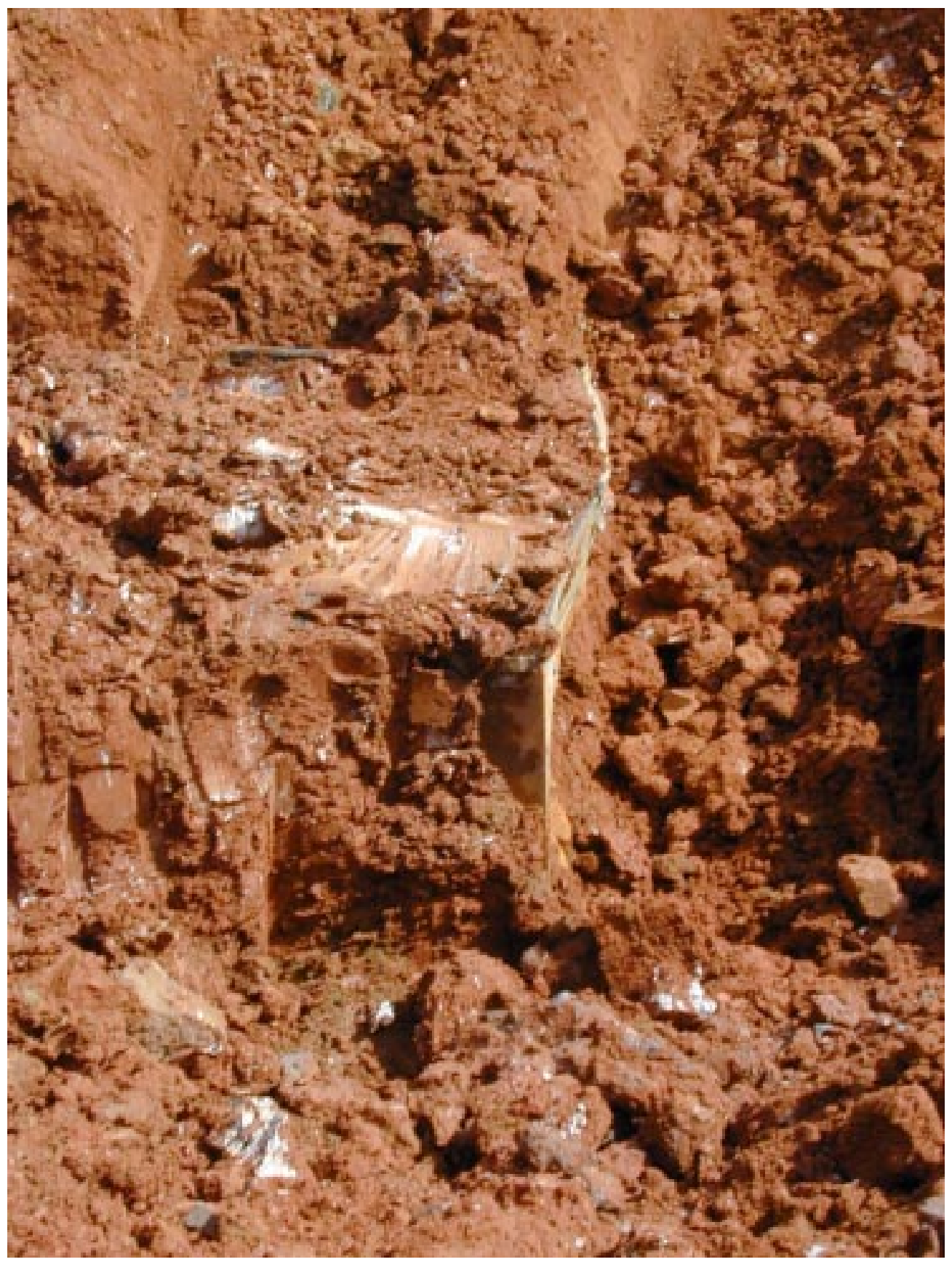

Figure C-12. B-25 southeast side, May 3, 2001. View to northeast. 


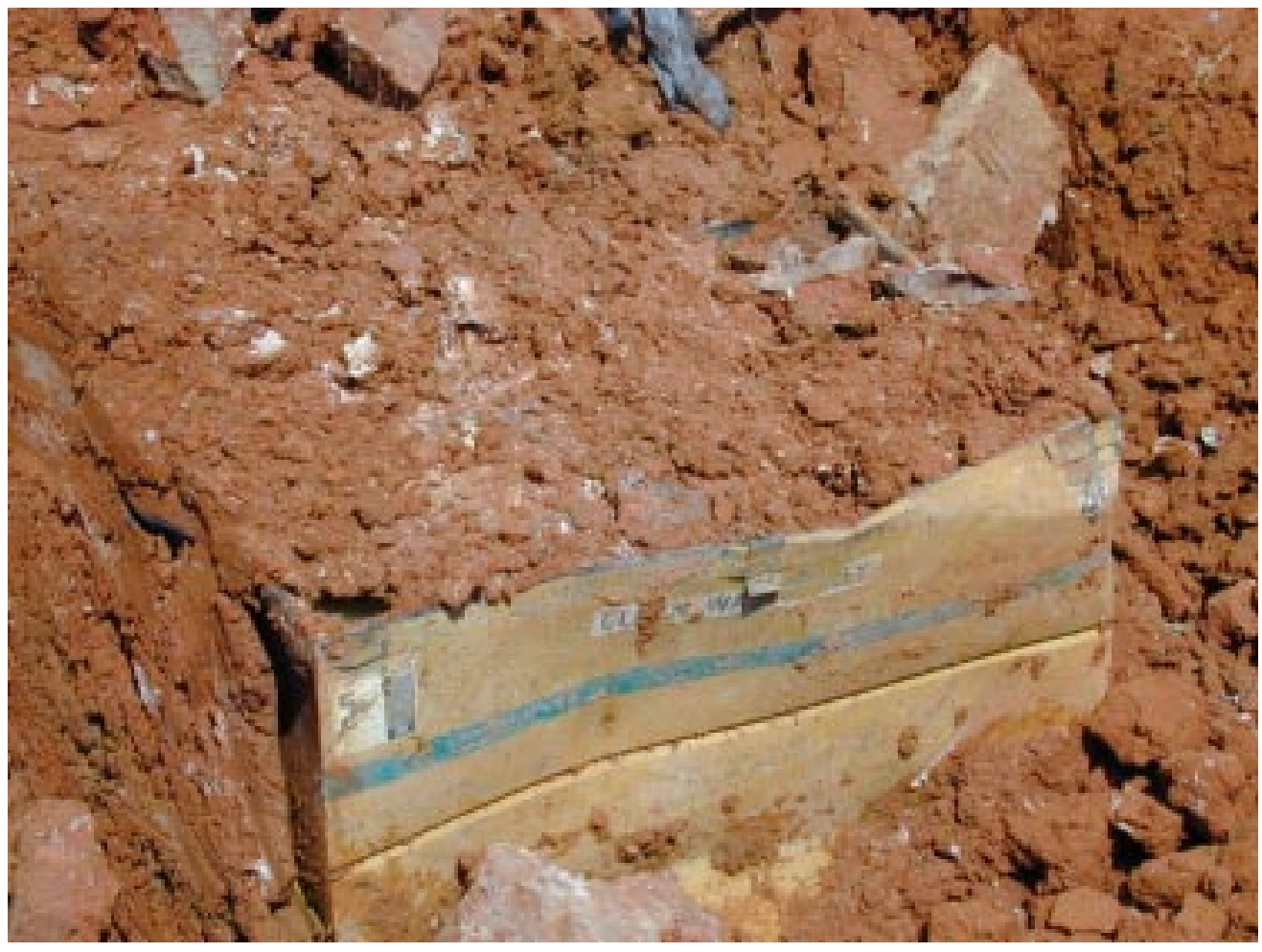

Figure C-13. B-25 southeast side, May 3, 2001. View to northwest.

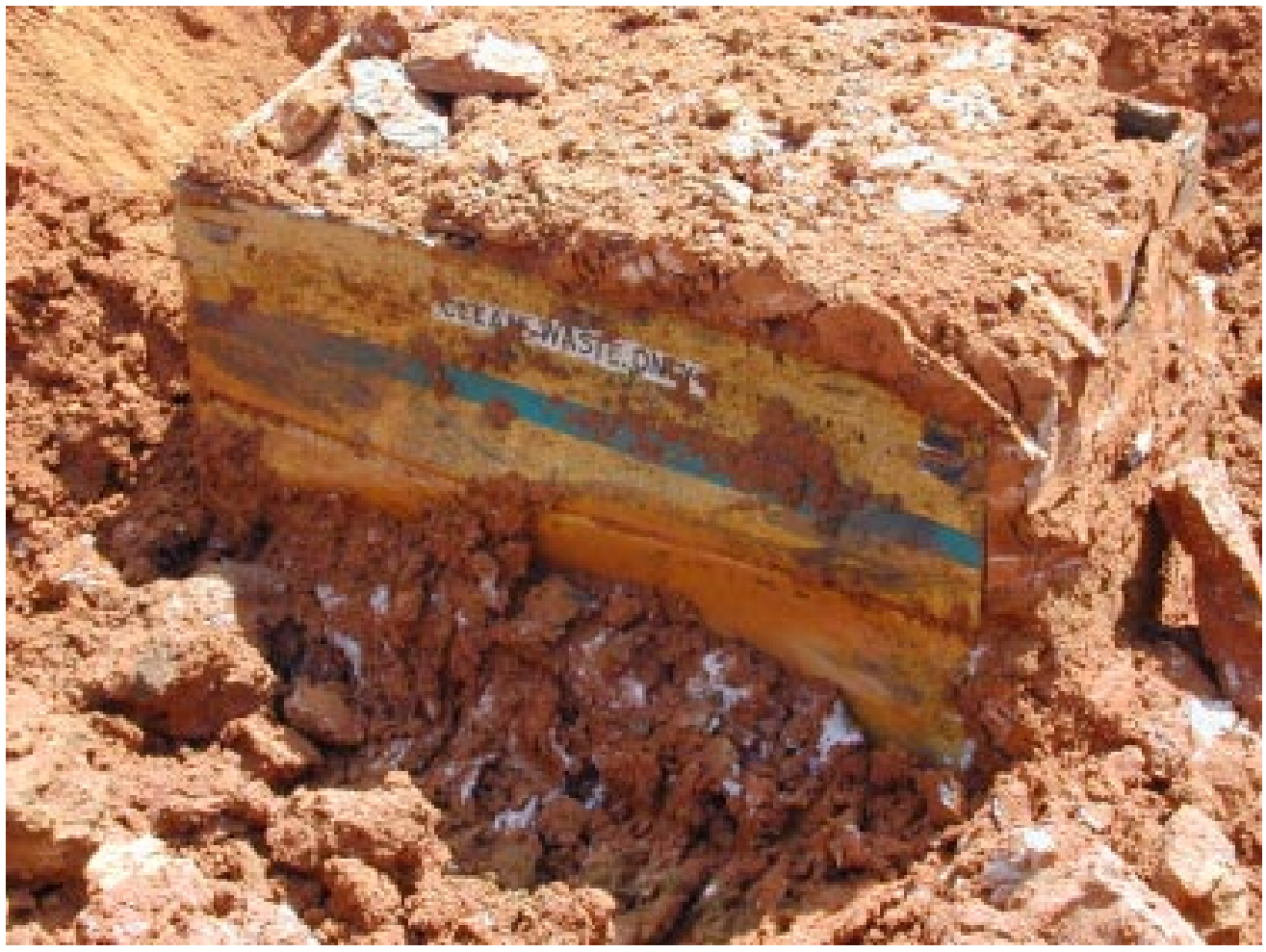

Figure C-14. B-25 northwest side, May 3, 2001. View to east. 


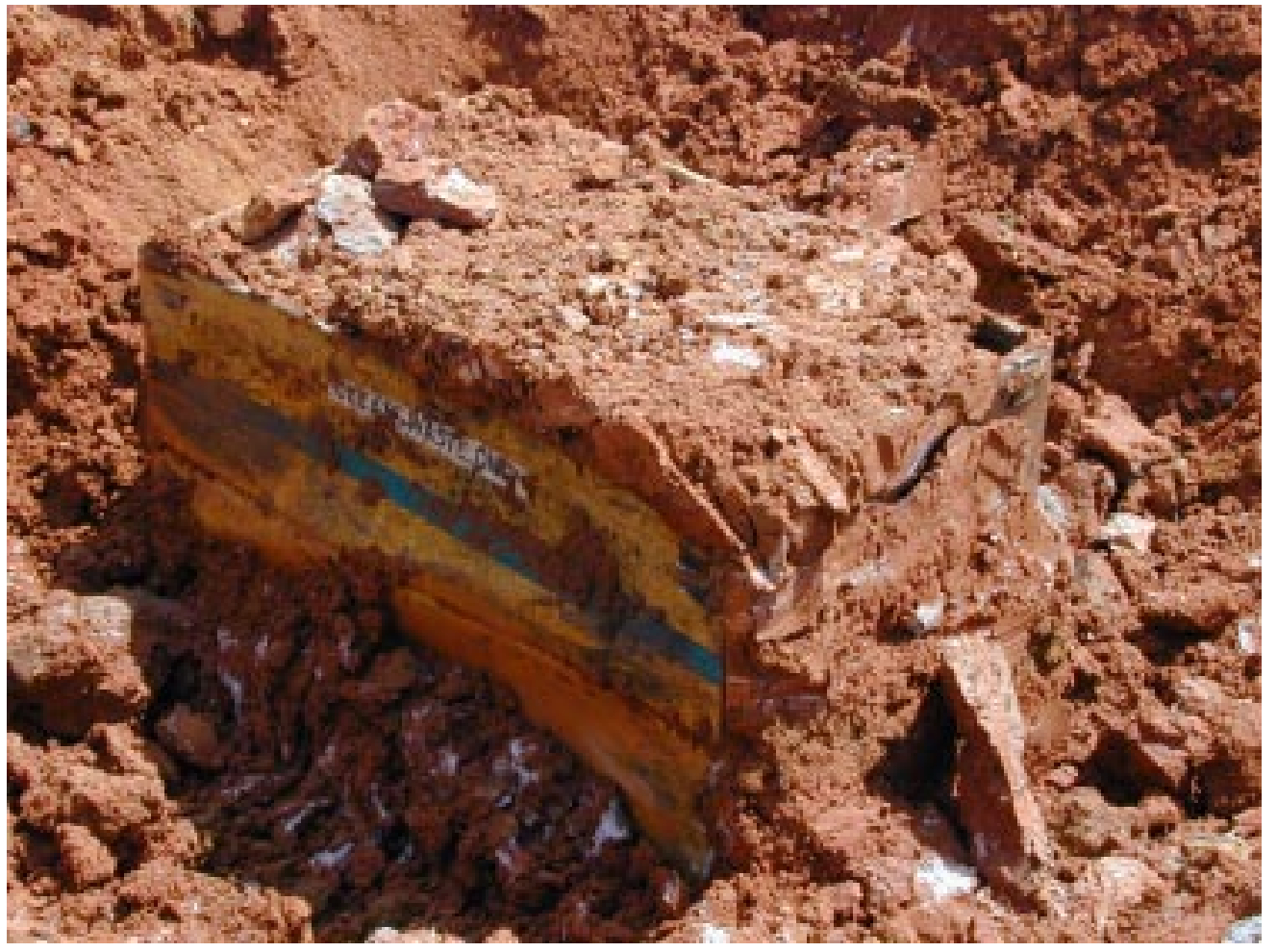

Figure C-15. B-25 northwest side, May 3, 2001. View to northeast.

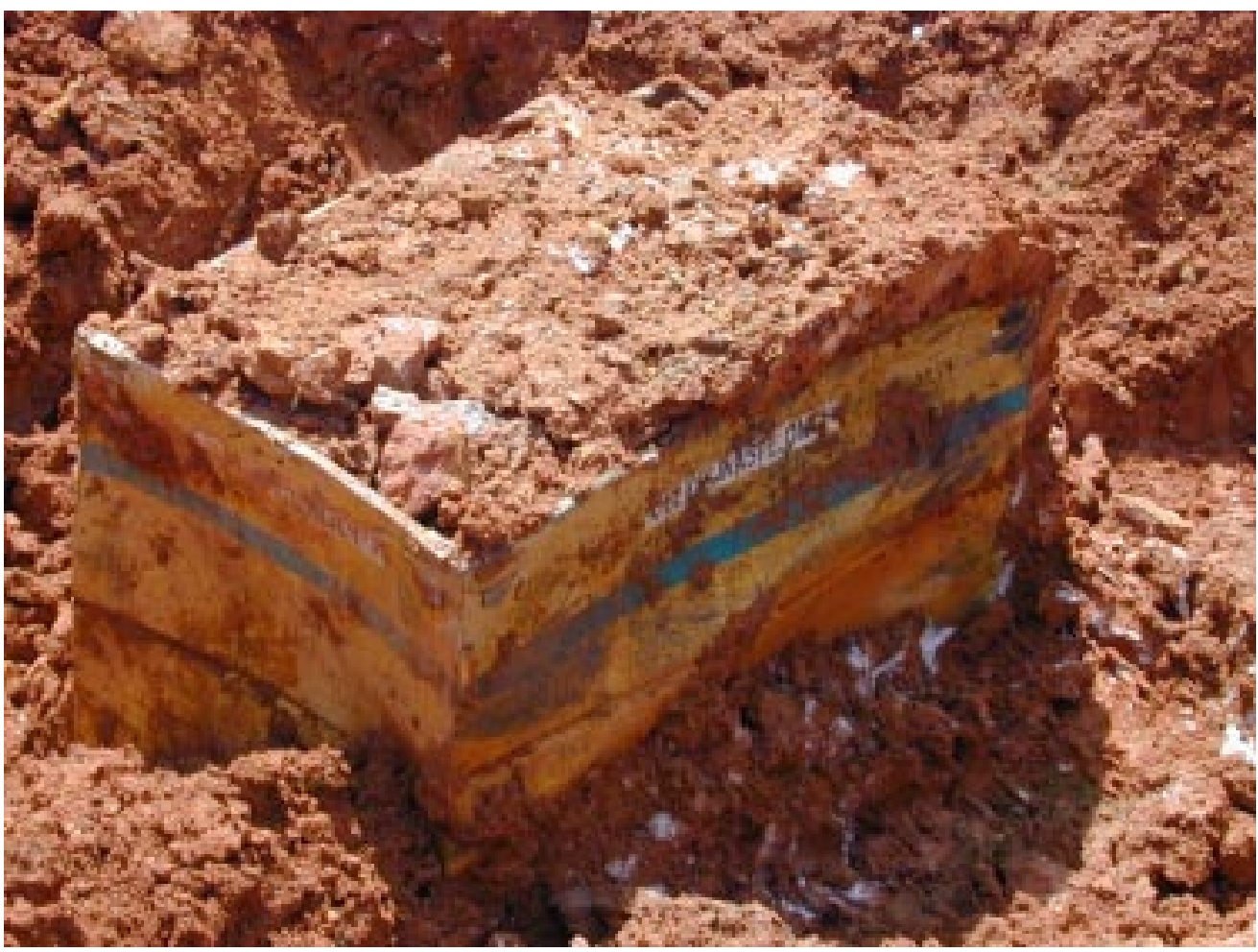

Figure C-16. B-25 north corner, May 3, 2001. View to south. 


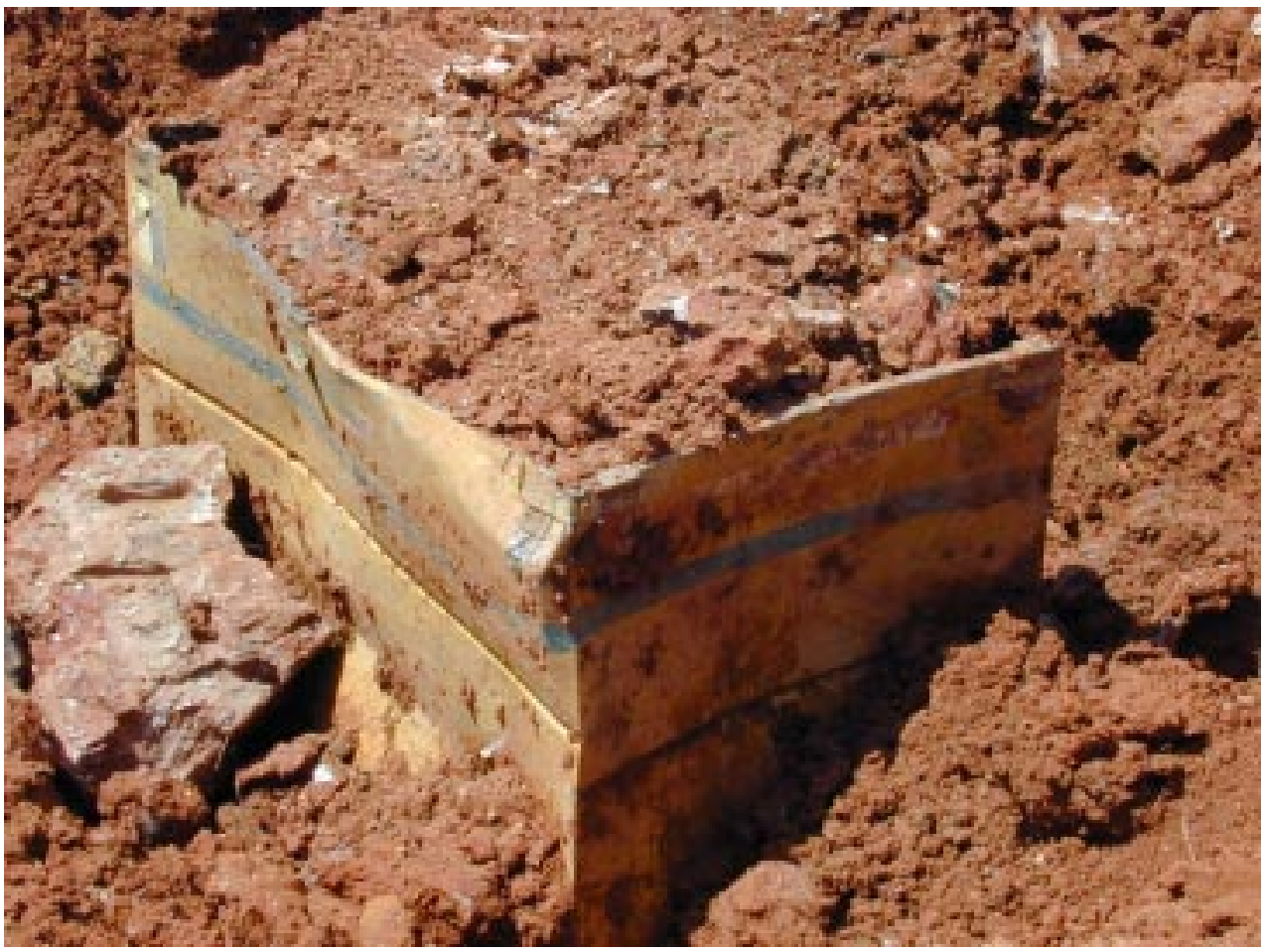

Figure C-17. B-25 north corner, May 3, 2001. View to southwest.

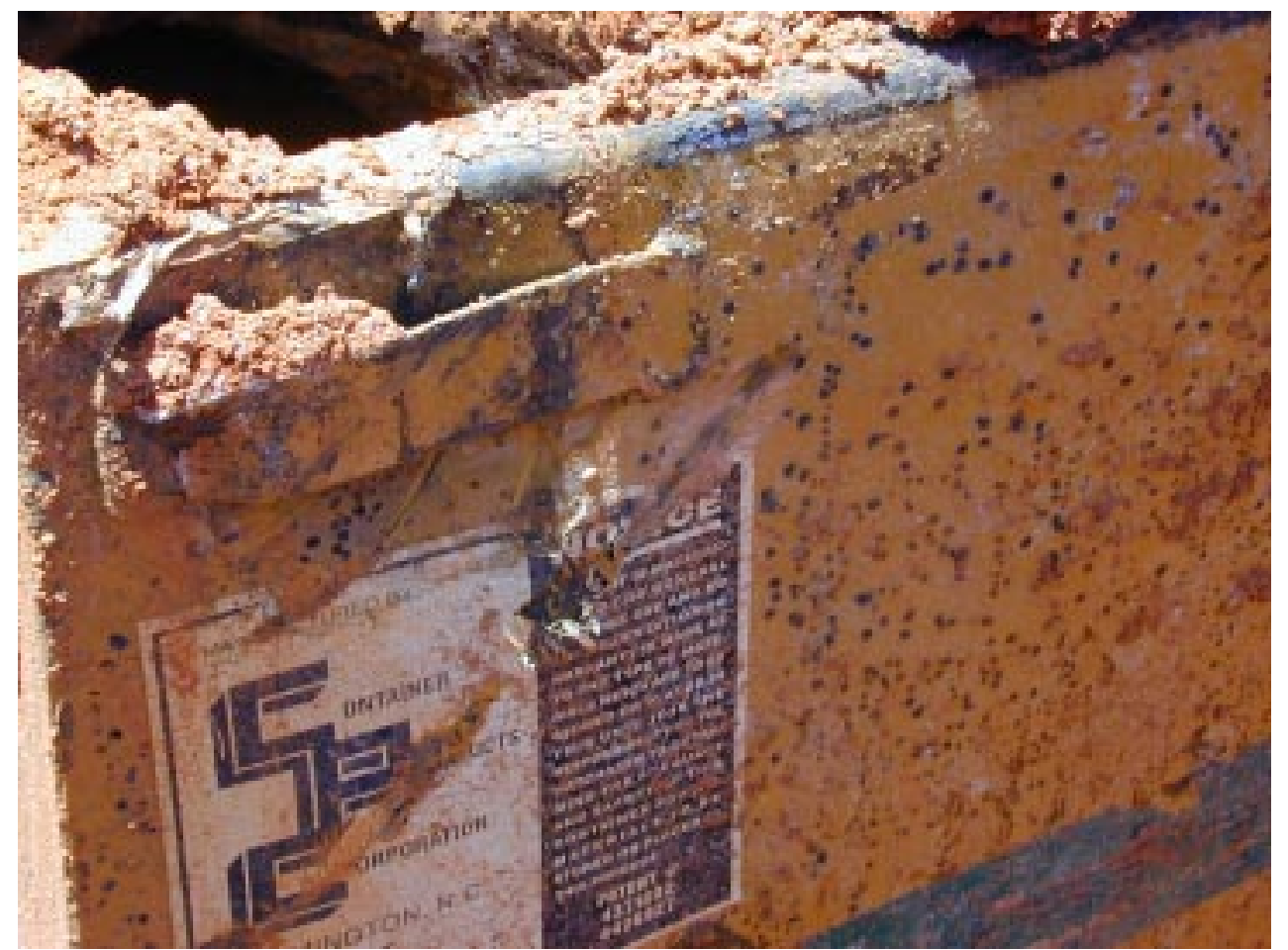

Figure C-18. B-25 south corner, southeast side close-up, May 3, 2001. Note ribbon-like delaminated paint. View to northwest. 


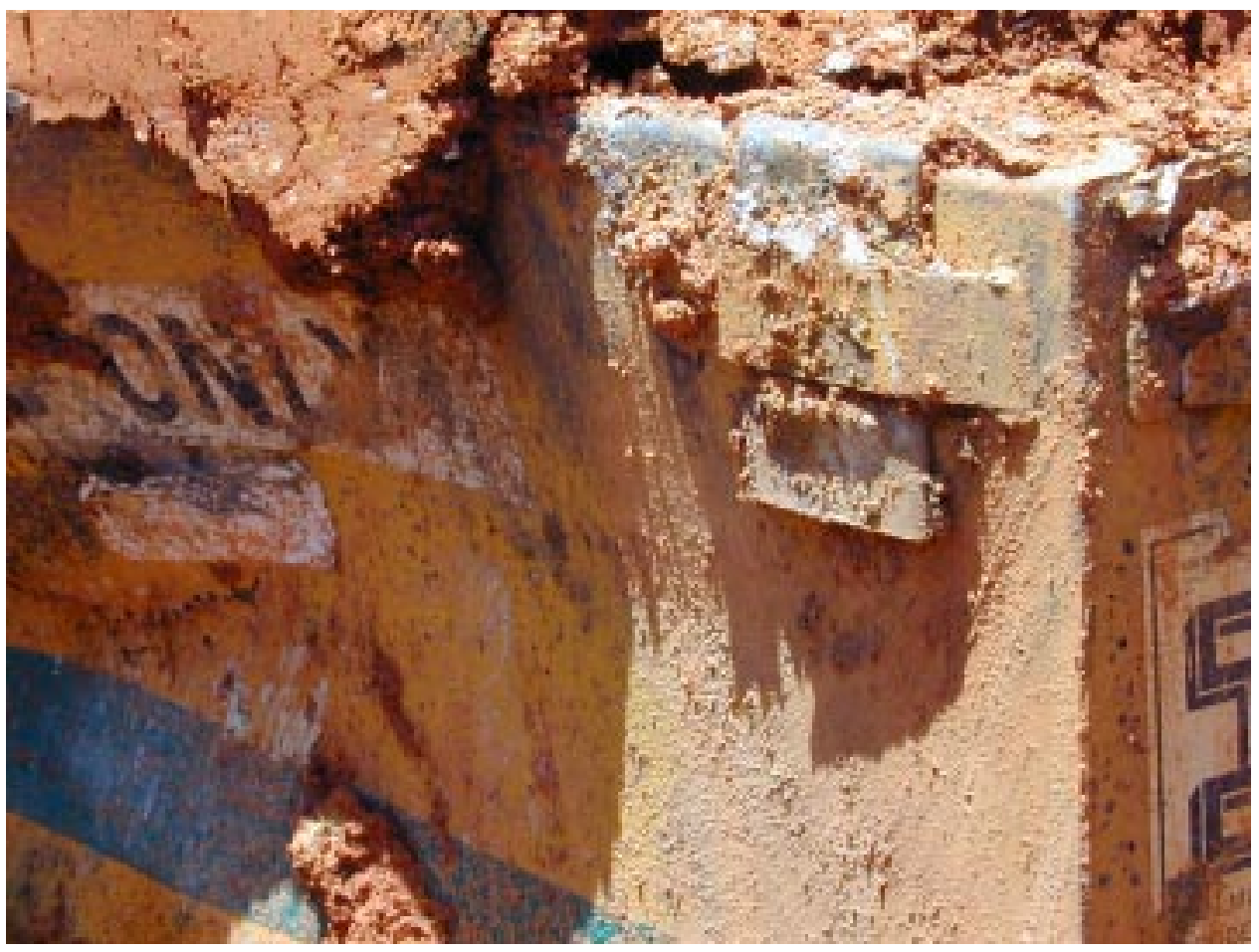

Figure C-19. B-25 south corner, southwest side close-up, May 3, 2001. Note ribbon-like delaminated paint. View to east.

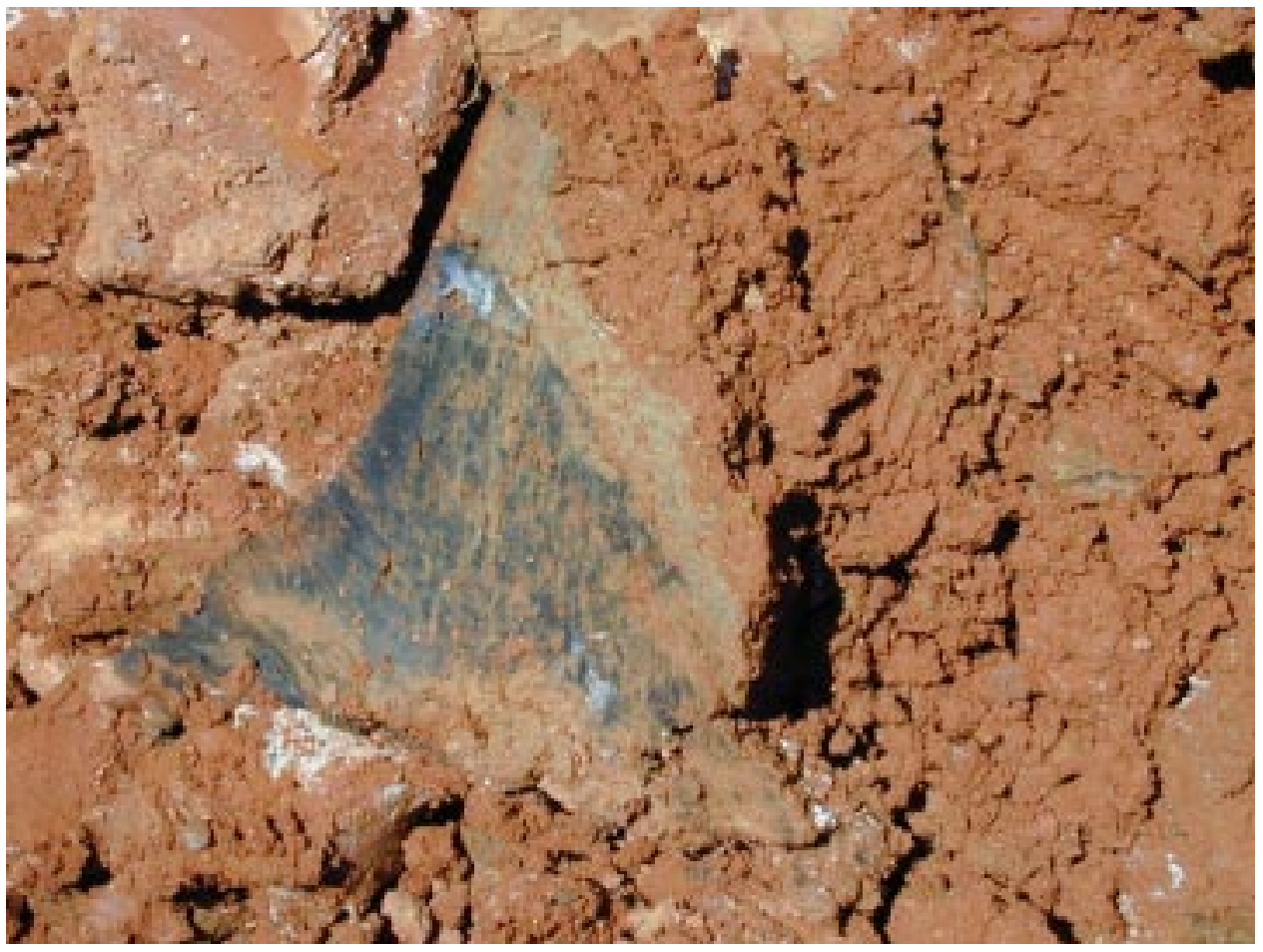

Figure C-20. Piece of soil about $1 \mathrm{ft}$. wide which fell from B-25 side, May 3, 2001. Note adhesion of paint and dark primer layer. 


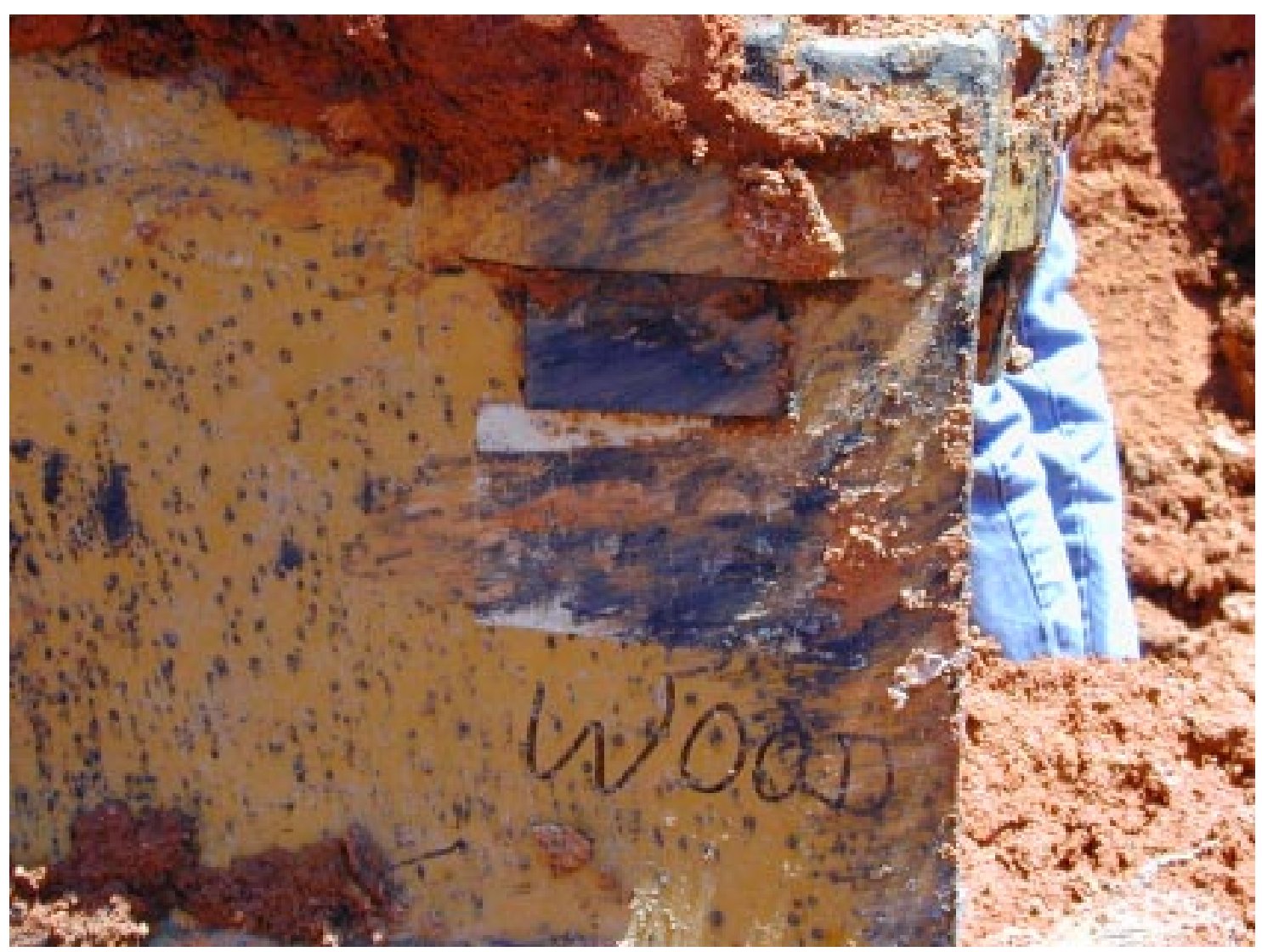

Figure C-21. B-25 west corner, northwest side, close-up, May 3, 2001. Original contents hand-label "wood" legible. 


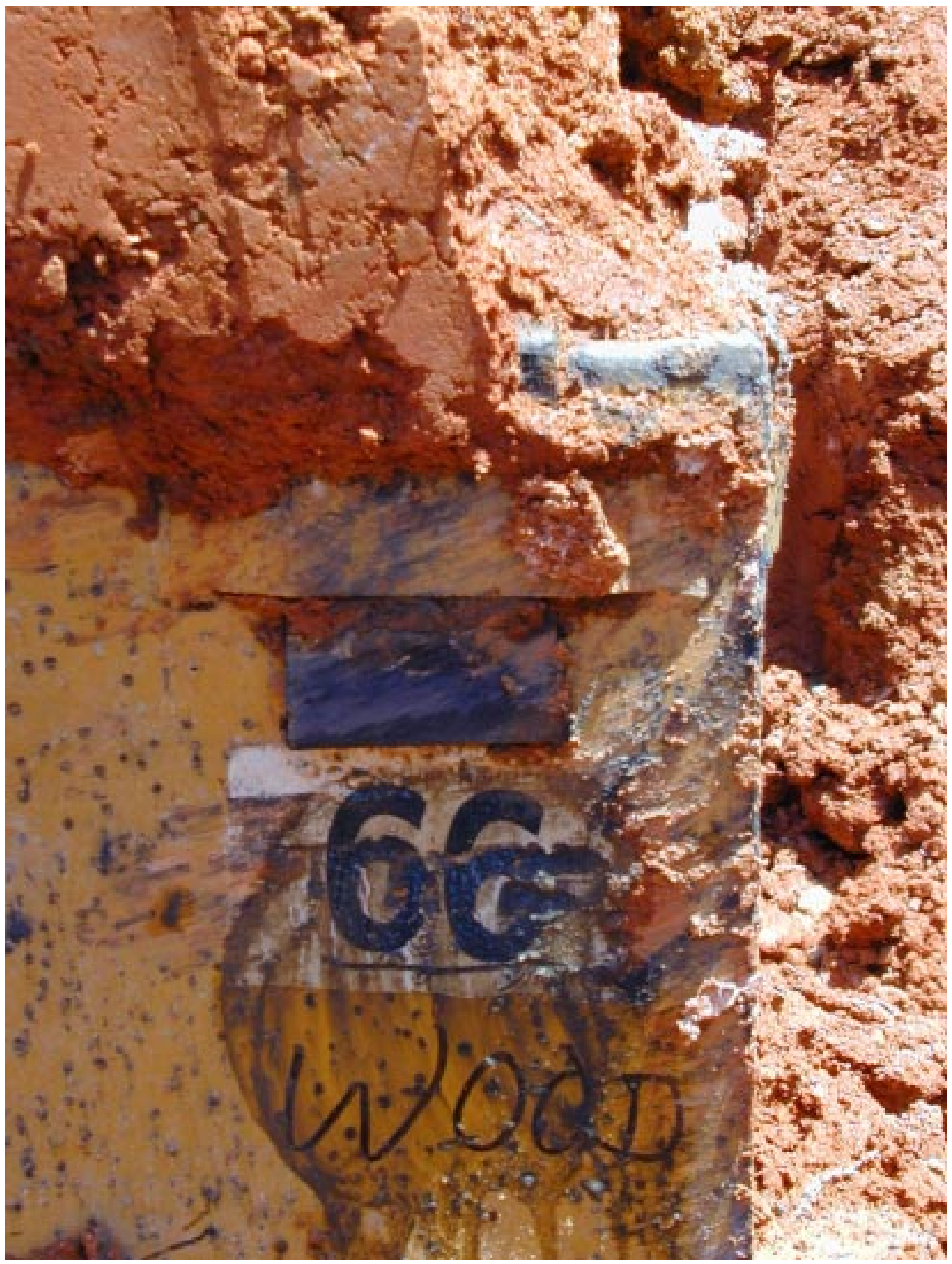

Figure C-22. B-25 west corner, northwest side, close-up, May 3, 2001. Dark corrosion product wiped off to expose container "66" designation. 


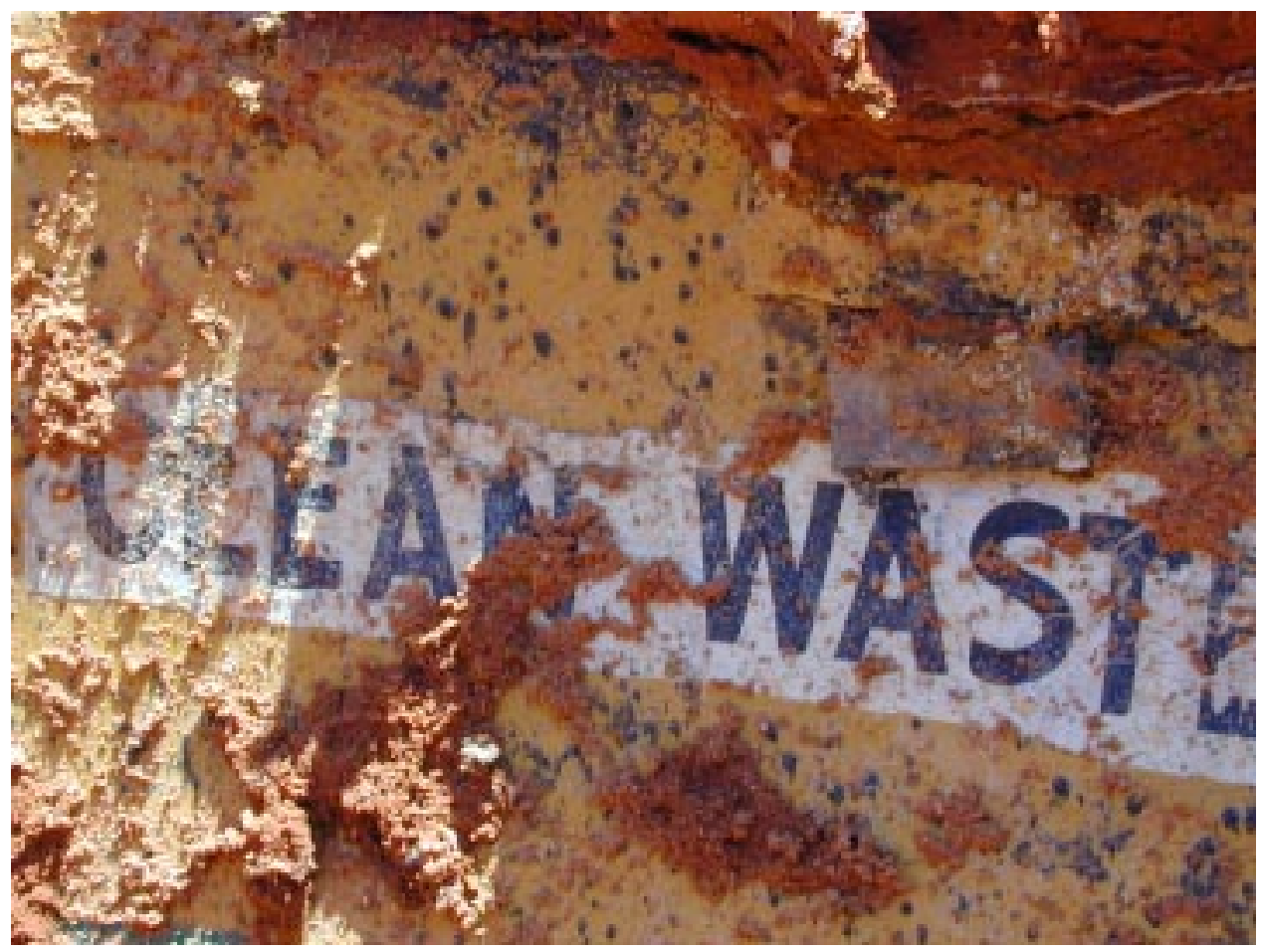

FigureC- 23. B-25 northwest side close-up, May 3, 2001. Note some blisters lacking paint covering, while other still covered by upwelled paint.

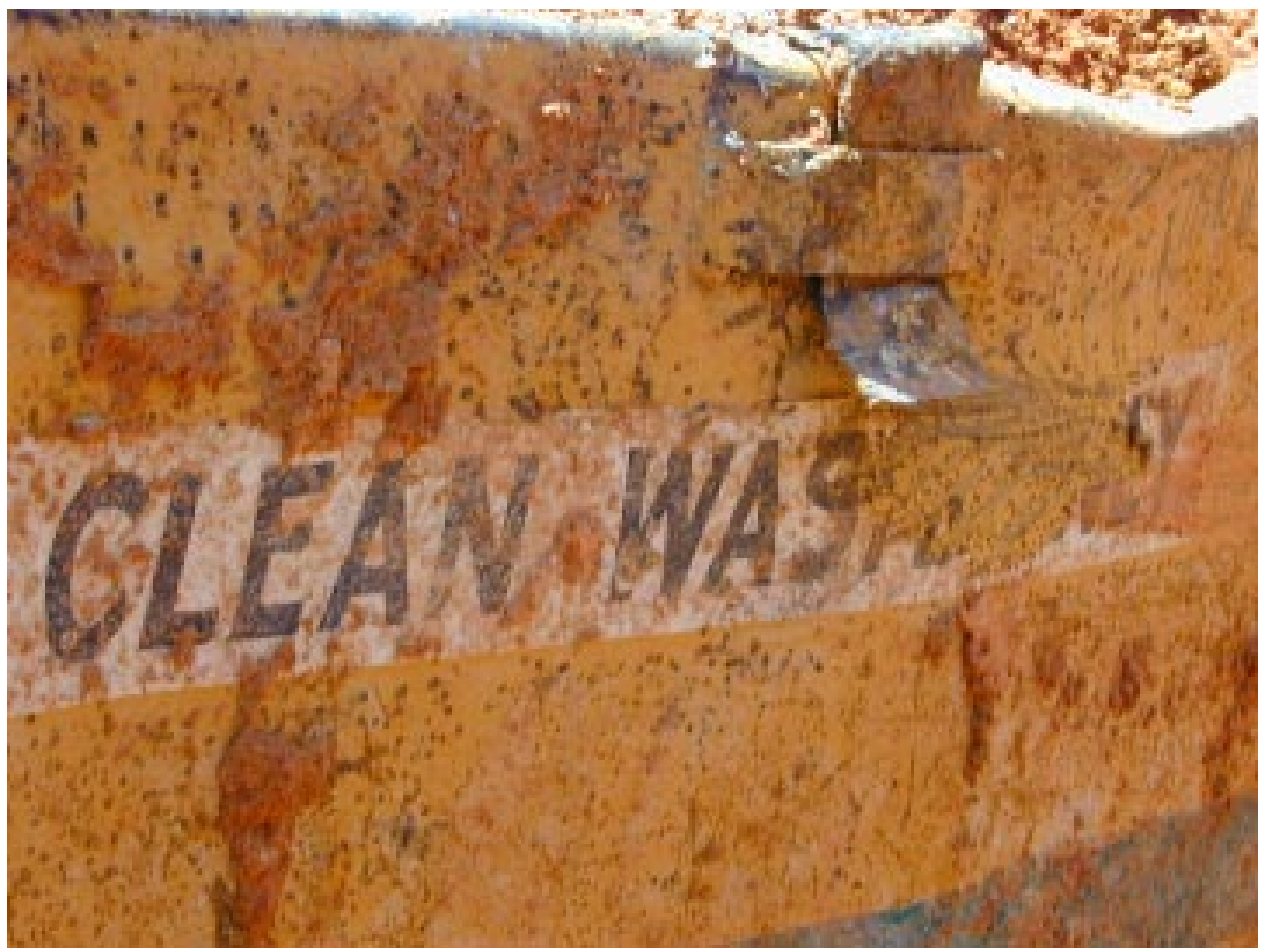

Figure C-24. B-25 southeast side close-up, May 3, 2001. Note some blisters lacking paint covering, while other still covered by upwelled paint. 


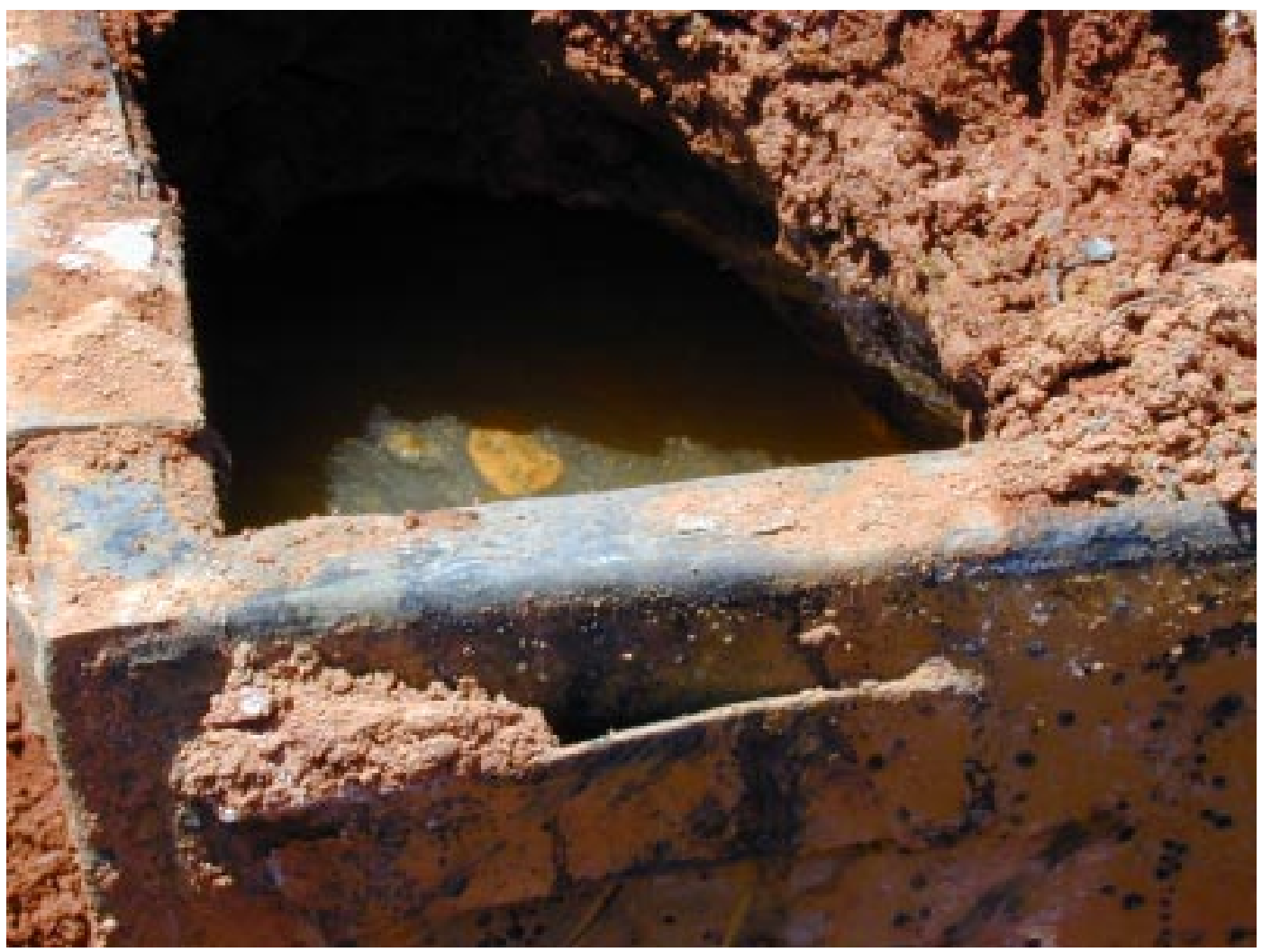

Figure C-25. B-25 south corner close-up, May 3, 2001. Note B-25 is full of water and soil. 


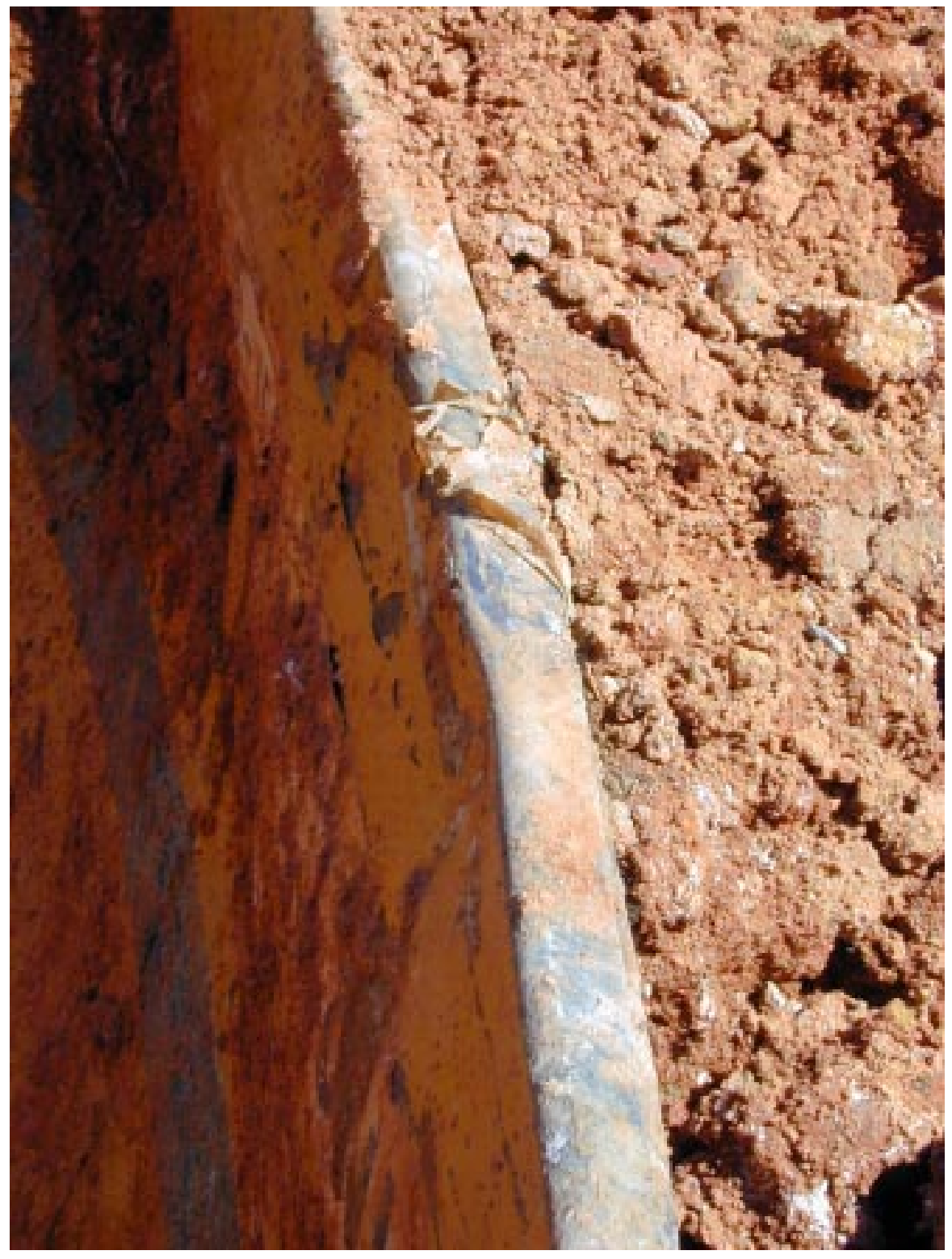

Figure C-26. B-25 upper edge. Top has been pushed down into B-25 and covered with soil. Note delaminated paint along edge. 


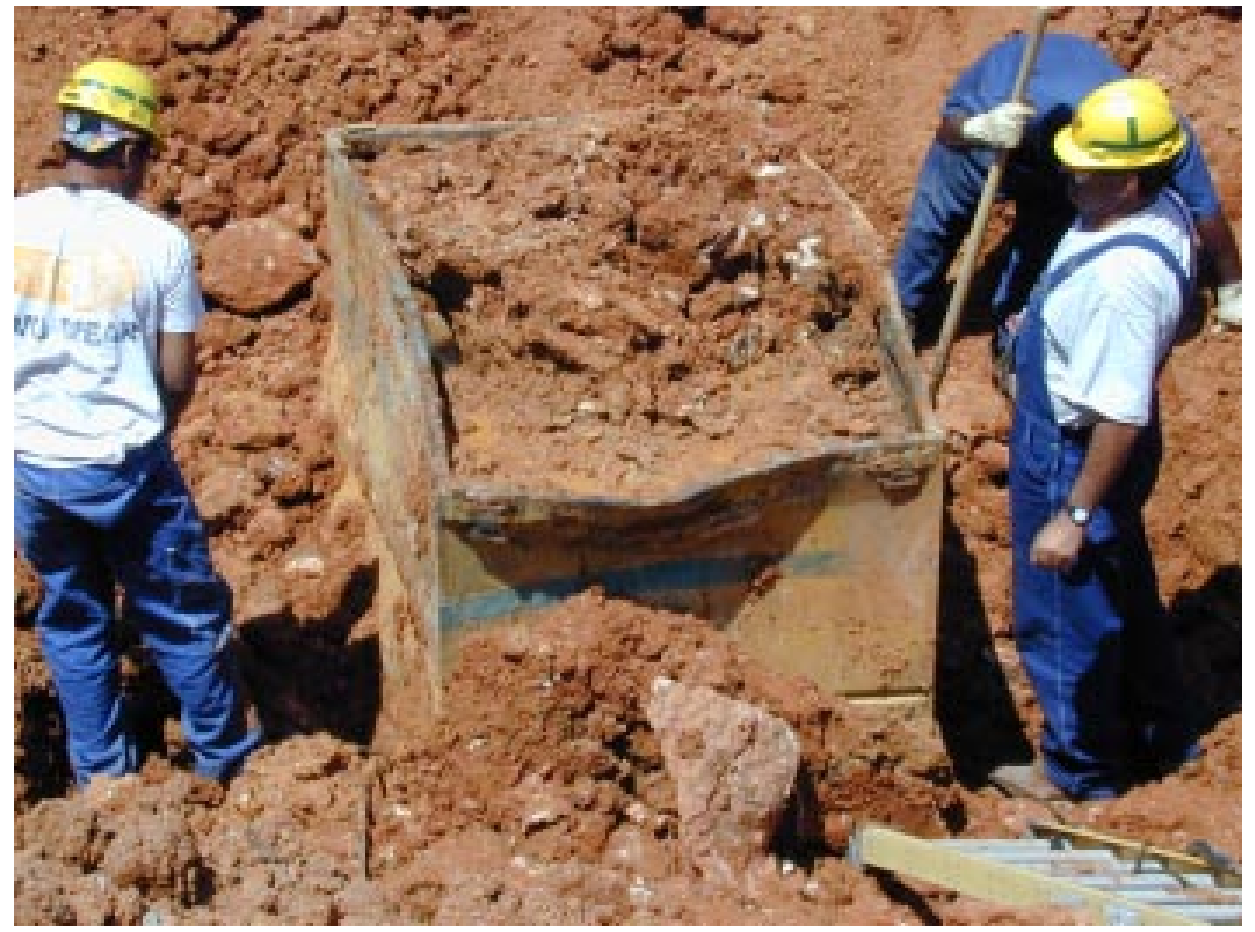

Figure C-27. B-25 being cleared for removal from excavation. Note water and soil within B-25.

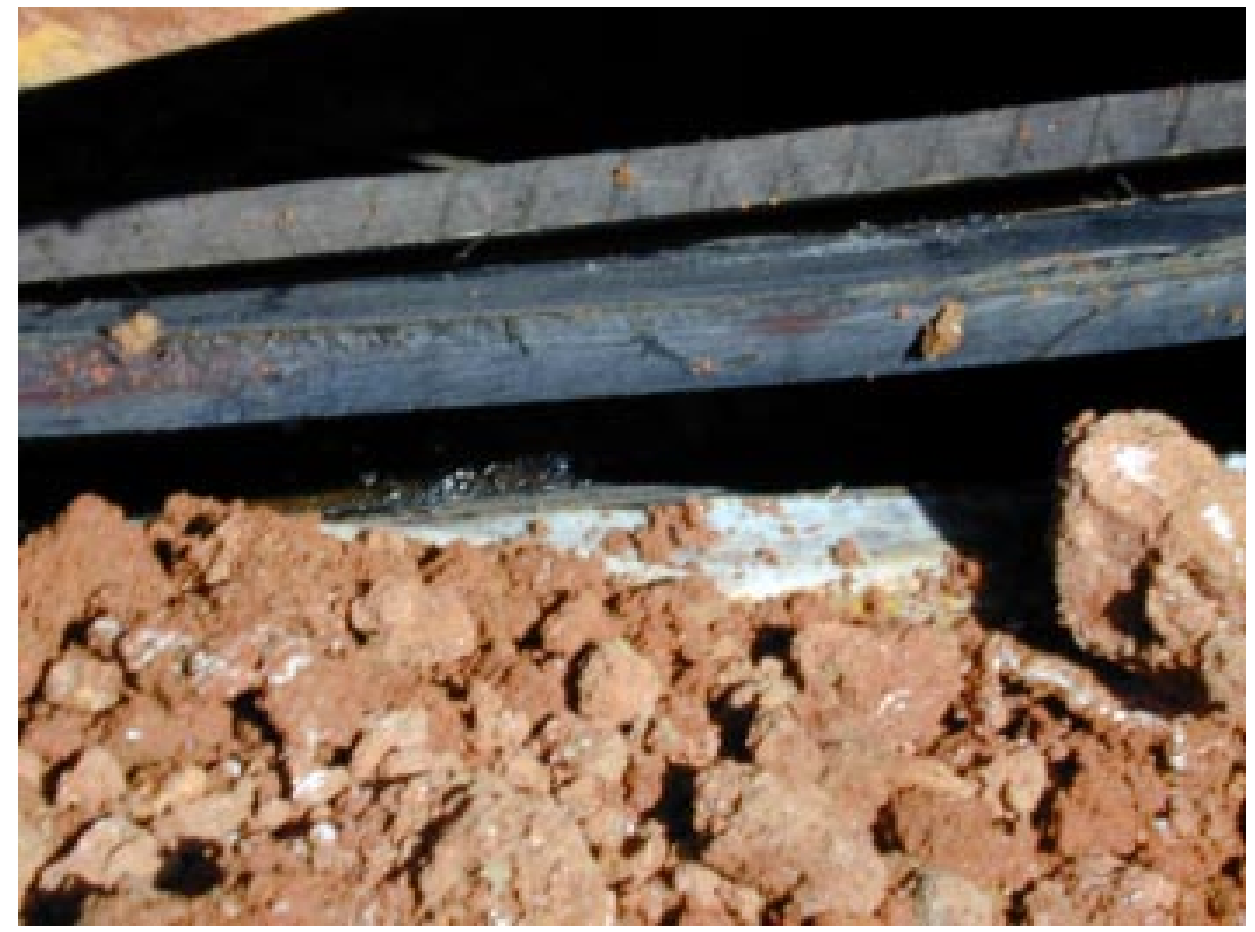

Figure C-28. Wood simulated waste within B-25 underlying the excavated B-25, northwest side.

Note wood's dark color and water within the underlying B-25 (about half-full of water). Interior of underlying B-25 also had obvious "landfill" odor. 


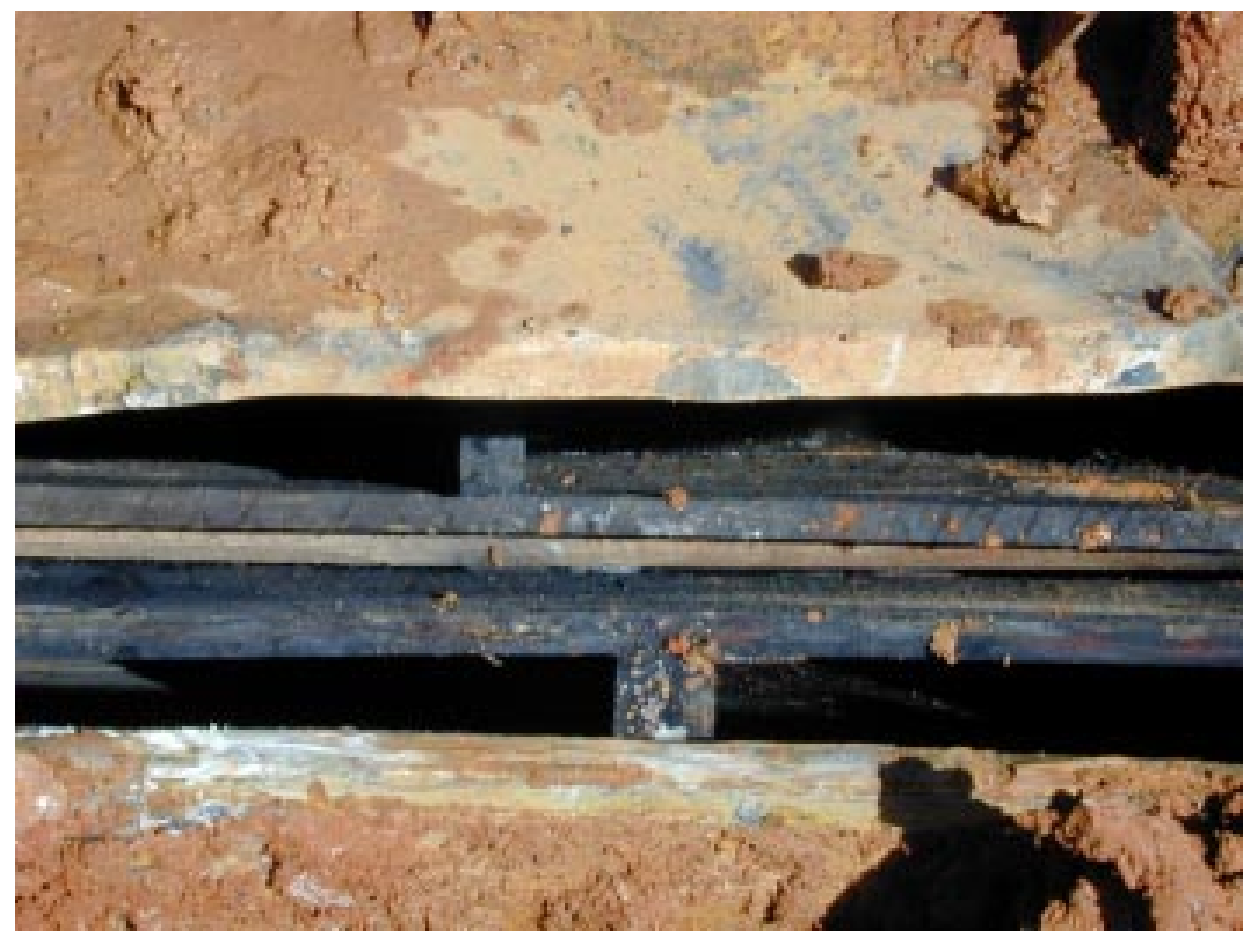

Figure C-29. Wood simulated waste within B-25 underlying the excavated B-25, northwest side. Note in-place saturated soil that has accumulated on lid of underlying B-25.

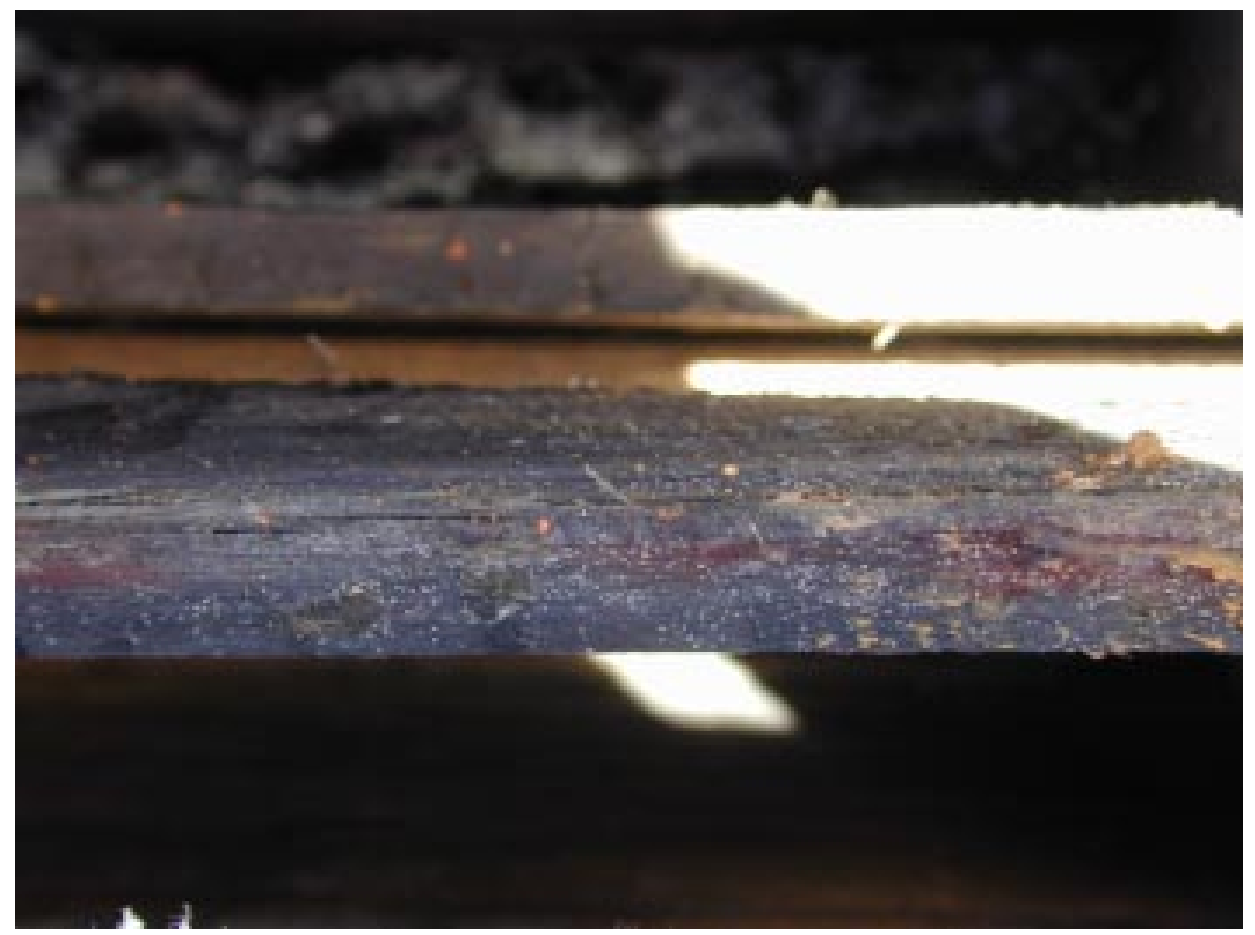

Figure C-30. Close-up of wood simulated waste within B-25 underlying the excavated B-25, northwest side. Water within underlying B-25 is visible along top of photograph. 


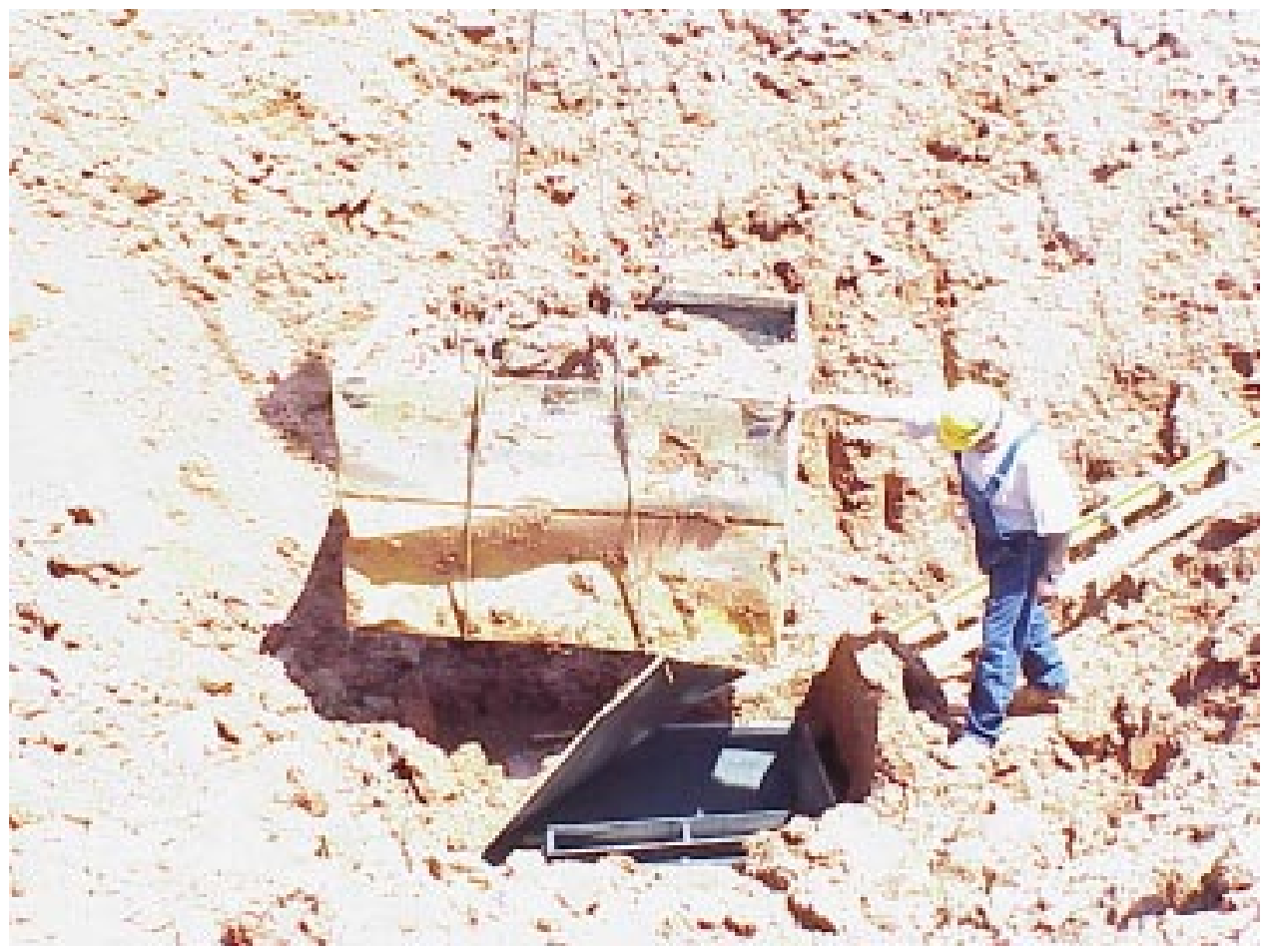

Figure C-31. Initial lifting of B-25. Cables inadvertently run through handles on top of underlying B-25 pulled its lid up. B-25 was lowered, and cables re-routed to leave underlying B-25 top in place.

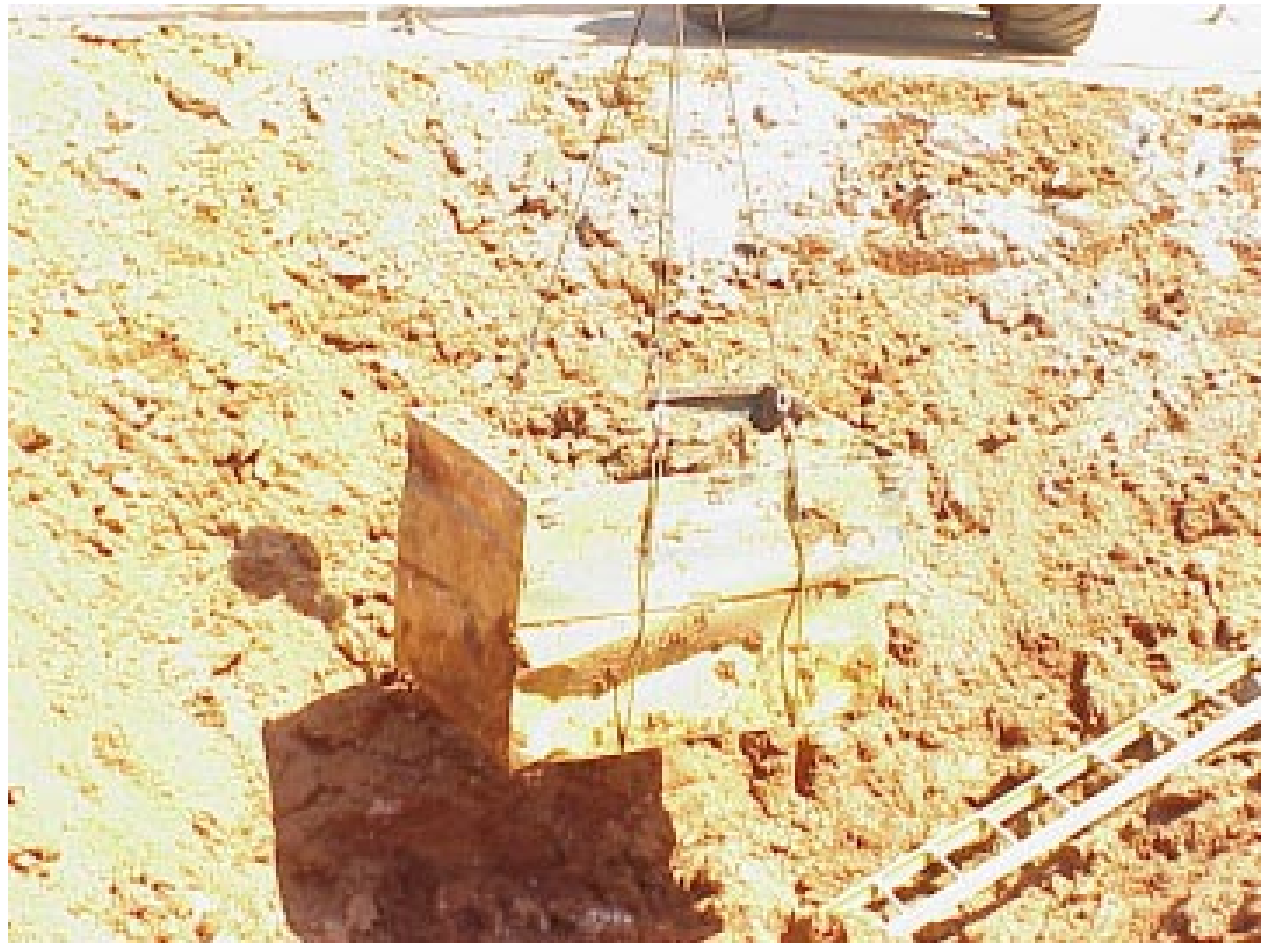

Figure C-32. B-25 being lifted from excavation. 


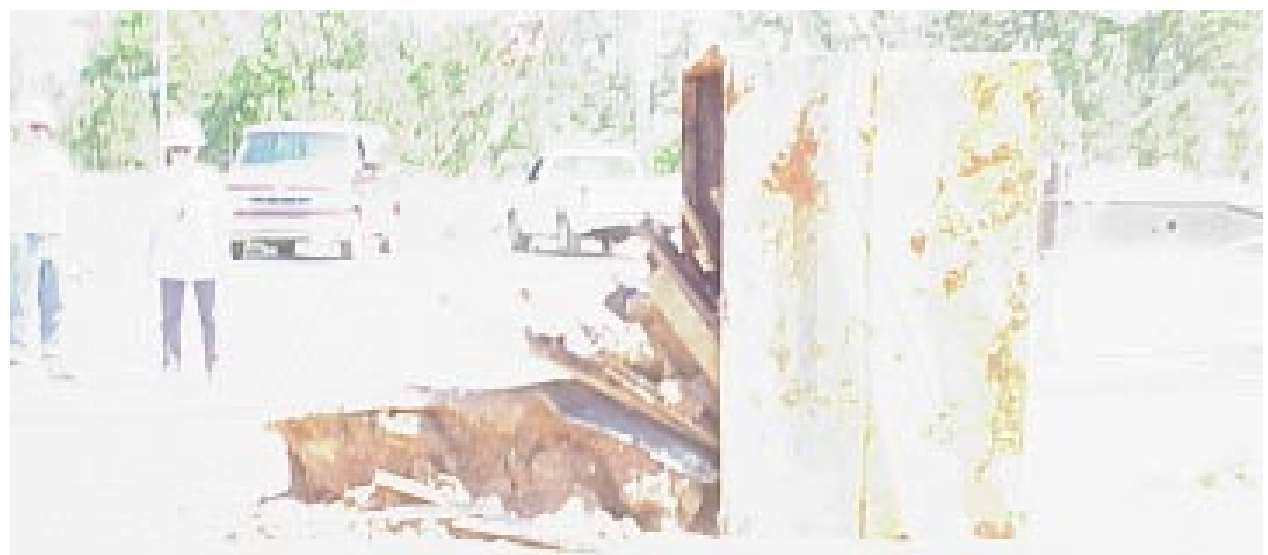

Figure C-33. B-25 turned on side at grade to remove soil and water to facilitate transport to laboratory. Note soil thickness approximately $2 \mathrm{ft}$. toward center of lid.
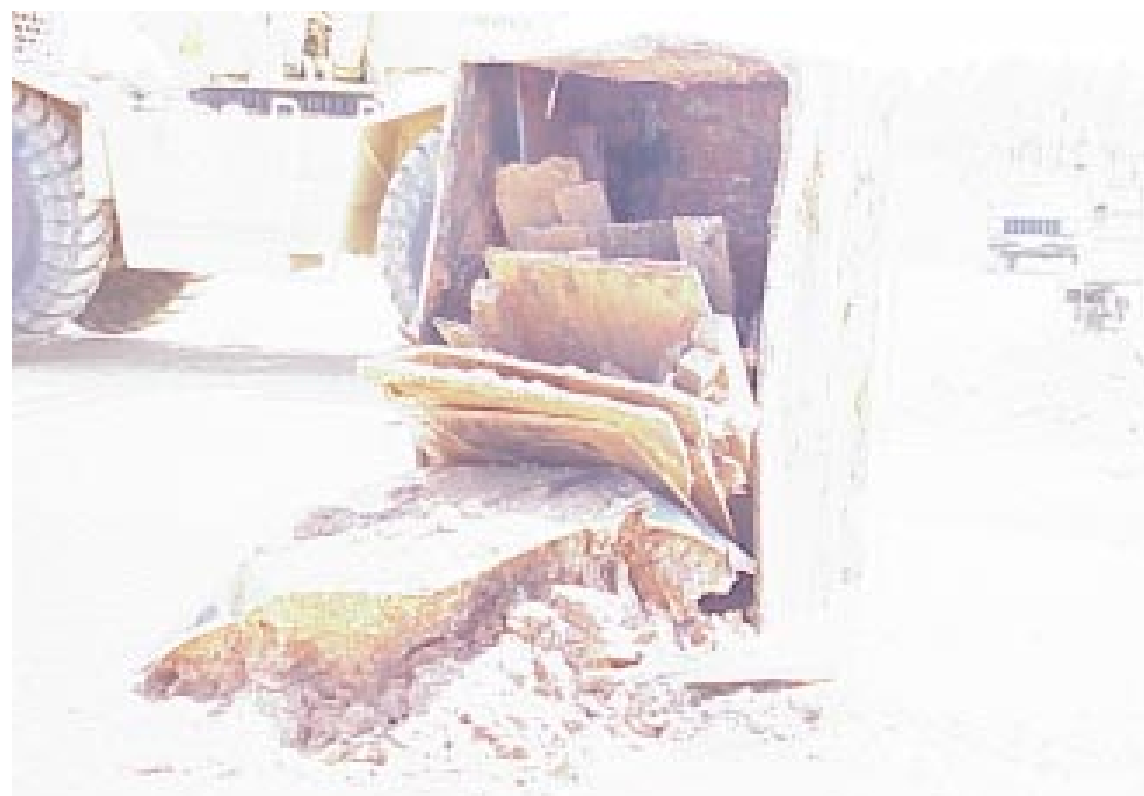

Figure C-34. B-25 turned on side at grade to remove soil and water to facilitate transport to laboratory. Note wood simulated waste material. 


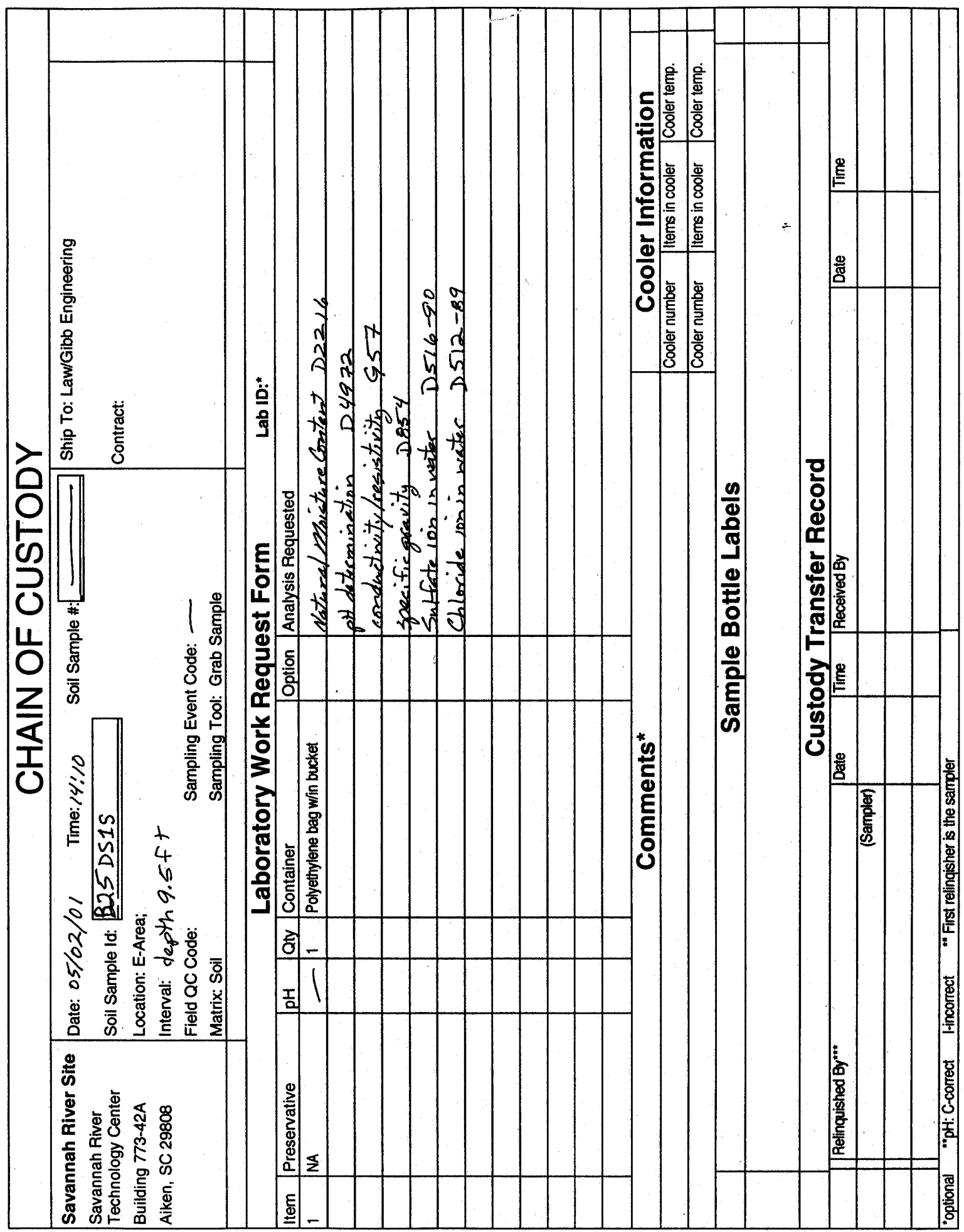

Figure C-35. Chain of Custody form for samples. 


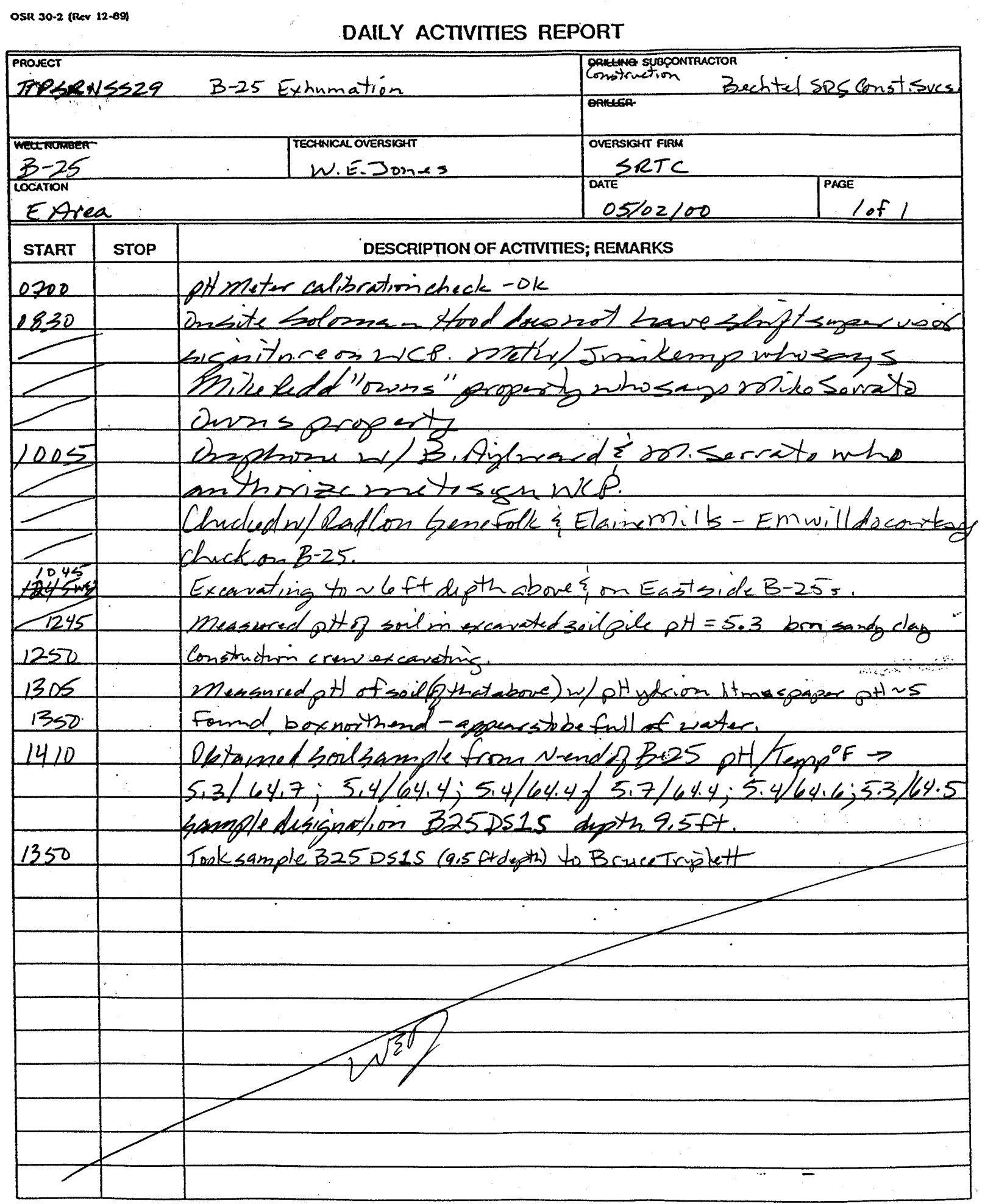

TECHNICAL OVERSIGHT SIGNATURE YNY

DATE $5 / 2 / 01$

Figure C-36. Daily Activities Report for May 2, 2001.

Page 258 of 298 
OSR 30.2 (Rev 12-69)

DAILY ACTIVITIES REPORT

\begin{tabular}{|c|c|c|c|}
\hline \multirow{2}{*}{\multicolumn{3}{|c|}{ PRONECT }} & \\
\hline \multirow{2}{*}{\multicolumn{3}{|c|}{ TTPSR IISS29 B-25 Exhnmation }} & Construction \\
\hline & & & \\
\hline \multicolumn{3}{|l|}{ etrater } & VERSIGHT FIRM \\
\hline \multirow{2}{*}{\multicolumn{3}{|c|}{$\frac{B-25}{\text { LOCATON }}$}} & \\
\hline & & & $05 / 03 / 01$ \\
\hline STA & & \multicolumn{2}{|c|}{ DESCRIPTION OF ACTIV } \\
\hline & & \multicolumn{2}{|c|}{ Arrived wodksite. Backhoe oporator clearing overburden. } \\
\hline 0725 & & \multicolumn{2}{|c|}{ Phoned Bruce Triplettere: grab solbamplefrom yestiorday } \\
\hline & & \multicolumn{2}{|c|}{ Checked pHt of soil (reddish brown sandy clay) excanated from $\sim 6$ Af dopth } \\
\hline & & \multicolumn{2}{|c|}{$p H \sim 5$ to 6 by pttpaper (itmuspagece). } \\
\hline 07 & & \multicolumn{2}{|c|}{ North side of box expesed s, pheto grephed - a pears to be m jovodshagee - } \\
\hline & & \multicolumn{2}{|c|}{ 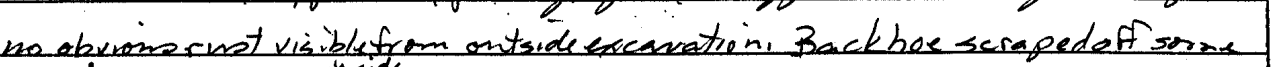 } \\
\hline & & \multicolumn{2}{|c|}{ 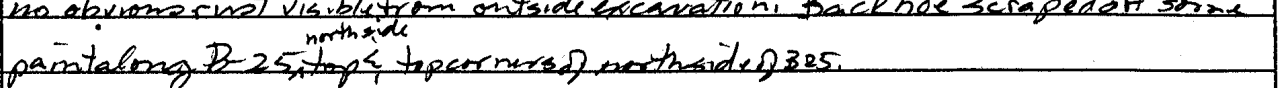 } \\
\hline & & \multicolumn{2}{|c|}{ Kerry Dunn onsite w/tuchniciesis. } \\
\hline 30 & & \multicolumn{2}{|c|}{ 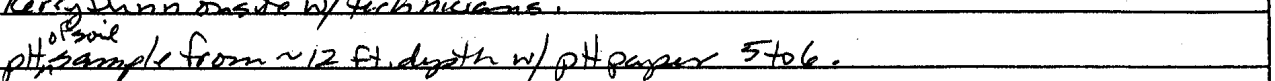 } \\
\hline & & \multicolumn{2}{|c|}{ Pulled ont $3-25^{*}$ - topef, and r ly in box beconcom in upelue } \\
\hline & & \multicolumn{2}{|c|}{ 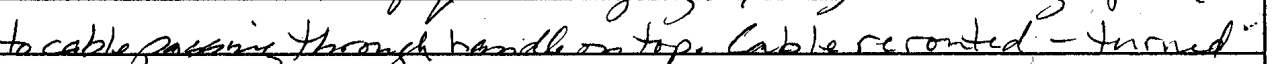 } \\
\hline & & \multicolumn{2}{|c|}{ 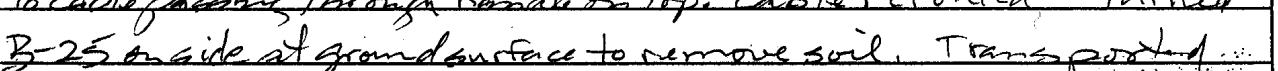 } \\
\hline & & \multicolumn{2}{|c|}{ To Aprea ato Red Con swiped 1 OK'd. } \\
\hline & & \multicolumn{2}{|c|}{ * Little to no rnst observed on $3-25$ remoured $(B-25$ had \#66 on } \\
\hline & & \multicolumn{2}{|c|}{ upper right western side w/. "Wood" "iand invrittenl. Dutur coat of } \\
\hline & & \multirow{2}{*}{\multicolumn{2}{|c|}{ 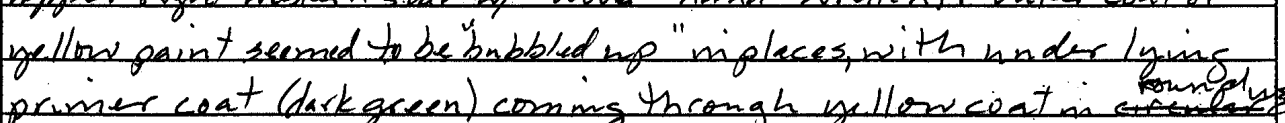 }} \\
\hline & & & \\
\hline & & \multicolumn{2}{|c|}{ "buckshot" puttern. Topof upperbox (exhumed box) was in side the } \\
\hline & & \multirow{2}{*}{\multicolumn{2}{|c|}{ B-25, 2 /suil s, water above, goil, water is wood sminulated }} \\
\hline & & & \\
\hline & & \multicolumn{2}{|c|}{ 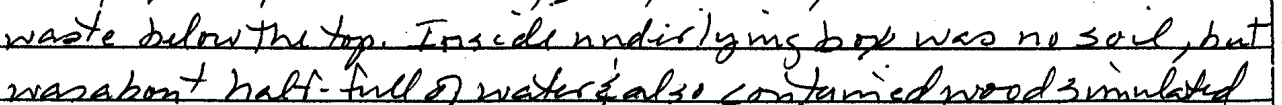 } \\
\hline & & \multicolumn{2}{|c|}{ waste. Wood in both breses was b/ack to b/uc-black. Obviowo } \\
\hline & & \multicolumn{2}{|c|}{ "Iand fill" ador from buth boxe. The top of the Bax westo the } \\
\hline & & \multicolumn{2}{|c|}{ 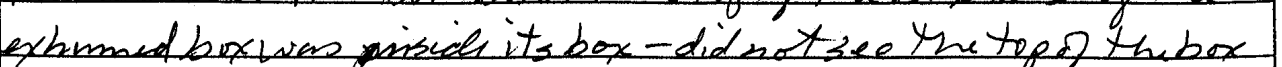 } \\
\hline & & \multicolumn{2}{|c|}{ 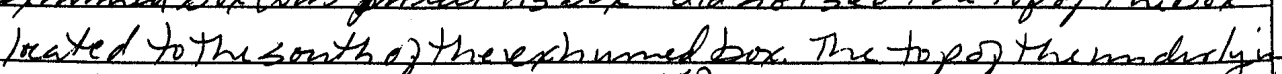 } \\
\hline & & \multicolumn{2}{|c|}{ 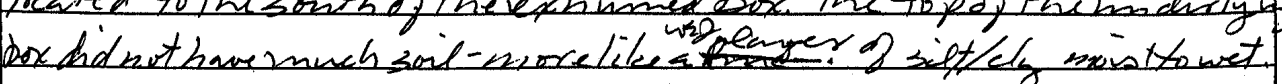 } \\
\hline & & & \\
\hline & & & \\
\hline
\end{tabular}

TECHNICAL OVERSIGHT SIGNATURE

1270 DATE $15 / 03,101$

Figure C-37. Daily Activities Report for May 3, 2001. 
This page intentionally left blank.

Page 260 of 298 


\title{
APPENDIX D
}

\section{PROCUREMENT SPECIFICATIONS}

\author{
BURIAL BOX SPECIFICATION \\ PROJECT PROBLEM No. 2-8200 \\ Revision No. 10 \\ November 12, 1986
}

C-SPP-G-00101

LOW LEVEL WASTE B-12 AND B-25 BOX SPECIFICATION

Revision 5

May 29, 2001 
This page intentionally left blank. 


\section{TABLE OF CONTENTS}

BURIAL BOX SPECIFICATION - 1986 ................................................................................. 265

LOW LEVEL WASTE B-12 AND B-25 BOX SPECIFICATION .............................................. 271 
This page intentionally left blank. 
OsR $34 n$

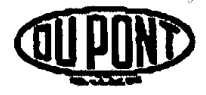

\section{INTER-OFFICE MEMORANDUM}

sayannah River Plant

November 12,1986

TO: B: L. GODWIN, 742-A

$P$ \& GS DEPARTMENT

EROM: T. J. H. POSEY, 706-E

LOW LEVEL WASTE BURIAL BOXES

Burlal box purchase orders placed during the next six months should refer to the atcached burial box Specification (Revision No. 10) and SRP Drawing S4-G-183 (Revision No. 13). Revision 10 increases the vendor supply to 200 boxes per week. Revision 13 adds closure design, Detail ' $v$ '. If there. are any questions please call me at 74491 .

T.JHP: kshy

CC: L. C. Thomas, $724-7 G$ ?

T. A. Drew, 703-F

T. L. Hendrix, 773-A

C. V. Lester, 221-10F

R. M. Damm, 773-A

R. O. Pekkala, 707-C

G. H. Street, 706-F

J. W. Jennings, 706-F

J. W. Crichton, Jr., 703-A

J. E. Haywood, 703-F

R. F. Mayock, 703-A 
BURIAL BOX SPECTFICATION

PROJECT EROBLEM NO. 2-8200

DATE: November 12, 1986

REVISION NO. 10

Page 1 of 4

\section{IDENTIFICATION}

Low-Level Waste Burial Boxes

\section{GENERAL}

The following specification describes the requirements for a carbon steel burtal box for low-level solid waste. Refer to Du Pont drawing S4-G-183 (Rev. 13). This box is not designed for use in a compactor.

\section{CONSTRUCTION}

Material: Carbon Steel, ASTM A-569.

Th1ckness: 14 gauge.

Size; Outside dimensions of burial box (without lid) to be 6'-0" long $x$ $3^{\prime}-10^{\prime \prime}$ wide $\times 3^{\prime}-11^{\prime \prime}$ high. All tolerances to be $\pm 1 / 4^{\prime \prime}$.

Capacity: 5,000 Ibs. (solid-11ke material)

Serength: Burlal box (when half fllled) must be able to support a uniform load of four times the capacity on its top. Vendor to provide stiffeners or crimping as specified on drawing. All relnforcing must be to the interior of the box.

Lid: The lid shall be fabricated to allow. removal by a forklift. Handles shall be provided on each end of the 1fd to allow manual guiding and lifelng of Ifd by personnel. The Ild lifting lugs and handles must be posicioned as to not interfere with box scacking. Provisions must be made to ensure fast positive sealing of $11 d$ to the burfal box in order to retain contente, seal against weather, and reduce radiation exposure while sealing. Vendor must use closure design shown on S4-G-183 or design approved by Du Pont.

Gisker: A 1/2" thick $\times 1^{\prime \prime}$ wide gasket, closed-cell neoprene (ASTM D-1056-73, Grade $C E-41$ ), shall be provided on the lid. Gasket should have removable tape to prevent gasket from sticking to box rim until lid is removed prior to filling.

Welding: All welding shall be in accordance with requirements of ASME Section IX.

Lifeing Provisions: Means to facilitate safe handling of burial box by forklife must be provided on bottom of box. 
BURIAL BOX SPECIFICATION

PROJECT PROBLEM NO. 2-8200

DATE; November 12, 1986

REVISION NO. 10

Page 2 of 4

\section{CONSTRUCTION Continued}

Finlsh: Interior and excerior of burial box and lid must be free of all burrs and sharp edges. A zinc chromate primer is to be applied to che interior of the box. Exterior of box shall have a zinc chromate primer with a top coat of alkyd enamel. Finish color to be high visibility yellow. Du Pont shail approve protective coating procedure prior to fabrication.

\section{MISCELLANEOUS}

Storage: Burial boxes to be stackable (up to four high) when filled.

Quotation: The quotation shall include six (6) copies of detail drawings for Du Pont approval. Drawings must show materials, dimensions and typical weld detalls.

Dellvery: Vendor must be capable of supplying 200 boxes per week on demand. Marking: The following information must be stenciled on each box:

1. Empty weight (for example, $3501 \mathrm{~b}$. )

2. Volume (for example, $90 \mathrm{ft}^{3}$ )

3. Pay load - (for examp1e, 5000 Ib.)

4. Total Pay load - (for example, 5350 1b.)

5. DO NOT place cadmium, lead, or mercury in this box.

\section{INSPECTION}

Inspection of random samples of burial boxes to be performed at the verdor's site in accordance with the attached inspection specification. 
PROJECT PROBLEM NO. 2-8200

DATE: November 12, 1986

REVISION NO, 10

Page 3 of 4

\section{INSPECTION SPECIFICATION}

Inspection - Burial Boxee

1.0 Opportunity to inspect this equipment by a Du Pont Quality Assurance Field Representative (QAFR) is required prior to shipment in accordance wich the following instructions. Notify Quality Assurance Engineering Scheduling at least 48 hours before each inspection is required by calling (302) 366-360I.

2.0 When major components or service are obcained from sub-vendors, the QAFR may inspect these items at the point of manufacture (witness point). It is the vendor's responsibility to include Du Pont inspection and notification requirements in sub-orders.

\subsection{Special Considerations}

3.1 Welders and procedures to be qualified per ASME.

3.2 A standing water test may be witnessed (witness polnt, minimum 5\%).

3.3 A uniform load test $(20,000$ 1bs.) may be witnessed (witness point, minimum 5\%). Box to be half full of sand or water.

3.4 The sealing technique shall be demonstrated for fast, positive sealing. A one-time demonstration will suffice but must be re-demonstraced when any revision in design is made by the vendor.

3.5 Removal of lid without damage to lid or gasket material.

4.0 Inspection Schedule (Vendor to request Inspection at the following points)

4.1 Preliminary - Vendor should completely fabricate only one box for inspection. Should box not meet specifications, changes can be made prior to fabricating a large quantiey of units. Du Pont may choose to walve preliminary inspection if fabricator has supplied boxes on previous orders.

4.2 Final - After fabrication and prior to painting of boxes.

5.0 Inspection lnstructions (The following inspections will be performed on $5 \%$ minimum of total order and may be witnessed by the QAFR)

5.1 Verify by review of.documentation that welders and procedures used were qualified per ASME Section IX.

5.2 Visually inspect welding for quality and for weld detall compliance to approved drawings. 
INSPECTION SPECIFICATION

PROJECT PROBLEM NO. 2-8200

DATE: November 12, 1986

REVISION No. 10

Page 4 of 4

5.3 Verify that ail edges and burrs are removed from interlor and exterior of box and lid.

5.4 Conduct 4-hour standing water test. Box to be filled a minimum of 6" deep with water. No leaks are permitted. If leaks are found, perform test on $10 z$ of total order. If further leaks are found, test 1007 of toral order. Any leaking boxes will be repaired by the vendor and retested (w/0 charge).

5.5 Conduct uniform load cest. Box shall be half full of sand or vacer.

5.6 Review surface preparation and painting requirements.

5.7 Check boxes for general dimensions and trial fic of lid. Verify materials and inspect box interior for no distortions greacer than $1 / 2^{\prime \prime}$ deformation.

5.8 Review sealing technique and effectiveness. A one-time dimensional check of the sealing design is required to insure gasket compression of 20-30z.

5.9 Check boxes to assure that .11d can be removed without gasket materlal adhering to box rim. LId and gasket material must not show damage during this procedure. Perform test on $5 \%$ of total order.

\subsection{Document rest results.}

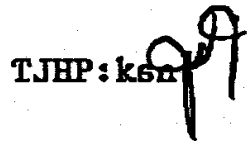


This page intentionally left blank. 


\section{LOW LEVEL WASTE B-12 AND B-25 BOX SPECIFICATION}

OSR 45-10 (Rev 12-28-95)

\section{Procurement Specification Cover Sheet}

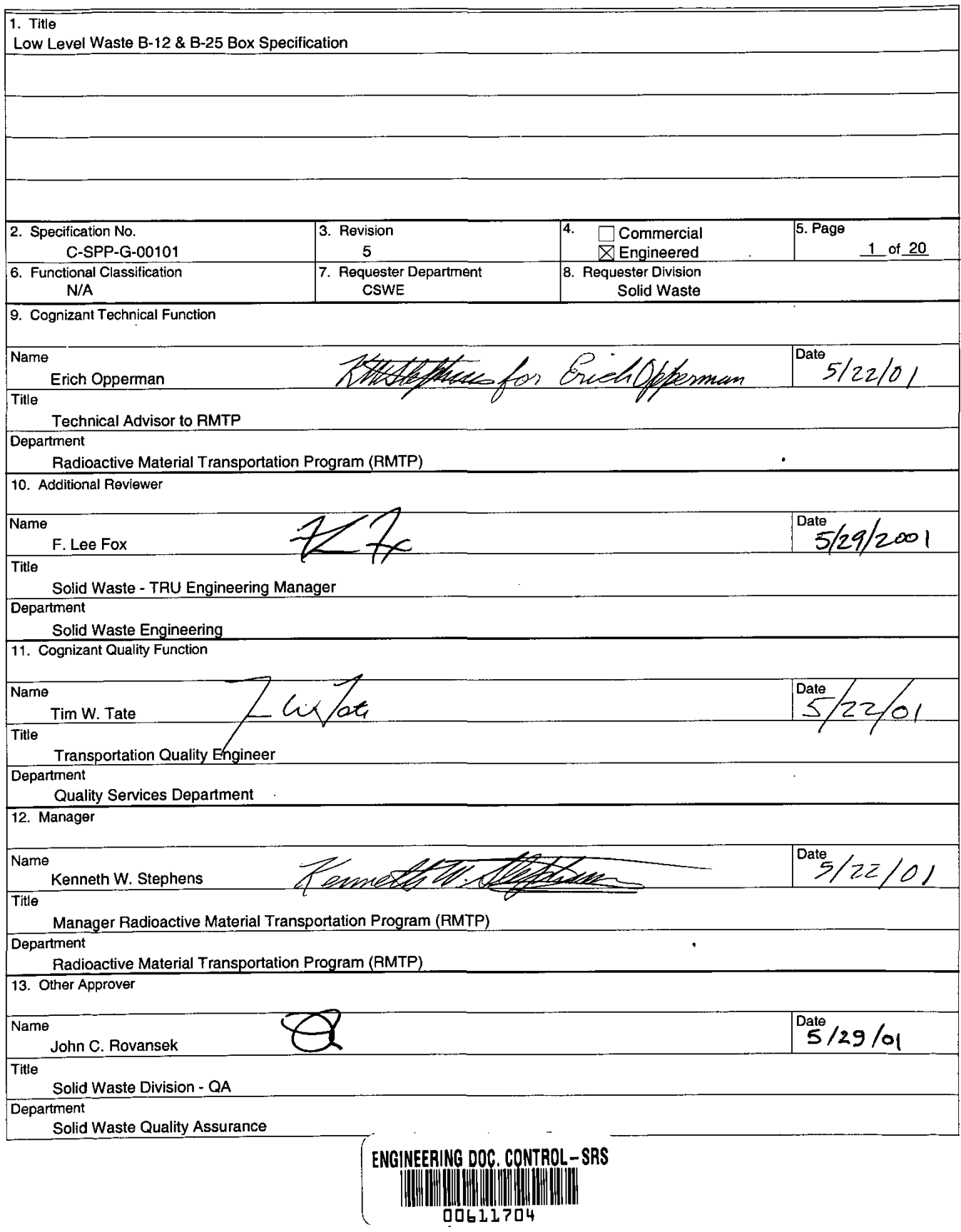

Page 271 of 298 
OSR 45-9\# (Rev 12-28-95)

\section{Standard Procurement Specification Revision History Sheet}

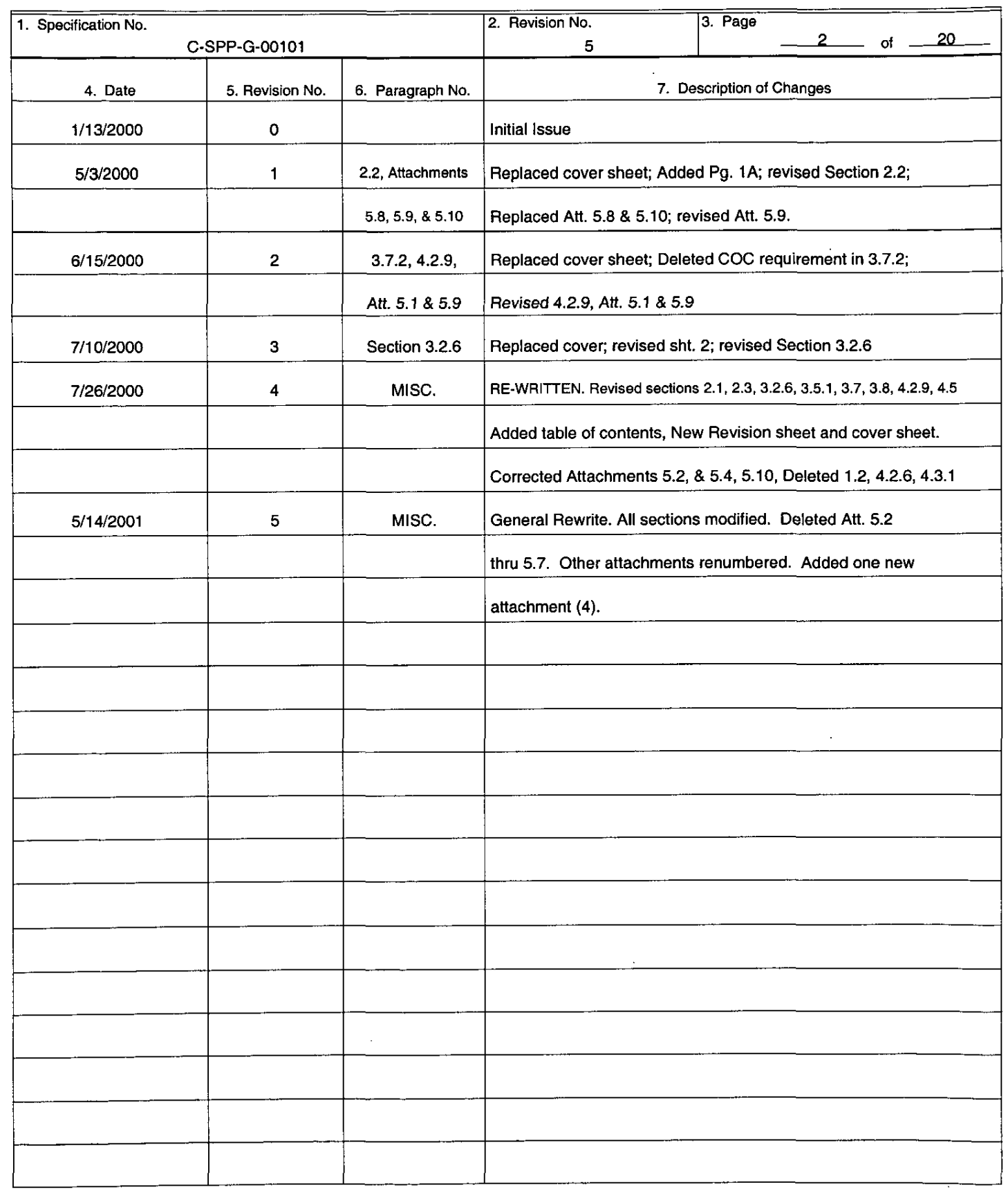


TABLE OF CONTENTS

1.0 SCOPE

1.1 General Description of the Item

1.2 Background

2.0 REFERENCES

2.1 Definitions

2.2 Codes/Standards/Orders/Regulations

3.0 ITEM REQUIREMENTS

3.1 Performance Requirements

3.2 Design Requirements

3.3 Service Conditions

3.4 Fabrication and Assembly Requirements

3.5 Quality Requirements

3.6 Personnel Qualifications/Certifications

3.7 Deliverables (Including Submittals)

3.8 Packaging, Shipping, Handling, and Storage Requirements_ 12

3.9 Marking and Identification Requirements__ 12

3.10 Exceptions____ 13

4.0 ACCEPTANCE OF ITEM__ 14

4.1 Final Acceptance Method

14

4.2 Inspection/Testing Requirements

4.3 WSRC Surveillance and Audits 17 
Low Level Waste B-12 \& B-25 Box Specification Procurement Specification No. C-SPP-G-00101, Revision 5

Page 4 of 20

\subsection{SCOPE}

\subsection{General Description of the Item}

This specification covers design, fabrication, assembly, inspection, test and delivery of Low Level Waste leak proof (B-Series) metal boxes. These boxes are to meet Department of Transportation (DOT) requirements specified in section 2.2.1. Two sizes of boxes are required as described below:

1.1.1 Box B-12 (45 Cu. Ft. nominal)

1.1.2 Box B-25 (90 Cu. Ft. nominal)

\subsection{Background:}

Boxes are used for packing, transporting and storage of Low Level Solid Radioactive Waste, low specific activity (LSA) material, or surface contaminated objects (SCO) containing not more than $1 \%$ liquid by volume.

\subsection{REFERENCES}

\subsection{Definitions}

WSRC - Westinghouse Savannah River Company and its representatives SSR - Source Surveillance Representative

\subsection{Codes / Standards / Orders / Regulations}

\subsubsection{Codes/Regulations}

Title 49 CFR 173.410

\subsubsection{Standards}

Use of any other edition, revision, or issue requires approval by WSRC.

- ASTM A569-93, Steel, Carbon (0.15\%) Hot-rolled, Sheet and Strip, Commercial Quality

- ASTM D1056-98, Specification for Flexible Cellular Materials

- AWS D1.1-98, Structural Welding Code-Steel

- AWS D1.3-98, Structural Welding Code-Sheet Metal

- 1998 ASME Boiler and Pressure Vessel Code, Section IX, Welding and Brazing Qualifications 
Low Level Waste B-12 \& B-25 Box Specification Procurement Specification No. C-SPP-G-00101, Revision 5 Page 5 of 20

\subsection{ITEM REQUIREMENTS}

\subsection{Performance Requirements}

Each box shall be capable of holding (without release) its contents of radioactive waste during transportation and storage.

\subsection{Design Requirements}

Boxes are to be designed and built in accordance with 49 CFR 173.410 requirements and this specification. Based on the following information, Supplier to provide Box Fabrication Drawings to WSRC for approval in accordance with Attachment 3.

\subsubsection{Box Dimensions}

Attachment 1 provides suggested design criteria for both boxes.

Note: Box configuration given in Attachment 1 (relative to length, width and height) is essential for WSRC use. Fabrication drawings will be reviewed by WSRC to ensure this relative configuration is maintained.

\subsubsection{Box Capacity}

1. Each $\mathbf{B}-\mathbf{1 2}$ box shall be capable of holding five-thousand pounds $(5,000 \mathrm{lbs})$ of solid radioactive waste (with not more than one percent $(1 \%)$ liquid by volume).

2. Each $\mathbf{B}-25$ box shall be capable of holding six-thousand pounds $(6,000 \mathrm{lbs})$ of solid radioactive waste (with not more than one percent ( $1 \%$ ) liquid by volume).

\subsubsection{Box Strength}

Each box shall be capable of being stacked five (5) high. The bottom box shall support:

1. For a B-12 box twenty thousand pounds $(20,000$ lbs.) payload plus box and lid weights with minimal distortion of the side wall (ref. Section 4.2.6 Uniform Load Test requirements).

2. For a $\mathbf{B}-\mathbf{2 5}$ box twenty-four thousand pounds (24,000 lbs.) payload plus box and lid weights with minimal distortion of the side wall (ref. Section 4.2.6 Uniform Load Test requirements). 
Low Level Waste B-12 \& B-25 Box Specification Procurement Specification No. C-SPP-G-00101, Revision 5

Page 6 of 20

\subsubsection{Closure Mechanism}

1. Supplier shall submit a Closure Mechanism Design to WSRC for approval in accordance with Attachment 3.

2. Provisions shall be made to ensure fast, positive closure of the lid to the box:

a. Closure mechanism shall achieve twenty percent $(20 \%)$ minimum compression of the gasket between the lid and box after closure.

b. Supplier shall identify to WSRC the methods and objective data substantiating that this requirement has been met.

3. Closure mechanism shall not interfere with the box stacking capabilities.

4. Supplier shall deliver Closure Instructions to WSRC with each shipment in accordance with Attachment 5.

\subsubsection{Lifting}

1. Each box shall be configured to allow for manipulation of the box with a fork truck.

2. Boxes, whether empty or loaded, shall NOT be lifted by the lid.

3. The lid shall be configured to allow lifting of the lid off the box by either hand or fork truck (using lid lifting lugs or lid handles shown on Attachment 1).

4. Neither configuration shall interfere with the stacking capabilities of the box.

Note: Removable eyes and/or lifting lugs shall NOT be considered as a viable alternative to manipulate these boxes. The outer box support legs shall be located at least 2 " in from the 3'-10" side of the box for convenience in installing rope/sling for lifting (See Attachment 1).

\subsubsection{Finish}

1. Box surfaces shall be primed with a primer that is a rust inhibitor (minimum dry film thickness of $2.0 \mathrm{mil}$ ).

2. The box exterior shall be painted with a compatible alkyd enamel finish (minimum dry film thickness of 1.25 mil).

3. Outer color shall be yellow or gray as required by WSRC.

4. The resultant cured coating shall be RCRA non-hazardous. 
Low Level Waste B-12 \& B-25 Box Specification Procurement Specification No. C-SPP-G-00101, Revision 5 Page 7 of 20

5. Supplier shall submit the Material Safety Data Sheet (MSDS) for each type of coating to WSRC for review in accordance with Attachment 3.

6. Supplier shall submit Cleaning and Coating Procedures and a Coating Repair Procedure to WSRC for approval and use in accordance with Attachment 3.

7. Supplier shall verify dry film thickness and deliver a Dry Film Thickness Report to WSRC in accordance with Attachment 5.

\subsection{Service Conditions}

These boxes may be subjected to transportation vibrations, pressures due to temperature rise and fall, and various weather conditions (typical for the Southeastern U.S.) due to being transported/stored outdoors.

\subsection{Fabrication and Assembly Requirements}

Supplier shall submit Fabrication and Inspection Procedure(s) to WSRC for approval in accordance with Attachment 3.

\subsubsection{Materials of Construction}

1. All equipment, material, and articles incorporated in the work covered by this specification shall be:

- new and unused

- free from defects that would adversely affect the performance or maintainability of individual components across the overall assembly of this box

2. Materials not specified herein shall be of the same quality as materials used for the intended purpose in commercial practice.

3. Sheet metal shall be a minimum of 12-gauge carbon steel, ASTM A569-93.

4. Unless approved by WSRC, no material of foreign origin shall be used in the manufacture of these boxes.

\subsubsection{Steel Fabrication}

1. Steel shall be free from kinks, sharp bends, and other conditions that would be deleterious to the finished product.

2. Fabrication processes shall not reduce the strength of the steel to a value less than required by design.

3. All bends shall be made by controlled means to ensure uniformity of size and shape. 
Low Level Waste B-12 \& B-25 Box Specification Procurement Specification No. C-SPP-G-00101, Revision 5 Page 8 of 20

\subsubsection{Welding}

1. Welding, weld procedures and weld inspection procedures shall be in accordance with AWS D1.1, AWS D1.3 or ASME Section IX as appropriate. For weld procedures and weld inspection procedures, the Supplier shall identify the specific code(s) applicable to the work.

2. Welding shall be as follows:

- surface of parts to be welded shall be free from rust, scale, paint, grease, or other foreign matter

- welds shall be of sufficient size and shape to develop the full strength of the parts connected by the weld

- welds shall transmit stress without permanent deformation or failure when the parts connected by the weld are subjected to proof and service loading

- no weld shall be less than $3 / 32$ "

3. Supplier shall submit Weld Procedures and Weld Inspection Procedures to WSRC for approval in accordance with Attachment 3.

\subsubsection{Gasket}

1. Material shall meet ASTM D1056-98.

2. Documentation of Shelf Life for Neoprene Gasket shall be provided to WSRC with each shipment in accordance with Attachment 5, and identify the following:
a. Date of manufacture (cure date)
b. Shelf-life of gasket prior to installation
c. Useful life of gasket after installation/compression
d. WSRC Purchase Order Number

\subsubsection{Spare Parts}

Supplier shall submit a Spare Parts List with related data for ordering in accordance with Attachment 3. 
Low Level Waste B-12 \& B-25 Box Specification Procurement Specification No. C-SPP-G-00101, Revision 5 Page 9 of 20

\subsection{Quality Requirements}

3.5.1 For work to this specification, Supplier shall possess a Quality Assurance Program that contains, at a minimum, QA controls for items/activities associated with box fabrication, inspection, testing, and personnel qualifications, instructions, and records.

3.5.2 Supplier shall submit their Quality Assurance Manual to WSRC for approval in accordance with Attachment 3.

3.5.3 Supplier shall identify specific inspections, with acceptance criteria, in Fabrication and Inspection Procedures (ref. Section 3.4). Supplier shall document fabrication and dimensional inspections in Inspection Reports and deliver them to WSRC with each shipment in accordance with Attachment 5.

1. Inspection Reports shall list the identification number of the box inspected and be traceable to the fabrication drawings.

2. Supplier shall maintain a copy of the signed Inspection Reports with their Quality Assurance Records.

3.5.4 Technical and $Q A$ requirements of this specification shall be invoked on sub-tier suppliers when the Supplier contracts others to provide for services, items, or parts thereof.

\subsubsection{Supplier Records}

The following records generated in association with this specification, shall be maintained by the supplier in an Underwriter's Laboratory approved fire resistant safe or fire resistant file cabinet for a minimum of one (1) year after shipment, and shall be made available to WSRC representatives.

- This specification with any revisions

- The contract with any revisions

- Approved Non-conformance Reports

- Product deviation documentation with approved SDDR

- Corrective Action Reports with associated WSRC Requests for Supplier Corrective Action forms, as applicable

- Procedures used to fabricate, inspect, and test

- Supplier's Quality Assurance Manual associated with the order

- Training Certification Records for welders and other personnel performing critical functions affecting product quality

- Any documentation generated that certifies product quality

Note: These records shall be made available to the SSR during every visit and when other WSRC authorized representatives request them. 
Low Level Waste B-12 \& B-25 Box Specification Procurement Specification No. C-SPP-G-00101, Revision 5

Page 10 of 20

\subsection{Personnel Qualifications/Certification}

3.6.1 Personnel shall be qualified or certified in accordance with the Supplier's approved Quality Assurance Program.

3.6.2 Comprehensive Training Records/Certifications shall be maintained by the Supplier to demonstrate employee qualifications.

3.6.3 Welders shall be qualified in accordance with AWS D1.3 or ASME Section IX as appropriate. The applicable code shall be documented in qualification records.

3.6.4 Weld inspectors shall be qualified in accordance with AWS D1.198, Structural Welding Code-Steel.

\subsection{Deliverables (including Submittals)}

All Supplier paper records shall be on white (or white recycled) paper. The use of $100 \%$-recycled paper is prohibited.

\subsubsection{Submittals}

1. The Engineering Document Requirements (EDR) form, Attachment 3, provides a consolidated list of documents to be submitted to WSRC for review, approval, and/or use. Instructions for submitting documents (quantity, schedule, etc.) are provided on the form. For first-time purchases using this specification, all documents listed on the EDR shall be submitted to WSRC. For repeat orders, the Supplier may substitute an Engineering Documents Summary List for documents that have not been changed/revised from a previous submittal. The following shall apply:

- A revision or change to any part of a document will require the resubmittal of the entire document.

- The Summary List (and its use) is not applicable to Quality Verification documents, any Engineering document that is unique to an item or lot of items, or documents excluded from this provision by the Purchase Order.

- A sample Summary List is provided in Attachment 4. The information required in the attachment shall be provided regardless of format used by the Supplier.

- The EDR form requirements for proceeding with work, submittal schedule, and statusing by WSRC will apply to the Summary List commensurate with the documents listed therein.

WSRC will review and status the Summary List in accordance with Section 3.7.1.3. 
Low Level Waste B-12 \& B-25 Box Specification Procurement Specification No. C-SPP-G-00101, Revision 5 Page 11 of 20

2. Submit EDR Documents, with a Cover Sheet specifically identifying Supplier's name, Specification Number, list of enclosed documents and Purchase Order Number and/or Engineering Documents Summary List, to the address shown below with a copy of Cover Sheet and/or Summary List to the WSRC buyer:

\section{Westinghouse Savannah River Company Document Control Center 704-1N \\ Aiken, SC 29808}

3. EDR document(s)/Summary List submitted by the supplier in accordance with this specification will be reviewed and processed by WSRC within 30 calendar days from the date of receipt. The supplier will be informed of each document status as follows:

Status 1 Work may proceed

Status 2 Submit final document, work may proceed

Status 3 Revise and resubmit, work may proceed subject to resolution of comments

Status 4 Revise and resubmit, work may not proceed

Status 5 Permission to proceed not required

The supplier shall incorporate changes as required by WSRC comments and resubmit corrected engineering documents/Summary List for review within 15 calendar days. Supplier shall not change Status 1 documents without notifying WSRC and resubmitting the documents.

Assignment of Status 1 to the documents by WSRC does not relieve the supplier of any part of these obligations to meet all of the requirements of the specification or the responsibility for the correctness of such documents and the adequacy and suitability of materials and equipment represented thereon for their intended function.

\subsubsection{Deliverables}

1. Low Level Waste B-12 and/or B-25 boxes. Quantity delivered as specified by Purchase Order.

2. Using Attachment 5, Quality Verification Document Requirements (QVDR) Form as a cover sheet, Supplier shall provide a document package with each shipment. The document package shall consist of all items listed on the QVDR. The items shall be traceable to the WSRC Purchase Order Number. 
Low Level Waste B-12 \& B-25 Box Specification Procurement Specification No. C-SPP-G-00101, Revision 5

Page 12 of 20

\subsubsection{Changes/Revisions}

Changes or revisions to requirements of this specification, or to requirements of WSRC approved Supplier submittals will be authorized by WSRC only.

\subsection{Packaging, Shipping, Handling, and Storage Requirements}

Packaging, shipping, handling, and storage requirements to be Level D as described below:

3.8.1. Prior to packaging, dirt, oil residue, water, metal chips, or other forms of contaminates shall be removed.

3.8.2. During shipping lid shall be fastened to box using nylon cable ties.

3.8.3. Items shall be properly packaged. All loose items shall be boxed blocked, anchored, braced, and/or cushioned to prevent physical damage. Items shall be stored on cribbing, dunnage, or pallets for air circulation and to avoid trapping water.

3.8.4. Prior to shipping to WSRC, boxes shall be stored as follows:

1. may be stored outdoors

2. stored on paved or gravel surface

3. removed from high traffic areas to minimize damage from moving equipment

4. covered, at suppliers discretion, to provide protection from the elements

\subsection{Marking and Identification Requirements}

3.9.1 Supplier shall uniquely identify each box by embossing the following information on a secure, durable, steel tag(s) welded, in an upper corner of the long side of the box or by stenciling with paint. (Note: Attaching of any tag requires a full perimeter weld to facilitate decontamination - minimum weld size does not apply.) The identification shall consist of:

- Purchase Order Number

- Sequential Number for the box (for example, KX123456-02, indicating the second box of order KX123456)

3.9.2 Embossed tag shall be prepared and painted same as the box. 
Low Level Waste B-12 \& B-25 Box Specification Procurement Specification No. C-SPP-G-00101, Revision 5 Page 13 of 20

3.9.3 In addition to the above:

1. The following line items with appropriate values shall be stenciled (Minimum 1" lettering) on both long sides of the box on the upper 2/3 (ref. Attachment 1):

- Empty Weight in Lbs. (e.g., 350 lbs. - Average of 5 empty boxes minimum)

- Volume in $\mathrm{Ft}^{3}$ (e.g., $45 \mathrm{ft}^{3}$ )

2. The following line items with a blank left for the values shall be stenciled (Minimum 1" lettering) on both long sides of the box on the upper $2 / 3$ (ref. Attachment 1 ):

- *Payload in Lbs.

- "Total Gross Wt. in Lbs.

"Actual values to be stenciled by WSRC after loading.

Note: Example above is for B-12. Appropriate information will be required for B-25.

3.9.4 All stenciling shall be paint of contrasting color and be compatible with the exterior coating.

\subsection{Exceptions}

3.10.1 After subcontract award, Supplier shall submit a "Supplier Deviation Disposition Request" (SDDR) Form (Attachment 2) for each deviation to this specification and for each proposed deviation after receipt of the order from WSRC. An SDDR form is attached to this specification for copy and use. The supplier shall submit SDDR forms to WSRC Document Control at address below and forward a copy to the WSRC buyer. Approved SDDR forms must be furnished with shipment.

Westinghouse Savannah River Company

Document Control

BIdg. 704-1N

Aiken, SC 29808 
Low Level Waste B-12 \& B-25 Box Specification Procurement Specification No. C-SPP-G-00101, Revision 5 Page 14 of 20

3.10.2 For each deviation, the supplier shall:

1. Identify the specification and revision number.

2. Identify the criteria that cannot be met by item and section number.

3. Present an explanation for the deviation.

4. Present a proposal with technical justification for resolution of the deviation.

5. Present a price adjustment for deviation resolution, if applicable.

3.10.3 The Supplier shall not perform or make delivery of any item for which an SDDR is submitted until written authorization is received from WSRC.

\subsection{ACCEPTANCE OF ITEM}

\subsection{Final Acceptance Method}

4.1.1 Prior to shipment to WSRC, the SSR shall:

1. Verify inspections/tests including vendor inspections are complete and accepted.

2. Verify compliance with features listed on page 19, Prior to Shipment Inspection Criteria.

3. Verify the documentation package that accompanies the shipment is in accordance with Attachment 5, Quality Verification Document Requirements.

4.1.2 Final acceptance shall be based upon the satisfactory completion of receiving inspection (RI) at SRS. Receiving Inspection (RI) shall verify the criteria listed on page 20, Receiving Inspection Acceptance Criteria.

4.1.3 The Supplier, free of charge, shall replace any item received at WSRC that does not meet this specification.

\subsection{Inspection / Testing Requirements}

4.2.1 It shall be the supplier's responsibility through their own quality control system, to perform inspections necessary to ensure conformance with this specification and compliance with the requirements of 49 CFR 173.410 (ref. Section 3.5).

4.2.2 Non-conforming items shall be identified and segregated (when practical) by the supplier or sub-tier supplier. A SDDR shall be written for each "use-as-is" or "repair" disposition and submitted to WSRC for approval. A copy of the approved SDDR shall accompany the box when it is shipped to WSRC. It is the responsibility of the supplier to ensure that WSRC approves all SDDRs. 
Low Level Waste B-12 \& B-25 Box Specification Procurement Specification No. C-SPP-G-00101, Revision 5

Page 15 of 20

4.2.3 The supplier is responsible for providing 5 day advance notification to the WSRC buyer prior to the start of any test activities required by this specification.

Note: It is the responsibility of the supplier to coordinate a schedule of planned test activities with the SSR that will minimize SSR trips to the facility when witnessing of test is required.

4.2.4. WSRC Procurement determines when the Supplier Surveillance Representative (SSR) shall visit the supplier's facility and what items/activities shall be reviewed/witnessed. The SSR will perform surveillances using criteria from the WSRC Surveillance Plan based on verification/test requirements of Sections $4.2 \& 4.3$ and other applicable criteria of this specification.

4.2.5 Supplier shall perform a Weld Leak Test (prior to painting) on each box to ensure that all welds are leak tight.

1. A Weld Leak Test Procedure shall be submitted to WSRC for approval in accordance with Attachment 3.

2. The leak test shall be documented on a Weld Leak Test Report and delivered to WSRC with the shipment in accordance with Attachment 5.

3. As a minimum the report shall list the product tested (Box, B12 or B-25) and identification number, the date of the test, and the test results (per box).

4. The SSR shall witness five percent $(5 \%)$ or a minimum of 3 , whichever is more, of boxes selected at random (by the SSR). If a box leaks, an additional ten percent $(10 \%)$ of the boxes (lot) shall be witnessed. If a leak is detected in the additional $10 \%$, one hundred percent $(100 \%)$ of the lot shall be witnessed.

4.2.6 The Supplier shall perform at least one Uniform Load Test per box design. This test shall be witnessed by the SSR.

1. A Uniform Load Test Procedure shall be submitted to WSRC for approval in accordance with Attachment 3.

2. Test results shall be documented in a Uniform Load Test Report and delivered to WSRC with each shipment in accordance with Attachment 5.

3. As a minimum the report shall list the product tested (Box B-12 or $\mathrm{B}-\mathrm{25}$ ), the date of the test, and the test results. 
Low Level Waste B-12 \& B-25 Box Specification Procurement Specification No. C-SPP-G-00101, Revision 5

Page 16 of 20

4. Test criteria shall include the following:

- The test shall demonstrate that each box, half full of sand or water is capable of supporting a uniform load of twentythousand pounds for a B-12 and twenty-four thousand pounds for a B-25; plus

- The box and lid weight of four boxes $(20,000+4 \times 475=$ $21,900 \pm 300 \mathrm{lbs}$ for a B-12; \& $24000+4 \times 500=26000 \pm$ $300 \mathrm{lbs}$ for a B-25) on the top surface (lid) of the box for a minimum of four hours ( 4 hrs. \pm 5 minutes); with

- Less than three-eighth inch (3/8") deformation in the side walls.

4.2.7 The Supplier shall perform at least one Lid/Box Seal Test per box design. This test shall be witnessed by the SSR.

1. A Lid/Box Seal Test Procedure shall be submitted to WSRC for approval in accordance with Attachment 3.

2. Test results shall be documented in a Lid/Box Seal Test Report and delivered to WSRC with each shipment in accordance with Attachment 5.

3. As a minimum the report shall list the product tested (Box, B12 or $\mathrm{B}-25)$, the date of the test, and the test results.

4. A gasket compression of at least twenty-percent (20\%) shall be achieved.

4.2.8 The Supplier shall perform Visual Weld Inspections on each box in accordance with AWS D1.3-98. The visual weld inspection shall be documented on a Weld Inspection Report and delivered to WSRC with the shipment in accordance with Attachment 5. The report shall contain the following minimum information:

1. Product inspected (Box, B-12 or B-25) and ID\#

2. Date of inspection

3. Attributes inspected

4. Results of inspection

5. ID/Signature of Weld Inspector 
Low Level Waste B-12 \& B-25 Box Specification Procurement Specification No. C-SPP-G-00101, Revision 5 Page 17 of 20

4.2.9 The SSR shall visually verify (prior to painting) welds are acceptable in accordance with AWS D1.3-98. The verification shall be as follows:

1. All welds on the first piece of each design and five percent $(5 \%)$ or a minimum of 3 , whichever is more, of boxes selected at random by the SSR.

2. If a weld defect is detected, an additional ten percent (10\%) of the boxes (lot) shall be inspected.

3. If a weld defect is detected in the additional ten percent $(10 \%)$, the SSR shall visually verify one hundred percent $(100 \%)$ of the lot.

\subsection{WSRC Surveillance and Audits}

4.3.1 WSRC reserves the right of access to the supplier's facilities, including their sub-tier supplier's and subcontractor's facilities for the purpose of review, surveillance, and witnessing of inspection and testing activities.

4.3.2 WSRC Procurement will coordinate the schedule for supplier access visits with WSRC organizations/representatives and supplier organizations/suppliers.

4.3.3 The SSR shall witness testing and inspect boxes at the Manufacturer's facility for each new design and/or purchased lot as required by this specification. A Surveillance Plan will be developed to include the specified witnessing/verification per Section 4.2 and the following:

- Verify material requirements are met (e.g. - Min. 12 gauge carbon steel, per ASTM A569, gasket per ASTM D1056, etc.)

- Verify that box surfaces, handles and lid are free of sharp edges and burrs.

- Verify box fabrication dimension requirements are met.

- Verify fit up of lid to box.

- Verify primer and paint provide a uniform cover over the entire box surface.

- Review Dry Film Thickness Report and ensure coating thickness requirements of the specification were met.

- Verify that box lid can be removed without the gasket material adhering to the box rim. No damage shall occur to the lid, box, rim, or gasket material during this procedure. 
Low Level Waste B-12 \& B-25 Box Specification Procurement Specification No. C-SPP-G-00101, Revision 5

Page 18 of 20

The SSR shall conduct surveillances on five percent $(5 \%)$ or a minimum of 3 , whichever is more, of boxes selected at random (by the SSR). If defects that could affect the integrity or use of the box are found, an additional ten percent (10\%) of the boxes (lot) shall be verified. If critical defects are detected in the additional $10 \%$, one hundred percent $(100 \%)$ of the lot shall be verified.

4.3.4 A report of the surveillance/inspection results shall be documented and provided to the supplier with copies to the Buyer and WSRC Cognizant Technical Function (CTF).

\subsection{ATTACHMENTS}

1. Low Level Waste Burial Box B-12 Box Sketch (1 Page)

2. Supplier Deviation Disposition Request (SDDR) - OSR No. 45-4 (2 Pages)

3. Engineering Document Requirements (EDR) - OSR No. 45-6 (2 Pages)

4. Engineering Documents Summary List - Repeat Order (1 Page)

5. Quality Verification Document Requirements (QVDR) - OSR No. 45-5 (2 Pages) 


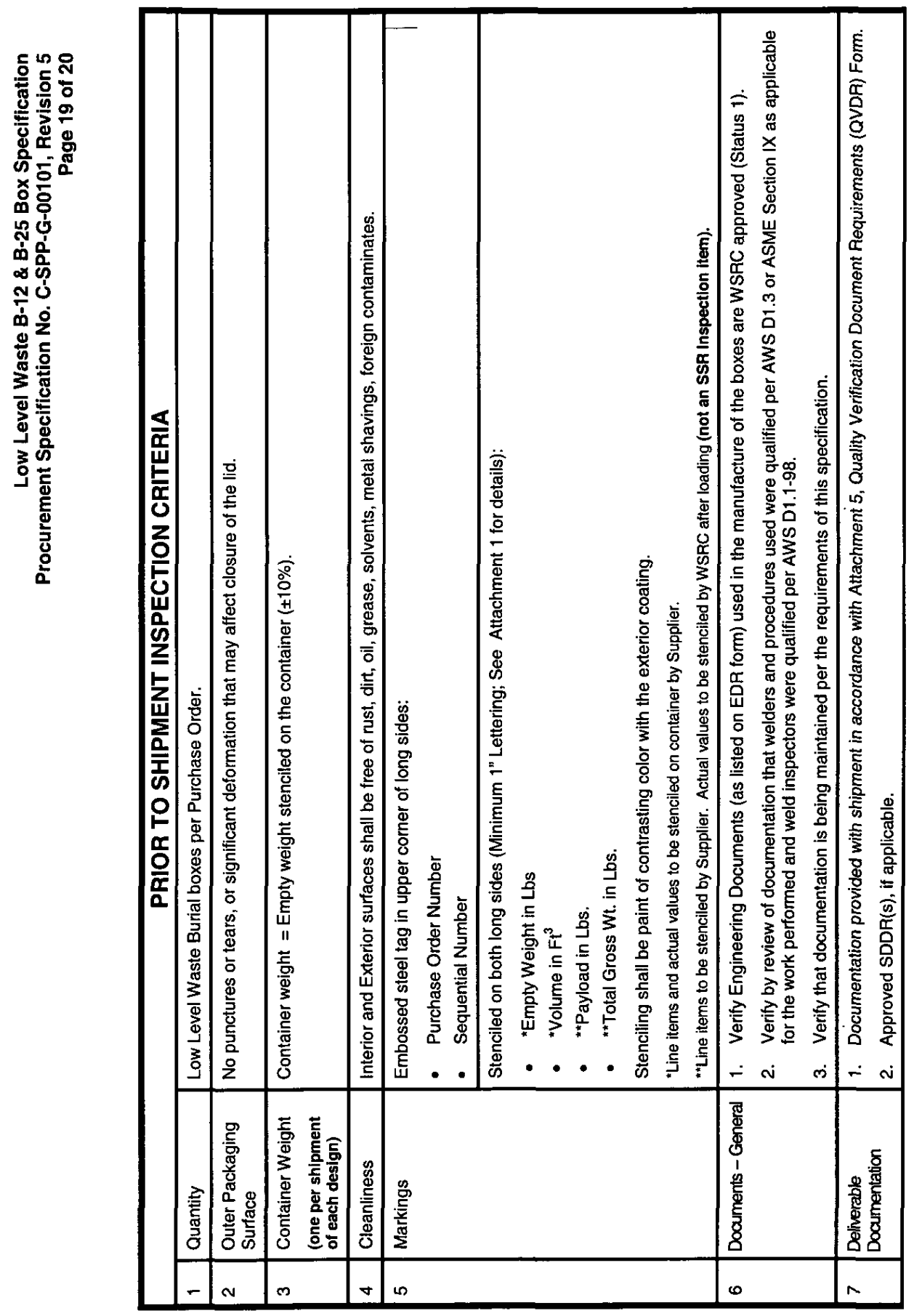

Page 289 of 298 


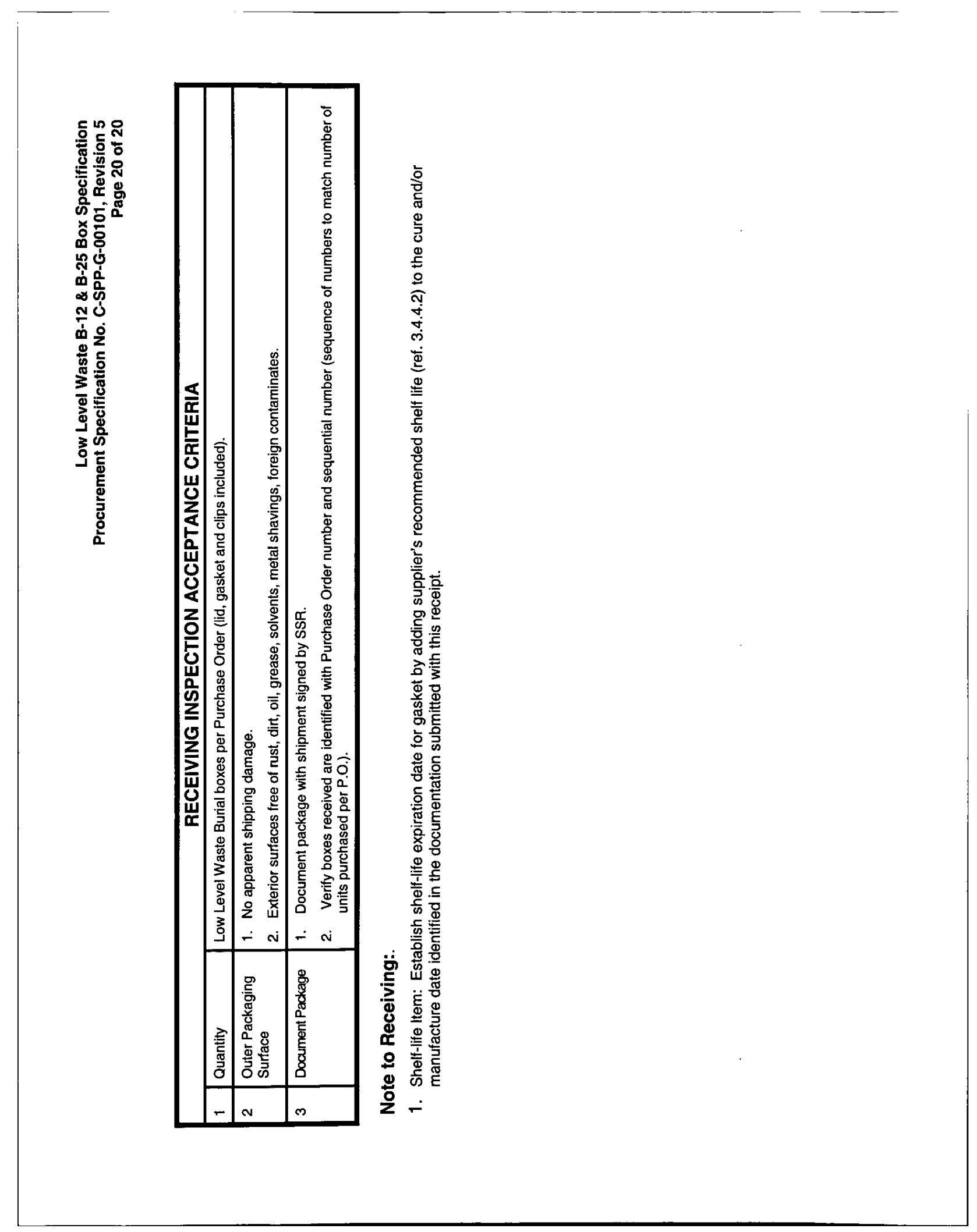

Page 290 of 298 
Low Level Waste B-12 \& B-25 Box Specification

Procurement Specification No. C-SPP-G-00101, Revision 5

Page 1 of 1

\section{Attachment 1}

\section{LOW LEVEL WASTE BURIAL BOX}

\section{B-12 BOX SKETCH}

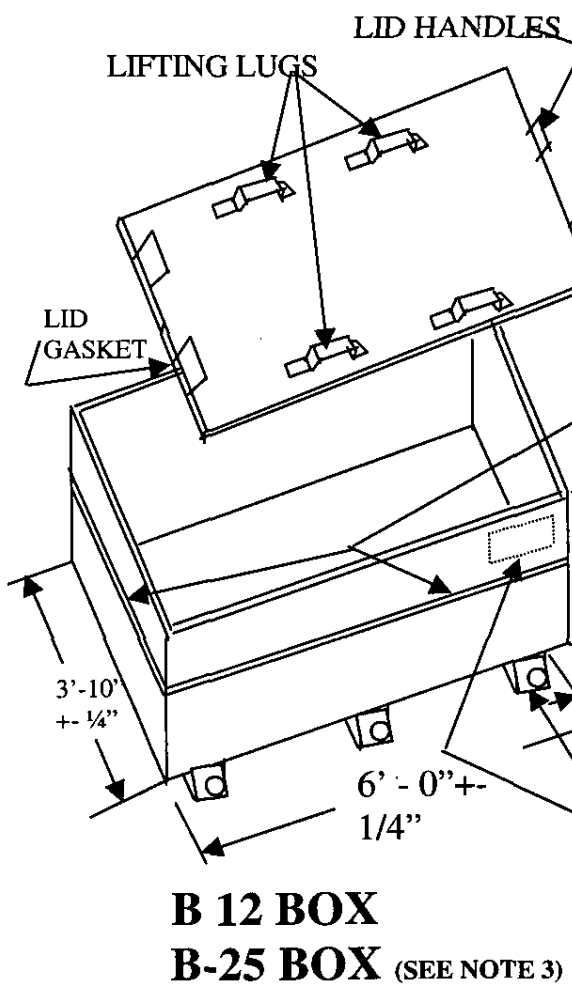

\section{GENERAL NOTES}

1. THIS YELLOW/GRAY BOX IS TO BE USED FOR DISPOSAL OF SOLID LOW LEVEL RADIOACTIVE WASTE AS DEFINED IN WAC 3.17.

2. SHEET METAL SHALL BE MINIMUM OF 12 GAGE CARBON STEEL, ASTM -A569 U.O.S.

3. DIMENSIONS SHOWN ARE INSIDE DIMENSIONS OF B-12 BOX HEIGHT FOR B-25 BOX IS 3 '-11", OTHER DIMENSIONS TO REMAIN SAME FOR B25. $\left(\mathrm{L}=6^{\prime}-0^{\prime \prime}, \mathrm{W}=3^{\prime}-10^{\prime \prime}\right)$

4. DURING SHIPPING, LID TO BE SECURELY FASTENED TO BOX USING NYLON CABLE TIES

5. THE BOX CLOSURE MECHANISM, LID LIFTING LUGS \& HANDLES SHALL NOT INTERFERE WITH BOX STACKING OR LID CLOSURE/ PLACEMENT. FINAL CLOSURE MECHANISM DESIGN

IS TO BE APPROVED BY WSRC. THIS MECHANISM WILL BE ONE OF THE CRITICAL ITEMS FOR REVIEW.

6. MIN. WELD SIZE SHALL BE 3/32".

V-CRIMP FOR WALI REINFORCEMENT. IF REOUIRED.

STENCIL IN FOLLOWING INFORMATION IN 1" MINIMUM LETTERS BOTH LONG SIDES OF BOX.

\begin{tabular}{|c|c|}
\hline EMPTY WT. & (Vendor Supply) LBS* \\
\hline VOLUME & (Vendor Supply) CU.FT \\
\hline PAY LOAD & (Blank) \\
\hline TOTAL LOAD & (Blank) \\
\hline
\end{tabular}

*AVG. OF 5 EMPTY BOXES PLATE (TYP.) $\underbrace{-1 T H E(T P)}$

B-25 BOX (SEE NOTE 3)

Emboss the following on a steel tag (ref section 3.9): Purchase Order Number

Sequential Number for the Packaging 


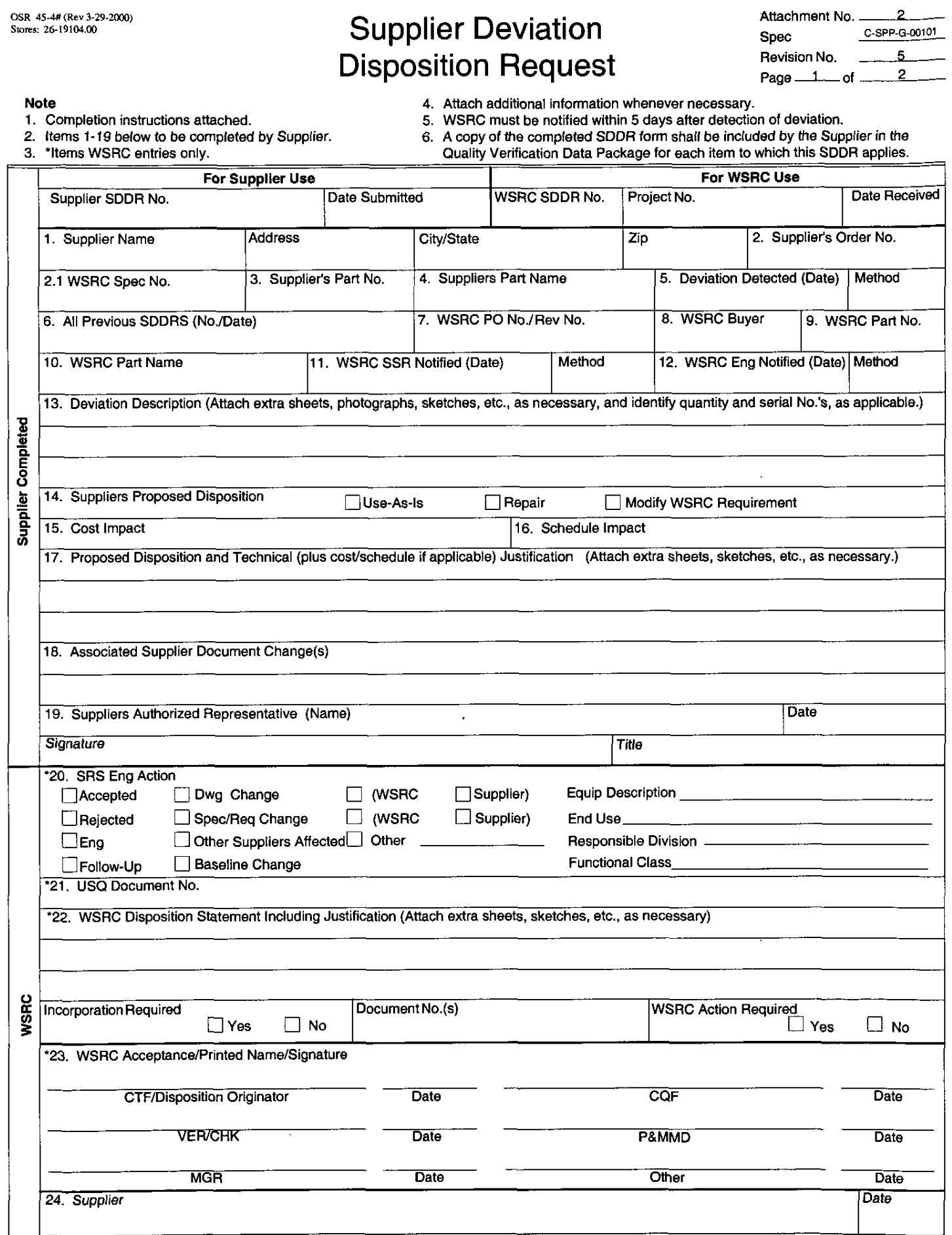


Back of

Back of
OSR 45-4A\# (Rev 3-29-2000)

Attachment No. $\frac{2}{\text { Spec }}$
$\begin{aligned} & \text { C-SPP-G-00101 } \\ & \text { Revision No. }\end{aligned}$
Page 2

Instructions

(Use Black Ink or Typewriter)

This form is to be used after Purchase Order Award by a supplier or subtier supplier to

a) Notify WSRC when manufactured product or service does not meet established contract requirements and to document the supplier's proposed disposition, with their technical proposed disposition, with their technical (and where appropriate, Cost Schedule) justification.

b) Notify WSRC when the supplier wants to propose changes to the contract documents unanticipated at time of award.

c) Record WSRC disposition of the SDDR.

A deviation is any departure from the requirements of the procuring documents, which the supplier has incorporated or proposes to incorporate in the completed item or service provided. Deviation disposition can be classified as Use-As-Is or Repair.

Repair is defined as the process of restoring a noncontorming characteristic to a condition such that the capability of an item to function reliably and safety is unimpaired, even though that item still may not conform to the original requirement. Repair includes alternations to the properties to the material through heat-treating, welding, metal deposition, chemical processing, etc. The SDDR form is not required for cases where WSRC has previously provided authorization to proceed, using an accepted repair method for a specific type of repair. Records must be maintained for each specific repair.

An WSRC Engineering action and disposition statement does not relieve the supplier from responsibility for the accuracy, adequacy, or suitability of the item or service being provided as defined in the procurement documents, nor does it constitute waiver of the right to renegotiate the terms of the procurement documents.

\section{Block No.}

\section{Entry Information}

1. Supplier's name and address - city, state, and zip code. List same information for subtier suppliers if applicable.

2. Supplier's order number if one has been assigned.

2.1 WSRC Spec. No. if one has been assigned.

3. Supplier's Part Number as applicable from the drawings, catalog, internal specification, etc.

4. Supplier's Part Name.

5. Date deviation detected and method used to detect deviation (NDE, dimensional, check, visual, etc.)

6. List all previous SDDRs and their dates that have been subrnitted for similar deviations requested on this purchase order.

7. WSRC Purchase Order Number and Revision Number.

8. WSRC Buyer Name.

9. WSRC Purchase Requisition (item, part, tag or code) Number(s)

10. WSRC Part Name, if one has been assigned.

11. Date and method (Fax, letter, etc.) used to notify the WSRC Supplier Surveillance Representative (SSR) whenever WSRC Quality Surveillance is applicable. If the Purchase Requisition identified no requirements for Supplier Surveillance, enter "Not Required."

12. Date and method (Fax, letter, etc.) used to notify WSRC Engineering.

13. Describe the deviating characteristics and define the extent of the out-of specification condition for each identified piece affected. Identify the location of the deviation characteristic by print coordinates or specific location, as applicable. Attach reproducible quality extra sheets, sketches, photographs, etc., as necessary. When proposing a change in either supplier or WSRC documents; describe the change; identify the documents completely including title or subject, date and revision; and where appropriate, attach a copy of areas in question.

14. State proposed disposition.

15. Enter cost impact that would result from proposed changes and which will be reflected in appropriate Procurement documents.

16. Enter delivery schedule impact that would result from proposed changes.

17. Describe the proposed disposition and provide technical (and where appropriate cost/schedule) justification for WSRC evaluation. Attach reproducible quality copies whenever required. If the deviation is correctable by repair, submit a detailed repair procedure or reference the procedure previously submitted and approved by WSRC for use in similar situations. Provide supplier control number and procedure title. For documents, provide suggested corrective wording, procedures, documents, etc. Provide a copy of each SDDR attachment to the WSRC SSR at the supplier's location.

18. Identify the nature of changes that may be needed on associated supplier documents (drawings, specifications, procedures, installation instructions, etc.).

19. Enter the name (typed or printed) and title of the supplier's representative authorizing the disposition request and have appropriate signature and date signed.

*20. Check all applicable boxes to define the action required by WSRC Engineering and include the appropriate equipment description, end use, responsible division and functional classification. Refer to baseline change procedures for baseline changes.

21. USQ Document No. "Repair", Modify WSRC Requirements" and "Use-as-is" disposition for nuclear and nuclear support facilities enter the applicable USC Document Number (e.g. Unreviewed Safety Question Screening, (USQS) and/or Unreviewed Safety Question Evaluation, (USQE), Categorical Exclusion document number) utilized to document the review performed by a USQ Qualified Person in accordance with 11Q, for all non-nuclear facilities, enter "N/A" for "Repair", "Use-as-is", "Rework", and "Reject" Requirements" dispositions.

*22. Provide appropriate justification for the WSRC action(s) indicated in Block 20. When changes to drawings, specifications, requisitions, or other WSRC documents are involved, each document should be identified and the associated change briefly described. If other suppliers are affected, indicate who they are and the documents that initiated resolution of that involvement. "Other" follow-up action (e.g., the need for additional WSRC calculations, additional drawings or sketches, inspection by WSRC Engineering representative, etc.) should also be identified here. If WSRC action is required, so indicate.

"23. Originator - Signature of Responsible Engineer. Verifier/Checker - Signature of the Verifier/Checker Reviewing the Engineering action and the date signed. MGR - Signature of the WSRC Department Manager and the date signed.

CQF - Signature of the Cognizant Quality Function Representative and the date signed

P\&MMD - Signature of the WSRC Procurement and Materials Management Department representative acknowledging the SDDR and the date signed.

24. Signature of the supplier's inspector or other representative authorized to verify that the accepted disposition was correctly accomplished and the date signed. Not required for "use-as-is" disposition. 
OSR 45-6B\# (Rev 8-27-91)

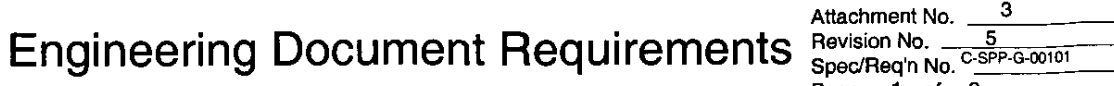 \\ Page 1 of 2}

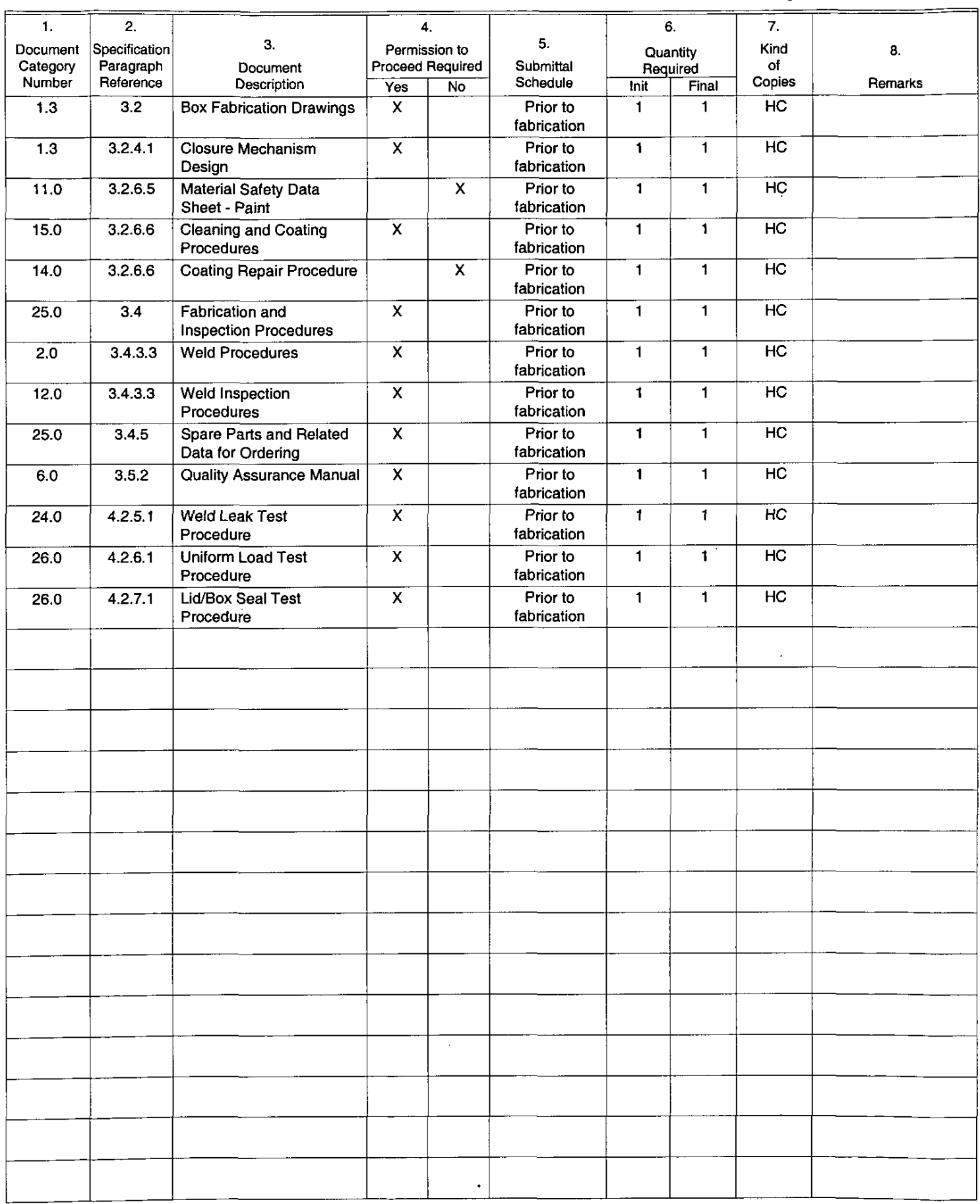




\section{Engineering Document Requirements Form Instructions}

Attachment No. $\frac{3}{5}$ Revision No. $\frac{5}{\text { Spec/Req'n No. C-SPP-G-00101 }}$ Pago 2 of 2

Purpose The Engineering Document Requirements (EDR) form is prepared by the originator, establishes a basis for actions required of a Supplier and provides the schedule for the submittal of engineering documents by the Supplier.

Legend

Entry

No.

1

3

Descriotion corresponding to document category number.

4 Permission to proceed with fabrication or other specific processes is marked yes, if required

6 List a milestone after award i.e., prior to

7 Reproducible, Mylar, Vellum, etc.

8 Enter remarks when appropriate.

1.0 Drawings

1.t Outline Dimensions, Services, Foundations and Mounting Details - Drawings providing external envelope, including lugs, centerline(s), location and size for electrical cable, conduit, fluid, and other service connections, isometrics and details related to foundations and mountings.

1.2 Assembly Drawings - Detailed drawings indicating sufficient information to facilitate assembly of the component parts of an equipment item.

1.3 Shop Detail Drawings - Drawings which provide sufficient detail to tacilitate fabrication, manufacture, or installation. This includes pipe spool drawings internal piping and wiring details, cross-section details and siructural and architectural details.

1.4 Wiring Diagrams - Drawings which show schematic diagram equipment, internal wiring diagrams, and interconnection wiring diagram for electrical items.

1.5 Control Logic Diagrams - Drawings which show paths which input signals must follow to accomplish the required responses.

1.6 Piping and Instrumentation Diagrams - Drawings which show piping system scheme and control elements.

2.0 Parts Lists and Costs - Sectional view with identified parts and recommended spare parts for one year's operation and specified with unit cost.

3.0 Complete WSRC Data Sheets - Intormation provided by Supplier on data sheets fumished by WSAC

4.0 Instructions

4.1 Erection/Installation - Detailed written procedures, instructions, and drawings required to erect or install material or equipment.

4.2 Operations - Detailed written instructions describing how an item or system should be operated.

4.3 Maintenance - Detailed written instructions required to disassemble, reassemble and maintain items or systems in an operating condition.

4.4 Site Storage and Handling - Detailed written instructions, requirements and time period for lubrication, rotation, heating, lifting or other handling requirements to prevent damage or deterioration during storage and handling at jobsite. This includes shipping instruction for return.

5.0 Schedules: Engineering and Fabrication/Erection - Bar charts or critical path method diagram which detail the chronological sequence of activities, i.e., Engineering submittals, fabrication and shipment.

6.0 Quality Assurance Manual/Procedures - The document(s) which describe(s) the planned and systematic measures that are used to assure that siructures, systems, and components will meet the requirements of the procurement documents.

7.0 Seismic Data Reports - The analytical or test report which provides information and demonstrates suitability of material, component or system in relation to the conditions imposed by the stated seismic criteria.

8.0 Analysis and Design Reports - The analytical data (stress, electrical loading, fluid dynamics, design verification reports, etc.) which demonstrate that an item satisfies specified requirements.

9.0 Acoustic Data Feports - The noise, sound and other acoustic vibration data required by the procurement documents.

10.0 Samples

10.1 Typical Quality Verification Documents - A representative data package which will be submitted for the items fumished as required in the procurement documents.

10.2 Typical Material Used - a representative example of the material to be used.

11.0 Material Descriptions - The technical data describing a material which a Supplier proposes to use. This usually applies to architectural items, e.g., metal siding, decking, doors, paints, coatings.

12.0 Welding Procedures and Qualifications - The welding procedure, specification and supporting qualitication records required for welding, hard facing, overlaying,

brazing and soldering.
13.0 Material Control Procedures - The procedures for controlling issuance, handling, storage and traceability of materials such as weld rod.

14.0 Repair Procedures - The procedures for controlling material removal and replacement by welding, brazing. etc.. subsequent thermal treatments, and final acceptance inspection.

15.0 Cleaning and Coating Procedures - The procedures for removal of dirt, grease or other surface contamination, and preparation and application of protective coatings.

16.0 Heat Treatment Procedures - The procedures for controlling temperature and time at temperature as a function of thickness, fumace atmosphere, cooling rate and methods, etc.

19.0 UT - Ultrasonic Examination Procedures - Procedures for detecting discontinuities and inclusions in materials by the use of high frequency acoustic energy.

20.0 RT - Radiographic Examination Procedures - Procedures for detecting discontinuities and inclusions in materials by $x$-ray or gamma ray exposure of photographic film.

21.0 MT - Magnetic Particle Examination Procedures - Procedures for detecting surface or near surface discontinuities in magnetic materials by the distortion of an applied magnetic field.

22.0 PT - Liquid Penetrant Examination Procedures - Procedures for detecting discontinuities in materials by the application of a penetrating liquid in conjunction with suitable developing materials.

23.0 Eddy Current Examination Procedures - Procedures for detecting discontinuities in materials by distortion of an applied electromagnetic field.

24.0 Pressure Test - Hydro, Air, Leak, Bubble or Vacuum Test Procedures - Procedures for performing hydrostatic or pneumatic structural integrity and leakage tests.

25.0 Inspection Procedures - Organized process followed for the purpose of determining that specified requirements (dimensions, properties, pertormance results, etc.) are met.

26. Performance Test Procedures - Test performed to dernonstrate that functional design and operational parameters are met.

26.1. Mechanical Tests - e.g.. pump performance, data, valve stroking, load, temperature rise, calibration, environmental, etc.

26.2 Electrical Tests - e.g., impulse, overload, continuity, voltage, temperature rise, calibration, saturation, loss, etc.
26.9

27.0 Prototype Test Reports - Reports of a test which is performed on a standard or typical examination of equipment or item, and which is not required for each item produced in order to substantiate the acceptability of equal items. This may include tests which result in damage to the item(s) tested.

28.0 Personnel Qualification Procedures - Procedures for qualifying welders, inspectors and other special process personnel.

29.0 Supplier Shipping Preparation Procedures - Procedures used by a Supplier to prepare finished materials or equipment for shipment from its facility to the jobsite. 
Low Level Waste B-12 \& B-25 Box Specification Procurement Specification No. C-SPP-G-00101, Revision 5 Page 1 of 1

\section{Attachment 4}

\section{Engineering Documents Summary List - Repeat Order}

WSRC Purchase Order Number:

Manufacturer (Cormany Name/Address):

Contact Name/Phone/Fax:
Specification Number

Purchase Order below:

\begin{tabular}{|l|l|l|l|}
\hline $\begin{array}{c}\text { SPEC } \\
\text { Paragraph } \\
\text { Reference }\end{array}$ & $\begin{array}{c}\text { Document Title(As shown on EDR } \\
\text { Form)/Number }\end{array}$ & $\begin{array}{c}\text { Rev/Eff. } \\
\text { Date* }\end{array}$ & $\begin{array}{c}\text { P.o. Under Which 'Document' was Submitted } \\
\text { and Approved by WSRC. }\end{array}$ \\
\hline & & & \\
\hline & & & \\
\hline & & & \\
\hline & & & \\
\hline & & & \\
\hline & & & \\
\hline & & & \\
\hline & & & \\
\hline & & & \\
\hline & & & \\
\hline & & & \\
\hline & & & \\
\hline & & & \\
\hline
\end{tabular}

*Record "No Change" if document has no revision/effective date.

Authenticated By:

Supplier Management Representative

Verified By:

WSRC CTF 
Attachment No. $\frac{5}{5}$ Revision No. 5

\section{Quality Verification Document Requirements}

Spec/Reg'n No. C-SPP-G-00101

Page 1 of 2

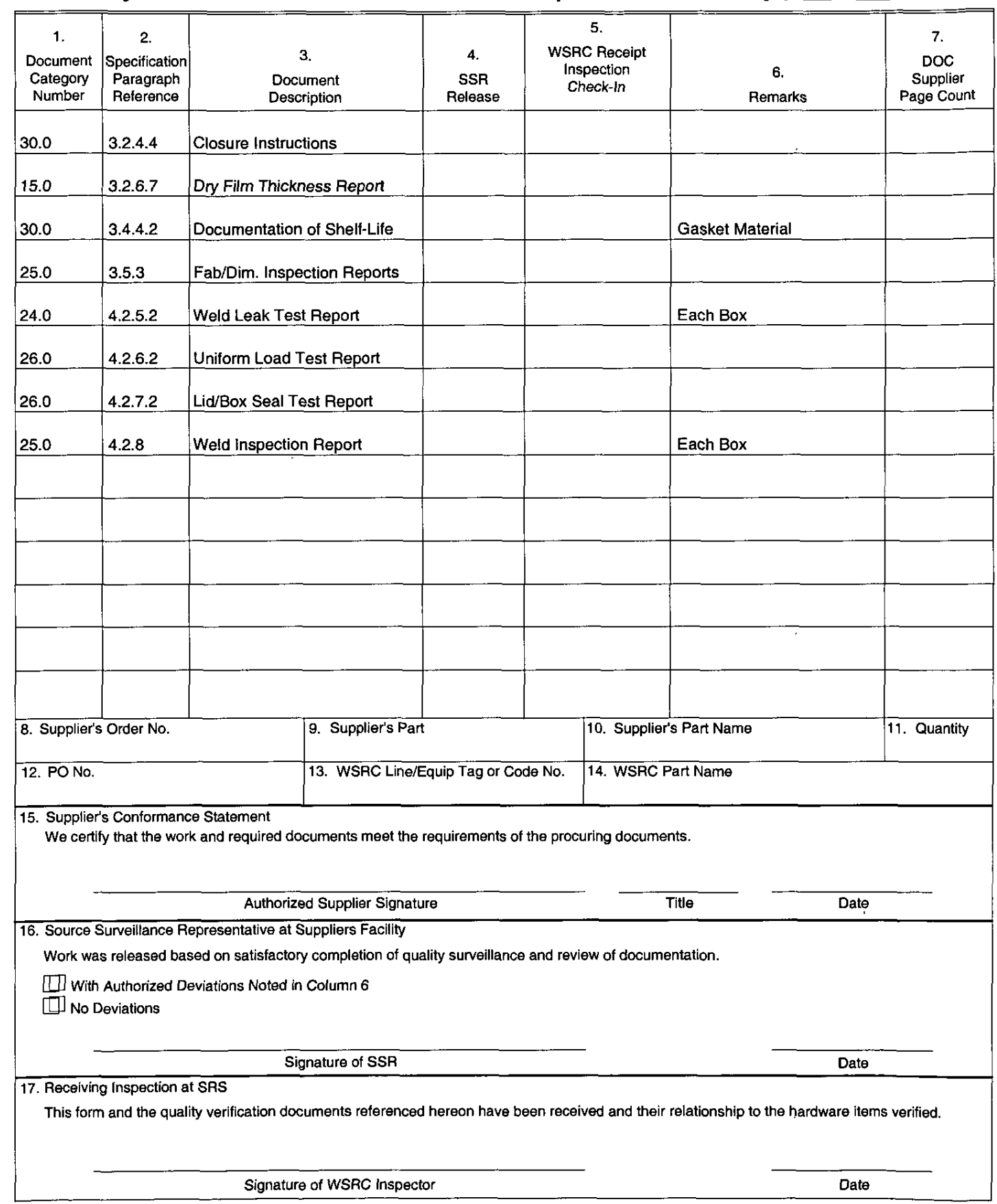




\section{Quality Verification Document Requirements Form Instructions}

Purpose The Quality Verification document Requirements (QVDR) is initiated by SRS and completed by the Supplier when providing quality verification documents. The QVDR is a multipurpose form to

Transmit quality verification documents from the Supplier,

Provide evidence of SSR release of documentation and/or work, and

Provide evidence of an SRS inspection check of documentation received at SRS.

\section{WSRC Entries}

\section{Entry No. Information Required}

1 Enter Document Category Number - see below.

2 Enter Specification Number and Paragraph Reference.

3 Enter Description corresponding to the Document Category Number.

4 SSR to initial upon item release.

6 Enter "Remarks: as appropriate.

16 SSR and dates release.

\section{Field Entries}

Entry No. Information Required

5 SRS inspector at the jobsite to complete check-in.

17 The SRS Inspector will review the quality verification documentation package. If found satisfactory, he signs and dates the check-in statement.

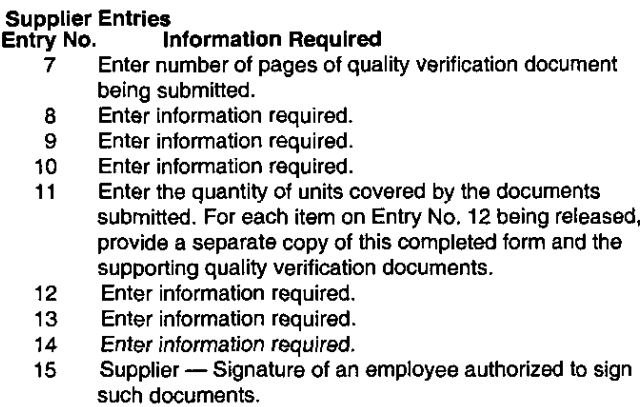

Document Category Numbers and Descriptions

12.0 Welding Verification Reports - Reports of welding performed to include weld identification, and certification that qualified welding procedures and welders were used.

13.0 Material Verification Reports - Reports relative to material which confirm, substantiate or assure that an activity or condition has been implemented in conformance with code and material specifications imposed by the procurement documents.

14.0 Major Repair Verification Reports - Reports may include weld repair locations (maps), material test reports for filler metal, pre- and post-weld heat treatment records, NDE records, etc. The resolution of whether a repair is major or not is an SRS responsibility.

15.0 Cleaning and Coating Verification Reports - Reports include a certification of visual examination for surface preparation, surface profile, materials, etc.; and also humidity data, temperature data and coating thickness data as required by the procurement documents.

16.0 Heat Treat Reports - Reports normally include furnace charts and similar records which identify and certity the item(s) treated, the procedure used, furnace atmosphere, time at temperature, cooling rate, etc.

17.0 Material Property Reports

17.1 MTR (Material Test Reports) - These reports include all chemical, physical, mechanical, and electrical property test data required by the material specification and applicable codes. These are applicable to cement, concrete, metals, cable jacket materials, rebar, rebar splices, etc.

17.2 Impact Test Data - Reports of Charpy or drop weight tests including specimen configuration, test temperature and fracture data

17.3 Ferrite Data - Reports of the ferrite percentage for stainless steel materials used, including castings and welding filler metals as deposited.

17.4 Material Certificate of Conformance - Documents which certify conformance to the requirements of the applicable material specification. 17.5 Electrical Property Reports - Reports of electrical characteristics, e.g., dielectric, impedance, resistance, flame tests, corona, etc.

18.0 Code Compliance - Verifying documents (such as data Forms U-1, M-2, State, etc.), which are prepared by the manufacturer or installer and certified by the Authorized Code Inspector.

19.0 UT - Uitrasonic Examination and Verification Reports - Examination results of certain characteristics of discontinuities and inclusions in material by the use of high frequency acoustic energy.

20.0 RT - Radiographic Examination and Verification Reports - Examination results of certain characteristics of discontinuities and inclusions in materials by $x$-ray or gamma-ray exposure of photographic film, including film itself.

21.0 MT - Magnetic Particle Examination and Verification Reports - Examination results of surface (or near surface) discontinuities in magnetic materials by distortion of an applied magnetic field.

22.0 PT - Liquid Penetrant Examination and Verification Reports - Examination results of surface discontinuities in materials by application of a penetrating liquid in conjunction with suitable developing techniques.

23.0 Eddy Current Examination and Verification Reports - Examination results of discontinuities in material by distortion of an applied electromagnetic field.

24.0 Pressure Test - Hydro, Air, Leak, Bubble or Vacuum Test and Verification Reports - Results of hydrostatic or pneumatic structural integrity and leakage tests.

25.0 Inspection and Verification Reports - Documented findings resulting from an inspection.

26.0 Pertormance Test and Verification Reports - Reports of Test Results 26.1 Mechanical Test, e.g., pump, periormance data, valve stroking, load, temperature rise, calibration, environment, etc. 26.2 Electrical Tests, e.g., load, impulse, overload, continuity, voltage, temperature rise, calibration, saturation, loss, etc.

27.0 Prototype Test Report - Report of the test which is performed on a standard or typical example of equipment, material or item, and which is not required for each item produced in order to substantiate the acceptability of equal items. This nomally includes tests which may, or could be expected to, result in damage to the item(s) tested.

28.0 Certificate of Conformance-A document signed or otherwise authenticated by an authorized individual certitying the degree to which items or services meet specified requirements. 